\title{
Promjena komunikacijske paradigme u visokom obrazovanju pod utjecajem društvenih medija
}

\section{Babić, Tihana}

\section{Doctoral thesis / Disertacija}

2021

Degree Grantor / Ustanova koja je dodijelila akademski / stručni stupanj: University of Zagreb, Faculty of Humanities and Social Sciences / Sveučilište u Zagrebu, Filozofski fakultet

https://doi.org/10.17234/diss.2021.8762

Permanent link / Trajna poveznica: https://urn.nsk.hr/urn:nbn:hr:131:074981

Rights / Prava: In copyright/Zaštićeno autorskim pravom.

Download date / Datum preuzimanja: 2023-04-26

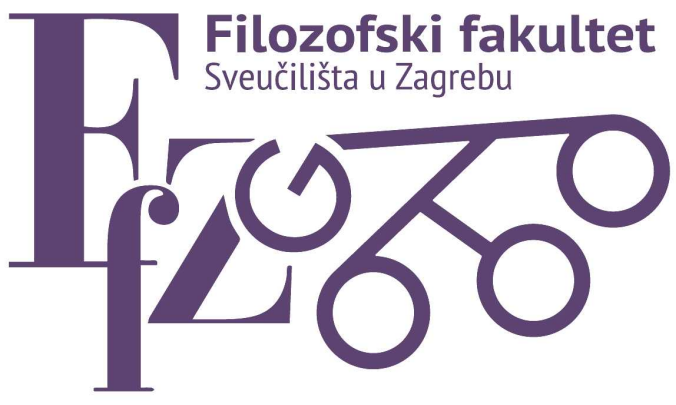

\section{Repository / Repozitorij:}

ODRAZ - open repository of the University of Zagreb Faculty of Humanities and Social Sciences
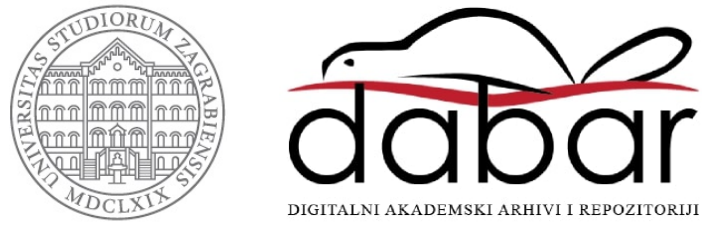


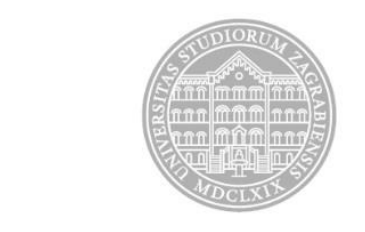

Sveučilište u Zagrebu

FILOZOFSKI FAKULTET

Tihana Babić

\section{PROMJENA KOMUNIKACIJSKE PARADIGME U VISOKOM OBRAZOVANJU POD UTJECAJEM DRUŠTVENIH MEDIJA}

DOKTORSKI RAD

Zagreb, travanj 2021. 


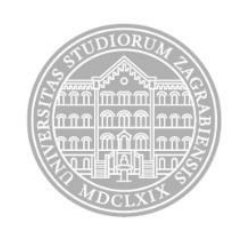

Sveučilište u Zagrebu

FILOZOFSKI FAKULTET

Tihana Babić

\title{
PROMJENA KOMUNIKACIJSKE PARADIGME U VISOKOM OBRAZOVANJU POD UTJECAJEM DRUŠTVENIH MEDIJA
}

DOKTORSKI RAD

\author{
Mentorice: \\ prof. dr. sc. Gordana Vilović \\ prof. dr. sc. Ljubica Bakić Tomić
}

Zagreb, travanj 2021. 


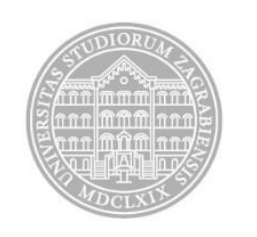

University of Zagreb

FACULTY OF HUMANITIES AND SOCIAL SCIENCES

Tihana Babić

\title{
CHANGING THE COMMUNICATION PARADIGM IN HIGHER EDUCATION UNDER THE INFLUENCE OF SOCIAL MEDIA
}

DOCTORAL THESIS

\author{
Supervisors: \\ prof. dr. sc. Gordana Vilović \\ prof. dr. sc. Ljubica Bakić Tomić
}

Zagreb, April 2021 


\section{Posveta}

Ovaj rad posvećujem svom prijatelju i učitelju, najplemenitijem čovjeku kojeg sam upoznala, gospodinu Rudolfu Vigu.

Bila je čast i privilegija poznavati Te, neizreciva radost $i$ veselje, i nosit ću Te u srcu dok živim.

Tihana Babić 


\section{Zahvale}

Zahvaljujem svojim roditeljima, Damiru i Anici, što su mi dali život, ali zahvaljujem i na svemu što su mi dali od svog života.

Hvala Manueli Babić što postoji; imam sestru i zato imam uspravan hod!

Od srca hvala mentoricama prof. dr. sc. Ljubici Bakić-Tomić i prof. dr. sc. Gordani Vilović! Velika hvala svim ekspertima koji su sudjelovali u studiji na vremenu, trudu i dobroj volji!

Zahvaljujem na podršci:

Visokom učilištu Algebra, doc. dr. sc. Mislavu Balkoviću, Silviji Grgić, prof., dr. sc. Nataši Trojak, prof. dr. sc. Davoru Pećnjaku, prof. dr. sc. Anđelku Milardoviću, doc. dr. sc. Damiri Đukec.

Zahvaljujem na profesionalnosti: prof. emerita dr. sc. Jadranki Lasić-Lazić, prof. dr. sc. Stjepanu Maloviću, doc. dr. sc. Vedranu Juričiću, a posebno prof. dr. sc. Sonji Špiranec. 


\section{Podaci o mentoricama}

Prof. dr. sc. Ljubica Bakić-Tomić rođena je 1955. godine u Zagrebu, gdje je završila cjelokupno svoje obrazovanje. Diplomirala je na Filozofskom fakultetu u Zagrebu pedagogiju i sociologiju, magistrirala na Poslijediplomskom studiju bibliotekarstva, dokumentacije i informacijskih znanosti Sveučilišta u Zagrebu, a doktorat znanosti stekla je na Filozofskom fakultetu Sveučilišta u Zagrebu, Odsjeku informacijskih znanosti 2003. godine, pod naslovom: „Komunikološko-menadžerski profil rukovoditelja u hrvatskoj policiji“.

Kao sveučilišni nastavnik radila je na Fakultetu Kriminalistike Sveučilišta u Zagrebu, Učiteljskom fakultetu Sveučilišta u Zagrebu te na Sveučilištu Sjever u Varaždinu. Od samih početaka vanjski je suradnik Veleučilišta Baltazar u Zaprešiću na diplomskim stručnim studijima Projektni menadžment $\mathrm{i}$ Komunikacijski menadžment, te kraće vrijeme i vanjski suradnik Sveučilišta u Dubrovniku. Na svim visokoškolskim institucijama uvodila je i bila nositelj brojnih kolegija: Komunikologija, Obrazovna komunikologija, Metodika informatike, Poslovno komuniciranje, Odnosi s javnošću, Persuazija i interpersonalna komunikacija, Metodika timskog rada, Kreativnost u odnosima s javnošću, Istraživanje u odnosima s javnošću, Persuazijska komunikologija, Inovativno korporativno komuniciranje i Intuitivno komuniciranje.

Od 2006. godine, u trogodišnjem mandatu obnašala je brojne rukovodne dužnosti: pročelnica Studija za predškolski odgoj Učiteljskog fakulteta u Zagrebu, prodekanica za opće poslove, studij i studente Odsjeka u Čakovcu, Učiteljskog fakulteta u Zagrebu, članica Vijeća područja društvenih i humanističkih znanosti Sveučilišta u Zagrebu, pročelnica odjela za Komunikologiju i odnose s javnostima gdje je vodila sveučilišni diplomski studij Odnosa s javnostima na Sveučilištu Sjever u Varaždinu. Bila je predsjednica etičkog povjerenstva Sveučilišta Sjever.

Od 2005. do 2012. godine prof. dr. sc. Ljubica Bakić-Tomić jedna je od voditeljica brojnih međunarodnih znanstvenih skupova CISKS: Communication and Information Sciences in the Knowledge Society, koji su se održavali u Baden-Badenu u Njemačkoj, Zadru, Zagrebu i Opatiji, te znanstvenih okruglih stolova „Društvo znanja“ zajedno s prof. dr. sc. Vjekoslavom Afrićem i prof. dr. sc. Darkom Polšekom. 2005. godine dobitnica je Priznanja za razvijanje nastavnih programa i izvrstan rad sa studentima od strane Visoke škole za poslovanje i upravljanje „Baltazar Adam Krčelić““ u Zaprešiću, Priznanja dekana Učiteljskog fakulteta prof. dr. sc. Ivana Prskala za doprinos razvoju Učiteljskog fakulteta u mandatnom radoblju 
prodekanice te priznanje za najbolji znanstveni rad od strane International Institute for Advanced Studies in Systems Research and Cybernetics za 2006. godinu u Baden-Badenu, Njemačka.

Od 2007. do 2014. godine bila je glavni istraživač i voditelj znanstvenog projekta „Informacijsko-komunikacijske kompetencije edukatora“ financiranog od MZOŠ-a RH, a godine 2013./14. voditeljica projekta "Jednake mogućnosti za sve - bolja integracija Roma u obrazovni sustav RH, financiran iz Fonda za razvoj Sveučilišta u Zagrebu. Od 2007. godine sudjeluje na Međunarodnom znanstvenom projektu Psychology and Sociology of Ecomomic Behaviour, voditeljice projekta Zuzane Hubinkove, PhD, kojeg je financirala Češka Republika. Prof. dr. sc. Ljubica Bakić-Tomić bila je članica autorskog tima koji je objavio i istoimeni sveučilišni udžbenik za Ekonomsko sveučilište u Pragu.

Sudjelovala je u izvođenju dva doktorska studija „Rani odgoj i obvezno obrazovanje“, na Učiteljskom fakultetu Sveučilišta u Zagrebu i doktorskog studija Informacijskih i komunikacijskih znanosti Filozofskog fakulteta u Zagrebu.

Prof. dr. sc. Ljubica Bakić-Tomić do sada je objavila 4 knjige (od toga dvije u inozemstvu), brojne zbornike u suautorstvu, te 63 znanstvena i stručna rada.

Godine 2019. prelazi na Veleučilište Baltazar u Zaprešiću gdje obnaša dužnost zamjenice dekana i prodekanice za nastavu i studente, te je ujedno i voditeljica stručnog specijalističkog studija Komunikacijski menadžment.

Prof. dr. sc. Gordana Vilović rođena je 3. ožujka 1957. godine u Makarskoj. Osnovnu školu završila je u Brelima, a gimnaziju u Makarskoj. U akademskoj godini 1975./76. upisala je studij politologije na Fakultetu političkih znanosti u Zagrebu. Diplomirala 18. veljače 1980. godine i stekla stručni naziv diplomirani politolog. Studij novinarstva na Fakultetu političkih znanosti završila je 9. srpnja 1992. godine i stekla stručni naziv novinar.

Poslijediplomski znanstveni studij Međunarodni odnosi završila je obranom magistarskog rada na temu „Utjecaj op-ed stranica The New York Timesa na vanjsku politiku SAD-a u odnosu na države bivše Jugoslavije“, 12. srpnja 2001. godine.

Doktorsku disertaciju pod nazivom ,Etičke kontroverzije u informativno-političkim tekstovima na primjeru Globusa i Nacionala 1999-2000“ obranila je na Fakultetu političkih znanosti Sveučilišta u Zagrebu 15. prosinca 2003. godine. 
Deset godina bavila se novinarskim poslovima, od toga (1985.-1990.) kao glavna urednica lokalnog lista čiji je izdavač bio Centar za kulturu i informacije Maksimir. U vrijeme rata u Hrvatskoj honorarno je radila kao vanjski suradnik novinar u Odjelu za informiranje Međunarodne federacije Crvenog križa i Crvenog polumjeseca - Delegacija u Hrvatskoj. Od 20. svibnja 1996. do 28. veljače 2005. godine radila je kao voditeljica medijske knjižnice (Freedom Forum Journalism Library) na Fakultetu političkih znanosti Sveučilišta u Zagrebu.

Od 1997. do 2000. godine bila je angažirana na različitim projektima obrazovanja novinara pri Hrvatskom novinarskom društvu, od kojih se izdvajaju četiri ciklusa Novinarske radionice namijenjene mladim hrvatskim novinarima.

Matični odbor za područje društvenih znanosti - polje politologije, sociologije, socijalne geografije i demografije izabralo je Gordanu Vilović, 15. prosinca 2005. godine u znanstveno zvanje znanstvenog suradnika u znanstvenom području društvenih znanosti - polje politologije.

Nastupno predavanje za izbor nastavnika u naslovno znanstveno-nastavno zvanje docenta održano je 24. siječnja 2006. na Fakultetu političkih znanosti Sveučilišta u Zagrebu na temu „Vrijednost vijesti - povijesni aspekti: oprimjereno na dnevnim listovima The New York Timesu i Novom listu od 2. siječnja 1900. godine“.

Vijeće društveno-humanističkog područja Sveučilišta u Zagrebu potvrdilo je izbor 13. travnja 2006. godine u naslovno zvanje docenta na području društvenih znanosti, polje politologija.

Senat Sveučilišta u Dubrovniku potvrdio je izbor u docenta na studiju „Mediji i kultura društva“, gdje je bila zaposlena od 1. studenoga 2005. do 31. svibnja 2010. godine.

Izbor u zvanje izvanrednog profesora, Vijeće društveno humanističkih znanosti potvrđen je 5. svibnja 2010. godine. Obzirom da je većina objavljenih radova Gordane Vilović, nakon izbora u docenta, bila u društvenim znanostima ali u polju informacijsko-komunikacijskih znanosti, izabrana je za izvanrednu profesoricu u polju informacijsko komunikacijskih znanosti, grana novinarstvo. Nakon provedenog natječaja, odlukom Fakultetskog vijeća Fakulteta političkih znanosti zaposlena je na radnom mjestu izvanredne profesorice 1. lipnja 2010. godine na studiju novinarstva.

Na prijedlog Fakultetskog vijeća Filozofskog fakulteta Sveučilišta u Zagrebu, održanoj 21. siječnja 2016. na kojoj je utvrđeno da Gordana Vilović ispunjava sve uvjete za izbor u 
znanstveno zvanje znanstvenog savjetnika u znanstvenom području društvenih znanosti - polje informacijske i komunikacijske znanosti, Matično povjerenstvo je 5. travnja 2016. godine izabralo Gordanu Vilović u znanstveno zvanje znanstvenog savjetnika, a Odlukom Senata Sveučilišta u Zagrebu, 16. studenoga 2016. godine izabrana je u zvanje redovite profesorice na Fakultetu političkih znanosti. Područje društvene znanosti - polje informacijske i komunikacijske znanosti.

Na Fakultetu političkih znanosti Gordana Vilović je koordinatorica za studente i studentice s invaliditetom od 2012. do 2016 . godine. Voditeljica je diplomskog studija novinarstva, a 1. listopada 2016. godine izabrana je za predstojnicu Odsjeka za novinarstvo i medijsku produkciju. Od 2018. do 2020. godine izabrana je za prodekanicu za nastavu i studente Fakulteta političkih znanosti.

U okviru stručnog usavršavanja specijaliziranog za sveučilišne nastavnike iz područja komunikacijskih znanosti i medija, provela je mjesec i pol dana na američkom Sveučilištu Florida (Gainsville) od 10. lipnja do 24. srpnja 2007. godine. Sudjelovala je na trotjednom programu o pravima čovjeka namijenjenom polaznicima država jugoistočne Europe u rujnu 2000. godine u Olimpijskom centru (Ancient Olimpya) u Grčkoj. Sudjelovala je u nizu specijaliziranih radionica za djecu i o djeci u organizaciji UNICEF-a, od kojih ističemo Etiopiju (2012.) i Budvu (2014.).

Sudjelovala je na četiri nacionalna i dva međunarodna projekta od kojih se ističe TEMPUS projekt u suradnji sa Sveučilištem u Beču (voditelj, sveučilišni profesor Thomas Bauer)

Objavila je 45 znanstvenih i stručnih radova i 6 knjiga kao autor i suaotor.

Na Fakultetu političkih znanosti - studiju novinarstva uvela je predmet Mediji i pravo djeteta i Povijest vijesti.

Članica je dvaju uredništava: znanstvenog časopisa Medijske studije $i$ znanstvenog časopisa Mediji i komunikacija.

Državljanka je Republike Hrvatske. Živi u Zagrebu. Registrirana je u registru znanstvenika u Ministarstvu znanosti, obrazovanja i sporta pod brojem 244196. 


\section{Sažetak}

Tema doktorskog rada doktorandice Tihane Babić nosi naslov Promjena komunikacijske paradigme u visokom obrazovanju pod utjecajem društvenih medija.

Uvod: Ova doktorska disertacija je nastala u okviru istraživanja teorije medija i masovnog komuniciranja te razvoja društvenih medija kao medija masovnog komuniciranja. Društvenim medijima se pristupa sa stajališta mogućnosti korištenja u visokoobrazovnim ustanovama, te detaljnije sa stajališta komunikacijskih mogućnosti.

Metode: Cilj doktorskog istraživanja bio je utvrditi čimbenike koji će omogućiti promjenu postojeće komunikacijske paradigme u visokom obrazovanju pod utjecajem društvenih medija temeljem predikcija na visokostručnoj razini, te oblikovanje smjernica nove komunikacijske paradigme putem društvenih medija za potrebe visokog obrazovanja. Kako bi se postigao navedeni cilj korištena je delfi studija provedena u 2020. godini u Republici Hrvatskoj na uzorku 37 značajnih IT eksperata u četiri kruga, od čega se posljednji krug odnosi na prezentaciju rezultata provedene delfi studije sudionicima istraživanja.

Rezultati: Istraživački pristup obradi i analizi odgovora dobivenih u prva tri kruga delfi studije bio je metodološka triangulacija, na temelju koje je utvrđeno 12 ključnih čimbenika promjene komunikacijske paradigme u visokom obrazovanju pod utjecajem društvenih medija. Kao najznačajniji čimbenici se ističu podrška vodstva visokih učilišta, razvoj tehnologija i motivacija nastavnika.

Zaključno, oblikovane su preporuke nove komunikacijske paradigme putem društvenih medija u visokom obrazovanju koje će profesionalcima u području obrazovanja biti smjernice za poboljšanje kvalitete obrazovnih politika, nastavnih planova i programa kako bi se komunikacijski potencijal društvenih medija upotrijebio za potrebe visokog obrazovanja.

Znanstveni doprinos ove disertacije u području informacijskih i komunikacijskih znanosti odnosno u teoriji komunikacije, specifično u problematici oblikovanja nove komunikacijske paradigme putem društvenih medija u kontekstu visokog obrazovanja.

\section{Ključne riječi:}

Komunikacijska paradigma, Masovna komunikacija; Masovni Mediji; Društveni mediji; Delfi studija; Informacijska i komunikacijska tehnologija; Infoetika; Visoko obrazovanje; Nastavnici; Studenti. 


\section{Extended (structured) abstract}

The topic of the doctoral thesis of doctoral student Tihana Babic is entitled Changing the Communication Paradigm in Higher Education under the Influence of Social Media.

This doctoral dissertation was created as a part of the research of media theory and mass communication and the development of mass communication media, such as social media. In this doctoral dissertation, social media are approached by dealing in more detail and depth with their use in higher education institutions.

The notion of social media is an unavoidable part of everyday life today, and the networking of individuals and new ways of communication and interaction have their reach in academic world as well. Social media are not just a tool for disseminating information, but more than any other existing medium they provide a multitude of communication possibilities. They are often discussed, but most often at the level of what is already known they enable, and very rarely about their potential and what else they could enable.

The theoretical part of this paper presents the current state of the communication paradigm in higher education under the influence of social media through a review of the literature and previous research. The purpose of the theoretical part of the doctoral thesis was to examine and describe in detail the reasons and forms of social media use so far, from the point of view of the higher education process, and to detect basic assumptions and determinants of the existing communication paradigm in higher education under the influence of social media.

The aim of the research was to understand the possibilities of using and future development of social media in higher education, to discover anomalies of the existing communication paradigm in higher education under the influence of social media, to determine the factors that will change the existing paradigm based on predictions at the higher level, and to shape the guidelines of the new communication paradigm through social media for the needs of higher education.

The introductory part of the dissertation presents an overview of the development of information technologies that enabled the communication-media paradigm of social media, explains the basic concepts of communication-media paradigm and aspects of ethical challenges facing the information society, and basic concepts and theoretical framework of social media. After that, the relationship between higher education and educational technology as a context of the use of social media for the needs of higher education is presented, as well as an overview of previous research on the use of social media in the higher education process. 
This is followed by presentations of preliminary research on students and teachers use of social media for higher education purposes.

The research questions cover the development of technology that will drive social media in the near future, the preconditions that need to be met in order to use the communication potential of social media for higher education, the factors influencing the integration of social media in the higher education process, the factors influencing the attitudes of higher education institutions, teachers and students towards social media and the ways in which the potentials of social media could be used to improve communication in higher education.

For the answers to the mentioned research questions, the Delphi study was used, ie the qualitative and quantitative approach. A survey was conducted in 2020 in the Republic of Croatia on a sample of 37 significant businessmen with many years of experience in the IT field, prominent scientists and researchers in the field of IT and leading experts in the field of IT education. The research was conducted in four rounds, last of which refers to the presentation of the results of the Delphi study to the research participants. The research approach to processing and analyzing the answers obtained in the first three rounds of the Delphi study was methodological triangulation, based on which 12 key factors of communication paradigm in higher education under the influence of social media and their rank according to the degrees of importance were determined by experts.

In conclusion, recommendations for a new communication paradigm through social media in higher education have been formulated, which will provide guidelines for education professionals to improve the quality of educational policies, curricula and programs in order to use the communication potential of social media for higher education purposes.

The scientific contribution of this dissertation is in the field of information and communication sciences, ie the scientific contribution in the theory of communication, specifically in the issue of shaping a new communication paradigm through social media in the context of higher education. The original insight into the issue, with a specific contribution of the assessment of the development direction in shaping the new communication paradigm, was achieved by applying the Delphi method, which will achieve multidimensional and critical foundation of the new communication paradigm in higher education under the influence of social media.

A further contribution of this doctoral dissertation are the guidelines for the new communication paradigm of using social media in higher education, which will be the guidelines for education professionals to improve the quality of educational policies, curricula and programs to use the communication potential of social media for higher education. 
This is the first scientific paper in the Republic of Croatia that deals with the communication paradigm in higher education under the influence of social media.

\section{Keywords:}

Communication paradigm, Mass communication; Mass Media; Social media; Delphi study; Information and communication technology; Infoethics; Higher Education; Teachers; Students. 


\section{Sadržaj}

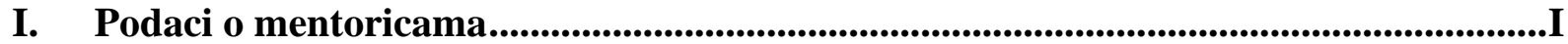

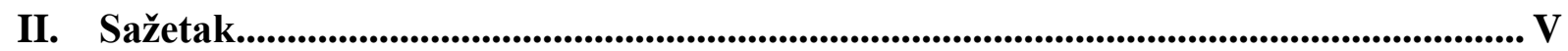

III. Extended (structured) abstract ...................................................................................VI

IV. Sadržaj.................................................................................................................................................. IX

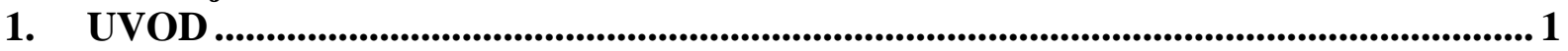

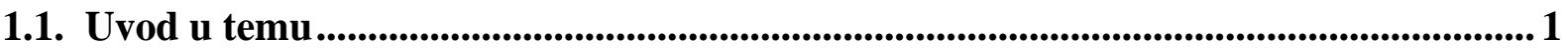

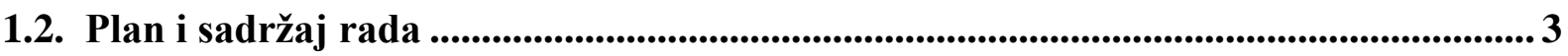

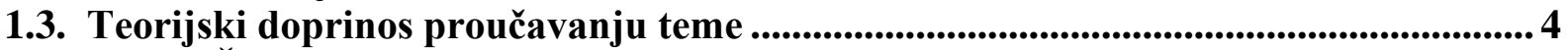

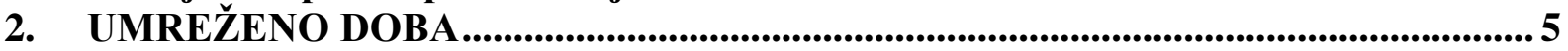

2.1. Informacijske tehnologije ............................................................................................................ 6

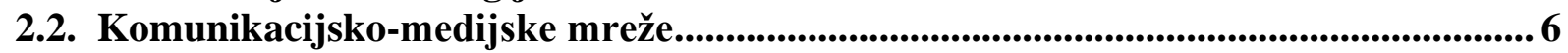

2.3. Perspektiva nove bezvremene kulture.................................................................... 7

2.4. Revolucija informacijske tehnologije .......................................................................................... 8

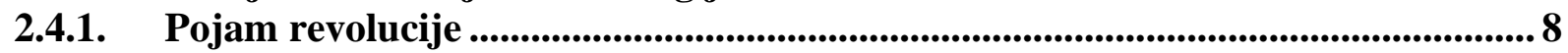

2.4.2. Od pisma do interneta .......................................................................................................9

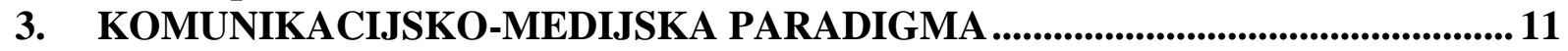

3.1. Komunikacija ........................................................................................................................... 11

3.2. Masovno komuniciranje i masovni mediji ............................................................. 13

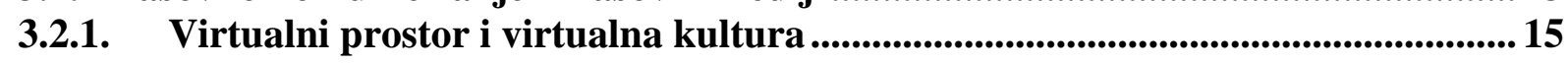

3.2.2. Internet i društveni mediji ..................................................................................................... 16

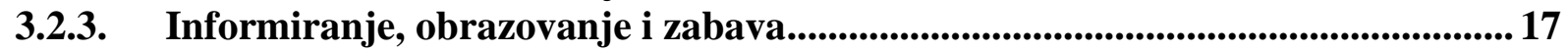

3.2.4. Moć društvenih medija ....................................................................................... 18

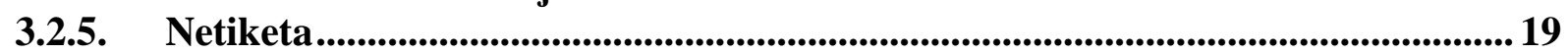

4. ETIČKI IZAZOVI INFORMACIJSKOG DRUŠTVA _........................................ 21

4.1. Aspekti informacijske etike .................................................................................... 21

4.1.1. Intelektualna sloboda .......................................................................................... 22

4.1.2. Jednakopravan ili slobodan pristup informacijama ........................................... 23

4.1.3. Cenzura...............................................................................................................23

4.1.4. Kontrola privatnosti na društvenim medijima ..................................................... 24

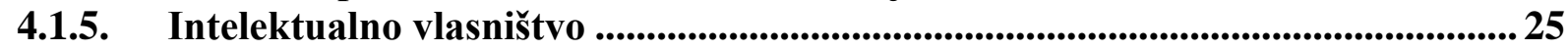

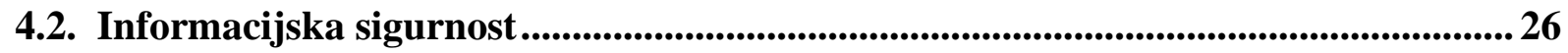

4.2.1. Prijetnje, ranjivosti i napadi......................................................................... 27

4.2.2. Računalni kriminal i zaštitne mjere.................................................................. 28

4.2.3. Zakonska regulativa sigurnosti informacijskih sustava ......................................28

4.3. Elektroničko nasilje............................................................................................................................ 29

4.3.1. Utjecaj medija na mlade ........................................................................................................ 30

4.3.2. Poštovanje sebe i svoje privatnosti...................................................................30

4.3.3. Poštovanje drugih osoba i tuđe privatnosti .........................................................31

4.3.4. Mladi i djeca - najzastupljenije i najugroženije dobne skupine na internetu i

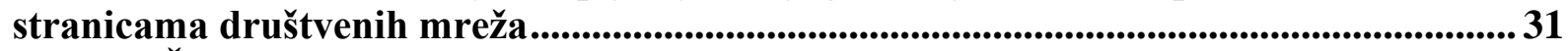

4.3.5. Štetna komunikacijska aktivnost $u$ virtualnom prostoru ................................... 35

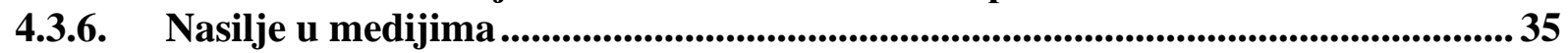

4.3.7. Od izbjegavanja rizika do upravljanja rizicima........................................................ 36

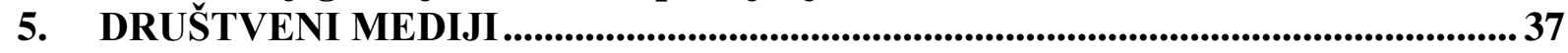

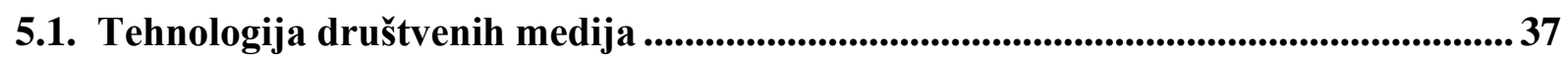

5.2. Prikaz tipova društvenih medija................................................................................................. 39

5.3. Važnost i ključne karakteristike društvenih medija .................................................. 41

5.4. Područja korištenja društvenih medija u industrijskom sektoru .............................. 43 


\section{KORIŠTENJE DRUŠTVENIH MEDIJA ZA POTREBE VISOKOG}

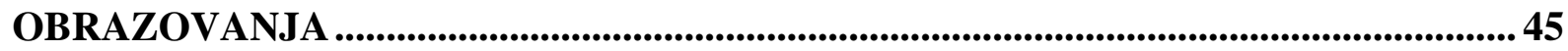

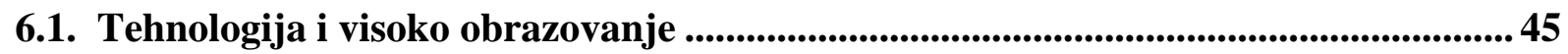

6.2. Korištenje obrazovne tehnologije u nastavi.....................................................................4 47

6.3. Online učenje i podučavanje: najbolje prakse i teorije .................................................. 48

6.4. Društveni mediji i visoko obrazovanje .....................................................................50

6.4.1. Društveni mediji i novi tipovi učenja .............................................................................5 51

6.5. Svrha korištenja društvenih medija za potrebe visokog obrazovanja ......................53

6.6. Modeli integracije društvenih medija u visoko obrazovanje .....................................55

6.7. Mogućnosti i izazovi korištenja društvenih medija u visokom obrazovanju ...........57

6.8. Nadzor nad korištenjem društvenih medija u visokom obrazovanju ........................58

6.8.1. Načela o profesionalnom ponašanju u visokom obrazovanju ............................... 60

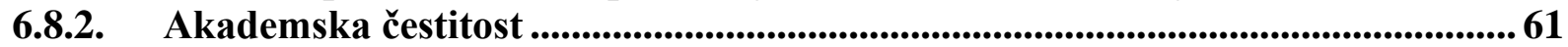

6.8.3. Regulacija korištenja društvenih medija za potrebe visokog obrazovanja ....... 62

6.9. Komunikacijska paradigma u visokom obrazovanju pod utjecajem društvenih

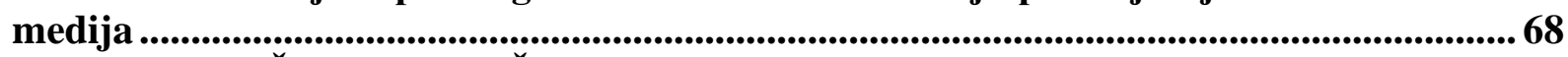

7. DOSADAŠNJA ISTRAŽIVANJA KOMUNIKACIJSKE PARADIGME PUTEM

DRUŠTVENIH MEDIJA ZA POTREBE VISOKOG OBRAZOVANJA......................... 70

7.1. Studenti na društvenim medijima ...........................................................................70

7.1.1. Podrška studentima.......................................................................................... 71

7.1.2. Povećanje kvalitete obrazovnoga procesa .......................................................... 72

7.1.3. Akademski uspjeh studenata................................................................................................ 73

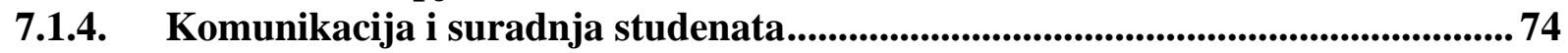

7.2. Odnos nastavnika prema korištenju društvenih medija ............................................ 76

7.3. Akademsko okruženje i društveni mediji ................................................................ 78

7.4. Istraživanje društvenih medija u svijetu................................................................ 80

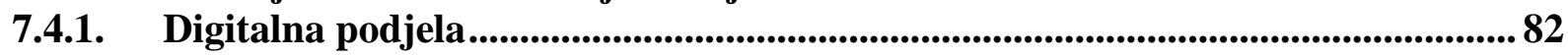

7.5. Istraživanje društvenih medija u Hrvatskoj.................................................................8 82

7.6. Društveni mediji u visokom obrazovanju: gdje smo sad i kamo dalje?.................... 83

7.6.1. Što nas je kriza uzrokovana Covid-19 pandemijom naučila o podučavanju? ... 84

8. PRELIMINARNA EMPIRIJSKA ISTRAŽIVANJA O KOMUNIKACIJSKOJ PARADIGMI U VISOKOM OBRAZOVANJU POD UTJECAJEM DRUŠTVENIH

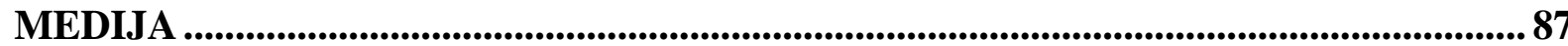

8.1. Preliminarno istraživanje 1: Društvene mreže kao komunikacijski kanal studenata 87

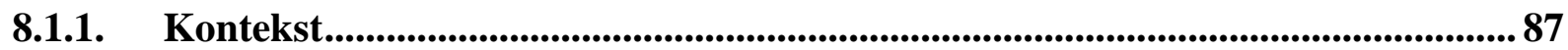

8.1.2. Predmet, cilj, svrha i hipoteze ...................................................................... 87

8.1.3. Metodološki okvir istraživanja ........................................................................8 88

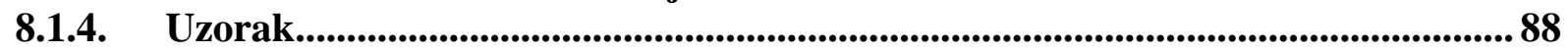

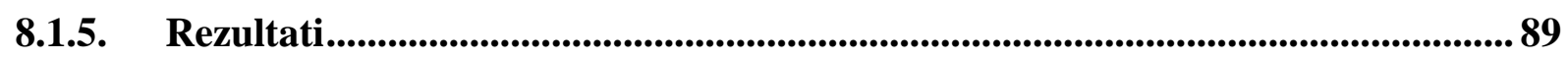

8.1.6. Ograničavajući elementi istraživanja i prijedlozi za buduća istraživanja ......... 90

8.1.7. Zaključak............................................................................................................91

8.2. Preliminarno istraživanje 2: Elektroničko nasilje prilikom korištenja društvenih

mreža kao komunikacijskog kanala studenata ........................................................992

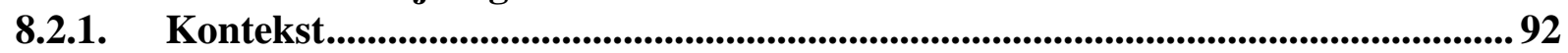

8.2.2. Predmet, cilj, svrha i hipoteze .........................................................................93

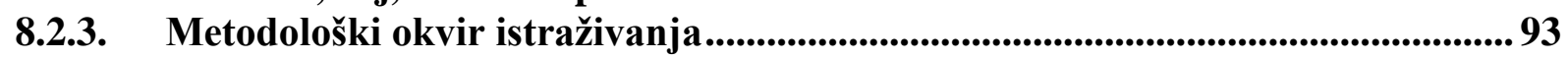

8.2.4. Uzorak.............................................................................................................994

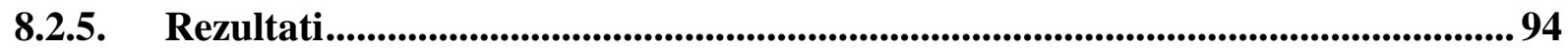

8.2.6. Ograničavajući elementi istraživanja i prijedlozi za buduća istraživanja .........96 
8.2.7. Zaključak.

8.3. Preliminarno istraživanje 3: Informacijska etika prilikom korištenja društvenih mreža kao komunikacijskog kanala studenata .....................................................................98

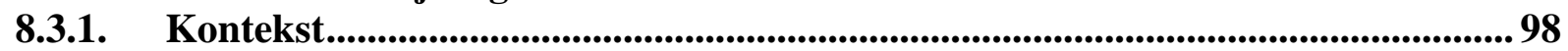

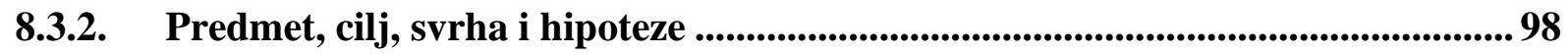

8.3.3. Metodološki okvir istraživanja .........................................................................99

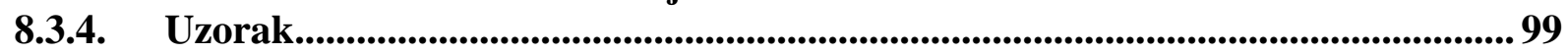

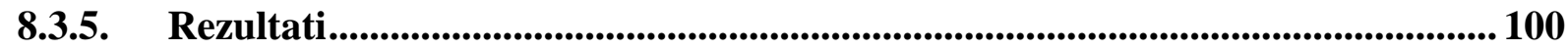

8.3.6. Ograničavajući elementi istraživanja i prijedlozi za buduća istraživanja ....... 101

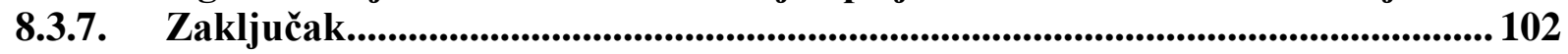

8.4. Preliminarno istraživanje 4: Nastavnici i korištenje društvenih medija ................. 103

8.4.1. Kontekst.............................................................................................................................. 103

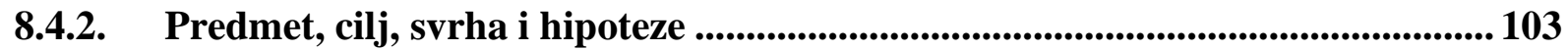

8.4.3. Metodološki okvir istraživanja ...................................................................... 104

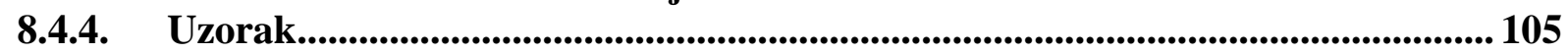

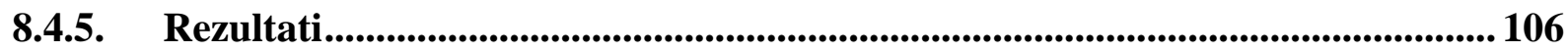

8.4.5.1. Nedostaci korištenja društvenih medija za potrebe visokog obrazovanja ... 111

8.4.6. Ograničavajući elementi istraživanja i prijedlozi za buduća istraživanja ....... 113

8.4.7. Diskusija sa zaključkom............................................................................. 113

9. EMPIRIJSKO ISTRAŽIVANJE KOMUNIKACIJSKE PARADIGME U

VISOKOM OBRAZOVANJU POD UTJECAJEM DRUŠTVENIH MEDIJA ZA

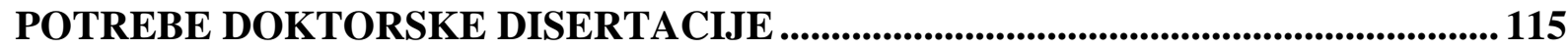

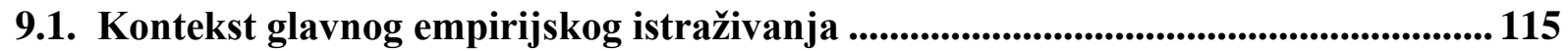

9.2. Svrha, cilj i istraživačka pitanja ............................................................................ 117

9.3. Metoda i instrumenti istraživanja ................................................................... 118

9.3.1. Dizajn istraživanja: delfi metoda ................................................................. 118

9.3.2. Identifikacija i selekcija stručnjaka .............................................................. 121

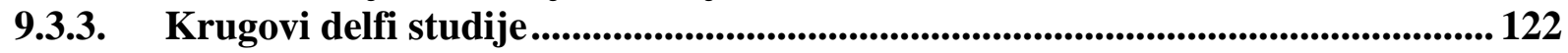

9.3.4. Istraživački pristup: metodološka triangulacija........................................................ 124

9.3.5. Valjanost i pouzdanost ..................................................................................... 137

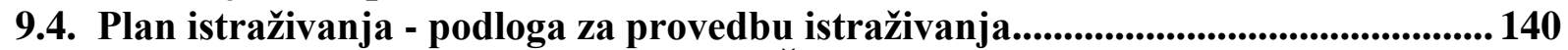

10. REZULTATI EMPIRIJSKOG ISTRAŽIVANJA S DISKUSIJOM ..................... 142

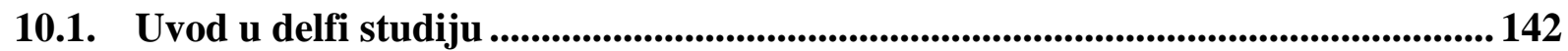

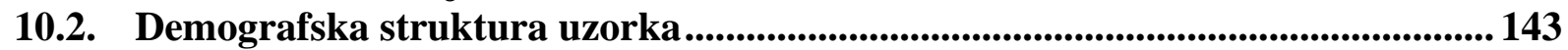

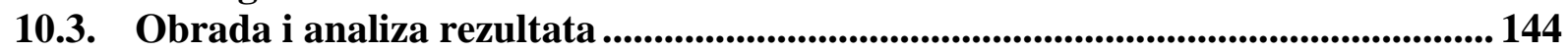

10.3.1. Prvi krug delfi studije ...................................................................................... 144

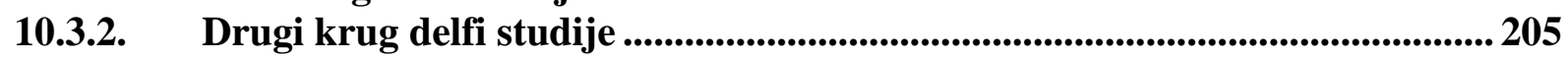

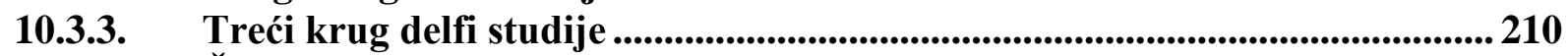

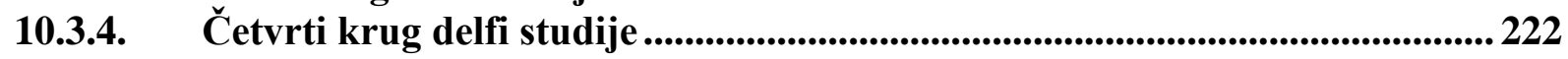

10.4. Izazovi i ograničenja delfi studije ..................................................................................... 224

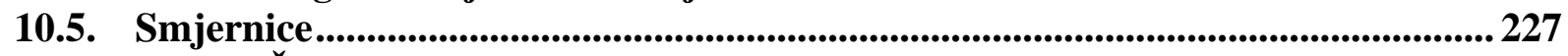

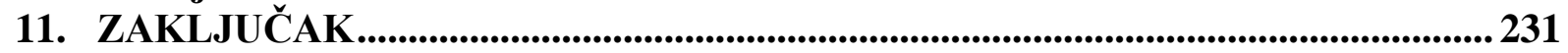

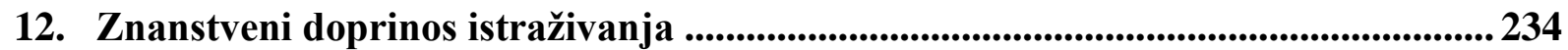

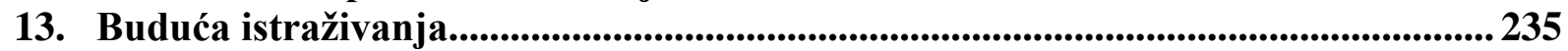

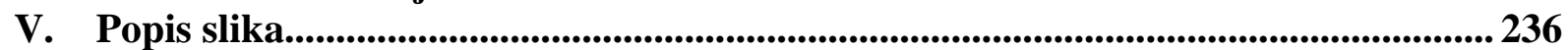

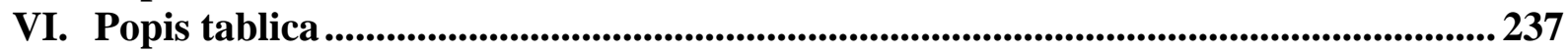

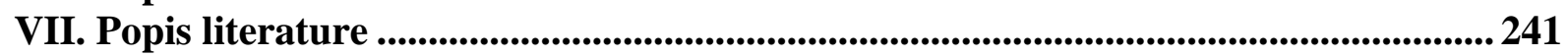

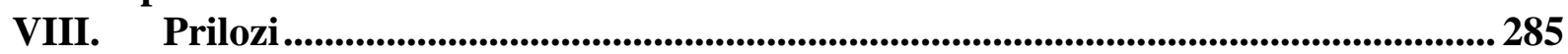

IX. Životopis kandidatkinje s popisom objavljenih djela ............................................. 331 



\section{UVOD}

„Sve bi trebalo biti učinjeno što jednostavnije moguće, ali ne i jednostavnije.“

- Albert Einstein

\subsection{Uvod u temu}

Društveni mediji temelje se na web 2.0 tehnologiji, omogućavaju stvaranje i dijeljenje informacija, ideja i interesa kroz virtualne zajednice i mreže čija je svrha komunikaciju preokrenuti u interaktivni dijalog. Obuhvaćaju 13 podtipova: blogove, mikroblogove, poslovne mreže, društvene mreže, suradničke projekte, forume, alate za poslovnu suradnju, alate za recenziju proizvoda i usluga, alate za dijeljenje fotografija, alate za dijeljenje videozapisa, društvene knjižne oznake, društvene igre i virtualne svjetove (Aichner, Jacob, 2015). Dostupni su 24 sata na dan, 7 dana u tjednu preko niza uređaja i s različitih lokacija, te ovise, dakle, samo o dostupnosti interneta i volji njihovih korisnika. Utjecali su na društvo, na ekonomiju, na politiku, znanost i obrazovanje.

Snaga društvenog umrežavanja toliko je velika da je broj aktivnih korisnika društvenih medija diljem svijeta od 2018. godine s 2,62 milijarde narastao na trenutnih 3,43 milijarde što je oko $49 \%$ ukupne Zemljine populacije (Statista, 2020), što premašuje čak i najsmjelija očekivanja tada jer se očekivao porast na 3,02 milijarde do 2021. godine, što je oko trećine ukupne Zemljine populacije (Statista, 2018). Statistički podaci govore da je u Republici Hrvatskoj u siječnju 2020. godine bilo $51 \%$ aktivnih korisnika društvenih medija (Kemp, 2020). Istraživanja o utjecajima društvenih medija provode se u svim područjima ljudskog djelovanja, stoga akademsko okruženje nije izuzetak. Istraživanja računalno posredovane komunikacije te mogućnosti primjene društvenih medija u visokom obrazovanju najčešće se bave aktivnostima studenata na društvenim medijima (Vivian i sur., 2014; Echeng i sur., 2016), potvrđujući da predstavljaju novi tip studenata i uče na nove načine (Selwyn, 2011) te da su njihove vrijednosti često u koliziji s tradicionalnim vrijednostima visokih učilišta (Ulbrich i sur., 2011).

Studenti koji danas studiraju pripadnici su generacije koja je za vrijeme svog odrastanja počela i virtualni život na društvenim medijima odnosno ne poznaju svijet u kojem ne postoje računala, mobiteli i društveni mediji. Društveni mediji primjer su tehnologija koje su studenti široko usvojili, i posljedično, imaju potencijal da postanu dragocjeni resursi za podržavanje obrazovne komunikacije i suradnju studenata s fakultetom (Arsović, 2012). Ipak, brojna istraživanja ukazuju na digitalni jaz između studenata i njihovih obrazovnih institucija, te postojanje trenda 
prema ne-adaptaciji novih tehnologija u visokoobrazovnim ustanovama; studenti su voljni koristiti ih, a zaposlenici fakulteta nisu (Roblyer i sur., 2010).

Alati i aplikacije društvenih medija predstavljaju izazov konceptu formalnog obrazovanja kakvog danas poznajemo (Selwyn, 2011).

Istraživanja provedena o stavovima $i$ iskustvima integracije društvenih medija $u$ visokoobrazovne ustanove (Echeng i sur., 2016; Josefsson, 2017) pokazuju da postoji potreba integracije društvenih medija u nastavni proces (Okello-Obura, Ssekitto, 2015) te brojne prednosti i pozitivne učinke na proces učenja i poučavanja (Alsolamy i sur., 2017; Coleman i sur., 2018) kao što je kvaliteta nastave (Silvestru i sur., 2016) i akademski uspjeh studenata (Tamayo i sur., 2014). Dok studenti doživljavaju društvene medije kao nešto što se samopodrazumijeva, nastavnici su skloniji promišljati nedostatke i opasnosti (Raut i sur., 2016; Willems i sur., 2018).

U Republici Hrvatskoj se studije isto tako bave pojavom društvenih medija i promjenama koje su nastale uslijed njihove pojave te se raspravlja kako bi sveučilišna zajednica i njezini dionici trebali biti dio tih promjena (Matešić i sur., 2010), kao i potrebi službene prisutnosti i zastupljenosti visokoškolskih ustanova na društvenim medijima (Golubić, Lasić-Lazić, 2012). Jednako tako, predmetom istraživanja bili su kultura net-generacije na uzorku studenata hrvatskog govornog područja (Čačić, 2012) te digitalizacija i umrežavanje studenata u Hrvatskoj (Potočnik, 2014). Manji broj istraživanja provodi se o tome kako nastavnici koriste informacijske i komunikacijske tehnologije (Kučina Softić i sur., 2016).

O društvenim medijima se vrlo često raspravlja, ali najčešće na razini onoga što se potvrđeno zna da mogu i omogućavaju, a vrlo rijetko o njihovim mogućnostima i što sve zapravo omogućavaju. No, isto tako, vrlo često se društveni mediji tretiraju kao samo još jedan komunikacijski medij, istražuju se objave na stranicama društvenih medija, ili komunikacijske aktivnosti na društvenim medijima, ali ako se uzme u obzir McLuhanova premisa da su mediji „produžeci ljudi“ (McLuhan, 2008), onda se postavlja pitanje na koji način društveni mediji proširuju naša osjetila i iskustvo, a ne samo kako se oni koriste jer su na mnoge načine drugačiji od ostalih medija (Kent, 2015). Društveni mediji nisu samo oruđe za širenje informacija, već imaju višestruke mogućnosti i stanja u isto vrijeme (informativno, relacijsko, uvjeravačko), jedinstveni su utoliko što nude korisnicima mogućnost da u većoj mjeri komuniciraju s drugim ljudima, više su međuljudski ideal, te više nego bilo koji drugi postojeći medij omogućuju mnoštvo komunikacijskih mogućnosti (sinkrone, asinkrone, vizualne, slušne, tekstualne, hiperrealističke i hipervezane) (Kent, 2015 prema Theunissen 2015). Mnoga pitanja u svezi s društvenim medijima još uvijek su nedovoljno istražena, uključujući kako dobro koristiti 
društvene medije izvan konteksta marketinga i oglašavanja, i vrlo malo znamo o ulozi koju igraju u životima ljudi (Kent, 2015), kao i o složenim vezama među korisnicima koji ih koriste, tehnologijama koje ih pokreću, ekonomskim strukturama koje ih omogućuju i institucionalnim tijelima koja ih ugrađuju (Van Dijck, Poell, 2013).

Informacijske i komunikacijske znanosti bave se fenomenima koji su dinamični, kompleksni te vrlo često interdisciplinarni, stoga postojeće teorije brzo zastarijevaju i/ili nisu dostatne za njihovo tumačenje. Sama svrha istraživanja komunikacijske paradigme putem društvenih medija u visokom obrazovanju kroz delfi studiju nije znati budućnost, već na temelju uvida koje imaju eksperti pomoći predvidjeti prilike i prijetnje, razmotriti kako ih riješiti te $u$ modernom svijetu, uvelike uvjetovanim eksponencijalnim razvojem tehnologija koje svojim današnjim razvojem utječu na našu budućnost, otvoriti mogućnost da budemo aktivni sudionik tih promjena umjesto da samo reagiramo na promjene koje je za nas kreirao netko drugi.

Budućnost visokog obrazovanja isto tako se intenzivno i neprestano razmatra, s obzirom da se visoko obrazovanje smatra glavnim generatorom promjena u društvu (Hrvatski sabor, 2014a), no o korištenju društvenih medija za potrebe visokog obrazovanja ne postoji univerzalan stav i „porota još zasjeda“. U ovom doktorskom radu će se iz neutralne pozicije u teoretskom dijelu izložiti trenutna komunikacijska paradigma u visokom obrazovanju pod utjecajem društvenih medija kroz teorijski okvir i dosadašnja istraživanja, a zatim (pre)oblikovati komunikacijska paradigma društvenih medija za potrebe visokog obrazovanja na temelju mišljenja vodećih stručnjaka.

\subsection{Plan i sadržaj rada}

U uvodnom ove dijelu disertacije bit će izložen pregled razvoja informacijskih tehnologija koje su omogućile komunikacijsko-medijsku paradigmu društvenih medija, objašnjeni osnovni pojmovi komunikacijsko-medijske paradigme i aspekti etičkih izazova s kojima se susreće informacijsko društvo, te osnovni pojmovi i teorijski okvir društvenih medija. Nakon toga bit će predstavljen odnos visokog obrazovanja i obrazovne tehnologije kao kontekst komunikacijske paradigme putem društvenih medija u visokom obrazovanju te pregled dosadašnjih istraživanja korištenja društvenih medija u visokoobrazovnom procesu.

Uslijedit će prikaz preliminarnih istraživanja; koriste li studenti društvene mreže kao primarni komunikacijski kanal kojim se informiraju o studiju i studentskim obvezama, jesu li studenti koji koriste društvene mreže kao komunikacijski kanal upoznati s pojmovima i 
vrstama radnji koji se tiču sigurnosti komuniciranja i elektroničkog nasilja, pristupaju li studenti na etičan način pristupaju proizvodnji, prikupljanju, diseminaciji i korištenju informacija na društvenim mrežama. Prikaz posljednjeg, četvrtog preliminarnog istraživanja odnosi se na istraživačko pitanje koriste li nastavnici društvene medije te u kojoj mjeri procjenjuju društvene medije kao važan komunikacijski kanal za potrebe visokog obrazovanja.

U posljednjem dijelu bit će prikazano glavno empirijsko istraživanje komunikacijske paradigme putem društvenih medija u visokom obrazovanju kroz kontekst, svrhu, cilj i istraživačka pitanja, metode i instrumente istraživanja te finalno, bit će izloženi rezultati i analiza delfi studije provedene u Republici Hrvatskoj na uzorku značajnih gospodarstvenika s dugogodišnjim iskustvom rada u IT području, istaknutih znanstvenika i istraživača iz IT područja te vodećih stručnjaka iz područja provedbe IT obrazovanja.

Zaključno, bit će prikazane praktične preporuke odnosno smjernice za promjenu trenutne komunikacijske paradigme u visokom obrazovanju pod utjecajem društvenih medija, kreirane prema elementima „tehnološkog predviđanja“ koje uključuje spajanje ključnih agenata promjena i izvora znanja, kako bi se razvile strateške vizije i anticipativna inteligencija.

\subsection{Teorijski doprinos proučavanju teme}

Cjelovita analiza i rezultati empirijskog dijela omogućit će daljnja komunikacijska i medijska istraživanja o važnosti korištenja društvenih medija za potrebe visokog obrazovanja.

Profesionalcima u području obrazovanja rezultati istraživanja bit će smjernica za poboljšanje kvalitete obrazovnih politika i nastavnih planova i programa, te će ukazati na važnost promjene postojeće komunikacijske paradigme u visokom obrazovanju pod utjecajem društvenih medija. 


\section{UMREŽENO DOBA}

Danas, pola stoljeća otkako su se pojavili prvi upotrebljivi modeli, osobna računala prožimaju sva područja našeg života do mjere da više ne znamo funkcionirati bez njih i sumnjamo bismo li to više uopće i mogli. Kad bi, uslijed npr. nuklearnog rata, kojeg stručnjaci smatraju najvećom opasnošću današnjice, bilo uništeno električno napajanje računalne mreže, čija posljedica bi bila raspad svih komunikacijskih i informacijskih sustava, bilo bi nemoguće uspostaviti telefonsku vezu, primati radijski i televizijski signal, ne bi više bilo tekućih i štednih računa kao ni mogućnosti ulaganja te knjigovodstva (Van Doren, 2005). Sustavi proizvodnje, distribucije i administriranja svih vrsta robe i većina usluga prestali bi postojati, a mi bismo se trenutačno vratili u srednji vijek (Van Doren, 2005). S razlikom što bi ovaj puta naša situacija bila gora od one najsiromašnijeg europskog seljaka, jer, za razliku od seljaka koji su živjeli u srednjem vijeku, mi uopće nemamo iskustva u takvom životu što bi nas najvjerojatnije stajalo života (Van Doren, 2005).

Castells (2000) ističe da posljednja dva desetljeća protekloga 20. stoljeća predstavljaju jedan od rijetkih intervala ljudske povijesti kada je prekinut normalni razvojni kontinuitet i došlo je do radikalnih promjena, kada je rođena nova tehnološka i društvena paradigma. Za razliku od industrijske revolucije, u okviru nove tehnološke revolucije, korisnici inovacija ne samo da prihvaćaju i primjenjuju te inovacije, već ih u tom procesu često redefiniraju i usavršavaju, čime se tehnološki napredak ubrzava i širi dosad neviđenom brzinom baš zbog izuzetnog ubrzanja kumulativnog slijeda povratnih informacija između procesa inovacija i procesa njihove uporabe (Castells, 2000).

Računala i komunikacijski sustavi nemaju samo funkcionalnu ulogu, već i veliku dinamičku i kreativnu moć. Naime, korisnici informatičke tehnologije imaju mogućnosti i podstrek da je i dalje razvijaju, odnosno da time i sami postaju inovatori. S tim u skladu, može se reći da računala i telekomunikacijski sustavi postaju produžeci ljudskog uma, što vodi sve većoj integraciji uma i stroja, a za razliku od industrijske epohe, kada je um posredno utjecao na razvoj proizvodnih snaga društva, sada um postaje izravna proizvodna snaga (Mesarić, 2005). Dok su industrijskoj revoluciji bila potrebna dva stoljeća da bi se proširila cijelim svijetom, informacijskoj revoluciji bilo je potrebno samo dva desetljeća, od 1975. godine do 1995. godine (Mesarić, 2005). Ipak, još postoje veliki dijelovi svijeta koji, kao i priličan broj stanovništva koji su isključeni iz tog sustava, kao što su npr. veći dio Afrike, siromašna ruralna područja Kine i Indije i u tome leži izvor nejednakosti u suvremenom svijetu (Mesarić, 2005). 


\subsection{Informacijske tehnologije}

U razvijenom suvremenom svijetu, sve je manji diskontinuitet ljudi i strojeva, a sve veća integracija ljudskih umova i strojeva što uzrokuje promjenu iz temelja cjelokupnog načina ljudskog života. Castells (1996) navodi pet osnovnih principa nove paradigme informacijske tehnologije koje, uzete zajedno, čine materijalnu osnovu informacijskog društva: 1. informacija je sirovina nove paradigme jer ne samo što djeluje na tehnologiju, nego i tehnologije djeluju na informaciju; 2. nove tehnologije imaju sveprožimajući učinak te oblikuju sve procese našeg individualnog i kolektivnog postojanja; 3. sustavi imaju mrežni ustroj te se logika umrežavanja bilo kojeg sustava dobro prilagođava povećanoj složenosti interakcija i nepredvidivim obrascima razvoja koji proizlaze iz stvaralačke snage takve interakcije, prema čemu se 4. paradigma informacijske tehnologije temelji na fleksibilnosti elemenata; 5. tehnologije konvergiraju u visoko povezani sustav, unutar kojeg se odvojene tehnološke putanje ne mogu razabrati.

Ova paradigma informacijske tehnologije ne kreće se prema zatvaranju u sustav, unatoč prodoru u samu srž života i mišljenja, ne determinira razvoj društva, već se smjer i smisao razvoja i dalje mogu i moraju propitivati (Matković, 2000 prema Castells, 1996).

\subsection{Komunikacijsko-medijske mreže}

Informacijsko odnosno tzv. umreženo društvo, donijelo je sa sobom promjene kako na ekonomskom, tako i na socijalnom, političkom i kulturnom planu. To novo informacijsko društvo nastalo iz konvergencije dvaju neovisnih povijesnih procesa: a) informatičke revolucije, koja je stvorila nužnu tehnološku infrastrukturu i b) restrukturiranja industrijskog kapitalističkog modela, koji je nastojao nadvladati svoja ograničenja i nedostatke (Castells, 2000).

Prema najpoznatijoj teoriji umreženoga društva (engl. Networked Society) Manuela Castellsa (2000), društvo se promatra isključivo kao globalno društvo čiji su odnosi organizirani u komunikacijsko-medijskim mrežama. Tako organizirani odnosi zamjenjuju komunikaciju licem u lice. Društvo je podijeljeno na one koji grade i sastavljaju mreže; one koji su uključeni u te mreže i antipode - one koji su društveno isključeni i u njoj ne sudjeluju. Stvarnost se dijeli na fizičku i virtualnu, izmišljenu. Ta izmišljena, simbolička, virtualna stvarnost postaje prava stvarnost, jer ljudi misle o stvarima na način na koji ih prezentiraju mediji, publika živi kroz 
multimedije. Temeljna jedinica informacijskog umreženog društva je mreža. On navodi da su informacijske mreže postale najučinkovitiji organizacijski oblik zahvaljujući svojim trima obilježjima: 1. fleksibilnosti (odnosi se na sposobnost promjene i obnove u skladu s promjenama u okruženju, zadržavanju svojih ciljeva iako se mijenjaju njene komponente, te zaobilaženje blokada u komunikacijskim kanalima pronalaskom novih veza), 2. skalabilnosti (odnosi se na mogućnost proširenja ili smanjenja veličine s vrlo malo ometanja) i 3. izdržljivosti (odnosi se na sposobnost mreža da izdrže napade na svoje čvorove i kodove putem reproduciranja i pronalaska novog načina djelovanja budući da nemaju jedan centar i mogu raditi u širokom rasponu konfiguracija) (Castells, 2000).

\subsection{Perspektiva nove bezvremene kulture}

Informacijske mreže su pod utjecajem novih medija i komunikacijskih tehnologija dovele do pojave nove bezvremene kulture. Castellsova teza je da živimo u dobu koje je označilo kraj Gutembergove galaksije (McLuhan, 1962), a to doba društvene promjene obilježavaju decentralizirani i dehijerarhizirani umreženi odnosi. Ono što su nekad bile tvornice, danas je mreža, ono što je nekad predstavljala električna energija, danas predstavlja internet (Castells, 2003).

Shodno tome, očita je činjenica da živimo u digitalnom dobu koje svoj uzlet proživljava na krilima novih tehnoloških informacijskih i komunikacijskih inovacija, pri čemu svjedočimo fenomenu u kojem su se granice vremena i prostora pomakle do još nedavno neslućenih razmjera. Brzina kojom možemo primiti ili poslati informaciju je trenutna ili s kratkotrajnim odmakom, komunicirati možemo gotovo sa svim ljudima (barem s onima koji imaju dostupnu infrastrukturu) i na svim područjima svijeta (biti prisutni barem putem virtualnog svijeta, ako već ne fizički) te biti upućeni u događaje od kojih smo udaljeni stotinama tisuća kilometara. U skladu s navedenim, promjene u komunikacijskoj perspektivi vremena i mjesta izravno djeluju na približavanje pojedinaca, država i kultura. Međutim, obzirom da postoje i velike mogućnosti zlouporabe novih tehnologija te da istraživanja pokazuju da je tendencija ljudi koji se oslanjaju na online komunikaciju kako bi zadovoljili svoje komunikacijske potrebe da se osjećaju usamljeno i depresivno, još uvijek ostaje otvoreno pitanje budućnosti modernoga svijeta koji je tako dobro računalno povezan da ga je Marshall McLuhan davno nazvao ,globalnim selom“ (McLuhan, 1962, McLuhan, Powers, 1989). 
Možda se Papa Pio XII., kako navodi McLuhan u svom djelu „Razumijevanje medija“, s pravom zalagao za provedbu ozbiljnih istraživanja današnjih medija, slijedom čega je 17. veljače 1950. godine napisao: „Nije pretjerano reći da budućnost modernoga društva i stabilnost njegova unutarnjeg života umnogome ovise o održavanju ravnoteže između snage tehnika komuniciranja i sposobnosti vlastite reakcije pojedinca“ (McLuhan, 2008).

\subsection{Revolucija informacijske tehnologije}

\subsubsection{Pojam revolucije}

Riječ revolucija korijen ima u latinskoj riječi revolutio odnosno preokret, a odnosi se pritom na temeljnu promjenu moći ili organizacijskih struktura koje se događaju u vrlo kratkom razdoblju, posljedično čiji rezultati utječu na društvene, gospodarske i političke sustave na nekom području, a koji se u dogledno vrijeme proširuju i na druga područja i dijelove svijeta. Već je Aristotel (350 pr. Kr.) opisao dvije vrste revolucija, pritom misleći na političke:

1. potpuna promjena jednog sustava u drugi

2. izmjena trenutnog stanja.

S obzirom na to da se razumijevanje te složene pojave može analizirati s više gledišta, u ovom radu fokus je na informacijskim revolucijama, a poseban naglasak stavljen je na razvoj informacijske tehnologije.

U djelu „A history of mass communication: six information revolutions“, autor Irving Fang, identificira šest informacijskih revolucija: pismo, tisak, masovne medije, uporabu medija u svrhu zabave, pretvaranje doma u središte primanja informacija te informacijsku autocestu (Fang, 1997).

Prvu informacijsku revoluciju, smatra, potaknula je čovjekova želja za pamćenjem putem zapisa. Ta i revolucije koje su slijedile oblikovale su ljudsko društvo više nego su mogli bilo koji rat ili kraljevi. S nekoliko ogrebotina, naši inovativni preci pokrenuli su beskrajnu priču zapisanih informacija, komunikacije i pohranu znanja izvan uma (Fang, 1997).

Riječ revolucija implicira naglu i često nasilnu promjenu, ali revolucije mogu biti i suptilnije te se razvijati kroz desetljeća, pa čak i kroz stoljeća. U najširem smislu, revolucija označava društveni napredak. No, davno je riječ postala klišej. Stoga u ovom kontekstu, pod pojmom „,informacijska revolucija“ razmatraju se promjene koje uključuju nove načine komunikacije, a koje su trajno utjecale na cijelo društvo, potresale političke strukture i utjecale na gospodarski razvoj, komunalnu djelatnost i osobno ponašanje ljudi. Za razliku od mnogih ratova i promjena 
vladara, informacijske revolucije stvaraju promjene, namjerno ili slučajno, koje ostaju dio društva promjena. Čini se očitim da, za uspješnu informacijsku revoluciju, mediji koji će omogućiti nova značenja komunikacije trebaju biti proslijeđeni unutar društva koje već prolaze kroz promjenu (Fang, 1997).

\subsubsection{Od pisma do interneta}

Prva od šest informacijskih revolucija, prema Fangu (1997), može se okarakterizirati kao revolucija pisanja. Iako je započela izumom pisma sredinom 4. tisućljeća prije Krista, svoj uzlet počinje u Grčkoj 8 stoljeća prije Krista upotrebom fonetske abecede, uvezenom iz Fenicije na istoku, i papirusom, uvezenim iz Egipta na jugu. Prvi korišteni medij za pohranu bio je zid špilje te materijali koji su preuzeti izravno iz prirode, kao što su životinjska koža, kora stabala, lišće, drvo, vosak, metal, kamen, školjke, keramika, svila, pamuk, slonovača i slično. Glinene pločice korištene su na području Mezopotamije u starom vijeku, a papirus i pergamena zamijenili su kodeks od svitaka na području Rimskog carstva između 1. i 5. stoljeća. Pomoću pisma, osobito nakon početka upotrebe papira nakon 8. stoljeća, pohrana ljudskog znanja više nije ograničena granicama pamćenja, već je znanje postalo neograničeno.

Druga informacijska revolucija, revolucija tiskanja, započela je u Europi u drugoj polovici 15. stoljeća s upotrebom papira, koji je uvezen iz Kine, a kasnije iz arapske i maurske kulture, i tiskarskog stroja s pomičnim slovima kojeg je razvio njemački zlatar Johannes Gutenberg. Tiskanje je prethodilo ogromnim političkim, vjerskim, ekonomskim, obrazovnim i osobnim promjenama. Te promjene, nazvane reformacija, renesansa, humanizam i merkantilizam, označile su kraj feudalizma, a tiskanje je označilo početak modernoga svijeta. Važno je napomenuti da se komunikacija se nikada ne može svesti na jedan medij (Papić, Jakopec, Mičunović, 2011 prema Love, 2003), iako je tisak prouzročio istinsku komunikacijsku revoluciju jer je opsegom i brzinom omogućio dotad neviđenu razmjenu informacija i ideja (Papić, Jakopec, Mičunović, 2011 prema Eisenstein, 1993). Drugim riječima rečeno, tisak se kao nov medij pridružio starima, nije ih poništio, već je supostojao s njima. Iako je pomogao povećavanju komunikacijskih mogućnosti i njihovu zgušnjavanju, nije dokinuo prethodne komunikacijske tehnologije i tako će biti i sa svakom narednom komunikacijskom revolucijom (Papić, Jakopec, Mičunović, 2011).

Treća informacijska revolucija započela je, na temeljima građanskih revolucija, razvoja sustava obrazovanja i tehnološkog razvoja, u zapadnoj Europi i u istočnim državama SAD-a sredinom 
19. stoljeća s napretkom proizvodnje papira i metoda tiskanja, izumom telegrafa, koji je promijenio način na koji se informacije prenose. Po prvi put, dnevne novine, ilustrirani časopisi i romani bili su dostupni običnom čovjeku, uključujući radništvu, ženama i djeci. Zajedno s novinarskom revolucijom - novinari počinju izvještavati o važnim događajima, a ljudi žele čitati o njima bilo da su iz njihove bliske ili daleke okoline. Fotografija je govorila izravno njihovom srcu. Javne škole i javne knjižnice postale su dio seoskog krajolika, kao i rastućih gradova. Za široke mase, pismenost je došla nadohvat ruke.

Četvrta informacijska revolucija, revolucija zabave, započela je u zapadnoj Europi i sjevernoj Americi krajem 19. stoljeća s tehnologijama koje su omogućavale uporabu medija u svrhu zabave, kroz pohranu zvuka, video zapisa i pokretne fotografije. Priče su se tiskale i prodavale jeftino. Knjige su se tiskale, kupovale i posuđivale neovisno o kvaliteti, a ljudi počeli čitati da bi skratili vrijeme i zabavili se. No zabava se proširila i na područje glazbe i filma te se mogla beskonačno reproducirati. U desetljećima koja su dolazila, mogla se čuti i na radiju. Cijeli svijet zavolio je proizvode za zabavu. Na početku revolucije zabave nitko nije mogao predvidjeti broj sati koje ćemo provoditi baveći se tom ljubavi.

Kao petu informacijsku revoluciju, započetu sredinom 20. stoljeća na temelju poboljšanih uvjeta života i porastom količine slobodnog vremena pojedinaca koji su to vrijeme željeli provesti zabavljajući se, Fang (1997) je identificirao pretvaranje doma u središte primanja informacija i zabave. Ta revolucija postala je moguća zahvaljujući uporabi telefona, emitiranju emisija, snimanju, poboljšanjima u tehnologijama tiskanja i jeftinoj, univerzalnoj usluzi pošte. To stoljeće je, naravno, bilo razdoblje teške političke, kulturne situacije i psihološkog nemira. Gramofoni, radioprijemnici i TV-prijemnici postali su cjenovno dostupni i poželjni, a tehnologija prijenosa radijskih i televizijskih signala toliko razvijena da su ti uređaji počeli nuditi izbor između brojnih programa odnosno raznolikih sadržaja. Činjenica da su komunikacijski mediji postali nerazdvojni dio naših života tema je mnogobrojnih (zabrinutih) članaka, knjiga i znanstvenih radova, a posebice jer ljudi više ne moraju nužno posjećivati koncerte, kazališta ili kinopredstave u potrazi za zabavom i informacijama, već one same dolaze u njihove domove (Papić, Jakopec, Mičunović, 2011).

Šesta informacijska revolucija, informacijska autocesta, temelji se na konvergenciji računala, emitiranja odnosno prijenosa programa, satelita i vizualnih tehnologija; ukratko na digitalizaciji, i u njoj se nalazimo danas. Komunikacija je postala dio našeg poslovanja, edukacije i zabave, a uslijed konvergencije medija različita društva i kulture koje su svoj povijesni put započele odvojeno, sada putuju istom „informacijskom autocestom“ (Weiner, 1996). 


\section{KOMUNIKACIJSKO-MEDIJSKA PARADIGMA}

\subsection{Komunikacija}

Čovjek je jedinstveno biće, prvenstveno po svojoj sposobnosti komuniciranja na sveobuhvatnoj razini (Malović, Maletić, Vilović, Kurtić, 2014). Ta sposobnost omogućuje mu razmjenu informacija o prošlosti, sadašnjosti i budućnosti, izražavati misli i osjećaje, svladavati vještine, usvajati nova znanja i razvijati ih, bazirano na podacima koje je prikupio, obradio i sistematizirao. Suvremena znanost nema spoznaja da je tu razinu doseglo ijedno drugo živo biće. Može se reći da svi „znaju“ što je komunikacija i na što se odnosi, ali definirati... U Merriam-Webster rječniku medija i komuniciranja (2017), pojam „komuniciranje“ određen je kao: „Transmisija ili razmjena informacija, signala, poruka ili podataka u svim oblicima, kao što su razgovor (verbalno komuniciranje), pisanje (pisana komunikacija), oči u oči (personalno komuniciranje) ili putem telefona, brzojava, radija ili drugim kanalima unutar skupine, grupe ili usmjereno prema nekim osobama ili skupinama. Pojam je često u pluralnom obliku. Komunikator može slati i primati poruke pričajući, pišući ili gestikulirajući. Komunikacijske sposobnosti uključuju umješnost prenošenja informacija, signala ili poruka govorom, pisanjem ili drugim sredstvima od jednog medija (osobe, sprave, točke) prema drugoj.“

Na Slici 1. prikazana je skala komuniciranja podijeljena na stupnjeve. Na vrhu se nalaze rjeđi slučajevi, na dnu češći slučajevi (McQuail, 2010).

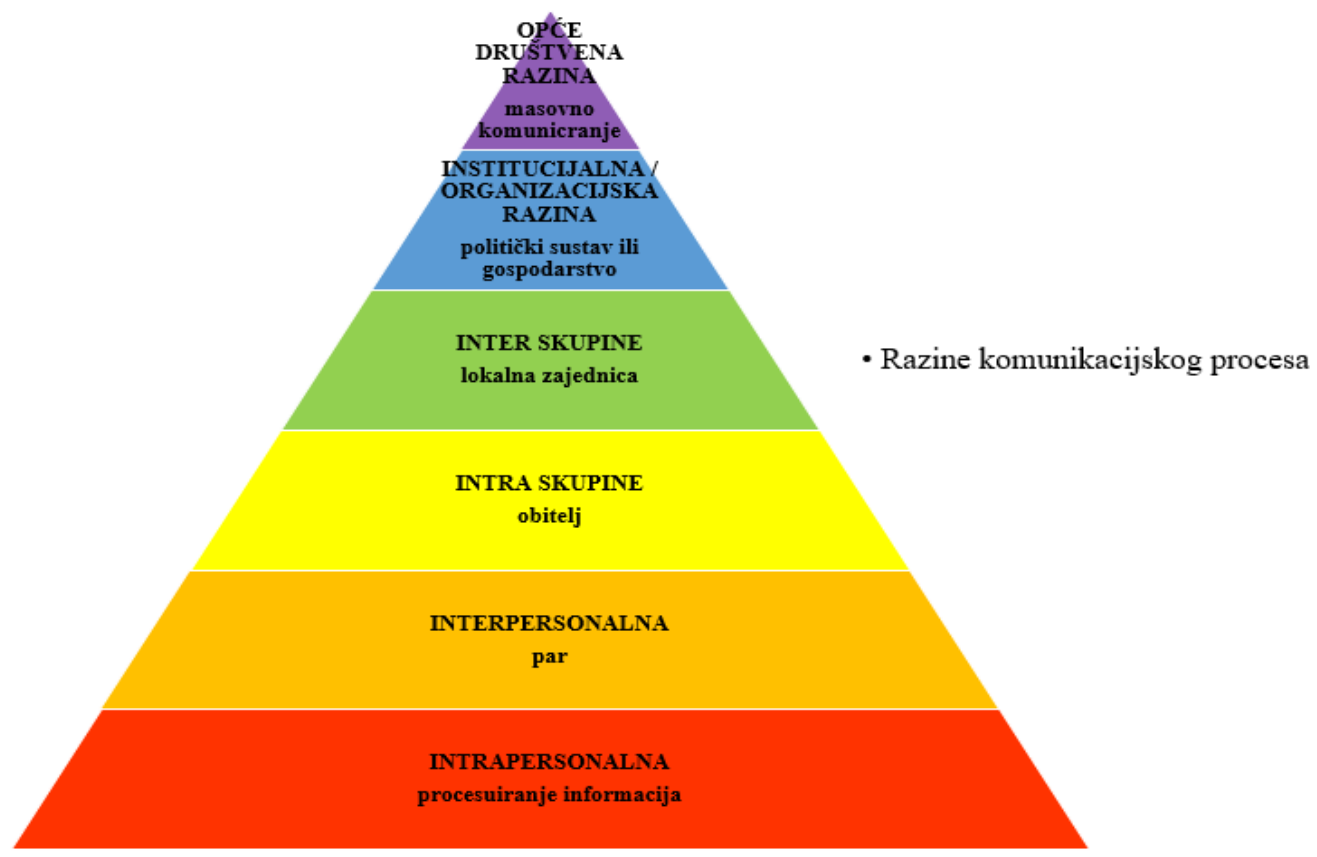

Slika 1. Skala komuniciranja (izvor: izrada autorice prema McQuail, 2010) 
Bez komunikacije ne bi moglo postojati nijedno društvo, neovisno radi li se o najrazvijenijim društvima, u kojima je na svim područjima društva računalna tehnologija postala nezaobilazna, ili slabo razvijena i siromašna društva koja se bore s osnovnim egzistencijalnim problemima. $\mathrm{S}$ obzirom na to da se svako društvo sastoji od pojedinaca, društvene promjene rezultat su zakonitosti koje se tiču čovjeka i njegove sposobnosti komuniciranja. Paul Watzlawick i suradnici istaknuli su bitne aksiome komuniciranja (Watzlawick, Beavin-Bavelas, Jackson, 1967):

1. Čovjek ne može ne komunicirati.

2. Svaka komunikacija ima svoj sadržaj i odnose, koji obilježavaju prijašnje komuniciranje, pa tako postaju metakomunikacije.

Metakomunikacija, kao „komunikacija o komunikaciji“ ili sekundarna komunikacija, se odnosi na poruke koje prate ono što govorimo i radimo. Metakomunikacija su svi neverbalni znakovi (ton glasa, govor tijela, geste, izraz lica, itd.) koji nose značenje i koji ili pojačavaju ono što kažemo riječima ili znače nešto sasvim suprotno, pri čemu je razvidno da se zapravo cijeli jedan razgovor odvija ispod površine (Grof, 1981 prema Bateson, 1951).

3. Narav odnosa ovisna je o načinu na koji se partneri međusobno izražavaju.

Vrijedi i obrnuto, sam odnos partnera tj. njegova narav ovisna je o izražavanju partnera, vrlo često i neverbalnom, a kontekst izrečenog (tzv. relacijske poruke kojima neverbalnim putem priopćavamo svoj stav, mišljenje, osjećaje npr. tonom glasa) može izmijeniti smisao rečenog, definira treći aksiom.

4. Ljudsko komuniciranje uključuje i digitalne i analogne modalitete.

Pojmovi „digitalni“ i ,analogni“ ${ }^{\text {“ }}$ modalitet koji se koriste u četvrtom aksiomu, u ovom kontekstu nisu istoznačni pojmovima koji se koriste u računalnoj tehnologiji, već se u komuniciranju digitalni modalitet odnosi na točno određeno značenje riječi, dok se analogni modalitet odnosi na ne sasvim jasno određeno značenje i korištenje riječi koje imaju više različitih značenja te predstavlja smetnju u komunikaciji.

Odnosi mogu biti ravnopravni, odnosno simetrični ili komplementarni tj. između nadređenih i podređenih osoba, sukladno čemu se razlikuje jesu li ili nisu na istoj razini komuniciranja. Ta (ne)ravnopravnost, kako kaže peti aksiom, svoj temelj ima u različitosti ili pak u sličnostima odnosno zajedništvu.

5. Postupci u međuljudskom komuniciranju su ili simetrični ili komplementarni, ovisno o odnosima među partnerima koji se temelje na razlikama ili zajedništvu. 
Ljudi komuniciraju čak i kad ne komuniciraju riječima. Oni to čine i neverbalnom komunikacijom, pri čemu to primjerice može biti ponašanje, držanje tijela, djela i slično, a vrlo često čak i ne reći ništa na postavljeno pitanje znači reći „nešto“.

\subsection{Masovno komuniciranje i masovni mediji}

Masovni mediji su novine, časopisi, knjige, radio, film, televizija, internet i najnoviji masovni medij - društvene mreže.

Tehnologije su načini pretvaranja jedne vrste znanja u drugu, kaže Marshall McLuhan, a svi mediji imaju moć pretvarati iskustvo u nove oblike. Govorna riječ bila je prva tehnologija kojom se čovjek mogao osloboditi svoje sredine da bi je shvatio na nov način. U ovo električno doba, kadri smo sve više poprimati druge oblike izražavanja, koji nas i nadilaze (McLuhan, 2008).

Već samom pojavom pisma započelo je razvijeno komuniciranje, ali kroz masovne medije ono je pokazalo takvu snagu da se više ne može zanemariti i valja ozbiljno uzimati u obzir potrebu komuniciranja na društveno prihvatljiv način. Zato Stjepan Malović (2005) s pravom konstatira da je „društvo postalo komunikacijsko društvo i stupanj razvijenosti mjeri se stupnjem komuniciranja“, a „društva koja se brzo razvijaju krajem 20. stoljeća i početkom 21. stoljeća temelje svoj razvoj na primjeni računalne tehnologije u komuniciranju te rastu obrazovanosti“ (Papić, Jakopec, Mičunović, 2011).

To je među prvima shvatio Harold Lasswell kada je 1948. godine svojom paradigmom nastojao obuhvatiti složene procese koji se pojavljuju u suvremenom društvu u kojem su masovni mediji dosegli svoj nagli razvitak (Martinić, 1985). Odredio je masovnu komunikaciju kao linearni proces odgovora na pet pitanja, a ukratko se može prikazati rečenicom: „Komunikator šalje poruku putem medija publici očekujući neke efekte“"(Malović, 2005).

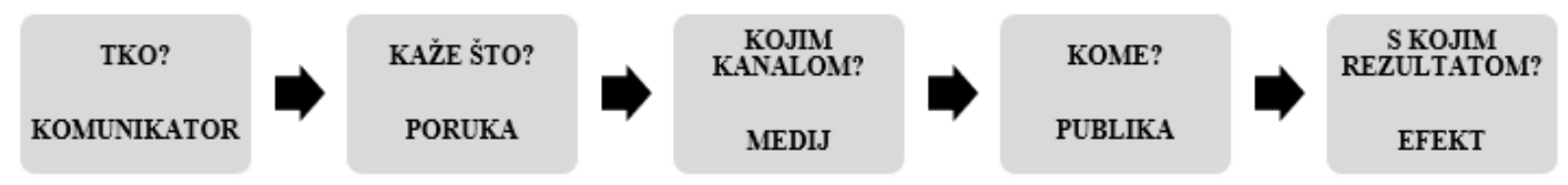

Slika 2. Lasswellow model komuniciranja (izvor: izrada autorice prema Lasswell, 1948) 
Uz Lasswellov model komunikacije, Shannon i Weaver (1949) razvili su najčešće korišten model komunikacije, koji uključuje šest osnovnih elemenata: izvor ili pošiljatelja informacije, koji stvara poruku; informaciju tj. poruku; enkodiranje, pretvaranje informacije u signal; komunikacijski kanal, kojim signal putuje; dekodiranje, rekonstruiranje poruke iz primljenog signala; primatelja informacije, koji prihvaća poruku. Osim ovih elemenata, prisutan je i šum ili buka kao ometajući čimbenik komunikacijskog procesa, navodi CARNet (2020), pri čemu je, u komunikološkom smislu, šum svaka pojava koja mijenja signal ili s njime međudjeluje. Može se pojaviti kod oblikovanja poruke (npr. nerazgovjetna, nerazumljiva ili dvosmislena poruka), pri njezinu prijenosu (gubitak dijelova poruke, ometajući signali i informacije) kao i kod primanja poruke (nepozornost ili informacijska preopterećenost primatelja, nerazumijevanje i pogrešno tumačenje poruka) (CARNet, 2020 prema Shannon i Weaver, 1949). Šum nije uvijek po svojoj prirodi zvučan pa primjerice, pogreške u pisanju adresa web sjedišta ili adresa elektroničke pošte, također predstavljaju šum u komunikološkom smislu riječi (CARNet, 2020 prema Shannon i Weaver, 1949). Što je manja „buka u kanalu“ time je i manja vjerojatnost da će informacija biti djelomično ili potpuno krivo reinterpretirana, što smanjuje i neizvjesnost oko javne informacije.

Teško je predvidjeti gdje je kraj masovne komunikacije jer uza sve teškoće s kojima su se susrele novine, s čijom pojavom je započelo masovno komuniciranje, su ostale do danas jedan od najmasovnijih medija, unatoč pojavi novih uvijek atraktivnijih medija kao što su radio, televizija i internet. Posebno stoga, kako ih je determinirao Gerhard Maletzke, mediji su zapravo tehnička distribucijska sredstva koja distribuiraju poruke, prilikom čega su pošiljatelji i primatelji razdvojeni (postoji dakle prostorna i/ili vremenska udaljenost između komunikatora i primatelja poruke) i nemaju interakciju (poruke se daju jednostrano disperziranoj, nenazočnoj publici) (Kunczik i Zipfel, 2006). Masovni mediji kao što su novine, radio i televizija naprosto nisu imali povratnu informaciju, već su reagiranje primatelja mjerili čitanošću, slušanošću i gledanošću.

Razvoj novih medija i njihovo sve veće stapanje, postavlja nova pitanja pred znanost o medijima i zahtijeva modifikaciju postojećih stavova, što vrijedi i za pojam i modele masovne komunikacije. Pojam „multimediji“, kako navode Kunczik i Zipfel (2006), vrlo je nespecifičan, jer ovisno o potrebi pojam se razumijeva kao multimedijski uređaji, aplikacije i tehnički mediji prijenosa. Za razumijevanje pojma „multimedija“ može poslužiti definicija: „svi proizvodi komunikacije koji su računalno i interaktivno medijski, a sadržavaju najmanje tri medijska oblika kao što su tekst, slika, pokretna slika i ton“ (Kunczik i Zipfel, 2006 prema BVDW, 2005). 
Pojam „multimediji“ se još može pojasniti kao „nadređen pojam za mnoštvo novih proizvoda i usluga s područja računalstva, telekomunikacija i medija“" s tri bitne zajedničke osobine:

1. mogućnost interaktivnog korištenja tj. korisnik nije isključivo primatelj nego može mijenjati sadržaje i inicirati akcije,

2. mogu se interaktivno kombinirati različiti medijski tipovi, tj. dinamički (video i audio sekvence) sa statičkim medijima (npr. podaci i tekst),

3. digitalna tehnika služi kao baza aplikacija koja znatno pojednostavljuje i uopće omogućuje pohranu i kasniju obradu podataka, dijelom i zahvaljujući postupcima kompresije (Kunczik i Zipfel, 2006 prema Allen, Hamilton, 1995).

Interaktivnost je doista najistaknutije obilježje multimedijalnih aplikacija kod kojih korisnik može intervenirati na mnoge načine, stoga se sadržaji tek na njegov zahtjev prikazuju ili generiraju u određenom obliku (Kunczik i Zipfel, 2006). Novi mediji su zbog svojih tehnoloških mogućnosti došli u poziciju da mogu pružiti dvosmjerno komuniciranje (McLuhan, 2008). Ono što je omogućilo takvu komunikaciju je pojava virtualnog prostora, poznatog pod engleskim nazivom Cyberspace odnosno pod pojmom „mreža“ (engl. Net).

\subsubsection{Virtualni prostor i virtualna kultura}

Virtualni prostor (engl. Cyberspace) novi je medij nastao na globalnoj povezanosti računala. Pojam se ne odnosi samo na materijalnu infrastrukturu digitalnih komunikacija, već i na oceanski svemir informacija koje sadrži, kao i na osobe koje navigiraju i razvijaju tu infrastrukturu.

Zajedno s porastom virtualnog prostora, razvija se sustav tehnologija (materijalnih i intelektualnih), praksi, stavova, modela razmišljanja i vrijednosti.

Važno je istaknuti da su informacije na internetu virtualne, i iako postoje fizički negdje na mreži, one su zapravo dostupne i prisutne na svim čvorovima u mreži gdje su zatražene, pa tako internet potiče uspostavu komunikacijskih veza koje su neovisne o fizičkoj, zemljopisnoj lokaciji i vremenskoj istodobnosti. Medij interneta, kojem Pierre Lévy (2001) u svom djelu „Cyber kultura“ (engl. Cyberculture) pripisuje osobinu kolektivne inteligencije, omogućuje sinergiju aktivnosti njegovih sudionika tj. korisnika, a ljudske aktivnosti sve više se šire u virtualnu sferu (Uzelac, 2004). 


\subsubsection{Internet i društveni mediji}

Kao medij koji se velikim dijelom ostvaruje u virtualnom prostoru, internet je prekoračio granice država, politike i drugih načina kontrole. On je više od drugih medija interaktivan, što znači da „dobrim dijelom može biti uređivan i odozdo, ne samo odozgor“ (Kolar, 2013). No, bojazan koja se protezala kroz cijelu povijest medija - da će s pojavom novog medija oni stari izumrijeti, pokazala se neutemeljenom jer novi mediji u pravilu imaju ,aditivnu“, a ne „supstantivnu“ snagu, ali povijesna logika također nalaže i obrnuto - novi mediji u pravilu uspijevaju izboriti svoje mjesto i preživjeti konkurenciju postojećih medija (Kolar, 2013).

Internet je svojim značajkama utabao put novim medijima kao što su društvene mreže, na način da osnovicu društvenih medija predstavljaju mediji koji se temelje na web i mobilnoj tehnologiji, a koji se koriste kako bi se komunikacija preokrenula u interaktivni dijalog. Andreas Kaplan i Michael Haenlein društvene medije definiraju kao ,skupinu internet aplikacija koje su izgrađene na ideološkim i tehnološkim osnovicama web 2.0 tehnologije koje omogućavaju kreiranje i razmjenu korisnički generiranog sadržaja“ (Kaplan, Haenlein, 2010).

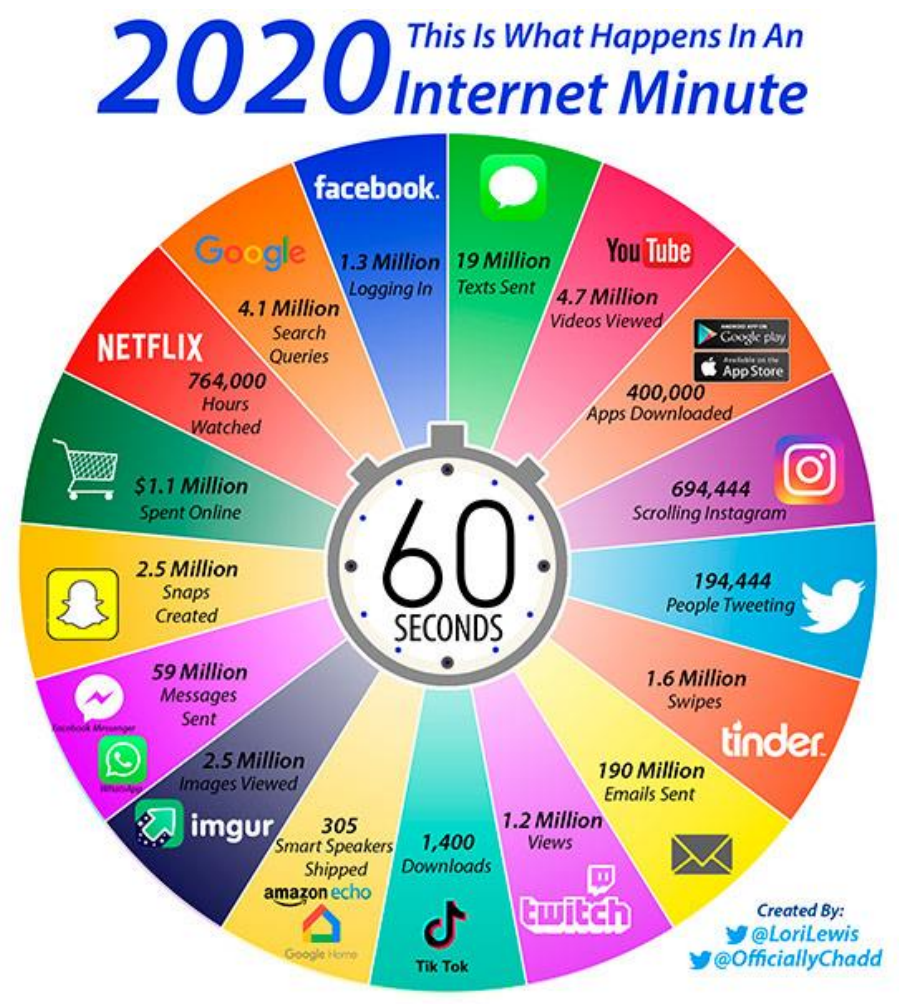

Slika 3. Što se desi na internetu u minuti 2020. godine (izvor: Lori Lewis, 2020) 
Posebno značajne odlike online platformi su njihova otvorenost javnosti, uglavnom nepoznatoj publici i dostupnost 24 sata na dan, svih 7 dana u tjednu preko niza uređaja i s različitih lokacija - ovise dakle, samo o pristupu internetu i volji korisnika. Zanimljiv je primjer da se čak začuđujuće fascinantne brojke trenutno aktivnih korisnika interneta i nekih bitnih platformi, a koje se neprestano mijenjaju, mogu uživo pratiti na stranici www.internetlivestats.com (Internet Live Stats, 2020).

\subsubsection{Informiranje, obrazovanje i zabava}

Sastavni dijelovi „svetog trojstva medija“, kako su Asa Briggs i Peter Burke (2011) naslovili poglavlje u svojoj knjizi „Socijalna povijest medija“, su informiranje, obrazovanje i zabava. Iako je svaki novi medij u svojim počecima izazivao kontroverze, prve rasprave o korisnosti ili štetnosti nekog medija u kojima je sudjelovao doslovno cijeli svijet, izazvala je pojava filma i to prvenstveno iz razloga što je za razliku od ostalih medija na prvo mjesto svoje funkcije stavio zabavu. Prije toga su mediji nastajali u proizvodne, vojne i druge slične praktične svrhe, a film je bio prvi koji je bio namijenjen širokoj masi, a ozbiljnije ga je, tek sredinom 20. stoljeća, poremetio „televizijski bum“. Masovna recepcija, utjecaj kapitala i neuravnoteženost socijalnih funkcija medija početkom 20. stoljeća pogodila je i druge medije pa su se počeli pojavljivati tzv. hibridni medijski sadržaji koji kombiniraju informiranje i zabavu, te se zato obično nazivaju „,infotainment“, ali i stapanja medija, pojave koja se naziva „compunications“ što predstavlja hibrid računala i komunikacije. Prema kraju stoljeća, došlo je i do višestrukih ,,medijskih konvergencija“, a sve više medijskog prostora koriste i oglašivači, što kao posljedicu ima da ideal ,informirane javnosti“ počinje popuštati pred činjenicom „tržišta“ (Kolar, 2013).

Brian Solis, suosnivač Kluba društvenih medija (engl. Social Media Club) predstavio je „Prizmu razgovora“, koju opisuje kao „umjetnost slušanja, učenja i dijeljenja“ (Solis, 2008a). Grafička prizma (Slika 4.) ilustrira široku lepezu alata društvenih medija koji su danas dostupni. 


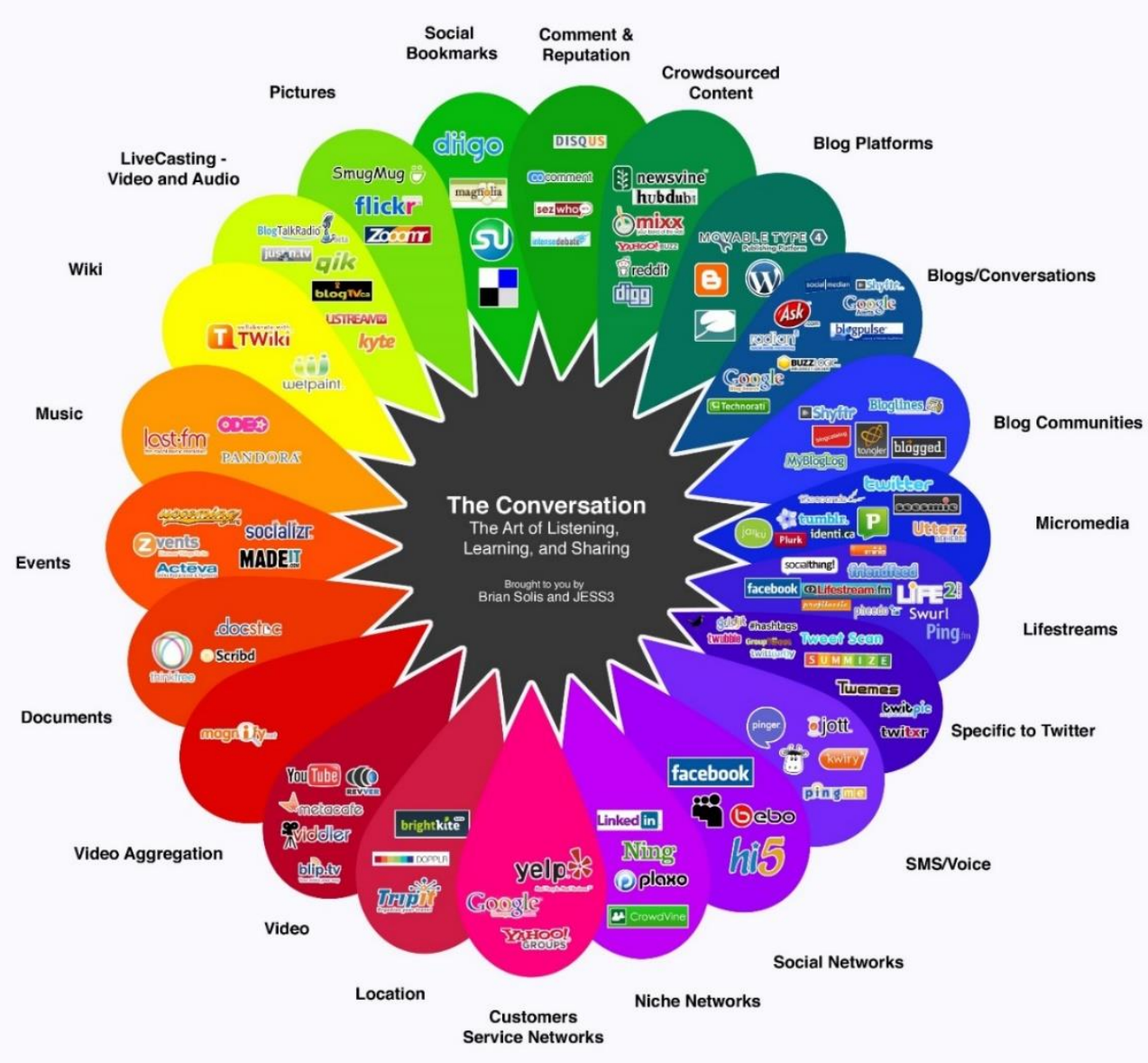

Slika 4. Mnoštvo društvenih medija te aktivnosti i usluga koje pružaju (izvor: Brian Solis, 2008a)

\subsubsection{Moć društvenih medija}

Moć društvenih medija je utjecaj (engl. Influence) (Poliska, 2016). Društveni mediji omogućavaju tvrtkama ne samo da surađuju s korisnicima, već su jedan od esencijalnih poslovnih alata za komunikaciju i pronalazak potencijalnih te zadržavanje postojećih kupaca (Ong, 2020).

Snaga društvenih medija može se slikovito prikazati i kroz prizmu demografskih statističkih podataka te socijalnih pojava, primjerice 2020. godine 7 od 10 parova upoznalo se online, a ne u stvarnom svijetu, dok 72 \% samaca smatra da su veze koje su započele online sretnije od veza koje su počele na drugi način (Dating Sites Reviews, 2020).

Broj aktivnih korisnika interneta i društvenih medija u stalnom je drastičnom porastu, pa je $u$ travnju 2020. godine broj aktivnih korisnika interneta dosegao brojku od 4,57 milijardi, što je oko 59 \% ukupnog broja svjetskog stanovništva tj. 7,79 milijardi (Worldometers, 2020). 
Društvene medije od toga je koristilo 3,81 milijardi, što je $49 \%$ svjetske populacije. Za usporedbu, Regan (2015) navodi da je 2015. godine broj aktivnih korisnika interneta bio 3,175 milijardi, što je bilo oko $43 \%$ ukupnog broja svjetskog stanovništva (7,357 milijardi). Društvene medije od toga je koristilo 2,206 milijardi, što je bilo $30 \%$ svjetske populacije (Regan, 2015).

Statistički podaci govore da je u Republici Hrvatskoj u siječnju 2020. godine bilo $51 \%$ aktivnih korisnika društvenih medija (Kemp, 2020), dok je u siječnju 2018. godine u Republici Hrvatskoj bilo $48 \%$ aktivnih korisnika društvenih medija koji se prijavljuju na usluge društvenih medija barem jednom mjesečno (Statista, 2019).

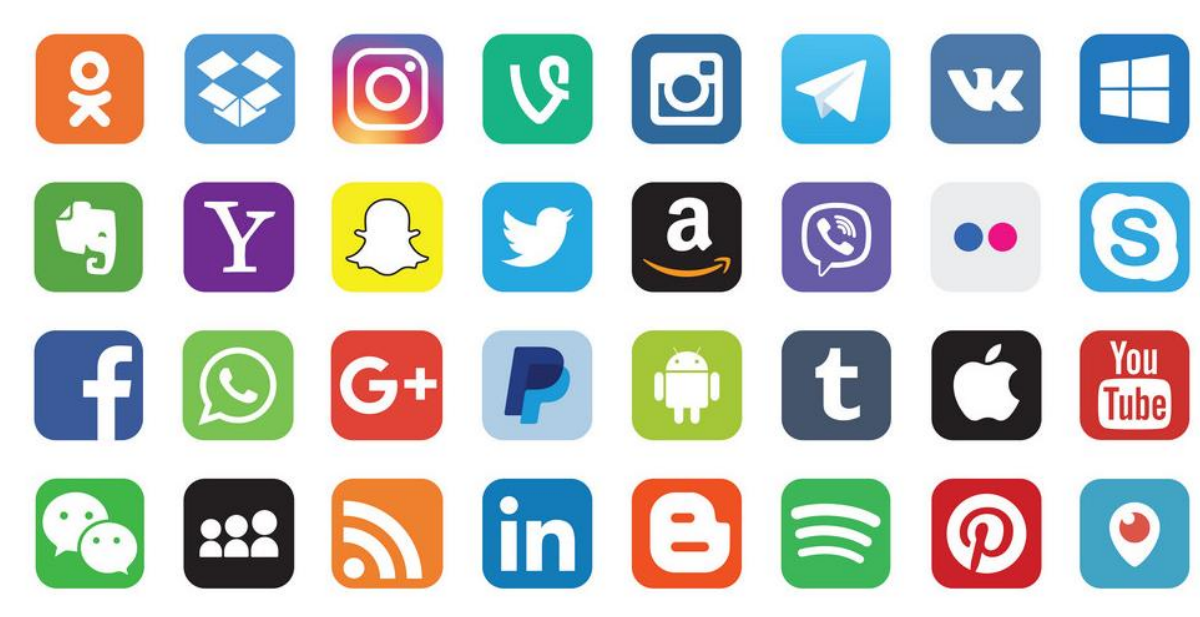

Slika 5. 32 ikone najpoznatijih društvenih medija (izvor: Shayli, 2020)

\subsubsection{Netiketa}

Netiquette pravila (engl. Netiquette) odnose se na pravila poželjnog ponašanja u internet zajednici. Network Working Group 1995. godine objavilo je netiketa vodič, javno dostupan dokument RFC1855, obuhvativši komunikaciju osobe s osobom koja uključuje poštu (e-mail) i razgovore, komunikaciju unutar grupe ljudi koja uključuje distribucijske liste (e-mail liste), objave (postove) vidljive grupi/grupama ljudi, forume, chatove i informacijske usluge (Gopher, Wais, www, ftp, telnet) koja se tiču pravila pristojnosti elektroničke komunikacije te ih organizacije i pojedinci mogu preuzeti i prilagoditi za svoje korištenje. Neovisno o tome tko pruža pristup internetu, bilo da je to pružatelj internetskih usluga putem privatnog računa ili studentski račun na sveučilištu, ili korisnički račun preko tvrtke, korisnici trebaju biti svjesni 
da te organizacije imaju propise o vlasništvu pošte i datoteka, o tome što je pravilno objaviti ili poslati i kako se predstaviti (Network Working Group, 1995).

Internet nije samo mreža računala, nego i velika neformalna zajednica s vlastitim kodeksom ponašanja (CARNet, 2008). Pravila ponašanja na internetu slična su onima u svakodnevnom životu pa su i na internetu razni oblici agresivnog i uvredljivog ponašanja te povrede privatnosti neprihvatljivi (CARNet, 2008). Međutim, postoje i pravila specifična samo za internet:

- poruke pisane isključivo velikim slovima smatraju se vikanjem,

- emotikon (engl. Emoticon) - izraz za kombinaciju znakova koja izražava raspoloženje i pomaže da poruka bude ispravno protumačena: :-) označava smijeh ili vedro raspoloženje, a :-( označava žalosno raspoloženje. Postoje i druge kombinacije, ali se ne koriste toliko često (CARNet, 2008).

Kako navodi CARNet (2008), pravila ponašanja u komunikaciji pojedinaca na internetu najvećim dijelom odnose se na autorska prava, neželjene sadržaje, lančana pisma, komercijalne lance i oglašavanje, veličine poruke i privitke, poznavanje rada s e-mail programom, formatiranje poruka, dok se pravila ponašanja u komunikaciji unutar grupe odnose na ponašanje u news grupama i distribucijskim listama, poznavanje sadržaja i teme grupe ili liste, veličine poruke, privatne i zatvorene liste te pravila ponašanja na forumima.

Komunikacijom putem interneta se koristi velik broj ljudi, često na neodgovarajući način, zbog nepoznavanja osnovnih pravila, stoga i kultura komuniciranja putem interneta zahtijeva učenje (CARNet, 2008). 


\section{ETIČKI IZAZOVI INFORMACIJSKOG DRUŠTVA}

Već se na prvom (virtualnom) forumu, održanom na temu informacijske etike, organizirao je UNESCO, od listopada 1997. godine do travnja 1998. godine, raspravljalo o etičkim aspektima globalnih tržišta informacija. Ova tema uključivala je: povjerenje, vlasništvo, i valjanost informacija; privatnost, ne/povjerljivost, sigurnost, mržnju i nasilje na internetu (Capurro, 2000).

\subsection{Aspekti informacijske etike}

Sve veća povezanost, komunikacija i razmjena informacija među ljudima i to kad oni čak nisu fizički blizu (Krunić, 2012), dovodi do proširenja pojma ,infoetika“ što se može računati kao centar moralnih zahtjeva, koji sada uključuje svaku instancu informacija, bez obzira na to da li je fizički realizirana ili nije.

Informacijska etika (infoetika) bavi se stavovima, pravilima i vrijednostima (tj. moralom) u digitalnoj sredini, vezano uz proizvodnju, prikupljanje, diseminaciju i korištenje informacija (Horvat, 2016). Ona predstavlja izučavanje etičkih teorija i načina njihovog uključivanja u probleme upravljanja informacijama (engl. Information Management) (Etika bibliotekarstva, 2016).

Razvoj moderne tehnologije napreduje toliko brzo da se čini da razmatranje društvenih i etičkih implikacija ne mogu ići s tim razvojem u korak, ali svakako je uzrok preispitivanja mnogih društvenih i zakonodavnih normi. Informacijska etika dijeli se na 5 širih kategorija: vlasništvo (engl. Ownership), pristup (engl. Access), privatnost (engl. Privacy), sigurnost (engl. Security), zajednica (engl. Community), a shodno tome kao osnovna problemska područja informacijske etike određena su sljedeća područja:

- intelektualne slobode

- jednakopravan pristup informacijama

- cenzura

- privatnost

- intelektualno vlasništvo (Etika bibliotekarstva, 2016). 


\subsubsection{Intelektualna sloboda}

Pojam ,intelektualna sloboda“ danas se odnosi na slobodu mišljenja, slobodu izražavanja i slobodu promicanja ideja i uvjerenja. Pa primjerice, „IFLA (Međunarodno udruženje knjižničarskih društava i ustanova) podržava, brani i promiče intelektualnu slobodu kao što ju određuje Opća deklaracija Ujedinjenih naroda o ljudskim pravima (Opća skupština Ujedinjenih naroda, 1948). IFLA izjavljuje da ljudska bića imaju temeljno pravo pristupa svim oblicima znanja, stvaralačkog mišljenja i intelektualne aktivnosti, kao i javnog izražavanja svojih pogleda. IFLA vjeruje da su pravo na znanje i sloboda izražavanja dva oblika istog načela. Pravo na znanje zahtijeva slobodu mišljenja i savjesti; sloboda mišljenja i sloboda izražavanja preduvjet su za slobodan pristup informacijama. IFLA utvrđuje da je zauzimanje za intelektualnu slobodu osnovna odgovornost knjižničarske i informacijske struke. IFLA stoga poziva knjižnice i knjižnično osoblje da se drže načela intelektualne slobode, neometanog pristupa informacijama i slobode izražavanja i da poštuju privatnost korisnika knjižnice (Izvršni odbor IFLA, 1999).

Međutim, važno je spomenuti da su razvoj moderne tehnologije i pojava novih medija pogodovali jačanju senzacionalizma u medijima, zbog čega vrlo često svjedočimo kako se zbog povećanja naklade ili gledanosti zanemaruje etika informiranja, razonoda postaje prioritet, a „infotainment“ (Demers, 2005) sastavni dio medija (Ružić, 2008).

U Republici Hrvatskoj prava koja se tiču navedenih problemskih područja informacijske etike zajamčena su svim građanima Republike Hrvatske bez obzira na spol, dob, nacionalnost, vjeru ili osobne stavove u članku 38. Ustava Republike Hrvatske (Hrvatski sabor, 2014b).

„Jamči se sloboda mišljenja i izražavanja misli.

Sloboda izražavanja misli obuhvaća osobito slobodu tiska i drugih sredstava priopćavanja, slobodu govora i javnog nastupa i slobodno osnivanje svih ustanova javnog priopćavanja. Zabranjuje se cenzura. Novinari imaju pravo na slobodu izvještavanja i pristupa informaciji. Jamči se pravo na pristup informacijama koje posjeduju tijela javne vlasti. Ograničenja prava na pristup informacijama moraju biti razmjerna naravi potrebe za ograničenjem u svakom pojedinom slučaju te nužna u slobodnom i demokratskom društvu, a propisuju se zakonom. Jamči se pravo na ispravak svakomu komu je javnom viješću povrijeđeno Ustavom i zakonom utvrđeno pravo.“ 


\subsubsection{Jednakopravan ili slobodan pristup informacijama}

Jednakopravan ili slobodan pristup informacijama temeljno je ljudsko pravo, koje se štiti Ustavom Republike Hrvatske (Hrvatski sabor, 2014b), (Europskom) Konvencijom o ljudskim pravima i slobodama (Vijeće Europe, 2010), Konvencijom o pristupu službenim dokumentima (Vijeće Europe, 2009), i Zakonom o pravu na pristup informacijama (Hrvatski sabor, 2015). Informacijom se smatra svaki podatak koji posjeduje tijelo javne vlasti, neovisno o obliku u kojem je nastala, a zajamčeno pravo odnosi se na pravo svih fizičkih i pravnih osoba na dobivanje informacija koje posjeduju tijela javne vlasti u Republici Hrvatskoj, neovisno o svrsi za koju ili u koju se informacija želi koristiti (Povjerenik za informiranje, 2017). Otvoreni podaci su podaci koji su javno i besplatno dostupni, a namijenjeni su ponovnoj uporabi u komercijalnu ili nekomercijalnu svrhu koja je različita od svrhe za koju su izvorno izrađeni ili prikupljeni (Povjerenik za informiranje, 2020a).

Obveznici pružanja informacija su tijela javne vlasti; državna uprava i državna tijela, lokalna samouprava, javne ustanove i druga tijela s javnim ovlastima, pravne osobe čiji je osnivač država ili jedinice lokalne samouprave, pravne osobe koje se temeljem posebnog zakona pretežito ili u cijelosti financiraju iz državnog proračuna odnosno iz javnih sredstava. Ima ih oko 6000 u Republici Hrvatskoj, a njihov popis vodi Povjerenik za informiranje. Javno je dostupan popis na: http://tjv.pristupinfo.hr (Povjerenik za informiranje, 2020b). Tijela javne vlasti obvezna su u strojno čitljivom obliku objavljivati registre i baze podataka koje su izradili u okviru svoje nadležnosti, a za koja ne postoje zakonska ograničenja, što je temeljni preduvjet za razvoj mogućnosti koje pruža Zakon o pravu na pristup informacijama - ponovne uporabe informacija, u komercijalne ili nekomercijalne svrhe, različite od one radi koje su nastali.

(Povjerenik za informiranje, 2020a). Dodatno, tijela su bez obzira na karakter skupa podataka, odnosno čak i ako postoje zakonska ograničenja, obavezna objaviti popis o registrima i bazama podataka iz svoje nadležnosti (engl. Asset List), uz metapodatke i informaciju o načnu pristupa odnosno ponovne uporabe (npr. otvoreni podaci, djelomično otvoreni, dostupni samo određenom krugu ovlaštenika i sl.) (Povjerenik za informiranje, 2020a).

\subsubsection{Cenzura}

Cenzura koja nosi zakonska ograničenja ili potpuna sloboda izražavanja?, pitanje je za čiji odgovor se teoretičari najčešće odlučuju za dvije krajnje točke gledišta. Prema prvoj, nužna je 
cenzura i kontrola sadržaja na internetu, dok se druga temelji na činjenici da živimo u demokraciji pa je stoga uvođenje ograničenja radikalna mjera. Međutim, kao što navodi Nataša Ružić (2008), demokracija i amoralnost nisu sinonimi, stoga pornografski sajt, snimka ubojstva ili prodaja organa na internetu ne mogu biti smatrani odrazom slobode i demokracije. Ljudi trebaju imati slobodu izbora, ali istinska sloboda izbora može postojati samo u visoko intelektualnom društvu, no s obzirom na to da većina društava to još uvijek nije, zakonska regulacija slobode izbora je prijeko potrebna i sloboda izbora mora biti u skladu sa zakonom (Ružić, 2008).

Članak 10. (Europske) Konvencije za zaštitu ljudskih prava i temeljnih sloboda (Vijeće Europe, 2010), koji utvrđuje pravo na slobodno izražavanje, u drugom stavku kaže da se to pravo može ograničiti i u demokratskom društvu, kad je to u interesu nacionalne sigurnosti, teritorijalne cjelovitosti ili javne sigurnosti, kad se žele spriječiti neredi ili zločini, zaštititi zdravlje ili moral, ugled ili pravo drugih pojedinaca, te kad treba očuvati autoritet i nepristranost suda. I u pojedinim se nacionalnim zakonima nalaze slična ograničenja. No ta je ograničenja tehnički teško primijeniti u mrežnoj sredini pa se zadnjih nekoliko godina u svjetskim krugovima uvelike raspravlja o mogućnostima uvođenja nadzora nad mrežom i načinima njezina uređenja. Lakoća i brzina umnožavanja i širenja sadržaja na mreži potencijalno ugrožava i nositelje prava na različite vrste intelektualnog vlasništva (Horvat, 2006).

\subsubsection{Kontrola privatnosti na društvenim medijima}

U rujnu 2014. godine društvena mreža Facebooka uvela je novi alat Privacy Checkup (Underwood, 2014), koji se odnosi na vlastito upravljanje odnosno provjerom postavki privatnosti od strane korisnika, u tri jednostavna koraka:

- provjera dijele li svoje statuse s pravim osobama: s prijateljima, javnosti ili uskim krugom odabranih ljudi;

- provjera koje su aplikacije povezane s njihovim Facebook profilom te tko vidi sadržaj koji aplikacija postavlja u ime korisnika i

- provjera kome su vidljivi osobni podaci korisnika kao što su npr. mjesto rođenja, tvrtka u kojoj radi i slično.

No, vrlo često se navodi da je set pravila o privatnosti kompliciran, čak i ako se čini drugačije, jer osim što se pravila neprestano mijenjaju, nikad ne možete biti u potpunosti sigurni što je 
drugim korisnicima vidljivo, a što nije, čak i ako se čini da je korisnički račun dobro zaštićen (Biberović, 2014).

Vrlo često, kritike dolaze na račun Facebooka zbog problema privatnosti, ali također i zbog pitanja cenzure te zbog toga što su informacije koje korisnici odaju o sebi korištene za marketinška istraživanja, eksperimente koji utječu na korisnike, praćenje korisnika na cijelom internetu, krađe podataka (Newcomb, 2018), internih istraga sveučilišta i kompanija, pa čak i policije (Romm, 2019).

\subsubsection{Intelektualno vlasništvo}

Intelektualno vlasništvo obuhvaća nematerijalna dobra koja predstavljaju proizvodi ljudskog uma, a imaju vrijednost u umnožavanju, upotrebi i prikazivanju drugim ljudima, te ih nije svrhovito, a često niti moguće, zaštiti sakrivanjem, zatvaranjem ili drugim mjerama fizičke zaštite. Zbog njihove društvene vrijednosti, kreativna ili umjetnička realizacija neke ideje kao ploda ljudskog intelekta, predstavlja pod određenim uvjetima intelektualno vlasništvo njezinog stvaratelja. Intelektualno vlasništvo, iako neopipljivo u fizičkom smislu, ima sve karakteristike imovine, a sukladno tome ono se može kupiti, prodati, licencirati, zamijeniti, pokloniti ili naslijediti kao i svako drugo vlasništvo. U poslovnom smislu, ono predstavlja nematerijalnu imovinu koja je temelj ili doprinos uspješnom poslovanju (Državni zavod za intelektualno vlasništvo, 2017).

Da bi se zaštitila ova vrsta dobara, a time potaknula ljudska kreativnost koja doprinosi općem razvoju društva, razvijen je odgovarajući sustav pravne zaštite intelektualnog vlasništva koje obuhvaća niz instrumenata kojima se uređuje način stjecanja i način zaštite intelektualnog vlasništva od neovlaštenog korištenja. S tim u skladu, neovlaštena uporaba ili umnožavanje objekata intelektualnog vlasništva predstavlja povredu prava, a pravo je vlasnika raspolaganje, upotreba i stjecanje koristi od takvog vlasništva te se štiti sredstvima i institucijama pravnog sustava.

Intelektualno vlasništvo obuhvaća dvije podgrupe prava:

- autorsko i srodna prava - autorsko pravo je isključivo pravo autora da raspolaže svojim književnim, znanstvenim ili umjetničkim djelima, te drugim područjima stvaralaštva, dok se srodna prava odnose na prava umjetnika, proizvođača fonograma i emitiranja radija i televizije na sličan način, 
- industrijsko vlasništvo - skup prava koja proizvođačima omogućava zaštitu svojih poslovnih interesa, položaj na tržištu i uložena sredstva u istraživanje, razvoj i promociju od konkurenata (Državni zavod za intelektualno vlasništvo, 2017).

\subsection{Informacijska sigurnost}

„Jedini informacijski sustav koji je zaista siguran je onaj koji je isključen iz napajanja, zakopan u betonskom bloku, zapečaćen u sobi od olova, te okružen naoružanim čuvarima. Čak i tad, imao bih svoje sumnje.”

- Eugene Spafford (1989)

$\mathrm{Na}$ osnovno pitanje koje se tiče informacijske sigurnosti, zašto informacijski sustavi nisu sigurni, još 1988. godine Gasser je pojasnio: „problem su ljudi, ne računala.“

Pojam „informacijska sigurnost“, u literaturi može naći i pod nazivima računalna sigurnost (engl. Computer security), kibernetička ili cyber-sigurnost (engl. Cyber Security) ili sigurnost informacijske tehnologije (IT sigurnost) (engl. Information Technology Security) te se još uvijek nastoji usuglasiti terminologija (Schatz, Bashroush, Wall, 2017).

Informacijska sigurnost se odnosi na zaštitu računalnih sustava i mreža od krađe ili oštećenja hardvera, softvera ili elektroničkih podataka, kao i od poremećaja ili neispravnosti usluga koje pružaju (Glīzds, 2017 prema Gasser, 1988). To uključuje kontrolu fizičkog pristupa hardveru, kao i zaštitu od štete koja može doći putem mrežnog pristupa, unosa podataka i koda i zbog zloupotrebe operatora, bilo slučajnih, bilo namjernih (Glīzds, 2017) kao što je primjerice društveni inženjering (napad koji se u velikoj mjeri oslanja na ljudsku interakciju i često uključuje manipuliranje ljudima kako bi prekršili uobičajene sigurnosne postupke i najbolje prakse kako bi dobili pristup sustavima, mrežama ili fizičkim lokacijama ili radi financijske dobiti) (Rouse, 2015).

Osim zaštite podataka i mreža, može se odnositi i na zaštitu računalne snage. Zaštita podataka (sigurnost informacija) smatra se najvažnijom. Zaštita mreža važna je radi sprečavanja gubitka resursa servera, kao i radi zaštite mreže od ilegalnih korištenja. Zaštita računalne snage relevantna je samo za skupe strojeve poput velikih superračunala (PCMag Encyclopedia, 2020). Područje postaje sve važnije zbog sve većeg oslanjanja na računalne sustave, internet, bežične mreže, kao što su Bluetooth i Wi-Fi, i zbog rasta „pametnih“ uređaja, uključujući pametne telefone, televizore i razne uređaje koji čine ,internet stvari“ (Glīzds, 2017). 
Osnovni cilj informacijske sigurnosti kao discipline je „osigurati zaštitu informacija i informacijskih sustava od neovlaštenog pristupa, korištenja, primjene ili uništavanja" (UNIZD, 2016). Informacije je potrebno zaštititi: od neovlaštenih izmjena (osigurati integritet), od objavljivanja tajnih informacija (osigurati povjerljivost), od uskraćivanja dostupnosti informacija ovlaštenim korisnicima (osigurati raspoloživost/dostupnost) (Vukelić, 2016 prema Gasser, 1988). Informacijska sigurnost također uključuje: oporavak informacijskih sustava, detekciju i odvraćanje napada, primjenu zakonskih propisa koji se odnose na privatnost, računalni kriminal, računalnu forenziku i slično (Vukelić, 2016).

\subsubsection{Prijetnje, ranjivosti i napadi}

Sigurnost informacijskih sustava može biti ugrožena na više načina (Vukelić, 2016). U kontekstu informacijske sigurnosti, Vukelić (2016) definira prijetnju kao objekt, osobu ili drugi entitet koji predstavlja stalnu opasnost za imovinu organizacije. Ranjivost sama po sebi ne nanosi štetu, već je ona stanje ili skup stanja koji može omogućiti nekoj prijetnji da utječe na resurse (HNB, 2006) odnosno slabost imovine ili grupe imovina koju jedna ili više prijetnji mogu iskoristiti (Vukelić, 2016 prema FOI, 2016). Napadi su akcije koje su usmjerene na ugrožavanje sigurnosti informacija, računalnih sustava i mreža (Vukelić, 2016), to je djelo, akcija koja iskorištava priliku postojanja ranjivosti kako bi se kompromitirao informacijski sustav koji treba zaštititi (Vukelić, 2016 prema Hajdina, 2009).

Svaki se napad prema cilju koji nastoji ostvariti, prema Dragičeviću (2004), može svrstati u jednu od sljedeće tri kategorije:

- napad pristupa (engl. Access Attack); napadač želi zadobiti pristup povjerljivim resursima za koje nije ovlašten, kao što su primjerice pretraživanje, premetanje po podacima, prisluškivanje, maskiranje, krađa identiteta (engl. Phishing), socijalni inženjering (za pristup tajnama kao što su lozinke, brojevi kartica i sl.), softversko piratstvo;

- napad modifikacije (engl. Modification Attack); napadač želi prisilno izmijeniti informacije u sustavu za koje nije ovlašten, kao što su npr. zamke, trojanski konji, virusi, crvi, logičke bombe, tehnika slame;

- napad uskraćivanje usluge (engl. Denial of Service Attack); napadač želi poremetiti i onemogućiti rad mreže, usluga, sustava u cjelini. 


\subsubsection{Računalni kriminal i zaštitne mjere}

Do danas ne postoji opće prihvaćena definicija računalnog kriminala, pa čak niti jedinstven pogled na sadržaj i oblike koje on obuhvaća, navodi Vukelić (2016), no s razvojem tehnologije napadi su postali složeniji i lakši za izvedbu, a njihovom rastu doprinijela je i obrazovanost ljudi, ovisno o obliku kriminala.

Postupanje s računalnim kriminalom odnosi se na:

- prevenciju - procjenu rizika i analizu prijetnji, fizičku sigurnost, sigurnost osoblja, komunikacijsku sigurnost, operacijsku sigurnost, planiranje načina za borbu protiv računalnog kriminala;

- otkrivanje - mjere otkrivanja, tim za rukovođenje kriznim situacijama, obradu i praćenje upada, istragu i pravosudni progon, bilježenje tragova, prikupljanje dokaza; te

- kažnjavanje - rukovanje s dokazima, vještačenje eksperata, prezentaciju na sudu, aktivnosti nakon presude (Vukelić, 2016).

Mjere koje u praksi postižu dobre rezultate pri implementaciji informacijske sigurnosti jesu: sigurnosna politika, podjela odgovornosti informacijske sigurnosti, svijest o informacijskoj sigurnosti, edukacija i trening, ispravno procesiranje podataka u aplikacijama, upravljanje ranjivostima, upravljanje poslovnim kontinuitetom te upravljanje sigurnosnim incidentima i poboljšanjima sustava (Vukelić, 2016).

\subsubsection{Zakonska regulativa sigurnosti informacijskih sustava}

Informacijska sigurnost je zahvaljujući svojoj složenosti, osim u pogledu tehnologije, i u pogledu politike, također jedan od glavnih izazova u suvremenom svijetu (Stevens, 2018). Informacijska sigurnost u području komunikacijskih i informacijskih sustava definira se, kako navodi Vijeće Europske unije (2020), kao povjerenje da će takvi sustavi štititi podatke koje obrađuju i da će funkcionirati onako kako trebaju, kada trebaju i uz kontrolu zakonitih korisnika. Učinkovitom informacijskom sigurnošću moraju se osigurati odgovarajuće razine tajnosti, cjelovitosti, dostupnosti, nepobitnosti i autentičnosti (Vijeće Europske unije, 2020). Stoga je Odlukom Vijeća o sigurnosnim pravilima za zaštitu klasificiranih podataka Europske unije (EUCI) određeno da komunikacijski i informacijski sustavi trebaju obrađivati klasificirane podatke Europske unije u skladu s konceptom informacijske sigurnosti. 
Sigurnosno-obavještajna agencija Republike Hrvatske (SOA, 2020) na svojoj web stranici navodi da informacijska sigurnost obuhvaća pet područja: sigurnosnu provjeru, fizičku sigurnost, sigurnost podatka, sigurnost informacijskog sustava i sigurnost poslovne suradnje (SOA, 2020). U Republici Hrvatskoj je Ured Vijeća za nacionalnu sigurnost (UVNS) odgovoran za utvrđivanje i provedbu mjera i standarda informacijske sigurnosti (SOA, 2020), koji informacijsku sigurnost opisuje kao ,stanje povjerljivosti, cjelovitosti i raspoloživosti podatka, koje se postiže primjenom propisanih mjera i standarda informacijske sigurnosti te organizacijskom potporom za poslove planiranja, provedbe, provjere i dorade mjera i standarda“ (UVNS, 2020), sukladno Zakonu o informacijskoj sigurnosti koji je hrvatska vlada donijela 2017. godine (NN 79/07). 2018. godine stupila je snagu Opća uredba o zaštiti podataka (OUZP) (engl. General Data Protection Regulation (GDPR)) koja osim privatnosti osnovnih podataka kao što su ime i prezime, broja osobne iskaznice, lokacijskih podataka, podataka s kreditnih kartica, zdravstvenog kartona (invaliditet, povijest bolesti i sl.), biometrijskih podataka (sken rožnice, otisci prsta itd.), genetskih podataka (DNA i sl.), vjerskog i filozofskog uvjerenja, etničke pripadnosti, ekonomskog stanja, članstva u sindikatu, seksualne orijentacije i spolnog života, obuhvaća i štiti kategorije podataka kao što su IP adrese, osobne poruke epošte, kolačiće u pregledniku, pseudonimizirane podatke (European Parliament and the Council of the European Union, 2016). Njome se utvrđuju detaljni zahtjevi za poduzeća i organizacije u pogledu prikupljanja osobnih podataka, njihove pohrane te upravljanja osobnim podacima te se primjenjuju na europske organizacije koje obrađuju osobne podatke pojedinaca u Europskoj uniji te organizacije izvan Europske unije koje su usmjerene na ljude koji žive u Europskoj uniji (Vaša Europa, 2020).

S obzirom na brojnost i varijacije računalnih tehnologija, a paralelno i brojnim mogućnostima računalnih prijetnji i napada, problem informacijske sigurnosti isto tako nastoji se suzbijati kroz aktivnosti na pojedinačnoj razini kao što su medijsko opismenjavanje, na razini poduzeća $i$ ustanova ili kroz državne agencije, te na razini nadnacionalnih savjetodavnih, regulatornih i zakonskih postupaka, koji se za potrebe ovog rada navode uglavnom deklarativno.

\subsection{Elektroničko nasilje}

Razvoj i dostupnost informacijske i komunikacijske tehnologije omogućili su gotovo trenutnu komunikaciju i pristup informacijama neovisno o vremenskoj i prostornoj udaljenosti sudionika komunikacijskog procesa ili izvora informacija. S pojavom interneta, vrlo često nazivanog „mrežom svih mreža“, počelo je umrežavanje pojedinaca, a koje s pojavom društvenih mreža 
proživljava dosad neviđeni uzlet. Zbog svojih karakteristika kao što su jednostavnost korištenja i pristupačnost te što u sebi sadrže sve do sad poznate medije, društvene mreže svakim danom imaju sve više korisnika. Međutim, paralelno s porastom korisnika interneta, a posebno društvenih mreža, raste i broj neželjenih negativnih i štetnih učinaka i sadržaja, kao što su elektroničko nasilje.

\subsubsection{Utjecaj medija na mlade}

U Hrvatskoj se, kako navodi Čačić (2012), pojmovi mladi, mladež, omladina, mlada generacija javljaju kao istoznačnice. Mladost se u suvremenom društvu smatra razdobljem života između djetinjstva i odraslosti s tendencijskom stalnog produljivanja tog razdoblja. Utjecaj mrežnog okružja toliko je intenzivan da se sve češće u literaturi mlađe generacije definiraju kroz medije i tehnologiju. Riječ je o generaciji mladih osoba koje se zabavljaju, socijaliziraju, uče, rade, kupuju i komuniciraju uz pomoć tehnologije, te provode vrijeme na internetu objedinjujući zabavu i učenje (Čačić, 2012).

Dostupnost informacija umnogome utječe na vezu pojedinca s vanjskim svijetom. Kakvi će biti stavovi pojedinca, te sukladno tome odnosi s okolinom, ovisi o njegovom idejnom sustavu i usvojenoj informaciji. Uloga idejnog sustava je primanje, filtriranje i odabir medijskih sadržaja, pa tamo gdje nema mentalnog sustava koji pročišćava informaciju i snažne ideološke strukture koja će je uvrstiti u cjelinu, informacija postaje šum. No, pojedinci i kolektiv koji imaju čvrstu mentalnu strukturu (stavove i uvjerenja), usvajat će informacije koje tu strukturu potvrđuju, dok će one koje joj se suprotstavljaju odbaciti. Može se zaključiti da, s jedne strane, dostupnost i izloženost velikoj količini informacija predstavlja povećanje izbora i sloboda, a s druge strane, one nose rizik ukoliko pojedinci, posebno djeca i mladi, nemaju izgrađen sustav evaluacije (Čačić, 2012).

\subsubsection{Poštovanje sebe i svoje privatnosti}

Poštovanje sebe usko je vezano uz javno (ne) obznanjivanje osobnih podataka i privatnih informacija (Bilić, 2015). Međutim, pripadnici mrežne generacije, obzirom da su im životi srasli s informacijskom tehnologijom, vode malo računa o osobnim informacijama koje iznose na društvenim mrežama. Čak i Tapscott, kao zagovornik mrežne generacije, smatra da 
zahvaljujući društvenim mrežama njihovi životi postaju sve manje osobni, a privatnost postaje temeljni i najveći problem o kojem mladi ljudi nedovoljno znaju. Oni bez velikog razmišljanja o dugoročnim posljedicama postavljaju na mrežu informacije o sebi i drugima s namjerom da razmijene ono što smatraju zanimljivim, a pritom zanemaruju da internet ne poznaje zaborav (Bilić, 2015 prema Tapscott, 2011).

\subsubsection{Poštovanje drugih osoba i tuđe privatnosti}

Poštovanje drugih smatra se velikim moralnim problemom mladih u virtualnom svijetu. Rašireno mišljenje ili zabluda o internetu jest da je to svijet u kojem nema prepreka, ni ograničenja, a još uvijek nema ni jasno određenih pravila ponašanja. Zatim, anonimnost je još jedan faktor koji smanjuje strah počinitelja da će biti otkriveni i sankcionirani. Uz to, nedostatak afektivne povratne informacije o šteti i boli koje mogu svojim ponašanjem prouzročiti žrtvama, kao i mišljenje da se njihovo ponašanje ne može smatrati nemoralnim jer nema vidljivih posljedica te udaljenost od štete koju izazivaju njihove aktivnosti, potiče ih da vrlo često navedeno smatraju kao zabavu ili šalu (Bilić, 2015).

Kao zaključak nameće se da su odgoj i učenje odgovornog ponašanja prema sebi i drugima posebno važni za budućnost mladih ljudi.

\subsubsection{Mladi i djeca - najzastupljenije i najugroženije dobne skupine na internetu i stranicama društvenih mreža}

Prema podacima Državnog zavoda za statistiku Republike Hrvatske (RH) objavljenima za 2019. godinu, primijećen je minimalni porast u svim dobnim skupinama korisnika računala u odnosu na prethodnu godinu, kao i porast u svim dobnim skupinama korisnika interneta $\mathrm{u}$ odnosu na prethodnu godinu. No, najmlađa populacija (između 16 i 24 godine) još uvijek prednjači i u uporabi računala (vidi Sliku 6.) i u uporabi interneta kod pojedinaca (vidi Sliku 7.), a broj korisnika opada proporcionalno njihovoj dobi. Sličan trend primijećen je i u strukturi prema radnom statusu u kojoj učenici i studenti kao najmlađa skupina najčešće upotrebljavaju računala (vidi Sliku 8.) i internet (vidi Sliku 9.). 


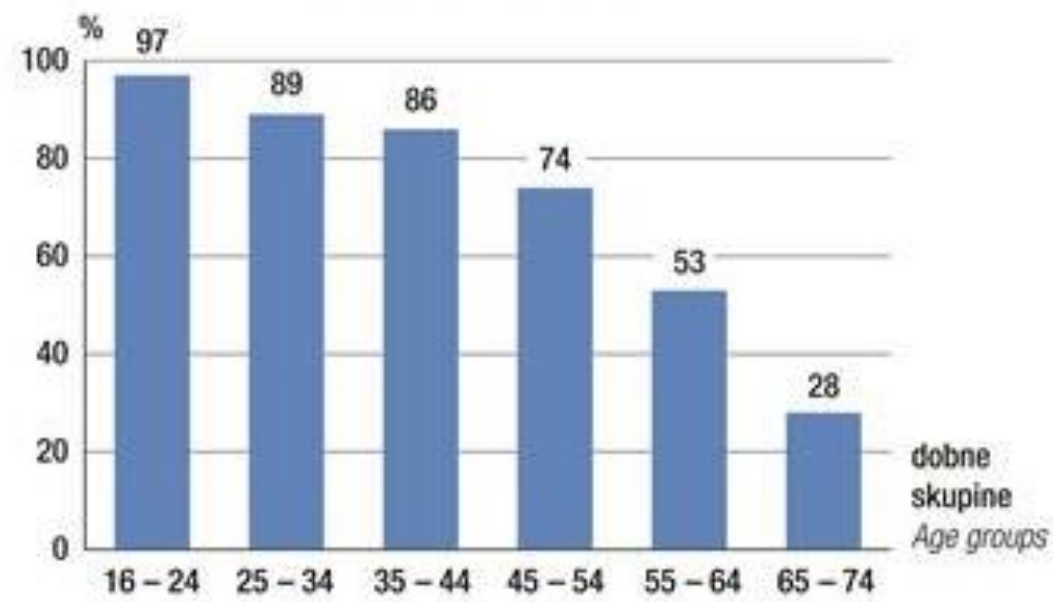

Slika 6. Korisnici računala u Republici Hrvatskoj prema dobnim skupinama 2019. godine (izvor: Državni zavod za statistiku RH, 2019)

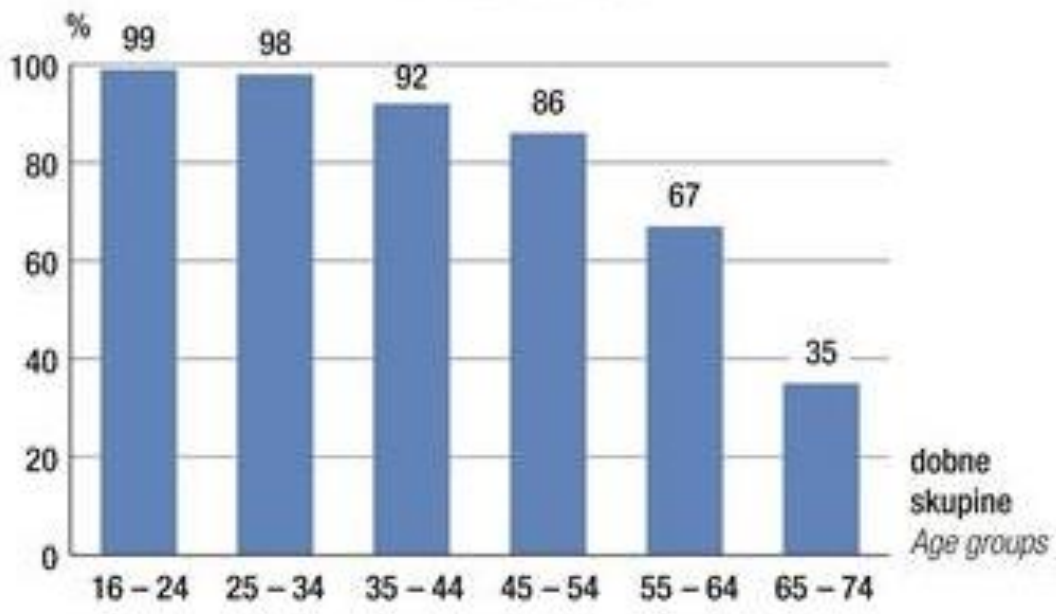

Slika 7. Korisnici interneta u Republici Hrvatskoj prema dobnim skupinama 2019. godine (izvor: Državni zavod za statistiku RH, 2019) 


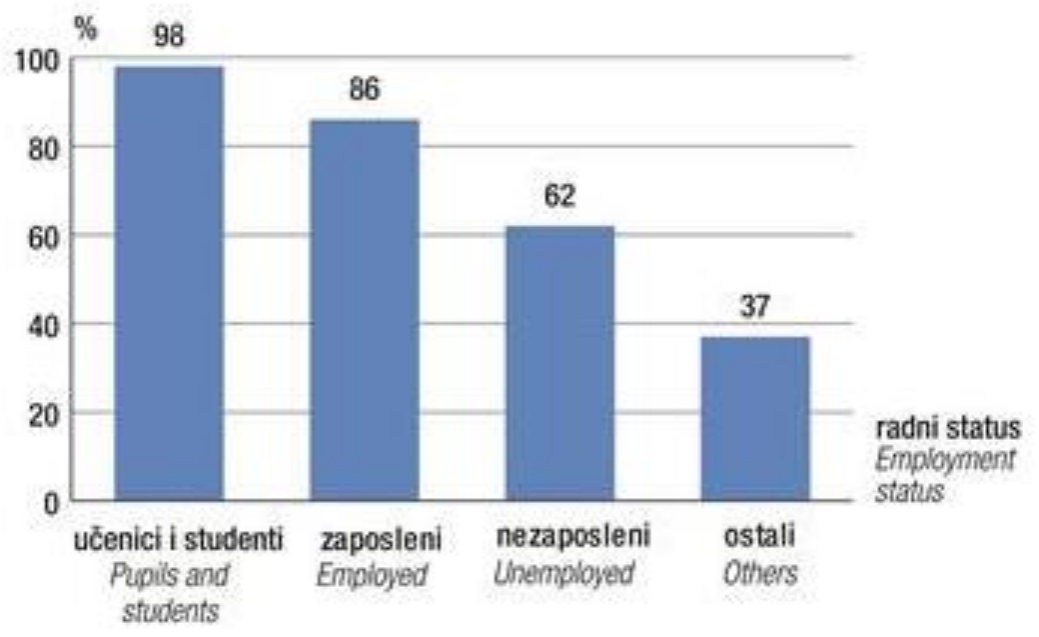

Slika 8. Korisnici računala u Republici Hrvatskoj prema radnom statusu 2019. godine (izvor: Državni zavod za statistiku RH, 2019)

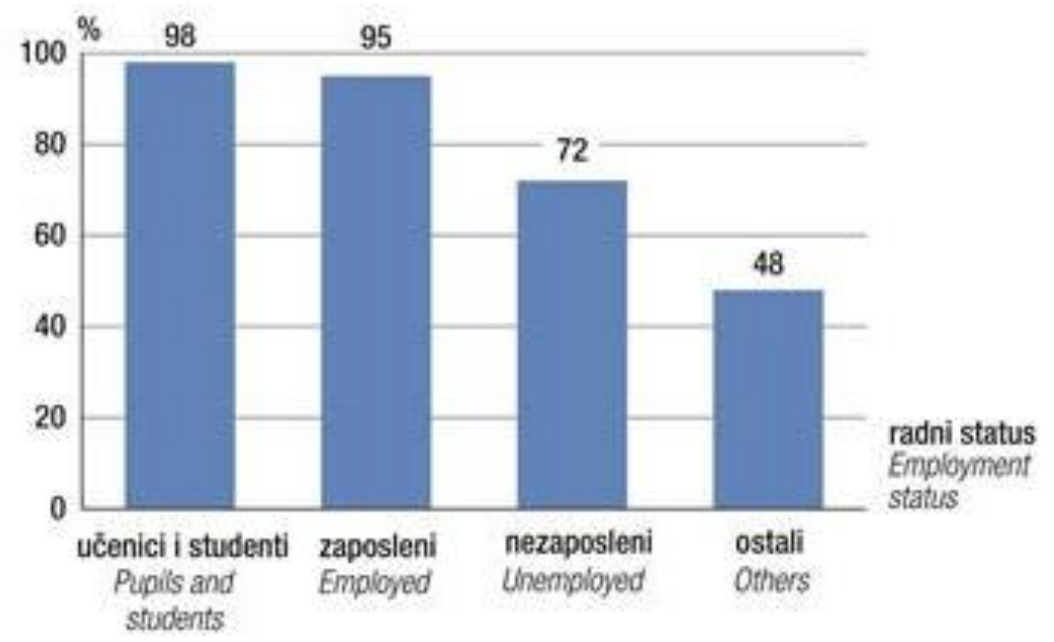

Slika 9. Korisnici interneta u Republici Hrvatskoj prema radnom statusu 2019. godine (izvor: Državni zavod za statistiku RH, 2019)

Ako se rezultati Državnog zavoda za statistiku koji se tiču namjene upotrebe interneta kod pojedinaca u 2019. godini za Republiku Hrvatsku usporede s podacima iz prethodne godine, može se uočiti da se navike nisu bitnije promijenile. Pojedinci se najčešće koriste internetom za prikupljanje informacija o proizvodima i uslugama (93\%), čitanje dnevnih novosti i časopisa (91\%), prikupljanje informacija o zdravlju (79 \%), upotrebu e-pošte (74 \%), slanje poruka putem telefonskih aplikacija (87 \%) te sudjelovanje na društvenim mrežama (73 \%) (vidi Sliku 10.). 


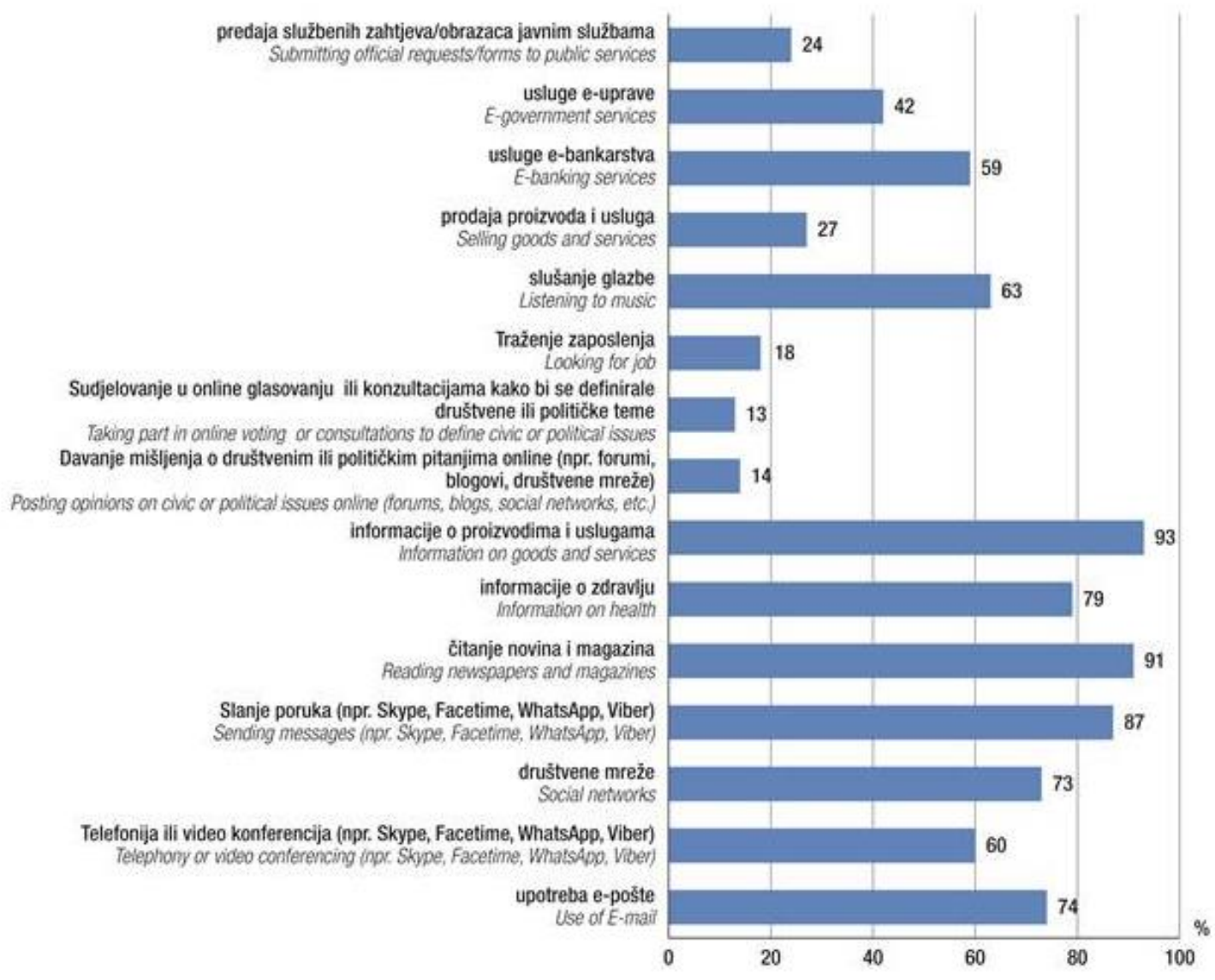

Slika 10. Namjena upotrebe interneta kod pojedinaca u Republici Hrvatskoj 2019. godine (izvor: Državni zavod za statistiku RH, 2019)

Što se tiče korištenja društvenih medija, početkom 2019. godine najčešće korištena društvena mreža je Facebook, pa primjerice ukupni broj aktivnih Facebook korisnika u Republici Hrvatskoj iznosi približno 1.900,000 korisnika, što znači 4 od 9 stanovnika Republike Hrvatske, dok Instagram koristi 1 od 4 stanovnika Republike Hrvatske odnosno 1.900,000 korisnika. Na Instagramu je više populacije od 13-17 godina nego na Facebooku te prevladavaju korisnici starosti 18-24 godine, dok na Facebooku prevladavaju korisnici starosti 25-34 godine.

Suvremeno informacijsko društvo nije samo „društvo znanja“ već i društvo koje se suočava s problemima u odgojno-obrazovnom razvoju, kao što je npr. problem ekspanzije vrijednosti koje su orijentirane na hedonistički i/ili dokoličarski koncept života. Tisak, radio, TV program i internet sve više nude zabavnog sadržaja naspram informativnog, obrazovnog ili znanstvenog. (Miliša, Tolić, Vertovšek, 2009, prema Miliša, 2006). 


\subsection{5. Štetna komunikacijska aktivnost u virtualnom prostoru}

Za potpunije razumijevanje složenosti novih oblika nasilja koji se pojavljuju u digitalnom okruženju, a kojima su posebno izloženi pripadnici mlađe generacije, važno je definirati ključne pojmove kao što su elektroničko nasilje (engl. Cyberbulling), odnosno nasilje u medijima te drugi online rizici u koje se ubrajaju namjerna, ali i nenamjerna iskustva koja povećavaju vjerojatnost štete na račun internet korisnika.

Virtualni prostor ili cyber prostor (engl. Cyberspace) novi je medij nastao na globalnoj povezanosti računala, a odnosi se ne samo na materijalnu infrastrukturu informacijskih tehnologija, već i na sveukupnost informacija koje sadrži, kao i na osobe koje razvijaju i upravljaju tom infrastrukturom.

Elektroničkim nasiljem (engl. Cyberbullying) može se smatrati svaka komunikacijska aktivnost (putem e-mailova, web stranica, blogova, videa, bilo posredstvom računala bilo mobitela, tableta i sl.) koja služi kako bi se neka osoba ponizila, zadirkivala, prijetilo joj se ili ju se teroriziralo na neki drugi način (Poliklinika za zaštitu djece grada Zagreba, 2012). Osobito je problematično kad se radi o djeci i mladima, jer je uvijek cilj povrijediti, uznemiriti i na bilo koji drugi način naštetiti djetetu, bilo u obliku tekstualnih ili video poruka, fotografija ili poziva ili negativnih komentara. Može ga činiti jedna ili više osoba, ali i djece. Poliklinika za zaštitu djece grada Zagreba (2012) definira „nasilje preko interneta“ kao opći pojam za svaku komunikacijsku aktivnost cyber tehnologijom koja se može smatrati štetnom kako za pojedinca, tako za opće dobro.

\subsubsection{Nasilje u medijima}

Nasilni sadržaji u medijima već su dugi niz godina u središtu pozornosti mnogih znanstvenika, ali u Republici Hrvatskoj je provedeno malo istraživanja o toj temi. Djeca provode više vremena pred televizijskim ekranima i računalima, nego u školi ili u druženju s vršnjacima u prirodi, stoga mediji, prije svega televizija, zaista postaju odgojitelji mlađih generacija (Kanižaj, Ciboci, 2011). Nove tehnologije dovode i do novih oblika nasilja, stoga elektroničko nasilje postaje problem koji se sve više istražuje, čak i u Hrvatskoj (Kanižaj, Ciboci, 2011). Obzirom da se raspravljajući o nasilju u medijima, mnogi znanstvenici ne mogu složiti što se sve podrazumijeva pod nasilnim sadržajima, tri su ključna elementa po kojima se definicije razlikuju: 
- namjera - postavlja se pitanje mora li postojati namjera za činjenje nasilja, primjerice spadaju li u nasilje ubojstvo i drugi oblici nanošenja teških fizičkih ozljeda ili se i nesreće i prirodne katastrofe mogu smatrati nasilnim djelima?;

- šteta koja se postiže određenim nasilnim djelom - može li se nasiljem smatrati samo bol nanesena ljudskim bićima, ili i životinjama, pa i nasilna djela počinjena nad materijalnim stvarima?;

- $\quad$ vrsta nasilja - je li nasilje samo fizičko nasilje ili i verbalno nasilje? (Kanižaj, Ciboci, 2011, prema Potter, 1999).

Jedna od novijih definicija koja se u posljednje vrijeme najviše koristi je Potterova definicija medijskog nasilja prema kojoj se nasilje definira kao ,povreda nečije fizičke i emocionalne dobrobiti“ koja je obuhvatila sve dosad navedene elemente (Kanižaj, Ciboci, 2011, prema Potter, 1999).

\subsubsection{Od izbjegavanja rizika do upravljanja rizicima}

Nove digitalne tehnologije i masovni mediji predstavljaju izazov današnjem društvu, osobito u području odgoja djece i mladih. Oni s jedne strane mogu štetiti međuljudskim odnosima i neposrednoj interpersonalnoj komunikaciji, a s druge strane, na kognitivnoj razini moguće je uočiti problem ,pretjerane informiranosti“, „zagušenja informacijama“ koje se često brkaju sa znanjem, a pri čemu je vidljiv gubitak ,specifične težine“ informacija zbog nepobitne činjenice da je u bujici informacija koje nas zapljuskuju sa svih strana teško razlučiti koje su bitne, a koje su potpuno nevažne (Labaš, 2011).

Osim nevažnih, izloženi smo moralno i ljudski štetnim informacijama o rasizmu, vjerskoj netoleranciji, terorizmu, pornografiji, nasilju ili informacijama koje promiču različite vjerske i ekonomske ideologije, od kojih neke imaju svoj „odraz“ u tzv. digitalnom jazu između zemalja bogatih informacijama i onih koje nemaju pristup informacijama koje su nužne za ravnomjeran i uravnotežen razvitak i napredak cijeloga svijeta, posebno siromašnih zemalja (Nevins, 2004). $\mathrm{S}$ druge strane, korištenje novih medija, a posebno interneta, danas predstavlja ulaznicu u uobičajeni život: tko nije „medijski pismen“ nalazi se u opasnosti da će biti isključen iz različitih razina života. Pedagozi i odgojitelji smatraju da već kasne na odgojnom planu te da moraju nadoknaditi izgubljeno ili propušteno vrijeme, a njihovi pristupi odgoju za medije ili medijskoj pismenosti su različiti (Labaš, 2015 prema Uldrijan, 2011). 


\section{DRUŠTVENI MEDIJI}

„E-pošta je prethodila internetu ... blogovi postoje više od deset godina, wikiji postoje od 1995. godine ... Ako većina ovih stvari postoji (dva)deset godina, zašto mi sada govorimo o tome? Jer nije riječ o alatima, riječ je o ljudima. Razlog zašto je sada to važno jest zato što mi sada doživljavamo seizmički rast - radi se o ljudima koje ti alati okupljaju.“

- Ethan Zuckerman (2007)

\subsection{Tehnologija društvenih medija}

„Tehnologija društvenih medija je složena, i podsjeća na opis Rusije Winstona Churchilla (1939); ona je poput 'zagonetke, umotane u misteriju, unutar enigme' koja se neprekidno istražuje i kratko je shvaćena prije nego što se još jednom promijeni.“

Davis III i sur. (2012)

Pojam „web 2.0“ označava način rada web aplikacija koje korisnicima omogućavaju da stvaraju svoje web stranice, na njih uvrštavaju informacijske sadržaje kao što su tekstovi, fotografije, glazba, video zapisi. Sjedišta (domene) na kojima ih objavljuju omogućuju posjetiocima i korisnicima tih web stranica da ih komentiraju. Glavna odlika web 2.0 aplikacija je mogućnosti njihovih korisnika da se predstave javnosti, putem objave podataka o sebi, vlastitih radova ili tuđih radova koji se korisniku sviđaju, pa iz tih činjenica proizlaze pojmovi kojima se opisuju: „,interaktivno dijeljenje informacija“, „interoperabilnost“, „dizajn okrenut korisniku“ (Radovan, 2014).

Mnogi znanstvenici ističu da se društveni mediji razlikuju od web 2.0 (Kaplan, Haenlein, 2010; Weinberg, Pehlivan, 2011; Berthon i sur. 2012). No, kako navode Aichner i Jacob (2015), web 2.0 tehnologija omogućuje društvene medije i služi kao krovni pojam za opisivanje različitih tehnologija koje se izvode u pozadini aplikacija i platformi za društvene medije. Stoga se određuju i kao hibrid jer imaju mješovito podrijetlo tehnologije i medija koji omogućavaju trenutnu komunikaciju u realnom vremenu i koriste multi-medijalne formate i brojne platforme koje omogućavaju globalni doseg (Mangold, Faulds, 2009).

Društveni mediji su online servisi koji prosječnom korisniku omogućuju da s drugima surađuje online. Popularni su jer ne iziskuju visoku razinu informatičkog znanja. Dvije su temeljne vrste društvenih medija, navodi Brautović (2011): društveni mediji za razmjenu napisa, videa, 
knjižnih oznaka (engl. Bookmark) i fotografija, primjerice Youtube (video), Wikipedia (napisi), Flickr (fotografije), Del.icio.us (knjižne oznake) te društveni mediji za umrežavanje odnosno društvene mreže, primjerice Facebook, LinkedIn (Brautović, 2011).

Kako navode Aichner i Jacob (2015), društveni mediji su web-bazirane aplikacije i interaktivne platforme koje olakšavaju stvaranje, raspravu, izmjenu i razmjenu sadržaja koje je stvorio korisnik (Kaplan, Haenlein 2010; Kietzmann i sur. 2011), stoga nisu ograničeni na društvene mreže poput Facebooka, jer, uz društvene mreže, uključuju blogove, poslovne mreže, suradničke projekte, poslovne forume, mikrobloge, dijeljenje fotografija, alate za recenziju proizvoda / usluga, društvene knjižne oznake, društvene igre, dijeljenje videozapisa i virtualne svjetove (Aichner i Jacob, 2015).

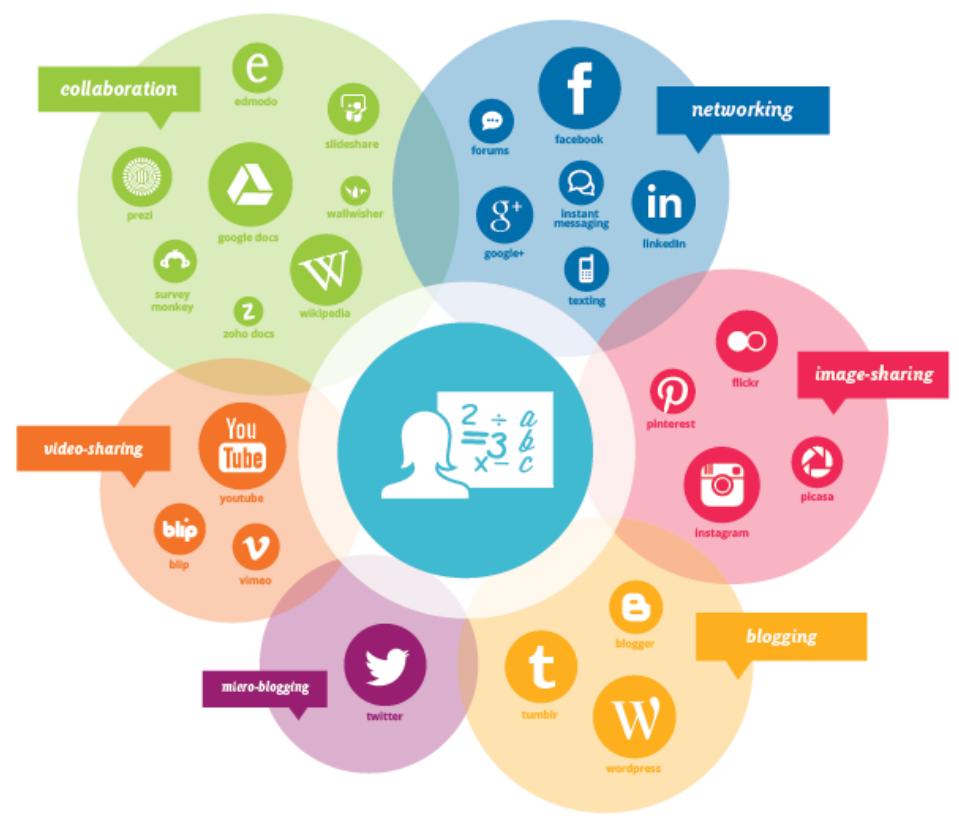

Slika 11. Mapa društvenih medija i njihovih karakteristika (izvor: New Zealand Teaching Council, 2013)

Gore navedene definicije mogu se sažeti dijeljenjem složenog pojma „društveni mediji“ $u$ njegove dvije komponente, ,društvenu “ i ,,medijsku “. „Društveni““ dio odnosi se na aktivnosti koje se obavljaju među ljudima, dok se „mediji“ odnose na internet alate i tehnologije koje se koriste za obavljanje takvih aktivnosti (Ngai i sur., 2015). 


\subsection{Prikaz tipova društvenih medija}

Slijedi prikaz tipova društvenih medija. Mnogo je podjela društvenih medija, a svakim danom moguća je pojava novih podtipova. Za potrebe ovog doktorskog rada, zbog opsežnosti i detaljnosti, koristila se tipologija prema Aichner i Jacob (2015). Sljedeća tipologija definira opseg i primjenjivost odnosno korištenje predloženih modela. U Tablici 1. navedeni su tipovi društvenih medija s primjerima.

Tablica 1. Tipovi društvenih medija s primjerima (izvor: izrada autorice prema Aichner, Jacob, 2015)

\begin{tabular}{|c|c|c|}
\hline \multirow[b]{2}{*}{ Tipovi društvenih medija } & \multicolumn{2}{|c|}{ Primjeri } \\
\hline & Naziv & Web stranica \\
\hline \multirow{2}{*}{ Blogovi } & Mojblog, & Mojblog.hr, \\
\hline & Blog & Blog.hr \\
\hline \multirow{2}{*}{ Dijeljenje fotografija } & Instagram, & Instagram.com, \\
\hline & Flickr & Flickr.com \\
\hline \multirow[b]{2}{*}{ Dijeljenje videozapisa } & YouTube, & YouTube.com, \\
\hline & Vimeo & Vimeo.com \\
\hline \multirow{2}{*}{ Društvene igre } & World of Warcraft, & Worldofwarcraft.com, \\
\hline & Mafia Wars & Mafiawars.com \\
\hline \multirow{2}{*}{ Društvene mreže } & Facebook, & Facebook.com, \\
\hline & Google+ & Plus.google.com \\
\hline \multirow{3}{*}{ Društvene mreže poduzeća } & Yammer, & Yammer.com, \\
\hline & Informacijski sustav visokih & Isvu.hr \\
\hline & učilišta RH (ISVU) & \\
\hline \multirow{2}{*}{ Forumi } & Forum, & Forum.hr, \\
\hline & Bug Online Forum & Forum.bug.hr \\
\hline \multirow{2}{*}{ Društvene knjižne oznake } & Pinterest, & Pinterest.com, \\
\hline & Reddit & Reddit.com \\
\hline \multirow{2}{*}{ Mikroblogovi } & Twitter, & Twitter.com, \\
\hline & Tumblr & Tumblr.com \\
\hline \multirow{3}{*}{ Poslovne mreže } & LinkedIn, & LinkedIn.com, \\
\hline & Enterprise Europe Network & Een.ec.europa.eu \\
\hline & (Europska poduzetnička mreža) & \\
\hline \multirow{2}{*}{ Pregled proizvoda i usluga } & Amazon, & Amazon.com, \\
\hline & Njuškalo & Njuskalo.hr \\
\hline \multirow{2}{*}{ Suradnički projekti } & Wikipedia, & Wikipedia.org, \\
\hline & Mozilla & Mozilla.org \\
\hline \multirow{2}{*}{ Virtualni svjetovi } & Second Life, & Secondlife.com, \\
\hline & Twinity & Twinity.com \\
\hline
\end{tabular}




\section{Prema navedenoj tipologiji u Tablici 2. opisani su tipovi društvenih medija, kako su ih strukturirali Aichner i Jacob (2015).}

Tablica 2. Opis društvenih medija (izvor: izrada autorice prema tipologiji Aichner, Jacob, 2015)

\begin{tabular}{|c|c|}
\hline $\begin{array}{l}\text { Tipovi } \\
\text { društvenih medija }\end{array}$ & Opis \\
\hline $\begin{array}{l}\text { Blogovi } \\
\text { (od engl. , Web“ i ,Log“) }\end{array}$ & $\begin{array}{l}\text { Mrežni dnevnik, dnevak, blog ili web blog; kronološki je popis objava na webu } \\
\text { koje posjetitelji mogu pročitati i komentirati, poredanih na način da se najnovije } \\
\text { vijesti/članci nalaze na vrhu stranice. Njima upravljaju pojedinci ili tvrtke, mogu } \\
\text { biti osobni, poslovni, tematski, u obliku časopisa. Prvi hrvatski blog alat je } \\
\text { MojBlog.hr koji se pojavio 2004. godine. Iste godine s radom počinje i Blog.hr. }\end{array}$ \\
\hline Dijeljenje fotografija & $\begin{array}{l}\text { Web servisi za dijeljenje fotografija omogućavaju svojim korisnicima usluge kao } \\
\text { što su primjerice prijenos, usluge poslužitelja (engl. Hosting), dijeljenje i } \\
\text { upravljanje fotografijama: mrežno uređivanje, organizacija u albume, korisnici ih } \\
\text { mogu međusobno gledati, komentirati i slično. }\end{array}$ \\
\hline Dijeljenje videozapisa & $\begin{array}{l}\text { Web stranice ili softveri koji svojim korisnicima omogućavaju dijeljenje, gledanje } \\
\text { i pretraživanje video zapisa. Postoje servisi koji nude opcije privatnog dijeljenja } \\
\text { video zapisa, kao i servisi za javnu objavu video sadržaja. Iako mogu naplaćivati } \\
\text { svoje usluge, uglavnom su dostupni besplatno. Mogu imati definirane restrikcije i } \\
\text { veličini zapisa, trajanju, temi ili formatu, a osobito u svezi s objavom } \\
\text { neprimjerenih sadržaja ili ograničavanjem pristupa maloljetnih korisnika. Tvrtke } \\
\text { ih često koriste za oglašavanje (i time za smanjenje troškova koji su mnogo niži u } \\
\text { usporedbi s TV oglašavanjem). }\end{array}$ \\
\hline
\end{tabular}

Mrežno igranje društvenih igara koje omogućava ili zahtijeva socijalnu interakciju između igrača, u suprotnosti primjerice sa samostalnim igranjem online igara.

Društvene igre Često uključuju više igrača, primjerice igre kartama, igre na pločama (u kojima se postavljaju, premještaju ili uklanjaju figure ili dijelovi na predefiniranoj i označenoj površini prema određenom skupu pravila) igranje uloga, igre alternativnih stvarnosti, masovne video igre i slično.

Online servisi koji omogućavaju organiziranje, spremanje poveznica (engl. Link) te označavanje prema ključnim riječima (engl. Tag) na centraliziranoj platformi kako bi ga podijelili s prijateljima i drugim korisnicima da bi im sadržaj bio lakše

Društvene knjižne oznake dostupan i pretraživ, iako neke stranice imaju mogućnost privatnog pohranjivanja knjižnih oznaka (engl. Bookmark). Web stranice za društveno knjižno označavanje vrijedan su pokazatelj popularnosti web stranica i drugih web sadržaja.

Vrsta internetskih servisa koji služe za umrežavanje/povezivanje njihovih korisnika, međusobno upoznavanje, dijeljenje zajedničkih interesa, sudjelovanje u zajedničkim ili sličnim aktivnostima. Korisnici imaju svoj vlastiti, pojedinačni

Društvene mreže profil, mogu ih pronaći drugi korisnici ako koriste svoje puno (stvarno) ime i prezime, mogu prenositi i objavljivati/dijeliti svoje misli, ideje, fotografije, video zapise. Isto tako, mogu ih koristiti tvrtke kako bi informirali ili pružali podršku postojećim ili novih korisnicima njihovih usluga i proizvoda.

Društvene mreže poduzeća otvorene za zaposlenike određene tvrtke ili grupe. S obzirom na to da imaju zajedničke poslovne interese i/ili aktivnosti umrežavanje povećava učinkovitost upravljanja znanjem unutar tvrtke. Nude slične značajke kao društvene mreže npr. osobni profil, fotografije profila i dr. Pomažu

Društvene mreže poduzeća međusobno upoznavanje te dijeljenje iskustva i ideja. Društveni softver koristi se uglavnom u kontekstu „tvrtke/poduzeća“ kao poslovni ili komercijalni alat, npr. intranet, za organizaciju komunikacije, suradnje i druge aspekte svog poslovanja, no i vanjskog društvenog umrežavanja kako bi povećale „vidljivost“" svojih poduzeća.

Internetski forum koji putem web preglednika omogućava razmjenu mišljenja i iskustva svojim korisnicima. Upotreba je jednostavna jer nalikuje na oglasnu

Forumi ploču (engl. Message Board), a sudionici na njoj mogu čitati i objavljivati poruke (ne u realnom vremenu kao npr. za vrijeme chat-a). Najčešće je organiziran tematski radi lakšeg snalaženja. U diskusiji na određenu temu korisnici mogu 
sudjelovati anonimnom objavom poruka (engl. Post), bez objave pravog identiteta, ali koje su vidljive svim korisnicima sve dok/ako ih ne obriše moderator/administrator foruma.

\begin{tabular}{|c|c|}
\hline $\begin{array}{l}\text { Mikroblogovi } \\
\text { (od engl. ,,Micro“ i } \\
\text { „Blog“) }\end{array}$ & $\begin{array}{l}\text { Mrežni mikrodnevnik, kraći blog koji se od klasičnih blogova razlikuje po tome } \\
\text { što sadrži isključivo kratke poruke do } 200 \text { znakova, fotografije, video i druge } \\
\text { zapise, okvirno se kao kriterij uzima duljina poruka na Twitteru (ograničenje je } \\
140 \text { znakova). Korisnici se mogu pretplatiti (postati „pratitelji“) na vijesti/objave } \\
\text { drugih korisnika, slavnih osoba, tvrtki, brandova i slično. Predstavljaju } \\
\text { kombinaciju blogova i društvenih mreža. }\end{array}$ \\
\hline Poslovne mreže & $\begin{array}{l}\text { Složena mreža poduzeća koje zadržavaju svoju autonomiju ali se udružuju i } \\
\text { djeluju zajednički radi ostvarenja određenih strateških i operativnih poslovnih } \\
\text { ciljeva, te povećanja konkurentnosti i inovativnosti. Često uključuju sporazume o } \\
\text { suradnji kako bi tvrtke koje djeluju u različitim zemljama/regijama lakše } \\
\text { ostvarivale zajedničke ciljeve na međunarodnom tržištu. Sinergija poslovne mreže } \\
\text { više je od zbroja pojedinačnih tvrtki. Uključuje dobavljače, distributere, kupce, } \\
\text { programere i druge, kako bi se podržali informacijski i operativni zahtjevi } \\
\text { poslovanja. }\end{array}$ \\
\hline Pregled proizvoda i usluga & $\begin{array}{l}\text { Web stranice koje omogućavaju pregled proizvoda i/ili usluga, pružaju } \\
\text { informacije o njima i prodaju ih. Korisnici imaju mogućnost ocjenjivanja i } \\
\text { komentiranja proizvoda i usluga ili njihovih određenih karakteristika i atributa, } \\
\text { primjerice kvalitete, te mogu pisati ili čitati postojeće recenzije istih. Ovaj tip web } \\
\text { stranica obično je profesionalno dizajniran, pa često zbog specijaliziranog } \\
\text { marketinga recenzije nisu objektivne. Isto tako, postoji mogućnost da negativne } \\
\text { kritike budu napisane od strane konkurencije, nezadovoljnih zaposlenika ili trećih } \\
\text { negativno i/ili neobjektivno orijentiranih strana. }\end{array}$ \\
\hline $\begin{array}{l}\text { Suradnički (kolaborativni) } \\
\text { projekti }\end{array}$ & $\begin{array}{l}\text { Aplikacije društvenih medija s dvije potkategorije; istraživački i razvojni projekti, } \\
\text { koje okupljaju korisnike sa zajedničkim interesom ili znanjem kako bi planirali, } \\
\text { razvijali, istraživali, testirali tehnološke, akademske, znanstvene ili zabavne } \\
\text { projekte. Omogućuju zajedničku i simultanu kreaciju npr. programa, kodova, } \\
\text { otkrića, igara, postizanje rezultata. Obično se distribuiraju kao otvoreni kod (engl. } \\
\text { Open Source) i stavljaju na raspolaganje javnosti bez naknade. }\end{array}$ \\
\hline Virtualni svjetovi & $\begin{array}{l}\text { Računalno podržane društvene okoline koje dizajniraju i dijele korisnici kako bi } \\
\text { mogli interaktivno sudjelovati u simuliranom i od strane korisnika stvorenom } \\
\text { svijetu. Mogu stvoriti osobnog avatara te simultano sudjelovati u istraživanju } \\
\text { virtualnog svijeta, ali i komunikaciji i aktivnostima s drugim korisnicima te tako } \\
\text { istraživati i ljudsku prirodu te korisničke mogućnosti. Za razliku od video igara, } \\
\text { u virtualnim svjetovima vrijeme se nastavlja čak i kad korisnik nije prisutan } \\
\text { odnosno prijavljen (engl. Log). Često se koriste virtualne valute koje imaju stvarne } \\
\text { vrijednosti. Svrha im je često zabava, ali imaju i društvenu, edukacijsku te mnoge } \\
\text { druge svrhe. }\end{array}$ \\
\hline
\end{tabular}

\subsection{Važnost i ključne karakteristike društvenih medija}

Neovisno o tome koju definiciju društvenih medija smatrali polazišnom, sve imaju zajedničko to što se prema društvenim medijima odnose kao prema alatima koji olakšavaju socijalizaciju sadržaja. Isto tako, smatraju se evoluirajućim fenomenom, promjenom u načinu na koji ljudi otkrivaju, čitaju i dijele vijesti, informacije i sadržaje. To je fuzija sociologije i tehnologije, pretvarajući monolog (jedan mnogima) u dijalog (mnogi mnogima) (Malita, 2010 prema Solis, 2007). Stoga većina društvenih medija potiče suradnju, interakciju i komunikaciju kroz 
raspravu, povratne informacije, glasovanje, komentare i razmjenu informacija svih zainteresiranih strana (Malita, 2010).

Otkako su, kao sadržaj kreiran od korisnika, krajem 2006. godine proglašeni „Osobom godine“ magazina Time, društveni mediji dominiraju načinima na koji se digitalna tehnologija danas koristi širom svijeta (Selwyn, 2011).

Bradley (2010) izdvaja šest načela na kojima se temelji vrijednost društvenih medija i, u kombinaciji, služe kao ključne karakteristike koje društvene medije izdvajaju od ostalih oblika komunikacije, interakcije i suradnje:

1. Sudjelovanje - uspješni društveni medij koriste snagu masovne suradnje kroz sudjelovanje korisnika. Jedini način postizanja značajne koristi od društvenih medija je mobiliziranje zajednice kako bi dala svoj doprinos. Ne može se zabilježiti „mudrost zajednice“ ako zajednica ne sudjeluje.

2. Kolektivnost - kao temeljno načelo društvenih medija, upotreba termina „kolektiv“ usko je usklađena sa značenjem „skupiti“. Sudionici se „okupljaju“ oko objedinjujućeg entiteta odnosno oko sadržaja kako bi dali svoj doprinos, a ne kako bi pojedinačno stvorili sadržaj i distribuirali ga. Postoji mnoštvo stranica društvenih medija na kojima korisnici skupljaju informacije kako bi promijenili sadržaj i proširili ga svijetom, dijeljenjem. Nadalje, korisnici mogu koristiti pogodnosti koje nudi interoperabilnost između aplikacija za pristup informacijama koje su već pohranjene na mreži.

3. Transparentnost - pomoću društvenih medija nije dovoljno prikupiti doprinos sudionika, već pružaju transparentnost prema kojoj sudionici imaju povjerenja u sudjelovanje jedni drugih. Oni mogu vidjeti, koristiti, ponovo upotrijebiti, povećati, potvrditi, kritizirati i ocjenjivati doprinose. Bez transparentnosti ne postoji suradnja sudionika na sadržaju. Upravo u toj transparentnosti zajednica poboljšava sadržaj, objedinjuje informacije, samoupravlja se, ispravlja se, razvija, stvara pojave i na druge načine potiče vlastiti napredak.

4. Neovisnost - znači da svaki sudionik može dati svoj doprinos potpuno neovisno od bilo kojeg drugog sudionika. Koordinacija među suradnicima nije potrebna. Korisnici mogu sudjelovati bilo kada, s bilo kojeg mjesta i kad god požele. Štoviše, to je još jedna karakteristika društvenih medija povezana s ne-cenzurom, većina sadržaja slobodno i trenutačno teče internetom.

5. Postojanost - pomoću društvenih medija sadržaji sudionika trajno se bilježe da bi ih drugi mogli vidjeti, podijeliti i povećati. Sviđalo nam se to ne ili ne, digitalni su sadržaji dostupni i postojani u vremenu, kao i stečena reputacija (Malita, 2010). Čak i ako netko 
može pomisliti da ga „,nitko ne poznaje na internetu“, postoje različiti načini za pronalaženje ,izvora“. No, ljudi često ne vode računa ili ne mare dovoljno za svoju internetsku reputaciju (Malita, 2010).

6. Pojavnost - nije moguće predvidjeti, modelirati, dizajnirati i kontrolirati svu ljudsku interakciju i suradnju i optimizirati ih kao da se radi o fiksnom poslovnom procesu. Jedna od prednosti društvenih medija jest nastanak društvenih struktura. Te strukture mogu biti latentne ili skrivene organizacijske strukture, stručnost, radni procesi, organizacija sadržaja, informacijske taksonomije i još mnogo toga. Stoga, postoji i slaganje oko toga da društveni mediji nikada nisu potpuno predvidljivi ili s posve izvjesnim odnosima (Bradley, 2010).

Uz sve navedeno, kako navodi Malita (2010), dodatni jedinstveni aspekt društvenih medija jest ideja da korisnici mogu ostati spojeni ili vezani s drugim web stranicama, izvorima i ljudima. Postoji očigledan trend: biti otvoreniji za druge stranice društvenih medija, čak i iz niše istih aplikacija. Važnije je zadržati korisnike društvenih medija kako ih ne bi napustili, nego ih izgubiti u korist konkurenta. U svakom slučaju, iako su alati informacijske tehnologije za podršku suradnje, interakcije i komunikacije postojali desetljećima prije pojave web 2.0, s pojavom novih tehnologija društvenih medija, suradnja je omogućena u puno većoj mjeri i podržava korištenje snage kolektiva na načine koji su prethodno bili nedostižni (Malita, 2010). Aplikacije društvenih medija omogućuju korisnicima međusobni razgovor i interakciju; stvaranje, uređivanje i dijeljenje novih oblika tekstualnog, vizualnog i audio sadržaja; te kategoriziranje, označavanje i preporučivanje postojećih oblika sadržaja. Možda je ključna karakteristika svih tih praksi društvenih medija ona „masovne socijalizacije“ - tj. iskorištavanje snage kolektivnih akcija mrežnih zajednica korisnika, a ne pojedinačnih korisnika (Shirky, 2008).

\subsection{Područja korištenja društvenih medija u industrijskom sektoru}

Društveni mediji su široko primjenjivi za različite poslovne domene i brojne studije navode kako pojedinci sve više koriste aplikacije društvenih medija u posebne svrhe. Ngai i suradnici (2015) ističu 3 glavna industrijska sektora u kojima se koriste društveni mediji: javni sektor koji uključuje vladu i nevladine organizacije, sektor obrazovanja i komercijalni sektor. Područje primjene društvenih medija je multidisciplinarno, a uključuje područja poput marketinga, upravljanja odnosima s korisnicima, dijeljenje znanja, suradničke aktivnosti, organizacijsku 
komunikaciju, edukaciju i usavršavanje, i drugo (primjerice turizam, odnose s javnošću i medicinski sektor) te s njima povezana područja primjene (vidi Tablicu 3.).

Tablica 3. Primjena društvenih medija (izvor: izrada autorice prema Ngai i sur., 2015).

\begin{tabular}{|c|c|}
\hline Primjena društvenih medija & Povezana područja \\
\hline \multirow{5}{*}{ Marketing } & Stavovi i ponašanje korisnika \\
\hline & Komunikacija i preporuka korisnika \\
\hline & Povjerenje korisnika \\
\hline & Brendiranje \\
\hline & Upravljanje marketingom \\
\hline \multirow{3}{*}{ CRM (Upravljanje odnosima s korisnicima) } & Korisničko iskustvo \\
\hline & Kvaliteta odnosa i zadovoljstvo korisnika \\
\hline & Upravljanje znanjem korisnika i njegovanje povjerenja \\
\hline \multirow{4}{*}{$\begin{array}{l}\text { Dijeljenje znanja (među pojedincima, } \\
\text { prijateljima, obiteljima, zajednicama, } \\
\text { organizacijama) }\end{array}$} & $\begin{array}{l}\text { Motivacija za dijeljenje informacija i znanja (intrinzična } \\
\text { motivacija, zajednički ciljevi, povjerenje i sl.) }\end{array}$ \\
\hline & Profesionalne virtualne zajednice \\
\hline & Hitni slučajevi (u slučaju više sile, krize i sl.) \\
\hline & $\begin{array}{l}\text { Stavovi korisnika i njihov utjecaj na druge korisnike } \\
\text { (altruizam i reputacija dva su najveća faktora utjecaja) }\end{array}$ \\
\hline \multirow{3}{*}{ Suradničke aktivnosti } & Učenje \\
\hline & Dizajn proizvoda i projektne aktivnosti \\
\hline & Suradničko ponašanje \\
\hline \multirow{2}{*}{ Organizacijska komunikacija } & $\begin{array}{l}\text { Poboljšanje unutarnje } \\
\text { organizacijama }\end{array}$ \\
\hline & Vlada i javni sektor \\
\hline \multirow{4}{*}{ Edukacija i usavršavanje } & Pedagoška uloga \\
\hline & Nastavno okruženje \\
\hline & Razvoj kurikuluma \\
\hline & Obrazovne upute i sadržaji \\
\hline \multirow{3}{*}{ Drugo } & Turistička industrija \\
\hline & Odnosi s javnošću \\
\hline & Medicinski sektor \\
\hline
\end{tabular}




\section{KORIŠTENJE DRUŠTVENIH MEDIJA ZA POTREBE VISOKOG OBRAZOVANJA}

\subsection{Tehnologija i visoko obrazovanje}

„Uvijek precjenjujemo promjenu koja će se dogoditi u sljedeće dvije godine i podcjenjujemo promjenu koja će se dogoditi u idućih deset.“

- Bill Gates (1995)

Kao rezultat novonastalog globalizirajućeg okružja, različite društvene, ekonomske, kulturne i demografske promjene, zahtijevaju dugoročno promišljanje o položaju obrazovanja i znanosti u društvu, osobito jer kapital ljudskoga znanja u modernim društvima znači prednost u odnosu na financijski kapital. Stoga se u modernim društvima znatno povećavaju ulaganja u znanje, kako se navodi i u Strategiji obrazovanja, znanosti i tehnologije Republike Hrvatske (dalje u tekstu Strategija). U samom uvodu Strategije koju je Hrvatski sabor donio na sjednici 17. listopada 2014. godine, a koja se odnosi na period od 2016. do 2020. godine, navodi se da „Hrvatska prepoznaje obrazovanje i znanost kao svoje razvojne prioritete koji joj jedini mogu donijeti dugoročnu društvenu stabilnost, ekonomski napredak i osiguranje kulturnoga identiteta jer je suočena s dinamičnim promjenama u društvu, gospodarstvu i kulturi, u globaliziranom svijetu u kojem nijedna država ne postoji kao izdvojena zajednica, jer je suočena s izazovima poput primjena novih tehnologija, zaštite okoliša i starenja stanovništva, a koje s uspjehom može rješavati samo uz pomoć znanosti, jer ima ograničene ljudske, materijalne i prirodne resurse kojima se mora koristiti na najbolji način, jer je suočena s ograničenim mogućnostima predviđanja dugoročnog razvoja te mora biti spremna na prilagodbe. Za postizanje razine visokorazvijenih zemalja Hrvatska mora biti otvoreno, mobilno i inovativno društvo“ (Hrvatski sabor, 2014a).

U tim uvodnim odredbama već je jasno navedeno da su promjene u globaliziranom svijetu zahvaljujući razvoju novih tehnologija brze i teško predvidive, a obrazovanje može svoju ulogu u trokutu znanja; cjeloživotnom učenju, znanosti i inovacijama, trajnije ispunjavati ako rezultati istraživanja i inovacija budu primjereno utjecali na obrazovne procese. Shodno tome, obrazovna okružja moraju biti unaprijeđena poticanjem stvaralačkog razmišljanja i inovativnog djelovanja (Hrvatski sabor, 2014a). Posebno se ističe da Strategija predviđa mjere za razvoj i 
širenje e-učenja, uvođenje ekspertnih sustava za poučavanje te drugih suvremenih metoda poučavanja utemeljenih na informacijskoj i komunikacijskoj tehnologiji, čiji dinamičan razvoj i primjena korjenito mijenjaju paradigme učenja i obrazovanja, s teško predvidivim utjecajima i posljedicama na buduće načine stjecanja, prijenosa i primjene znanja, vještina, vrijednosti i stavova (Hrvatski sabor, 2014a).

Znanost i tehnologija u Republici Hrvatskoj strateški se razrađuju sukladno europskom programskom okviru za istraživanje i inovacije Obzor 2020. (European Commission, 2011). U svim dokumentima Europske unije, a posebice strategiji pametnog, održivog i uključujućeg rasta Europa 2020. (European Commission, 2010a), pridruženim stožernim inicijativama Inovacijska unija (European Commission, 2010b) i Digitalna agenda za Europu (European Commission, 2010c) te programskom okviru Obzor 2020 (European Commission, 2011), povezuju se istraživanja i inovacije i razrađuje trokut znanja između obrazovanja, istraživanja i inovacija, na čijoj osnovi treba graditi učinkovit sustav visokog obrazovanja, znanosti i tehnološkog razvoja.

Tehnološki razvoj u EU-u strateški je određen dvama dimenzijama: programskim okvirom za istraživanje i inovacije Obzor 2020. te konceptom mudre specijalizacije. Obzor 2020 sadrži tehnologiju u ključnim prioritetima, čime su ujedno definirane smjernice zajedničke europske tehnološke politike: buduće i nastajuće tehnologije uz izvrsnu znanost. Procjenjuje se da više od $10 \%$ svjetskog BDP-a ovisi o informacijskoj i komunikacijskoj tehnologiji, a internet i web ključni su za pokretanje inovacija i kreativnost u društvu i gospodarstvu. Od strateškog su značenja napredne mreže, računarstvo u oblaku s velikim mogućnostima obrade podataka te senzorski i komunikacijski uređaji za pametna umrežena okružja koja će omogućiti mnoge nove primjene i vrhunsku informacijsku infrastrukturu (Vlada Republike Hrvatske, 2013).

Nadalje, kako se navodi, E-infrastruktura je svugdje u svijetu, pa tako i u Hrvatskoj, jedna od temeljnih, de facto osnovna zajednička infrastruktura sustava znanosti i visokog obrazovanja. E-infrastruktura označava okružje u kojem znanstvenici, istraživači, studenti i drugi članovi akademske $\mathrm{i}$ istraživačke zajednice zajednički ostvaruju pristup raspodijeljenim i/ili jedinstvenim istraživačkim sredstvima kao što su skupi instrumenti, napredna računalna sredstva, komunikacije i podaci, bez obzira na vrstu i zemljopisni smještaj tih sredstava. Einfrastruktura namijenjena znanosti i povezivanju istraživača mora biti za red veličine kvalitetnija od komercijalno raspoložive. Bez napredne i razvijene e-infrastrukture sustav visokog obrazovanja i znanosti ne može uspješno ostvarivati promjene i svoju ulogu u društvu i gospodarstvu (Vlada Republike Hrvatske, 2013). 
I na kraju, nije zanemariva činjenica da je pismenost za nove medije (sposobnost kreiranja sadržaja korištenjem kanala novih medija), jedna od 10 ključnih vještina budućih diplomanata za 2020. godinu, uz pronalaženje smisla (vještina kritičkog razmišljanja), društvenu inteligenciju (sposobnost efektivnog angažiranja s ljudima), inovativno i prilagodljivo razmišljanje (sposobnost pronalaženja ideja i razmišljanja ,izvan okvira“), međukulturalnu kompetenciju (sposobnost rada u različitim kulturalnim okruženjima), računsko razmišljanje (sposobnost rada $\mathrm{s}$ velikim skupovima podataka), transdisciplinarnost (sposobnost razumijevanja koncepata kroz multidisciplinarni pristup), dizajnerski način razmišljanja (sposobnost prilagodbe radnog okruženja radi postizanja željenih rezultata), upravljanje kognitivnim opterećenjem (sposobnost filtriranja dolaznih podataka i postavljanja prioriteta na temelju dolaznih podataka), te virtualnu suradnju (sposobnost komuniciranja i izvedbe $u$ virtualnim timovima) (Drokina, 2017).

\subsection{Korištenje obrazovne tehnologije u nastavi}

„Računala su nevjerojatno brza, točna i glupa; ljudi su nevjerojatno spori, netočni i briljantni; zajedno su moćni izvan svake mašte.“ - Instrument Society of America (1969)

Različiti modeli obrazovanja nastavnika za korištenje obrazovne tehnologije tema su većeg broja istraživanja, koja reflektiraju obrazovne propise u određenim zemljama (Batarelo, 2005). Potrebno je napomenuti da se u nekim studijama koristi termin ,informacijska i komunikacijska tehnologija“, ali zbog aspekta pomoći pri učenju koji nije sadržan u terminu informacijske i komunikacijske tehnologije, u ovom radu koristi se termin „obrazovna tehnologija“ (Batarelo, 2005). No, prilikom definiranja obrazovne tehnologije pogrešno je poistovjećivati izraz „obrazovna tehnologija“ s „korištenjem medija u nastavi“ (Matijević, 2002).

Prema Batarelo (2005), u literaturi se često koristi definicija obrazovne tehnologije, formulirana od strane Udruženja za obrazovne komunikacije i tehnologiju (Association for Educational Communications and Technology - AECT, 1977), prema kojoj se obrazovna tehnologija definira kao složeni proces koji uključuje ljude, procedure, ideje, pomagala, te organizaciju za analiziranje problema, biranje pomagala, evaluaciju za različite aspekte ljudskog učenja (AECT, 1997).

Čimbenici koji utječu na uspješno korištenje obrazovne tehnologije u nastavi: 
a) stručno obrazovanje i priprema nastavnika za korištenje obrazovne tehnologije - kako su pokazala istraživanja u SAD-u, nastavnici koji se osjećaju bolje pripremljeni za uporabu tehnologije, vjerojatnije je da će je koristiti od nastavnika koji se osjećaju manje pripremljeno; b) radno okruženje nastavnika - sposobnost i spremnost nastavnika za upotrebu računala $i$ interneta može u određenoj mjeri ovisiti o školama i učionicama u kojima rade odnosno o opremi: dovoljnom broju računala, drugih obrazovnih tehnologija i multimedijskih programa te pristup internetu, kao i o dostupnoj tehničkoj podršci;

c) dovoljno vremena ostavljenog u školskom rasporedu za efektivno korištenje tehnologije;

d) vodstvo odnosno čelnici ustanova koji podržavaju najbolje prakse podučavanja i ocjenjivanja i pružaju nastavnicima smjernice za njihovo korištenje (Smerdon i sur., 2000).

Obrazovna tehnologija se ne može efektivno koristiti bez nastavnika koji poznaju tehnologiju i načine rada koji omogućavaju ostvarivanje obrazovnih ciljeva (Batarelo, 2005). Priprema budućih nastavnika za korištenje obrazovne tehnologije presudna je za djelotvorno i svrhovito korištenje novih tehnologija u nastavi, a pri kreiranju programa za obrazovanje nastavnika treba uzeti u obzir sljedeće odrednice:

a) važnost utvrđivanja jasnih zakonskih odrednica i programa za obrazovanje;

b) uvođenje kolegija iz obrazovne tehnologije u programe za obrazovanje nastavnika;

c) jače povezivanje institucija za obrazovanje nastavnika sa školama u kojima se provodi stručna praksa;

d) omogućavanje učenja budućih nastavnika putem tehnologije (Batarelo, 2005).

\subsection{Online učenje i podučavanje: najbolje prakse i teorije}

Već više od desetljeća, najbolje online pedagoške prakse u središtu su mnogih istraživanja, s obzirom na to da su i obrazovni i korporativni sektor usvojili neki oblik e-učenja, bilo u potpunosti online ili neki od hibridnih modela učenja. Za opću osnovu u dizajniranju i provođenju online učenja, navodi Hunter (2008), edukatori se pozivaju na prethodnu praksu učenja i djela Blooma (1956), Chickeringa i Ehrmanna (1987) i Gagnea i suradnika (1992).

Benjamin Bloom, američki psiholog (1913.-1999.), sudjelovao je 1956. godine u sastavljanju novog klasifikacijskog sustava kojim je u učenju izdvojio tri područja: kognitivno (obuhvaća mišljenje, znanje i rješavanje problema), psihomotoričko (manipulativne i motoričke sposobnosti) i afektivno (djeluje na razvoj trajnih vrijednosnih sustava, stavova, emocija i međuljudskih odnosa) (Dukić, 2013). 2001. godine Bloomovi suradnici Anderson i Kratwohl 
su u postojeću taksonomiju uveli još četiri dimenzije znanja (činjenično, konceptualno, proceduralno i metakognitivno) te je na taj način revidirali (Dukić, 2013). Bloom (1956) je koristio imenice, a Anderson i Kratwohl (2001) su koristili glagole. To je važno jer utječe na način na koji prikazujemo te sposobnosti kao stvari koje činimo (University of South Australia, 2020). Anderson i Kratwohl (2001) taksonomija uvodi ideju kreativnosti i stavlja je u sam vrh, kao najviši oblik učenja (Tablica 4.).

Tablica 4. Shema usporedbe dimenzija kognitivnih procesa 1956. i 2001. (izvor: izrada autorice prema Bloom, Andersen, Kratwohl, 2020).

\begin{tabular}{ll}
\hline Bloomova taksonomija & Andersen i Kratwohl revidirana taksonomija \\
\hline Evaluacija & Stvarati/Kreirati \\
Sinteza & Prosuđivati/Evaluirati \\
Analiza & Analizirati \\
Primjena & Primijeniti \\
Razumijevanje & Shvatiti/Razumjeti \\
Znanje & Zapamtiti \\
& \\
\hline
\end{tabular}

Prema Hunter (2008), mnogi kreatori poučavanja oslanjaju se na kategorizaciju učenja u intelektualne vještine, kognitivne strategije, verbalne informacije, motoričke sposobnosti i stavove Gagnea i suradnika (1992) te njihovih devet koraka u e-učenju:

(1) skretanje pažnje;

(2) upoznavanje s ishodima (ciljem);

(3) prisjećanje na prethodno naučeno gradivo učenja;

(4) prezentiranje informacija;

(5) vodstvo u učenju;

(6) aktivno sudjelovanje;

(7) pružanje povratnih informacija;

(8) provjera naučenog (ocjenjivanje);

(9) podrška transfera znanja (Jandrić, Livazović, 2013).

Sedam principa Chickeringa i Ehrmanna (1987) mogu poslužiti kao osnova svih oblika mrežnog učenja. Predstavljaju primjer dobre prakse u visokom obrazovanju, jer mrežno učenje:

(1) potiče kontakt studenata i nastavnika;

(2) razvija reciprocitet i suradnju među studentima;

(3) potiče aktivno učenje; 
(4) daje brzu povratnu informaciju;

(5) naglašava vrijeme na zadatku;

(6) komunicira visoka očekivanja; i

(7) poštuje različite talente i načine učenja (Hunter, 2008).

„Nove tehnologije mogu prenijeti visoka očekivanja eksplicitno i učinkovito. Značajni problemi iz stvarnog života, sukobljene perspektive ili paradoksalni skupovi podataka mogu postaviti snažne izazove učenja koji natjeraju studente da ne samo usvajaju informacije, već i izoštre svoje kognitivne vještine analize, sinteze, primjene i evaluacije“(Chickering, Ehrmann, 1996).

\subsection{Društveni mediji i visoko obrazovanje}

„Panta rhei.“( (Samo mijena stalna jest.“) - Heraklit

Društveni mediji utjecali su, a to čine i dalje, na društvo, na globalizaciju, na ekonomiju, na politiku, ali svakako i na znanost, kao i na obrazovanje.

Prema Thomas i Thomas (2012), u posljednja tri desetljeća došlo je do brzog rasta i razvoja na području informacijskih i komunikacijskih tehnologija (IKT; engl. ICT). Porast korištenja web 2.0 tehnologija i društvenih medija dramatično je utjecao na način na koji ljudi komuniciraju (Thomas, Thomas, 2012). Platforme društvenih medija kao što su Facebook, Twitter ili LinkedIn imaju potencijal da postanu „remetilačke tehnologije“ (engl. Disruptive Technologies) (Christensen 1997, Mutula, 2013), ali Fleck (2007), međutim, primjećuje da su dosadašnje primjene ICT-ja potaknule razvoj e-učenja više kao mehanizme potpore i neupadljive tehnologije.

Ta poboljšanja učenja obično uključuju Microsoftove Office alate (npr. Power Point), e-poštu i inovativnije aplikacije poput internetskih interaktivnih web chatova, posebnih interesnih foruma, prijenos video zapisa, elektroničkih konferencija i sustava glas-putem-internetprotokola (VoIP) kao što je npr. Skype, te programi „kombiniranog učenja“ (engl. Blended Learning) (Hawawini 2005) odnosno mješovitog učenja (koje se odnosi na pristup obrazovanju koji kombinira internetske i obrazovne materijale digitalnih medija i mogućnosti interakcije na mreži s tradicionalnim metodama utemeljenim-na-mjestu tj. u učionici te zahtijeva fizičku 
prisutnost nastavnika i studenta, uz neke elemente kontrole studenta nad vremenom, mjestom, smjerom ili tempom (Friesen, 2012, Staker, Horn, 2012, Banditvilai, 2016)).

U osnovi, kako ističu Okello-Obura i SSekitto (2015) ove tehnologije potiču fleksibilniji pristup učenju koje se odvija preko različitih „dodirnih točaka“, tj. učionice, izvan kampusa, na radnom mjestu i gotovo bilo gdje s pristupom internetu. Takav „miješani“ pristup učenju prvo se dogodio unutar područja cjeloživotnog obrazovanja na fakultetima, i globalno gledajući, mnogi akademici prihvaćaju korištenje tehnologija web 2.0 u poučavanju i učenju (Okello-Obura, Ssekitto, 2015). Brzi proboj i korištenje ovih tehnoloških platformi također je potaknuto porastom (financijski) dostupnih pametnih telefona (Mutula, 2013).

Pa kakvi su nam okviri potrebni kako bismo učenje učinili smislenim u našem svijetu stalnih promjena? Thomas i Seely Brown (2011) smatraju da nova kultura učenja zapravo sadrži dva elementa. Prvi je masivna informacijska mreža koja pruža gotovo neograničen pristup i resurse za učenje o bilo čemu. Drugi je ograničeno i strukturirano okruženje koje omogućuje neograničeno stvaranje i eksperimentiranje sa stvarima unutar tih granica. Razlog što nismo uspjeli prihvatiti ta poimanja je taj što niti jedan zasebno ne omogućuje učinkovito učenje. Upravo kombinacija to dvoje i međusobna povezanost čine novu kulturu učenja tako snažnom (Thomas, Seely Brown, 2011).

Promjene motiviraju, izazivaju i jasno pokazuju kada su stvari zastarjele ili su nadmašile svoju korisnost, ali najviše od svega, promjene prisiljavaju ljude da uče drugačije (Thomas, Seely Brown, 2011). Ljudi više ne mogu računati da će biti podučeni ili osposobljeni kako rukovati svakim novim promijenjenim alatom, medijima ili načinima na koje komuniciraju, stoga prihvatiti promjene, a ne se sustavno boriti protiv njih, znači radovati se što će uslijediti sljedeće i promatrati budućnosti kao skup novih mogućnosti, a ne kao nešto što nas prisiljava na prilagodbu (Thomas, Seely Brown, 2011). Izazov je u tome pronaći način kako spojiti strukturu prijenosa postojećeg znanja, ali i slobodu stvaranja novog.

\subsubsection{Društveni mediji i novi tipovi učenja}

„Živimo u trenutku povijesti u kojem je promjena tako ubrzana da počinjemo vidjeti sadašnjost tek kad počne iščezavati..."

- Ronald David Laing (1967) 
$\mathrm{U}$ tradicionalnom pogledu podučavanja informacije se prenose s jedne osobe (nastavnik) u drugu (student). No, taj pogled pretpostavlja postojanje znanja koje istodobno vrijedi komunicirati i nema tendenciju značajno se mijenjati s vremenom (Thomas, Seely Brown, 2011). No, kako zamjećuju Thomas i Seely Brown (2011), ironično je da upravo ta stabilnost onemogućava održavanje modela dok se svijet neprestano mijenja. U tome se nalazi glavna zamka modela poučavanja dvadeset prvog stoljeća - naime, vjerovanje da će većina onoga što znamo ostati relativno nepromijenjeno dovoljno dugo da ostane vrijedno truda potrebnog za prijenos. Svakako postoje neke ideje, činjenice i pojmovi za koje je to istina. Ali, količina nepromjenjivih resursa se smanjuje (Thomas, Seely Brown, 2011).

Glavna obrazovna implikacija društvenih medija je naizgled promjenjiva priroda odnosa studenata i informacija te znanja. Društveni mediji podržavaju oblike konzumacije i konstrukcije znanja koji se vrlo razlikuju od epistemoloških principa formalnog obrazovanja i individualizirane nastave (Selwyn, 2011). Te su promjene sadržane u opisu Thomasa i Seely Browna (2011) tehnološki poboljšane „nove kulture učenja“ - tj. učenja koje se temelji na načelima kolektivnog istraživanja, igre i inovacija, a ne na individualiziranom podučavanju. Kao što to kaže Siemens (2004), učenje se stoga može promišljati u smislu „sposobnosti znati više“" putem društvenih medija, a ne oslanjanja na pojedinačno nakupljanje prethodnih znanja u smislu „onoga što se trenutno zna“.

Naravno, ti argumenti nikako nisu novi, pojašnjava Selwyn (2011). Samuel Johnson tvrdio je 1700-ih da postoje ,dvije vrste znanja“. Znamo sam predmet ili znamo gdje možemo pronaći informacije o njemu. Međutim, opisi poput „konektivizma“ odražavaju rastuću vjeru nastavnika da se temeljne vještine učenja u doba prožetim društvenim medijima mijenjaju. Stoga, naglasak koji institucije visokog obrazovanja stavljaju na podršku studentima da pasivno čuvaju informacije možda je manje važan od podržavanja vještina pristupa i aktivnog korištenja informacija pohranjenih na drugom mjestu kada je to potrebno (Selwyn, 2011). U tom pogledu, trenutni oblici visokog obrazovanja se ne slažu s pojmovima kao što su tehnološki zasnovana kolektivna ili fluidna inteligencija i ,produkorištenje“ (engl. Produsage) (proizvodnja / korištenje) znanja - tj. ,gdje znanje ostaje uvijek u procesu razvoja, i gdje informacije uvijek ostaju nedovršene, proširive i razvijaju se“ (Selwyn, 2011 prema Bruns, 2008).

To ne znači da se visoko obrazovanje ne može prilagoditi tim promjenama i imati koristi od njih (Selwyn, 2011). Zapravo, mnogi nastavnici vjeruju da su visoka učilišta u dobrom položaju da koriste prakse društvenih medija kako bi podržali kolektivno stvaranje znanja među studentima i široj zajednici (Moskaliuk i sur., 2009). Mnoga visoka učilišta sada nastoje razviti načine korištenja društvenih medija kako bi podržali ove nove oblike učenja (Conole, Alevizou, 
2010). Iako se ove promjene mogu vidjeti kao potpuno korisne, neki komentatori ostaju sumnjičavi - posebno u pogledu potencijalnog smanjenja intelektualnih sposobnosti studenata (Selwyn, 2011). I dalje se izražava zabrinutost zbog intelektualnog zaglupljivanja i smanjenja vještina povezano s korištenjem društvenih medija za pristup informacijama i znanju (Selwyn, 2011). Carr, na primjer, tvrdi da ono što doživljavamo jest, u metaforičkom smislu, preokret ranog puta civilizacije odnosno da se korisnici društvenih medija razvijaju od kultivatora osobnog znanja u lovce i sakupljače u šumi elektroničkih podataka. U tom se procesu čini da smo sudbinski žrtvovali velik dio onoga što čini naš um tako zanimljivim (Carr, 2010). Slične teme pokrenuli su i kritičari poput Keena (2007), koji ne samo da navodi da internet ubija našu ekonomiju, kulturu i vrijednosti, već opominje „mlađu generaciju intelektualnih kleptomana“. Iako se rijetko temelje na snažnim istraživačkim dokazima, takvi su se argumenti pokazali nevjerojatno popularnima - čak i među samim studentima (Selwyn, 2011).

Omotani smo u ,oblak sveprisutnih digitalnih informacija u kojem se znanje ne nalazi nego stvara i autoritet se neprekidno pregovara kroz diskusiju i sudjelovanje“ (Wesch, 2008), kako su to slikovito opisali Okello-Obura i Ssekitto (2015), a web 2.0 alati daju korisniku/studentu snagu jer se oslanjaju na sadržaj koji je generirao korisnik i na interaktivnost (O'Reilly 2005). To znači da studenti imaju kontrolu nad sadržajem i nad izborom onoga što će biti sačuvano i što se odbacuje (Jordan 2012). Greenhow, Robelia i Hughes (2009) primjećuju: „Znanje je decentralizirano, dostupno i rekonstruirano među širokom bazom korisnika“. Web 2.0 omogućuje studentima da sudjeluju u ovom oblaku, kroz pet glavnih karakteristika, suradnju, kreativnost, komunikaciju, zajedništvo i kontrolu (Hicks i Graber 2010).

Kao što je napomenuo Tyagi (2012), korištenje web 2.0 alata pruža mogućnost ugradnje personaliziranih, skalabilnih i prilagodljivih sustava. Nastavnik opremljen za ekonomiju znanja mora biti pripremljen kako se nositi s nejasnoćama, mora biti prilagodljiv, visoko mobilan, poduzetan i kreativan (Tyagi 2012). Vjerojatno je da će svaka obrazovna praksa koja se odnosi na razigrane, izražajne, reflektivne ili istraživačke aspekte izgradnje znanja, u web 2.0 alatima i uslugama pronaći snažan resurs (Rice 2011, Mutula 2013).

\subsection{Svrha korištenja društvenih medija za potrebe visokog obrazovanja}

„Srce web 2.0 tehnologija su korisnici...Alati osnažuju, ali ljudi čine.“

- $\quad$ Susan Mernit (2006) 
Lepeza društvenih medija omogućavaju veoma širok dijapazon mogućih svrhovitih načina korištenja, a uz to one se neprestano povećavaju i generiraju nove mogućnosti korištenja. Neke moguće svrhe navedene su u tablici koja slijedi (Tablica 5.).

Tablica 5. Svrhe korištenja društvenih medija u visokom obrazovanju (izvor: izrada autorice, 2020).

\begin{tabular}{|c|c|}
\hline $\begin{array}{l}\text { Svrha korištenja društvenih } \\
\text { medija u visokom obrazovanju }\end{array}$ & Područja primjene \\
\hline OPĆA INFORMIRANOST & $\begin{array}{l}\text { - } \quad \text { Općenita informiranost. } \\
\text { - } \quad \text { Za ažuriranje predstojećih i prošlih događaja. } \\
\text { - } \quad \text { Praćenje događaja u stvarnom vremenu. } \\
\text { - } \quad \text { Dijeljenje prezentacija o posebnim događajima. } \\
\text { inermacija koje se tiču studija. }\end{array}$ \\
\hline ORGANIZACIJA & $\begin{array}{l}\text { - } \quad \text { Organizaciju sastanaka. } \\
\text { - } \quad \text { Organizacija događaja. } \\
\text { - } \quad \text { Osobnu organizaciju studenata i osoblja visokih učilišta. } \\
\text { Zastave. }\end{array}$ \\
\hline MARKETING & $\begin{array}{l}\text { - } \quad \text { Privlačenje novih studenata. } \\
\text { - } \quad \text { Promoviranje visokog učilišta. } \\
\text { Promoviranje kvalitete i izvrsnosti. }\end{array}$ \\
\hline NASTAVA & $\begin{array}{l}\text { - } \quad \text { Prezentacija nastavih sadržaja. } \\
\text { - } \quad \text { Informiranje studenata o kolegijima. } \\
\text { - } \quad \text { Informiranje studenata o nastavnoj literaturi. } \\
\text { Inje studenata o ispitima. }\end{array}$ \\
\hline ISTRAŽIVAČKI RAD & $\begin{array}{l}\text { - } \quad \text { Istraživačke svrhe. } \\
\text { - } \quad \text { Za pronalazak izvora i reference. } \\
\text { - } \quad \text { U objavu časopisa. } \\
\text { - } \quad \text { praćenje metrike. } \\
\text { - } \quad \text { Objava stručnih ili znanstvenih radova sa studentima. } \\
\quad \text { kolegama nastavnicima. } \\
\text { - Za konferencije ili kao dio prezentacija. }\end{array}$ \\
\hline PROJEKTNI RAD & $\begin{array}{l}\text { - Olakšavanje projektnog rada. } \\
\text { - } \quad \text { Poticanje rada na projektima. } \\
\text { Za radionice. }\end{array}$ \\
\hline PODRŠKA STUDENTIMA & $\begin{array}{ll}\text { - } & \text { Pružaju podršku studentima van studija. } \\
\text { - } & \text { Savjetovanje o osobnom razvoju studenata. } \\
\text { - } & \text { Radionice o financijskoj pomoći i stipendijama. } \\
\text { - } & \text { Podrška radi zadržavanja studenata. } \\
& \text { Povećavanje zadovoljstva studenata. }\end{array}$ \\
\hline POMOĆ U UČENJU & $\begin{array}{l}\text { - } \quad \text { Poticanje aktivnog učenja. } \\
\text { - } \quad \text { Poštovanje različitih talenata i načina učenja. } \\
\text { - } \quad \text { Radionice o lakšem učenju. } \\
\text { - } \quad \text { Za pobolionice o mentalnom mapiranju. } \\
\text { znanost, tehnologija, pismenost, okoliš, humanizam, } \\
\text { STEAM te ostalih nastavnih područja i tema. } \\
\text { - } \quad \text { adahnjivanje pisanja i kreativnosti. } \\
\text { - Združivanje aplikacija na društvenim medijima. }\end{array}$ \\
\hline IZGRADNJA ZAJEDNICE & $\begin{array}{l}\text { - } \quad \text { Povećanje pozornosti studenata. } \\
\text { - } \quad \text { Poticanje veza između studenata i visokih učilišta. } \\
\text { - } \quad \text { Omoljšanje komunikacije između visokih učilišta i studenata. } \\
\text { - } \quad \text { Izgradnja i jačanje zajednice u kampusu. } \\
\text { - } \quad \text { Stvaranje i održavanje osobnih okruženja za učenje itd. }\end{array}$ \\
\hline
\end{tabular}


- Povećavanje osjećaja pripadnosti studenata koji studiraju online.

- Korištenje za podršku nekog događanja, podršku tima i zajednice.

STVARANJE VEZA SA ŠIROM

- Poticanje studenata u sudjelovanju u aktivnostima šire zajednice.

ZAJEDNICOM

- Pohvale postignuća i uspjeha studenata.

- Pohvale postignuća nastavnika.

ODRŽAVANJE VEZE S - Održavanje veza s alumnima.

ALUMNIMA - Povezivanje upisanih studenata s alumnima.

$\begin{array}{lll}\text { PROFESIONALNA ORIJENTACIJA } & \text { - } & \text { Informiranje studenata o praksi. } \\ & \text { Dijeljenje materijala za profesionalni razvoj. }\end{array}$

\subsection{Modeli integracije društvenih medija u visoko obrazovanje}

Klaster društvenih medija omogućuje, osim visokim učilištima i nastavnicima, također i studentima sudjelovanje u raspravama, suradnji, istraživanju, stvaranju, otkrivanju i dizajniranju. Ovisno o vrsti društvenih medija, mogućnosti integracije društvenih medija u visoko obrazovanje su brojne i višestruke (Tablica 6.).

Tablica 6. Modeli integracije društvenih medija u visoko obrazovanje prema tipovima društvenih medija (izvor: izrada autorice, prilagođeno prema Grosseck, 2009 i Cobbs, 2008).

\begin{tabular}{|c|c|}
\hline Društveni mediji & Moguća obrazovna primjena \\
\hline Blogovi & $\begin{array}{l}\text { - } \quad \text { Korištenje blogova za iskustvo pisanja o stvarnom svijetu. } \\
\text { - } \quad \text { Grupiranje klase blogova u jedno zajedničko područje za lakše praćenje. } \\
\text { - } \quad \text { drugima. } \\
\text { - } \quad \text { Studenti mogu koristiti vršnjačke mreže za razvoj vlastitog znanja. } \\
\text { Pomoću komentara u blogovima nastavnici mogu potaknuti studente da } \\
\text { pomažu jedni drugima u pisanju i dobiti odgovore na pitanja bez } \\
\text { dobivanja istog odgovora dvadeset puta itd. }\end{array}$ \\
\hline Dijeljenje fotografija & $\begin{array}{l}\text { - Dijeljenje, komentiranje i dodavanje bilješki fotografijama ili slikama } \\
\text { koje će se koristiti u učionici. } \\
\text { Nadahnjivanje pisanja i kreativnosti; stvaranja prezentacije pomoću } \\
\text { fotografija. } \\
\text { Pronalaženje fotografija područja i događaja širom svijeta pomoću } \\
\text { oznaka za korištenje u učionici. } \\
\text { Postavljanje studentskih prezentacija autentičnoj publici i dobivanje } \\
\text { povratnih informacija iz cijelog svijeta. } \\
\text { Dijeljenje materijala za profesionalni razvoj i mogućnost pristupa na } \\
\text { bilo kojem mjestu i u bilo kojem trenutku; dijeljenje prezentacija o } \\
\text { posebnim događajima. }\end{array}$ \\
\hline Dijeljenje videozapisa & $\begin{array}{l}\text { - Za profesionalni razvoj videozapisa pod vlastitim uvjetima; stvaranje } \\
\text { vlastitog videozapise sa studentima. } \\
\text { - Korištenje web mjesta za dijeljenje videozapisa, za pronalaženje } \\
\text { videozapisa o trenutačnim problemima itd. } \\
\text { - Za ažuriranje događaja, praćenje događaja u stvarnom vremenu. }\end{array}$ \\
\hline Društvene igre & - $\quad$ Korištenje za debate i rasprave u učionici. \\
\hline
\end{tabular}


- Za poboljšanje znanja i vještina iz područja kao što su znanost, tehnologija, pismenost, okoliš, humanizam, STEAM te ostalih nastavnih područja i tema.

- Za upravljanje projektima.

Društveno knjižno

označavanje

Društvene mreže poduzeća

Mikroblogovi projekti

Virtualni svjetovi

Drugi alati društvenih medija
- Za procjenu mišljenja

- Za konferencije ili kao dio prezentacija ili radionica.

- Za reference ili istraživanje.

- Korištenje za podršku nekog događanja, podršku tima i zajednice.

- Združivanje aplikacija na društvenim medijima

- Stvaranje i održavanje osobnih okruženja za učenje itd.

- Korištenje kao prezentacijskog alata (kao e-portfelje).

- Upravljanje dokumentima visokog učilišta i učionice.

- Korištenje kao kolaborativnog materijala za studente; pisanje: knjige i časopise stvorene za studente.

- Stvaranje i održavanje studentskih često postavljanih pitanja (engl. FAQ).

- Ažuriranje novih informacija, kao što su domaće zadaće i zadaci.

- Mjesto za objedinjavanje web resursa; potporni odbori, radne skupine i sveučilišni projekti itd.

- Za profesionalni razvoj, uštedu vremena; ažurirane informacije o nastavnom području.

- Za informacije koje dolaze iz ograničavajućih izvora; dijeljenje rada s drugim nastavnicima.

- Mogu potencijalno smanjiti preopterećenje e-pošte.

- Mogu se koristiti za održavanje specifičnih web stranica aktualnima i relevantnima itd.

- Stvaranje zajednice u učionici, istraživanje suradničkog pisanja, za odgovore čitatelja, suradnju s drugim visokim učilištima, državama, platforme za metakogniciju, stvaranje iskustva učenja, stvaranje mreže za osobno učenje.

- Korištenje za širenje nastavničkih publikacija i materijala, pronalaženje izvornih ideja, citata, omogućava vrlo fokusirane i konkretne povratne informacije studentima kako bi pročistili svoje razmišljanje i poboljšali svoje vještine, neformalna istraživanja, za pripovijedanje (engl. Storytelling), dobili povratne informacije o idejama, izgradili povjerenje, izgradili zajednicu itd.

- Profesionalni razvoj.

- Praćenje profesionalaca i tvrtki.

- Njegovanje profesionalnih veza.

- Korištenje za studentske projekte.

- Za suradnju na idejama.

- Organiziranje dokumenata i resursa od pojedinaca i grupe studenata.

- Korištenje kao grupnog istraživačkog projekta za određenu ideju.

- Mogu se koristiti za virtualne konferencije i seminare, sastanke tima $\mathrm{i}$ prostore za suradnju, simulacije, olakšavanje virtualne rasprave $u$ učionici itd.

- Trenutačno slanje poruka povećava osjećaj zajedništva i pristupačnosti koji su potrebni za suradničko učenje.

- Glasovna komunikacija korištenjem internet protokola (engl. VoIP) pomaže promicati međunarodnu suradnju i razumijevanje.

- Kalendari bilježe kalendarske događaje, domaće zadaće.

- Ankete i upitnici, mrežni dijagrami i web-procesori za obradu teksta, online proračunske tablice, društveno pretraživanje, izrada mentalnih mapa.

- Sve što korisnici žele dostupno je osim na računalima i tabletima, na mobilnim uređajima povezanim na internet. 


\subsection{Mogućnosti i izazovi korištenja društvenih medija u visokom obrazovanju}

Društveni mediji učinili su svijet manjim mjestom, saželi su Raut i Patil (2016); sada ljudi imaju više informacija, više znanja i veće mogućnosti njihovog korištenja. Poboljšali su sposobnosti apsorpcije informacija, koje bi ljudima samo prije 20 godina bile previše za svladati i pomoću njih omogućena je ekstremna lakoća njihove obrade, a osim što olakšavaju naše obrazovanje i poslovanje, i talenti se otkrivaju brže (Raut, Patil, 2016).

Jasno je da postoje razlozi za, ali i protiv korištenja društvenih medija za potrebe visokog obrazovanja. Kako bismo dobili dublji uvid u društvene medije, važno je istaknuti njihove prednosti (Tablica 7.).

Tablica 7. Prednosti korištenja društvenih medija u visokom obrazovanju (izvor: izrada autorice, prilagođeno prema Grosseck, 2009; Mabić, 2014; Raut, Patil, 2016).

\section{Prednosti korištenja društvenih medija u visokom obrazovanju}

- Besplatan pristup (nekim društvenim medijima)

- Smanjenje troškova

- Fleksibilnost što se tiče odabira tehnologija

- Neobavezan pristup

- Lakši i brži pristup informacijama, kada i gdje je to potrebno

- Mogućnost integracije raznih web 2.0 tehnologija u aktivnosti učenja i poučavanja

- Mogućnost kontrole pristupa putem autentifikacije korisnika

- Dijeljenje ideja, iskustava i izvora

- Neovisnost od pojedine platforme (npr. računala, dostupnost već uz pristup internetu i preglednik)

- Kompatibilnost s područjima obrazovanja

- Niska razina složenosti upotrebe (potrebne minimalne vještine)

- Pouzdanost u kontinuiranom korištenju tijekom duljeg vremenskog razdoblja

- Manje vremena potrebno za pretraživanje i upravljanje informacijama

- Manje napora potrebno za pretraživanje i upravljanje informacijama

- Povećanje načina učenja zbog raznolikosti novih tehnologija

- Mogućnost testiranja postojećih modela poučavanja

- Fokus na inovacijama u učenju, ne na samoj tehnologiji

- Mogućnost stvaranja digitalnog sadržaja

- Marketing i oglašavanje

- Regrutacija novih studenata

- Održavanje postojećih kontakata i veza

- Stjecanje informatičkog obrazovanja

- Mogućnost stjecanja novih poznanstava

- Praćenje aktualnih tema

- Podržavanje postojećih ili novih poslova

- Dijeljenje fotografija i videozapisa

- Jačanje motivacije kroz interakciju s drugim korisnicima

- Jačanje samopouzdanja kroz interakciju s drugim korisnicima

- Jačanje veza sa širom lokalnom zajednicom

- Jačanje veza s ljudima diljem svijeta/međunarodnom zajednicom

- Brze povratne reakcije 
Kao jedan od primarnih negativnih utjecaja društvenih medija navodi se ovisnost i konstantno provjeravanje novosti na društvenim medijima, što može imati negativan utjecaj na druge aktivnosti koje se tiču studiranja, ali ne samo studiranja već i u (ne)bavljenju sportom, komunikaciju uživo i ignoriranju stvarnog života (Raut, Patil, 2016). Stoga je jednako važno voditi računa o nedostacima korištenja društvenih medija u visokom obrazovanju (Tablica 8).

Tablica 8. Nedostaci korištenja društvenih medija u visokom obrazovanju (izvor: izrada autorice, prilagođeno prema Grosseck, 2009; Mabić, 2014; Raut, Patil, 2016).

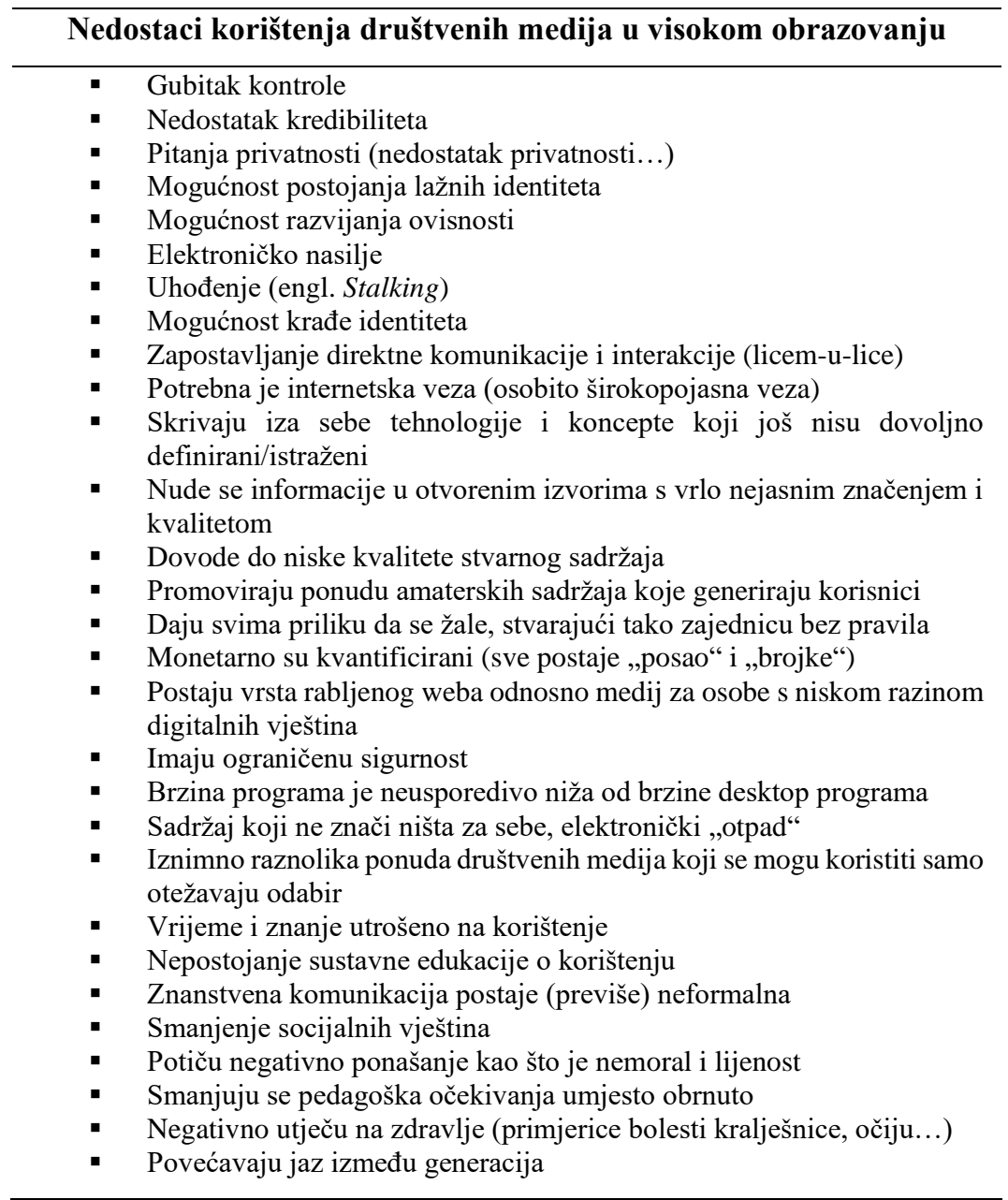

\subsection{Nadzor nad korištenjem društvenih medija u visokom obrazovanju}

Zabrinutost visokih učilišta, osim već navedenih mogućih negativnih utjecaja društvenih medija, temelji se i na sljedećim mogućim okolnostima (Reuben, 2008): 
- Gubitak kontrole - društveni mediji omogućuju upisanim studentima da dijele svoja fakultetska iskustva, time direktno utječu na privlačenje i upis budućih studenata, kao što je to primjerice putem blogiranja (Reuben, 2008 Johnson, 2007). Isto tako, otvaranje mogućnosti za pisanje komentara kako bi se omogućio dvosmjerni dijalog, savršen je primjer gubitka kontrole (Reuben, 2008). Iako negativnost sama po sebi ne nestaje, samo zato što joj onemogućimo sudjelovanje. U najmanju ruku, može se reći da su negativni komentari prilika za promjenu percepcije za koju su visoka učilišta ili znala ili nisu znala da postoje (Solis, 2008b). Uz to, internet sadržaj više nije moguće ukloniti - on je u potpunosti integriran u sve elemente poslovanja i društva (Li, Bernoff, 2008), stoga je moguće prikupiti negativne primjedbe ili povratne informacije. Ipak, većina ovih alata donosi više koristi nego što štete, i iako možda nije moguće kontrolirati objave ili u potpunosti kontrolirati percepciju, visoka učilišta mogu ih usmjeriti ako su dio razgovora. Mogu pomoći u uklanjanju zabluda i promicati željene, istinske pozitivne povratne informacije, što je neprocjenjivo za potencijalne studente (Reuben, 2008). Korisnici društvenih mreža na mreži imaju tri puta veće povjerenje u mišljenje svojih vršnjaka o oglašavanju prilikom donošenja odluka (Reuben, 2008 prema Juniper Research 2007).

- Vremenska obveza - mnogi profesionalci u visokom obrazovanju bave se radnim opterećenjem, obavljaju više uloga, i bore se za opstanak. Bavljenje društvenim medijima može postati vremenski intenzivno. Mora postojati strateški razlog i plan za korištenje društvenih medija; svoju web lokaciju važno je ažurirati najmanje jednom tjedno i moći će se svakodnevno moderirati komentari. Za to je obično potrebno potrošiti od 1-10 sati tjedno ako se društveni mediji upotrebljavaju kao dio marketinške strategije (Reuben, 2008).

- Preopterećenje informacijama - prije nekoliko godina menadžeri su se zabrinuli zbog nedostatka produktivnosti zbog vremena koje su članovi osoblja provodili u pisanju trenutačnih poruka za osobnu upotrebu, no tada su ih savjetnici za upise i studentsko osoblje počeli koristiti kao dio svojih poslova za komunikaciju s potencijalnim studentima. Zbog pojave mnogih novih aplikacija društvenih medija, lako je moguće osjetiti preopterećenost kada pokušavaju biti ukorak s ,tradicionalnim medijima“, poput e-pošte, tiskanih publikacija i trenutnih poruka (Reuben, 2008).

- Svatko može stvoriti (lažni) „službeni““ račun za visoko učilište - visoka učilišta trebaju pretražiti stranice društvenih medija kako bi provjerili što se pojavljuje. Ako još ne postoji službeni profil visokog učilišta bilo bi uputno stvoriti ga kako bi barem 
rezervirali ime visokog učilišta na onim alatima koje još nisu spremni koristiti. Ukoliko ne rezerviraju svoje ime, moguće je da će to učiniti netko drugi - bilo da se radi o članu osoblja s dobrim namjerama ili o nezadovoljnom studentu, a aplikacije društvenih medija ne rade pozadinske provjere pojedinaca koji žele stvoriti korisnički račun s imenom visokog učilišta (Reuben, 2008).

\subsubsection{Načela o profesionalnom ponašanju u visokom obrazovanju}

Etički kodeks definira se kao skup načela o profesionalnom ponašanju. Ako se postavi pitanje je li etički kodeks potreba ili hir?, postaje jasno da etički kodeks koji nije od struke definiran niti zakonom usvojen, ostavlja previše prostora za rasprave oko smjernica i naputaka djelovanja, a premalo za preuzimanje odgovornosti za posljedice tog djelovanja (Vivodinac, 2010).

No, čak i kad kodeks postoji, i bio on definiran kao etički te kao skup principa i načela kojima se profesija vodi, problem je što se vrlo teško provodi u praksi, jer su mnogi puta profesionalni principi u koliziji s načelima javne politike ili zakona, ili ne postoje odgovarajući mehanizmi kojima bi se na adekvatan način moglo sankcionirati neodgovorno ponašanje članova kao što je npr. povreda nečije privatnosti, kršenje zakona o autorskom pravu, otuđenje građe i slično, a isto tako postoji i dihotomija između profesionalnih i osobnih uvjerenja članova na koje se odnosi (Vivodinac, 2010).

Etički kodeks visokih učilišta skup je normi ponašanja koje sadržavaju moralna načela i načela profesionalne etike kojima se $\mathrm{u}$ svom profesionalnom i javnom djelovanju trebaju ravnati studenti, nastavnici i drugi zaposlenici na visokom učilištu. Njime su definirana temeljna prava i slobode studenata i zaposlenih, temeljne obveze studenata i zaposlenih, što se smatra neprihvatljivim ponašanjem, etička pravila u nastavnom procesu obvezuju nastavnike $\mathrm{i}$ zaposlenike, kao i etička pravila stručnog i znanstvenog rada te odredbe o sastavu i postupku pred etičkim povjerenstvom koje daje svoje mišljenje o ostvarivanju načela i pravila etičkog kodeksa te o usklađenosti ponašanja osoba na koje se on odnosi (Visoko učilište Algebra, 2018a).

Najšire rečeno, s obzirom na to da je cilj visokih učilišta svojim ukupnim radom doprinositi ostvarenju nacionalnih interesa, razvoju gospodarstva i društva u cjelini kroz profesionalni napredak i izgradnju svojih nastavnika, zaposlenika i studenata, etičkim kodeksom nastoje se istaknuti vrijednosti koje će se poticati kroz svaku aktivnost visokog učilišta; istinoljubivost, 
nepristranost, jednakost prilike, slobodna i razborita rasprava, otvorenost prema konstruktivnim promjenama, osobno dostojanstvo, poštovanje prava svih pojedinaca i trajna izgradnja izvrsnosti, a u svrhu usmjeravanja svih napora, sredstava i mogućnosti u izgradnju i osiguranje uvjeta za intelektualni, osobni, društveni i etički razvoj zaposlenika i studenata.

No, čak niti odredbama etičkog kodeksa nije moguće sasvim obuhvatiti sva neprihvatljiva i neželjena ponašanja koja se tiču odnosa prema visokim učilištima, nastavnom i nenastavnom osoblju, drugim studentima, kao i prema samima sebi (kao što je primjerice konzumacija opojnih sredstava) te akademske čestitosti, stoga neka visoka učilišta donose i kodekse ponašanja studenata (Visoko učilište Algebra, 2018b).

\subsubsection{Akademska čestitost}

Akademska čestitost, kako ju definira Etički kodeks Sveučilišta u Rijeci (2018), podrazumijeva odgovornost svih članova/ica akademske zajednice ,za svoje riječi i postupke, primjenu primjerenih istraživačkih metoda i za postignute rezultate“. Smatra se osnovnom vrijednošću akademske zajednice i njenim kršenjem ugrožava se kvaliteta obrazovanja i obezvređuje istinska postignuća članova/ica akademske zajednice tj. čini se akademsko nepoštenje (Studentski zbor Sveučilišta u Rijeci, 2020).

Neki od oblika akademskog nepoštenja uključuju, ali nisu ograničeni samo na:

1. bilo koju vrstu prijevare vezane za postupak prijavljivanja, ispitivanja ili provjere znanja

2. plagiranje i krivotvorenje radova ili dijelova radova drugih osoba te iznošenje ideja drugih osoba kao vlastitih, bez znanja autora ili navođenja izvora (Studentski zbor Sveučilišta u Rijeci, 2020).

Najčešće se za oblike akademskog nepoštenja, koje se definiraju kao teške povrede obaveza studenata i koje ugrožavaju obrazovne i znanstvene procese te narušavaju ugled ustanove, predviđaju stegovne mjere. One mogu biti lakše kao što su zabrane polaganje ispita pa sve do težih koje predviđaju privremeno (do godinu dana) ili trajno isključenje sa studija.

Važnost znanstvene čestitosti možda se najjasnije očituje kroz stav dr. sc. Irene Zrinski Antonac: „Snaga pojedine društvene zajednice sve se više procjenjuje upravo spram znanja i znanosti, tako najutjecajnije i visoko razvijene postaju zajednice usmjerene prema znanju i razvoju znanosti. Ljepota i vrijednost znanosti počiva i u činjenici kako je ona univerzalna, globalna, pripada čovječanstvu u cjelini te doprinosi općoj dobrobiti u svagdašnjem životu. Pritom uvijek treba istaknuti kako upravo znanstvenici moraju biti oni koji će u 
društvenom poretku promicati i isticati najviše etičke norme kao jedine prihvatljive, jer na njima počiva njihov rad, povjerenje zajednice i njezina dobrobit“ (Nacionalni repozitorij završnih i diplomskih radova ZIR, 2015).

\subsubsection{Regulacija korištenja društvenih medija za potrebe visokog obrazovanja}

Pokazuje se u praksi, kao i u istraživanjima (Willems, Adachi, Grevtseva, 2016, Willems i sur., 2018), da je područje društvenih medija u visokom obrazovanju teško podložno nadzoru navedenih vrijednosti, bilo u pravnom, profesionalnom ili moralnom smislu.

Sa stajališta visokoškolskih ustanova, promjene u korištenju tehnologije mogu prouzročiti poremećaj statusa quo, a sami društveni mediji promatraju se kao remeteća tehnologija (engl. Disruptive Technology) dok se istodobno sve više koriste, te na taj način postaju dominantna tehnologija (Willems, Adachi, Grevtseva, 2016 prema Flavin, 2012). Za upravljanje društvenim medijima potrebne su institucionalne politike, definirane kao „formalni zakoni, propisi, pravila i smjernice koje upravljaju ustanovama“ (Willems, Adachi, Grevtseva, 2016 prema Johnson i sur., 2016). Te politike pak mogu promovirati ili ubrzati usvajanje i korištenje određenih tehnologija za učenje (Willems, Adachi, Grevtseva, 2016 prema Johnson i sur., 2016) ili ih blokirati (Willems, Adachi, Grevtseva, 2016). Isto tako je moguće da „postojeće institucionalne politike i procedure mogu biti kontradiktorne s obzirom na to da promoviraju jedan aspekt korištenja društvenih medija, ali odvraćaju drugi“, jer su nastale prije postojanja i jačanja ovih tehnologija, ili pak ih nisu s dužnom pažnjom uzele u obzir, ,što uzrokuje zbrku u tumačenju vladajućih politika u različitim kontekstima ili pak institucionalna politika može biti jasna, ali je korisnici mogu namjerno ili slučajno previdjeti“ (Willems, Adachi, Grevtseva, 2016).

Visokoobrazovne institucije uglavnom nemaju definirane i uspostavljene jasne i lako razumljive politike korištenja društvenih medija, prema kojima bi se moglo upravljati korištenjem društvenih medija za potrebe visokog obrazovanja. Stoga, čak i u slučajevima u kojima su nastavnici prihvatili korištenje društvenih medija u pedagoške svrhe, za svoj profesionalni razvoj ili razvoj medijske pismenosti ili pak same ustanove, koriste društvene medije za izgradnju digitalne prepoznatljivosti i identiteta, i dalje ostaju otvorena pitanja kao što su:

1. Kako visoka učilišta mogu održavati kontrolu nad komercijalno utemeljenim tehnologijama?;

2. Kako se mogu zaštititi od parnica?; 
3. Kako mogu štititi kršenje privatnosti njihovih studenata?;

4. Kako mogu upravljati novim tehnologijama kad ne mogu predvidjeti njihove posljedice?;

5. Kako mogu financirati potrebno upravljanje promjenama povezano s uvođenjem nove tehnologije? (Willems i sur., 2018 prema Stahl i sur., 2016).

Visoka učilišta već se susreću s izazovima razmatranja utjecaja institucionalnog zaostajanja, stalnog profesionalnog razvoj osoblja, razvijanja medijske pismenosti kao ključne kompetencije studenata $u$ digitalnom svijetu i procjenjivanja temeljnih pedagogija (Willems i sur., 2018). Akademske politike trebale bi biti jasne i izravne kako ne bi bile dodatna prepreka za korištenje društvenih medija u visokom obrazovanju te podržavati razvoj načina koji će pomoći u njegovanju i iskorištavanju prednosti korištenja društvenih medija za potrebe visokog obrazovanja, umjesto da podržavaju i potencijalno obeshrabruju korištenje društvenih medija za potrebe visokog obrazovanja (Willems i sur., 2018).

Tablica 9. Primjeri politika visokih učilišta u Republici Hrvatskoj koje potencijalno obeshrabruju korištenje društvenih medija za potrebe visokog obrazovanja (izvor: izrada autorice, prilagođeno prema Willems i sur., 2018)

POLITIKA UPRAVLJANJA INTELEKTUALNIM

\section{VLASNIŠTVOM}

(navedeni su primjeri za Sveučilište u Zagrebu prema Knešaurek, I., Matanović Vučković, R., Petrović, V., Sučić, T. (2015))
(2) Student se obvezuje obavijesti o intelektualnim tvorevinama i podacima uputiti sastavnici u pisanom obliku na obrascu kojeg odredi sastavnica najkasnije u roku od xx dana od dana završetka istraživanja, stvaranja autorskog djela, predmeta srodnih prava, dizajna i predmeta koji se štite pravima industrijskog vlasništva.

(4) Student se obvezuje zajedno s obavijesti iz točke 2. ove izjave i bez posebne naknade ponuditi sastavnici stjecanje prava na intelektualnim tvorevinama koje se štite industrijskim vlasništvom (izumi, tehnička unaprjeđenja, znanje i iskustvo, oznake razlikovanja, oznake podrijetla i kakvoće i sl.) i podacima koja su potrebna za njihovu registraciju i/ili komercijalno iskorištavanje.

(7) Student se obvezuje da će do ostvarenja točke 5. i 6. iz ove izjave čuvati predmetne intelektualne tvorevine i podatke kao tajnu te ih ni na koji način neće objaviti trećim osobama ili javnosti.

(8) Student se obvezuje da će na zahtjev sastavnice predati sve materijale, alate, sredstva i druge predmete koji su potrebni za komercijalno iskorištavanje predmetnih intelektualnih tvorevina i podataka.

(9) Student ovlašćuje sastavnicu, sveučilište i druge sastavnice da se koriste intelektualnim tvorevinama i podacima u svrhu daljnjeg istraživanja te u obrazovne i znanstvene svrhe, u svakom slučaju.

(10) Student je suglasan da se njegov završni/diplomski/magistarski/doktorski ili slični radovi objave u cijelosti ili dijelu, bez naknade, na internet stranici sastavnice $\mathrm{i} /$ ili sveučilišta u svrhu informiranja javnosti i/ili promocije sastavnice $\mathrm{i} / \mathrm{ili}$ sveučilišta. 


\section{PROCEDURE KORIŠTENJA INFORMACIJSKIH I KOMUNIKACIJSKIH TEHNOLOGIJA}

(navedeni primjer iz Pravilnika o studiranju na Akademiji primijenjenih umjetnosti, Sveučilište u Rijeci (2018))

(11) Student bez posebne naknade za sastavnicu osniva sljedeća prava iskorištavanja autorskih djela, predmeta srodnih prava odnosno dizajna iz točke 1. ove izjave: pravo reproduciranja, distribuiranja, priopćavanja javnosti (što uključuje i stavljanje na raspolaganje javnosti putem interneta) i pravo prerade. Navedena prava se osnivaju kao ne/isključiva, bez vremenskog i prostornog ograničenja. Ako je riječ o dizajnu, sastavnica stječe pravo registrirati dizajn na svoje ime kao industrijski dizajn te sva tome pripadajuća prava. Dobitak koji se ostvari od komercijalnog iskorištavanja autorskih djela, predmeta srodnih prava odnosno dizajna iz točke 1 . ove izjave pripada sastavnici koja ga je dužna utrošiti na unaprjeđenje svoje djelatnosti te stvaranje novih autorskih djela, predmeta srodnih prava odnosno dizajna.

Članak. 22.

Student ima obvezu poštovati režim studija i opće akte Sveučilišta i Akademije te uredno izvršavati svoje nastavne i druge studentske obveze, a posebno: ...

- $\quad$ koristiti vlastiti elektronički identitet i službenu email adresu dobivenu od strane Studentske službe Akademije.

\section{Članak 5.}

Stegovna djela su:

\section{POLITIKA MEDIJA}

(navedeni je primjer iz Pravilnika o stegovnoj odgovornosti nastavnika i suradnika Sveučilišta u Rijeci (2018))
(16) neovlašteni istupi $\mathrm{u}$ javnosti $\mathrm{u}$ ime Poslodavca (Sveučilišta ili sastavnice), istupi u javnosti u kojima se iznose netočne informacije o radu i poslovanju Poslodavca (Sveučilišta ili sastavnice) ili predstavljanje osobnih stavova kao službenih stavova Poslodavca (Sveučilišta ili sastavnice, uključujući neovlašteno korištenje imena ili logotipa Sveučilišta ili sastavnice kako bi se stvorio dojam sveučilišnog autoriteta)...

\section{Članak 4}

(1) Fakultet osobne podatke obrađuje zakonito, pošteno i transparentno s obzirom na ispitanike i njihova prava.

(2) Fakultet obrađuje samo primjerene i relevantne osobne podatke $i$ to isključivo u posebne, izričite i zakonite svrhe te se dalje ne obrađuju na način koji nije u skladu s tim svrhama.

(3) Osobni podaci koje Fakultet obrađuje su točni te se po potrebi ažuriraju. Osobni podaci koji nisu točni bez odlaganja se brišu ili ispravljaju.

(4) Fakultet osobne podatke čuva u obliku koji omogućuje identifikaciju ispitanika $\mathrm{i}$ to samo onoliko dugo koliko je potrebno u svrhe radi kojih se osobni podaci obrađuju. Iznimno, osobni podaci mogu se pohraniti i na dulja razdoblja, ali samo ako će se isti obrađivati isključivo u svrhe arhiviranja u javnom interesu, u svrhe znanstvenog ili povijesnog istraživanja ili u statističke svrhe.

(5) Fakultet osobne podatke obrađuje isključivo na način kojim se osigurava odgovarajuća sigurnost osobnih podataka, uključujući zaštitu od neovlaštene ili nezakonite obrade te od slučajnog gubitka, uništenja ili oštećenja primjenom odgovarajućih tehničkih ili organizacijskih mjera.

Članak 5

Fakultet osobne podatke obrađuje samo ako i u onoj mjeri u kojoj je ispunjen najmanje jedan od sljedećih uvjeta:

(1) da je ispitanik dao privolu za obradu svojih osobnih podataka u jednu ili više posebnih svrha; 
(2) da je obrada nužna za izvršavanje ugovora u kojem je ispitanik stranka ili kako bi se poduzele radnje na zahtjev ispitanika prije sklapanja ugovora;

(3) da je obrada nužna radi poštovanja pravnih obveza Fakulteta;

(4) da je obrada nužna kako bi se zaštitili interesi ispitanika ili druge fizičke osobe;

(5) da je obrada nužna za izvršavanje zadaće od javnog interesa ili pri izvršavanju službenih ovlasti Fakulteta;

(6) da je obrada nužna za potrebe legitimnih interesa Fakulteta ili treće strane, osim u slučaju kada su od tih interesa jači interesi ili temeljna prava i slobode ispitanika koji zahtijevaju zaštitu osobnih podataka.

Članak 6.

(1) Kada se obrada temelji na privoli, Fakultet mora moći dokazati da je ispitanik dao privolu za obradu svojih osobnih podataka.

(2) Privola kojom ispitanik Fakultetu daje pristanak za obradu osobnih podataka koji se na njega odnose mora biti dobrovoljna, dana u obliku pisane izjave, u razumljivom i lako dostupnom obliku, uz upotrebu jasnog i jednostavnog jezika te u njoj ne bi smjelo biti nedopuštenih uvjeta.

(3) Ne može se smatrati da je privola dana dobrovoljno ako ispitanik nema istinski ili slobodan izbor ili ako nije u mogućnosti odbiti ili povući privolu bez posljedica.

(4) Ispitanik ima pravo u svakom trenutku povući svoju privolu, a povlačenje privole mora biti jednako jednostavno kao i njezino davanje.

(5) Povlačenje privole ne utječe na zakonitost obrade podataka na temelju privole prije njezina povlačenja.

Iako je definiranje institucionalnih politika koje podržavaju prednosti, a ne podržavaju nedostatke korištenja društvenih medija za potrebe visokog obrazovanja (vidi Tablicu 9.), izuzetno složeno, ne samo radi opsežnosti uvjeta koje trebaju obuhvatiti u području samih ustanova, već i zbog toga što društveni mediji zahtijevaju registraciju svojih korisnika te prihvaćanje njihovih uvjeta korištenja, koji izlaze izvan nadležnosti visokih učilišta i njihovih institucionalnih politika (Willems, Adachi, Grevtseva, 2016).

No, postoje pomaci u ustavljanju politika koje se konkretno tiču korištenja društvenih medija za potrebe visokog obrazovanja, pa je primjerice Udruženje informatičkih sustava sveučilišta i koledža u Velikoj Britaniji osmislilo priručnik za korištenje društvenih medija (Willems i sur., 2018 prema Universities and Colleges Information Systems Association in the United Kingdom, 2015) koji se može koristiti kao referentna točka u razvoju društvenih medija za učenje i poučavanje te praktičan vodič u postizanju prednosti i upravljanju rizicima korištenja društvenih medija za potrebe visokog obrazovanja (Universities and Colleges Information Systems Association in the United Kingdom, 2015). Primjeri politika visokih učilišta $u$ Republici Hrvatskoj koje potencijalno ohrabruju korištenje društvenih medija za potrebe visokog obrazovanja prikazani su u Tablici 10. 
Tablica 10. Primjeri politika visokih učilišta u Republici Hrvatskoj koje potencijalno ohrabruju korištenje društvenih medija za potrebe visokog obrazovanja (izvor: izrada autorice, prilagođeno prema Willems i sur.,

\section{POLITIKA MEDIJA}

*(navedeni su primjeri iz Statuta Sveučilišta u Splitu (2009))

** (navedeni je primjer iz Strategije Sveučilišta Josipa Jurja Strossmayera u Osijeku 2011.-2020. (2011))

*** (navedeni je primjer iz Strategije razvoja Sveučilišta u Zadru 2017.-2022. (2017))

\section{Članak 2.}

(2) Visoko obrazovanje i znanstvena djelatnost na Sveučilištu temelji se na akademskim slobodama, akademskoj samoupravi i autonomiji Sveučilišta i sastavnica, u skladu s Ustavom, međunarodnim ugovorima i Zakonom.

(3) Članovi sveučilišne akademske zajednice su svi nastavnici, znanstvenici, suradnici, studenti i drugi sudionici u procesu visokog obrazovanja.

(4) Akademske slobode pripadaju svim članovima akademske zajednice, a obuhvaćaju slobodu znanstvenog i umjetničkog istraživanja i stvaralaštva, poučavanja, međusobne suradnje i udruživanja.*

\section{II.2. Mogućnosti}

(5) Bolja promidžba aktivnosti, unaprijediti suradnju s medijima.**

Mjera 1.2.2. Unaprjeđenje internetske $\mathrm{i}$ intranetske mreže

Cilj ove mjere jest unaprjeđenje postojeće informacijskokomunikacijske infrastrukture te njezin daljnji razvoj sa svrhom dodatnog unaprjeđenja rada studenata i nastavnika na Sveučilištu u Zadru, omogućavanje lakšeg pristupa informacijama vezanim za rad Sveučilišta, primjerenije promoviranje odrađenih $\mathrm{i} / \mathrm{ili}$ planiranih aktivnosti te formiranje prikladnog informacijsko-elektroničkog identiteta Sveučilišta. Pod pitanjem internetske mreže naglasak se stavlja na jasno definiranje online vizualnog identiteta Sveučilišta, utvrđivanje neophodnih informacija dostupnih javnosti te osiguravanje jednostavne dostupnosti istih. Pod pitanjem intranetske mreže naglasak se stavlja na razvijanje zasebne platforme koja će služiti kao komunikacijski medij za sve djelatnike i studente Sveučilišta, kao izvor trenutnih i općih informacija vezanih za rad samog Sveučilišta te aktivnosti koje se na njemu odvijaju. $* * *$

\section{Obavijest za studente o elektroničkoj pošti i Google Suite usluzi}

Svi studenti našeg Sveučilišta od danas imaju mogućnost korištenja aplikacija iz alata Google Suite. Prije svega Google Suite koristimo za primanje i slanje e-pošte, vođenje dijeljenih i osobnih kalendara, e-učenje i grupni rad. Svim studentima omogućeno je korištenje e-pošte na domeni student.unipu.hr, a koristi se za svu službenu komunikaciju unutar Sveučilišta. Studenti su dužni, u komunikaciji s nastavnicima i službama Sveučilišta, koristiti se računom epošte na domeni student.unipu.hr, a nastavnici i djelatnici nisu dužni uzimati u obzir poruke poslane s drugih adresa e-pošte. Sve obavijesti uprava Sveučilišta i sastavnica Sveučilišta, odnosno zajedničkih službi, dostavljat će se na adrese studenata na domeni student.unipu.hr.

\section{POLITIKA NASTAVE I UČENJA (KOLEGIJI NA VISOKIM UČILIŠTIMA)}

\section{Razvojna projekcija}

Uvođenje obrazovnoga pristupa u kojem je student u središtu procesa i ima aktivnu ulogu, te kurikuluma koji se temelji na ishodima učenja koji su široko postavljeni kako bi ostavili prostora kreativnosti nastavnika i studenata, nije moguće bez 


\footnotetext{
* (navedeni je primjer iz Strategije studija i studiranja Sveučilišta u Zagrebu (2014.-2025.) (2014))

** (navedeni je primjer iz Strategije razvoja Sveučilišta u Dubrovniku 2016.-2025. (2016))

***(navedeni su primjeri iz Strategije Sveučilišta Josipa

Jurja Strossmayera u Osijeku 2011.-2020. (2011))

***** (navedeni je primjer iz Strategije 2015-2020

Sveučilišta u Splitu (2015))
}

opredijeljenosti nastavnika za takav pristup, pa poseban naglasak treba staviti na podizanje svijesti kod nastavnika o nužnosti promjene pristupa nastavi kao i sustavnoj edukaciji o mogućim konkretnim načinima primjene ovih pristupa. Preduvjet za motiviranoga studenta jest motivirani nastavnik. Sveučilište treba ulagati i osiguravati kreativno i motivirajuće okruženje, kako za razvoj studenta tako i za razvoj nastavnika, uz odgovarajuće poticajne mehanizme. Sastavni dio obrazovnoga procesa jest i sveučilišno virtualno okruženje za učenje i poučavanje u kojem se teži da u 2015. svaki kolegij ima svoju e-inačicu na 2. razini primjene tehnologija e-učenja. Sukladno tome potrebno je uvesti postupak recenzije e-kolegija koji uz tehničku i sadržajnu recenziju treba sadržavati i recenziju vezanu uz metodiku ekolegija.*

Sveučilište u Dubrovniku postavlja zadatke:

1.3.2. Svim svojim nastavnicima i studentima treba osiguravati jednaku mogućnost pristupa resursima za učenje na daljinu i e-učenje.

Vremenski okvir: kontinuirano.

Nositelj(i) aktivnosti: prorektor za studije i studente, pročelnici odjelâ.**

\section{III.5.2. Informacijski i komunikacijski susta}

Sveučilište Josipa Jurja Strossmayera u Osijeku aktivno je uključeno u procese informatizacije i uvođenje suvremenih informatičkih tehnologija u različite aspekte djelovanja kako bi se uspješno uključilo u suvremeno informacijsko društvo - društvo znanja. Primjena suvremenih informatičkih tehnologija podrazumijeva kvalitetnu informatičku infrastrukturu, koja će omogućiti primjenu novih tehnologija $\mathrm{u}$ istraživanju i nastavi. Stoga je Sveučilište u Osijeku izgradilo temeljnu informatičku kabelsku mrežu (DTK) koja će biti dugoročna osnovica povezivanja informatičke opreme unutar prostora sveučilišnog Campusa. Uvođenje novih informacijskih tehnologija omogućeno je suradnjom s Hrvatskom akademskom i istraživačkom mrežom CARNet, pri čemu je uspostavljen novi CARNet centar u prostoru Campusa, i koji je opremljen najsuvremenijom opremom za potrebe Sveučilišta.

$\cdots$

E-učenje

Elektroničko učenje ili e-učenje (engl. Electronic learning, E-learning) je opći naziv za učenje potpomognuto računalom. E-učenje je u širem smislu izvođenje obrazovnog procesa uz pomoć informacijsko-komunikacijske tehnologije. Takav obrazovni proces može biti nastava na daljinu u kojoj nastavnik i polaznici nisu fizički na istome mjestu (npr. online kolegiji ili videokonferencijsko predavanje na daljinu), ali može biti i obogaćivanje nastave u učionici (npr. korištenjem interneta, digitalnim prezentacijama ili multimedijalnim materijalima).

Sveučilište će u sljedećem strateškom razdoblju unaprjeđivati postojeće sustave E-učenja te poticati uvođenje novih metoda i alata za elektroničko i udaljeno učenje.***

\section{STRATEŠKI CILJ 2.}

Sveučilište u Splitu osmišljava i izvodi programe cjeloživotnog učenja te učenja na daljinu.

Zadatak

(2) Povećati postotak nastavnog sadržaja kojeg studenti mogu pratiti kroz e-učenje.

Ciljna vrijednost

Svi kolegiji svakog studijskog programa su pokriveni barem $25 \%$ nastavnim sadržajima e-učenja. $* * * *$ 


\section{POLITIKA NASTAVE NA DALJINU / ONLINE \\ NASTAVE (tijekom Covid-19 pandemije 2020.)}

* (navedeni je primjer iz obavijesti za studente Alati servisi za nastavu na daljinu objavljenoj na web stranici Sveučilišta u Zagrebu (2020))

** (navedeni je primjer iz obavijesti za studente Upute za provođenje nastave na daljinu objavljenoj na web stranici Sveučilišta Sjever (2020))

*** (navedeni je primjer iz Smjernica za učenje i rad na daljinu Fakulteta građevinarstva, arhitekture i geodezije u Splitu, Sveučilište u Splitu (2020))

\section{Alati i servisi za nastavu na daljinu}

$\mathrm{Za}$ potrebe izvođenja nastave na daljinu Sveučilište $u$ Zagrebu izradilo je niz video poduka (uputa) koje opisuju kako uspostaviti asinkroni i sinkroni model izvođenja nastave. Poseban naglasak stavljen je na mogućnost izravne dvosmjerne komunikacije sa studentima. Prikazana je i tehnologija koja se može upotrebljavati za sastanke nastavnika, poslovodnih kolegija, ustrojbenih jedinica, zavoda ili katedri. Ove video poduke namijenjene su kao neobvezna preporuka prije svega profesorima i nastavnicima Sveučilišta u Zagrebu, ali i svim ostalim zainteresiranim djelatnicima i institucijama obrazovnog sustava...*

\section{Online nastava}

Za potrebe izvođenja nastave na daljinu izrađeno je niz video poduka (uputa) koje opisuju kako uspostaviti asinkroni i sinkroni model izvođenja nastave. Poseban naglasak stavljen je na mogućnost izravne dvosmjerne komunikacije sa studentima. Prikazana je i tehnologija koja se može upotrebljavati za sastanke nastavnika, poslovodnih kolegija, ustrojbenih jedinica, zavoda ili katedri.

Ove video poduke namijenjene su kao neobvezna preporuka svim profesorima i nastavnicima Sveučilišta Sjever...**

Smjernice za učenje $i$ rad na daljinu Fakulteta građevinarstva, arhitekture i geodezije u Splitu

Ovim Smjernicama za učenje i rad na daljinu definiraju se svrha, obuhvat, raspoloživi resursi (ljudski, organizacijski i administrativni, infrastrukturni i tehnički), podrška dionicima u nastavnom procesu, opisivanje predmeta $\mathrm{i}$ provjera znanja tijekom implementacije i provedbe učenja i rada na daljinu Fakulteta građevinarstva, arhitekture i geodezije u Splitu (dalje: Fakulteta), a radi svladavanja posebnih uvjeta u kojima se nalazi ili se može naći Fakultet.***

\subsection{Komunikacijska paradigma u visokom obrazovanju pod utjecajem društvenih medija}

U suvremenom društvu, u kojem se društveni mediji naglo razvijaju, zadatak koji se nastoji postići definiranjem komunikacijske paradigme u visokom obrazovanju putem društvenih medija jest obuhvaćanje složenih komunikacijskih procesa koji se tiču onih koji tvore i upravljaju komunikacijskim procesom (Lasswellov „tko“) odnosno ,analizom upravljanja“; elemenata obavijesnog sklopa (Lasswellov „,̌to“) odnosno ,analizom sadržaja“; svojstava društvenih medija (Lasswellov „kojim kanalom“) odnosno ,,analizom medija“; osoba koje su u dohvatu društvenih medija (Lasswellov „kome“) odnosno „,analizi priomaoca, publike“; te posljedica komunikacijskog procesa (Lasswellov „s kojim učinkom“) odnosno „,analizi učinka“ (Martinić, 1985 prema Lasswell, 1948). S obzirom na to, očito je da postoji više elemenata komunikacijske paradigme u visokom obrazovanju pod utjecajem društvenih medija koji mogu biti fokus istraživačkog područja. Međutim, iako su i u ovom radu u svrhu razgraničavanja 
komunikacijskog procesa pojedini aspekti iznesene paradigme pojedinačno cjelovitije sagledani, važno je ne izgubiti iz vida cjelinu samog fenomena (Martinić, 1985 prema Lasswell, 1948).

Efikasnost komunikacijskog procesa u visokom obrazovanju putem društvenih medija potrebno je odrediti „racionalnim prosuđivanjem kojim se postavljaju u suodnos ciljevi i vrijednosti““, vodeći pritom računa da postoje „mnogostruki činioci efikasne komunikacije, od medijskih mogućnosti, do ljudskih sposobnosti““ (Martinić, 1985 prema Lasswell, 1948). Tako se, primjerice, obavijesni tokovi u visokom obrazovanju putem društvenih medija mogu poremetiti jer nastavno i nenastavno „osoblje koje skuplja i odašilje informacije nije dovoljno kvalificirano, te neprestano iskrivljuje i zanemaruje određene činjenice“, ili pak „nepoznavanje novih tehničkih mogućnosti sprečava da se ne samo proširi dijapazon obavijesnog dohvata, nego i da se sadržajno obogati komunikacijski proces“ (Martinić, 1985 prema Lasswell, 1948). Stoga je neophodno, da bi se dobila točna slika o protočnosti informacija, pomno ispitivati sve značajne činioce u obavijesnom lancu, i svatko tko ispunjava neku ulogu u prijenosu obavijesti, od njezina ulaska do izlaska, treba biti objektom u proučavanju komunikacijskog čina (Martinić, 1985 prema Lasswell, 1948). No, za razliku od Lasswellove paradigme, prema kojoj je „odnos između 'tko' i 'kome' odnos pošiljaoca i primaoca poruke, relacija između onoga tko dominira i onoga koji mu se podređuje, stručnjaka i nestručnjaka, a recipijent, primalac, uzima se gotovo kao neispunjen prostor, koji se popunjava njemu pridodanim oblicima“ (Martinić, 1985 prema Lasswell, 1948), u komunikacijskom procesu u visokom obrazovanju putem društvenih medija, važno je naglasiti da se recipijenti odnosno studenti, u „obrazovanju usmjerenom na studenta“, koje osim što obuhvaća metode poučavanja koje usmjeravaju fokus poučavanja s nastavnika na studenta, ima za cilj razviti autonomiju i neovisnost studenata (Jones, 2007), ne mogu više promatrati kao „neispunjeni prostor“ i kao pasivni akteri, a isto tako niti kao nestručnjaci u digitalnom okruženju i oni koji se podređuju u komunikacijskom činu. 


\section{DOSADAŠNJA ISTRAŽIVANJA KOMUNIKACIJSKE PARADIGME PUTEM DRUŠTVENIH MEDIJA ZA POTREBE VISOKOG OBRAZOVANJA}

\subsection{Studenti na društvenim medijima}

„Učitelji otvaraju vrata, ali ući moraš sam.“

- Kineska poslovica

Douglas Adams (2002) opisao je naš odnos prema tehnologijama kroz 3 pravila:

„1. Sve što postoji na svijetu kada se rodiš, normalno je i obično.

2. Sve što nastane kada imaš između 15 i 35 godina je novo i uzbudljivo i vjerojatno ćeš pronaći karijeru u tome.

3. Sve što nastaje nakon toga je 'neprirodno' (protivno prirodnom poretku stvari).“

Studenti koji danas studiraju pripadnici su generacija koje su za vrijeme svog odrastanja počela i virtualni život na društvenim medijima ili čak i ne poznaju svijet u kojem ne postoje internet (Bauman, 2010), računala, mobiteli i društveni mediji.

Istraživanja o utjecajima društvenih medija provode se u svim područjima ljudskog djelovanja, stoga akademsko okruženje nije izuzetak. Najčešće se bave aktivnostima studenata na društvenim medijima (Vivian i sur., 2014; Echeng i sur., 2016) potvrđujući da:

- predstavljaju novi tip studenata;

- uče na nove načine (Selwyn, 2011) i

- njihove su vrijednosti često u koliziji s tradicionalnim vrijednostima visokih učilišta (Ulbrich i sur., 2011).

Selwyn (2011) ističe kako je neposredni značaj društvenih medija za visoko obrazovanje naizgled promjenjiva priroda studenata koji upisuju fakultet. U praktičnom smislu, vidi se da povezane, kolektivne i kreativne kvalitete aplikacija društvenih medija odražavaju (i donekle pokreću) fleksibilnije, fluidnije i ubrzane načine postojanja. Društveni su mediji stoga povezani s povećanom tendencijom da mladi danas imaju sposobnost istodobnoga obavljanja više poslova ili zadataka (engl. Multitasking) i da se oslanjaju na „digitalno žongliranje“ dnevnih aktivnosti i obveza (Subrahmanyam i Šmahel, 2011).

Ove tehnologije su također povezane s pojačanom društvenom autonomijom - s mladim ljudima koji su navikli da imaju povećanu kontrolu nad prirodom i oblikom onoga što rade, kao i gdje, 
kada i kako to rade, stoga se korisnici društvenih medija opisuju da imaju pojačane kapacitete za samoorganiziranje i zarađivanje za sebe (Selwyn, 2011). Kao što nastavljaju Tapscott i Williams (2007), ti mladi ljudi „nisu zadovoljni time da budu pasivni potrošači i sve više zadovoljavaju svoju želju za izborom, udobnošću, prilagodbom i kontrolom kroz dizajniranje, proizvodnju i distribuciju samih proizvoda“".

Uz navedeno, zanemaruje se činjenica da se današnji studenti, iako dolaze u visoko obrazovanje $\mathrm{s}$ bogatim iskustvom u korištenju društvenih medija (Wankel, 2009) i sami se moraju nositi s novim tehnologijama i često konfliktnim promjenama okruženja. Nove generacije studenata postavile su nove zahtjeve, jer su digitalno pismeni, uvijek povezani s internetom i društvenim medijima. Oni reagiraju brzo i rješavaju više zadataka odjednom, preferiraju eksperimentalni radni pristup, komunikativni su i trebaju prilagođeno učenje i radno okruženje (Ras, Rech, 2009).

Dosadašnja istraživanja, ističu Mungofa i Peter (2015), pokazuju da uključivanje društvenih medija u učenje i podučavanje može donijeti nove načine istraživanja, komunikacije, suradnje, razvoja znanja; ali pored toga može imati negativne ili pozitivne kognitivne, socijalne i emocionalne utjecaje (Gao i sur., 2012; Greenhow, Burton, 2011; Pimmeri sur., 2012; Ranieri, i sur., 2012).

Isto tako, prema rezultatima dosadašnjih istraživanja izgledno je da studenti koriste društvene medije na mnogo načina tijekom studija kako bi pojačali svoje obrazovne aktivnosti i povećali svoj akademski uspjeh. Zachos i suradnici (2018) su dali pregled istraživanja korištenja društvenih medija za potrebe visokog obrazovanja, a koja se tiču studentske strane, kroz aspekte „podrške studentima, povećanja kvalitete obrazovnoga procesa, akademskog uspjeha studenata te komunikacije i suradnje“, kako slijedi.

\subsubsection{Podrška studentima}

Neke studije još nastoje istražiti učinkovitost obrazovnih programa kada se izvode u okruženjima sličnim društvenim mrežama (Cuellar i sur., 2011; Tuncay i sur., 2011; Teng, Lin, 2013), dok su druge (Ellison i sur., 2007; Madge i sur., 2009; Yu i sur., 2010) ustvrdile da je prilagođavanje sveučilišnoj kulturi već nesmetano postignuto. Gray i suradnici (2013) su, na temelju provedene studije, istaknuli da društvena interakcija putem društvenih mreža ,pomaže studentima da se osjećaju povezano s fakultetom, što može naknadno povećati vjerojatnost da će ustrajati u studiranju i nakon svoje prve godine“. U istraživanju koje su proveli Forkosh- 
Baruch i Hershkovitz (2012) nekoliko je sveučilišta u Izraelu otvorilo korisničke račune na društvenim medijima zahvaljujući čemu je stvorena mreža podrške za neformalno učenje i rezultati koji se odnose na širenje znanja bili su prilično ohrabrujući.

Nadalje, Tower i sur. (2014) proučavali su utjecaj društvenih mreža na samopoštovanje studenata. Uočili su poboljšanu učinkovitost studenata i naveli da su društveni mediji postali važno potporno sredstvo u njihovim procesima učenja. Zaključili su da „društveni mediji mogu podržati studente da razviju dublju razinu znanja“ (Tower i sur., 2014). U Madhusudhanovoj studiji (2012) provedenoj u Indiji pokazalo se da studenti više vole koristiti društvene medije u svoje istraživačke svrhe (kao alate koji mogu olakšati njihovo istraživanje). Slično mišljenje iznijeli su i studenti farmakologije sa sveučilišta u Bostonu (Camiel i sur., 2014), koji su Twitter prepoznali kao alat koji može olakšati rast vlastite mreže učenja nazvane „mreža za osobno učenje“ odnosno ,zbirke resursa koju pojedinci koriste kako bi povećali svoje znanje i uključili se u svoje vlastito učenje“".

\subsubsection{Povećanje kvalitete obrazovnoga procesa}

Studije Wodzickija i sur. (2012), Manasijevića i sur. (2016) i Cookea (2017) pokazale su da društveni mediji stvaraju nove perspektive u procesu stjecanja znanja na način da web-lokacije na društvenim mrežama omogućuju studentima sudjelovanje u formalnim (npr. proučavanju materijala za kolegije) i neformalnim (npr. pretraživanje korisnih informacija) uvjetima učenja. Studenti mogu surađivati s ljudima koji imaju sličan način razmišljanja i razmjenjivati znanja na neformalni način (npr. razmjena obrazovnih iskustava) u obrazovne svrhe (Greenhow i sur., 2009; Madge i sur., 2009; Cheung i sur., 2011). Na primjer, studenti prve godine mogu dobiti sve potrebne informacije o svom fakultetu kroz komunikaciju sa starijim kolegama, što može pomoći da se naviknu na svoj novi akademski život i kako bi bolje organizirali svoj novi život (Wodzicki i sur., 2012).

Slično tome, Hussain (2012) je primijetio da je dijeljenje iskustava učenja između studenata putem društvenih medija povezano s razvojem virtualne zajednice širom svijeta. Lewis i sur. (2010) nazivali su ih „suradničkim zajednicama za izgradnju znanja“. Osim toga, studija koja je provedena u Maleziji pokazala je da studenti smatraju Facebook vrijednim i važnim alatom koji bi mogao podržati i poboljšati njihove jezične vještine na engleskom jeziku (Kabilan i sur., 2010). Rezultati istraživanja provedenog u Australiji (Waycott i sur., 2013), u kojem su predavači od studenata tražili da izrade i distribuiraju svoj rad koristeći društvene mreže, 
pokazali su da omogućavanje transparentnosti radova studenata putem društvenih mreža stvara nove perspektive u učenju, ali može stvoriti i zabrinutost studenata zbog mogućeg kopiranja i osjećaj nezaštićenosti. Autori su zaključili da je potrebno „razmotriti stavove studenata i daljnje ispitivanje središnjih pitanja koja se tiču učinkovitog korištenja tehnologija društvenih mreža u visokom obrazovanju“ (Waycott i sur., 2013). Međutim, Mohamad (2011) sugerira da svaki primjer korištenja Facebooka u obrazovnom procesu povećava motivaciju i razumijevanje studenata.

\subsubsection{Akademski uspjeh studenata}

Sve navedene studije, ističu pozitivne utjecaje korištenja društvenih medija za podršku i nadogradnju obrazovnih procesa, paralelno s uspješnim rezultatima obrazovanja. One istražuju područja na koja društveni mediji mogu utjecati (npr. suradničko učenje, komunikaciju, akademsku kulturu itd.) i podržavaju da društveni mediji mogu stvoriti učinkovitije obrazovno okruženje i povećati (ili se očekuje da će povećati) obrazovnu uspješnost (Mazer i sur., 2007). Manje studija (Maqableh i sur., 2015, Lee i sur., 2017) spominje pozitivne utjecaje korištenja društvenih medija na akademski uspjeh studenata.

Međutim, čini se da u bibliografiji nedostaju mjerljivi akademski rezultati. Na primjer, koliko dugo student koristi društvene medije i koji akademski uspjeh postiže zahvaljujući tome nije zabilježeno. Neke studije čak su rezervirane prema pozitivnim učincima društvenih medija u visokom obrazovanju (Waycott i sur., 2013), dok druge predstavljaju negativne učinke na „akademski uspjeh“ studenata (Kirschner, Karpinski, 2010, Paul i sur., 2012). Paul i sur. (2012) navode da ,akademska uspješnost funkcija je raspona pozornosti, vještina upravljanja vremenom, osobnih karakteristika studenata i akademske sposobnosti“" te su otkrili statistički značajnu negativnu vezu između akademske uspješnosti studenata i vremena koje provode na društvenim medijima. Čini se da se Junco (2015) dijelom slaže s ovom tvrdnjom, jer tvrdi da je „vrijeme provedeno na Facebooku bilo značajan negativan prediktor prosjeka ocjena (engl. GPA) novih studenata, ali ne prosjeka ocjena ostalih studenata“. Prosjek ocjena (engl. GPA) jedina je metoda koja se u literaturi koristi za mjerenje rezultata i akademskog uspjeha studenata na fakultetima (Kirschner, Karpinski, 2010, Junco, 2012, Junco, 2015)

Michikyan i sur. (2015) tvrde da postoji i obrnuti odnos; to jest, da bi akademski uspjeh mogao dati procjenu razine aktivnosti na Facebooku. Njihovo istraživanje pokazuje da studenti koji mogu imati poteškoća za vrijeme studija i koji mogu imati slabiji uspjeh (kao što to ukazuje 
niži prosjek ocjena) koriste društvene mreže za dobivanje podrške. Michikyan i sur. (2015) također su naveli da je aktivnost korisnika (na Facebooku) važnija od vremena koje provode na društvenim mrežama. Međutim, nije zabilježena značajna veza između vremena korištenja Facebooka i akademskog uspjeha (Pasek i sur., 2009, Michikyan i sur., 2015).U skladu s navedenim, Rosen i sur. (2013) istraživali su distrakcije kod studenata, otkrivši da su niske performanse (prosjek ocjena) primijećene tijekom korištenja društvenih mreža u obrazovne svrhe. Kako bi se smanjile distrakcije, preporučili su male dizajnirane „tehnološke pauze“ da bi se povećala koncentracija studenata.

Studenti pak žele koristiti društvene mreže za vrijeme studiranja (Rosmala, Rosmala, 2012), čak i ako se to smatra neučinkovitim (Brooks, 2015). Prema rezultatima studije (Rosmala, Rosmala, 2012), studenti i predavači koriste besplatni (internetski) pristup tijekom akademskog vremena, ne samo za zabavu, već i za komunikaciju, predviđanje stavova i znanja, kao i za podupiranje nastavnih aktivnosti. Kako proizlazi iz njihovog rada, nije ključno donošenje odluke o implementaciji ograničenog pristupa na web mjesta društvenih medija, već pronalazak učinkovitog načina na koji će se koristiti svi uključeni dionici (Rosmala, Rosmala, 2012). Konačno, Paul i sur. (2012) naglasili su da, čak i ako su studenti potpuno uvjereni da društveni mediji poboljšavaju njihove obrazovne mogućnosti, oni ipak ne koriste rado društvene medije, ali očekuju da nastavnici to čine.

\subsubsection{Komunikacija i suradnja studenata}

Kao što je spomenuto, postoje sukobljena stajališta o društvenim medijima i pozitivnog utjecaja na akademski uspjeh studenata (Zachos i sur., 2018). No Zachos i sur. (2018) navode da, s druge strane, postoji širi konsenzus oko njihovog doprinosa u komunikaciji i suradnji između pružatelja obrazovanja.

Prvo, čini se da je (računalno posredovana) komunikacija, bilo putem korištenja tradicionalnijih načina informacijske računalne tehnologije (IKT, engl. ICT) (npr. e-pošta i razmjena trenutnih poruka) ili društvenih medija (moderniji način), neovisna o prethodnoj digitalnoj pismenosti korisnika kako se naziva u literaturi, a definira se kao jednostavnost korištenja elektroničkih uređaja (pametnih telefona, računala itd.) (Eshet-Alkalai, 2004), kao i o značajkama njihovih korisničkih profila (Vrocharidou, Efthymiou, 2012).

Međutim, samo nekoliko godina ranije bilo je predstavljano da prijašnje korištenje računala za komunikaciju s drugim korisnicima pomaže u lakšem svladavanju novih računalnih sustava 
učenja. Posebno su Cho i suradnici (2007) tvrdili da studenti koji koriste društvene medije imaju veću fleksibilnost u korištenju računalnih sustava učenja (računalno podržano suradničko učenje, engl. Computer-Supported Collaborative Learning, kratica CSCL).

Na ovaj ili onaj način, većina se istraživanja slaže da društvene mreže i alati društvenih medija i općenito platforme poboljšavaju suradnju studenata općenito (Mazer i sur., 2007, Munoz, 2009, Roblyer i sur., 2010, Visagie, de Villiers, 2010). Nadalje, Madhusudhan (2012) je na temelju studije provedene među studentskom populacijom u Indiji dokazao prednosti zajedničkog učenja putem korištenja društvenih medija, a rezultati istraživanja provedenog na sveučilištu u Pakistanu, pokazali su da je upotreba Facebooka dovoljno korisna za njihove akademske aktivnosti, posebno za razmjenu informacija s kolegama iz inozemstva (Hussain, 2012). Nadalje, LaRueovo istraživanje (2012) u SAD-u također je pokazalo kako društvene mreže pomažu u učenju-baziranom-na-grupi (engl. Group-Based Learning, kratica GBL, prema Haigh i Schmidt, 1956), a rezultati istraživanja Paliktzogloua i Suhonena (2014) provedenog u Bahreinu pokazali su da korištenje Facebooka može povećati angažman studenata kroz komunikaciju i suradnju što ga čini važnim obrazovnim alatom za podršku učenju baziranog na problemu (engl. Problem based learning, kratica $P B L$ ).

Thompson i suradnici (2014) istaknuli su da je socijalna komponenta učenja jednako važna kao i kognitivna komponenta, te se ta dva elementa ne bi trebala odvajati dok studenti pokušavaju učiti. Uz to, studenti mogu djelovati i autonomno i kolaborativno. Iz tog su razloga, Sánchez i njegovi kolege istraživači (2014) snažno preporučili da bi nastavnici trebali koristiti društvene mreže kako bi postigli veće razine suradnje i timskog rada u obrazovnim aktivnostima.

Zaključno, Zachos i suradnici (2018) sumiraju da studenti uživaju u korištenju društvenih medija u svojim obrazovnim procesima. Obično imaju uspješne rezultate, posebno što se tiče komunikacije i suradnje, i mada još nije jasno pomaže li korištenje društvenih medija za potrebe visokog obrazovanja u poboljšanju ocjena, društveni mediji služe im kao alat za podršku i/ili upoznavanje ,prijatelja“ koji će im pomoći u njihovom životu na fakultetu i na studiju (Zachos i sur., 2018).

I na kraju, poslovne i druge organizacije i očekuju da će njihovi budući zaposlenici imati veliko znanje u ovim tehnologijama (Wankel, 2009). Stoga, visoko obrazovanje, kao most između tržišta rada odnosno gospodarstva te studenata kao budućih zaposlenika tih istih poslodavaca, niti u tom smislu ne može zanemariti važnost svoje uloge i prilagodbe postojećim okolnostima. 


\subsection{Odnos nastavnika prema korištenju društvenih medija}

„Sporost u prihvaćanju promjena ne pogađa nastavnike...već studente.“

Društveni mediji primjer su, kako je već navedeno, tehnologija koje su studenti široko usvojili, i posljedično, imaju potencijal da postanu dragocjeni resursi za podržavanje obrazovne komunikacije i suradnju studenata s fakultetom (Arsović, 2012). Ipak, brojna istraživanja ukazuju na:

- digitalni jaz u smislu interesa prema različitim mogućnostima korištenja društvenih medija između studenata i njihovih obrazovnih institucija,

- postojanje trenda prema ne-adaptaciji odnosno sporoj adaptaciji novih tehnologija u visokoobrazovnim ustanovama (Roblyer i sur., 2010).

Studenti su voljni koristiti ih, a zaposlenici fakulteta nisu (Roblyer i sur., 2010), barem ne jednako snažno kao studenti (Visagie, de Villiers, 2010; Tess, 2013; Sánchez i sur., 2014). Sada već tradicionalno, studenti dolaze na fakultet „napajani“ najnovijim dostupnim tehnologijama - ali često ih moraju ostaviti na vratima, jer ih fakulteti ne koriste u učionicama, a često su i skeptični prema njima. Društveni mediji primjer su potencijalne nepovezanosti između alata koji preferiraju studenti i onih koje koriste nastavnici (Roblyer i sur., 2010). Prema podacima američkog National Center for Education Statistics (NCES) (Kleiner i sur., 2007) zaključeno je da nevoljkost ostaje glavna prepreka učinkovitoj integraciji tehnologija u pripremi nastavnika (Roblyer i sur., 2010).

Kao rezultat toga što su nastavnici digitalni imigranti, kako to pojašnjava Levin (2008), oni se često „osjećaju zastrašeno ako naslućuju da studenti znaju više od njih“. Ako nastavnici nisu dorasli tehnologiji koju koriste, studenti i/ili nastavnici možda neće aktivnost shvatiti ozbiljno (Canough, 2013). Drugi problem s kojim se suočavaju nastavnici tijekom asimilacije novih tehnologija jest taj što mnogi od njih ne vide smisao promjene svoje pedagogije kada su u prošlosti bili uspješni (Canough, 2013), a „to znači da nastavnici moraju biti uključeni u najmanje dvije radikalne promjene; moraju naučiti koristiti tehnologiju i moraju fundamentalno promijeniti način na koji podučavaju“ (Levin, 2008).

Prema Teoriji transakcijske udaljenosti Michaela Moora (1997), posebno značajnoj za učenje na daljinu, „obrazovanje na daljinu nije samo zemljopisno razdvajanje učenika i učitelja, već je još važnije da je pedagoški koncept". Čak i u nastavi licem u lice postoji neki element transakcijske distance (Rumble 1986). Transakcijska udaljenost karakteristika je svakog 
obrazovnog programa. Teorija posebno naglašava da kako se nivo interakcije između nastavnika i studenata smanjuje, autonomija studenata mora se povećavati (Moore, 1997).

Jednostavno rečeno, što je nastavnik manje u interakciji sa studentom, to je potrebno više autonomije za studente, a nastavnici kao dizajneri učenja donose odluke o stupnju strukture i dijalogu koji će pružiti e-učenje (Puljić, 2019). Prema autoru, izraz „dijalog“ koristi se za opisivanje interakcije ili niza interakcija koje imaju pozitivne kvalitete koje druge interakcije možda nemaju. Dijalog je svrsishodan, konstruktivan i poštuju ga obje strane. Rezerviran je za pozitivne interakcije, pri čemu se vrijednost stavlja u sinergijsku prirodu odnosa uključenih strana. Smjer dijaloga u odgojno-obrazovnom odnosu je prema boljem razumijevanju studenata. Jasno je da priroda svakog komunikacijskog medija izravno utječe na opseg i kvalitetu dijaloga između nastavnika i učenika (Moore, 1997).

Postoje i drugi faktori koji utječu na dijalog i time na transakcijsku distancu; kao što je to broj studenata za koje nastavnik mora pripremiti poduku, učestalost prilika za komunikaciju (obično određene administrativnim i financijskim ograničenjima), fizičko okruženje u kojem nastavnici podučavaju, emocionalno okruženje nastavnika (primjerice stupanj nepoštovanja njihovih nastavničkih dostignuća od strane njihovih administratora), emocionalno okruženje studenata (osobito kako njihovo studiranje vide njima važni ljudi kod kuće ili na poslu) (Moore, 1997). Nadalje, pojašnjava Moore (1997), na dijalog dodatno utječu osobine ličnosti nastavnika, osobine ličnosti studenata i sadržaj. Stoga se ne može sa sigurnošću reći da će svaki medij, ma koliko interaktivan bio njegov potencijal, pružiti visoko dijaloški program, jer njime upravljaju nastavnici koji mogu iz dobrih ili iz loših razloga odlučiti da ne iskoriste njegovu interaktivnost, a isto tako možda ga koriste studenti koji nisu u stanju ili nisu voljni stupiti u dijalog sa svojim nastavnicima (Moore, 1997). Napokon, bez obzira na dinamiku svake transakcije učenja, jedna od glavnih odrednica u kojoj će mjeri prevladati transakcijsku udaljenost jest mogućnost dijaloga između studenata i nastavnika, i u kojoj mjeri se postiže. U praksi to postaje izuzetno složeno pitanje, jer ovisi o instituciji i o pojedinim nastavnicima koji pružaju (ne)odgovarajuće mogućnosti dijaloga između nastavnika i studenata, kao i o odgovarajuće strukturiranim nastavnim materijalima (Moore, 1997).

Iako korištenje društvenih medija za potrebe visokog obrazovanja, može, ali i ne mora, značiti prostornu udaljenost između nastavnika i studenata, udaljenost koja nastaje pod njihovih utjecajem, osim što je digitalna, ona je i psihičke prirode.

Kako se navodi u dokumentu Europa 2020 Europske komisije, „nastavnici su najvažniji obrazovni resurs dostupan većini studenata. Stoga je važno da nastavnici u potpunosti znaju i razumiju predmet koji podučavaju, da raspolažu svim potrebnim vještinama i iskustvom za 
učinkovito prenošenje svoga znanja studentima u različitim nastavnim kontekstima, te da dobivaju povratne informacije o svome radu. Prilikom zapošljavanja i angažiranja novog osoblja, učilišta moraju osigurati da novi nastavnici imaju barem minimalnu razinu potrebnih kompetencija“ (European Commission, 2010a).

Pregledom postojeće literature moguće je pronaći veliki broj postojećih teorija i modela kojima je moguće objasniti prihvaćanje tehnologije i inovacija u različitim okruženjima, a kako navodi Babić (2016) kompetentni su oni visokoškolski nastavnici koji uspješno i učinkovito ostvaruju ciljeve nastavnog procesa kroz neke od oblika e-učenja pomoću prilagođenih znanja, vještina, sposobnosti (osobne, društvene, metodološke; prema Europskom kvalifikacijskom okviru, kratica EKO (engl. European Qualifications Framework, kratica EQF) / Hrvatskom kvalifikacijskom okviru, kratica HKO (engl. Croatian Qualifications Framework, kratica $C Q F)$. Znanja, vještine te određeni stavovi i vrijednosti povezani s e-obrazovanjem, čine osnovnu i ključnu kompetenciju visokoškolskih nastavnika za primjenu e-učenja tzv. spremnost za djelovanje (Babić, 2016 prema Weinert, 2001 i Schneckenberg, Johannes 2006). Uz navedeno, jedan od ključnih činitelja opće kompetencije visokoškolskih nastavnika u primjeni tehnologije u e-učenju jesu odgovornost i predanost kvaliteti u radu (Babić, 2016 prema Ehlers, 2007). Navedeni činitelji povezani su s kategorijom činitelja osobnih karakteristika visokoškolskih nastavnika, pri čemu je važno znanje o kvaliteti e-obrazovanja te način na koji ga visokoškolska institucija potiče i razvija (Babić, 2016).

\subsection{Akademsko okruženje i društveni mediji}

„Kvaliteta sveučilišta više se treba mjeriti kvalitetom studenata koji iz njega izlaze, negoli kvalitetom studenata koji u njega ulaze.“

- R. J. Kibber (1970)

Alati i aplikacije društvenih medija predstavljaju izazov konceptu formalnog obrazovanja kakvog danas poznajemo (Selwyn, 2011). Korištenje društvenih medija podrazumijeva, na primjer, da studenti trebaju biti ,aktivni ko-stvaratelji“ znanja, a ne „pasivni potrošači““ sadržaja, a učenje treba biti "sudionički, društveni proces" koji podržava osobne životne ciljeve i potrebe (Lee, McLoughlin, 2010). U tom smislu, ostaje napetost između onih koji vjeruju da se društveni mediji mogu koristiti za jačanje i poboljšanje visokog učilišta u sadašnjem obliku 
i onih koji vjeruju da društveni mediji postoje da bi poremetili (i u konačnici zamijenili) visoka učilišta u potpunosti.

Sukladno navedenom, mijenja se uloga nastavnika, a mnogi nastavnici tvrde da se društveni mediji mogu uspješno koristiti za podršku pružanju onoga što Goodyear i Ellis (2008) nazivaju „ozbiljno učenje usmjereno na studenta“. Naravno, čak i najstrukturiranija primjena društvenih medija u visoko obrazovnim situacijama podrazumijeva određeni stupanj obrazovanja „usmjerenog na korisnika“ tj. omogućava polaznicima da preuzmu aktivnije uloge u onome što uče, kao i kako i kada to uče (Selwyn, 2011). Ipak, s obzirom da brojna istraživanja pokazuju da postoji potreba integracije društvenih medija u nastavni proces (Okello-Obura, Ssekitto, 2015), mnogi visokoškolski nastavnici vjeruju da su visoka učilišta sposobna prihvatiti ove promjene i imati koristi od njih, a govori se i potrebi razvijanja ,pedagogije 2.0“ - tj. ,,inovativne pedagogije koje koristi ove prilike da podrže izbor i autonomiju studenata“" (Selwyn, 2011 prema Lee, McLoughlin, 2010).

Isto tako, brojni istraživači ističu prednosti i pozitivne učinke korištenja društvenih medija na proces učenja i poučavanja (Alsolamy, i sur., 2017; Coleman, i sur., 2018) kao što je kvaliteta nastave (Silvestru, i sur., 2016) i akademski uspjeh studenata (Tamayo, i sur., 2014). No, postoje i oni koji smatraju da sama suština društvenih medija negira potrebu za institucionalnim učenjem u cjelini, te su skloniji promišljati nedostatke i opasnosti (Raut, i sur., 2016; Willems, i sur., 2018), iako ih studenti doživljavaju kao nešto što se samopodrazumijeva. Trenutno su neki od značajnijih trendova učenja poduprtih društvenim medijima pozicionirani izvan - za razliku od unutar - formalnog sustava visokog obrazovanja (Selwyn, 2011).

Vrlo često, čak i visoka učilišta koja imaju najbolje namjere mogu samo ponuditi svojim studentima umjetno regulirano i ograničeno korištenje društvenih medija (Selwyn, 2011). Zbog toga se, uz ostale institucije poput škola, knjižnica i muzeja, visoka učilišta suočavaju s nepovjerenjem i sve većim porastom gubitka vjere među mlađim generacijama (Downes, 2010). Ovaj je sukob posebno vidljiv u pogledu linearnih i hijerarhijskih načina na koje visoka učilišta imaju za cilj strukturirati komunikaciju, učenje i pristup znanju. Ulbrich i sur. (2011) tvrde: „Pripadnici novih generacija studenata koriste web na drugačije načine, oni se drugačije umrežavaju i drugačije uče. Kad upišu studij, tradicionalne vrijednosti visokih učilišta o tome kako razvijati znanje sudaraju se s njihovim vrijednostima. Mnoge nastavne tehnike koje su desetljećima funkcionirale, više ne funkcioniraju, jer i novi studenti uče drugačije; rade kolaborativno, izvršavaju nekoliko zadataka istovremeno i koriste web za stjecanje znanja.“ Ali, paralelno se u mnogim raspravama, postavlja pitanje koji se aspekti korištenja društvenih medija zapravo odnose na obrazovanje, učenje i znanje (Selwyn, 2011). U tom smislu, Hosein 
i sur. (2010) čine korisnu razliku između životnih tehnologija (tj. tehnologija koje studenti biraju za svakodnevni društveni život i u slobodno vrijeme) i tehnologija učenja (tj. tehnologija koje studenti prvenstveno koriste u svrhe studija). Kao što ovo razlikovanje sugerira, iako može postojati preklapanje između to dvoje, pogrešno je pretpostaviti da su svi aspekti svakodnevnog korištenja društvenih medija od obrazovnog značaja (Selwyn, 2011).

Vrlo je vjerojatno da je većim dijelom korištenje društvenih medija sačinjeno od „običnih životnih stvari““ (Shirky, 2008), a ne kreativnih, suradničkih i zajedničkih aktivnosti. Trenutno je malo dokaza da većina korisnika koristi aplikacije na posebno inovativne, participativne, interaktivne ili čak društvene načine (Selwyn, 2011 prema Jones i sur., 2009). Postoje i empirijska istraživanja studentskih korištenja društvenih medija koja ukazuju na nedostatak onoga što bi se moglo smatrati autentičnim ili čak korisnim aktivnostima participativnog učenja (Selwyn, 2011) te izvještavaju o iznenađujućem nedostatku sofisticiranog ili naprednog korištenja društvenih medija među studentima (Waycott i sur., 2010, Lee, McLoughlin, 2010, Rowlands i sur., 2009).

No, isto tako može biti pogrešna pretpostavka da su svi studenti nužno oduševljeni i motivirani korištenjem društvenih medija, stoga je u tom smislu nerazumno pretpostaviti da će se interes, motivacija ili afiniteti svih studenata povećati uključivanjem društvenih medija u bilo koji obrazovni kontekst (Selwyn, 2011).

\subsection{Istraživanje društvenih medija u svijetu}

Diljem svijeta provode se istraživanja koja se tiču korištenja društvenih medija, a mnoga se tiču benefita koje društveni mediji donose u poslovanje tvrtki, osobito što se tiče marketinga, ciljanog oglašavanja i brendiranja kao što su promocija tvrtke, promocije brenda, promocije sadržaja, generiranje leadova (privlačenje i pretvaranje stranaca u zainteresirane osobe, prema Kolšek, 2017), povećanja utjecaja, povećanja prodaje, upravljanja reputacijom, povećanja angažmana (oko) kupaca i publike, praćenja novosti i komunikacije koja se tiče brenda tvrtke, konkurentnih tvrtki i niše poslovanja, izradu i/ili objavu izvještaja i analitika, te kriznu komunikaciju (Newberry, 2018).

Iako društveni mediji imaju široko područje primjene, ipak se još uvijek nedovoljno zna o benefitima njihovog korištenja za potrebe visokog obrazovanja, osobito za posebne svrhe, kao što su marketing, upisi, učenje, angažman studenata (Davis III i sur., 2012). Istraživanje „Getting Connected“ koje je 2012. godine obuhvatilo 224 visokih učilišta u SAD-u, kako 
navode Davis III i suradnici (2012) pokazalo je da čak i ako koriste društvene medije i dalje dominira jednosmjerna komunikacija, pri čemu visoka učilišta stavljaju objave odnosno obavijesti o nadolazećim događajima i aktivnostima, igrama i natjecanjima, rokovima, podsjetnike, opće najave, upozorenja, zatim marketinške objave, a samo malobrojna visoka učilišta koristila je društvene medije za odgovore na upite studenata. Iznenađujuće je bilo samo korištenje društvenih medija za povezivanje sa alumnima i donatorima te za druge razvojne svrhe. Sveukupno, 22 visoka učilišta pojavila su se kao iznimke od spomenutih uzoraka; ti su fakulteti opisali korištenje društvenih medija izvan navedenih razloga. Ono što je značajno za istaknuti jest da su ta visoka učilišta zabilježila više akademskih i studentskih uspjeha. Načini na koje su ti fakulteti opisali svoju višestruku i raznovrsnu upotrebu društvenih medija prikazana je u Tablici 11 .

Tablica 11. Korištenje društvenih medija u visokom obrazovanju u SAD-u (izvor: izrada autorice prema Davis III i sur., 2012)

\begin{tabular}{|c|c|c|c|}
\hline UČENJE/NASTAVA & $\begin{array}{c}\text { PODRŠKA } \\
\text { STUDENTIMA }\end{array}$ & $\begin{array}{l}\text { IZGRADNJA } \\
\text { ZAJEDNICE }\end{array}$ & ŠIRENJE VEZA \\
\hline $\begin{array}{l}\text { Fakultet komunicira sa } \\
\text { studentima i uključuje ih u } \\
\text { njihove kolegije }\end{array}$ & Pružaju podršku studentima & $\begin{array}{l}\text { Grade i jačaju zajednicu u } \\
\text { kampusu }\end{array}$ & Povezuju studente s alumnima \\
\hline $\begin{array}{l}\text { Izgrađena veza između } \\
\text { Facebooka i Blackboarda tako } \\
\text { da studenti mogu pratiti } \\
\text { nastavne zadatke i primati } \\
\text { najave s kolegija }\end{array}$ & $\begin{array}{l}\text { Nude radionice o financijskoj } \\
\text { pomoći }\end{array}$ & $\begin{array}{l}\text { Povećavaju osjećaj pripadnosti } \\
\text { studenata koji studiraju online }\end{array}$ & $\begin{array}{l}\text { Šire dosege povezanosti na } \\
\text { zajednicu }\end{array}$ \\
\hline $\begin{array}{l}\text { Stvaraju jače zajednice za } \\
\text { učenje }\end{array}$ & $\begin{array}{l}\text { Rješavaju probleme i } \\
\text { omogućavaju studentima i } \\
\text { zajednici mogućnost pružanja } \\
\text { povratnih informacija o } \\
\text { fakultetu }\end{array}$ & $\begin{array}{l}\text { Aktivno potiču i podržavaju } \\
\text { uključenost studenata i } \\
\text { sudjelovanje u aktivnostima }\end{array}$ & \\
\hline $\begin{array}{l}\text { Objavljuju dijelove predavanja } \\
\text { koji se mogu preuzeti }\end{array}$ & Nude profesionalnu orijentaciju & $\begin{array}{l}\text { Pozivaju na sudjelovanje u } \\
\text { blogovima širom kampusa (tj. } \\
\text { studentskim blogovima, } \\
\text { predsjednikovom blogu, blogu } \\
\text { fokusiranom na } \\
\text { inovacija u poučavanju). }\end{array}$ & \\
\hline $\begin{array}{l}\text { Olakšavaju raspravu u učionici } \\
\text { i grupni projektni rad }\end{array}$ & $\begin{array}{l}\text { Omogućavaju mentorstvo } \\
\text { studentima }\end{array}$ & & \\
\hline $\begin{array}{l}\text { Potiču studijske grupe i druge } \\
\text { oblike suradnje u nastavi }\end{array}$ & $\begin{array}{l}\text { Pomažu u postupku prijave za } \\
\text { upis }\end{array}$ & & \\
\hline $\begin{array}{l}\text { Hvale se akademskim } \\
\text { postignućima studenata }\end{array}$ & $\begin{array}{l}\text { Pomažu u poboljšavanju } \\
\text { zadržavanja studenata }\end{array}$ & & \\
\hline
\end{tabular}




\subsubsection{Digitalna podjela}

Digitalne nejednakosti posebno su izražene u odnosu na socijalno-ekonomski status, društveni razred/klasu, rasu, spol, zemljopis, dob i obrazovanje - podjele koje vrijede za mlađe generacije studenata kao i za starije generacije sveučilišnog osoblja (Selwyn, 2011, Jones, Fox, 2009, Helsper, Eynon, 2009). Iako više nije popularan pojam u Americi, spektar digitalne podjele (engl. Digital Divide) ostaje velik kako je sve više dokaza da korištenje društvenih medija nije pravedna i demokratska aktivnost kako se često prikazuje (Selwyn, 2011). Čak i kad je u mogućnosti pristupiti tehnologiji, vrste društvenih medija koje pojedinac koristi, načini korištenja i ishodi, navodi Selwyn (2011), kompromitirani su nizom faktora drugog reda koji dovode do digitalne nejednakosti. Na primjer, postoje studije koje sugeriraju da studentske preferencije pojedinih aplikacija društvenih medija u odnosu na ostale slijede razlike na temelju društvenog statusa (Selwyn, 2011). Jasne društveno-ekonomske razlike postoje i u sklonosti pojedinaca za izradu (a ne samo za konzumiranje) internetskih sadržaja, bilo da ih objavljuju, dijele ili stvaraju (Schradie, 2011). Ostale studije američkih koledža navode da okruženja na društvenim mrežama nisu više društveno integrirana od izvanmrežnih konteksta. Primjerice, utvrđeno je da je rasa ostala najvažniji prediktor jesu li studenti na Facebooku prijatelji ili ne (Mayer, Puller, 2008). Slično tome, društveni mediji ne pomažu nužno prevladati probleme s invaliditetom, već često pogoršavaju granice invaliditeta (Selwyn, 2011 prema Lewthwaite, 2011).

\subsection{Istraživanje društvenih medija u Hrvatskoj}

U Hrvatskoj se studije isto tako bave pojavom društvenih medija i promjenama koje su nastale uslijed njihove pojave te se raspravlja kako bi sveučilišna zajednica i njezini dionici trebali biti dio tih promjena (Matešić, Vučković, Dovedan, 2010), kao i potrebi službene prisutnosti i zastupljenosti visokoškolskih ustanova na društvenim medijima (Golubić, Lasić-Lazić, 2012; Golubić, 2017).

Jednako tako, predmetom istraživanja bili su kultura net-generacije na uzorku studenata hrvatskog govornog područja (Čačić, 2012), digitalizacija i umrežavanje studenata u Hrvatskoj (Potočnik, 2014), o perspektivi studenata o informacijskoj etici na društvenim mrežama (Babić i sur., 2019) te o net generaciji i perspektivi elektroničkog nasilja (Babić, Grgić, 2019). 
Manji broj istraživanja provodi se o tome kako nastavnici koriste informacijske i komunikacijske tehnologije (Kučina Softić, Jandrić, Rako, 2016), o činiteljima nastavničkoga prihvaćanja e-učenja i kompetencije za njegovu primjenu na visokoškolskim ustanovama (Babić, 2016), te o nastavničkom korištenju društvenih medija za potrebe visokog obrazovanja (Babić, Vilović, Bakić-Tomić, 2019).

\subsection{Društveni mediji u visokom obrazovanju: gdje smo sad i kamo dalje?}

„Onaj tko neće primjenjivati nova sredstva za postojeće probleme mora očekivati nova zla; jer vrijeme je najveći inovator.“

- Francis Bacon

Očito je da postoji jasna razlika između obrazovne retorike i obrazovne stvarnosti korištenja društvenih medija (Selwyn, 2011). Postojala je dugogodišnja tendencija da na kraju digitalne tehnologije ne ispune početna pretjerana očekivanja, što se može opisati kao ciklus ,uzbuđenja, nade i razočaranja“ (Gouseti, 2010). Stoga, možda je trenutno najveći izazov za visokoškolsku zajednicu uključivanje u realne rasprave o tome kako najbolje koristiti društvene medije na prikladne načine koji će umanjiti eventualno razočaranje (Selwyn, 2011).

Naravno, potrebno je, kako navodi Selwyn (2011) uspostaviti jasne granice između praktičnih zadataka razvijanja oblika društvenih medija koji se bolje uklapaju u formalni sustav visokog obrazovanja i rješavanja prilično težih, dugoročnih pitanja o reformi i redizajnu cijelog obrazovnog sustava.

U smislu ove posljednje točke, postoji jasna potreba da se temeljito razmotri i raspravlja o tome što je visoko obrazovanje i koje bi to oblike trebalo poprimiti u digitalnom dobu 21. stoljeća jer zapravo, mnoge kontroverze i napetosti u vezi s korištenjem društvenih medija u visokom obrazovanju imaju malo veze sa samom tehnologijom (Selwyn, 2011). Umjesto toga, to su pitanja koja su potaknuta osobnim uvjerenjem i mišljenjem o ,suštinski etičkom pitanju (onoga) što se smatra važnim“ odnosno vrijednim učenjem i vrijednim školovanjem (Standish, 2008). U tom su smislu, društveni mediji društveno razarajuće tehnologije koje potiču niz duboko ideoloških (a ne čisto tehničkih) pitanja o prirodi institucionaliziranog obrazovanja (Selwyn, 2011).

Unatoč ovim dubljim raspravama nego što se to na prvi pogled čini, visoko obrazovne institucije trebaju i dalje razmatrati, primjerice, praktične izazove kako procijeniti suradnički 
rad studenata ili kako najbolje osmisliti kombinirane nastavne programe (vidjeti Gray i sur., 2010; Buckley i sur., 2010). Isto tako je važno razmotriti kako najbolje podržati nastavnike i studente u održivom i smislenom korištenju ovih internetskih tehnologija (Selwyn, 2011). Na ovaj način visoka učilišta moraju igrati važnu ulogu u podržavanju navodno samostalnih aktivnosti studenata - pružajući studentima podršku i upravu u kreiranju učenja baziranog na tehnologijama (Crook, 2008). Napokon, tehnologija društvenih medija nešto je što bi trebali stvoriti njeni korisnici - uključujući visokoškolske ustanove i nastavnike (Selwyn, 2011).

\subsection{1. Što nas je kriza uzrokovana Covid-19 pandemijom naučila o podučavanju?}

„Blago onima koji žive u zanimljivim vremenima.“

- Frederic R. Coudert (1939)

Godina 2020. donijela je nove izazove pred cjelokupno čovječanstvo, globalnu ekonomiju, ali i cjelokupno obrazovanje, koje još samo prije par mjeseci nitko nije mogao ni zamisliti. Kako se svijetom širio virus nazvan Covid-19 odnosno koronavirus SARS-CoV-2, visokoškolske ustanove bile su suočene s velikim izazovom: kako nastaviti nastavu ako su predavanja licem u licem zabranjena prema uputama vlade te stožera civilne zaštite odnosno nadležnog ministarstva? Brojna visoka učilišta nisu bila spremna za taj izazov, osobito u početku, i te su se ustanove zaista našle pred ispitom svog funkcioniranja, na tragu zloslutnog predviđanja Druckera (1997): „Trideset godina od sada, visoka učilišta neće preživjeti ...visoko obrazovanje je u dubokoj krizi. Visoka učilišta neće preživjeti kao rezidencijalne ustanove. Današnje zgrade (fakulteta) beznadno su neprilagođene i potpuno nepotrebne“. Posebno zato što više nitko ne može sa sigurnošću predvidjeti što nam nosi budućnost, te su još uvijek u trenutku pisanja ovog rada veoma izgledne mogućnosti da će se sličan scenarij ponoviti ukoliko dođe do novog vala pandemije. Druge su pak visokoškolske ustanove bile nešto spremnije i krenule su, odmah ili uskoro po zatvaranju, s online nastavom kao kratkoročnim rješenjem. Osobito su nastavnici, kao voditelji online nastave, trebali uložiti dodatne napore kako bi se (detaljnije) upoznali s tehnologijom i koristili nove digitalne alate putem kojih je određeno visoko učilište izvodilo nastavu (dijeljenje zaslona, prezentacije, chat, anketa, čak i održavanje online ispita itd.), uglavnom uz pomoć tehničke podrške. 
Brojna istraživanja su u tijeku koja se tiču zadovoljstva online nastavom, a sudeći prema trenutnom iskustvu, nastavnici i studenti koji su sudjelovali u ovoj vrsti „prisilne“ i „,nepripremljene“ ili točnije nenadane online nastave, smatra da je ta online nastava bila najbolje moguće rješenje u danom trenutku i u danim okolnostima, ali mnogi se slažu da nikako ne može zamijeniti iskustvo nastave licem u lice. Vrlo često su rezultati studija o učenju na daljinu nasuprot učenju licem u lice, koje se provode već od 2000-ih, pokazivali da (i) studenti više vole nastavu licem u lice, no, isto tako i da se studenti žele aktivno baviti vlastitim učenjem, pa neka napredna svjetska sveučilišta, kao što su to Columbia University, Carnegie Mellon University te University of Texas, Austin predlažu nove oblike poučavanja i učenja, navodi Eurydice (2020). Obrazovanje na daljinu i MOOC-ovi (engl. Massive Open Online Courses) pomoću unaprijed snimljenog materijala vrlo su popularno rješenje za ovaj izazov, ali postoji još jedna specifična vrsta učenja na daljinu: sinkrono učenje na daljinu, koje za razliku od asinkronog učenja na daljinu (koje nastaje kada nastavnik i studenti stupaju u interakciju na različitim mjestima i u različitim vremenima), nastaje kada nastavnik i studenti stupaju u interakciju na različitim mjestima, ali istovremeno (Littlefield, 2020) te u kojem i studenti licem u lice i studenti na daljinu dobivaju poduke zajedno i u stvarnom vremenu (Eurydice, 2020), pri čemu primjerice iskustva visokih učilišta koja provode online studije, kao što je to DOBA Fakultet, pokazuju da $92 \%$ studenata smatra da su online mentori ključni za njihov uspjeh jer su „,sinonim za neprestanu prisutnost, praćenje, razumijevanje i momentalnu odazivnost“ (Strmšek, 2020). Kao jedan od izazova u provedbi nastave pokazao se pristup nekih visokih učilišta odnosno nastavnika na način da dostave nastavne materijale studentima, pri čemu su oni dalje prepušteni vlastitim mogućnostima svladavanja nastavnog gradiva i pri čemu se vodilo malo računa o tome da je umjetnost poučavanja zapravo umjetnost pomaganja u dolasku do otkrića (Van Doren, 1943). Alate društvenih medija mnogim su nastavnicima ipak uvelike služili kao alati induktivnih metoda, kroz koje studenti stvaraju, istražuju ili otkrivaju važne ideje kroz interakciju s konkretnim materijalima ili drugim izvorima podataka te njihovim vršnjacima što istovremeno stvara oštar kontrast izravnom poučavanju, ili pak pukoj dostavi nastavnih materijala koje je potrebno samostalno svladati.

Izvanredne preventivne mjere zbog prijetnje zarazom koronavirusom SAR-CoV-2, osim straha i neizvjesnosti, značajno su izmijenile život pojedinaca i zajednice, a što je onda dodatno izazvalo stres i prijetnju mentalnom zdravlju pojedinca i cjelokupne zajednice (Muslić, 2020), te su brojni stručnjaci nastojali komunicirati preporuke kako sačuvati mentalno zdravlje i kako „upravljati“ našim doživljajem rizika i straha. Jedna od najznačajnijih preporuka bila je „važno je međusobno povezivanje i davanje podrške i pomoći, ali uvažavajući sve preporuke 
zdravstvenih i drugih nadležnih institucija, posebno socijalne distance. U tome nam može pomoći i suvremena tehnologija odnosno društvene mreže, e-mail, mobitel i sl., koji nam omogućavaju komunikaciju s nama dragim osobama uvažavajući preporuke stručnjaka o smanjenim izravnim kontaktima i socijalnoj distanci“ (Muslić, 2020). Prilagodba novonastaloj izvanrednoj situaciji, obilježena je dakle korištenjem (digitalnih) interaktivnih alata, najčešće društvenih medija, putem kojih se gotovo bezizlazna situacija pretvarala u prebrodivu. Osim samog straha od ugroze te posljedične neizvjesnosti, društvena odvojenost i distanciranje ljudi koje također negativno utječu na psihičko zdravlje čovjeka, bile su ublažene posredstvom tih digitalnih alata koji su omogućili barem djelomično funkcioniranje života kakvog smo poznavali ranije te nastavka studija naspram apsolutnog zaustavljanja ,života“. No, primjerice istraživanje „Kako smo - život u Hrvatskoj u doba korone“ pokazalo je da je online nastava bila izvor velikog stresa (Jokić-Begić, 2020), izazova je bilo mnogo, a osim rada od kuće pri čemu se gube jasne granice između poslovnog i privatnog života, zapravo većina ih je vezana uz sve dosad navedeno u ovom doktorskom radu. Ono što se sukladno tome, postavlja kao temeljno pitanje jest: bi li stres, uzrokovan online nastavom i korištenjem novih digitalnih alata, bio puno blaži da se s prilagodbom digitalnom okruženju počelo ranije odnosno da smo se s tim digitalnim alatima detaljnije upoznali prije spomenutih izvanrednih okolnosti i prije no što je to postala svojevrsna nužnost i ,prisila“?

Zaključno, o integraciji i korištenju društvenih medija za potrebe visokog obrazovanja ne postoji univerzalan stav i ,porota još zasjeda“ (Tess, 2013). Iako prema novim tehnologijama i društvenim medijima možemo imati optimističan stav i doživljavati njihov utjecaj kao nešto što obogaćuje i olakšava naše živote, omogućuje nam veću slobodu mišljenja i izražavanja, kao veću solidarnost i povezivanje na svim razinama, ili pak imati pesimističniji pogled na njihov utjecaj s fokusom na povećanju „otuđenja“ među ljudima, slabljenju „stvarnih“ međuljudskih odnosa, mnoštvu neprovjerenih informacija i elektroničkog nasilja, bojazni od toga što na internetu ne postoji zaborav, ono što svakako ne možemo jest zanemariti promjene koje se dogodile, ali se i dalje neprestano odvijaju, pod njihovim utjecajem kakvim god ga doživljavali.

Ovom doktorskom disertacijom nastojat će se iz neutralne pozicije istražiti trenutni utjecaj društvenih medija u visokom obrazovanju, te mogući scenarij budućnosti koja nam u tom području predstoji. 


\section{PRELIMINARNA EMPIRIJSKA ISTRAŽIVANJA O KOMUNIKACIJSKOJ PARADIGMI U VISOKOM OBRAZOVANJU POD UTJECAJEM DRUŠTVENIH MEDIJA}

\subsection{Preliminarno istraživanje 1: Društvene mreže kao komunikacijski kanal studenata}

\subsubsection{Kontekst}

Početno znanstveno predistraživanje se provelo samo u Republici Hrvatskoj, detaljnije samo na Visokom učilišta Algebra (100 \% ispitanika bili su studenti) u ljetnom semestru akademske godine 2015./2016. Trebalo je provjeriti koriste li i u kojoj mjeri studenti društvene mreže kao komunikacijski kanal za potrebe visokog obrazovanja. Rezultati istraživanja koristili su se za uvid u studensko poimanje korištenja društvenih mreža u kontekstu visokog obrazovanja i uvod u glavno empirijsko istraživanje.

Primarni razlog odabira ovog visokog učilišta odnosno studija računarstva koji osposobljavaju studente za tržište rada u kojem se poslovanje i edukacija ostvaruju na suvremene načine i posredovane digitalnom tehnologijom. Pretpostavka je bila da ti mladi ljudi odnosno studenti/ice koriste društvene mreže za komunikaciju općenito, a sukladno tomu i za potrebe visokog obrazovanja.

\subsubsection{Predmet, cilj, svrha i hipoteze}

Predmet ovog istraživanja bile su društvene mreže i koriste li ih studenti kao primarni komunikacijski kanal kojim se informiraju o studiju i studentskim obvezama. Cilj je bio ispitati kako studenti procjenjuju ulogu i važnost društvenih mreža kao komunikacijskog kanala za razmjenu informacija o studiju i studiranju.

Svrha predistraživanja bila je utvrditi koriste li studenti Visokog učilišta Algebra društvene mreže, u kojem opsegu, dobiti uvid u glavne svrhe njihova korištenja te služe li im kao primarni komunikacijski kanal za razmjenu informacija o studiju i studiranju. 
Hipoteze ovog istraživanja bile su:

H1: Studenti koriste mrežne izvore (internet) za informiranje o studiju i studentskim obvezama. H2: Studenti su korisnici društvenih mreža.

H3: Studenti koriste društvene mreže kao primarni komunikacijski kanal kojim se informiraju o studiju i studentskim obvezama.

\subsubsection{Metodološki okvir istraživanja}

U ovom istraživanju korišten je posebno konstruirani instrument „Upitnik - Korištenje društvenih mreža kao komunikacijskog kanala studenata za potrebe visokog obrazovanja“, detaljnije vidjeti Prilog 1. Anonimna anketa provedena je na obaveznim predavanjima studenata preddiplomskih stručnih studija Primijenjenog računarstva i Multimedijskog računarstva u lipnju 2016. godine. Studenti su dobrovoljno popunili anonimni anketni upitnik, koji je sadržavao 10 pitanja s uglavnom unaprijed ponuđenim odgovorima zatvorenog tipa, te s mogućnošću da na 4 pitanja kao jednu od mogućnosti unesu odgovor vlastitim riječima. Nejasnoće u upitniku nisu bile prijavljene, iz čega se zaključuje da su pitanja bila nedvosmislena, a čestice jasne. Podaci su obrađeni kvantitativnom statističkom analizom unaprijed izoliranih varijabli te opisom stanja i ustanovljavanjem uzročno-posljedičnih veza između pojedinih komponenti.

\subsubsection{Uzorak}

Uzorak istraživanja bio je prigodni, bilo je ispitano 81 studenata i studentica koji su polazili preddiplomske studije (što je 13,7 \% studenata od ukupno 590 studenata s aktivnim statusom studenta u akademskoj godini 2015./2016. na Visokom učilištu Algebra). Struktura uzorka bila je sljedeća: 65 \% studenata Primijenjenog računarstva, od čega 48 \% Programskog inženjerstva, a $17 \%$ studenata Sistemskog inženjerstva, te $35 \%$ studenata upisanih na studij Multimedijskog računarstva. Ukupni omjer studenata sudionika prema rodu bio je 94 \% muške populacije studenata i samo $6 \%$ ženske populacije. Muški rod bio je znatno više zastupljen među studentima. U strukturi uzorka studenata u preliminarnom istraživanju prevladavali su studenti koji imaju status redovitog studenta $(85,1 \%)$, dok je zaposlenih studenata bilo daleko manje $(14,9 \%)$. 


\subsubsection{Rezultati}

Rezultati pokazuju kako najviše studenata, njih 59,2 \%, informacije o studiju obično dobivaju preko sustava digitalne referade Infoeduka, njih $42 \%$ od nastavnika, a $37 \%$ studenata odgovorilo je da se informiraju od drugih studenata. Na web stranicama visokog učilišta obično se informira njih $29,6 \%$, samo $0,2 \%$ od nenastavnog osoblja, dok njih $18,5 \%$ za informiranje koristi društvene mreže. Nijedan student nije odabrao opciju da se informira preko nekog drugog izvora informiranja, iako je bila ponuđena opcija za neki drugi izvor i sudionici su ga mogli navesti slobodnim unosom.

Više od polovina anketiranih ispitanika, njih 64,2 \%, obično koriste pretraživače sadržaja, 40,7 \% koriste platforme na kojima mogu skidati i/ili slušati glazbu i gledati glazbu i/ili filmove, a $39,5 \%$ studenata su obično korisnici društvenih mreža. Za slanje i primanje e-mailova internet koristi $25,9 \%$ student, a samo njih 3,7 \% za nešto drugo od čega je njih dvoje navelo odgovore Wikipediju i Reddit.

Za druženje i zabavu, internet koristi čak 76,5\% studenata, za potrebe studija njih $45,7 \%$, za potrebe posla $28,4 \%$, a samo $2,5 \%$ za neke druge svrhe kao što su npr. dodatno obrazovanje što je navelo $1,2 \%$ studenata i $1,2 \%$ za samostalno učenje.

8,6 \% studenata izjasnilo da nema kreiran profil na nekoj od društvenih mreža, ali puno više njih, čak njih 91,4 \%, korisnički profil ima na nekoj od društvenih mreža.

Pokazalo se da 96,1 \% studenata koji imaju korisnički profil, imaju ga na društvenoj mreži Facebook. Na Instagramu su korisnici njih 40,5 \%, na LinkedInu 36,5 \%, na Twitteru profil ima 29,7 \% studenata. Kao svoj odgovor opciju da imaju kreiran profil na nekom društvenom mediju koja nije ponuđena odabralo je 10,8 \% studenata, od 1,2 \% njih ima profil na Redditu, Pintarestu, Google+, a 1,2 \% na čak pet društvenih medija: Snapchat, Pintarest, Tumbir, Swarn, Dribble. 9,9 \% njih nije nikad prisutno na društvenim mrežama, a rijetko su prisutni njih 11,1 $\%$. Vrlo često odnosno svaki dan na društvenim mrežama vrijeme provodi $34,6 \%$ studenata, a često njih 13,6 \%. Povremeni korisnici društvenih mreža su njih 30,9 \%.

Najveći broj ispitanika na društvenim mrežama provodi manje od sat vremena dnevno, njih $45,6 \%$, dok 26,6 \% studenata tamo prvodi dva do tri sata dnevno, njih 7,6 \% odgovorilo da ne koristi društvene mreže. Tri do pet sati dnevno na društvenim mrežama provodi $11,4 \%$ studenata, a čak više od pet sati njih $8,9 \%$.

Najviše studenata društvene mreže koristi za druženje i dogovore s prijateljima i to 64,9 \% studenata, $50 \%$ društvene mreže koristi za potrebe studija. Za druženje s poznanicima putem 
društvenih mreža njih 29,7 \%, 18,9 \% za potrebe posla, a za upoznavanje novih ljudi odlučilo se samo njih $6,8 \%$.

29,5 \% sudionika istraživanja koristi društvene mreže za potrebe studiranja često, 26,9 \% student povremeno, $21,8 \%$ rijetko. Vrlo često odnosno svaki dan u svrhu studiranja društvene mreže koristi $9 \%$ studenata, a njih $12,8 \%$ nikad.

Najviše odgovora studenata na pitanje koriste li društvene mreže za potrebe studiranja odnosno u koje svrhe obično, njih 63,4\% odgovorilo je za općenitu informiranost, 43,7\% studenata putem društvenih mreža saznaje informacije koje se odnose na ispite, a 25,4 \% o nastavnoj literaturi. 18,3 \% studenata na društvenim mrežama informira se o nastavnicima i kolegijima, a 1,2\% ispitanika navelo je i dodatnu opciju za druge svrhe, odnosno upisao je da se putem društvenih mreža informira o novostima u svezi s Pučkim otvorenim učilištem Algebra i Visokim učilištem Algebra.

Možemo zaključiti, što se iskristaliziralo kroz odgovore studenata ispitanika, da se o studijskim obvezama najčešće informiraju putem nekih drugih izvora, kao što su npr. sustav digitalne referade Infoeduka ili od samih nastavnika, a ne putem društvenih mreža. Iz odgovora je evidentno da su mrežni izvori na internetu, kao što su primjerice pretraživači sadržaja, studentima uobičajeni za upotrebu više nego društvene mreže koje su čak i malo manje korištene od platformi na kojima studenti mogu skidati, slušati glazbu ili gledati filmove, a postalo je sasvim razvidno da društvene mreže studenti najčešće koriste u svrhu druženja i zabave.

Iako je istraživanje pokazalo da gotovo svi studenti koriste društvene mreže, više od 95 \% njih, i to $8,6 \%$ studenata od ukupnog broja sudionika istraživanja koji su naveli da nemaju profil na društvenim mrežama, nastavilo odgovarati na pitanja koja se tiču korištenja društvenih mreža, stoga su rezultati nedosljedni što se toga tiče.

No, ono što je očito za primijetiti i nije zanemarivo, jest da društvene mreže uglavnom ne koriste za potrebe studija, to je svrha koju ipak smatraju sekundarnom, manje od trećine ispitanika koristi društvene mreže za potrebe studiranja.

\subsubsection{Ograničavajući elementi istraživanja i prijedlozi za buduća istraživanja}

Poteškoće ovog istraživanja bile su što je uzorak bio mali i prigodni - studenti Primijenjenog i Multimedijskog računarstva koji su se na dan istraživanja zatekli na predavanju. Način 
distribucije bilo je ograničenje pri uzorkovanju. Kao glavno ograničenje pokazalo se to što nekoliko studenata nije ispunilo dio pitanja anketnog upitnika.

Bilo bi uputno provesti usporedno istraživanje među studentskom populacijom na drugim visokim učilištima, iako je od studenata računarstva bilo veće očekivanje da će društvene mreže koristiti u svrhu informiranja o studiju obzirom na odabranu struku, čime bi se u korelaciju dovelo njihovo predmetno studiranje i kasniji posao koji ih očekuje temeljem obrazovanja u području računarstva, a koji će, izglednije je, obavljati putem računala, računalnih mreža, a onda moguće i izglednije putem društvenih mreža. Iz istraživanja nismo uspjeli saznati razloge zbog kojih studenti računarstva na Visokom učilištu Algebra društvene mreže ne koriste kao primarni izvor informacija o studiju; radi li se o kvalitetnim i lako dostupnim nastavnim materijalima i oglednim primjercima ispitnih pitanja na sustavu digitalne referade Infoeduka ili snažno ukorijenjenom shvaćanju te tendenciji i motivaciji studenata da društvene mreže prvenstveno služe za zabavu i druženje.

Bilo bi dobro ispitati međusobne odnose studenata u kontekstualnom smislu; ima li i koje su razlike u njihovim međusobnim odnosima u komunikaciji uživo i putem društvenih mreža, te kvalitetu odnosa koja se održava kroz te vrste odnosno razine komunikacijskih kanala. Ta pitanja bi prethodila daljnjem ispitivanju njihovih međusobnih odnosa u akademskom smislu odnosno u kontekstu studiranja, odnosa studenata s upravom visokog učilišta (nenastavnog osoblja) te kvaliteti informacija koje se razmjenjuju u tim odnosima, a ovisno o određenim tipovima komunikacijskih kanala.

\subsubsection{Zaključak}

Ovo istraživanje pružilo je uvid u studentsko korištenje mrežnih izvora i društvenih mreža, posebice kao komunikacijskog kanala kojim se informiraju o studiju i studentskim obvezama. Iako su potrebne metodološke korekcije, posebice u korištenju termina, s obzirom na to da se pojam „društvene mreže“ zapravo koristio kao sinonim za pojam „društvenih medija“, istraživanje je pokazalo da studenti koriste mrežne izvore (internet) za informiranje o studiju i studentskim obvezama, prema čemu se prva hipoteza prihvaća. Isto tako, studenti jesu korisnici društvenih mreža i one jesu komunikacijski kanal studenata, prema čemu se druga hipoteza prihvaća. No studenti ne koriste društvene mreže kao primarni komunikacijski kanal kojim se informiraju o studiju i studentskim obvezama, čime se treća hipoteza odbacuje. 
Društvene mreže postale su virtualni prostor na koji su njegovi korisnici preselili svoje živote i svaki dio života sada ima svoje mjesto na Facebooku (Družeta, Zgrabljić Rotar, 2017), stoga studij i studiranje ne bi trebali biti izdvojeni od toga. Iako je istraživanje bilo metodološki nedorađeno i uzorak nije bio reprezentativan, ipak je ilustrativan primjer kako društveni mediji imaju snažan potencijal postati komunikacijski kanal studenata kojim se informiraju o studiju i studentskim obvezama. Daljnja istraživanja trebala bi se usredotočiti na mogućnosti iskorištavanja potencijala društvenih medija u akademske svrhe odnosno za potrebe studiranja. Razmjere budućeg korištenja društvenih mreža, kao i hoće li one ikad postati studentima na nekim ili svim visokim učilištima glavni izvor informacija, u ovom trenutku teško je predvidjeti. Obzirom da su današnji studenti već upoznati s društvenim mrežama, može se zaključiti da će korištenje društvenih mreža u akademskom (ili nekom drugom) smislu prije imati evolutivnu narav nego li revolutivnu, što je u ovom trenutku teško reći za slučaj pojave nekog novog masovnog medija koji bi se mogao koristiti u edukativne svrhe.

\subsection{Preliminarno istraživanje 2: Elektroničko nasilje prilikom korištenja društvenih mreža kao komunikacijskog kanala studenata}

\subsubsection{Kontekst}

Drugo znanstveno predistraživanje se provelo samo u Republici Hrvatskoj (RH), tj. u instituciji Visoko učilište Algebra u ljetnom semestru akademske godine 2015./2016. (100 \% ispitanika bili su studenti). Trebalo je provjeriti jesu li studenti upoznati s pojmovima koji se tiču sigurnosti komunikacije i elektroničkog nasilja na internetu, posebice na društvenim mrežama. Također, nastojalo se uvidjeti jesu li studenti ikad sudjelovali u nekoj vrsti elektroničkog nasilja.

Primarni razlog odabira ovog visokog učilišta odnosno studija računarstva koji osposobljavaju studente za tržište rada u kojem se poslovanje i edukacija ostvaruju na suvremene načine i posredovane digitalnom tehnologijom. Pretpostavka je bila da ti studenti/ice koriste društvene mreže, a sukladno tomu trebalo je provjeriti jesu li studenti upoznati s pojmovima koji se tiču sigurnosti komunikacije i elektroničkog nasilja te provjeriti jesu li studenti ikad sudjelovali u nekoj vrsti elektroničkog nasilja. 


\subsubsection{Predmet, cilj, svrha i hipoteze}

Predmet ovog istraživanja bile su društvene mreže i jesu li studenti upoznati s pojmovima i vrstama radnji koji se tiču sigurnosti komuniciranja i elektroničkog nasilja. Cilj je bio ispitati jesu li studenti koji koriste društvene mreže kao komunikacijski kanal upoznati s pojmovima i vrstama radnji koji se tiču sigurnosti komuniciranja i elektroničkog nasilja.

Svrha ovog predistraživanja bila je utvrditi jesu li studenti Visokog učilišta Algebra koji koriste društvene mreže upoznati s pojmovima elektroničkog nasilja na društvenim mrežama, što sve ono obuhvaća te jesu li ikad bili žrtva elektroničkog nasilja na društvenim mrežama ili pak sudjelovali u nekoj vrsti elektroničkog nasilja nad nekom osobom na društvenim mrežama. Hipoteze ovog istraživanja bile su:

H1: Studenti su upoznati s pojmovima i vrstama radnji koje se tiču elektroničkog nasilja na društvenim mrežama.

H2: Studenti korisnici društvenih mreža bili su žrtva elektroničkog nasilja na društvenim mrežama.

H3: Studenti korisnici društvenih mrě̌a sudjelovali su u nekoj vrsti elektroničkog nasilja nad nekom osobom na društvenim mrežama.

H4: Studenti korisnici društvenih mreža smatraju elektroničko nasilje bezopasnim.

\subsubsection{Metodološki okvir istraživanja}

U ovom istraživanju korišten je posebno konstruirani instrument „Upitnik - Elektroničko nasilje prilikom studentskog korištenja društvenih mreža za potrebe studiranja“, detaljnije vidjeti Prilog 2. Anonimna anketa provedena je na obaveznim predavanjima studenata preddiplomskih stručnih studija Primijenjenog računarstva i Multimedijskog računarstva u lipnju 2016. godine. Studenti su dobrovoljno popunili anonimni anketni upitnik, koji je sadržavao 12 pitanja s uglavnom unaprijed ponuđenim odgovorima zatvorenog tipa, te $\mathrm{s}$ mogućnošću da na 6 pitanja kao jednu od mogućnosti unesu odgovor vlastitim riječima. Nejasnoće u upitniku nisu bile prijavljene, iz čega se zaključuje da su pitanja bila nedvosmislena, a čestice jasne. Podaci su obrađeni kvantitativnom statističkom analizom unaprijed izoliranih varijabli te opisom stanja i ustanovljavanjem uzročno-posljedičnih veza između pojedinih komponenti. 


\subsubsection{Uzorak}

Uzorak istraživanja bio je prigodni, bilo je ispitano 73 studenata i studentica koji su polazili preddiplomske studije (što je 12,4 \% studenata od ukupno 590 studenata s aktivnim statusom studenta u akademskoj godini 2015./2016. na Visokom učilištu Algebra). Struktura uzorka bila je sljedeća: 67 \% studenata Primijenjenog računarstva, od čega 52 \% Programskog inženjerstva, a $15 \%$ studenata Sistemskog inženjerstva, $33 \%$ studenata upisanih na studij Multimedijskog računarstva. Ukupni omjer studenata sudionika prema rodu bio je 93,2 \% muške populacije studenata i samo 6,8 \% ženske populacije. Muški rod bio je znatno više zastupljen među ispitanicima. U strukturi uzorka studenata u preliminarnom istraživanju prevladavali su studenti koji imaju status redovitog studenta $(86,3 \%)$, dok je zaposlenih studenata bilo daleko manje $(13,7 \%)$.

\subsubsection{Rezultati}

Najviše studenata, njih 88,7 \%, odgovorilo je da se pojam ,sigurnost“" na društvenim mrežama odnosi na sprječavanje direktne prijetnje javnoj ili osobnoj sigurnosti na društvenim mrežama. $21,1 \%$ odabranih odgovora odnosilo se na sprječavanje prijetnji financijske štete, a samo po 7 \% odgovora sprječavanje samoranjavanja ili samoubojstva i sprječavanje prijetnji vandalizma. 5,6 \% ispitanika ponudilo je kao vlastiti odgovor sljedeće: 1. zaštita privatnih informacija, 2. lažno predstavljanje maloljetnicima, 3. privatnost, otkrivanje informacija, 4. sprječavanje neovlaštenog pristupa korisničkom profilu. Samo 4,2 \% ispitanika smatra da se pojam „sigurnost“" na društvenim mrežama odnosi na sve navedeno.

Rezultati su pokazali da $93 \%$ ispitanika smatra da je elektroničko nasilje na društvenim mrežama pojam koji se odnosi na bilo kakav oblik višestruko slanih poruka internetom ili mobitelom čiji je cilj povrijediti, uznemiriti ili na bilo koji drugi način oštetiti dijete, mlade ili odrasle koji se ne mogu zaštiti od takvih postupaka, 81,9 \% njih da su to fotografije čiji je cilj povrijediti, uznemiriti ili na bilo koji drugi način oštetiti dijete, mlade ili odrasle koji se ne mogu zaštiti od takvih postupaka, 80,6 \% ispitanika podrazumijeva da su to tekstualne ili videoporuke čiji je cilj povrijediti, uznemiriti ili na bilo koji drugi način oštetiti dijete, mlade ili odrasle koji se ne mogu zaštiti od takvih postupaka, dok njih $75 \%$ navodi da su to pozivi čiji je cilj povrijediti, uznemiriti ili na bilo koji drugi način oštetiti dijete, mlade ili odrasle koji se ne mogu zaštiti od takvih postupaka. Ukupno $72,2 \%$ pod tim pojmom smatra sve navedeno. 
Gotovo tri četvrtine studenata tj. 74,6 \% ispitanika navelo je da nikada nisu bili žrtva elektroničkog nasilja na društvenim mrežama. 16,9 \% ispitanika navelo je da su rijetko bili žrtva elektroničkog nasilja na društvenim mrežama, a $7 \%$ studenata povremeno. Varijablu „često“ ispitanici nisu odabrali kao svoj odgovor, ali je 1,4 \% ispitanika navelo je da je žrtva elektroničkog nasilja na društvenim mrežama bio vrlo često.

Od studenata koji su naveli da su bili žrtva elektroničkog nasilja, N=18, 44,4 \% studenata odgovorilo je da su bili žrtva elektroničkog nasilja kao napada na privatnost, 38,9 \% širenja nasilnih i uvredljivih komentara, 27,8 \% slanja prijetećih i okrutnih poruka, 27,8\% lažnog predstavljanja, 22,2 \% poticane grupne mržnje, 22,2 \% slanja virusa, fotografija i neželjene pošte na e-mail ili mobitel, 16,6 \% uznemiravanja, uhođenja i vrijeđanja, 16,6 \% slanja njihovih fotografija od strane njihovih kolega te traženje ostalih da ih procjenjuju po određenim karakteristikama, $11,1 \%$ kreiranja stranica koje sadrže priče, crteže, slike i šale na njihov račun, $11,1 \%$ krađe i promjene lozinke, 5,5 \% provaljivanja u vašu e-mail adresu. Sve navedeno kao odgovor je navelo $5,5 \%$ ispitanika.

Na pitanje jesu li ikada sudjelovali u elektroničkom nasilju nad nekom osobom na društvenim mrežama $81,7 \%$ sudionika navelo je da nikada nisu sudjelovali u elektroničkom nasilju nad nekom osobom na društvenim mrežama. 11,3 \% studenata ipak, navelo je da su u elektroničkom nasilju nad nekom osobom na društvenim mrežama sudjelovali rijetko, njih 4,2 \% povremeno, a po $1,4 \%$ student sudjelovao je često ili čak vrlo često. Od ukupnog broja ispitanika koji su sudjelovali u elektroničkom nasilju nad drugom osobom, $\mathrm{N}=13$, njih 53,8 \%, navodi da su sudjelovali u lažnom predstavljanju na društvenim mrežama, 46,2 \% u poticanju grupne mržnje, $30,8 \%$ u napadu na privatnost, 30,8 \% u širenju nasilnih i uvredljivih komentara, 30,8 \% u slanju virusa, fotografija i neželjene pošte na e-mail ili mobitel drugih, 23,1 \% u kreiranju stranica koje sadrže priče, crteže, slike i šale na račun vršnjaka, 23,1 \% provaljivanju u tuđu email adresu, 23,1 \% u krađi i promjeni tuđe lozinke, 15,4\% u uznemiravanju, uhođenju i vrijeđanju, 7,7 \% u slanju prijetećih i okrutnih poruka, 7,7 \% u slanju tuđih fotografija te traženje ostalih da ih procjenjuju po određenim karakteristikama, 7,7 \% u iznošenju osobnih ili obiteljskih prilika drugih. $0 \%$ sudionika odnosno niti jedan sudionik istraživanja nije naveo da je sudjelovao u dječjoj pornografiji.

Na pitanje smatraju li da bi trebali nešto poduzeti, kada bi čuli za slučaj elektroničkog nasilja među svojim kolegama na studiju, najviše ispitanika, njih $37 \%$, navelo je kao svoj odgovor navelo je niti da, niti ne. $28,7 \%$ studenata smatra da bi trebali nešto poduzeti, a 24,7\% ispitanika se djelomično slaže da bi. 5,5 \% studenata ne slaže se da bi trebali nešto poduzeti, a $1,4 \%$ se djelomično slaže da ne bi. 
Više od polovice studenata odnosno $63,8 \%$ ispitanika navelo je da ne smatra da je elektroničko nasilje bezopasno i zabavno, dok njih 13 \% navodi kao odgovor djelomično ne. S tvrdnjom da je elektroničko nasilje bezopasno i zabavno slaže se 2,9 \% studenata, a djelomično se slaže njih 5,8 \%. Niti se slaže, niti se ne slaže da je elektroničko nasilje bezopasno i zabavno odgovorilo je ukupno 14,5\% sudionika ovog predistraživanja.

Rezultati ovog predistraživanja su pokazali da su studenti koji koriste društvene mreže kao komunikacijski kanal većinom upoznati s barem nekim pojmovima i vrstama radnji koji se tiču sigurnosti komuniciranja, ali vrlo mali broj njih, i to samo $4,1 \%$ je u potpunosti upoznato na što točno se pojam sigurnost na društvenim mrežama odnosi. Također, pokazalo se da su studenti uglavnom upoznati, njih prosječno između $60 \%$ i $70 \%$, s pojmovima kao što su cyberbullying, bullying i uznemiravanje na društvenim mrežama, ali još uvijek velik postotak studenata nije upoznat sa svim varijablama tih radnji. Nešto veći postotak studenata upoznat je s pojmovima koji se odnose na pojam elektroničkog nasilja, prosječno između $70 \%$ i $90 \%$.

Svaki četvrti student prepoznao je sebe kao žrtva elektroničkog nasilja na društvenim mrežama, dok je svaki peti student sudjelovao u nekoj vrsti elektroničkog nasilja nad drugom osobom. Najčešće vrste elektroničkog nasilja čije su žrtve bili su napad na privatnost, širenja nasilnih i uvredljivih komentara, slanje prijetećih, okrutnih poruka, lažno predstavljanje, slanja virusa, fotografija i neželjene pošte na e-mail ili mobitel te poticanje grupne mržnje prema njima. Najčešći oblici elektroničkog nasilja u kojem su sudjelovali su lažno predstavljanje, poticanje grupne mržnje prema drugima, napadi na privatnost drugih, širenje nasilnih i uvredljivih komentara o drugim osobama, kreiranju stranica koje sadrže priče, crteže, slike i šale na račun vršnjaka, provaljivanja u tuđu e-mail adresu te krađi i promjeni tuđe lozinke.

Odgovori ispitanika pokazali su da više od $90 \%$ njih elektroničko nasilje ne smatra bezopasnim i/li zabavnim, ali da ga takvim smatra ipak svaki deseti student.

\subsubsection{Ograničavajući elementi istraživanja i prijedlozi za buduća istraživanja}

Poteškoće ovog istraživanja bile su što je uzorak bio mali i prigodni - studenti Primijenjenog i Multimedijskog računarstva koji su se na dan istraživanja zatekli na predavanju. Način distribucije bilo je ograničenje pri uzorkovanju. Kao glavno ograničenje pokazalo se to što nekoliko studenata nije ispunilo dio pitanja anketnog upitnika. 
S obzirom na to da su ispitanici provedenog istraživanja pripadnici mrežne generacije, pa su samim time bili izloženi većoj količini nasilnih i štetnih sadržaja u medijima od prethodnih generacija, moguće je da postoji korelacija izloženosti nasilnim sadržajima u odnosu na toleranciju na elektroničko nasilje te sklonost činjenju nasilnih radnji. To, nažalost, zbog teško dokazivih dugoročnih posljedica izloženosti medijskom nasilju ovog časa nije razvidno, ali bi u budućnosti, ukoliko se pojavi adekvatan model ispitivanja te korelacije, bilo uputno ispitati utjecaj, učinke i posljedice medijskog nasilja na živote ljudi koji su odrasli kao pripadnici mrežne generacije.

\subsubsection{Zaključak}

Ovo istraživanje pružilo je uvid u upoznatost studenata s pojmovima i radnjama koje se tiču elektroničkog nasilja. Iako su potrebne metodološke korekcije, posebice u korištenju termina, s obzirom na to da se pojam društvene mreže zapravo koristio kao sinonim za pojam društvenih medija, istraživanje je pokazalo da su studenti upoznati s pojmovima i vrstama radnji koje se tiču elektroničkog nasilja na društvenim mrežama, prema čemu se prihvaća prva hipoteza. Studenti korisnici društvenih mreža bili su žrtva elektroničkog nasilja na društvenim mrežama, prema čemu se djelomično prihvaća druga hipoteza. Studenti korisnici društvenih mreža sudjelovali su u nekoj vrsti elektroničkog nasilja nad nekom osobom na društvenim mrežama, prema čemu se djelomično prihvaća treća hipoteza. Studenti korisnici društvenih mreža uglavnom ne smatraju elektroničko nasilje bezopasnim, čime se četvrta hipoteza odbacuje.

Iako je istraživanje bilo metodološki nedorađeno i uzorak nije bio reprezentativan, ipak je ilustrativan primjer kako društvene mreže potencijalno mogu biti izvor raznih vrsta nasilja i prijetnji sigurnosti, stoga se sustavna edukacija o novim vrstama medija postavlja kao nužnost. Daljnja istraživanja trebala bi se usredotočiti na mogućnosti iskorištavanja prednosti društvenih medija, te neutralizirane nedostataka društvenih medija, osobito kada se oni koriste $u$ akademske svrhe odnosno za potrebe studiranja.

Rezultati istraživanja korišteni za uvid u aspekte elektroničkog nasilja prilikom studenskog korištenja društvenih mreža u kontekstu visokog obrazovanja i uvod u glavno empirijsko istraživanje te su djelomično objavljeni u radu „Net generation and a perception of the electronic violence“ (Babić, Grgić, 2019). 


\subsection{Preliminarno istraživanje 3: Informacijska etika prilikom korištenja društvenih mreža kao komunikacijskog kanala studenata}

\subsubsection{Kontekst}

Treće znanstveno predistraživanje se provelo u samo Republici Hrvatskoj, tj. u instituciji: Visoko učilište Algebra u ljetnom semestru akademske godine 2015./2016. (100 \% ispitanika bili su studenti). Trebalo je provjeriti da li studenti koji koriste društvene mreže kao komunikacijski kanal za potrebe visokog obrazovanja, na etičan način pristupaju proizvodnji, prikupljanju, diseminaciji i korištenju informacija na društvenim mrežama.

Primarni razlog odabira ovog visokog učilišta odnosno studija računarstva, multimedije i digitalnog marketinga koji osposobljavaju studente za tržište rada u kojem se poslovanje i edukacija ostvaruju na suvremene načine i posredovane digitalnom tehnologijom. Pretpostavka je bila da ti studenti/ice koriste društvene mreže, a sukladno tomu trebalo je provjeriti da li na etičan način pristupaju proizvodnji, prikupljanju, diseminaciji i korištenju informacija na društvenim mrežama.

\subsubsection{Predmet, cilj, svrha i hipoteze}

Predmet ovog istraživanja bile su društvene mreže i da li studenti na etičan način pristupaju proizvodnji, prikupljanju, diseminaciji i korištenju informacija na društvenim mrežama. Cilj je bio ispitati kako studenti procjenjuju etičan način pristupanja proizvodnji, prikupljanju, diseminaciji i korištenju informacija na društvenim mrežama.

Svrha predistraživanja bila je utvrditi da li studenti Visokog učilišta Algebra koji koriste društvene mreže na etičan način pristupaju proizvodnji, prikupljanju, diseminaciji i korištenju informacija na društvenim mrežama, vodeći pritom računa o temeljnim vrijednostima Visokog učilišta Algebra (koje su definirane u etičkom kodeksu Visokog učilišta Algebra), propisima ponašanja odnosno pravilima ponašanja na društvenim mrežama (primjerice Facebooku), informacijskoj privatnosti, intelektualnoj slobodi i intelektualnom vlasništvu.

Hipoteze ovog istraživanja bile su:

H1: Studenti su upoznati s temeljnim vrijednostima etičkog kodeksa visokog učilišta na kojem studiraju. 
H2: Studenti su upoznati s temeljnim propisima ponašanja odnosno pravilima ponašanja na društvenim mrežama (primjerice Facebooku).

H3: Studenti smatraju važnima prava koja se tiču intelektualne slobode.

H4: Studenti smatraju važnima prava koja se tiču intelektualnog vlasništva.

\subsubsection{Metodološki okvir istraživanja}

U ovom istraživanju korišten je posebno konstruirani instrument „Upitnik - Informacijska etika studenata prilikom korištenja društvenih mreža za potrebe studiranja“, detaljnije vidjeti Prilog 3. Anonimna anketa provedena je na obaveznim predavanjima studenata preddiplomskih stručnih studija Primijenjenog računarstva, Multimedijskog računarstva i Digitalnog marketinga u lipnju 2016. godine. Studenti su dobrovoljno popunili anonimni anketni upitnik, koji je sadržavao 12 pitanja s uglavnom unaprijed ponuđenim odgovorima zatvorenog tipa, te s mogućnošću da na 1 pitanje kao jednu od mogućnosti unesu odgovor vlastitim riječima. Nejasnoće u upitniku nisu bile prijavljene, iz čega se zaključuje da su pitanja bila nedvosmislena, a čestice jasne. Podaci su obrađeni kvantitativnom statističkom analizom unaprijed izoliranih varijabli te opisom stanja i ustanovljavanjem uzročno-posljedičnih veza između pojedinih komponenti.

\subsubsection{Uzorak}

Uzorak istraživanja bio je prigodni, bilo je ispitano 73 studenata i studentica koji su polazili preddiplomske studije (što je 12,4 \% studenata od ukupno 590 studenata s aktivnim statusom studenta u akademskoj godini 2015./2016. na Visokom učilištu Algebra). Struktura uzorka bila je sljedeća: 49 \% studenata Primijenjenog računarstva, od čega 38 \% Programskog inženjerstva, a $11 \%$ studenata Sistemskog inženjerstva, $14 \%$ studenata upisanih na studij Multimedijskog računarstva, te $37 \%$ studenata upisanih na studij Digitalnog marketinga.

Ukupni omjer studenata sudionika prema rodu bio je 78 \% muške populacije studenata i samo 22 \% ženske populacije. Muški rod bio je znatno više zastupljen među studentima.

U strukturi uzorka studenata u preliminarnom istraživanju prevladavali su studenti koji imaju status redovitog studenta $(85,1 \%)$, dok je zaposlenih studenata bilo daleko manje $(14,9 \%)$. 


\subsubsection{Rezultati}

Više od polovice studenata odgovorilo je da su djelomično upoznati s etičkim kodeksom odnosno temeljnim vrijednostima Visokog učilišta Algebra, i to njih 53,4 \%. 19,2 \% studenata s njima uopće nije upoznato, a 13,7 \% uglavnom nije. Izuzetno mali broj studenata upoznat je s etičkim kodeksom/temeljnim vrijednostima visokog učilišta koje pohađa, njih samo 2,7\% studenta ispitanika, a uglavnom da je upoznato $11 \%$ studenata.

S pravilima ponašanja na društvenim mrežama (npr. Facebooku), upoznato je $41 \%$ ispitanika, njih $32 \%$ s njima je upoznato tek djelomično, dok $14 \%$ ispitanika uglavnom s njima nije upoznato. Najmanji postotak su sudionici koji su u potpunosti upoznati, njih $5 \%$, a $8 \%$ studenata s pravilima ponašanja na društvenim mrežama nisu uopće upoznati.

Dok $38 \%$ uglavnom ne čita propise na društvenim mrežama te pravila ponašanja prilikom stvaranja profila, a njih $29 \%$ s njima uopće nije upoznato, djelomično njih $30 \%$, a samo $3 \%$ studenata uglavnom čita propise na društvenim mrežama te pravila ponašanja prilikom stvaranja profila.

Gotovo polovica ispitanika, njih 47,2 \% smatra intelektualnu slobodu jako važnom, te 34,7 \% studenata sudionika istraživanja ju smatra uglavnom važnom. 11,1 \% studenata ispitanika smatra da je donekle važno da svaka osoba ima pravo reći, misliti, učiti i pisati o tome što želi, $2,8 \%$ smatra da uglavnom to pravo nije važno, a za $4,2 \%$ to uopće nije važno, što je $1,4 \%$ ispitanika objasnilo ,jer postoji previše glupih ljudi““.

$12,5 \%$ ispitanika smatra intelektualnu slobodu jako važnom čak i iako zadire u prava drugih ljudi, a 12,5 \% ju smatra uglavnom važnom. 33,3 \% studenata koji su sudjelovali u istraživanju smatra da je donekle važno da svaka osoba ima pravo reći, misliti, učiti i pisati o tome čak i ako to zadire u prava drugih ljudi, no $25 \%$ ispitanika smatra da to uglavnom u tom slučaju nije važno, a 16,7 \% da uopće nije važno.

Više od polovice ukupnog broja ispitanika odnosno 54,2 \% studenata sudionika ovog istraživanja smatra da je jako važno poštovati pravila citiranja (navoditi pravog autora, nakladnika i godinu objave) prilikom prikupljanja, širenja i korištenja informacija vezano za studij, $25 \%$ da je uglavnom to važno, a $12,5 \%$ da je to donekle važno. 6,9 \% studenata smatra da uglavnom pravila citiranja nije važno poštovati, a 1,4 \% sudionika istraživanja to uopće ne smatra važnim.

Za razliku od odgovora na prošlo pitanje, koje je gotovo identično osim što je specificiralo da se pravila citiranja odnose na prikupljanje i objavu informacija na društvenim mrežama (i ne tiču se nužno studija), puno manji broj ispitanika odnosno 22,5 \% smatra da je jako važno 
poštovati pravila citiranja (navoditi pravog autora, nakladnika i godinu objave). 26,7 \% studenata sudionika smatra da je uglavnom to važno, a najveći broj ispitanika, njih $31 \%$, to smatra donekle važnim. 9,9 \% studenata smatra da uglavnom pravila citiranja na društvenim mrežama nije važno poštovati, kao i 9,9 \% sudionika istraživanja koji to uopće ne smatraju važnim.

Na temelju odgovora ispitanika utvrđeno je da su studenti tek djelomično upoznati s etičkim kodeksom odnosno temeljnim vrijednostima Visokog učilišta Algebra, a prosječno tek šesti student je s njima uglavnom ili u potpunosti upoznat, dok ih je ipak više upoznato s pravilima ponašanja na društvenim mrežama, primjerice Facebooku, ali još uvijek nešto manje od polovice, što je u nesrazmjeru s njihovim odgovorima da ih više od $60 \%$ ne čita propise zajednice odnosno pravila ponašanja na društvenim mrežama prilikom stvaranja profila na nekoj od tih zajednica. Može se zaključiti da su s propisima zajednice upoznati tek iz posrednih izvora i/ili tek nakon što su već ,pristali“ na njih.

Iz rezultata istraživanja također je identificirano da gotovo polovica studenata Visokog učilišta Algebra smatra da je jako važno pravo svake osobe da kaže, misli uči i piše o onome što želi, odnosno dodatno svaki treći studentu intelektualnu slobodu smatra uglavnom važnom, međutim tek svaki peti student smatra da to pravo ima čak i ako to zadire u prava drugih ljudi.

Isto tako, više od polovice ih smatra da je jako važno poštovati pravila citiranja (navoditi pravog autora, nakladnika i godinu objave) prilikom prikupljanja, širenja i korištenja informacija vezano za studij, a još gotovo $40 \%$ da je to uglavnom ili donekle važno, dok ih manje od $10 \%$ to smatra nevažnim. Ipak, na postavljeno gotovo identično pitanje koje se tiče konkretnog slučaja važnosti poštovanja pravila citiranja (navođenja pravog autora, nakladnika i godine objave) prilikom prikupljanja i objave informacija na društvenim mrežama, svaki peti ispitanik smatra da to nije važno. Iz rezultata nije jasno zašto se udvostručio broj ispitanika koji na društvenim mrežama prava intelektualnog vlasništva autora ne smatraju bitnima.

\subsubsection{Ograničavajući elementi istraživanja i prijedlozi za buduća istraživanja}

Poteškoće ovog istraživanja bile su što je uzorak bio mali i prigodni - studenti Primijenjenog i Multimedijskog računarstva te Digitalnog marketinga koji su se na dan istraživanja zatekli na predavanju. Način distribucije bilo je ograničenje pri uzorkovanju. Kao glavno ograničenje pokazalo se to što nekoliko studenata nije ispunilo dio pitanja anketnog upitnika. 
Iako je istraživanje pokazalo da studenti Visokog učilišta Algebra, koji koriste društvene mreže, uglavnom nastoje na etičan način pristupati proizvodnji, prikupljanju, diseminaciji i korištenju informacija na društvenim mrežama, potrebno je daljnje ispitivanje korelacije ponašanja studenata u odnosu na ono što smatraju kad odgovaraju na teoretska pitanja koja se tiču iste navedene tematike, kao i usporedno istraživanje među studentskom populacijom na drugim visokim učilištima.

\subsubsection{Zaključak}

Ovo istraživanje pružilo je uvid u etičnost načina na koje studenti pristupaju proizvodnji, prikupljanju, diseminaciji i korištenju informacija na društvenim mrežama, vodeći pritom računa o temeljnim vrijednostima visokog učilišta na kojem studiraju (koje su definirane $u$ Etičkom kodeksu Visokog učilišta Algebra), propisima ponašanja odnosno pravilima ponašanja na društvenim mrežama (primjerice Facebooku), informacijskoj privatnosti, intelektualnoj slobodi i intelektualnom vlasništvu.

Istraživanje je pokazalo da je više od polovice studenata tek djelomično upoznato s temeljnim vrijednostima etičkog kodeksa visokog učilišta na kojem studiraju, čime se djelomično prihvaća prva hipoteza.

Ipak, niti jedan student u potpunosti ne čita pravila ponašanja na društvenim mrežama te njihove propise $u$ trenutku stvaranja profila što znači da niti jedan student s njima nije upoznat $u$ potpunosti, prema čemu se druga hipoteza odbacuje.

Više od 80 \% studenata smatra da je važno pravo svake osobe da kaže, misli uči i piše o onome što želi, odnosno prava koja se tiču intelektualne slobode, prema čemu se treća hipoteza prihvaća.

Isto tako, više od polovice ih smatra da je jako važno poštovati pravila citiranja (navoditi pravog autora, nakladnika i godinu objave) prilikom prikupljanja, širenja i korištenja informacija vezano za studij, a još gotovo $40 \%$ da je to uglavnom ili donekle važno, dok ih manje od $10 \%$ to smatra nevažnim, prema čemu se četvrta hipoteza prihvaća.

Rezultati ovog istraživanja djelomično su bili objavljeni u radu „Informacijska etika na društvenim mrežama: perspektiva studenata“ (Babić, Vunarić, Lacković, 2019).

Sumarno, sva tri preliminarna istraživanja provedena među studentskom populacijom na temu društvenih mreža odnosno društvenih medija, pokazala su da se pojam društveni mediji 
najčešće podrazumijeva kao pojam društvene mreže i obrnuto, kao da se radi o istoznačnici. S obzirom na to da je najčešće korištena društvena mreža Facebook, ujedno je Facebook i prva asocijacija na spomen društvenih medija. To postaje razvidno prilikom tumačenja pojmova pri popunjavanju anketnih upitnika, pri čemu se ostalih 12 podtipova, kako su ih definirali Aichner i Jacob (2015) najčešće uopće ne podrazumijevaju kao društveni mediji, a time se ne uzimaju u obzir ni mogućnosti koje ti interaktivni alati pružaju. Stoga je u istraživanju koje je uslijedilo, četvrto po redu, poseban naglasak stavljen na samo pojašnjenje pojma društveni mediji prije popunjavanja upitnika.

Osim navedenog, zanimljivo je primijetiti da se u prvom preliminarnom istraživanju nisu svi ispitanici deklarirali kao korisnici društvenih mreža (a time ni društvenih medija), dok su u sljedeća dva, drugom i trećem preliminarnom istraživanju, svi ispitanici odgovarali na pitanja kao da se podrazumijeva da su apsolutno svi, bez iznimke, korisnici istih.

\subsection{Preliminarno istraživanje 4: Nastavnici i korištenje društvenih medija}

\subsubsection{Kontekst}

Četvrto znanstveno predistraživanje provedeno je u Republici Hrvatskoj (RH), u institucijama Visoko učilište Algebra te Veleučilište Baltazar Zaprešić, u ljetnom semestru akademske godine 2018./2019., $100 \%$ ispitanika bili su nastavnici.

Trebalo je istražiti nastavničku percepciju društvenih medija te koriste li i u kojoj mjeri nastavnici društvene medije za potrebe visokog obrazovanja.

Uzorak ovog istraživanja bio je prigodan. Sudjelovale su 73 osobe u znanstveno-nastavnim i suradničkim zvanjima koje su zaposleni nastavnici ili vanjski suradnici u nastavi na Visokom učilišta Algebra Zagreb (52 \% ispitanika) te Veleučilištu Baltazar Zaprešić (48 \% ispitanika).

\subsubsection{Predmet, cilj, svrha i hipoteze}

Predmet ovog istraživanja bile su društveni mediji i koriste li ih nastavnici za potrebe visokog obrazovanja. Cilj je bio ispitati kako nastavnici procjenjuju ulogu i važnost društvenih medija kao komunikacijskog kanala za potrebe visokog obrazovanja. 
Svrha predistraživanja bila je utvrditi koriste li nastavnici društvene medije za potrebe visokog obrazovanja, utječu li demografska obilježja kao što su dob, spol i znanstveno područje znanstveno-nastavnog i/ili suradničkog zvanja nastavnika, te varijable stavovi nastavnika, društveni utjecaj, anksioznost i samopouzdanje prilikom korištenja društvenih medija, organizacijski čimbenici, olakšavajući uvjeti, očekivana lakoća korištenja, očekivani radni učinci te namjera korištenja na učestalost nastavničkog korištenja društvenih medija za potrebe visokog obrazovanja.

\subsubsection{Metodološki okvir istraživanja}

U ovom istraživanju korišten je posebno konstruirani instrument „Upitnik - Nastavničko korištenje društvenih medija za potrebe visokog obrazovanja“, detaljnije vidjeti cjelokupan Prilog 4. Nastavnici su dobrovoljno popunili anonimni anketni upitnik, koji je sadržavao 22 pitanja s uglavnom unaprijed ponuđenim odgovorima zatvorenog tipa, dok su na 4 pitanja kao jednu od mogućnosti mogli unijeti odgovor vlastitim riječima. Nejasnoće u upitniku nisu bile prijavljene, iz čega se zaključuje da su pitanja bila nedvosmislena, a čestice jasne.

Strukturirani anketni upitnik oblikovan je prema prilagođenom UTAUT modelu (Venkatesh i sur. 2003). Na korištenje tehnologije općenito mogu utjecati brojni čimbenici, stoga su Venkatesh i suradnici 2003. godine temeljem pregleda 8 modela ranijih teorija te konsolidacijom konstrukata izradili i empirijski validirali Jedinstvenu teoriju prihvaćanja i upotrebe tehnologije (engl. Unified Theory of Acceptance and Use of Technology, kratica UTAUT). Prema UTAUT modelu (Venkatesh i sur. 2003) razlikuju se namjera ponašanja (namjera korištenja u sljedećih 12-24 mjeseci) i (stvarno) ponašanje tj. korištenje tehnologije. Pretpostavlja se da na namjeru ponašanja značajno utječu:

- očekivani radni učinak (stupanj vjerovanja osobe da će korištenje tehnologije pomoći njenom radnom učinku),

- očekivani trud (stupanj vjerovanja osobe o lakoći korištenja tehnologije) i

- društveni utjecaj (stupanj percepcije osobe da njoj važni ljudi vjeruju kako bi ona trebala koristiti nove tehnologije).

Dok ponašajna namjera i olakšavajući uvjeti (stupanj vjerovanja osobe da postoji organizacijska i tehnološka infrastruktura koja podržava korištenje tehnologije) značajno doprinose stvarnom korištenju sustavom. 
UTAUT model ima različita područja primjene pa je tako znanstvenicima u nekim zemljama model poslužio kao teorijska osnova za implementaciju društvenog računarstva $u$ visoka učilišta (Hussein, 2013) te identificiranje čimbenika koji utječu na studentsko korištenje platformi društvenih medija u akademske svrhe (Ali i sur., 2017).

U Hrvatskoj se model koristio primjerice za istraživanje relevantnih čimbenika koji utječu na prihvaćanje otvorenog pristupa znanstvenim i obrazovnim sadržajima u akademskom okruženju (Krelja Kurelović, 2017), no opsežno istraživanje koji sve čimbenici i u kojoj mjeri utječu na prihvaćanje i korištenje društvenih medija u visokom obrazovanju još nije provedeno. Nastavnici na preddiplomskim i diplomskim studijima su dobrovoljno popunili anonimni anketni upitnik. Rezultati istraživanja korišteni za uvid u nastavničku percepciju društvenih medija te korištenja društvenih medija u kontekstu visokog obrazovanja i uvod u glavno empirijsko istraživanje.

Podaci istraživanja prikupljeni su pomoću posebno dizajniranog anketnog upitnika u alatu Google obrasci koji je distribuiran nastavnicima putem elektroničke pošte. Sudjelovanje ispitanika bilo je dobrovoljno i anonimno. Strukturirani anketni upitnik sastojao se od dvije cjeline grupiranih pitanja zatvorenog tipa o općim demografskim podacima te korištenju društvenih medija za potrebe visokog obrazovanja. Kako bi se osiguralo jednoznačno razumijevanje pojma društvenih medija prije pitanja u upitniku navedena je opisna definicija pojma društvenih medija.

Podaci su obrađeni kvantitativnom statističkom analizom unaprijed izoliranih varijabli te opisom stanja i ustanovljavanjem uzročno-posljedičnih veza između pojedinih varijabli.

\subsubsection{Uzorak}

Uzorak istraživanja bio je prigodni, bilo ispitano 73 osobe u znanstveno-nastavnim i suradničkim zvanjima koje su zaposleni nastavnici ili vanjski suradnici u nastavi na Visokom učilišta Algebra Zagreb te Veleučilištu Baltazar Zaprešić. Struktura uzorka bila je sljedeća: 52 \% zaposlenih nastavnika ili vanjskih suradnika u nastavi na Visokom učilišta Algebra Zagreb te 48 \% zaposlenih nastavnika ili vanjskih suradnika na Veleučilištu Baltazar Zaprešić.

Struktura uzorka prema dobi bila je sljedeća: 0 \% nastavnika bilo je mlađe dobi od 20 godina starosti, te 8,2 \% dobi od 21-30 godina starosti, a isti je bio udio nastavnika starosti 61 godinu i više. Najveći udio je nastavnika od 31-40 godina starosti, njih 39,7 \%, te nastavnika dobi 4150 godina starosti čiji je udio bio $30,1 \%$. 
Ukupni omjer nastavnika sudionika prema rodu bio je 56,2 \% muške populacije i 43,8 \% ženske populacije. Muški rod bio je neznatno više zastupljen među nastavnicima.

U strukturi uzorka nastavnika u drugom preliminarnom istraživanju nastavnici koji predaju samo na preddiplomskoj razini studija bilo je 32,9\%, na diplomskoj razini $24,6 \%$, a 42,5\% predaje na obje razine studija.

Struktura uzorka prema godinama radnog iskustva bila je sljedeća: 33,3\% nastavnika ima manje od 5 godina radnog iskustva, 27,8 \% nastavnika ima između 5 i 10 godina radnog iskustva, a isti postotak tj. 27,8 \% nastavnika ima 11 do 20 godina radnog iskustva. Najmanji postotak, 2,8 \% nastavnika ima između 21 i 30 godina radnog iskustva, te $8,3 \%$ ima više od 31 godine radnog iskustva.

\subsubsection{Rezultati}

Rezultati ovog istraživanja o nastavničkom korištenju društvenih medija za potrebe visokog obrazovanja prikazani su s obzirom na učestalost korištenja i podtipove društvenih medija koje nastavnici koriste.

$\mathrm{Na}$ istraživačko pitanje koliko često nastavnici koriste društvene medije za potrebe visokog obrazovanja, 13,7 \% nastavnika odgovorilo je da ih nikada ne koriste. Samo 8,2 \% nastavnika ih koristi za te svrhe svaki dan odnosno uvijek, dok ih gotovo polovica, njih najviše tj. 42,5\%, to čini povremeno. 17,8 \% nastavnika ispitanika društvene medije za potrebe visokog obrazovanja koristi rijetko, a isti postotak ispitanika, 17,8 \%, iste koristi često za potrebe visokog obrazovanja.

Gotovo polovica nastavnika ispitanika, njih 47,9\%, koristi društvene medije za potrebe visokog obrazovanja svakodnevno, ali manje od sat vremena dnevno, dok ih najmanji postotak, njih 9,6 $\%$ to čini nekoliko sati dnevno. 32,8 \% nastavnika čini to u rasponu između nekoliko sati tjedno do nekoliko sati mjesečno, a 13,7 \% ispitanika uopće ne koristi društvene medije za potrebe visokog obrazovanja.

Kako bi se odgovorilo na istraživačko pitanje koje društvene medije nastavnici koriste za potrebe visokog obrazovanja te dobio dublji uvid u nastavničko korištenje društvenih medija, ispitanicima je bi ponuđeno 13 podtipova društvenih medija (prema Aichner i Jacob, 2015) s primjerom istih, te su zamoljeni da navedu koje od njih koriste za potrebe visokog obrazovanja. Ispitanici su naveli da najviše koriste društvene mreže kao što su Facebook, Google+ (49,3 \%), društvene medije za dijeljenje videozapisa primjerice YouTube, Vimeo (46,6 \%) i poslovne 
mreže kao što je LinkedIn (43,8 \%), dok najmanje koriste društvene igre, npr. World of Warcraft ili Mafia Wars (2,7 \%) ili društvene medije za knjižno označavanje kao što su Pinterest i Reditt (12,3 \%). 13,7 \% sudionika istraživanja ne koristi niti jedan od podtipova društvenih medija za potrebe visokog obrazovanja.

Što se tiče utjecaja varijabli iz prilagođenog UTAUT modela na učestalost nastavničkog korištenja društvenih medija za potrebe visokog obrazovanja, rezultati ovog istraživanja pokazali su da spol, dob i znanstveno područje zvanja nastavnika, samopouzdanje prilikom korištenja društvenih medija, organizacijski čimbenici, olakšavajući uvjeti i očekivana lakoća korištenja ne utječu značajno na stvarno nastavničko korištenje društvenih medija, ali svakako se ne može zanemariti da postoje statistički signifikantne veze između pojedinih stavova nastavnika prema korištenju društvenih medija, društvenog utjecaja, varijacija anksioznosti prilikom korištenja društvenih medija, očekivanog radnog učinka i namjera nastavnika da koriste društvene medije za potrebe visokog obrazovanja na učestalost nastavničkog korištenja društvenih medija, kako je sumarno prikazano u Tablici 12.

Tablica 12. Sumarni prikaz čimbenika koji (ne) utječu na učestalost nastavničkog korištenja društvenih medija za potrebe visokog obrazovanja; Pearsonov hi-kvadrat test (izvor: upitnik, SPSS, obrada autorice)

\begin{tabular}{|c|c|c|}
\hline ZAVISNA VARIJABLA & NEZAVISNA VARIJABLA & OBRAZLOŽENJE \\
\hline \multirow{9}{*}{$\begin{array}{l}\text { Korištenje društvenih medija } \\
\text { za potrebe visokog } \\
\text { obrazovanja }\end{array}$} & Spol & Ne postoji statistički značajna veza \\
\hline & Dob & Ne postoji statistički značajna veza \\
\hline & Znanstveno područje & Ne postoji statistički značajna veza \\
\hline & Stavovi nastavnika prema & Ne postoji statistički značajna veza za: \\
\hline & korištenju društvenih medija & - $\quad$ Nastavnici bi trebali aktivnije koristiti društvene \\
\hline & $\begin{array}{l}\text { za potrebe visokog } \\
\text { obrazovanja }\end{array}$ & $\begin{array}{l}\text { medije za potrebe poučavanja studenata. } \\
\text { - Visoka učilišta trebala bi usvojiti politiku } \\
\text { korištenja društvenih medija za potrebe } \\
\text { studiranja. }\end{array}$ \\
\hline & & $\begin{array}{l}\text { Postoji statistički značajna veza za: } \\
\text { - Visoka učilišta trebala bi provoditi educiranje } \\
\text { nastavnika o korištenju društvenih medija. } \\
\text { - Visoka učilišta trebala bi provoditi educiranje } \\
\text { studenata o korištenju društvenih medija. }\end{array}$ \\
\hline & Društveni utjecaj & Ne postoji statistički značajna veza za: \\
\hline & & $\begin{array}{l}\text { - Kolege nastavnici koji koriste društvene medije za } \\
\text { potrebe visokog obrazovanja. } \\
\text { - Prijatelji i bliski poznanici nastavnika koji koriste } \\
\text { društvene medije za potrebe visokog obrazovanja. } \\
\text { Oklijevanje prilikom korištenja društvenih medija } \\
\text { za potrebe visokog obrazovanja zbog straha od } \\
\text { pogrešaka koje se ne mogu ispraviti. } \\
\text { Postoji statistički značajna veza za: } \\
\text { - Osjećaj da je korištenje društvenih medija za } \\
\text { potrebe visokog obrazovanja pomalo } \\
\text { zastrašujuće. }\end{array}$ \\
\hline
\end{tabular}


Anksioznost prilikom

korištenja društvenih medija

za potrebe visokog

obrazovanja

Ne postoji statistički značajna veza za:

- Osjećaj zabrinutosti zbog korištenja društvenih medija za potrebe visokog obrazovanja

- Osjećaj uplašenosti da bi mogao/mogla izgubiti puno informacija prilikom korištenja društvenih medija za potrebe visokog obrazovanja ako nešto krivo unese.

- $\quad$ Oklijevanje prilikom korištenja društvenih medija za potrebe visokog obrazovanja zbog straha od pogrešaka koje se ne mogu ispraviti.

Postoji statistički značajna veza za:

- Studenti koji smatraju da nastavnici trebaju koristiti društvene medije za potrebe visokog obrazovanja.

- Uprava fakulteta koja podržava korištenje društvenih medija za potrebe visokog obrazovanja.

Samopouzdanje nastavnika

prilikom korištenja društvenih

medija za potrebe visokog

obrazovanja
Ne postoji statistički značajna veza za:

- Mogao/mogla bih dovršiti posao korištenjem društvenih medija za potrebe visokog obrazovanja čak i kad ne bi bilo nikoga tko bi mi rekao što da radim tijekom izvršavanja.

- Mogao/mogla bih dovršiti posao korištenjem društvenih medija za potrebe visokog obrazovanja kad bih imao/imala na raspolaganju stručnu pomoć kad zapnem.

- Mogao/mogla bih dovršiti posao korištenjem društvenih medija za potrebe visokog obrazovanja kad bih imao/imala dovoljno vremena na raspolaganju.

- Mogao/mogla bih dovršiti posao korištenjem društvenih medija za potrebe visokog obrazovanja ako bih imao/imala ugrađen sustav za pomoć.
Organizacijski čimbenici

Ne postoji statistički značajna veza za:

- Visokoškolska ustanova na kojoj radim otvorena je i fleksibilna za nove ideje.

- Smatram da bi hrvatske visokoškolske ustanove trebale usvojiti politiku korištenja društvenih medija za potrebe visokog obrazovanja.

- Smatram da bi hrvatske visokoškolske trebale provoditi educiranje nastavnika o korištenju društvenih medija za potrebe visokog obrazovanja.

- Smatram da bi hrvatske visokoškolske trebale provoditi educiranje studenata o korištenju društvenih medija za potrebe visokog obrazovanja.

Olakšavajući čimbenici

(uvjeti) korištenja društvenih medija za potrebe visokog

obrazovanja
Ne postoji statistički značajna veza za:

- Imam resurse potrebne za korištenje društvenih medija za potrebe visokog obrazovanja (primjerice pristup internetu, računalo/tablet/mobilni uređaj...).

- Imam znanje potrebno za korištenje društvenih medija za potrebe visokog obrazovanja.

- Visokoškolska ustanova na kojoj radim potiče korištenje društvenih medija za potrebe visokog obrazovanja.

- Dostupna mi je stručna pomoć za sva pitanja koja se tiču korištenja društvenih medija za potrebe visokog obrazovanja. 


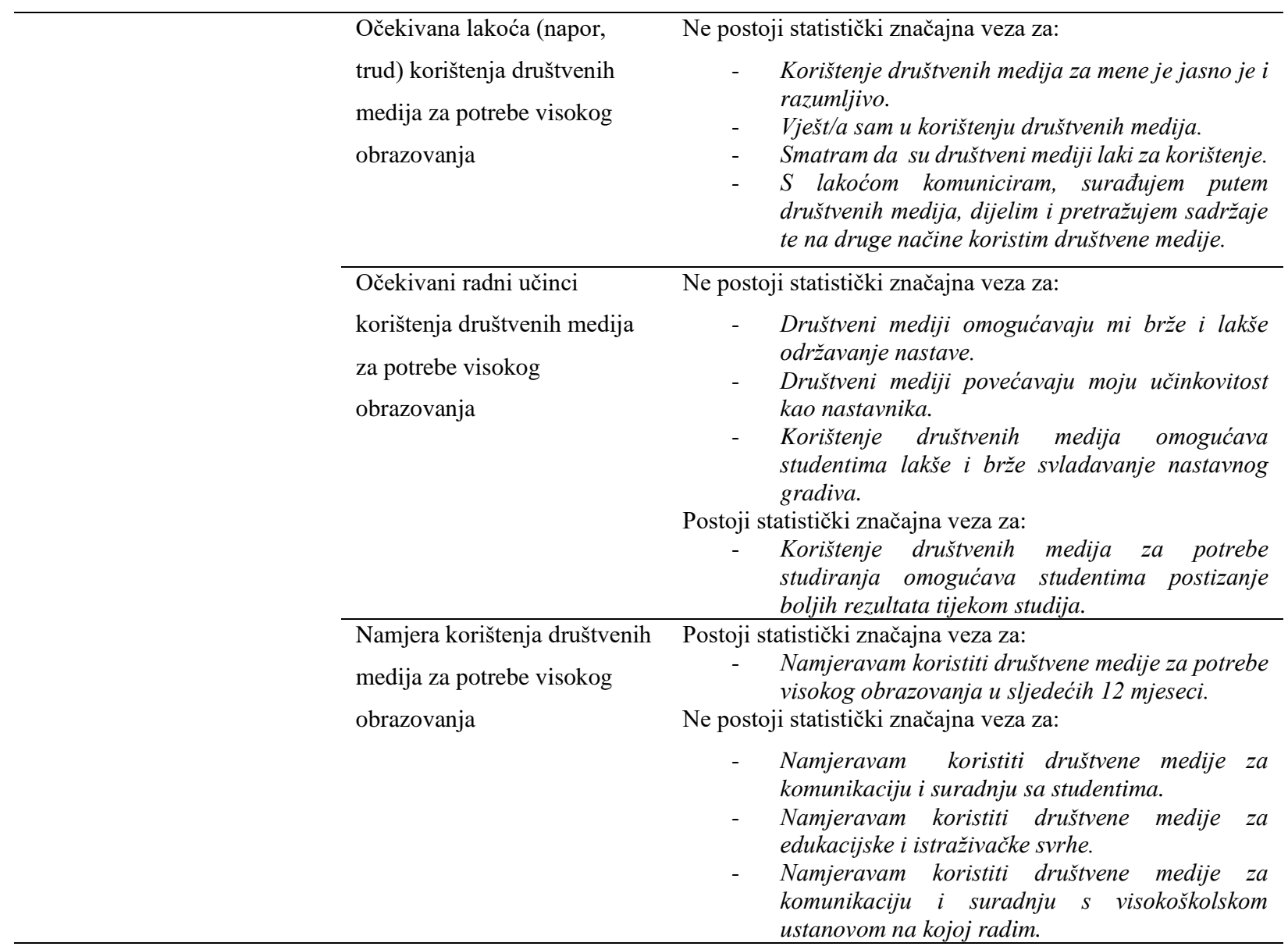

Kako bi se odgovorilo na istraživačko pitanje koje karakteristike društvenih medija nastavnici smatraju prednostima, rezultati su numerički prikazani u Tablici 13. kako slijedi.

Tablica 13. Karakteristike društvenih medija koje nastavnici smatraju prednostima (izvor: upitnik, Google obrasci, obrada autorice)

\section{Karakteristike društvenih medija koje nastavnici smatraju prednostima:}

\begin{tabular}{|c|c|c|}
\hline Lakši i brži pristup informacijama, kada i gdje je to potrebno & $\begin{array}{l}\% \\
\mathrm{~N}\end{array}$ & $\begin{array}{c}76,7 \% \\
56\end{array}$ \\
\hline Dijeljenje ideja i iskustava & $\begin{array}{l}\% \\
\mathrm{~N}\end{array}$ & $\begin{array}{c}64,4 \% \\
47\end{array}$ \\
\hline Dijeljenje fotografija i videozapisa & $\begin{array}{l}\% \\
\mathrm{~N}\end{array}$ & $\begin{array}{c}64,4 \% \\
47\end{array}$ \\
\hline Fleksibilnost što se tiče odabira tehnologija & $\begin{array}{l}\% \\
\mathrm{~N}\end{array}$ & $\begin{array}{c}57,5 \% \\
42\end{array}$ \\
\hline
\end{tabular}




\begin{tabular}{|c|c|c|}
\hline Brze povratne reakcije & $\%$ & $\begin{array}{c}53,4 \% \\
39\end{array}$ \\
\hline Mogućnost stvaranja digitalnog sadržaja & $\%$ & $\begin{array}{c}50,7 \% \\
37\end{array}$ \\
\hline Praćenje aktualnih tema & $\%$ & $\begin{array}{c}49,3 \% \\
36\end{array}$ \\
\hline Marketing i regrutaciju novih studenata & $\%$ & $\begin{array}{c}47,9 \% \\
35\end{array}$ \\
\hline Smanjenje troškova & $\%$ & $\begin{array}{c}45,2 \% \\
33\end{array}$ \\
\hline $\begin{array}{l}\text { Jačanje veza sa širom lokalnom zajednicom, ali i s ljudima diljem svijeta/međunarodnom } \\
\text { zajednicom }\end{array}$ & $\%$ & $\begin{array}{c}40,1 \% \\
30\end{array}$ \\
\hline Neovisnost od pojedine platforme (npr. računala, dostupnost već uz pristup internetu i preglednik) & $\%$ & $\begin{array}{c}39,7 \% \\
29\end{array}$ \\
\hline Mogućnost integracije raznih web 2.0 tehnologija u aktivnostima učenja i poučavanja & $\begin{array}{l}\% \\
\mathrm{~N}\end{array}$ & $\begin{array}{c}37,0 \% \\
27\end{array}$ \\
\hline Manje vremena i napora potrebno za pretraživanje i upravljanje informacijama & $\begin{array}{l}\% \\
\mathrm{~N}\end{array}$ & $\begin{array}{c}37,0 \% \\
27\end{array}$ \\
\hline Neobavezan pristup & $\begin{array}{l}\% \\
\mathrm{~N}\end{array}$ & $\begin{array}{c}35,6 \% \\
26\end{array}$ \\
\hline Održavanje postojećih kontakata i veza & $\begin{array}{l}\% \\
\mathrm{~N}\end{array}$ & $\begin{array}{c}35,6 \% \\
26\end{array}$ \\
\hline Mogućnost kontrole pristupa putem autentifikacije korisnika & $\begin{array}{l}\% \\
\mathrm{~N}\end{array}$ & $\begin{array}{c}31,5 \% \\
23\end{array}$ \\
\hline Niska razina složenosti upotrebe (potrebne minimalne vještine) & $\begin{array}{l}\% \\
\mathrm{~N}\end{array}$ & $\begin{array}{c}31,5 \% \\
23\end{array}$ \\
\hline Fokus na inovacijama u učenju, ne na samoj tehnologiji & $\begin{array}{l}\% \\
\mathrm{~N}\end{array}$ & $\begin{array}{c}31,5 \% \\
23\end{array}$ \\
\hline Stjecanje informatičkog obrazovanja & $\begin{array}{l}\% \\
\mathrm{~N}\end{array}$ & $\begin{array}{c}28,8 \% \\
21\end{array}$ \\
\hline Mogućnost stjecanja novih poznanstava & $\begin{array}{l}\% \\
\mathrm{~N}\end{array}$ & $\begin{array}{c}28,8 \% \\
21\end{array}$ \\
\hline Povećanje načina učenja zbog raznolikosti novih tehnologija & $\begin{array}{l}\% \\
\mathrm{~N}\end{array}$ & $\begin{array}{c}27,4 \% \\
20\end{array}$ \\
\hline Jačanje samopouzdanja i motivacije kroz interakciju s drugim korisnicima & $\begin{array}{l}\% \\
\mathrm{~N}\end{array}$ & $\begin{array}{c}27,4 \% \\
20\end{array}$ \\
\hline Kompatibilnost s područjima obrazovanja & $\begin{array}{l}\% \\
\mathrm{~N}\end{array}$ & $\begin{array}{c}23,3 \% \\
17\end{array}$ \\
\hline Podržavanje postojećih ili novih poslova & $\begin{array}{l}\% \\
\mathrm{~N}\end{array}$ & $23,3 \%$ \\
\hline
\end{tabular}




\begin{tabular}{|c|c|c|}
\hline & & 17 \\
\hline \multirow{2}{*}{ Pouzdanost u kontinuiranom korištenju tijekom duljeg vremenskog razdoblja } & $\%$ & $19,2 \%$ \\
\hline & $\mathrm{N}$ & 14 \\
\hline \multirow{2}{*}{ Mogućnost testiranja postojećih modela poučavanja } & $\%$ & $15,1 \%$ \\
\hline & $\mathrm{N}$ & \\
\hline \multirow{2}{*}{ Ništa od navedenog } & $\%$ & $2,7 \%$ \\
\hline & $\mathrm{N}$ & 2 \\
\hline
\end{tabular}

\subsubsection{Nedostaci korištenja društvenih medija za potrebe visokog obrazovanja}

Kako bi se odgovorilo na istraživačko pitanje koje karakteristike društvenih medija nastavnici smatraju nedostacima, rezultati su numerički prikazani u Tablici 14. kako slijedi.

Tablica 14. Karakteristike društvenih medija koje nastavnici smatraju nedostacima (izvor: upitnik, Google obrasci, obrada autorice).

\section{Karakteristike društvenih medija koje nastavnici smatraju nedostacima:}

\begin{tabular}{|c|c|c|}
\hline Zapostavljanje direktne komunikacije (licem-u-lice) & $\begin{array}{l}\% \\
\mathrm{~N}\end{array}$ & $\begin{array}{c}58,9 \% \\
43\end{array}$ \\
\hline Mogućnost postojanja lažnih identiteta & $\begin{array}{l}\% \\
\mathrm{~N}\end{array}$ & $\begin{array}{c}57,5 \% \\
42\end{array}$ \\
\hline Pitanja privatnosti (nedostatak privatnosti...) & $\begin{array}{l}\% \\
\mathrm{~N}\end{array}$ & $\begin{array}{c}52,1 \% \\
38\end{array}$ \\
\hline Smanjenje socijalnih vještina & $\begin{array}{l}\% \\
\mathrm{~N}\end{array}$ & $\begin{array}{c}49,3 \% \\
36\end{array}$ \\
\hline Promoviraju ponudu amaterskih sadržaja koje generiraju korisnici & $\begin{array}{l}\% \\
\mathrm{~N}\end{array}$ & $\begin{array}{c}39,7 \% \\
29\end{array}$ \\
\hline Uhođenje (eng. Stalking) & $\begin{array}{l}\% \\
\mathrm{~N}\end{array}$ & $\begin{array}{c}38,4 \% \\
28\end{array}$ \\
\hline Elektroničko nasilje & $\begin{array}{l}\% \\
\mathrm{~N}\end{array}$ & $\begin{array}{c}34,2 \% \\
25\end{array}$ \\
\hline Nude se informacije u otvorenim izvorima s vrlo nejasnim značenjem i kvalitetom & $\begin{array}{l}\% \\
\mathrm{~N}\end{array}$ & $\begin{array}{c}34,2 \% \\
25\end{array}$ \\
\hline Mogućnost razvijanja ovisnosti & $\begin{array}{l}\% \\
\mathrm{~N}\end{array}$ & $\begin{array}{c}30,1 \% \\
22\end{array}$ \\
\hline
\end{tabular}




\begin{tabular}{|c|c|c|}
\hline Dovode do niske kvalitete stvarnog sadržaja & $\begin{array}{l}\% \\
\mathrm{~N}\end{array}$ & $\begin{array}{c}26,0 \% \\
19\end{array}$ \\
\hline Imaju ograničenu sigurnost & $\begin{array}{l}\% \\
\mathrm{~N}\end{array}$ & $\begin{array}{c}26,0 \% \\
19\end{array}$ \\
\hline Daju svima priliku da se žale, stvarajući tako zajednicu bez pravila & $\begin{array}{l}\% \\
\mathrm{~N}\end{array}$ & $\begin{array}{c}23,3 \% \\
17\end{array}$ \\
\hline Potiču negativno ponašanje kao što je nemoral i lijenost & $\begin{array}{l}\% \\
\mathrm{~N}\end{array}$ & $\begin{array}{c}21,9 \% \\
16\end{array}$ \\
\hline Smanjuju se pedagoška očekivanja umjesto obrnuto & $\begin{array}{l}\% \\
\mathrm{~N}\end{array}$ & $\begin{array}{c}21,9 \% \\
16\end{array}$ \\
\hline Nepostojanje sustavne edukacije o korištenju & $\begin{array}{l}\% \\
\mathrm{~N}\end{array}$ & $\begin{array}{c}20,5 \% \\
15\end{array}$ \\
\hline Znanstvena komunikacija postaje (previše) neformalna & $\begin{array}{l}\% \\
\mathrm{~N}\end{array}$ & $\begin{array}{c}20,5 \% \\
15\end{array}$ \\
\hline Potrebna je internetska veza (osobito širokopojasna veza) & $\begin{array}{l}\% \% \\
\mathrm{~N}\end{array}$ & $\begin{array}{c}16,4 \% \\
12\end{array}$ \\
\hline Negativno utječu na zdravlje (primjerice bolesti kralježnice, očiju...) & $\begin{array}{l}\% \\
\mathrm{~N}\end{array}$ & $\begin{array}{c}16,4 \% \\
12\end{array}$ \\
\hline Povećavaju jaz između generacija & $\begin{array}{l}\% \\
\mathrm{~N}\end{array}$ & $\begin{array}{c}16,4 \% \\
12\end{array}$ \\
\hline Iznimno raznolika ponuda društvenih medija koji se mogu koristiti samo otežavaju odabir & $\begin{array}{l}\% \\
\mathrm{~N}\end{array}$ & $\begin{array}{c}11,0 \% \\
8\end{array}$ \\
\hline Monetarno su kvantificirani (sve postaje „posao“ i „,brojke“) & $\begin{array}{l}\% \\
\mathrm{~N}\end{array}$ & $\begin{array}{c}9,6 \% \\
7\end{array}$ \\
\hline Skrivaju iza sebe tehnologije i koncepte koji još nisu dovoljno definirani/istraženi & $\begin{array}{l}\% \\
\mathrm{~N}\end{array}$ & $\begin{array}{c}9,6 \% \\
7\end{array}$ \\
\hline Postaju vrsta rabljenog web-a odnosno medij za osobe s niskom razinom digitalnih vještina & $\begin{array}{l}\% \\
\mathrm{~N}\end{array}$ & $\begin{array}{c}6,8 \% \\
5\end{array}$ \\
\hline Vrijeme i znanje utrošeno na korištenje & $\begin{array}{l}\% \\
\mathrm{~N}\end{array}$ & $\begin{array}{c}6,8 \% \\
5\end{array}$ \\
\hline Brzina programa je neusporedivo niža od brzine desktop programa & $\begin{array}{l}\% \\
\mathrm{~N}\end{array}$ & $\begin{array}{c}5,5 \% \\
4\end{array}$ \\
\hline Sadržaj ne znači ništa za sebe, on je samo elektronički „otpad“ & $\begin{array}{l}\% \\
\mathrm{~N}\end{array}$ & $\begin{array}{c}4,1 \% \\
3\end{array}$ \\
\hline Ništa od navedenog & $\begin{array}{l}\% \\
\mathrm{~N}\end{array}$ & $\begin{array}{c}5,5 \% \\
4\end{array}$ \\
\hline
\end{tabular}

Rezultati ovog predistraživanja djelomično su objavljeni u radu „The Usage of Social Media for Higher Education Purposes“ (Babić, Vilović, Bakić-Tomić, 2019). 


\subsubsection{Ograničavajući elementi istraživanja i prijedlozi za buduća istraživanja}

Provedeno istraživanje imalo je i određene nedostatke koji bi se mogli ukloniti u budućim istraživanjima. Istraživanje je bilo provedeno na samo dva visoka učilišta, na malom uzorku, stoga rezultati istraživanja ne odražavaju nužno druga visoka učilišta. Istraživanje je obuhvatilo ograničeni broj relevantnih varijabli, a mogli bi se dobiti precizniji rezultati kada bi se istražilo u kojoj mjeri je pojedina varijabla statistički značajna te do koje mjere utječe na ponašanje nastavnika u svezi sa stvarnim korištenjem društvenih medija za potrebe visokog obrazovanja. Buduća istraživanja mogla bi proširiti analizu i na druge varijable kao što su primjerice u kojoj mjeri percepcija prednosti i percepcija nedostataka utječu na stvarno korištenje društvenih medija. Rezultati se mogu usporediti i između privatnih te državnih visokih učilišta.

\subsubsection{Diskusija sa zaključkom}

Rezultati ovog istraživanja pokazali su da demografska obilježja nastavnika kao što su dob, spol i znanstveno područje zvanja nastavnika ne utječu na učestalost nastavničkog korištenja društvenih medija za potrebe visokog obrazovanja, a to je slučaj i s pojedinim stavovima prema korištenju, društvenim utjecajima i anksioznošću prilikom korištenja. No, nije zanemarivo da bi u isto vrijeme na učestalost nastavničkog korištenja društvenih medija za potrebe visokog obrazovanja značajan pozitivan utjecaj imala visoka učilišta kroz provedbu edukacije i nastavnika i studenata o korištenju društvenih medija, čime bi se mogao umanjiti i njihov osjećaj da je korištenje društvenih medija za potrebe visokog obrazovanja pomalo zastrašujuće. Isto tako, za učestalost nastavničkog korištenja društvenih medija za potrebe visokog obrazovanja značajno je to što studenti smatraju da nastavnici trebaju koristiti društvene medije za potrebe visokog obrazovanja, kao i podrška uprave fakulteta u svezi s korištenjem društvenih medija za potrebe visokog obrazovanja.

Dodatno, istraživanje je pokazalo da ne postoji statistički značajna veza između samopouzdanja nastavnika prilikom korištenja društvenih medija za potrebe visokog obrazovanja, organizacijskih čimbenika, olakšavajućih uvjeta korištenja društvenih medija za potrebe visokog obrazovanja i očekivane lakoće (napor, trud) korištenja društvenih medija za potrebe visokog obrazovanja i učestalosti nastavničkog korištenja društvenih medija za potrebe visokog obrazovanja. No, isto tako rezultati su pokazali da postoji statistički značajna veza za očekivani radni učinak ,korištenja društvenih medija za potrebe studiranja omogućava studentima 
postizanje boljih rezultata tijekom studija" te nastavničke namjere korištenja društvenih medija za potrebe visokog obrazovanja u sljedećih 12 mjeseci i učestalosti nastavničkog korištenja društvenih medija za potrebe visokog obrazovanja.

Više od polovice nastavnika ispitanika kao glavne prednosti društvenih medija ističu lakši i brži pristup informacijama, kada i gdje je to potrebno, dijeljenje ideja i iskustava, dijeljenje fotografija i videozapisa, fleksibilnost što se tiče odabira tehnologija, brze povratne reakcije, mogućnost stvaranja digitalnog sadržaja, dok je manje od $20 \%$ njih kao prednosti istaknulo pouzdanost u kontinuiranom korištenju tijekom duljeg vremenskog razdoblja i mogućnost testiranja postojećih modela poučavanja.

Više od polovice nastavnika istaknulo je svaki od navedenih nedostataka; zapostavljanje direktne komunikacije (licem-u-lice), mogućnost postojanja lažnih identiteta i pitanja privatnosti (nedostatak privatnosti...), dok je manje od $10 \%$ istaknulo svaki od nedostataka, kako slijedi; monetarno su kvantificirani (sve postaje „posao“ i „brojke“), skrivaju iza sebe tehnologije i koncepte koji još nisu dovoljno definirani/istraženi, postaju vrsta rabljenog web-a odnosno medij za osobe s niskom razinom digitalnih vještina, vrijeme i znanje utrošeno na korištenje, brzina programa je neusporedivo niža od brzine desktop programa, sadržaj ne znači ništa za sebe, on je samo elektronički „otpad“. 


\section{EMPIRIJSKO ISTRAŽIVANJE KOMUNIKACIJSKE PARADIGME U VISOKOM OBRAZOVANJU POD UTJECAJEM DRUŠTVENIH MEDIJA ZA POTREBE DOKTORSKE DISERTACIJE}

„Najbolji način da predvidite budućnost jest da je izmislite.“ - Alan Kay

U teorijskom dijelu disertacije izložena je komunikacijska paradigma u visokom obrazovanju pod utjecajem društvenih medija kroz dosadašnji razvoj društvenih medija te dosege korištenja društvenih medija za potrebe visokog obrazovanja, a obuhvaćena su dosadašnja prethodna istraživanja u svijetu, kao i usporedba s istraživanjima u Republici Hrvatskoj. Isto tako, izložena je kritička analiza odnosa visokoobrazovnih ustanova, nastavnika i studenata prema korištenju društvenih medija za potrebe visokog obrazovanja kroz pregled trenutnog stanja.

U ovom dijelu doktorske disertacije, prikazat će se narativna struktura provedenog glavnog empirijskog znanstvenog istraživanja kroz definiranje svrhe i ciljeva istraživanja te istraživačkih pitanja, prikaz delfi studije, odabir i identifikaciju panela, prikupljanje podataka i analizu podataka.

\subsection{Kontekst glavnog empirijskog istraživanja}

Glavno empirijsko znanstveno istraživanje provodilo se u Republici Hrvatskoj (RH) tijekom ljetnog semestra akademske godine 2019./2020. Provedeno je kvalitativno i kvantitativno istraživanje kroz delfi studiju kako bi se odgovorilo na istraživačka pitanja. Prema procjenama na visoko stručnoj razini nastojao se utvrditi budući razvoj te načini korištenja društvenih medija u visokom obrazovanju kako bi se njihov potencijal upotrijebio za unaprjeđenje komunikacije u visokom obrazovanju i to kroz mapiranje složenih veza između platformi društvenih medija, korisnika koji ih koriste (nastavnika i studenata), tehnologija koje ih pokreću te njihov očekivani razvoj, ekonomskih struktura koje ih omogućuju i visokih učilišta te njihovih politika koje utječu na njihovu ugradnju. 
Faze provedenog glavnog empirijskog istraživanja uključivale su:

- fazu pripreme,

- fazu provedbe istraživanja,

- fazu obrade i analize rezultata, $\mathrm{i}$

- fazu oblikovanja smjernica.

Faze su realizirane kako slijedi:

1. Pripremna faza obuhvaćala je izradu uputa odnosno polustrukturiranog anketnog upitnika za utvrđivanje indikacija u svezi s budućim razvojem društvenih medija te njihovim korištenjem u visokom obrazovanju prema procjenama na visoko stručnoj razini.

2. Faza provedbe istraživanja određena je sljedećim parametrima:

- prostorni obuhvat: Republika Hrvatska,

- populacijski obuhvat: namjerni uzorak odabran je prema standardima defli studije (kompetentni pojedinci zainteresirani za predmet istraživanja ) i to najmanje;

a) 10 značajnih gospodarstvenika s dugogodišnjim iskustvom rada u IT području (koji svoje predikcije mogu temeljiti na svom radnom iskustvu),

b) 10 istaknutih znanstvenika i istraživača iz IT područja (koji svoje predikcije mogu temeljiti na svom znanstvenom i istraživačkom radu),

c) 10 vodećih stručnjaka iz područja provedbe IT obrazovanja, posebno iz područja web 2.0 aplikacija (koji svoje predikcije mogu temeljiti na svom praktičnom uvidu u najnovije tehnologije na području obrazovanja),

- vremenski obuhvat: 2020. godina,

- sadržajni obuhvat i problemsko područje: budućnost korištenja društvenih medija u visokom obrazovanju.

Realizacija provedbe istraživanja bila je putem anketiranja pomoću posebno dizajniranog anketnog upitnika u alatu Google obrasci (engl. Google Forms). Početno je uspostavljen osobni i/ili telefonski kontakt s ispitanicima koji su zamoljeni da sudjeluju u istraživanju putem online anketnog upitnika koji se nalazio unutar teksta maila koji im je bio distribuiran nakon uspostavljanja početnog kontakta. Sudjelovanje ispitanika bilo je dobrovoljno i anonimno.

Za potrebe provedbe ovog dijela istraživanja koristila se delfi studija kao metoda prognoziranja koja se ne temelji na premisi da će skupina ispitanika oblikovati rješenje problema, već da će na temelju svog mišljenja ponuditi mogućnosti i pripadna potkrepljenja koja će istraživač uzeti u obzir prilikom donošenja zaključka. 
3. U fazi obrade i analize rezultata interpretirani su rezultati kvalitativnog i kvantitativnog dijela istraživanja provedenog kroz delfi studiju.

Anketni upitnik bio je anoniman, tako da niti jedna osoba nije mogla dominirati ili nepotrebno utjecati na grupu prema svojim procjenama. Distribucija procjena prikazana je isto tako anonimno, a finalno se nastojala postići ukupna grupna prosudba kroz mogućnost postizanja konsenzusa.

4. U fazi oblikovanja smjernica korištena je metoda deskripcije i interpretacije proizašlih implikacija te zaključci.

\subsection{Svrha, cilj i istraživačka pitanja}

Svrha istraživanja provedenog u sklopu ove doktorske disertacije jest na temelju ekspertnog znanja (re)definirati komunikacijsku paradigmu putem društvenih medija u području visokog obrazovanja koja će služiti kao putokaz za premošćivanje, kroz prethodna istraživanja te analizu relevantne literature, utvrđenog digitalnog jaza koji se pokazao kao evidentan između visokoobrazovnih ustanova odnosno nastavnika te studenata.

Korištenje društvenih medija, pa i u području visokog obrazovanja, u fokusu je brojnih istraživanja provedenih diljem svijeta; međutim, još uvijek ne postoji ujednačena definicija pojma „društveni mediji“, a shodno tome nisu ujednačeno istražena područja na koje se odnose i u kojima se koriste. Najčešće se opsežnija istraživanja provode među studentskom populacijom, i to vrlo često samo za neke od tipova društvenih medija, za koju je nepobitno utvrđeno da postojeći studenti nikada niti nisu upoznali svijet bez društvenih medija. Rjeđe se pak provode istraživanja među populacijom nastavnika. Isto tako, o čimbenicima koji utječu na dinamiku odnosa visokoobrazovnih ustanova odnosno nastavnika te studenata što se tiče komunikacije putem društvenih medija, objavljeno je vrlo malo. Na temelju ove praznine u istraživanju, ovim se doktorskim istraživanjem nastojalo postići sljedeće ciljeve:

- na temelju mišljenja stručnjaka procijeniti budući razvoj i korištenje društvenih medija za potrebe visokog obrazovanja,

- identificirati glavne čimbenike koji stvaraju i utječu na komunikacijsku paradigmu u visokom obrazovanju pod utjecajem društvenih medija, te

- utvrditi njezine multidimenzionalne značajke (komunikacijske paradigme u visokom obrazovanju pod utjecajem društvenih medija). 
Kako bi se postigli ciljevi ovog istraživanja, definirana su sljedeća istraživačka pitanja:

- Istraživačko pitanje IP1.: Kakav se razvoj tehnologija koje pokreću društvene medije očekuje u budućnosti?

- Istraživačko pitanje IP2.: Koje je preduvjete potrebno ispuniti kako bi se potencijal društvenih medija upotrijebio za potrebe visokog obrazovanja?

- Istraživačko pitanje IP3.: Koji sve čimbenici utječu na ugradnju društvenih medija u visokoobrazovni proces?

- Istraživačko pitanje IP4.: Koji sve čimbenici utječu na odnos visokih učilišta, nastavnika $i$ studenata prema društvenim medijima?

- Istraživačko pitanje IP5.: Na koje bi se sve načine mogli iskoristiti potencijali društvenih medija za unaprjeđenje komunikacije u visokom obrazovanju?

Pitanja koja se odnose na paradigmu komunikacijskog protokola putem društvenih medija u visokom obrazovanju definirana $\mathrm{u}$ instrumentima istraživanja korištena su za utvrđivanje mogućeg konsenzusa mišljenja eksperata o tome koje su aktivnosti i procesi potrebni u ovom trenutku, kao i ona koja se smatraju važnima u narednim godinama.

\subsection{Metoda $\mathrm{i}$ instrumenti istraživanja}

\subsubsection{Dizajn istraživanja: delfi metoda}

Delfi studija je metoda istraživanja mišljenja grupe zainteresiranih eksperata o njezinim idejama o budućnosti. Delfi metoda naglašava strukturiranu anonimnu komunikaciju između pojedinaca koji posjeduju stručnost o određenoj temi s ciljem postizanja konsenzusa u području politika, prakse ili organizacijskog odlučivanja (Brady, 2015; Birdsall, 2004; Dalkey, Helmer, 1962). Metodu su prvi koristili Dalkey i Helmer (1962) u svom radu za RAND Coorporation, kao metodu istraživanja koja traži stručna mišljenja o složenom istraživačkom problemu, za koji ne postoje precizne informacije (Amidharmo, 2014 prema Linstone, Turoff, 2011). Podaci istraživanja, tj. stručno mišljenje, obično se prikupljaju pomoću nekoliko krugova intenzivnih upitnika, koji generiraju niz kvalitativnih i kvantitativnih podataka za analizu. Nalazi analize određuju oblik i sadržaj sljedećih upitnika, i tako sve dok se mišljenje grupe ne formira i postane stabilno (Gupta i Clarke, 1996). Metoda naglašava sistematiziranje procesa grupne komunikacije kako bi se postigla razumna konvergencija mišljenja skupine stručnjaka 
(Amidharmo, 2014 prema Linstone, Turoff, 2011 i Gupta, Clarke, 1996). Delfi studija u početku se sastojala od četiri ili pet krugova, no u kasnijim istraživanjima utvrđeno je da delfi studija daje valjane rezultate sa samo tri kruga (Tottossy, 2005 prema Pfeiffer, 1968 i Brooks, 1979).

Iako je prvotno korištena u vojne, ekonomske i druge svrhe, danas se često primjenjuje u suvremenim istraživanjima odgoja i obrazovanja (Eret, 2017). Najčešći razlozi primjene delfi studije za potrebe istraživanja su:

1. prognoziranje događaja obzirom na buduća istraživanja i razvoj u određenim područjima interesa;

2. poželjnost neke buduće okolnosti i

3. sredstva kojima bi se postigle ili izbjegle buduće okolnosti (Eret, 2017 prema Helmer, 1967; Brown, 1968; Sackman, 1974; Gordon, 1994; Mitroff i Turoff, 2002).

Primarni razlog popularnosti delfi studije leži u njezinoj jedinstvenoj snazi kao alata za planiranje, predviđanje i donošenje odluka. (Gupta, Clarke, 1996). Oslanja se na strukturirani, a ipak indirektni, pristup brzim i učinkovitim odgovorima stručnjaka koji se temelje na znanju, autoritetu i uvidu u problemsko područje (Gupta, Clarke, 1996 prema Gutierrez, 1989), dok istodobno promiče učenje među članovima panela (Gupta, Clarke, 1996 prema Van Dijk, 1990). Pomoću delfi studije moguće je obuhvatiti široki raspon međusobno povezanih varijabli i multidimenzionalnih značajki zajedničkih većini kompleksnih pitanja, a koje su obvezni elementi detaljnih znanstvenih analiza (Gupta, Clarke, 1996 prema Ray, Sahu, 1990). Isto tako, dokumentira činjenice i mišljenje panelista, dok se istodobno mogu izbjeći zamke interakcije licem u lice, kao što su konflikti u grupi ili dominacija pojedinaca (Gupta, Clarke, 1996).

Primarne značajke delfi studije, kako navodi Amidharmo (2014), četverostruke su:

1. Statistički odgovor grupe - upitnici su oblikovani tako da se odgovori mogu analizirati kvantitativno i statistički (Amidharmo, 2014 prema Landeta, 2006) (najčešće od 2. kruga istraživanja). To se može postići pomoću odgovora tipa poretka, poput Likertove klizne ljestvice od 1-5, gdje 1 predstavlja najmanju relevantnost, a 5 najrelevantnije.

2. Anonimnost sudionika studije - omogućava sudionicima da slobodno izraze svoja pojedinačna mišljenja bez tendencije da se prilagode dominantnom mišljenju grupe (Amidharmo, 2014 prema Skulmoski, Hartman, Krahn, 2007). Delfi studija je metoda koja također omogućava svako iskrivljenje mišljenja koje bi moglo proizaći iz izravnog sučeljavanja stručnjaka (Amidharmo, 2014 prema Okoli, Pawlowski, 2004) zbog njihovog statusa ili osobnosti (Amidharmo, 2014 prema Landeta, 2006). 
3. Kontrolirane povratne informacije - na temelju generiranih podataka tijekom istraživanja (primjerice u prvom krugu istraživanja), uklanjaju se nebitne informacije i istraživač formulira nova pitanja na temelju primljenih podataka (Amidharmo, 2014 prema Landeta, 2006). Ta značajka fleksibilnosti omogućuje istraživaču da usredotoči pristup potreban za rješavanje određenog istraživačkog problema ili da proširi studiju tako da uključi nove parametre koje prethodno istraživač nije identificirao (Amidharmo, 2014).

4. Ponavljanje prikupljanja podataka - ponavljanje krugova upitnika daje sudionicima priliku da preispitaju svoja mišljenja u svjetlu informacija dobivenih od ostalih sudionika (Amidharmo, 2014 prema Landeta, 2006). Na taj način, ponavljanje prikupljanja podataka olakšava postupno formiranje grupnog mišljenja. Broj krugova upitnika ovisi o stabilnosti ili konvergenciji odgovora, ne nužno i konsenzusu (Linstone i Turoff, 2011).

Tradicionalno, primarni cilj delfi studije bio je postići konsenzus i dosljednost mišljenja skupine stručnjaka u svezi s područjem interesa ili istraživanja (Tottossy, 2005 prema Hasson, Keeney i McKenna, 2000; Winzenreid, 1997; Yang, 2003). No Coates (1975) ističe: „Vrijednost delfi studije nije u izvještavanju podataka temeljem konsenzusa visoke pouzdanosti, već u upozoravanju sudionika na složenost pitanja prisiljavanjem, nagovaranjem, tjeranjem i izazivanjem na razmišljanje, navođenjem na osporavanje njihovih pretpostavki“ (Amidharmo, 2014 prema Linstone, Turoff, 2011). To je u suprotnosti tradicionalnom panelu kojim se želi postići konsenzus, a ponekad se forsira, što dovodi do iskrivljenja podataka istraživanja (Amidharmo, 2014 prema Linstone i Turoff, 2011).

Tradicionalna delfi studija dovršava se pomoću niza krugova prikupljanja podataka (Kennedy, 2017 prema Dalkey, Helmer, 1963). Početni krug sastoji se od niza otvorenih pitanja ili niza izjava o temi istraživanja na koju sudionici istraživanja odgovaraju metodom „oluja ideja“ (poznata i pod nazivom „oluja mozgova“, engl. Brainstorming). Zatim se upitnik distribuira sudionicima u nekoliko ponavljanja; sudionici rangiraju izjave prema razini važnosti odnosno slaganja, pri čemu istraživači dijele sve ljestvice sa sudionicima, sudionici su pozvani da revidiraju vlastite rang liste, a zatim istraživači ponovno analiziraju podatke (Sekayi, Kennedy, 2017). Ta „kontrolirana povratna informacija“, u kojoj istraživač sažima odgovore na pitanja Likertovog tipa i dijeli ih sa sudionicima, umjesto da sudionici izravno komuniciraju, je ujedno područje fleksibilnosti u načinu na koji je postupak primijenjen (Sekayi, Kennedy, 2017). Taj se postupak povratnih informacija 
nastavlja sve dok se ne postigne konsenzus, kako navode Sekayi i Kennedy (2017), pri čemu je konsenzus unaprijed definiran postotak suglasnosti panelista o rangiranju, stoga, istraživač može utvrditi da postoji konsenzus oko izjava kada se barem 80 \% sudionika istraživanja slaže ili se u potpunosti slaže s izjavom. U slučajevima kada konsenzus nije postignut primjerice, niti nakon nekoliko krugova povratnih informacija i mogućnosti revizije, te slaganje sudionika s izjavama nikad ne prelazi $50 \%$, naziva se stabilnošću, točka nakon koje panelisti više ne revidiraju svoje ljestvice (Sekayi, Kennedy, 2017). Konačna ljestvica sastoji se od kvantitativne kompilacije pojedinačnih povratnih informacija na temelju koje se formirao odgovor grupe te se koristi za informiranje o odluci ili temi istraživanja (Sekayi, Kennedy, 2017).

\subsubsection{Identifikacija i selekcija stručnjaka}

„U glavi početnika postoji mnogo mogućnosti, ali u umu stručnjaka ih je nekoliko.“ - Suzuki (2006)

Kvaliteta svake delfi studije uglavnom ovisi o kvalitetnom odabiru odgovarajućih stručnjaka. Sudionici ovog istraživanja bili su kompetentni pojedinci zainteresirani za predmet istraživanja. Za potrebe provedbe ovog istraživanja, postupak odabira stručnjaka bio je sličan onom koji je opisao Amidharmo, 2014 (prema Okoli, 2004).

1. Priprema popisa potrebnih znanja. Cilj je kategorizirati stručnjake kako bi se spriječila mogućnost previda bilo koje važne kategorija stručnjaka. Kako je ovo istraživanje usmjereno na korištenje društvenih medija u visokom obrazovanju, kategorije stručnjaka uključuju:

a) značajne gospodarstvenike s dugogodišnjim iskustvom rada u IT području (koji svoje predikcije mogu temeljiti na svom radnom iskustvu),

b) istaknute znanstvenike i istraživače iz IT područja (koji svoje predikcije mogu temeljiti na svom znanstvenom $\mathrm{i}$ istraživačkom radu),

c) vodeće stručnjake iz područja provedbe IT obrazovanja, posebno iz područja web 2.0 aplikacija (koji svoje predikcije mogu temeljiti na svom praktičnom uvidu u najnovije tehnologije na području obrazovanja).

2. Dopuna popisa potrebnih znanja imenima potencijalnih stručnjaka. Potencijalni stručnjaci identificirani su u različitim kategorijama. Upotrijebljena je profesionalna 
mreža kontakata dostupnih autorici, kao i savjeti i profesionalna mreža kontakata mentorica i kolegica/kolega autorice u svezi s prikladnošću potencijalnih stručnjaka za delfi istraživanje.

Delfi studija kao istraživačka metoda usmjerena na postizanje razumnog konsenzusa mišljenja u skupini stručnjaka, ne zahtijeva veliki broj sudionika. Namjerni uzorak odabran je prema standardima defli studije i to najmanje 10 stručnjaka po kategoriji, što ukupno iznosi najmanje 30 stručnjaka. Broj sudionika osiguravao je da svaka kategorija bude dovoljno zastupljena, a da se istovremeno održava upravljiv broj sudionika.

3. Poziv stručnjacima. Stručnjaci su pozvani na sudjelovanje te upućeni u istraživanje pojedinačno putem telefona ili izravnog sastanka, te finalno putem e-pošte. Tijekom početnog pristupa, stručnjaci su bili upoznati s istraživačkom studijom i delfi metodom. Inicijalni poziv bio je upućen 52 stručnjaka.

\subsubsection{Krugovi delfi studije}

Za potrebe ovog rada, provedena su 4 kruga istraživanja, pri čemu se prva 3 kruga odnose na samo istraživanje dok se 4 . krug odnosi na prezentaciju rezultata svim aktivnim panelistima 3 . kruga istraživanja:

1. krug istraživanja - „oluja ideja“ (poznata i pod nazivom „oluja mozgova“, engl. Brainstorming) o komunikacijskoj paradigmi u visokom obrazovanju pod utjecajem društvenih medija. U početnom krugu istraživanja bio je sastavljen i distribuiran polustrukturirani upitnik s otvorenim tipom pitanja kako bi se kroz metodu oluje ideja dobio uvid u specifičnosti problema istraživanja odnosno budućnost komunikacijske paradigme putem društvenih medija u visokom obrazovanju.

Pitanja za sudionike istraživanja djelomično su adaptirana prema Pollard, Pollard (2004) i Van Dijck, Poell (2013), a obuhvaćala su područja budućeg razvoja tehnologija koje pokreću društvene medije, preduvjeta (ekonomskih i drugih) koje je potrebno ispuniti kako bi se potencijal društvenih medija upotrijebio za potrebe visokog obrazovanja, čimbenika koji utječu na ugradnju društvenih medija u visokoobrazovni proces, kao i čimbenika koji utječu na odnos visokih učilišta, nastavnika i studenata prema društvenim medijima te načine na koje bi se mogli iskoristiti potencijali društvenih medija za unaprjeđenje komunikacije u visokom obrazovanju. Početnih 9 pitanja odnosilo se na socio-demografske podatke o panelistima, dok je broj pitanja 
koji se odnosio na komunikacijsku paradigmu putem društvenih medija u visokom obrazovanju bio ograničen na 11 (instrument Upitnik 1., vidi Prilog 9.).

\section{2. krug - Likertova skala procjene važnosti ključnih čimbenika promjene (KČP)}

komunikacijske paradigme u visokom obrazovanju pod utjecajem društvenih medija sastavljen i distribuiran strukturirani upitnik sa zatvorenim tipom pitanja (precizirana su i specificirana pitanja koja su upotrijebljena u 1. krugu u smislu popisa ideja i komentara članova panela kroz 12 ključnih čimbenika promjene (KC̆P) komunikacijske paradigme u visokom obrazovanju pod utjecajem društvenih medija) te se tražilo mišljenje eksperata o stupnju važnosti svakog pojedinog čimbenika. Broj pitanja bio je ograničen na 12 (instrument Upitnik 2., vidi Prilog 11.). Likertova skala je imala vrijednost 1-10, pri čemu stupanj 1 označava da čimbenik uopće nije važan, dok stupanj 10 označava da je čimbenik iznimno važan.

\section{3. krug - u svrhu mogućeg postizanja konsenzusa, ponovna procjena važnosti ključnih} čimbenika promjene (KČP) komunikacijske paradigme u visokom obrazovanju pod utjecajem društvenih medija, prema Likertovoj skali. Temeljem dobivenih odgovora panelista u 2., prethodnom krugu istraživanja, u 3. krugu bio je sastavljen i distribuiran strukturirani upitnik sa zatvorenim tipom pitanja (precizirana su i specificirana pitanja koja su upotrijebljena u 1. krugu u smislu popisa ideja i komentara članova panela kroz 12 ključnih čimbenika promjene (KČP) komunikacijske paradigme u visokom obrazovanju pod utjecajem društvenih medija) te se tražila ponovna procjena eksperata, a u svrhu mogućeg postizanja konsenzusa, odnosno panelisti su zamoljeni ponovno razmotre ukupne rezultate iz prethodnog kruga istraživanja i ponovno navedu stupanj važnosti svakog pojedinog čimbenika. Broj pitanja bio je ograničen na 12 (instrument Upitnik 3., vidi Prilog 13.). Likertova skala je imala vrijednost 1-10, pri čemu stupanj 1 označava da čimbenik uopće nije važan, dok stupanj 10 označava da je čimbenik iznimno važan.

4. krug - prezentacija rezultata panelistima koji su aktivno sudjelovali u 3. krugu ovog istraživanja. Na temelju dobivenih odgovora panelista u 3. krugu sastavit će se konačna verzija rezultata istraživanja koja se sastoji od popisa stupnjeva važnosti koje su panelisti dodijelili svakom od 12 ključnih čimbenika promjene (KČP) komunikacijske paradigme u visokom obrazovanju pod utjecajem društvenih medija. Stupnjevi važnosti određeni su prema Likertovoj skali važnosti, pri čemu stupanj 1 označava da čimbenik uopće nije važan, dok stupanj 10 označava da je čimbenik iznimno važan, te su rangirani na ljestvici od 1 do 12 , pri čemu čimbenik pod brojem 1 označava s najvišim stupnjem važnosti, a čimbenik 12 označava s najnižim stupnjem važnosti za komunikacijsku paradigmu u visokom obrazovanju pod utjecajem društvenih medija. 


\subsubsection{Istraživački pristup: metodološka triangulacija}

Delfi metoda najčešće se koristi kao triangulacija odnosno „kombinacija različitih metoda, koja omogućuje različite poglede na isti fenomen“ (Slišković, 2017). Metodološka triangulacija uključuje korištenje različitih metoda na istom predmetu proučavanja (Cohen, Manion, Morrison, 2007). U prvim krugovima delfi studije često se koristi kvalitativan pristup kako bi se dobio „dublji uvid, detaljniji opis i ako je moguće objašnjenje fenomena, objekta, procesa ili entiteta koji se istražuje“ (Slišković, 2017), dok u finalnim krugovima studije istraživači koriste kvantitativan pristup radi „,mogućnosti uopćavanja nalaza odnosno postizanja visoke vanjske valjanosti“ (Slišković, 2017). Za potrebe ovog rada, korištena je delfi metoda kao mješovita metoda koja kombinira kvalitativan i kvantitativan pristup, jer kako navodi Slišković (2017) „kvalitativan pristup nudi određene informacije istraživaču koje dalje može provjeriti kvantitativnim putem“.

Galvan (2004) ponudio je najjednostavnije razlikovanje kvantitativnog i kvalitativnog istraživačkog pristupa; kvantitativno istraživanje započinje hipotezom, uzorak ispitanika je slučajan, ali velik, podaci se prikupljaju standardiziranim mjernim instrumentima i statistički obrađuju, a onda zaključci generaliziraju; kvalitativno istraživanje započinje općim problemom bez specifičnih ciljeva i hipoteza, radi se na namjernom uzorku ispitanika koji je relativno malen, podaci se prikupljaju intenzivno i nestandardiziranim postupcima, provodi se dulje vrijeme s ispitanicima, a rezultati se izvještavaju u deskriptivnom obliku i odnose se na odabrani uzorak ispitanika (Vrabec Mojzeš, 2019).

Dok su u mnogim istraživačkim radovima, kako unutar tako i izvan tradicije delfi metode, dostupne smjernice o kvantitativnoj analizi podataka, mnogo je manje znanstvenih radova $\mathrm{u}$ kojima se navodi da bi kvalitativne delfi studije trebale koristiti tematske analize (Brady, 2015; Dalkey, Helmer, 1963; Linstone, Turoff, 1975). Čak se i neki istraživači koji koriste delfi studiju, primarno fokusiraju na statistički odgovor grupe te su upitnici već u prvom krugu istraživanja oblikovani tako da se odgovori mogu analizirati kvantitativno i statistički, kako je navedeno u poglavlju Dizajn istraživanja ovog rada (Amidharmo, 2014; Landeta, 2006). Ipak, važno je primijetiti da iako su se dugo vremena kvalitativni pristup i kvalitativna istraživanja smatrala manje pouzdanima i valjanima, u novije vrijeme važnost kvalitativnog istraživanja u društvenim znanostima sve se više prepoznaje i priznaje (Jeđud, 2007). Višestruka namjena različitih metoda i tehnika u praksi otežava istraživačima da se slože oko jedne jedinstvene definicije kvalitativnih istraživanja (Halmi, Crnoja, 2003). Nelson (1992) je pokušao dati generičku definiciju: „Kvalitativna istraživanja su interdisciplinarno, transdisciplinarno, a 
ponekad i kontradisciplinarno područje“ (Halmi, Crnoja, 2003 prema Nelson, 1992). Kvalitativni istraživači nazivaju se „mekim“ znanstvenicima i paraznanstvenicima, jer strategije kojima se služe nemaju mogućnost izvođenja pravog eksperimenta kao prirodoslovne znanosti (Halmi, Crnoja, 2003). To je dodatni razlog zašto kvalitativni istraživači moraju biti jasni što rade i zašto te u svoja izvješća uključiti često izostavljeno „kako“ su radili svoju analizu budućnosti (Braun, Clarke, 2006 prema Attride-Stirling, 2001). No, još važnije; ako nije poznato kako su istraživači analizirali svoje podatke ili koje su pretpostavke poslužile njihovoj analizi, teško je procijeniti istraživanja te ih usporediti i / ili sintetizirati s drugim studijama na tu temu, što, isto tako, može spriječiti druge istraživače u provedbi sličnih istraživanja u budućnosti (Braun, Clarke, 2006 prema Attride-Stirling, 2001). Govoreći o kvalitativnom istraživanju, teoretičari kritiziraju ovu metodu zbog problema interpretacije, poteškoća u odnosu teorije i istraživanja, kao i problemu generalizacije (Vrabec Mojzeš, 2019). To je stoga, što je kvalitativno istraživanje često je obilježeno subjektivizmom i metateorijom (Vrabec Mojzeš, 2019). Proces kvalitativnih istraživanja odvija se u pet faza u kojima je potrebno znati poziciju istraživača, interpretativne paradigme, metode prikupljanja i analiziranja empirijskih materijala te čin interpretacije i evaluacije (Vrabec Mojzeš, 2019 prema Halmi, 1996).

Faze u procesu kvalitativnih istraživanja (Halmi, Crnoja, 2003):

- Faza I: Istraživač kao multikulturalni subjekt

Multipla priroda kvalitativne metodologije može se označiti kao umijeće svega, a kvalitativnog istraživača kao stručnjaka za sve. Osnovno načelo kojega se drži kvalitativni istraživač jest da niti jedna metoda ne može pružiti gotova rješenja, stoga primjenjuje široku skalu metoda i tehnika iz različitih istraživačkih paradigmi razvijajući na taj način svestrane intervencijske strategije. Budući da su, kako navode Halmi i Crnoja (2003), kvalitativna istraživanja multimetodski i multiparadigmatski usmjerena, triangulacija metoda i tehnika vodi dubljem zahvaćanju problema, što onda postaje strategijska osnova za njegovo rješenje.

Istraživanje nije neutralno; istraživač je označen svojom poviješću, tradicijom i obrazovanjem, što istovremeno usmjerava i ograničava njegov rad (Vrabec Mojzeš, 2019 prema Halmi, 1996). No, kako navodi Sagadin (1991), istraživač je ključni instrument istraživanja, on neposredno (iz prve ruke) spoznaje socijalni svijet (Jeđud, 2007).

- Faza II: Teoretske paradigme i perspektive

Paradigma se može definirati kao skup znanja i uvjerenja sustavno izložen kao teorij koji ima funkciju iniciranja teoretske produkcije, a s tim u vezi i praktičnog istraživanja na nekom disciplinarnom području, te se u tom smislu pojavljuje kao ishodište neke buduće teoretske kompozicije, nadalje navode Halmi i Crnoja (2003). Skup epistemoloških, ontoloških ili 
metodoloških premisa naziva se paradigmom, odnosno interpretativnim okvirom koje usmjerava rad istraživača, ovisno o razini analize odnosno pitanjima koje se postavljaju s različitih pozicija i koja oblikuju proces istraživanja (Halmi, Crnoja, 2003).

Tijekom uobičajenog / tradicionalnog načina istraživanja istraživači na temelju proučavanja $i$ poznavanja teorije postavljaju hipoteze koje se temeljem obrade podataka na kraju prihvate ili odbace (Jeđud, 2007). Takav pristup, navodi Jeđud (2007), koristi se i u kvantitativnoj i u kvalitativnoj metodologiji, te na taj način u proces istraživanja ulaze opremljeni već postojećim znanjima i sigurni u izvjesnost rezultata istraživanja. No, kreće li se s pozicije ne-znanja, istraživači postaju osjetljiviji za sam proces istraživanja i ono što će iz njega nastati te pretpostavlja dubinski interes za sudionike i fenomen koji istražuje te slušanje s poštovanjem (Jeđud, 2007 prema Anderson, 2003). U literaturi, koristi se i izraz „planirana praznina“ za namjerno osiguravanje područja u našem umu koje je rezervirano za nepoznato i novo (Jeđud, 2007 prema Middleman, Goldberg Wood, 1990 i Malekoff, 1997).

- Faza III: Strategije istraživanja

Faza započinje s jasno definiranim planom (nacrtom) istraživanja, koji uključuje preciznu usmjerenost na istraživačka pitanja, svrhu i ciljeve istraživanja te informacije koje će se prikupljati tijekom procesa istraživanja (Halmi, Crnoja, 2003). Uz proceduralni okvir, nacrt istraživanja upućuje istraživače na specifične istraživačke strategije kojima raspolaže kvalitativna metodologija (Halmi, Crnoja, 2003).

No pri tom je važno, kako zaključuje Anglin (2002) da istraživač bude što otvoreniji u prikupljanju i analizi podataka, jer što manje isključuje, to je bogatiji materijal i bolje su šanse da dođe do „otkrivanja“ nove ideje / teorije na temelju tih materijala / podataka, ističući važnost otvorenosti uma u procesu istraživanja (Jeđud, 2007 prema Anglin, 2002). Ipak, otvorenost uma ne smije se nikako poistovjećivati s praznoglavošću, već s kritičkom vještinom istraživanja i pronalaženja što je moguće više teorija iz dostupnih podataka (Jeđud, 2007 prema Anglin, 2002 i Alasuutari, 1995).

- Faza IV: Metode prikupljanja i analize

Široki arsenal strategija istraživanja upućuje na primjenu jednog čitavog niza metoda i tehnika za prikupljanje podataka (Halmi, Crnoja, 2003). Suvremeni razvoj kompjuterske tehnologije i trendovi u kvalitativnoj metodologiji u fokus stavljaju mnoge tehnike i metode za prikupljanje i analizu kvalitativnog empirijskog materijala (Halmi, Crnoja, 2003).

Kvalitativno istraživanje je pak više usmjereno na induktivnu analizu podataka i induktivno kreiranje hipoteza umjesto na deduktivno postavljanje hipoteza i njihovo empirijsko testiranje 
i verificiranje, pri čemu je s otvorenošću i indukcijom povezana i procesnost, kooperativnost i interaktivnost, navodi Sagadin (1991).

- Faza V: Interpretacija, evaluacija i prezentacija

Kvalitativno istraživanje je, kako navode Halmi i Crnoja (2003), beskrajno kreativno i interpretativno. Na temelju obilja empirijskog materijala, istraživač konstruira svoje interpretacije vodeći će određenim kriterijima validacije, nakon čega piše istraživački izvještaj (Halmi, Crnoja, 2003).

Zaključno, kvalitativno istraživanje temelji se na interpretativnoj paradigmi s naglaskom na razumijevanju situacija, procesa i odnosa itd. iz osobne perspektive samih sudionika (Jeđud, 2007 prema Sagadin, 1991).

Stoga, istraživački pristup za potrebe delfi studije u ovoj doktorskoj disertaciji bit će metodološka triangulacija. U tom smislu, koristit će se kvalitativna i kvantitativna metoda analize odgovora panelista prikupljenih u 3 kruga delfi studije. U 1. krugu istraživanja koristit će se kvalitativan pristup istraživanju fenomena komunikacijske paradigme u visokom obrazovanju pod utjecajem društvenih medija, detekcije anomalija te krize postojeće komunikacijske paradigme (Kuhn, 1962) u visokom obrazovanju pod utjecajem društvenih medija koja je izložena u teorijskom dijelu ove disertacije. Ovaj pristup utemeljen je na filozofskoj poziciji koja je ,interpretativna“ odnosno zainteresirana za načine na koji se socijalni svijet interpretira, razumije, doživljava ili producira, metodama prikupljanja podataka koje su fleksibilne i osjetljive na socijalni kontekst u kojem se podaci produciraju i na metodama analize i građenja odnosno razvijanja objašnjenja koja uključuju razumijevanje kompleksnosti, detalja i konteksta (Jeđud, 2007 prema Mason, 1996). U svrhu analize dobivenih odgovora ispitanika u 1. krugu ovog istraživanja, koristit će se tematska analiza, što „podrazumijeva kategorizaciju podataka u određeni broj tema ili deskriptivnih kategorija“ (Slišković, 2017) te kodiranje, kako „se nazivaju operacije u kojima su podaci razlomljeni, konceptualizirani te nanovo spojeni na drugačiji način“ (Jeđud, 2007 prema Straus, Corbin, 1990 i Pandit 1996). U narednim krugovima (2. odnosno 3. krugu) za obradu podataka koristit će se kvantitativan pristup odnosno metoda deskriptivne statističke analize i Wilcoxonov test rangova zavisnih uzoraka. 


\subsubsection{Kvalitativan pristup: tematska analiza}

S obzirom na to da su kvalitativni pristupi nevjerojatno raznoliki, složeni i nijansirani kako navode Holloway i Todres (2003, prema Braun, Clarke, 2006), tematsku analizu treba promatrati kao temeljnu metodu kvalitativne analize. Tematska analiza metoda je za identificiranje, analizu i izvještavanje o obrascima (temama) unutar podataka (Braun, Clarke, 2006). Minimalno organizira i opisuje skup podataka u (bogatim) detaljima, međutim, to često ide i dalje od ovoga i tumači različite aspekte teme istraživanja (Braun, Clarke, 2006 prema Boyatzis, 1998).

S obzirom na prednosti fleksibilnosti tematske analize, važno je ne ograničiti tu fleksibilnost (Braun, Clarke, 2006), međutim, nedostatak jasnih i jezgrovitih smjernica oko tematske analize znači da se kritika kvalitativnog istraživanja (Braun, Clarke, 2006 prema Antaki i sur., 2002) može primijeniti u nekim slučajevima (Braun, Clarke, 2006). U skladu sa svim navedenim, glavna intencija prilikom obrade $\mathrm{i}$ analize rezultata kvalitativnog dijela istraživanja bit će zadržati fleksibilnost metode, ali provesti tematsku analizu prema „receptu“ koji su preporučili Braun i Clarke (2006) kako bi bila provedena na teoretski i metodološki valjan način.

Tematska analiza uključuje brojne izbore koji često nisu eksplicitni (ili se o njima obično ne raspravlja u odjeljku o metodama), ali koje treba izričito razmotriti i raspraviti (Braun, Clarke, 2006). U praksi, prije nego što započne analiza (a ponekad čak i prikupljanje) podataka, pojašnjavaju Braun i Clarke (2006), a istraživač ili istraživači trebaju voditi trajni refleksni dijalog u vezi s tim pitanjima tijekom cijelog analitičkog postupka. Početno pitanje, dalje pojašnjavaju, koje se postavlja jest što se računa kao tema? Tema bilježi nešto važno o podacima u vezi s istraživačkim pitanjem i predstavlja određenu razinu uzorkovanog odgovora ili značenja unutar skupa podataka, a prosudba istraživača neophodna je da bi se utvrdilo što je tema (Braun, Clarke, 2006). Isto tako, navode, važno pitanje koje treba riješiti u smislu kodiranja jest ono što se računa kao uzorak / tema ili koje „veličine“ treba biti tema? Idealno bi bilo da postoji niz primjera teme u skupu podataka, ali više primjera ne mora nužno značiti da je sama tema presudnija (Braun, Clarke, 2006). „Ključnost““ teme, dakle, ne ovisi nužno o mjerljivim mjerama - već u smislu uzima li nešto važno u odnosu na cjelokupno istraživačko pitanje (Braun, Clarke, 2006). Dio fleksibilnosti tematske analize jest taj što omogućuje određivanje tema (i rasprostranjenosti) na brojne načine, no važna je dosljednost u načinu na koji se to radi u određenoj analizi (Braun, Clarke, 2006). 
Analiza nije linearni proces u kojem se jednostavno prelazi iz jedne faze u sljedeću već je rekurzivniji postupak, u kojem se kreće naprijed-natrag po potrebi, te će za potrebe ovog rada biti provedena prema smjernicama za šest faza analize koje preporučuju Braun i Clarke (2006) (Tablica 15).

Tablica 15. Faze tematske analize (izvor: izrada autorice prema Braun, Clarke, 2006)

\begin{tabular}{ll}
\hline Faza & Opis postupka \\
\hline 1. Upoznavanje sa svojim podacima: & Prijepis podataka (ako je potrebno), čitanje i ponovno čitanje \\
& podataka, bilježenje početnih ideja. \\
\hline 2. Generiranje početnih kodova: & Sustavno kodiranje zanimljivih značajki podataka u cijelom \\
& skupu podataka, uspoređivanje podataka relevantnih za svaki \\
& kod. \\
\hline 3. Traženje tema: & $\begin{array}{l}\text { Spajanje kodova u potencijalne teme, prikupljanje svih } \\
\text { podataka relevantnih za svaku potencijalnu temu. }\end{array}$ \\
\hline 4. Pregled tema: & Provjera kako tema djeluje u odnosu na kodirane izvatke tj. \\
ekstrakte (razina 1) i cjelokupni skup podataka (razina 2), \\
generirajući tematsku „kartu“ analize. \\
\hline 5. Utvrđivanje i imenovanje tema: & $\begin{array}{l}\text { Sustavna analiza radi pročišćavanja specifičnosti svake teme } \\
\text { i cjelokupne priče koju analiza govori; generirajući jasne } \\
\text { definicije i nazive za svaku temu. }\end{array}$ \\
\hline
\end{tabular}

Nakon provedenih svih šest faza tematske analize podataka prikupljenih u 1. krugu istraživanja te izrađenog tematskog izvještaja, u skladu s preporukama (Braun, Clarke, 2006), isti će u 2. i 3. krugu istraživanja biti proslijeđen panelistima na ponovnu procjenu.

\subsubsection{Kvantitativan pristup: deskriptivna statistička analiza}

U 2. i 3. krugu eksperti će na temelju tematskog izvještaja ključnih čimbenika promjene komunikacijske paradigme u visokom obrazovanju pod utjecajem društvenih medija apstrahiranih tematskom analizom iz njihovih odgovora u prethodnom, 1. krugu istraživanja, 
biti zamoljeni da iste ocjene stupnjem važnosti prema Likertovoj skali 1-10. Skala od 10 stupnjeva odabrana je jer ljestvica s više bodova, a ne s manje bodova, omogućuje veću diferencijaciju predmeta koji se ocjenjuju, pri čemu ljestvica stupnjeva od 1 do 10 pruža najširu diferencijaciju, navode Wimmer i Dominick (2013). Široka diferencijacija mišljenja, percepcije i osjećaja važna je jer daje istraživaču više informacija (Wimmer, Dominick, 2013). Ograničavanje odgovora ispitanika koristeći premali raspon skale skriva raspon potencijalnih odgovora i ograničava potencijal bilo koje istraživačke studije (Wimmer, Dominick, 2013). Ljestvica 1-10 univerzalna je, gotovo svi razumiju skalu ocjena 1-10; 10 je najbolje ili savršeno, a 1 je najgore ili nesavršeno (Wimmer, Dominick, 2013). Wimmer i Dominick (2013) također pojašnjavaju da ne bi trebali koristiti 0-9 ili 1-9 ljestvicu ocjena, jer se, ispitanici ne povezuju dobro s ocjenom 9 kao najvećim brojem.

U svrhu analize dobivenih odgovora ispitanika u 2. i 3. krugu ovog istraživanja, koristit će se deskriptivna statistička analiza odgovora za moguće utvrđivanje konsenzusa. Odgovori iz 2. i 3. kruga istraživanja bit će prebačeni su iz alata Google obrasci u formi excel tablice u statistički program IBM SPSS Statistics verzija 2020, te će deskriptivne statističke analize biti provedene pomoću navedenog programa.

Iako se tradicionalna delfi metoda smatra kvalitativnom metodologijom, u literaturi su izneseni argumenti za korištenje daljnjeg ispitivanja, uključujući mješovite metode, za poboljšanje validacije (Holbrook Lewis, 2014 prema Kennedy, 2003). Prvenstveno se koristi kvalitativan pristup u prvom krugu, a zatim se koristi statistička analiza za procjenu rezultata 2. i 3. kruga (ili više) (Holbrook Lewis, 2014). Mogući komentari i primjedbe „koje sudionici daju radi daljnjeg kvalificiranja njihovih odgovora poboljšavaju pouzdanost“" (Holbrook Lewis, 2014).

Kao metoda obrade prikupljenih podataka, deskriptivna statistika se bavi se mjerama centralne tendencije (aritmetička sredina, medijana i mod), mjerama varijabiliteta (raspon, standardna devijacija, varijanca, interkvartilni raspon, semiinterkvartilni raspon i prosječno odstupanje), kao i grafičkim i tabelarnim prikazivanjem osnovnih statističkih vrijednosti.

- Karakteristike distribucije frekvencija

a) Mjere središnjih vrijednosti su karakteristike koje pokazuju na opću razinu čitave distribucije. Srednja vrijednost je, dakle, ona vrijednost oko koje se svrstavaju sve ostale vrijednosti (Mužić, 1976).

Računanje mjera centralne tendencije odnosno računanje središnje vrijednosti predstavlja jedan od najčešće primjenjivanih statističkih postupaka koji se koriste kako bi sažeto i zorno prikazali određeni skup podataka (Bubić, 2013). Računanjem središnje vrijednosti cijeli skup podataka zamjenjuje se jednom vrijednošću, za koju se smatra da 
ga dobro reprezentira, stoga je potrebno pažljivo odabrati prikladnu mjeru središnje vrijednosti (Bubić, 2013).

Vrste srednjih vrijednosti:

- MOD (dominantna ili najčešća vrijednost, engl. Mode) - vrijednost koja se u distribuciji pojavljuje češće nego druge vrijednosti, najčešća vrijednost (Mužić, 1976). Dominantna vrijednost $(D)$ predstavlja onu vrijednost koja među rezultatima ima najveću frekvenciju te na nju utječe samo broj, ali ne i vrijednost pojedinačnih rezultata (Bubić, 2013). Stoga se preporučuje koristiti ju kada postoji veliki broj rezultata od kojih neki mogu biti i ekstremni, te ako samo jedna vrijednost dominira čestinom. U slučaju da npr. distribucija ima dva ili više jednakih vrhova tada se očitaju dvije ili više dominantnih vrijednosti, te govorimo o bimodalnim (distribucija s dvije dominantne vrijednosti) ili multimodalnim (distribucija s više od dvije dominantne vrijednosti) distribucijama (Bubić, 2013). Iako dominantna vrijednost predstavlja najslabiju mjeru središnjih vrijednosti, pojašnjava Bubić (2013), u nekim situacijama i ona može biti informativna i korisna.

- MEDIJAN (središnja ili centralna vrijednost, kratica $C$, engl. Median) - vrijednost koja se nalazi u sredini između ostalih rezultata (Mužić, 1976).

Centralna vrijednost $(C)$ predstavlja vrijednost položaja odnosno onaj rezultat koji se u nizu rezultata poredanih po veličini nalazi točno po sredini (Bubić, 2013). Na nju ne utječu vrijednosti pojedinih rezultata već samo njihov broj, te je stoga pogodna za korištenje u situacijama kada se unutar skupa podataka može pronaći nekoliko ekstremnih rezultata (Bubić, 2013).

- ARITMETIČKA SREDINA (prosjek ili omjer zbroja svih vrijednosti u nekom skupu i ukupnog broja opažanja, engl. Mean, kratica $M$ ) - prosjek vrijednosti svih rezultata (Mužić, 1976).

Aritmetička sredina $(M)$ jedna od najčešće korištenih mjera središnjih vrijednosti, smatra se najboljim pokazateljem prave vrijednosti mjerenja, i jedina je vrijednost koju je opravdano koristiti u složenijim obradama podataka (Bubić, 2013). Aritmetička sredina predstavlja težište rezultata, jer je zbroj odstupanja pojedinačnih rezultata od aritmetičke sredine jednak 0 , dok je zbroj kvadrata tih odstupanja manji od zbroja kvadrata odstupanja od bilo koje druge vrijednosti u nekom skupu podataka (Bubić, 2013). Prema Bubić (2013) važno je naglasiti da je aritmetičku sredinu opravdano koristiti samo ako su ispunjeni sljedeći uvjeti:

- postoje pravi mjerni podaci koji su točno određeni barem na intervalnoj mjernoj skali, 
- izmjeren je dovoljan broj podataka (veći od 30),

- svi rezultati su dobiveni mjerenjem u istim uvjetima,

- distribucija rezultata je normalna, dakle i simetrična.

S obzirom na to da na vrijednost aritmetičke sredine djeluje svaki rezultat svojom veličinom, navodi Bubić (2013), kod računanja aritmetičke sredine veliki problem predstavlja postojanje ekstremnih vrijednosti, odnosno rezultata koji jako odstupaju od većine izmjerenih vrijednosti unutar jednog skupa. Općenito, što su podaci unutar nekog skupa podataka homogeniji, aritmetička sredina bolje reprezentira taj skup (Bubić, 2013).

b) Mjere disperzije upućuju na karakteristiku raspršenosti; pojedini podaci se oko neke srednje vrijednosti u raznim distribucijama raspoređuju, odnosno „raspršuju“, tj. distribuiraju na razne načine (Mužić, 1976).

Mjere raspršenja (razlikovanja) rezultata računaju se uz mjere središnjih vrijednosti, kako bi se dobio uvid u informacije o međusobnom razlikovanju rezultata, odnosno kako se rezultati raspodjeljuju, osobito kako se udaljenije vrijednosti šire od prosjeka (aritmetičke sredine). Svaka od njih se logički veže uz spomenute mjere središnjih vrijednosti (Mužić, 1976), kao što je prikazano u Tablici 16.

Tablica 16. Mjere disperzije i odgovarajuće srednje vrijednosti s pripadajućim kraticama (izvor: izrada autorice prema Mužić, 1976; Petz i sur., 2012; Bubić, 2013)

\begin{tabular}{lc}
\hline \multicolumn{1}{c}{ Mjere disperzije } & Odgovarajuća srednja vrijednost \\
\hline Raspon varijacije $(R V)$ & $\operatorname{Mod}(D)$ \\
\hline Kvartilno odstupanje $(Q)$ & Medijan $(C)$ \\
\hline Prosječno odstupanje $(P O)$ & \\
\hline Standardna devijacija $(S D)$ & Aritmetička sredina $(M)$ \\
\hline Varijanca $\left(S D^{2}\right)$ & \\
\hline Koeficijent varijabilnosti $(V)$ & \\
\hline
\end{tabular}

Vrste mjera disperzije (indeksi raspršenja):

- RASPON VARIJACIJE (raspon rezultata, kratica $R V$, engl. Range) najjednostavnija je od svih mjera disperzije, predstavlja raspon u kojem mogu varirati podaci unutar neke postojeće distribucije tj. broj raznih podataka koji se mogu pojaviti od najvišeg do najnižeg, stoga se pri njenom određivanju uzimaju se u obzir samo ekstremni podaci $t j$. 
najviši i najniži (Mužić, 1976). Međutim, ona počiva na samo dvije vrijednosti rezultata te je stoga jako osjetljiva na ekstremne rezultate, a osim toga, raspon najčešće raste $s$ porastom broja mjerenja (rezultata), te predstavlja vrlo nesigurnu mjeru raspršenja rezultata (Bubić, 2013). Prilikom izvještavanja o rasponu rezultata najčešće je korisno navesti i najveće (engl. Maximum) i najmanje izmjerene vrijednosti (engl. Minimum), navodi Bubić (2013), a ne njihovu razliku.

- PROSJEČNO ODSTUPANJE (srednje odstupanje, kratica PO, engl. Standard Error of Mean) je aritmetička sredina odstupanja svih rezultata distribucije oko odgovarajuće srednje vrijednosti tj. raspona te distribucije (Mužić, 1976). Prosječno odstupanje služi kao grubi pokazatelj razlikovanja rezultata od aritmetičke sredine (ili neke druge središnje vrijednosti, primjerice centralne ili dominantne vrijednosti) (Petz i sur., 2012).

- STANDARDNA DEVIJACIJA (kratica SD, engl. Standard Deviation) je vrijednost koja označava tipičnu, ili prosječnu kvadriranu razliku između pojedinačnih rezultata i aritmetičke sredine nekog skupa. Što je standardna devijacija manja, to aritmetička sredina bolje reprezentira dobivene rezultate jer se oni u prosjeku manje razlikuju od nje (Bubić, 2013). Standardna devijacija pokazuje nam donekle koliko „vrijedi“ dobivena aritmetička sredina, tj. je li ona dobar ili loš reprezentant rezultata (Petz i sur., 2012). Najčešće je korištena mjera raspršenja, a kao i varijanca, ni standardna devijacija ne računa se uz ostale mjere središnjih vrijednosti, već samo uz aritmetičku sredinu (Bubić, 2013).

- VARIJANCA (kratica $S D^{2}$, engl. Variance) predstavlja jednu od informativnijih mjera raspršenja rezultata koja se smije računati samo uz aritmetičku sredinu, a predstavlja prosjek sume kvadriranih odstupanja svakog rezultata od aritmetičke sredine (Bubić, 2013). Kod računanja varijance veća odstupanja kvadriranjem dolaze više do izražaja, te se na taj način „kažnjava“ postojanje ekstremnih rezultata u mjerenju, pa se općenito, kao samostalna vrijednost ne koristi često, iako je ona vrlo korisna prilikom provođenja složenijih statističkih analiza (Bubić, 2013).

- KOEFICIJENT VARIJABILNOSTI (kratica $V$, engl. Coefficient of Variation) pokazuje koliki postotak aritmetičke sredine iznosi vrijednost standardne devijacije te je vrlo korisna mjera za uvid u kojem svojstvu neka grupa varira više, a u kojem manje, i koja od grupa varira više, a koja manje u istom svojstvu (Petz i sur., 2012).

- KVARTILNO ODSTUPANJE (poluinterkvartilno raspršenje / interkvartilni raspon, engl. Quartiles, kratica $Q$ ) je polovina raspona između trećeg i prvog kvartila, a računa uz centralnu vrijednost, na rezultatima poredanim po veličini, od manjih prema većima 
(Petz i sur., 2012). Taj niz ima četiri kvartila, a granične vrijednosti tih kvartila označavaju se s $Q 1, Q 2, Q 3$ i $Q 4$, te se u svakome kvartilu nalazi se $25 \%$ rezultata (25 percentila, engl. Percentiles), a Q4 je gornja granica postignutih rezultata, ispod koje se nalaze svi rezultati (Petz i sur., 2012). Q2 dijeli niz rangiranih rezultata na dva dijela, što znači da je drugi kvartil je zapravo medijan (centralna vrijednost) (Mužić, 1976). Određuje se kao razlika između rezultata koji se nalazi na granici trećeg ili gornjeg kvartila (rezultat koji razdvaja $75 \%$ najnižih rezultata od onih većih) i onoga koji se nalazi na granici prvog ili donjeg kvartila (rezultat koji razdvaja 25 \% najnižih podataka od ostalih) (Petz i sur., 2012).

Pod pretpostavkom da mjerena osobina predstavlja neku relativno konstantu veličinu, raspršenje rezultata oko središnje vrijednosti ukazuje na točnost kojom je mjerenje izvršeno (Burić, 2018). Indeks raspršenja rezultata oko središnje vrijednosti ukazuje na veličinu pogreške mjerenja (Burić, 2018).

- Distribucije rezultata

Distribuciju (raspodjelu) rezultata čine sve učestalosti, odnosno pojedinačni rezultati i njihove frekvencije unutar nekog skupa podataka (Bubić, 2013).

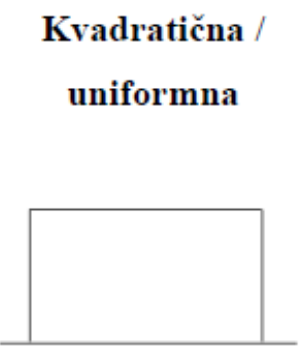

$$
\text { U - distribucija }
$$

Normalna distribucija predstavlja temeljni oblik distribucije koji u statistici ima neobično veliku važnost te predstavlja osnovu za razumijevanje pojmova statističke vjerojatnosti, naziva se i Gaussova krivulja (Bubić, 2013). Njezine temeljne osobine su zvonolik oblik, simetričnost i asimptotsko približavanje apscisi, što drugim riječima znači da se ona približava, ali nikad ne dodiruje apscisu (Bubić, 2013). Normalna raspodjela rezultata je velikog broja faktora, a glavni uvjeti da se kod nekog mjerenja dobije normalna raspodjela su (Petz i sur., 2012): 
1. Opravdano se može pretpostaviti kako postoji „prava“ vrijednost mjerenja (neki fenomen, pojava, psihološka veličina) koja je relativno stabilna u vremenu, te da pri njezinu mjerenju djeluju, osim nje same, samo još nesistematski varijabilni faktori.

2. Postoji veliki broj rezultata (mjerenja).

3. Sva mjerenja su provedena istom metodom i u što sličnijim vanjskim prilikama tj. jednakim prilikama.

4. Skupina na kojoj se obavljaju mjerenja je homogena po svim drugim svojstvima, a heterogena (neselektirana) po onom svojstvu koje mjerimo.

Odstupanja od normalne distribucije najčešće se određuju pomoću 2 parametra, pojašnjava Burić (2018): asimetričnosti (engl. Skewness) i kurtičnosti (spljoštenost, engl. Kurtosis). Kada se većina rezultata koncentrira na manjim vrijednostima, govori se o pozitivno asimetričnoj distribuciji (Skewness > 0), dok je kod negativno asimetrične distribucije većina rezulatata koncentrirana na većim vrijednostima (Skewness < 0) (Burić, 2018), odnosno o standardnim pogreškama asimetričnosti (engl. Standard Error of Skewness). Normalna distribucija ima vrijednost asimetrije 0 (Skewness $=0)$. Kurtičnost se odnosi na konveksnost krivulje normalne distribucije odnosno na koncentraciju rezultata oko aritmetičke sredine, pri čemu postoje tri razine: mezokurtičnost (normalna distribucija, ima „Zvonolik izgled“), te standardne pogreške u spljoštenosti (engl. Standard Error of Kurtosis) odnosno leptokuričnost (rezultati su izrazitije grupirani oko središnje vrijednosti, raspršenje je manje, krivulja izgleda „visoka i vitka“) i platikurtičnost (rezultati su slabije grupirani oko središnje vrijednosti, krivulja izgleda „spoljoštena i široka“) (Burić, 2018). Ako distribucija rezultata nije normalna, treba izbjegavati korištenje parametrijskih metoda obrade koje se inače koriste kod normalno distribuiranih rezultata, jer to može dovesti do pogrešnih zaključaka (Bubić, 2013).

\section{- PROCJENA PARAMETARA}

Kada se, na temelju podataka prikupljenih na nekom uzorku odredi vrijednost aritmetičke sredine na temelju koje se želi odrediti stvarna aritmetička sredina populacije, preporučljivo je prognozirati ne samo jednu, već raspon vrijednosti jer se uz vrijednosti izmjerene na uzorku uvijek veže određena pogreška koja se pokušava neutralizirati manje preciznim prognozama, odnosno prognoziranjem raspona umjesto jedne vrijednosti i navođenjem stupnja uvjerenja u donesene zaključke (Bubić, 2013). Proces određivanja raspona u kojem se, pojašnjava Bubić (2013), uz određenu sigurnost (rizik), nalazi vrijednost u populaciji ili parametar populacije naziva se procjena parametara, pri čemu se parametar može odnositi na npr. aritmetičku sredinu, proporciju, ili raspršenje unutar populacije. U praksi se procjena 
parametara najčešće radi za aritmetičku sredinu (kod podataka na intervalnim i omjernim skalama mjerenja), te proporciju (kod podataka na nominalnoj skali mjerenja) (2013). Nakon što se izračuna pogrešku uzorka, ta mjera može se koristiti za procjenu granica pouzdanosti koje označavaju raspon u kojem se, uz određeni stupanj sigurnosti kojeg odabire sam istraživač, nalazi prava vrijednost populacije (Bubić, 2013).

- GRANICE POUZDANOSTI (Burić, 2018):

- Standardna pogreška - izloženost pogrešci kada se iz neke vrijednosti dobivene mjerenjem na uzorku zaključuje o toj istoj vrijednosti (parametru) u populaciji (npr. o pravoj aritmetičkoj sredini, o pravoj korelaciji itd.). To je standardna devijacija pojedinih statističkih vrijednosti dobivenih na neizmjerno velikom broju uzoraka iste veličine, njihove aritmetičke sredine distribuiraju se normalno sa središnjom vrijednosti koja odgovara pravoj aritmetičkoj sredini populacije i s raspršenjem koje odgovara standardnoj pogrešci aritmetičke sredine (ako je $\mathrm{N}>30$ ).

- Standardna pogreška aritmetičke sredine - varijabilitet aritmetičkih sredina neizmjerno velikog broja uzoraka slučajno odabranih iz populacije, tj. veličina standardne pogreške aritmetičke sredine ovisi o varijabilnosti mjerene pojave u populaciji (što neka pojava manje varira u populaciji, raspršenje aritmetičkih sredina neizmjerno velikog broja uzoraka bit će manje) i veličini uzorka (što je veći N uzorka, standardna pogreška aritmetičke sredine je manja).

S obzirom na sve navedeno te malu veličinu uzorka, za daljnju delfi analizu podataka koristit će se neparametrijska statistička analiza podataka bez rigoroznih pretpostavki na distribuciju populacije, kako bi se izbjegla neopravdana pretpostavka normalnosti.

\subsubsection{Kvantitativan pristup: neparametrijska statistička analiza}

U svrhu dodatne analize dobivenih odgovora ispitanika u 2. i 3. krugu ovog istraživanja, provest će se Wilcoxonov test rangova zavisnih uzoraka kako bi se utvrdilo razlikuju li se stupnjevi važnosti koje su panelisti dodijelili ključnim čimbenicima promjene komunikacijske paradigme $\mathrm{u}$ visokom obrazovanju pod utjecajem društvenih medija u 2. krugu te stupnjevi u važnosti koje su panelisti dodijelili ključnim čimbenicima promjene komunikacijske paradigme u visokom obrazovanju pod utjecajem društvenih medija u 3. krugu na statistički značajan način odnosno kako bi se utvrdila stabilnost odgovora u svrhu postizanja konsenzusa. 
Test će biti korišten za usporedbu podataka odnosno rezultata 2. i 3. kruga, te za usporedbu stupnja važnosti svakog ključnog čimbenika promjene komunikacijske paradigme u visokom obrazovanju pod utjecajem društvenih medija sa stupnjem važnosti svakog ključnog čimbenika promjene komunikacijske paradigme u visokom obrazovanju pod utjecajem društvenih medija u 3. krugu.

Wilcoxonov test rangova zavisnih uzoraka neparametrijski je test ekvivalentan ovisnom t-testu (Laerd Statistics, 2020). Budući da Wilcoxonov test rangova zavisnih uzoraka ne pretpostavlja normalnost u podacima kao t-test, koristi se kada je upotreba ovisnog t-testa neprimjerena. Koristi se za usporedbu dva skupa rezultata koji dolaze od istih sudionika, kada se želi istražiti bilo kakva promjena rezultata iz jedne vremenske točke u drugu ili kad su pojedinci podvrgnuti više od jednog stanja (Laerd Statistics, 2020). Osnovne pretpostavke potrebne za korištenje ove metode ispitivanja su da su podaci iz iste populacije i upareni, podaci se mogu mjeriti na barem intervalnoj skali, a podaci su odabrani slučajnim odabirom i neovisno (Hayes, 2020). Pretpostavlja da postoje podaci o veličinama i znakovima razlika između uparenih promatranja (Hayes, 2020). Prikupljeni podaci u ovoj studiji o stupnjevima važnosti ključnih čimbenika promjene komunikacijske paradigme u visokom obrazovanju pod utjecajem društvenih medija bit će izraženi u vrijednostima prema ordinalnoj mjernoj skali, iz iste skupine eksperata i upareni.

Za usporedbu stupnjeva važnosti ključnih čimbenika promjene komunikacijske paradigme u visokom obrazovanju pod utjecajem društvenih medija u 2. krugu i stupnjeva važnosti ključnih čimbenika promjene komunikacijske paradigme u visokom obrazovanju pod utjecajem društvenih medija u 3. krugu bit će napravljeni testovi pomoću softvera za statističku analizu IBM SPSS Statistics verzija 2020.

Za međusobnu usporedbu stupnja važnosti svakog ključnog čimbenika promjene komunikacijske paradigme u visokom obrazovanju pod utjecajem društvenih medija sa stupnjem važnosti svih ostalih ključnih čimbenika promjene komunikacijske paradigme u visokom obrazovanju pod utjecajem društvenih medija u 3. krugu bit će napravljeni testovi pomoću softvera za statističku analizu IBM SPSS Statistics verzija 2020.

\subsubsection{Valjanost i pouzdanost}

„Valjanost je važan ključ uspješnog istraživanja“, navode Cohen i suradnici (2007), no „nemoguće je da istraživanja budu sto posto valjana; to je perfekcionistički optimizam“. Dok 
„kvantitativna istraživanja sadrže mjeru standardne, ugrađene pogreške koja se mora uzeti u obzir“, dotle „u kvalitativnim podacima subjektivnost ispitanika, njihovo mišljenje, stavovi i gledište zajedno mogu pridonijeti određenom stupnju pristranosti“ (Cohen i sur., 2007). „Valjanost dakle, treba promatrati kao stvar stupnja, a ne kao apsolutno stanje“ (Cohen i sur., 2007 prema Gronlund, 1981), tako da se u najboljem slučaju treba težiti minimiziranju nedostatka valjanosti, a maksimiziranju valjanosti. Kerlinger (1986) tvrdi da je glavna svrha dizajna istraživanja odgovoriti na istraživačka pitanja i da je glavna funkcija dizajna istraživanja minimiziranje pogrešaka i kontrola učinaka irelevantnih varijabli (Holbrook Lewis, 2014). Isto tako, kada istraživač predstavi izvještaj koji je dovoljno točan i dokumentiran, čitatelji mogu sami odrediti valjanost i vrijednost istraživanja (Holbrook Lewis, 2014 prema Kerlinger, 1986), stoga se Merriam (2009) zalaže za strogost $\mathrm{u}$ istraživanjima kako bi drugi mogli imati povjerenja u rezultate (Holbrook Lewis, 2014). Uz to, Merriam (2009) smatra da, kako bi istraživanje imalo utjecaja na praksu ili teoriju, mora biti „rigorozno provedeno“, a drugi istraživači moraju imati „povjerenje u provedeno istraživanje i u rezultate određene studije“ (Holbrook Lewis, 2014). Slišković (2017) pak navodi da se valjanost u kvalitativnim istraživanjima temelji na sljedećim elementima:

- sudionička valjanost odnosno da podaci sudionicima imaju smisla, pri čemu je važno da procedura kvalitativnog istraživanja mora osigurati ispitanicima da dovedu u pitanje/ isprave istraživačeve pretpostavke o značenju i važnosti koncepata i kategorija,

- visoka ekološka valjanost odnosno podaci moraju biti iz realnih situacija,

- valjanosti pridonosi refleksivnost odnosno istraživač konstantno mora sagledavati vlastitu ulogu u istraživanju, osobito u konstrukciji značenja,

- triangulacija odnosno povećavanje valjanosti rezultata istraživanja korištenjem dviju ili više metoda prikupljanja podataka.

Hammersley (1992) „tvrdi da valjanost u kvalitativnim istraživanjima zamjenjuje izvjesnost sigurnošću u naše rezultate, te da će, kako joj je stvarnost nezavisna od tvrdnji koje o njoj daju istraživači, naši opisi biti samo prikaz te stvarnosti, a ne njezino reproduciranje“"(Cohen i sur., 2007 prema Hammersley, 1992). Maxwell (1992) se zalaže za pet vrsta valjanosti u kvalitativnim metodama koje objašnjavaju njegov pojam „razumijevanja“:

- deskriptivna valjanost odnosno činjenična točnost opisa, da on nije izmišljen, selektivan ili iskrivljen!, u tom smislu valjanost podrazumijeva pouzdanost, što je blisko BlumenJonesovu (1995) pojmu ,istine“ u istraživanjima tj. onoga što se doista dogodilo (objektivno činjenično); 
- interpretativna valjanost odnosno sposobnost istraživanja da uhvati značenje, tumačenje, pojmove, namjere koje situacije i događaji, tj. podaci imaju za sudionike/ispitanike same, u njihovim terminima, što je blisko Blumen-Jonesovu (1995) pojmu „vjernosti“ tj. onoga što to znači za osobu ili skupinu koja se istražuje (subjektivno smisleno);

- teoretska valjanost odnosno teoretske konstrukcije koje istraživač unosi u istraživanje (uključivo i konstrukcije onih na kojima se istraživanje obavlja), teorija se ovdje promatra kao objašnjenje, a teoretska valjanost kao stupanj u kome istraživanje objašnjava pojave;

- mogućnost generalizacije odnosno gledište da izvedena teorija može biti korisna u razumijevanju drugih, sličnih situacija;

- evaluacijska valjanost odnosno primjena evaluacijskog okvira, koji prosuđuje ono što se istraživalo, umjesto deskriptivnog, eksplanatornog ili interpretativnog (Cohen i sur., 2007 prema Maxwell, 1992).

Stoga, za dizajn ovog istraživanja koristit će se delfi studija za pitanja koja se odnose na paradigmu komunikacijskog protokola putem društvenih medija u visokom obrazovanju za utvrđivanje mogućeg konsenzusa mišljenja eksperata o tome koje su aktivnosti i procesi potrebni u ovom trenutku, kao i ona koja se smatraju važnima u narednim godinama, kako bi se potencijali društvenih medija koristili za potrebe visokog obrazovanja. Vodeći se načelima koje predlažu Kerlinger (1986), Merriam (2002), Slišković (2017), Hammersley (1992) i Maxwell (1992), prikupit će se, analizirati i obraditi podaci za ovu studiju. Rezultati će biti u potpunosti dokumentirani kako bi budućim istraživačima omogućili prikladnu prenosivost informacija u njihovu istraživačku situaciju. Detaljno će se zabilježiti kako je provedeno istraživanje, kako su podaci analizirani i obrađeni, tako da disertacija može pružiti te detalje kao dio rasprave o podacima. Na taj će se način budući istraživači moći oslanjati na nalaze, unutar ograničenja studije, kako bi proširili provedeno istraživanje i mogli potvrditi rezultate ove studije.

Istinitost ove studije temeljit će se na naporima istraživačice da vjerno dokumentira studiju i iznese samo zaključke koji su potkrijepljeni podacima, s ciljem da svi rezultati budu točni u odnosu na utvrđeni kontekst i ograničenja. Isto tako, pouzdanost provedene i zabilježene delfi studije temeljit će se na više krugova istraživanja. Nakon svakog kruga sudionici će provjeravati rezultate prethodnog kruga. Ovaj kontinuirani pregled i provjera podataka smatra se presudnim za pouzdanost rezultata (Holbrook Lewis, 2014 prema Skulmoski, i sur., 2007). 


\subsection{Plan istraživanja - podloga za provedbu istraživanja}

Radi razumijevanja primijenjene metodologije korisno je razumjeti kronološku strukturu razvoja i primjene istraživačkih instrumenta. Strukturu primjene instrumenata prikazuje Slika 13.

1. Analiza relevantne literature i dostignuća u domeni istraživanja (siječanj 2016. - svibanj/lipanj 2020. godine).

$\bar{\downarrow}$

2. Provedba i analiza rezultata 1. predistraživanja (eksperimentalna skupina studenata) - instrument „Upitnik o studentskom korištenju društvenih mreža za potrebe studiranja“, (ljetni semestar ak. god. 2015./2016.).

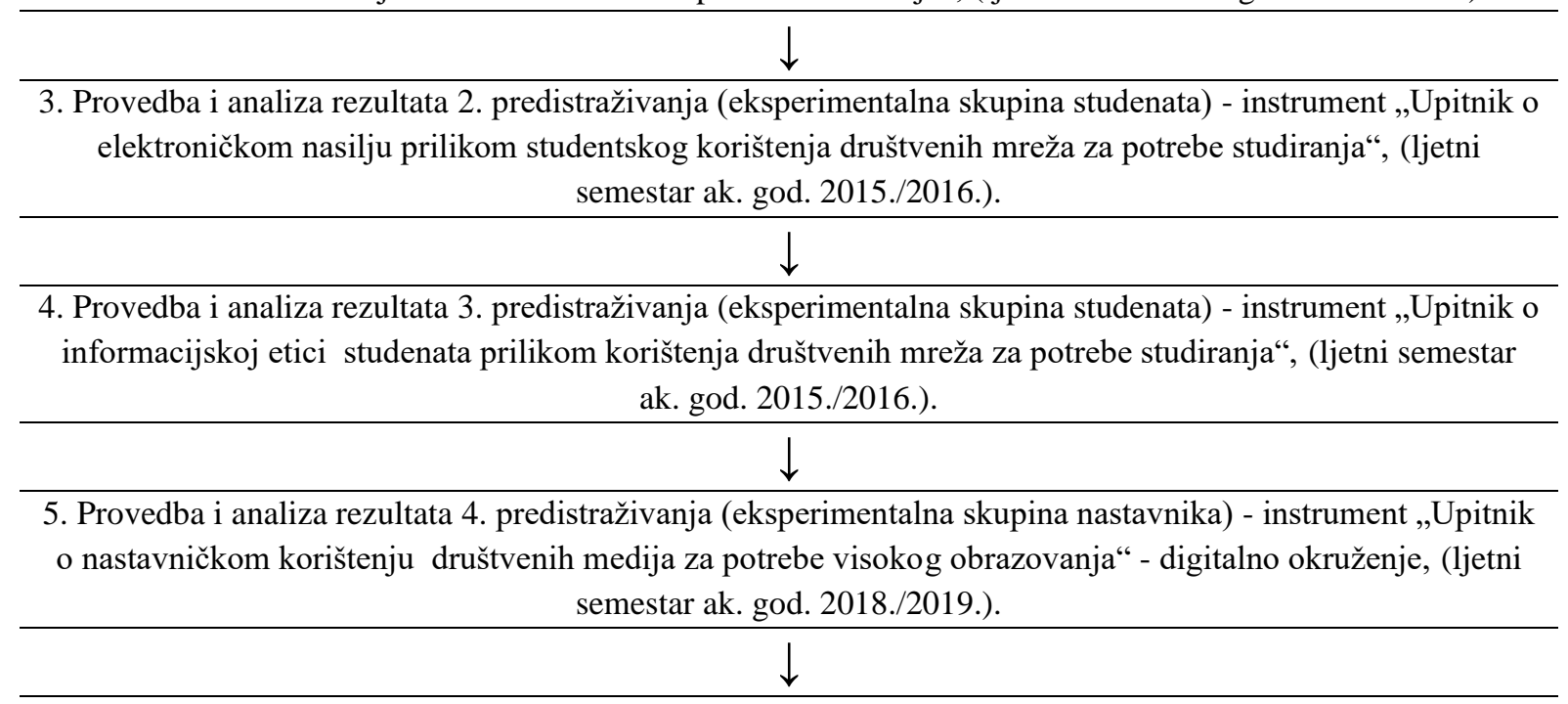

6. Razvoj novog (glavnog) istraživačkog upitnika, tj. instrumenta „Upitnik 1“ - Instrument delfi studija 1. krug istraživanja (ljetni semestar ak. god. 2019./2020.).

\begin{tabular}{r}
\hline \\
\hline 7. Provedba prvog dijela glavnog istraživanja - izrada instrumenta - „Upitnik 1“ - Instrument delfi studija - \\
1. krug istraživanja (svibanj i lipanj 2020. godine; ljetni semestar ak. god. 2019./2020.). \\
$\downarrow$ \\
\hline 8. Analiza i prikaz rezultata provedbe glavnog istraživanja putem: „Upitnik 1“ - Instrument delfi studija - \\
1. krug istraživanja (srpanj 2020. godine; ljetni semestar ak. god. 2019./2020.) \\
$\downarrow$
\end{tabular}

9. Razvoj novog (glavnog) istraživačkog upitnika, tj. instrumenta „Upitnik 2“ - Instrument delfi studija -

2. krug istraživanja (srpanj 2020. godine; ljetni semestar ak. god. 2019./2020.).

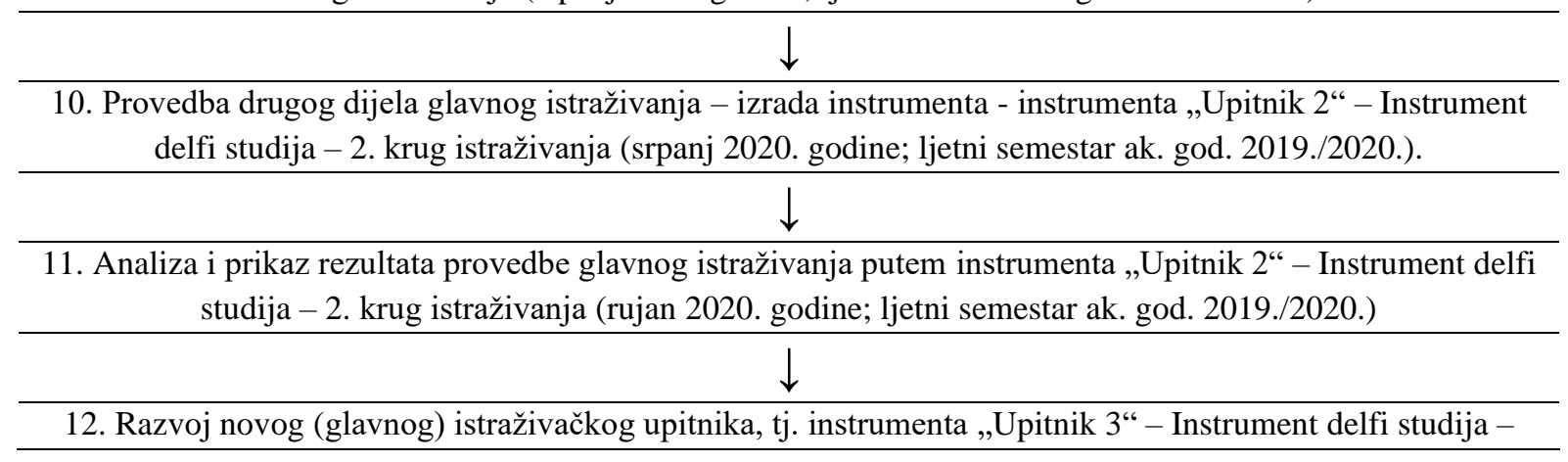


13. Provedba trećeg dijela glavnog istraživanja - izrada instrumenta - „Upitnik 3“ - Instrument delfi studija 3. krug istraživanja (rujan 2020. godine; ljetni semestar ak. god. 2019./2020.).

\begin{tabular}{r}
$\downarrow$ \\
\hline 14. Analiza i prikaz rezultata provedbe glavnog istraživanja putem „Upitnik 3“ - Instrument delfi studija - \\
3. krug istraživanja (listopad 2020. godine; zimski semestar ak. god. 2020./2021.) \\
$\downarrow$
\end{tabular}

15. Provedba četvrtog dijela glavnog istraživanja - izrada prikaza sumarnih rezultata - „Prezentacija rezultata“ - Instrument Sumarni prikaz rezultata delfi studije -

4. krug istraživanja (listopad 2020. godine; zimski semestar ak. god. 2020./2021.)

Pisanje doktorske disertacije.

Slika 13. Plan istraživanja - struktura korištenih istraživačkih metoda i instrumenata (izvor: izrada autorice) 


\section{REZULTATI EMPIRIJSKOG ISTRAŽIVANJA S DISKUSIJOM}

„Naša današnja postignuća samo su zbroj naših jučerašnjih misli. Vi ste danas tamo gdje su vas misli jučer dovele i bit ćete sutra tamo gdje će vas današnje misli odvesti.“

- Blaise Pascal

\subsection{Uvod u delfi studiju}

Glavno empirijsko istraživanje provodilo se u periodu od svibnja do listopada 2020. godine u četiri kruga delfi studije (vidi Tablicu 17.). Za istraživanje se u prvom krugu koristio instrument Upitnik 1. (Prilog 9.), koji je poslan sudionicima uz inicijalnu uputu panelistima za sudjelovanje u istraživanju (Prilog 6.). U 2. krugu koristio se instrument Upitnik 2. (Prilog 11.), koji je poslan sudionicima uz drugu uputu panelistima za sudjelovanje u istraživanju (Prilog 10.), a u 3. krugu koristio se instrument Upitnik 3. (Prilog 13.), koji je poslan sudionicima uz treću uputu panelistima za sudjelovanje u istraživanju (Prilog 12.). Istraživanje se provodilo individualno i anonimno, a upitnici su u bili distribuirani u digitalnom obliku putem linka koji je vodio na pitanja anketnog upitnika u formatu Google Obrasci. Link na upitnike je bio naveden i poslan putem e-pošte kako bi se povećala šansa za brzi povratak upitnika. Panelisti su bili zamoljeni da na svaki od upitnika odgovore u roku 7 dana. Dodatna e-pošta i pozivi u smislu podsjetnika upućeni su u slučaju da stručnjaci nisu poštovali predloženi rok.

Početni poziv za sudjelovanje $\mathrm{u}$ istraživanju odnosno Informativno pismo o sudjelovanju u istraživanju (Prilog 7.) i obrazac za suglasnost za sudjelovanje u istraživanju (Prilog 8.) poslani su e-poštom potencijalnim sudionicima delfi studije. U skladu s istraživačkom etičkom politikom, studija je započela kada su sudionici vratili potpisane primjerke suglasnosti za sudjelovanje u istraživanju. Od 52 pozvanih eksperata, 37 se složilo da će sudjelovati u ovoj studiji. Svih 37 panelista završilo je prva dva kruga istraživanja, a 1 panelist odustao je u trećem krugu. Rezultati s diskusijom prikazani su anonimno u ovom poglavlju kako bi se zaštitio identitet sudionika te predstavljaju ukupne rezultate procjene eksperata i interpretaciju autorice, a ne predstavljaju pojedinačno mišljenje svakog sudionika istraživanja ponaosob. Eksperti koji su započeli te dovršili sudjelovanje u sva tri kruga istraživanja navedeni su abecednim redom $u$ ovom radu u prikazu Panelisti delfi stručne skupine (Prilog 5.). 
Tablica 17. Trajanje i broj sudionika u svakom krugu provedene delfi studije provedene 2020. godine, $\mathrm{N}=37$ (izvor: izrada autorice)

\begin{tabular}{|c|c|c|c|c|}
\hline Krugovi & $\begin{array}{c}\text { Trajanje } \\
\text { (u danima) }\end{array}$ & $\begin{array}{c}\text { Inicijalno pozvani } \\
\text { sudionici }\end{array}$ & $\begin{array}{c}\text { Sudionici koji su } \\
\text { odgovorili }\end{array}$ & $\begin{array}{c}\text { Sudionici koji su } \\
\text { odustali u \% }\end{array}$ \\
\hline 1. krug & $\begin{array}{c}\text { 21.05.-13.07.2020. } \\
\mathbf{5 3}\end{array}$ & 52 & 37 & 28,8 \\
\hline 2. krug & $\begin{array}{c}\text { 13.07.-07.09.2020. } \\
\mathbf{5 7}\end{array}$ & 37 & 37 & 0 \\
\hline 3. krug & $\begin{array}{c}\text { 07.09.-12.10.2020. } \\
\mathbf{3 5}\end{array}$ & 37 & 36 & 2,7 \\
\hline
\end{tabular}

4. krug Objava rezultata istraživanja svim aktivnim sudionicima 3. kruga istraživanja.

\subsection{Demografska struktura uzorka}

Glavno empirijsko istraživanje inicijalno je provedeno kod ukupno 37 ispitanika. Obuhvaćalo je Republiku Hrvatsku. Odziv ispitanika bio je više nego zadovoljavajući (Tablica 18.).

Tablica 18. Struktura uzorka glavnog istraživanja, N=37 (izvor: izrada autorice)

\begin{tabular}{|c|c|c|c|}
\hline Varijabla & Skupina & $\mathrm{N}$ & $\%$ \\
\hline \multirow{6}{*}{$\begin{array}{l}\text { Kojoj dobnoj skupini } \\
\text { pripadate? }\end{array}$} & $18-30$ & 1 & $2,7 \%$ \\
\hline & $31-40$ & 9 & $24,3 \%$ \\
\hline & $41-50$ & 15 & $40,5 \%$ \\
\hline & $51-60$ & 9 & $24,3 \%$ \\
\hline & $61+$ & 3 & $8,1 \%$ \\
\hline & Total & 37 & $99,9 \%$ \\
\hline \multirow{3}{*}{ Rod } & M & 30 & $81,1 \%$ \\
\hline & Ž & 7 & $18,9 \%$ \\
\hline & Total & 37 & $100 \%$ \\
\hline \multirow{5}{*}{ Stručna sprema } & SSS & 1 & $2,7 \%$ \\
\hline & Prvostupnik & 1 & $2,7 \%$ \\
\hline & VSS ili mag. & 17 & $45,9 \%$ \\
\hline & mr.sc. ili dr.sc. & 18 & $48,6 \%$ \\
\hline & Total & 37 & $99,9 \%$ \\
\hline
\end{tabular}


Uzorak je trebao minimalno sadržavati 30 ispitanika, te je uvelike premašen (37 ispitanika). Inicijalno predviđena struktura uzorka prema stručnosti (kompetentni pojedinci zainteresirani za predmet istraživanja) bila je sljedeća, i to minimalno:

1. 10 značajnih gospodarstvenika s dugogodišnjim iskustvom rada u IT području (koji svoje predikcije mogu temeljiti na svom radnom iskustvu),

2. 10 istaknutih znanstvenika i istraživača iz IT područja (koji svoje predikcije mogu temeljiti na svom znanstvenom i istraživačkom radu),

3. 10 vodećih stručnjaka iz područja provedbe IT obrazovanja, posebno iz područja web 2.0 aplikacija (koji svoje predikcije mogu temeljiti na svom praktičnom uvidu u najnovije tehnologije na području obrazovanja).

S obzirom da se panelisti, sudionici ove delfi studije, u svom profesionalnom životu pojavljuju u više navedenih uloga, struktura uzorka je kako slijedi: posao gospodarstvenika obavlja njih $11(23,9 \%)$, znanstvenika 21 (45,7\%), IT edukatora njih $14(30,4 \%)$ prema čemu zbroj uzorka premašuje total od $100 \%$, ali je inicijalno predviđena struktura uzorka ispunjena, te u pojedinim kategorijama i uvelike premašena.

11 panelista $(29,7 \%)$ društvenim medijima bavi se 15 i više godina, 11 njih $(29,7 \%)$ se bavi njima između 10 i 15 godina, 6 panelista $(16,2 \%)$ od 6 do10 godina, a samo njih $9(24,3 \%)$ manje od 5 godina, pri čemu ih ipak, kako sami navode, redovito koriste i promiču. Svi sudionici istraživanja su eksperti su IT području.

\subsection{Obrada i analiza rezultata}

„Moramo koristiti našu sposobnost promatranja (primjećivanja) na induktivan način te dopustiti sebi da primijetimo istinitu životnu priču, tražeći obrasce i gradeći teoriju.“ - Jeđud, (2007) prema Gummesson (2002) i Glaser, Holton (2004)

\subsubsection{Prvi krug delfi studije}

U 1. krugu istraživanja panelisti su zamoljeni da metodom „oluja ideja“ (poznata i pod nazivom „oluja mozgova“, engl. Brainstorming) odgovaraju na 11 otvorenih pitanja o komunikacijskoj paradigmi u visokom obrazovanju pod utjecajem društvenih medija, koja su dizajnirana da prikupe širok raspon odgovora (instrument Upitnik 1., vidi Prilog 9.). Pitanja su se odnosila na 
predikcije koje se tiču budućeg razvoja tehnologija koje pokreću društvene medije, preduvjeta (ekonomskih i drugih) koje je potrebno ispuniti kako bi se potencijal društvenih medija upotrijebio za potrebe visokog obrazovanja, čimbenike koji utječu na ugradnju društvenih medija u visokoobrazovni proces i na odnos visokih učilišta, nastavnika i studenata prema društvenim medijima te načine na koje se potencijali društvenih medija mogu iskoristiti za unaprjeđenje komunikacije u visokom obrazovanju (instrument Upitnik 1., Prilog 9.).

U svrhu analize odgovora panelista koristila se tematska analiza, na induktivan način kroz postupak kodiranja podataka bez pokušaja da se uklopi u već postojeći teoretsko-paradigmatski okvir ili analitička preduvjerenja istraživačice. U tom smislu, oblik ove tematske analize temelji se na podacima koje su u svojim odgovorima iznijeli eksperti sudionici provedene delfi studije, uz važnu napomenu da se podaci ne kodiraju u epistemološkom vakuumu, kako to nazivaju Braun i Clarke (2006), jer se istraživači ne mogu sasvim osloboditi svojih teorijskih i epistemoloških veza, te se „teorijska“ tematska analiza može se voditi i istraživačkim teoretskim ili analitičkim interesom za to područje (Braun, Clarke, 2006).

Eliminirani su nepovezani ili nepotpuni odgovori, dok su ostali odgovori analizirani metodom tematske analize, te su rezultati na taj način i interpretirani. Za potrebe analize kvalitativnih odgovora na ostavljena pitanja otvorenog tipa u 1. krugu ove delfi studije, korištena je metoda kodiranja dobivenih odgovora iz sirovih podataka u koncepte kao temeljne jedinice analize (Jeđud, 2007 prema Corbin i Strauss, 1990), nakon čega je slijedilo grupiranje koncepata koji se odnose na isti fenomen u apstrahirane uopćene kategorije koje su međusobno povezane. „Kategorije su na višoj razini i apstraktnije od koncepata, te moraju imati 'moć objašnjavanja'“ (Jeđud, 2007 prema Corbin i Strauss, 1990). Kategorije su zatim ujedinjene u teme koje će se koristiti u 2. krugu istraživanja (prema Saldana, 2009).

Teorijskim uzorkovanjem, odnosno kružnim procesom usporedbe i refleksije poznatih informacija o trenutnom stanju/razvoju tehnologije i novog materijala dobivenog u odgovorima eksperata koji se tiču perspektive/budućeg razvoja tehnologija, ponavljanim nekoliko puta (prema Jeđud, 2007 i Hox, Boeije, 2005), dobiveni su prikazi u tablicama koje slijede, pri čemu se prvi stupac Koncepti (prema Corbin i Strauss, 1990) odnosi na vrstu tehnologije odnosno svojstva ili osobine koje se na nju odnose, drugi stupac Frekvencija odgovora sadrži učestalost Koncepata u ukupnim odgovorima sudionika istraživanja na to pitanje (iskazanu numerički i postotno), a treći stupac sadrži uopćene izjave apstrahirane iz Koncepata u Kategorije. Koncepti su rangirani na prvom mjestu u silaznom redoslijedu prema učestalosti (od najviše do najniže frekvencije) unutar svakog tematskog područja (Kategorije), a zatim se navode abecednim redom unutar svakog frekvencijskog područja (za iste frekvencije odgovora). 
Zaključno slijedi deskripcija i interpretacija predikcija panelista s naglaskom na razumijevanju osobne perspektive situacija, procesa i odnosa odnosno iz perspektive samih sudionika istraživanja (prema Jeđud, 2007 i Sagadin, 1991). Rezultati za svaku kategoriju, kao i interpretacija rezultata, nisu izloženi prema frekvenciji odnosno postotku odgovora koje su se odnosile na njih, već su, vodeći se preporukom Brauna i Clarka (2006) da ključnost teme, odnosno kategorije, ne ovisi nužno o mjerljivim mjerama, kategorije apstrahirane iz koncepata u smislu važnosti u odnosu na cjelokupno istraživačko pitanje.

\subsubsection{Razvoj tehnologija koje pokreću društvene medije}

Kako bi se odgovorilo na prvo istraživačko pitanje IP1.: Kakav se razvoj tehnologija koje pokreću društvene medije očekuje u budućnosti? panelistima su postavljena pitanja:

1. Kakav razvoj tehnologija koje pokreću društvene medije očekuju u idućih 5 godina?

2. Kakav razvoj tehnologija koje pokreću društvene medije očekuju u idućih 10 godina? Za potrebe analize kvalitativnih odgovora na prvo i drugo postavljeno pitanje otvorenog tipa $u$ ovoj delfi studiji, dobiveni odgovori su iz sirovih podataka kodirani u koncepte kao temeljne jedinice analize, nakon čega je slijedilo grupiranje koncepata koji se odnose na isti fenomen u uopćene kategorije koje su međusobno povezane. Kategorije su ujedinjene u temu „Razvoj tehnologija“" koja će se koristiti u 2. krugu istraživanja.

Teorijskim uzorkovanjem, odnosno kružnim procesom usporedbe i refleksije poznatih informacija o trenutnom stanju/razvoju tehnologije i novog materijala dobivenog u odgovorima eksperata koji se tiču perspektive/budućeg razvoja tehnologija, ponavljanim nekoliko puta dobiveni su prikazi u Tablici 20. i Tablici 21. pri čemu se prvi stupac Koncepti odnosi na vrstu tehnologije odnosno svojstva ili osobine koje se na nju odnose, drugi stupac Frekvencija odgovora sadrži učestalost Koncepata u ukupnim odgovorima sudionika istraživanja na to pitanje (iskazanu numerički i postotno), a treći stupac sadrži uopćene izjave apstrahirane iz Koncepata u Kategorije na temu „Razvoj tehnologija“ koje su korištene u 2. krugu istraživanja za opis Teme odnosno Ključnog čimbenika promjene (KČP) komunikacijske paradigme u visokom obrazovanju pod utjecajem društvenih medija broj 1. pod nazivom „Razvoj tehnologija“.

Zaključno slijedi deskripcija i interpretacija predikcija panelista s naglaskom na razumijevanju razvoja tehnologije u idućih 5 godina i u idućih 10 godina iz perspektive samih sudionika istraživanja. 
Radi lakšeg razumijevanja i razvidnosti cjelokupne materije koja se odnosi na vrstu tehnologije odnosno izraze i pojmove koje su koristili panelisti u odgovorima na navedena pitanja te lakšeg snalaženja u tumačenju rezultata koji slijede, u Tablici 19. prikazana je terminologija tehnoloških i ostalih (engleskih) izraza koje su koristili eksperti u svojim odgovorima, prema vrstama tehnologije s pripadajućim opisima i primjerima.

Tablica 19. Terminologija tehnoloških i ostalih (engleskih) izraza koje su koristili eksperti u svojim odgovorima tijekom1. kruga ove delfi studije (izvor: izrada autorice)

\begin{tabular}{ll}
\hline Vrsta tehnologije & \multicolumn{1}{c}{ Opis i primjeri } \\
\hline - & „Automatizacija, upravljanje strojevima, procesom ili sustavom s pomoću \\
mehaničkih i elektroničkih uređaja koji zamjenjuju ljudski rad; nadziranje i \\
donošenje odluka u poslovima koji su za čovjeka previše složeni, opasni ili \\
zamarajući. Elektronička računala glavna su poluga u automatizaciji fizičkih \\
i misaonih procesa. Automatizacija fizičkih procesa poglavito se tiče \\
proizvodnje energije i materijalnih dobara. Uvođenje računala potaknulo je \\
široku automatizaciju misaonih procesa, a naročito uredskog poslovanja, pri \\
čemu je vrlo važna automatska obradba podataka. Automatizacija je toliko \\
povećala proizvodnost da je uzrokovala globalnu prekvalifikaciju radne \\
snage, pa je broj osoba koje rade u različitim područjima obradbe \\
informacija prevladao nad onima u materijalnoj i energetskoj proizvodnji. \\
U razvijenim zemljama uvelike se smanjuje broj industrijskih radnika. Da \\
bi se taj proces ublažio, poduzimaju se protumjere: pravodobno upozorenje, \\
doškolovanje, preraspored, skraćivanje radnog vremena, prijevremena \\
mirovina. Sve se to već sada provodi u dogovoru između sindikata i \\
poslodavaca. Ali, usporedno s time, zahvaljujući informatičkim \\
tehnologijama koje su 'generičkoga' karaktera, otvaraju se sveudilj nova \\
radna mjesta, i to u sektoru usluga.“ (Hrvatska enciklopedija, 2020)
\end{tabular}

- Digitalna transformacija odnosi se na proces koji započinje od trenutka kada organizacija krene razmišljati o uvođenju digitalnih tehnologija u svim područjima poslovanja i traje do trenutka njihove potpune integracije. Međutim, digitalna transformacija uključuje i pojedince: nije dovoljno samo uvesti digitalnu tehnologiju u poslovanje, važno je i educirati zaposlenike. Digitalna transformacija može obuhvaćati područja kao što su digitalni marketing, digitalizacija i automatizacija poslovnih procesa, digitalna nabava, digitalizacija prodajnih predstavnika, Big Data i slično. U procesu digitalne transformacije želi se da tehnologija korisnicima omogući da traže ono što žele, i to kad god i kako god to žele. Razvoj novih tehnologija, softvera i aplikacija omogućio je da se organizacije povežu s korisnicima na različitim razinama - od informiranja o kupnji, pomoći pri odlučivanju i procesu kupnje do razmjene informacija o zadovoljstvu. Stoga digitalna transformacija znači i promjenu svih oblika poslovanja i procesa u kojima su zaposlenici organizacije u interakciji s njezinim korisnicima. Tako je nekim organizacijama dovoljno napraviti internetsku stranicu, otvoriti digitalne kanale komunikacije i zaposliti nekolicinu digitalnih stručnjaka, a druge trebaju uvesti mnogo složenije procese digitalnih tehnologija te zapošljavanje mnogo većeg broja stručnjaka na različitim razinama poslovanja. Svaka je organizacija individualna, stoga je i razvojni put digitalne transformacije svake organizacije različit. A to je i razlog zbog kojega se ovaj pojam vrlo često ne razumije u potpunosti. (Europska komisija, Predstavništvo u Hrvatskoj, 2020b)

- Danas se u poslovnom svijetu pod pojmom,,vendor“ podrazumijeva sve koji dobavljaju raznu robu i usluge, uključujući tu i sam rad. Dakle, vendori su

Dobavljač roba ili usluga koje su nam potrebne (engl. Vendor) dobavljači uredskog materijala, poduzetnici ili tvrtke koje isporučuju robu, serviseri koji održavaju opremu u tvrtki, odvjetnici, knjigovođe $\mathrm{i}$ - suradnici koji za obavljaju povremene ili privremene poslove, dakle honorarci. U ovu kategoriju nisu uključeni dobavljači materijala koji koriste za izradu 
proizvodu. Iako i oni, u najširem smislu, također spadaju u vendore, za njih se češće u engleskom jeziku i terminologiji modernog poslovnog žargona koristi riječ „suppliers“. (Vejković, 2015)

- Igrifikacija je „korištenje elemenata oblikovanja igre u neigrajućem kontekstu“, tj. izvan konteksta u kojem se igra obično provodi (npr. društveno okruženje, natjecanje, računalne igre i sl.)“(Lovrenčić i sur., 2018 prema Deterding i sur., 2011). Obuhvaća primjenu metafora igre „u zadacima realnog života kako bi se utjecalo na ponašanje, pojačala motivacija i povećala angažiranost osobe" (Lovrenčić i sur., 2018 prema

Igrifikacija (engl. Gemification) Marczewski, 2012). Osnovna razlika između ozbiljne igre i igrifikacije je da se u ozbiljnoj igri koristi cjelovita računalna aplikacija, tj. računalna igra, izrađena sa svrhom postizanja cilja igranja (učenje/stjecanje vještina), dok se u igrifikaciji koriste samo neki elementi igre (npr. bodovi, značke, rang liste itd.) s ciljem povećanja motivacije i angažiranosti osobe, te ona može biti podržana korištenjem računalne aplikacije ili realizirana u samom informacijskom sustavu (Lovrenčić i sur., 2018).

- Bot je softverska aplikacija koja je programirana za izvršavanje određenih zadataka. Botovi su automatizirani, što znači da rade prema zadanim uputama, a da ih ljudski korisnik ne mora pokretati. Često oponašaju ili zamjenjuju ponašanje ljudskog korisnika. Tipično rade zadatke koji se ponavljaju i mogu ih raditi puno brže nego što bi to mogli učiniti ljudi. Obično rade preko mreže; više od polovice internetskog prometa čine botovi koji skeniraju sadržaj, komuniciraju s web stranicama, razgovaraju s korisnicima ili traže ciljeve napada. Neki su botovi korisni, poput robota za tražilice koji indeksiraju sadržaj za pretraživanje ili botova za korisničku službu koji pomažu korisnicima. Ostali su „loši“ i programirani su za provaljivanje u korisničke račune, skeniranje weba za kontaktne podatke zbog slanja neželjene pošte ili obavljanje drugih zlonamjernih aktivnosti. (Cloudflare, 2020)

- „Naziv IoT obuhvaća tehnologiju povezivanja fizičkih uređaja, vozila i drugih stvari, koje prikupljaju, dijele i razmjenjuju podatke putem interneta. Spajanje uređaja može biti žično ili bežično te omogućuje potpuno nove mogućnosti za međusobnu interakciju (komunikaciju) između ljudi i različitih sustava. Na taj način stvari, uređaji i stvari/uređaji mogu komunicirati s ljudima, uz zajednički cilj olakšavanja i pojednostavnjivanja života ljudi. Primjerice, senzor pokreta na pametnoj narukvici omogućuje osobi da prati svoju tjelesnu aktivnost. Senzor „primjećuje“ pokret, spaja se putem interneta na server, na kojem postoji sustav za obradu podataka, te ga šalje natrag u aplikaciju na pametnoj narukvici. Pametna narukvica „uči“ te se ponaša u skladu s novim podacima. U ovisnosti o tome koliko je osoba aktivna i koliko želi biti aktivna, pametna će joj narukvica, prema unesenim parametrima i dosadašnjim podacima, kreirati rute, dojavljivati kad je vrijeme za aktivnosti i slično.“ (Europska komisija, Predstavništvo u Hrvatskoj, 2020a)

- „Cisco Internet of Everything (IoE) definira kao umreženu vezu ljudi, procesa, podataka i stvari. IoE stvara neviđene mogućnosti za organizacije, pojedince, zajednice i zemlje da shvate dramatično veću vrijednost umreženim vezama među ljudima, procesima, podacima i stvarima. Za usporedbu, ,internet stvari“ (IoT) odnosi se jednostavno na umreženu vezu fizičkih objekata (ne uključuje komponente ,ljudi““ i ,proces“ IoE-a). IoE nudi vladama priliku da naprave značajan napredak u pružanju usluga građanima. Kao velike organizacije, vladini odjeli i gradovi mogu izravno imati koristi od novih tehnologija koje transformiraju upravljanje lancem opskrbe i logistiku u privatnom sektoru. Slično tome, oni mogu graditi na potencijalu mobilne tehnologije za razvoj ,pametnog rada“ za svoje zaposlenike, što rezultira značajnom uštedom troškova. Strategije ,pametne gradnje" također mogu smanjiti troškove, istovremeno generirajući pozitivan utjecaj na okoliš. Neposredne IoE koristi pojavit će se u domeni statističkih usluga i dostupnosti podataka u gotovo stvarnom vremenu koji se odnose na različito ponašanje građana - njihovo mjesto, način na koji se roba prebacuje preko granica, potrošačke navike i njihove buduće namjere. Kada se primijene na velike populacije, Big Data i pridružena analitika sve će više omogućiti prediktivno modeliranje $i$, kao rezultat, poboljšanja javne infrastrukture. Te će mogućnosti također omogućiti bolje predviđanje novih trendova, kratkotrajne fluktuacije potražnje vođene vanjskim čimbenicima 
Jezične tehnologije (engl.

Language Technology) (poput vremenskih prilika ili javnih događaja) i bolje upravljanje hitnim reakcijama. U sigurnosti i sigurnosti, prediktivno modeliranje već se koristi za pomoć $\mathrm{u}$ raspoređivanju policijskih resursa radi veće učinkovitosti u borbi protiv kriminala.“ (Cisco, 2013)

- NLP tehnologije koje uključuju obradu prirodnoga jezika (engl. Natural language processing - NLP) i računalno jezikoslovlje te govorne tehnologije; sinonim: LT, HLT. (Mrežnik, 2020).

- Obrada prirodnog jezika (NLP) metoda je prevođenja između računala i ljudskog jezika. To je metoda pribavljanja računala razumljivom čitanju retka bez da se računalo unese u neku vrstu traga ili izračuna. Drugim riječima, NLP automatizira proces prevođenja između računala i ljudi. Nedavni napredak na ovom području uključuje softver za prepoznavanje glasa, prevođenje s ljudskog jezika, pronalaženje informacija i umjetnu inteligenciju. Postoje poteškoće u razvoju softvera za prevođenje s ljudskog jezika jer se jezik stalno mijenja. Također se razvija i obrada prirodnog jezika da bi se stvorio čitljiv čovjek i moglo bi se prevesti između jednog ljudskog jezika na drugog. Krajnji cilj NLP-a je izgraditi softver koji će prirodno analizirati, razumjeti i generirati ljudske jezike, omogućavajući komunikaciju s računalom kao da je ljudski. (Continuousdev, 2020)

- Izrazom „,mainstream media“ u engleskome se označuju masovni mediji koji odražavaju prevladavajuća mišljenja, utjecaje i aktivnosti nasuprot onim medijima koji su označeni izrazom alternative media i koji mogu uključivati sadržaj koji nije u skladu s prevladavajućim pogledima. Umjesto izraza mainstream mediji u hrvatskome je bolje upotrebljavati hrvatski izraz mediji glavne struje /prevladavajući mediji. (Bolje je hrvatski!, 2020b)

- Engleski rječnici nude detaljnije objašnjenje: široko rasprostranjeni način razmišljanja. Druga mogućnost - prevladavajući trend, glavni aspekt. Prema tome, značenje riječi „mainstream“ može se s određenom težinom reducirati na pojmove „tradicionalnog“, „opće prihvaćenog“ i ,ispravnog u masovnoj svijesti“. A za Amerikanca ili Europljana nema ničeg lošeg u tome što je dio mainstreama. U društvu koje je stabilno i relativno uspješno, „mainstream“ je nešto čemu se vrijedi pridržavati. Važno je napomenuti da glavna struja nije ideologija. Ona nastaje sama od sebe i nije nametnuta duhovnim ili svjetovnim vlastima. U početku se taj koncept koristio u odnosu na kulturu i umjetnost, a kasnije prešao u politiku, znanost i ekonomiju. (Punto marinero, 2019)

- Moderator je komunikacije između članova zajednice okupljenih na različitim društveno-mrežnim odredištima koje povezuje neki zajednički interes. Tu zajednicu mora dobro poznavati i s njom živjeti, znati kako na što reagira, kada je aktivna a kada spava. Njegov je zadatak tražiti i producirati sadržaj koji će joj biti interesantan, koristan i zanimljiv, dovoljno vrijedan da ga nagradi svojom pažnjom, likeom ili komentarom. Samo kvalitetan i relevantan sadržaj može biti ono što će povezati tu zajednicu. U konstantnoj je komunikaciji s klijentom i upoznat je s njegovom domenom poslovanja, tržištem, trendovima, konkurencijom. Njegov je posao zastupati brend na društvenim mrežama i biti online ambasador njegova imidža, a tu zadaću može kvalitetno obavljati samo ako vlada materijom, bilo da je riječ o telekomunikacijama, turističkoj destinaciji ili glazbi. Za svoje je korisnike dostupan stalno, u svako doba dana. Prati ponašanje i navike svojih korisnika, pri čemu bitnu ulogu ima metrika društvenih mreža. Statistika, izrada izvještaja, prikaza rezultata i praćenje aktivnosti na društvenim mrežama važan je aspekt ovog posla i rezultira vrijednim pokazateljima prilikom planiranja budućih aktivnosti, ne samo na društvenim mrežama, već i od strane klijenta. Prezentacija pravih podataka na pravi način za klijenta može biti ključna za njegovo poslovanje. Puno vremena ulaže u edukaciju i praćenje svih novosti u svijetu društvenih mreža, tehnologije i trendova $u$ industriji. Pristup strategiji nastupa na društvenim mrežama uvijek mora biti proaktivan, pri čemu veliku ulogu ima kreativnost. Vješto barata riječima. Složiti Facebook status ili tvit od 140 znakova zahtijeva puno više truda i promišljanja nego što bi se na prvi pogled moglo učiniti. On ponekad mora biti kratak i jasan, ponekad opširan, ponekad ozbiljan, ponekad duhovit, a nerijetko zanimljivošću prikriveno promotivan. Budući da je format ograničen, ovdje je zaista bitna svaka riječ 
odnosno znak, a na koncu, sve to pada u vodu bez dobrog poznavanja gramatike i pravopisa. (Jasno\&Glasno tim, 2013)

- Neuralne mreže nova su generacija sustava za informacijske analize (obradu), a karakterizira ih mogućnost učenja, pamćenja i generaliziranja na osnovi prethodno pripremljenih baza podataka kojima se treniraju. NN u okvirima umjetne inteligencije i primijenjenoga matematičkog modeliranja imaju sličnu strukturu kao i biološki neuronski sustavi, ali u znatno pojednostavljenom obliku. (Vouk i sur., 2011)

- Po strukturi, funkciji i obradi informacija uređena je po uzoru na ljudski mozak; NN „uče“ preko primjera (kao što djeca uče prepoznati konkretan predmet, objekt, proces ili pojavu preko odgovarajućih primjera) i posjeduju sposobnost za generalizaciju poslije tzv. uvježbavanja kroz niz ponavljajućih postupaka analize. Od cijeloga skupa podataka veći dio upotrijebljen je za učenje, a manji za ponovno predviđanje poznatih vrijednosti. Tako je moguće izračunati pogrješku predviđanja, koja bi $\mathrm{s}$ većim brojem pokušaja trebala biti manja. Takav postupak ,učenja” nalik je na ljudsko učenje iz iskustva pa odatle i naziv „neuronske mreže”. NM omogućavaju evolutivni razvoj softvera, tj. NN mreža se može naknadno adaptirati realnim i novonastalim uvjetima. NN imaju sposobnost da mijenjaju svoju strukturu i funkciju, za razliku od klasičnih algoritama koji nemaju toliku fleksibilnost. Primjenjuju se primjerice za prepoznavanje oblika, prepoznavanje rukopisa, prepoznavanje glasa i govora, financijske i ekonomske modele, predviđanje kretanja cijena na tržištu, upravljanje sustavima, upravljanje proizvodnim procesima, analizu električnih automobila, psihijatrijske procjene, sažimanje podataka, naftna istraživanja, kriminalistička istraživanja, analizu medicinskih testova, pronalaženje optimalnih rješenja, upravljanje robotima, vremensku prognozu i dr. (Ilić, 1999)

- Riječ webinar nastala je od riječi seminar, samo što je ovdje riječ o online obliku, tj. formi temeljenoj na prezentaciji putem interneta. Najčešće je snimljen unaprijed, a onda se prikazuje određenoj ciljnoj skupini da je upozna s problemima, informacijama, predavanjima ili prezentacijom određenog proizvoda ili usluge. Osim što može biti snimljen unaprijed (što je najčešće forma), može se održavati i uživo pa autori s članovima mogu voditi razgovor. Sa sudionicima webinara autori mogu podijeliti videozapise, audiozapise, fotografije ili bilo koje dokumente. Unaprijed se odredi točan datum i vrijeme početka webinara, a sudionici se najčešće ulogiraju u okviru određenog sistema. Također, webinari najčešće nisu dugački i preopširni jer takva izlaganja umaraju sudionike pa brže izgube koncentraciju. (Žena.hr, 2020)

- Podatkovna znanost je interdisciplinarno područje čiji je glavni zadatak ekstrakcija informacija i znanja iz podataka bilo da oni dolaze u strukturiranom ili možda nestrukturiranom obliku. Radi se o području koje obuhvaća tehnologiju velikih podataka, strojno učenje, vizualizaciju podataka te sve što je vezano uz izvlačenje znanja iz podataka (statistika, računalne znanosti...). (Data Science Croatia, 2020)

- Znanost o podacima je proučavanje uopćenog izdvajanja znanja iz podataka. Uobičajeni epistemiološki zahtjev za procjenu je li novo znanje djelotvorno za donošenje odluka jest njegova moć predviđanja, a ne samo sposobnost objašnjavanja prošlosti. Podatkovni znanstvenik treba posjedovati integrirani skup vještina koji obuhvaća matematiku, strojno učenje, umjetnu inteligenciju, statistiku, baze podataka i optimizaciju, zajedno s dubokim razumijevanjem zanata formuliranja problema kako bi stvorio učinkovita rješenja. (Dahr, 2013)

- Koristi se primjerice za prepoznavanje i predviđanje bolesti, prilagođene zdravstvene preporuke, optimizaciju putnih pravaca u stvarnom vremenu, izvlačenje najveće vrijednosti iz nogometnih postava, pronalaženje sportaša svjetske klase, ukidanje porezne prijevare, automatizaciju postavljanja digitalnih oglasa, kao algoritmi koji pomažu ljudima pronaći ljubav, predviđanje stope prijestupa i dr. (Rice, 2020)

- Mješovita stvarnost (MR) je istodobna upotreba tehnologija virtualne stvarnosti (VR) i proširene stvarnosti (AR) za stvaranje okruženja u kojem fizički i virtualni objekti mogu postojati i komunicirati u stvarnom vremenu. MR prekriva slike ili videozapise preko zaslona koji prikazuje stvarnost putem mobilne kamere, pametnih naočala ili slušalica. Sposobnost 
Poslovna inteligencija (engl. Business Intelligence - BI)

interakcije $\mathrm{s}$ fizičkim i virtualnim objektima daje tehnologijama miješane stvarnosti ogroman broj potencijalnih aplikacija. Primjerice mogu se koristiti u obrazovanju, pa su tako studenti Sveučilišta Case Western Reserve u Ohiju uspjeli iskoristiti uređaj Microsoft HoloLens 2 kako bi naučili anatomiju. Ovaj je uređaj također omogućio profesorima da podučavaju i komuniciraju sa studentima unatoč udaljenosti stotinama kilometara. Koristeći 3D projekcije i simulacije, studenti mogu komunicirati s virtualnim objektima i manipulirati njima kako bi ih proučavali na način koji je relevantan za njih same i njihove studije. Umetanjem trodimenzionalnih predmeta u učionicu kao sredstva za mjerenje veličine, oblika ili drugih značajki definiranog ,virtualnog“ objekta, studenti mogu steći dublji osjećaj razumijevanja onoga što proučavaju. (Lanner, 2019)

- BI je pojam koji uključuje strategije, procese, aplikacije, podatke, proizvode, tehnologije i tehničke arhitekture koji se koriste kao podrška prikupljanju, analizi, prezentaciji i širenju poslovnih informacija. (Dedić, Stanier, 2017)

- Razmatrana s makroaspekta poslovna je inteligencija složena, agregirana kategorija koja se stvara sustavnim ili unaprijed neciljanim prikupljanjem podataka o makroekonomskim kretanjima u određenoj geopolitičkoj sredini, njihovim pohranjivanjem, pretraživanjem, te logičkom i/ili računskom obradom poradi otkrivanja makroekonomskih trendova ili tendencija i predviđanja procesa u makroekonomskim sustavima. Organizacije koje tako shvaćaju poslovnu inteligenciju orijentirat će se prvenstveno okruženju u kojemu djeluju i u njemu tražiti izvore podataka iz kojih će graditi nova saznanja te izvoditi određene zaključke. Drugi kut promatranja fenomena poslovne inteligencije je kroz fokus mikroaspekta. Tada je riječ o otkrivanju prikrivenih znanja iz poslovnih podataka koje neka organizacija prikuplja rutinski, obavljajući svoje svakodnevne poslovne transakcije. Izvori podataka potrebnih za izvođenje tako shvaćene poslovne inteligencije pretežito su unutar same organizacije, a valja ih, dakako, svrhovito pohranjivati, pomno održavati i sustavno obrađivati. Uvjet za uspješno izvođenje novih ili prikrivenih znanja iz rutinski prikupljanih poslovnih podataka jest primjena informacijske $i$, posebice, internetske tehnologije uz uporabu odgovarajućih logičko/računskih metoda i softverskih alata. (Gotal 2006 prema Panian, Klepac, 2003)

- Primjena poslovne inteligencije poželjna je radi unapređenja poslovanja.

- Engleska sveza „, user friendly“ sastoji se od imenice „user“, koja znači korisnik, i pridjeva „friendly“, koji znači prijateljski, skon, blagonaklon, dobrohotan, srdačan. Ako za neki program kažemo da je „user friendly“, to znači da je prilagođen korisnicima, odnosno jednostavan za korištenje. Zato je u hrvatskome standardnom jeziku bolje umjesto engleske sveze ,user friendly" $\mathrm{i}$ doslovnoga prijevoda prijateljski prema korisnicima upotrijebiti svezu prilagođen korisnicima. (Bolje je hrvatski!, 2020c)

Prilagođen korisnicima (engl. User Friendly)

- „AR tehnologija omogućuje ljudima da putem aplikacije kroz zaslon nekog uređaja, najčešće mobilnog telefona, vide elemente koji ne postoje $u$ stvarnom životu. Ti elementi proširuju stvarnost oko nas, ali samo ako je gledamo kroz zaslon. Aplikacija omogućuje gledanje bez mogućnosti mijenjanja elemenata koji se vide, tj. bez mogućnosti ikakve interakcije s njima. Osim mobilnog uređaja, postoje i AR naočale, kroz čije leće ljudi vide stvarnost oko sebe, ali i dodatne elemente kojima se dopunjuje slika. Google i društvena mreža Snapchat razvili su jedne od prvih takvih naočala, no ta digitalna inovacija nije doživjela široku primjenu." (Europska komisija, Predstavništvo u Hrvatskoj, 2020a)

Proširena stvarnost (engl. Augmented Reality - AR)
- Proširena stvarnost (AR) je živi, izravan ili neizravni prikaz fizičkog okruženja u stvarnom svijetu čiji se elementi dopunjuju (ili nadopunjuju) računalno generiranim senzornim ulazom poput zvuka, video zapisa, grafike ili GPS podataka. Iako proširena stvarnost prekriva sadržaj stvarnog svijeta, taj sadržaj nije dio njega. Sadržaj iz stvarnog svijeta i računalno generirani sadržaj nisu u mogućnosti reagirati jedni na druge. Primjerice IKEA je razvila stol kao dio svoje konceptne kuhinje koja predlaže recepte na temelju sastojaka na stolu, što je odličan primjer AR-a koji potencijalno radi u stvarnom svijetu. (Foundry, 2020)

- Koristi se primjerice za medicinske vježbe, u maloprodaji kako bi kupci „vidjeli““ proizvode, za popravak i održavanje složene opreme (AR naočale predlažu potencijalne popravke i ukazuju na problematična područja), 
Računarstvo u oblaku (engl. Cloud Computing)

profesionalcima (arhitektima, inženjerima i dizajnerima za dizajn i modeliranje odnosno da vizualiziraju svoje konačne proizvode tijekom kreativnog procesa, za poslovnu logistiku tj. povećanje učinkovitosti i uštedu troškova kroz primjerice prijevoz, skladištenje i optimizaciju rute, $u$ turističkoj industriji kako bi putnicima pružili dublje iskustvo prije putovanja npr. kroz AR naočale kroz virtualnu šetnju mjestom, muzejima, kafićima koje žele posjetiti, za obrazovanje pa bi tako studenti astronomije mogli vidjeti potpunu mapu Sunčevog sustava ili bi studenti glazbe mogli vidjeti note u stvarnom vremenu dok uče svirati na instrumentu, za zabavu (primjerice senzacija Pokemon Go) i sl. (Paine, 2020)

- „Cloud computing je revolucionarni koncept koji nudi novi način pristupa osobnim podacima i aplikacijama, koji više nisu smješteni na računalu već u "oblaku" - što znači da programu, evidencijama i dokumentaciji možete pristupiti s većeg broja uređaja, u bilo koje vrijeme i s različitih lokacija. Sve što je potrebno je internet veza. Kao rezultat toga korisnici usluga $u$ „oblaku“ mogu bolje, brže i jednostavnije koristiti i mijenjati podatke. Prednosti korištenja usluga u oblaku su: Centralizacija-podaci su centralizirani i pohranjeni na jednom mjestu gdje su stalno dostupni, što korisniku omogućava mobilnost. Stalna dostupnost - do servisa i usluge pristupa se s različitih lokacija kada postoji internet veza (a ona je danas dostupna skoro svugdje). Model najma usluge - Za usluge u „oblaku“ ne treba ulagati u skupu informatičku infrastrukturu, obučavati i zapošljavati kadrove za održavanje usluga. Cloud servisi se koriste samo kada ih trebate, a o administraciji, podršci i razvoju poslovnih aplikaciju brigu vode davatelji usluge (kao što je Webit). U uslugu su uključene nadgradnje, svi sigurnosni mehanizmi, arhiviranje, kolokacije podataka, podrška korisnika, dr. Kontroliran korisnički pristup - korisničkom administracijom lako je ograničiti pristupe korisnicima (primjerice interno u prostorijama poduzeća, pogled na dio podataka), kao i mogućnosti izmjene, brisanja ili izvoza podataka. Sigurnost podataka - kod korištenja programskih usluga u „oblaku“ mogućnost gubitka podataka jako je mala - ako davatelj usluge koristi paletu sigurnosnih mehanizama (primjer kolokacije - podaci na više mjesta), dnevne sigurnosne kopije podataka i sl., rizik praktično ne postoji.“ (Sinarm Software, 2020)

- Riječ se developer sve češće i u engleskome i u hrvatskome upotrebljava u značenju osobe koja razvija i oblikuje računalne sustave, razvija i održava mrežne stranice, razvija nove igre itd. (Bolje je hrvatski!, 2020a)

- Developeri su uglavnom stvaratelji. Međutim, ne može svaki stručnjak za pisanje kodova biti developer. Developeri su stručnjaci za identificiranje načina rješavanja različitih problema, kao i za povezivanje komponenata kako bi ispunili neke zahtjeve. Ovi profesionalci rješavaju probleme

Razvojni inženjer (engl. Developer) poštujući određeni skup principa (dizajn i implementacija). (Telegraf, 2018).

- U ljudskim resursima, se zbog današnje tehnologije, digitalizacije i doba interneta, developere $\mathrm{i}$ informatičare obzirom na potražnju, smatra zvijezdama u regrutiranju. Posao developera zahtjeva posebne vještine i dobro razumijevanje svijeta kodova i algoritma. (Adorio, 2020)

- Robotika je interdisciplinarno znanstveno područje koje se bavi projektiranjem, konstruiranjem, upravljanjem i primjenom robota. Zasniva se na mehatronici, te objedinjuje niz znanstvenih područja i disciplina, poput strojarstva, elektrotehnike, elektronike, automatike, računarstva i umjetne inteligencije. Roboti, automatizirani strojevi višestruke namjene koji se sastoje od konstrukcije s pripadajućim pogonskim uređajima, senzora i upravljačkog uređaja, dijele se po stupnju pokretljivosti (statički i mobilni roboti), strukturi konstrukcije (mehatronički, biotronički i bioroboti), namjeni (industrijski, medicinski, edukacijski, podvodni, roboti za

Robotika (engl. Robotics) istraživanje svemira, vojni roboti, osobni roboti), veličini (makroroboti, mikroroboti i nanoroboti). Inteligentni roboti posjeduju sposobnost učenja, rasuđivanja i donošenja zaključaka te imaju visok stupanj funkcionalne, organizacijske i mobilne autonomnosti. Roboti te skupine razvijaju se ubrzano, usporedno s razvojem naprednih informacijskih tehnologija $\mathrm{i}$ umjetne inteligencije. Očekuje se kako će se inteligencija robota općenito, a posebice biorobota ostvarenih genetičkim inženjerstvom, približavati inteligenciji čovjeka. Danas se najviše primjenjuju industrijski roboti, npr. u automobilskoj industriji za sastavljanje dijelova vozila, bojenje ili 
zavarivanje karoserije i dr. Roboti se osobito rabe u okruženju opasnom za čovjeka (podvodni roboti, svemirske robotske letjelice, roboti za razminiranje i dr.), kao sredstva unutarnjeg transporta, ali i za zabavu, natjecanja te kao dječje igračke. Posebni se napori ulažu u razvoj čovjekolikoga robota, kakvog je npr. Banka Tokyo-Mitsubishi u poslovnici u Tokiju predstavila za rad na recepciji. (Novaković, 2018)

- Proces otkrivanja obrazaca u velikim skupovima podataka koji uključuju metode na sjecištu strojnog učenja, statistike i baza podataka (Chakrabarti i sur., 2006).

Rudarenje (pretraživanje) podataka ili podatkovno rudarenje (engl. Data Mining $D M)$

Strojno učenje (engl. Machine Learning - $M L$ )

- Strojno učenje i rudarenje podataka često koriste iste metode i značajno se preklapaju, ali dok se strojno učenje usredotočuje na predviđanje, na temelju poznatih svojstava naučenih iz podataka obuke, rudarenje podataka usredotočuje se na otkrivanje (ranije) nepoznatih svojstava u podacima (ovo je korak analize otkrivanja znanja u bazama podataka). U strojnom učenju izvedba se obično procjenjuje s obzirom na sposobnost reproduciranja poznatog znanja, dok je u rudarenju (pretraživanju) podataka ključni zadatak otkrivanje ranije nepoznatog znanja. (School for Analytics, 2020)

- Strojno učenje ili automatizirano prikupljanje znanja (Dalbelo Bašić, 2020), kao podskup umjetne inteligencije, interdisciplinarno je područje koje koristi statističke tehnike kako bi računalnim sustavima dalo mogućnost da „uče“ (npr. postupno poboljšavaju izvedbu određenog zadatka) iz podataka, a da nisu izričito programirani. (School for Analytics, 2020)

- Aplikacije se kreću od programa za miniranje podataka koji otkrivaju opća pravila u velikim skupovima podataka, do sustava za filtriranje informacija koji automatski uče interese korisnika. (Mitchell, 1997)

- Razvoj umjetne inteligencije kreće od tradicionalne sheme programa koji se temeljio na algoritmima i podacima, do nove sheme u kojem je ekspertno područno znanje temeljni oslonac u rješavanju problema, te se programi temelje na algoritmima, podacima plus znanju. Koristi se za potrebe (medicinske) dijagnostike, analize rizika (kod primjerice dodjele kredita), predviđanja, prevencije, upravljanja vozilima putem računala, npr. NASA je koristila stabla odluke za klasifikaciju nebeskih objekata (Weir, Fayyad, Djorgovski, 1995), implementaciju igara na računalu, raspoznavanje rukom pisanoga teksta i/ili znakova, klasifikaciju uzoraka, modeliranje sustava (pohranu mogućih uzoraka u memoriji, odnosno metoda strojnog učenja primjenjuje se za rješavanje složenih problema svih područja ljudske djelatnosti. (Dalbelo Bašić, 2020)

- Pod pojmom „networking“ se kod nas u široj javnosti često podrazumijevaju veze i poznanstva. U najboljem slučaju pod networkingom se smatra stisak ruke, „uvaljivanje“ posjetnice, ispijanje koktela, poslovni ručak... Kao i svako ulaganje u sebe, tako i networking zahtijeva jako puno vremena i truda. Većina počne ulagati u takve odnose tek kad traži posao ili treba uslugu. Zapravo bi na svojoj vidljivosti trebalo konstantno raditi pa kad takve stvari i zatrebaju već imamo izgrađene odnose i dio smo neke zajednice. Stvaranje velike socijalne mreže zapravo je dugotrajan proces i nije nešto što je moguće postići preko noći. Kvalitetu našeg studija možemo mjeriti i s ostvarenim odnosima s vodećim profesionalcima iz naše struke. (Mreža za izgradnju mira, 2020)

Širenje mreže poznanstva (engl. Networking)
- Networking je širenje mreže poznanstava, razvijanje odnosa koji obostrano donose korist. Osim širenja kruga poznanika, otvara se prostor za nove suradnje i nove mogućnosti: podjela znanja - uvijek postoji više nego jedan način za postizanje nekog cilja: podjelom znanja i iskustava šire se saznanja; mogućnosti - networking uvijek rezultira stvaranjem novih mogućnosti; povezivanje - osobe koje stalno razvijaju svoju društvenu mrežu sasvim sigurno mogu i puno bolje pomoći svojim prijateljima, networking zahtijeva proaktivan pristup; promocija - od blogova, preko Facebook statusa, pa i svakodnevnih kontakata s apsolutno nepoznatim ljudima - ostavljamo dojam. Važno je biti svjestan kakav. Networking definitivno pruža mogućnost da se jasno pokažu sve svoje kvalitete i snage. Prednosti su mnoge, da ne zaboravimo najvažniju: svi prekrasni ljude koji se upoznaju, možda i postanu prijatelji. (Moj Posao, 2011)

„Kriptovaluta je digitalni novac, kreiran u digitalnom obliku kao sredstvo digitalne razmjene. Postoje samo na internetu i nije ih izdala, niti ih nadzire središnja banka ili država. Upravo zato što ih ne nadzire središnja banka, formalno nisu novac. Kao što imate svoj novac na računu u banci, tako i 
svoje kriptovalute imate $\mathrm{u}$ svom digitalnom novčaniku na nekoj od internetskih stranica koje pružaju tu uslugu. Svaka transakcija koju napravite je vrlo uređeni digitalni zapis, odnosno datoteka koja se sastoji od količine prenesenih jedinica kriptovalute i određenih javnih i tajnih ključeva adresa digitalnih novčanika pošiljatelja i primatelja." (Europska komisija, Predstavništvo u Hrvatskoj, 2020d)

- „Blockchain' je glavna ili javna 'knjiga' u koju se zapisuju sve ovakve transakcije i vrijednosne izmjene jedinica kriptovaluta. Svaki se zapis temelji na složenoj matematičkoj kriptografiji i zapisuje se u slijedu, jedan blok šifri iza drugoga te tako stvaraju lanac blokova. Stoga nije moguće promijeniti podatke $\mathrm{u}$ lancu jer se pritom uzurpira stanje blokova podataka koji se na njemu nalaze. Blockchain se ne nalazi na jednom mjestu. Svatko tko posjeduje jedinicu neke kriptovalute ima i svoj primjerak blockchain knjige koji se sinkronizira među svim računalima u mreži.“ (Europska komisija, Predstavništvo u Hrvatskoj, 2020d)

- ,'Rudarenje' je proces potvrđivanja i dodavanja novih transakcija u 'blockchain'. Cijeli 'blockchain' sustav čine računala povezana u mrežu koja potvrđuju/verificiraju određene transakcije. 'Rudari' su osobe (ponekad i skup ljudi ili poslovni entiteti) koje dobrovoljno ustupaju svoja računala $i$ računalnu obradu svojih podataka 'digitalnog novčanika' kako bi se potvrdio skup transakcija provedenih $\mathrm{u}$ knjizi platnog prometa, odnosno 'blockchainu'. Za nagradu dobivaju određenu količinu jedinica kriptovalute. Bez rudara, 'blockchain' sustav ne bi lako funkcionirao." (Europska komisija, Predstavništvo u Hrvatskoj, 2020d)

Tehnologija velikih podataka (engl. Big Data - BD)

Umjetna inteligencija (engl. Artificial Intelligence - AI)

- „Big data je tehnologija prikupljanja, obrade i analize velikih količina podataka. Podaci mogu biti raznoliki, strukturirani i nestrukturirani, generiraju se i pristižu velikom brzinom i to u različitim intervalima (ponekad i u realnom vremenu), što ih čini vrlo složenima za analizu. Upravo je mogućnost obrade i analiza tih prikupljenih podataka za daljnju upotrebu ono što ovu tehnologiju čini vrlo vrijednom. Bez mogućnosti analize i potrebnih alata (složenih računalnih programa), bila bi to samo gomila prikupljenih podataka. Podaci koji se prikupljaju dolaze iz različitih uređaja ili sustava koje koristimo. Neki od njih su naši pametni telefoni, pametne narukvice ili satovi, pametni hladnjaci, bankomati i slično. Upravo takvi pametni uređaji omogućuju prikupljanje podataka, podaci se tada šalju na obradu i analizu te potom vraćaju natrag u obliku koji razumijemo i možemo upotrijebiti. Pa nam, primjerice, fitnes narukvica pokazuje količinu kalorija koje smo potrošili vježbanjem, hladnjak aplikacijom 'javlja' što sve trebate kupiti, a bankomat obavještava o stanju računa."(Europska komisija, Predstavništvo u Hrvatskoj, 2020a)

- „Umjetna inteligencija definira se kao područje računalne znanosti koje se bavi razvojem inteligentnih alata (strojeva, aparata, aplikacija) koje reagiraju i uče kao ljudi. U ovo područje ulaze i pojmovi poput „strojno učenje“ (engl. Machine Learning) i ,internet stvari“ (kratica IOT, engl. Internet of Things). Tehnološki dizajn AI sustava, među ostalim, uključuje razumijevanje i analizu jezika, govora, slike, prema čemu sustav uči kako reagirati, planirati ili rješavati određene zadatke. To znači pomoć u određenim radnjama. Kao što su nam dolaskom računala olakšani složeni matematički izračuni, pisanje dokumenata ili stvaranje umjetnosti, tako nam je dolaskom AI sustava olakšano pospremanje (mali robot usisavač), komunikacija (različiti virtualni asistenti na pametnim telefonima) ili briga o zdravlju (fitness narukvice). To su tek najosnovniji primjeri onoga što AI uistinu može učiniti za nas." (Europska komisija, Predstavništvo u Hrvatskoj, 2020a)

- „Za razliku od proširene stvarnosti (AR), za VR tehnologiju potrebno je koristiti naočale kroz koje ne vidite ništa oko sebe, već samo virtualno stvoreni svijet. U tom trenutku taj svijet koji gledate postaje vaša virtualna stvarnost, u kojoj interakcija s elementima koje vidite u aplikaciji nije

Virtualna stvarnost (engl. Virtual Reality - VR) moguća ili je pak moguća tek u minimalnoj mjeri - možete, primjerice, otvarati vrata, pomicati predmete, uvećavati prikaz i slično. Postoje VR sustavi koji su prilično jednostavni pa vam treba samo kartonski okvir u koji umetnete mobilni telefon na kojem pokrećete VR aplikaciju, dok drugi imaju nešto sofisticiranije dodatke koji vam omogućuju da dublje „uronite“ u novi svijet, pri čemu se koriste rukavice, slušalice ili neki drugi elementi, 
a moguće je čak i kretanje unutar 3D prostora." (Europska komisija, Predstavništvo u Hrvatskoj, 2020a)

- Može se koristiti za vojne treninge kroz široki spektar simulacija, kao što su simulacija leta, simulacija borbe, medicinska vježba, simulacija vožnje, za treninge u sportu, za liječenje post-traumatskog stresa, anksioznosti, fobija i depresija kroz stvaranje sigurnog okruženja za pacijente, za vježbu operacija i procedura u medicini, za učenje kroz trodimenzionalno okruženje, za virtualne izlete muzejima, u različita vremenska razdoblja, za modu kroz virtualna 360-stupnjeva iskustva u kojima kupci mogu virtualno isprobati odjeću (FDM, 2020), virtualne igre i sl., a koristeći se pritom audio, video ili pak haptičkom tehnologijom koja kroz mehaničku simulaciju oponaša osjećaj dodira kroz primjenu vibracije, snage i pokreta kod korisnika (Jokić, 2017).

- Virtualni avatar je grafička slika koja predstavlja osobu u virtualnom svijetu i sve je češća upotreba mrežnih avatara za stvaranje stvarnih situacija na poslovnim sastancima, sajmovima ili bilo kojoj vrsti događaja. U stvarnosti je naš alter ego na mreži; naš vlastiti odraz iza zaslona. Avatar je prikaz nas u 3D-u, na originalan i jedinstven način, s obzirom na to da ne postoje dva ista avatara, bilo da je to izgled, pomicanje ili interakcija unutar virtualnog svijeta. Načini na koje mogu komunicirati su beskrajni, a s obzirom na brzinu tehnološkog napretka, avatari će postati sve više i više nalik životu. Kako bi išli u korak s vremenima koja su se razvijala, digitalni profesionalci visoko cijene avatare koji neprestano preporučuju njihovu primjenu u raznim poslovnim akcijama. Primjerice, 3D avatari simuliraju svakog sudionika - čak i oponašaju njihov fizički izgled - i dopuštaju im da stvore scenarij u kojem mogu komunicirati na vrlo učinkovit način. Pa će tako sugovornici moći razmjenjivati bilo kakve informacije u različitim formatima, voditi razgovore uživo, pa čak i izražavati svoje osjećaje putem animacija (poput pljeska, mahanja ili čak palca gore, povezati se s kolegama iz iste tvrtke koji rade $\mathrm{s}$ različitih lokacija. Pokreti lica i tijela interaktivnih 3D avatara su prirodni, a kad ih prati integracija 3D tehnologija, virtualni alter ego ljudi oživljava. (McConnell, 2019)

- „Današnja tehnologija u djeliću sekunde šalje i prima podatke između pametnih uređaja i internetske mreže. Tako svakim dodirom zaslona pametni uređaj šalje čak desetke informacija u internetsku mrežu, a kod 5G tehnologije vrijeme odaziva je gotovo trenutno. Nova $5 \mathrm{G}$ mreža bit će brža za čak tisuću puta od $4 \mathrm{G}$ mreže. Imat će veću efikasnost uređaja, veću pouzdanost mreže te mogućnost spajanja do milijun uređaja na kvadratnom kilometru. Jednostavnije rečeno, ima vrlo brzi internet i stabilnu vezu bez pucanja. Smanjit će se kašnjenje signala, čime će se poboljšati i način gledanja prijenosa uživo. Upotrebom $5 \mathrm{G}$ mreže razvijat će se umjetna inteligencija te se otvara mogućnost njezine široke primjene u industriji, poljoprivredi, obrazovanju, zdravstvu, a gradit će se i pametna gradska infrastruktura, unaprjeđujući tako način funkcioniranja javnih službi.

$5 \mathrm{G}$ tehnologija Primjerice, policajci će nakon prometne nesreće biti brže obaviješteni o samom događaju, a semafori će se automatski prilagođavati stanju na prometnicama, vozila će moći komunicirati između sebe i razmjenjivati podatke, primjerice o stanju u prometu, a i s okolinom; za koliko će se sekundi promijeniti svjetlo na semaforu, što će vozaču omogućiti bolju reakciju i doprinijeti sigurnijoj vožnji. Razvojem $5 \mathrm{G}$ mreže unaprijedit će se medicina, koja će kirurzima omogućiti pružanje pomoći kolegama u operacijskim salama u stvarnom vremenu, a bit će moguće i izvođenje operacija na daljinu preko robotiziranih ruku. 5G mreža će omogućavati rad pametnih kućanskih uređaja, umreženih AI uređaja (uređaji koji koriste tehnologiju umjetne inteligencije), a mogla bi i u potpunosti promijeniti način na koji učimo i prenosimo znanja i vještine." (Europska komisija, Predstavništvo u Hrvatskoj, 2020c)

- „Južnokorejski tehnološki gigant Samsung iznio je svoju procjenu vremena otkrivanja $6 \mathrm{G}$ tehnologije, predviđajući da će se standard početi pojavljivati već 2028. godine, a masovna komercijalizacija trebala bi početi na početku idućeg desetljeća ili 2030. godine. Ta će tehnologija implementirati postojeću mogućnost "interneta stvari”, predviđenu za 5G, na sve postojeće uređaje: od autonomnih vozila do robotiziranih kućanskih uređaja koji će biti spojeni na internet koji će tada dosegnuti novu razinu, što će donijeti mogućnosti "hiper-povezivanja na internet u svaki kutak čovječanstva". 
Samsungova 6G vizija naglašava brojne futurističke koncepte, od široke uporabe internetskog povezivanja pomoću strojeva i umjetne inteligencije, do mogućnosti prikazivanja volumetrijskih holograma veličine čovjeka, pri trenutačno nespojivim brzinama.“ (Logično, 2020)

\section{A. Razvoj tehnologija koje pokreću društvene medije u idućih 5 godina}

Sljedeća tablica (Tablica 20.) prikazuje odgovore panelista delfi stručne skupine u svezi s budućim razvojem tehnologija koje pokreću društvene medije u idućih 5 godina. Ukupni broj panelista koji su odgovarali na ovo pitanje je $\mathrm{N}=37$, od čega je 3 panelista $(8,1 \%)$ navelo je da ne očekuje veće pomake, ništa novo ni bitno, stoga su u Tablici 20. prikazani odgovori ostalih panelista $\mathrm{N}=34(91,9 \%)$, ukupna frekvencija odgovora bila je 90.

Tablica 20. Rezultati 1. kruga delfi studije: Razvoj tehnologija koje pokreću društvene medije u idućih 5 godina, N=34 (izvor: upitnik, Google obrasci, obrada autorice)

\begin{tabular}{|c|c|c|c|}
\hline \multirow[t]{2}{*}{ Koncepti } & \multicolumn{2}{|c|}{$\begin{array}{c}\text { Frekvencija } \\
\text { odgovora }\end{array}$} & \multirow[t]{2}{*}{ Kategorije } \\
\hline & & & \\
\hline Više automatizacije poslova i procesa & 2 & 2,22 & \multirow{3}{*}{ Digitalna transformacija društva. } \\
\hline Veća dostupnost & 1 & 1,11 & \\
\hline Uvođenje 5G mreže & 1 & 1,11 & \\
\hline $\begin{array}{l}\text { Razvoj različitih formata društvenih } \\
\text { medija }\end{array}$ & 6 & 6,66 & \multirow{7}{*}{ Masovnije korištenje tehnologije, alata i aplikacija } \\
\hline $\begin{array}{l}\text { Predikcije i analize temeljene na } \\
\text { tehnologiji velikih podataka - BD }\end{array}$ & 3 & 3,33 & \\
\hline $\begin{array}{l}\text { Nastavak pretraživanja (rudarenja) } \\
\text { podataka - DM u razne svrhe }\end{array}$ & 2 & 2,22 & \\
\hline $\begin{array}{l}\text { Veće uključivanje podatkovne } \\
\text { znanosti }\end{array}$ & 2 & 2,22 & \\
\hline $\begin{array}{l}\text { Više specijaliziranih društvenih } \\
\text { medija }\end{array}$ & 2 & 2,22 & \\
\hline $\begin{array}{l}\text { Korištenje društvenih medija za } \\
\text { prikupljanje podataka - BD }\end{array}$ & 1 & 1,11 & \\
\hline $\begin{array}{l}\text { Razvoj društvenih medija za treniranje } \\
\text { modela korištenih u umjetnoj } \\
\text { inteligenciji - AI }\end{array}$ & 1 & 1,11 & \\
\hline Više umjetne inteligencije - AI & 9 & 10 & \multirow{4}{*}{$\begin{array}{l}\text { Više mogućnosti, personalizacija aplikacija i } \\
\text { sadržaja. }\end{array}$} \\
\hline $\begin{array}{l}\text { Više visoko individualiziranih usluga } \\
\text { (internet stvari - IoT) }\end{array}$ & 5 & 5,55 & \\
\hline Povećanje video sadržaja & 4 & 4,44 & \\
\hline $\begin{array}{l}\text { Veća implementacija proširene } \\
\text { realnosti - AR }\end{array}$ & 3 & 3,33 & \\
\hline
\end{tabular}




\begin{tabular}{|c|c|c|c|}
\hline $\begin{array}{l}\text { Strojno učenje - ML koje eliminira } \\
\text { rutinske operacije }\end{array}$ & 3 & 3,33 & \\
\hline $\begin{array}{l}\text { Veća implementacija virtualne } \\
\text { realnosti - VR }\end{array}$ & 3 & 3,33 & \\
\hline Kreiranje virtualnih avatara & 1 & 1,11 & \\
\hline Napredan razvoj robotike & 1 & 1,11 & \\
\hline Razvoj foto opreme & 1 & 1,11 & \\
\hline Veće korištenje interneta svega - IoE & 1 & 1,11 & \\
\hline $\begin{array}{l}\text { Veća implementacija pomiješane } \\
\text { realnosti - MR }\end{array}$ & 1 & 1,11 & \\
\hline $\begin{array}{l}\text { Završetak treninga neuralnih mreža - } \\
\text { ANN }\end{array}$ & 1 & 1,11 & \\
\hline Veća interaktivnost & 3 & 3,33 & \multirow{3}{*}{ Veća interaktivnost. } \\
\hline Bolje korisničko iskustvo & 2 & 2,22 & \\
\hline Više kreativnih mogućnosti & 2 & 2,22 & \\
\hline Unaprjeđena sigurnost & 5 & 5,55 & \multirow{9}{*}{ Veća interoperabilnost među sustavima i alatima. } \\
\hline Znatno veće brzine & 5 & 5,55 & \\
\hline Ciljano oglašavanje & 3 & 3,33 & \\
\hline Veća pouzdanost tehnologije & 3 & 3,33 & \\
\hline Korištenje poslovne inteligencije - BI & 1 & 1,11 & \\
\hline Pojava novih platformi & 1 & 1,11 & \\
\hline $\begin{array}{l}\text { Veća mogućnost spremanja } \\
\text { dokumenata }\end{array}$ & 1 & 1,11 & \\
\hline Veća privatnost & 1 & 1,11 & \\
\hline Veća sinkronost & 1 & 1,11 & \\
\hline $\begin{array}{l}\text { Grupe za učenje (konkretnih tema, } \\
\text { predmeta, studija) }\end{array}$ & 3 & 3,33 & \multirow{4}{*}{$\begin{array}{c}\text { Veća dostupnost tehnologija u visokom } \\
\text { obrazovanju. }\end{array}$} \\
\hline $\begin{array}{l}\text { Veća dostupnost tehnologija u } \\
\text { obrazovanju }\end{array}$ & 3 & 3,33 & \\
\hline Online pristup edukaciji & 1 & 1,11 & \\
\hline $\begin{array}{l}\text { Razvoj tehnologije distribuirane } \\
\text { knjige - BT u obrazovanju }\end{array}$ & 1 & 1,11 & \\
\hline Total & 90 & $100 \%$ & \\
\hline
\end{tabular}

Tablica 20. pokazuje kako ispitanici smatraju da će se razvoj tehnologija koje pokreću društvene medije u idućih 5 godina kretati u smjeru:

- veće digitalne transformacije društva (4,44 \% ukupnog broja odgovora na ovo pitanje) u smislu više automatizacije poslova, veće dostupnosti tehnologije i uvođenje 5G mreže;

- može se očekivati masovnije korištenje tehnologije, alata i aplikacija $(18,87 \%$ ukupnog broja odgovora na ovo pitanje) u smislu razvoja različitih formata društvenih medija i / ili specijaliziranijih kao što su primjerice korištenje društvenih medija za prikupljanje podataka ili pak za treniranje modela korištenih u umjetnoj inteligenciju, razvoja 
tehnologije velikih podataka, pretraživanja podataka i većeg uključivanja podatkovne znanosti (DS);

- Što će značiti više mogućnosti, personalizaciju aplikacija i sadržaja (36,64 \% ukupnog broja odgovora na ovo pitanje) odnosno više umjetne inteligencije (AI) i veća implementacija proširene (AR), virtualne (VR) i pomiješane realnosti (MR), više individualiziranih usluga (IoT) te veće korištenje interneta svega (IoE), povećanje video sadržaja i razvoja foto opreme, napredan razvoj robotike i kreiranje vizualnih avatara, završetak treninga neuralnih mreža (ANN) i veća implementacija strojnog učenja (ML) koje eliminira rutinske operacije;

- veću interaktivnost (7,77 \% ukupnog broja odgovora na ovo pitanje) kroz poboljšanja korisničkog iskustva i više mogućnosti kreativnog participiranja korisnika;

- veću interoperabilnost među sustavima i alatima (23,31\% ukupnog broja odgovora na ovo pitanje) temeljenu na znatno većim brzinama interneta i većoj pouzdanosti tehnologije, unaprjeđenoj informacijskoj sigurnosti, privatnosti i sinkronosti, pojavi novih platformi, alatima poslovne inteligencije (BI) te ciljanom oglašavanju;

- veću dostupnost tehnologija u visokom obrazovanju (8,88 \% ukupnog broja odgovora na ovo pitanje) i online pristup edukaciji te grupe za učenje konkretnih studija, predmeta i tema.

\section{B. Razvoj tehnologija koje pokreću društvene medije u idućih $\mathbf{1 0}$ godina}

Sljedeća tablica (Tablica 21.) prikazuje odgovore panelista delfi stručne skupine u svezi s budućim razvojem tehnologija koje pokreću društvene medije u idućih 10 godina. Ukupni broj panelista koji su odgovarali na ovo pitanje je 37, od čega je 5 panelista $(13,5 \%)$ navelo da će napredak biti rapidan, uz česte promjene, te je teško predvidiv, pri čemu 1 panelist pojašnjava: ,jer nas iskustvo uči kako se tehnologija munjevito razvija i deset godina je poput stoljeća. Sjetimo se samo što smo imali prije deset godina. Tako munjeviti razvoj, a vjerojatno još i veći, možemo očekivati u sljedećih 10 godina, što čini svako očekivanje bespredmetnim“. 2 panelista $(5,4 \%)$ navelo je da ne mogu procijeniti, dok je 3 panelista $(8,1 \%)$ navelo da očekuje još viši stupanj razvoja nego su naveli u odgovoru na prethodno pitanje. U Tablici 21. prikazani odgovori ostalih panelista $\mathrm{N}=27$, ukupna frekvencija odgovora je 69. 
Tablica 21. Rezultati 1. kruga delfi studije: Razvoj tehnologija koje pokreću društvene medije u idućih 10 godina, N=27 (izvor: upitnik, Google obrasci, obrada autorice)

\begin{tabular}{|c|c|c|c|}
\hline Koncepti & & $\begin{array}{l}\text { encija } \\
\text { vora } \\
\%\end{array}$ & Kategorije \\
\hline Više automatizacije poslova i procesa & 2 & 2,9 & \multirow{6}{*}{ Digitalna transformacija društva. } \\
\hline Veća dostupnost & 2 & 2,9 & \\
\hline $\begin{array}{l}\text { Dostupnost } 5 \mathrm{G} \text { mobilnih velikih } \\
\text { sustava }\end{array}$ & 1 & 1,45 & \\
\hline Niže cijene & 1 & 1,45 & \\
\hline Razvoj 6G tehnologija & 1 & 1,45 & \\
\hline Veće brzine interneta & 1 & 1,45 & \\
\hline $\begin{array}{l}\text { Implementacija virtualne realnosti - } \\
\text { VR u svim segmentima }\end{array}$ & 3 & 4,35 & \multirow{9}{*}{ Masovnije korištenje tehnologije, alata i aplikacija. } \\
\hline $\begin{array}{l}\text { Masovna primjena umjetne } \\
\text { inteligencije - AI (servisa i } \\
\text { tehnologija) }\end{array}$ & 3 & 4,35 & \\
\hline Sve veća analiza podataka - DS & 3 & 4,35 & \\
\hline $\begin{array}{l}\text { Pomiješana realnost - MR postat će } \\
\text { uobičajen dio života }\end{array}$ & 2 & 2,9 & \\
\hline $\begin{array}{l}\text { Implementacija visoko } \\
\text { individualiziranih usluga u dnevni } \\
\text { život pojedinaca (internet stvari - IoT) }\end{array}$ & 1 & 1,45 & \\
\hline Razvoj prediktivne analitike - BD & 1 & 1,45 & \\
\hline $\begin{array}{l}\text { Razvoj tehnologije za obradu velikih } \\
\text { količina podataka - BD }\end{array}$ & 1 & 1,45 & \\
\hline $\begin{array}{l}\text { Spajanje fizioloških podataka } \\
\text { korisnika izravno u društvene medije }\end{array}$ & 1 & 1,45 & \\
\hline $\begin{array}{l}\text { Veća moć obrade podataka - BD } \\
\text { prikupljenih na društvenim medijima }\end{array}$ & 1 & 1,45 & \\
\hline $\begin{array}{l}\text { Pojava novih nepredvidivih aplikacija } \\
\text { (platformi i usluga) }\end{array}$ & 4 & 5,8 & \multirow{10}{*}{$\begin{array}{l}\text { Više mogućnosti, personalizacija aplikacija i } \\
\text { sadržaja. }\end{array}$} \\
\hline $\begin{array}{l}\text { Razvoj umjetne inteligencije - AI koja } \\
\text { će kreirati i kontrolirati sadržaj }\end{array}$ & 3 & 4,35 & \\
\hline Brži i ekonomičniji prijenos podataka & 2 & 2,9 & \\
\hline $\begin{array}{l}\text { Daljnji razvoj algoritama za strojno } \\
\text { učenje - ML }\end{array}$ & 2 & 2,9 & \\
\hline Pojava novih tehnoloških platformi & 2 & 2,9 & \\
\hline Jači kapacitet računala & 1 & 1,45 & \\
\hline Kvalitetniji sadržaj društvenih medija & 1 & 1,45 & \\
\hline $\begin{array}{l}\text { Lakše pronalaženje kvalitetnih } \\
\text { informacija }\end{array}$ & 1 & 1,45 & \\
\hline $\begin{array}{l}\text { Mehanizmi tehnologije distribuirane } \\
\text { knjige - BT za bolji podatkovni } \\
\text { integritet }\end{array}$ & 1 & 1,45 & \\
\hline $\begin{array}{l}\text { Mehanizmi tehnologije distribuirane } \\
\text { knjige - BT za pouzdanost }\end{array}$ & 1 & 1,45 & \\
\hline
\end{tabular}




\begin{tabular}{|c|c|c|c|}
\hline $\begin{array}{l}\text { Mehanizmi tehnologije distribuirane } \\
\text { knjige - BT za privatnost korisnika }\end{array}$ & 1 & 1,45 & \\
\hline Nova sučelja za unos sadržaja & 1 & 1,45 & \\
\hline $\begin{array}{l}\text { Nove mogućnosti prikazivanja } \\
\text { sadržaja }\end{array}$ & 1 & 1,45 & \\
\hline $\begin{array}{l}\text { Veliki napredak proširene realnosti - } \\
\text { AR }\end{array}$ & 1 & 1,45 & \\
\hline Više „user friendly“ aplikacija & 1 & 1,45 & \\
\hline $\begin{array}{l}\text { Vrlo ozbiljne predikcije potreba } \\
\text { pojedinaca }\end{array}$ & 1 & 1,45 & \\
\hline $\begin{array}{l}\text { Uređaji koji će znati više o } \\
\text { korisnicima nego oni sami }\end{array}$ & 1 & 1,45 & \\
\hline Znatno manje tipkanja na tipkovnice & 1 & 1,45 & \\
\hline $\begin{array}{l}\text { Korištenje tehnologije kao neizbježne } \\
\text { podrške }\end{array}$ & 2 & 2,9 & \multirow{3}{*}{ Veća interaktivnost. } \\
\hline $\begin{array}{l}\text { Društveni mediji intuitivniji za } \\
\text { korištenje }\end{array}$ & 1 & 1,45 & \\
\hline $\begin{array}{l}\text { Korištenje virtualnih avatara koji će } \\
\text { imati slično ponašanje kao osobe čiji } \\
\text { su avatari }\end{array}$ & 1 & 1,45 & \\
\hline $\begin{array}{l}\text { Dodatno ugrožena privatnost } \mathrm{i} \\
\text { sigurnost }\end{array}$ & 2 & 2,9 & \multirow{7}{*}{ Veća interoperabilnost među sustavima i alatima. } \\
\hline $\begin{array}{l}\text { Povezivanje društvenih medija sa } \\
\text { svime oko nas } 0-24 \text { kroz proširenu } \\
\text { realnost - AR }\end{array}$ & 2 & 2,9 & \\
\hline Veća privatnost & 2 & 2,9 & \\
\hline Integracija društvenih medija & 1 & 1,45 & \\
\hline $\begin{array}{l}\text { Migracija korisnika s jednih na druge } \\
\text { aplikacije }\end{array}$ & 1 & 1,45 & \\
\hline $\begin{array}{l}\text { Pomiješana realnost }-\mathrm{MR} \\
\text { implementirana u društvene medije }\end{array}$ & 1 & 1,45 & \\
\hline Veća sigurnost & 1 & 1,45 & \\
\hline $\begin{array}{l}\text { Važna edukacijska uloga društvenih } \\
\text { medija }\end{array}$ & 3 & 4,35 & \multirow{3}{*}{$\begin{array}{c}\text { Veća dostupnost tehnologija u visokom } \\
\text { obrazovanju. }\end{array}$} \\
\hline $\begin{array}{l}\text { Aktivno uključivanje virtualne } \\
\text { realnosti - VR u obrazovni proces }\end{array}$ & 1 & 1,45 & \\
\hline $\begin{array}{l}\text { Veća orijentiranost na online } \\
\text { okruženje u obrazovanju }\end{array}$ & 1 & 1,45 & \\
\hline Total & 69 & $100 \%$ & \\
\hline
\end{tabular}

Tablica 21. pokazuje kako ispitanici smatraju da će se razvoj tehnologija koje pokreću društvene medije u idućih 10 godina kretati u smjeru:

- veće digitalne transformacije društva (11,6 \% ukupnog broja odgovora na ovo pitanje) u smislu više automatizacije poslova i procesa, veće dostupnosti tehnologije i $5 \mathrm{G}$ velikih mobilnih sustava, nižih cijena i veće brzine interneta te razvoja 6G mreže; 
- može se očekivati masovnije korištenje tehnologije, alata i aplikacija (23,2 \% ukupnog broja odgovora na ovo pitanje) u smislu implementacije virtualne realnosti (VR) u sve segmente života, pri čemu će i pomiješana realnost (MR) postati uobičajeni dio života, masovnu primjenu servisa i tehnologija umjetne inteligencije (AI), i sve veću analizu podataka (DS) i razvoj tehnologije za obradu velikih količina podataka i prediktivne analitike (BD), prikupljenih osobito na društvenim medijima, implementaciju visoko individualiziranih usluga u dnevni život pojedinaca (IoT) te spajanje fizioloških podataka izravno u društvene medije;

- Što će značiti više mogućnosti, personalizaciju aplikacija i sadržaja (37,7 \% ukupnog broja odgovora na ovo pitanje) odnosno pojavu novih nepredvidivih aplikacija, platformi i usluga koje će omogućavati nova i „user friendly“ sučelja za unos sadržaja, kao i novih tehnoloških platformi, jači kapacitet računala i brži i ekonomičniji prijenos podataka, razvoj umjetne inteligencije (AI) koja će kreirati i kontrolirati sadržaj, daljnji razvoj algoritama za strojno učenje (ML) i mehanizama tehnologije distribuirane knjige (BT) za bolji i pouzdaniji podatkovni integritet te privatnost korisnika, uređaji koji će znati više o korisnicima nego oni sami i vrlo ozbiljne predikcije potreba pojedinaca, lakše pronalaženje kvalitetnih informacija i kvalitetniji sadržaj društvenih medija te veliki napredak proširene realnosti (AR);

- veću interaktivnost (5,9 \% ukupnog broja odgovora na ovo pitanje) kroz korištenje tehnologije kao neizbježne podrške, društvenih medija koji će biti intuitivniji za korištenje te korištenje virtualnih avatara koji će imati slično ponašanje kao osobe čiji su avatari;

- veću interoperabilnost među sustavima i alatima (14,5\% ukupnog broja odgovora na ovo pitanje) kroz integraciju društvenih medija odnosno povezivanje društvenih medija sa svime oko nas $0-24$ kroz proširenu realnost (AR) te implementiranu pomiješanu realnost (MR) u društvene medije, migraciju korisnika s jednih na druge aplikacije, za što neki eksperti smatraju da će dodatno ugroziti privatnost i sigurnost korisnika dok drugi pak smatraju da će jamčiti veću privatnost i veću sigurnost;

- veću dostupnost tehnologija u visokom obrazovanju (7,25 \% ukupnog broja odgovora na ovo pitanje) odnosno društveni mediji će imati važnu edukacijsku ulogu, te će se povećati orijentiranost na online okruženje u obrazovanju i aktivno uključiti virtualna realnost (VR) u obrazovni proces. 


\subsubsection{Preduvjeti korištenja društvenih medija u visokom obrazovanju}

Kako bi se odgovorilo na drugo istraživačko pitanje IP2.: Koje je preduvjete potrebno ispuniti kako bi se potencijal društvenih medija upotrijebio za potrebe visokog obrazovanja? panelistima su postavljena pitanja:

3. Koje (ekonomske i druge) preduvjete treba ispuniti da se potencijal društvenih medija može koristiti za potrebe visokog obrazovanja, u sljedećih 5 godina?

4. Koje (ekonomske i druge) preduvjete treba ispuniti da se potencijal društvenih medija može koristiti za potrebe visokog obrazovanja, u sljedećih 10 godina?

Za potrebe analize kvalitativnih odgovora na treće i četvrto postavljeno pitanje otvorenog tipa u ovoj delfi studiji, dobiveni odgovori su iz sirovih podataka kodirani u koncepte kao temeljne jedinice analize, nakon čega je slijedilo grupiranje koncepata koji se odnose na isti fenomen u apstrahirane i uopćene kategorije koje su međusobno povezane. Zatim su kategorije ujedinjene u teme koje će se koristiti u 2. krugu istraživanja.

Teorijskim uzorkovanjem, odnosno kružnim procesom usporedbe i refleksije poznatih informacija o uvjetima koji utječu na implementaciju društvenih medija u visokoobrazovni proces i novog materijala dobivenog u odgovorima eksperata koji se tiču preduvjeta koje je potrebno ispuniti kako bi se potencijal društvenih medija mogao koristiti za potrebe visokog obrazovanja, ponavljanim nekoliko puta dobiveni su prikazi u Tablici 22. i Tablici 23. pri čemu se prvi stupac Koncepti odnosi na svojstva ili osobine potrebnih preduvjeta, drugi stupac Frekvencija odgovora sadrži učestalost koncepata u odgovorima sudionika istraživanja (iskazanu numerički i postotno), treći stupac sadrži uopćene izjave apstrahirane iz Koncepata u Kategorije su korištene u 2. krugu istraživanja za opis Tema u koje su grupirane. Teme koje su se pojavile bile su, nakon obrade odgovora na sva istraživačka pitanja, sumarizirane i korištene u 2. krugu istraživanja kao ključni čimbenici promjene komunikacijske paradigme u visokom obrazovanju pod utjecajem društvenih medija.

Zaključno slijedi deskripcija i interpretacija predikcija panelista s naglaskom na razumijevanju preduvjeta koje je potrebno ispuniti kako bi se potencijal društvenih medija mogao koristiti za potrebe visokog obrazovanja u sljedećih 5 godina i u sljedećih 10 godina iz perspektive samih sudionika istraživanja. 


\section{A. Preduvjeti korištenja društvenih medija u visokom obrazovanju u sljedećih 5 godina}

Sljedeća tablica (Tablica 22.) prikazuje odgovore panelista delfi stručne skupine u svezi s preduvjetima koje je potrebno ispuniti u idućih 5 godina kako bi se potencijal društvenih medija iskoristio za potrebe visokog obrazovanja. Ukupni broj panelista koji su odgovarali na ovo pitanje je 37, svi panelisti odgovorili su na ovo pitanje. U Tablici 22. prikazani su odgovori panelista $\mathrm{N}=37$, ukupna frekvencija odgovora bila je 90.

Tablica 22. Rezultati 1. kruga delfi studije: Preduvjeti koje je potrebno ispuniti kako bi se potencijal društvenih medija mogao koristiti za potrebe visokog obrazovanja u sljedećih 5 godina, N=37 (izvor: upitnik, Google obrasci, obrada autorice)

\begin{tabular}{|c|c|c|c|c|}
\hline \multirow[t]{2}{*}{ Koncepti } & \multicolumn{2}{|c|}{$\begin{array}{c}\text { Frekvencija } \\
\text { odgovora }\end{array}$} & \multirow[t]{2}{*}{ Kategorije } & \multirow[t]{2}{*}{ Tema } \\
\hline & $\mathbf{N}$ & $\%$ & & \\
\hline Resursi financijski dostupni & 4 & 4,44 & \multirow{5}{*}{ Financijska sredstva i izvori. } & \multirow{5}{*}{ Dostupnost resursa (RES) } \\
\hline Adekvatna računala i oprema & 2 & 2,22 & & \\
\hline $\begin{array}{l}\text { Financiranje istraživanja o } \\
\text { društvenim medijima }\end{array}$ & 1 & 1,11 & & \\
\hline $\begin{array}{l}\text { Pronalazak održivih mehanizama } \\
\text { financiranja }\end{array}$ & 1 & 1,11 & & \\
\hline Ulaganje u razvoj brzih mreža & 1 & 1,11 & & \\
\hline Masovno korištenje tehnologije & 1 & 1,11 & \multirow{3}{*}{ Trendovi. } & \multirow{4}{*}{ Društvo u cjelini (DR) } \\
\hline $\begin{array}{l}\text { Povećanje educiranosti } \\
\text { „prosječnog“ čovjeka }\end{array}$ & 1 & 1,11 & & \\
\hline $\begin{array}{l}\text { Svijest cijelog društva o važnosti } \\
\text { ulaganja u obrazovanje }\end{array}$ & 1 & 1,11 & & \\
\hline Manjak društvene interakcije & 1 & 1,11 & $\begin{array}{l}\text { Viša sila, npr. pandemija } \\
\text { korona virusa Covid- } 19 .\end{array}$ & \\
\hline Tehnička opremljenost & 3 & 3,33 & $\begin{array}{l}\text { Vlasništvo nad DM odnosno } \\
\text { licencama. }\end{array}$ & \multirow{4}{*}{$\begin{array}{l}\text { Infrastruktura upravljanja } \\
\text { znanjem (INFR) }\end{array}$} \\
\hline Tehnička podrška nastavnicima & 3 & 3,33 & $\begin{array}{l}\text { Tehnička podrška; stvaranje } \\
\text { namjenskih uloga za } \\
\text { filtriranje, ažuriranje i } \\
\text { održavanje DM. }\end{array}$ & \\
\hline Režimi obuke & 1 & 1,11 & $\begin{array}{l}\text { Režimi obuke za korištenje } \\
\text { DM. }\end{array}$ & \\
\hline Veća sigurnost & 1 & 1,11 & $\begin{array}{c}\text { Prepoznavanje i upravljanje } \\
\text { rizicima. }\end{array}$ & \\
\hline Troše previše vremena & 1 & 1,11 & $\begin{array}{l}\text { Jednostavnost korištenja } \\
\text { DM. }\end{array}$ & \multirow{3}{*}{$\begin{array}{l}\text { Kvaliteta društvenih } \\
\text { medija (DM) }\end{array}$} \\
\hline Kvalitetni alati & 3 & 3,33 & \multirow[t]{2}{*}{ Pouzdanost korištenja DM. } & \\
\hline Ugrožavaju privatnost korisnika & 1 & 1,11 & & \\
\hline Edukacija nastavnika & 7 & 7,77 & \multirow{4}{*}{$\begin{array}{l}\text { Sustavna edukacija o } \\
\text { korištenju DM. }\end{array}$} & \multirow{4}{*}{$\begin{array}{l}\text { Kultura razmjene znanja } \\
\text { (KUL) }\end{array}$} \\
\hline Edukacija studenata & 2 & 2,22 & & \\
\hline Poznavanje operativnog sustava & 2 & 2,22 & & \\
\hline Poznavanje uređaja & 1 & 1,11 & & \\
\hline
\end{tabular}




\begin{tabular}{|c|c|c|c|c|}
\hline Podizanje svijesti nastavnika & 2 & 2,22 & \multirow{3}{*}{$\begin{array}{l}\text { Svo osoblje treba stalno biti } \\
\text { informirano o novim } \\
\text { saznanjima o korištenju DM } \\
\text { za potrebe visokog } \\
\text { obrazovanja, npr. mjesečne } \\
\text { sesije dijeljenja znanja. }\end{array}$} & \\
\hline Podizanje svijesti studenata & 2 & 2,22 & & \\
\hline $\begin{array}{l}\text { Uklanjanje predrasuda prema } \\
\text { online učenju }\end{array}$ & 1 & 1,11 & & \\
\hline Promjena stava & 1 & 1,11 & $\begin{array}{c}\text { Proslava uspjeha i učenje iz } \\
\text { neuspjeha. }\end{array}$ & \\
\hline E bonton & 1 & 1,11 & \multirow{2}{*}{$\begin{array}{l}\text { Kultura suradnje, koja nije } \\
\text { konkurentna. }\end{array}$} & \\
\hline Stvaranje kulture suradnje & 1 & 1,11 & & \\
\hline Materijalna podrška nastavnicima & 1 & 1,11 & $\begin{array}{l}\text { Poticajni programi koji } \\
\text { nagrađuju zaposlenike koji } \\
\text { koriste / doprinose za DM. }\end{array}$ & $\begin{array}{l}\text { Motivacija nastavnika } \\
\text { (NAST) }\end{array}$ \\
\hline $\begin{array}{l}\text { Poticaj za sadržaje na hrvatskom } \\
\text { jeziku }\end{array}$ & 1 & 1,11 & \multirow{4}{*}{$\begin{array}{c}\text { Nacionalne strategije } \\
\text { obrazovanja. }\end{array}$} & \multirow{12}{*}{$\begin{array}{c}\text { Nacionalne } \\
\text { politike/strategije } \\
\text { obrazovanja (POL) }\end{array}$} \\
\hline $\begin{array}{l}\text { Strategije za primjenu društvenih } \\
\text { medija u obrazovanju }\end{array}$ & 1 & 1,11 & & \\
\hline $\begin{array}{l}\text { Strategije za primjenu tehnologije } \\
\text { u obrazovanju }\end{array}$ & 1 & 1,11 & & \\
\hline $\begin{array}{l}\text { Ulaganje u ljude, ne samo } \\
\text { tehnologije }\end{array}$ & 1 & 1,11 & & \\
\hline Razvoj digitalne pedagogije & 1 & 1,11 & Uključuje i niže razine & \\
\hline $\begin{array}{l}\text { Razvoj društvenih medija za } \\
\text { prikupljanje podataka o ponašanju } \\
\text { u obrazovnom procesu }\end{array}$ & 1 & 1,11 & $\begin{array}{c}\text { obrazovanja } \\
\text { (osnovnoškolsko, } \\
\text { srednjoškolsko) te } \\
\text { visokoškolsko obrazovanje. }\end{array}$ & \\
\hline Podrška nadležnih institucija & 2 & 2,22 & \multirow{3}{*}{ Podrška državnih institucija. } & \\
\hline $\begin{array}{l}\text { Sustavan pristup države prema } \\
\text { korištenju društvenih medija }\end{array}$ & 1 & 1,11 & & \\
\hline $\begin{array}{l}\text { Sustavan pristup države prema } \\
\text { nabavci društvenih medija }\end{array}$ & 1 & 1,11 & & \\
\hline Veća zaštita podataka & 3 & 3,33 & \multirow{3}{*}{ Pravna regulacija. } & \\
\hline $\begin{array}{l}\text { Regulacija problematičnog } \\
\text { pravnog okvira }\end{array}$ & 1 & 1,11 & & \\
\hline Veća zaštita privatnosti & 1 & 1,11 & & \\
\hline $\begin{array}{l}\text { Direktna komunikacija sa } \\
\text { studentima putem platformi i } \\
\text { aplikacija }\end{array}$ & 1 & 1,11 & $\begin{array}{l}\text { Komuniciraju i surađuju na } \\
\text { nove načine. }\end{array}$ & $\begin{array}{c}\text { Očekivanja studenata } \\
\text { (STU) }\end{array}$ \\
\hline Autonomija visokih učilišta & 1 & 1,11 & \multirow{2}{*}{$\begin{array}{l}\text { Vodstvo odozgo od } \\
\text { strane uprave visokih } \\
\text { učilišta. }\end{array}$} & \multirow{2}{*}{$\begin{array}{l}\text { Podrška vodstva } \\
\text { visokih učilišta (VU) }\end{array}$} \\
\hline Podrška uprave visokih učilišta & 1 & 1,11 & & \\
\hline Korištenje $5 \mathrm{G}$ mreže & 1 & 1,11 & \multirow{2}{*}{$\begin{array}{l}\text { Digitalna transformacija } \\
\text { društva. }\end{array}$} & \multirow{8}{*}{ Razvoj tehnologija (TEH) } \\
\hline Širenje mobilnih mreža & 1 & 1,11 & & \\
\hline $\begin{array}{l}\text { Proširiti korištenje pomiješane } \\
\text { realnosti - MR }\end{array}$ & 1 & 1,11 & \multirow{3}{*}{$\begin{array}{c}\text { Masovnije korištenje } \\
\text { tehnologije, alata i } \\
\text { aplikacija. }\end{array}$} & \\
\hline $\begin{array}{l}\text { Proširiti korištenje proširene } \\
\text { realnosti - AR }\end{array}$ & 1 & 1,11 & & \\
\hline $\begin{array}{l}\text { Proširiti korištenje virtualne } \\
\text { realnosti - VR }\end{array}$ & 1 & 1,11 & & \\
\hline Pouzdani informacijski sustavi & 1 & 1,11 & \multirow{3}{*}{$\begin{array}{l}\text { Više mogućnosti, } \\
\text { personalizacija aplikacija i } \\
\text { sadržaja. }\end{array}$} & \\
\hline Razvoj alata & 1 & 1,11 & & \\
\hline Sigurni informacijski sustavi & 1 & 1,11 & & \\
\hline
\end{tabular}




\begin{tabular}{|c|c|c|c|c|}
\hline $\begin{array}{l}\text { Više jednostavnih oblika } \\
\text { interakcije i komunikacije } \\
\text { podržane tehnologijom }\end{array}$ & 1 & 1,11 & Veća interaktivnost. & \\
\hline $\begin{array}{l}\text { Sadržaj na „cloud“ baziranim } \\
\text { servisima }\end{array}$ & 1 & 1,11 & $\begin{array}{l}\text { Veća interoperabilnost } \\
\text { među sustavima i alatima. }\end{array}$ & \\
\hline Nova generacija nastavnika & 1 & 1,11 & \multirow{7}{*}{$\begin{array}{l}\text { Promjena od tradicionalnog } \\
\text { ka inovativnim oblicima } \\
\text { učenja i poučavanja. }\end{array}$} & \multirow{15}{*}{$\begin{array}{l}\text { Strategija upravljanja } \\
\text { znanjem (ZNA) }\end{array}$} \\
\hline $\begin{array}{l}\text { Odmak nastavnika od } \\
\text { tradicionalnih vrijednosti i metoda } \\
\text { poučavanja }\end{array}$ & 1 & 1,11 & & \\
\hline Promjena paradigme razmišljanja & 1 & 1,11 & & \\
\hline $\begin{array}{l}\text { Potpuno drukčiji stav prema } \\
\text { ishodima učenja }\end{array}$ & 1 & 1,11 & & \\
\hline $\begin{array}{l}\text { Potpuno drukčiji stav prema } \\
\text { obrazovanju }\end{array}$ & 1 & 1,11 & & \\
\hline $\begin{array}{l}\text { Potpuno drukčiji stav prema ulozi } \\
\text { nastavnika }\end{array}$ & 1 & 1,11 & & \\
\hline Transformacija obrazovanja & 1 & 1,11 & & \\
\hline $\begin{array}{l}\text { Kreiranje formalnog okvira za } \\
\text { nastavu na daljinu }\end{array}$ & 1 & 1,11 & \multirow{4}{*}{$\begin{array}{l}\text { Usklađivanje strategije } \\
\text { korištenja DM s poslovnim } \\
\text { modelom i postojećim } \\
\text { sustavima i procesima VU. }\end{array}$} & \\
\hline $\begin{array}{l}\text { Nema alternative korištenju } \\
\text { društvenih medija već sada }\end{array}$ & 1 & 1,11 & & \\
\hline $\begin{array}{l}\text { Odvajanje od marketinških } \\
\text { aktivnosti }\end{array}$ & 1 & 1,11 & & \\
\hline $\begin{array}{l}\text { Visoka učilišta sustavno biti } \\
\text { prisutna na društvenim medijima }\end{array}$ & 1 & 1,11 & & \\
\hline $\begin{array}{l}\text { Jača popularizacija (promocija) } \\
\text { društvenih medija u obrazovanju }\end{array}$ & 1 & 1,11 & $\begin{array}{l}\text { Komuniciranje strategije } \\
\text { korištenja DM svim } \\
\text { dionicima. }\end{array}$ & \\
\hline Hibridno iskustvo nastave & 1 & 1,11 & \multirow{3}{*}{ Primjeri dobre prakse. } & \\
\hline $\begin{array}{l}\text { Korištenje neuronske mreže za } \\
\text { provedbu personaliziranih ispita }\end{array}$ & 1 & 1,11 & & \\
\hline Uključiti strojno učenje u ispite & 1 & 1,11 & & \\
\hline Total & 90 & $100 \%$ & & \\
\hline
\end{tabular}

Tablica 22. pokazuje uvjete koji utječu korištenje društvenih medija u visokom obrazovanju odnosno preduvjete koje ispitanici smatraju da je potrebno ispuniti kako bi se potencijal društvenih medija mogao iskoristiti za potrebe visokog obrazovanja u sljedećih 5 godina:

Dostupnost resursa $-10 \%$ ukupnog broja odgovora na ovo pitanje;

- financijska sredstva i izvori - važno je da resursi budu financijski dostupni, da su su računala i oprema adekvatni, kao i pronalazak održivih mehanizama financiranja, ulaganje u razvoj brzih mreža i financiranje istraživanja o društvenim medijima.

Društvo u cjelini - 4,44 \% ukupnog broja odgovora na ovo pitanje;

- trendovi - s obzirom na masovno korištenje tehnologije, potrebno je povećati educiranost „prosječnog“ čovjeka o istoj te podići svijest cijelog društva o važnosti ulaganja u obrazovanje, osobito jer je zbog utjecaja kao što je 
- viša sila (primjerice pandemija korona virusa Covid-19) - prisutan manjak odnosno nemogućnost do sad poznatih mogućnosti društvene interakcije.

Infrastruktura upravljanja znanjem $-8,88 \%$ ukupnog broja odgovora na ovo pitanje;

- vlasništvo nad društvenim medijima odnosno licencama - odnosno tehnička opremljenost,

- tehnička podrška, stvaranje namjenskih uloga za filtriranje, ažuriranje i održavanje društvenih medija - kroz tehničku podršku nastavnicima,

- režimi obuke za korištenje društvenih medija,

- prepoznavanje i upravljanje rizicima - koji bi primjerice jamčili veću sigurnost podataka i korisnika.

Kultura razmjene znanja - 22,22 \% ukupnog broja odgovora na ovo pitanje;

- sustavna edukacija o korištenju društvenih medija - potrebna je sustavna edukacija i to osobito nastavnika, ali i studenata, kroz poznavanje operativnog sustava i poznavanje uređaja,

- svo osoblje treba stalno biti informirano o novim saznanjima o korištenju DM za potrebe visokog obrazovanja, npr. mjesečne sesije dijeljenja znanja - pri čemu je osobito važno podizanje svijesti nastavnika, ali i podizanje svijesti studenata te uklanjanje predrasuda prema online učenju,

- proslava uspjeha i učenje iz neuspjeha - odnosno promjena postojećeg stava,

- kultura suradnje, koja nije konkurentna - tj. stvaranje kulture suradnje, pa i kroz učenje i primjenu E bontona.

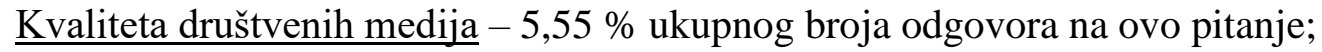

- jednostavnost korištenja društvenih medija - jer inače troše previše vremena,

- pouzdanost korištenja društvenih medija - važni su kvalitetni alati, osobito koji ne ugrožavaju privatnost korisnika.

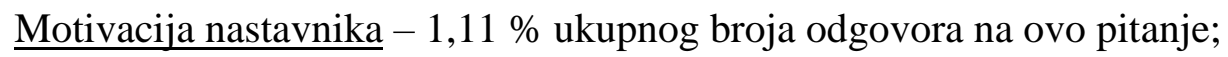

- poticajni programi koji nagrađuju zaposlenike koji koriste / doprinose za društvene medije - kroz materijalnu podršku nastavnicima.

Nacionalne politike / strategije obrazovanja - 16,66 \% ukupnog broja odgovora na ovo pitanje;

- nacionalne strategije obrazovanja - odnosno strategije za primjenu tehnologije, posebice društvenih medija u obrazovanju, kao i poticaj za sadržaje koji će biti na hrvatskom jeziku, no nije dovoljno ulaganje samo u tehnologije, već je potrebno ulaganje u ljude, 
- podrška državnih institucija - $\mathrm{i}$ to osobito kroz sustavan pristup države prema nabavci i sustavan pristup društvenih medija,

- pravna regulacija - koja će omogućiti veću zaštitu podataka, veću zaštitu privatnosti i regulaciju problematičnog pravnog okvira,

- uključuje i niže razine obrazovanja (osnovnoškolsko, srednjoškolsko) te visokoškolsko obrazovanje - što se odnosi na razvoj digitalne pedagogije i razvoj društvenih medija za prikupljanje podataka o ponašanju u obrazovnom procesu.

Očekivanja studenata $-1,11 \%$ ukupnog broja odgovora na ovo pitanje;

- komuniciraju i surađuju na nove načine - stoga je važna je direktna komunikacija sa studentima putem platformi i aplikacija.

Podrška vodstva visokih učilišta $-2,22 \%$ ukupnog broja odgovora na ovo pitanje;

- vodstvo odozgo od strane uprave visokih učilišta - pri čemu je potrebna je autonomija visokih učilišta, ali i podrška uprave visokih učilišta.

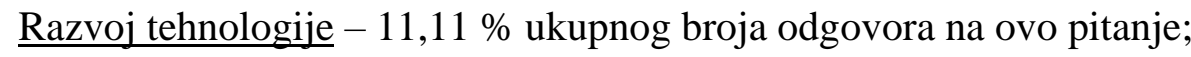

- digitalna transformacija društva - kroz korištenje 5G mreže i širenje mobilnih mreža,

- masovnije korištenje tehnologije, alata i aplikacija - važno je proširiti korištenje pomiješane realnosti (MR), proširene realnosti (AR) i virtualne realnosti (VR),

- više mogućnosti, personalizacija aplikacija i sadržaja - potrebni su pouzdani i sigurni informacijski sustavi, kao i razvoj alata,

- veća interaktivnost - odnosno više jednostavnih oblika interakcije i komunikacije podržane tehnologijom, te

- veća interoperabilnost među sustavima i alatima - primjerice sadržaj na „cloud“ baziranim servisima.

Strategija upravljanja znanjem - 16,66 \% ukupnog broja odgovora na ovo pitanje;

- promjena od tradicionalnog ka inovativnim oblicima učenja i poučavanja - što podrazumijeva odmak nastavnika od tradicionalnih vrijednosti i metoda poučavanja odnosno novu generaciju nastavnika, odnosno promjenu paradigme razmišljanja, te potpuno drukčiji stav prema ulozi nastavnika, obrazovanju i ishodima učenja odnosno transformaciju trenutnog obrazovanja,

- usklađivanje strategije korištenja društvenih medija s poslovnim modelom i postojećim sustavima i procesima visokih učilišta - pri čemu je potrebno kreirati formalni okvir za nastavu na daljinu jer nema alternative korištenju društvenih medija već sada, i iako bi visoka učilišta trebala biti sustavno prisutna na društvenim medijima trebalo bi te aktivnosti odvojiti od marketinških aktivnosti, 
- komuniciranje strategije korištenja društvenih medija svim dionicima - odnosno jača promocija i popularizacija društvenih medija u obrazovanju,

- primjeri dobre prakse - kao što su hibridno iskustvo nastave, korištenje neuronske mreže za provedbu personaliziranih ispita te uključivanje strojnog učenja $u$ ispite.

\section{B. Preduvjeti korištenja društvenih medija u visokom obrazovanju u sljedećih $\mathbf{1 0}$ godina}

Sljedeća tablica (Tablica 23.) prikazuje odgovore panelista delfi stručne skupine u svezi s preduvjetima koje je potrebno ispuniti u idućih 10 godina kako bi se potencijal društvenih medija iskoristio za potrebe visokog obrazovanja. Ukupni broj panelista koji su odgovarali na ovo pitanje je 37, svi panelisti odgovorili su na ovo pitanje. U Tablici 23. prikazani odgovori panelista $\mathrm{N}=37$, ukupna frekvencija odgovora bila je 56.

Tablica 23. Rezultati 1. kruga delfi studije: Preduvjeti koje je potrebno ispuniti kako bi se potencijal društvenih medija mogao koristiti za potrebe visokog obrazovanja u sljedećih 10 godina, N=37 (izvor: upitnik, Google obrasci, obrada autorice)

\begin{tabular}{|c|c|c|c|c|}
\hline \multirow[t]{2}{*}{ Koncepti } & \multicolumn{2}{|c|}{$\begin{array}{l}\text { Frekvencija } \\
\text { odgovora }\end{array}$} & \multirow[t]{2}{*}{ Kategorije } & \multirow[t]{2}{*}{ Teme } \\
\hline & & $\%$ & & \\
\hline Održiv sustav financiranja & 1 & 1,79 & \multirow{3}{*}{ Financijska sredstva i izvori. } & \multirow{3}{*}{ Dostupnost resursa (RES) } \\
\hline Resursi financijski dostupni & 1 & 1,79 & & \\
\hline $\begin{array}{l}\text { Ulaganje u tehničke uvjete za } \\
\text { edukaciju na udaljenim lokacijama }\end{array}$ & 1 & 1,79 & & \\
\hline $\begin{array}{l}\text { Suradnja s tvrtkama koje se bave } \\
\text { tehnološkim napretkom }\end{array}$ & 1 & 1,79 & Privlačenje investitora. & \multirow{2}{*}{ Društvo u cjelini (DR) } \\
\hline $\begin{array}{l}\text { Praćenje i prilagodba svjetskim } \\
\text { trendovima }\end{array}$ & 1 & 1,79 & Trendovi. & \\
\hline Tehnički uvjeti & 1 & 1,79 & $\begin{array}{c}\text { Vlasništvo nad DM odnosno } \\
\text { licencama. }\end{array}$ & \multirow{6}{*}{$\begin{array}{c}\text { Infrastruktura upravljanja } \\
\text { znanjem (INFR) }\end{array}$} \\
\hline Informatička infrastruktura & 1 & 1,79 & \multirow{2}{*}{$\begin{array}{c}\text { Tehnička podrška; stvaranje } \\
\text { namjenskih uloga za } \\
\text { filtriranje, ažuriranje i } \\
\text { održavanje DM. }\end{array}$} & \\
\hline $\begin{array}{l}\text { Ulaganje u infrastrukturu koja } \\
\text { omogućava virtualno poučavanje }\end{array}$ & 1 & 1,79 & & \\
\hline $\begin{array}{l}\text { Educiranje o novim IT } \\
\text { tehnologijama }\end{array}$ & 2 & 3,58 & \multirow{2}{*}{$\begin{array}{c}\text { Režimi obuke za korištenje } \\
\text { DM. }\end{array}$} & \\
\hline $\begin{array}{l}\text { Znanje korištenja društvenih } \\
\text { medija }\end{array}$ & 1 & 1,79 & & \\
\hline Sprečavanje štetnih utjecaja & 1 & 1,79 & $\begin{array}{c}\text { Prepoznavanje i upravljanje } \\
\text { rizicima. }\end{array}$ & \\
\hline $\begin{array}{l}\text { Jednostavnost korištenja } \\
\text { društvenih medija }\end{array}$ & 2 & 3,58 & $\begin{array}{c}\text { Jednostavnost korištenja } \\
\text { DM. }\end{array}$ & $\begin{array}{l}\text { Kvaliteta društvenih } \\
\text { medija (DM) }\end{array}$ \\
\hline
\end{tabular}




\begin{tabular}{|c|c|c|c|c|}
\hline $\begin{array}{l}\text { Sigurnost korištenja društvenih } \\
\text { medija }\end{array}$ & 1 & 1,79 & Pouzdanost korištenja DM. & \\
\hline $\begin{array}{l}\text { Procjena korištenja društvenih } \\
\text { medija za pojedino područje }\end{array}$ & 1 & 1,79 & $\begin{array}{c}\text { Redovitost ažuriranja DM } \\
\text { kako bi odražavalo trenutno } \\
\text { znanje. }\end{array}$ & \\
\hline $\begin{array}{l}\text { Razvoj alata koje će koristiti } \\
\text { strukture društvenih medija }\end{array}$ & 1 & 1,79 & $\begin{array}{l}\text { Odgovarajuće povezivanje } \\
\text { DM s drugim alatima } \\
\text { (interoperabilnost). }\end{array}$ & \\
\hline $\begin{array}{l}\text { Bolje razumijevanje i korištenje } \\
\text { umjetne inteligencije - AI od } \\
\text { nastavnika }\end{array}$ & 1 & 1,79 & \multirow{4}{*}{$\begin{array}{l}\text { Sustavna edukacija o } \\
\text { korištenju DM. }\end{array}$} & \multirow{8}{*}{$\begin{array}{l}\text { Kultura razmjene znanja } \\
\text { (KUL) }\end{array}$} \\
\hline Edukacija svih dionika & 1 & 1,79 & & \\
\hline $\begin{array}{l}\text { Kvalitetna edukacija „developera“ } \\
\text { (programera) }\end{array}$ & 1 & 1,79 & & \\
\hline $\begin{array}{l}\text { Kontinuirano praćenje razvoja } \\
\text { novih tehnologija za učenje i } \\
\text { poučavanje }\end{array}$ & 1 & 1,79 & & \\
\hline Podizanje svijesti svih dionika & 1 & 1,79 & \multirow[b]{2}{*}{$\begin{array}{l}\text { Svo osoblje treba stalno biti } \\
\text { informirano o novim } \\
\text { saznanjima o korištenju DM } \\
\text { za potrebe visokog } \\
\text { obrazovanja, npr. mjesečne } \\
\text { sesije dijeljenja znanja. }\end{array}$} & \\
\hline $\begin{array}{l}\text { Promocija benefita korištenja } \\
\text { društvenih medija u visokom } \\
\text { obrazovanju }\end{array}$ & 1 & 1,79 & & \\
\hline E bonton & 1 & 1,79 & \multirow{2}{*}{$\begin{array}{l}\text { Kultura suradnje, koja nije } \\
\text { konkurentna. }\end{array}$} & \\
\hline Jaka želja za učenjem & 1 & 1,79 & & \\
\hline Bolje mogućnosti provjere & 1 & 1,79 & \multirow{4}{*}{$\begin{array}{c}\text { Uspostava ključnih } \\
\text { indikatora uspješnosti } \\
\text { korištenja DM u visokom } \\
\text { obrazovanju kako bi se } \\
\text { mogao pratiti napredak i } \\
\text { olakšalo kontinuirano } \\
\text { poboljšavanje. }\end{array}$} & \multirow{4}{*}{ Metrike uspješnosti (USP) } \\
\hline $\begin{array}{l}\text { Jednostavni sustavi za valoriziranje } \\
\text { studenata }\end{array}$ & 1 & 1,79 & & \\
\hline $\begin{array}{l}\text { Pouzdani sustavi za valoriziranje } \\
\text { studenata }\end{array}$ & 1 & 1,79 & & \\
\hline $\begin{array}{l}\text { Sigurni sustavi za valoriziranje } \\
\text { studenata }\end{array}$ & 1 & 1,79 & & \\
\hline $\begin{array}{l}\text { Jedinstvena nabavka društvenih } \\
\text { medija }\end{array}$ & 1 & 1,79 & \multirow{2}{*}{ Podrška državnih institucija. } & \multirow{7}{*}{$\begin{array}{c}\text { Nacionalne } \\
\text { politike/strategije } \\
\text { obrazovanja (POL) }\end{array}$} \\
\hline $\begin{array}{l}\text { Pojeftinjenje nabavke društvenih } \\
\text { medija }\end{array}$ & 1 & 1,79 & & \\
\hline $\begin{array}{l}\text { Formalni (pravni i organizacijski) } \\
\text { okvir za prikupljanje i analizu } \\
\text { podataka o studentima }\end{array}$ & 1 & 1,79 & \multirow{5}{*}{ Pravna regulacija. } & \\
\hline Kontrola korištenja podataka & 1 & 1,79 & & \\
\hline $\begin{array}{l}\text { Neovisna državna kontrola } \\
\text { korištenja društvenih medija }\end{array}$ & 1 & 1,79 & & \\
\hline Zaštita osobnosti & 1 & 1,79 & & \\
\hline Zaštita privatnosti & 1 & 1,79 & & \\
\hline Praćenje načina življenja studenata & 1 & 1,79 & $\begin{array}{l}\text { Ne poznaju svijet bez } \\
\text { tehnologije. }\end{array}$ & \multirow{3}{*}{$\begin{array}{l}\text { Očekivanja studenata } \\
\text { (STU) }\end{array}$} \\
\hline Praćenje načina učenja studenata & 1 & 1,79 & Uče na nove načine. & \\
\hline $\begin{array}{l}\text { Komunikacija sa studentima putem } \\
\text { svih uređaja koje koriste }\end{array}$ & 1 & 1,79 & $\begin{array}{l}\text { Komuniciraju i surađuju na } \\
\text { nove načine. }\end{array}$ & \\
\hline $\begin{array}{l}\text { Izbjegavanje tehnološke } \\
\text { agnostičnosti }\end{array}$ & 1 & 1,79 & $\begin{array}{c}\text { Digitalna transformacija } \\
\text { društva. }\end{array}$ & Razvoj tehnologija (TEH) \\
\hline
\end{tabular}




\begin{tabular}{|c|c|c|c|c|}
\hline $\begin{array}{l}\text { Izbjegavanje tehnološke različitosti } \\
\text { kod „,vendora“ Microsoft, Mac, } \\
\text { Adobe }\end{array}$ & 1 & 1,79 & & \\
\hline $\begin{array}{l}\text { Stvaranje uređaja pomiješane } \\
\text { realnosti - MR }\end{array}$ & 1 & 1,79 & \multirow{3}{*}{$\begin{array}{l}\text { Masovnije korištenje } \\
\text { tehnologije, alata i } \\
\text { aplikacija. }\end{array}$} & \\
\hline $\begin{array}{l}\text { Stvaranje uređaja proširene } \\
\text { realnosti - AR }\end{array}$ & 1 & 1,79 & & \\
\hline $\begin{array}{l}\text { Stvaranje uređaja virtualne } \\
\text { realnosti - VR }\end{array}$ & 1 & 1,79 & & \\
\hline Dodatni razvoj didaktičkih alata & 1 & 1,79 & \multirow{7}{*}{$\begin{array}{c}\text { Više mogućnosti, } \\
\text { personalizacija aplikacija i } \\
\text { sadržaja. }\end{array}$} & \\
\hline $\begin{array}{l}\text { Dodatni razvoj didaktičkih } \\
\text { pomagala }\end{array}$ & 1 & 1,79 & & \\
\hline Dodatni razvoj didaktičke robotike & 1 & 1,79 & & \\
\hline $\begin{array}{l}\text { Dodatni razvoj didaktičke } \\
\text { tehnologije }\end{array}$ & 1 & 1,79 & & \\
\hline $\begin{array}{l}\text { Korištenje mogućnosti računarstva } \\
\text { u oblaku }\end{array}$ & 1 & 1,79 & & \\
\hline Orijentacija na personalizaciju & 1 & 1,79 & & \\
\hline $\begin{array}{l}\text { Umjetna inteligencija - AI za } \\
\text { poosobnjeno učenje }\end{array}$ & 1 & 1,79 & & \\
\hline Kompatibilnost IT platformi & 1 & 1,79 & $\begin{array}{l}\text { Veća interoperabilnost } \\
\text { među sustavima i alatima. }\end{array}$ & \\
\hline Multidisciplinarnost & 1 & 1,79 & \multirow{3}{*}{$\begin{array}{l}\text { Promjena od tradicionalnog } \\
\text { ka inovativnim oblicima } \\
\text { učenja i poučavanja. }\end{array}$} & \multirow{4}{*}{$\begin{array}{l}\text { Strategija upravljanja } \\
\text { znanjem (ZNA) }\end{array}$} \\
\hline $\begin{array}{l}\text { Odvojiti podučavanje od } \\
\text { certificiranja }\end{array}$ & 1 & 1,79 & & \\
\hline $\begin{array}{l}\text { Promjena paradigme } \\
\text { tradicionalnog obrazovanja }\end{array}$ & 1 & 1,79 & & \\
\hline Usporedba dobrih praksi & 1 & 1,79 & Primjeri dobre prakse. & \\
\hline Total & 56 & $100 \%$ & & \\
\hline
\end{tabular}

Tablica 23. pokazuje uvjete koji utječu na korištenje društvenih medija u visokom obrazovanju odnosno preduvjete, za koje ispitanici smatraju da je potrebno ispuniti, kako bi se potencijal društvenih medija mogao iskoristiti za potrebe visokog obrazovanja u sljedećih 10 godina:

Dostupnost resursa - 5,37 \% ukupnog broja odgovora na ovo pitanje;

- financijska sredstva i izvori - potreban je održiv sustav financiranja, resursi koji su financijski dostupni i ulaganje u tehničke uvjete za edukaciju na udaljenim lokacijama.

Društvo u cjelini - 3,58 \% ukupnog broja odgovora na ovo pitanje;

- privlačenje investitora - odnosno suradnja s tvrtkama koje se bave tehnološkim napretkom,

- trendovi - odnosno praćenje i prilagodbu svjetskim trendovima.

$\underline{\text { Infrastruktura upravljanja znanjem }}-12,53 \%$ ukupnog broja odgovora na ovo pitanje;

- vlasništvo nad društvenim medijima odnosno licencama - odnosno tehnički uvjeti, 
- tehnička podrška, stvaranje namjenskih uloga za filtriranje, ažuriranje i održavanje društvenih medija - kroz informatičku infrastrukturu i ulaganje u infrastrukturu koja omogućava virtualno poučavanje,

- režimi obuke za korištenje društvenih medija - odnosno educiranje o novim IT tehnologijama i znanje korištenja društvenih medija,

- prepoznavanje i upravljanje rizicima - kroz sprečavanje štetnih utjecaja.

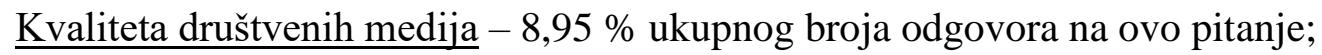

- jednostavnost korištenja društvenih medija - jer inače troše previše vremena,

- pouzdanost korištenja društvenih medija - važni su kvalitetni alati, osobito koji ne ugrožavaju privatnost korisnika.

Kultura razmjene znanja - 14,32 \% ukupnog broja odgovora na ovo pitanje;

- sustavna edukacija o korištenju društvenih medija - potrebna je edukacija svih dionika, kontinuirano praćenje razvoja novih tehnologija za učenje i poučavanje, bolje razumijevanje i korištenje umjetne inteligencije (AI) od nastavnika i kvalitetna edukacija „developera“ (programera),

- svo osoblje treba stalno biti informirano o novim saznanjima o korištenju DM za potrebe visokog obrazovanja, npr. mjesečne sesije dijeljenja znanja - kroz podizanje svijesti svih dionika i promociju benefita korištenja društvenih medija u visokom obrazovanju,

- kultura suradnje, koja nije konkurentna - kroz jaku želju za učenjem i primjenu ebontona.

Metrike uspješnosti - 7,16 \% ukupnog broja odgovora na ovo pitanje;

- uspostava ključnih indikatora uspješnosti korištenja društvenih medija u visokom obrazovanju kako bi se mogao pratiti napredak i olakšalo kontinuirano poboljšavanje odnosno bolje mogućnosti provjere, jednostavni, pouzdani i sigurni sustavi za valoriziranje napretka studenata.

Nacionalne politike / strategije obrazovanja - 12,53 \% ukupnog broja odgovora na ovo pitanje;

- podrška državnih institucija - i to kroz jedinstvenu nabavku i pojeftinjenje nabavke društvenih medija,

- pravna regulacija - potrebno je odrediti formalni okvir (pravni i organizacijski) za prikupljanje i analizu podataka o studentima, kontrolu korištenja podataka, neovisnu državnu kontrolu društvenih medija, zaštitu osobnosti i zaštitu privatnosti.

Očekivanja studenata $-5,37 \%$ ukupnog broja odgovora na ovo pitanje;

- ne poznaju svijet bez tehnologije - potrebno je pratiti življenje studenata,

- uče na nove načine - potrebno je pratiti učenje studenata, 
- $\quad$ komuniciraju i surađuju na nove načine - važna je komunikacija sa studentima putem svih uređaja koje koriste.

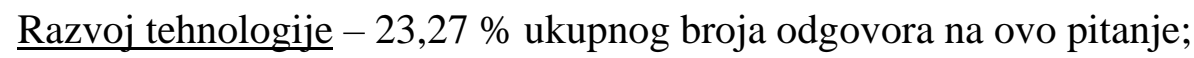

- digitalna transformacija društva - kroz izbjegavanje tehnološke agnostičnosti i tehnološke različitosti kod „,vendora“ Microsoft, Mac, Adobe,

- masovnije korištenje tehnologije, alata i aplikacija - kroz stvaranje uređaja pomiješane realnosti (MR), proširene realnosti (AR) i virtualne realnosti (VR),

- više mogućnosti, personalizacija aplikacija i sadržaja - kroz orijentacije na personalizaciju, umjetnu inteligenciju (AI) za poosobnjeno učenje, dodatni razvoj didaktičkih alata, pomagala, didaktičke tehnologije i robotike, korištenje mogućnosti računarstva u oblaku,

- veća interoperabilnost među sustavima i alatima - kroz kompatibilnost IT platformi.

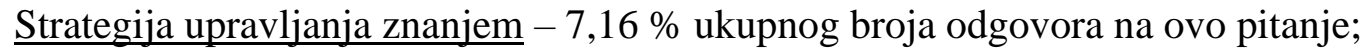

- promjena od tradicionalnog ka inovativnim oblicima učenja i poučavanja - što podrazumijeva multidisciplinarnost, promjenu paradigme tradicionalnog obrazovanja, usporedbu dobrih praksi i odvajanje podučavanja od certificiranja.

- primjeri dobre prakse - odnosno usporedbu dobrih praksi.

\subsubsection{3. Čimbenici koji utječu na ugradnju društvenih medija u visokoobrazovni proces}

Kako bi se odgovorilo na treće istraživačko pitanje IP3.: Koji sve čimbenici utječu na ugradnju društvenih medija u visokoobrazovni proces? panelistima su postavljena pitanja:

5. Koji sve čimbenici utječu na korištenje društvenih medija u visokoobrazovnom procesu (molimo navedite moguće čimbenike)?

6. Opišite važne čimbenike koji mogu unaprijediti korištenje društvenih medija $u$ visokoobrazovnom procesu?

Za potrebe analize kvalitativnih odgovora na peto i šesto postavljeno pitanje otvorenog tipa $u$ ovoj delfi studiji, pri čemu su se odgovori na šesto pitanje tretirali kao dopuna odgovorima na peto pitanje, dobiveni odgovori su iz sirovih podataka kodirani u koncepte kao temeljne jedinice analize, nakon čega je slijedilo grupiranje koncepata koji se odnose na isti fenomen $\mathrm{u}$ apstrahirane i uopćene kategorije koje su međusobno povezane. Zatim su kategorije ujedinjene u teme koje će se koristiti u 2. krugu istraživanja. 
Teorijskim uzorkovanjem, odnosno kružnim procesom usporedbe i refleksije poznatih informacija o čimbenicima koji utječu na implementaciju društvenih medija u visokoobrazovni proces i novog materijala dobivenog u odgovorima eksperata, ponavljanim nekoliko puta dobiveni su prikazi u Tablici 24. pri čemu se prvi stupac Koncepti odnosi na ključne riječi i opisnice čimbenika koji utječu na ugradnju društvenih medija u visokoobrazovni proces, drugi stupac Frekvencija odgovora sadrži učestalost Koncepata u odgovorima sudionika istraživanja (iskazanu numerički i postotno), treći stupac sadrži uopćene izjave apstrahirane iz Koncepata u Kategorije koje su korištene u 2. krugu istraživanja za opis Tema u koje su grupirane. Teme koje su se pojavile bile su, nakon obrade odgovora na sva istraživačka pitanja, sumarizirane i korištene u 2. krugu istraživanja kao ključni čimbenici promjene komunikacijske paradigme u visokom obrazovanju pod utjecajem društvenih medija.

Zaključno slijedi deskripcija i interpretacija predikcija panelista s naglaskom na razumijevanju čimbenika koji utječu na ugradnju društvenih medija u visokoobrazovni proces iz perspektive samih sudionika istraživanja.

Sljedeća tablica (Tablica 24.) prikazuje odgovore panelista delfi stručne skupine u svezi s čimbenicima koji utječu na ugradnju društvenih medija u visokoobrazovni proces. Ukupni broj panelista koji su odgovarali na ovo pitanje je 37, svi panelisti odgovorili su na ovo pitanje. U Tablici 24. prikazani odgovori panelista $\mathrm{N}=37$, ukupna frekvencija odgovora bila je 141.

Tablica 24. Rezultati 1. kruga delfi studije: Čimbenici koji utječu na ugradnju društvenih medija u visokoobrazovni proces, $\mathrm{N}=37$ (izvor: upitnik, Google obrasci, obrada autorice)

\begin{tabular}{|c|c|c|c|c|}
\hline Koncepti & & $\begin{array}{l}\text { ncija } \\
\text { ora } \\
\%\end{array}$ & Kategorije & Teme \\
\hline $\begin{array}{l}\text { Dostupnost tehnologije i alata koji } \\
\text { mogu biti podrška obrazovnom } \\
\text { procesu }\end{array}$ & 2 & 1,42 & \multirow{8}{*}{ Financijska sredstva i izvori. } & \multirow{9}{*}{ Dostupnost resursa (RES) } \\
\hline Dostupnost internet veze & 2 & 1,42 & & \\
\hline Cijena društvenih medija & 1 & 0,71 & & \\
\hline Dostupnost društvenih medija & 1 & 0,71 & & \\
\hline Dostupnost mobilnih platformi & 1 & 0,71 & & \\
\hline Dostupnost potrebne opreme & 1 & 0,71 & & \\
\hline Dostupnost struje & 1 & 0,71 & & \\
\hline $\begin{array}{l}\text { Mogućnost nabave uređaja (klijent } \\
\text { za pristup mediju) }\end{array}$ & 2 & 1,42 & & \\
\hline $\begin{array}{l}\text { Stručna pomoć za nepredviđene } \\
\text { situacije }\end{array}$ & 1 & 0,71 & $\begin{array}{l}\text { Administrativna korisnička } \\
\text { podrška. }\end{array}$ & \\
\hline Stav okoline (društva) & 2 & 1,42 & Trendovi. & \\
\hline
\end{tabular}




\begin{tabular}{|c|c|c|c|c|}
\hline $\begin{array}{l}\text { Razina educiranosti stanovništva } \\
\text { (da znaju koristiti } \\
\text { računala/mobilne uređaje) }\end{array}$ & 1 & 0,71 & & Društvo u cjelini (DR) \\
\hline Kulturološke razlike & 1 & 0,71 & Kulturološke razlike & Diustvo u ejermil (DN) \\
\hline Viša sila (npr. korona) & 1 & 0,71 & $\begin{array}{l}\text { Viša sila, npr. pandemija } \\
\text { korona virusa Covid- } 19 .\end{array}$ & \\
\hline $\begin{array}{l}\text { Tehnički uvjeti i razvijenost } \\
\text { infrastrukture }\end{array}$ & 4 & 2,84 & $\begin{array}{l}\text { Vlasništvo nad DM odnosno } \\
\text { licencama. }\end{array}$ & \multirow{6}{*}{$\begin{array}{c}\text { Infrastruktura upravljanja } \\
\text { znanjem (INFR) }\end{array}$} \\
\hline $\begin{array}{l}\text { Prilagođenost sustava za sve } \\
\text { namjene visokoobrazovnog } \\
\text { procesa }\end{array}$ & 1 & 0,71 & \multirow{3}{*}{$\begin{array}{c}\text { Tehnička podrška; stvaranje } \\
\text { namjenskih uloga za } \\
\text { filtriranje, ažuriranje i } \\
\text { održavanje DM. }\end{array}$} & \\
\hline $\begin{array}{l}\text { Sloboda izbora i korištenja } \\
\text { dodatnih alata }\end{array}$ & 1 & 0,71 & & \\
\hline Tehnička podrška & 1 & 0,71 & & \\
\hline Standardizacija glavnih platformi & 1 & 0,71 & $\begin{array}{l}\text { Režimi obuke za korištenje } \\
\text { DM. }\end{array}$ & \\
\hline Predviđanje i upravljanje rizicima & 1 & 0,71 & $\begin{array}{c}\text { Prepoznavanje i upravljanje } \\
\text { rizicima. }\end{array}$ & \\
\hline $\begin{array}{l}\text { Educiranost (kompetencije) } \\
\text { nastavnika }\end{array}$ & 12 & 8,52 & \multirow{4}{*}{$\begin{array}{l}\text { Sustavna edukacija o } \\
\text { korištenju DM. }\end{array}$} & \multirow{16}{*}{$\begin{array}{l}\text { Kultura razmjene znanja } \\
\text { (KUL) }\end{array}$} \\
\hline $\begin{array}{l}\text { Educiranost (kompetencije) } \\
\text { administracije }\end{array}$ & 4 & 2,84 & & \\
\hline $\begin{array}{l}\text { Educiranost (kompetencije) } \\
\text { studenata }\end{array}$ & 4 & 2,84 & & \\
\hline $\begin{array}{l}\text { Digitalna (IT) pismenost } \\
\text { nastavnika, studenata i osoblja na } \\
\text { visokim učilištima }\end{array}$ & 1 & 0,71 & & \\
\hline Dostupnost edukacijskih programa & 1 & 0,71 & \multirow{4}{*}{$\begin{array}{l}\text { Svo osoblje treba stalno biti } \\
\text { informirano o novim } \\
\text { saznanjima o korištenju DM } \\
\text { za potrebe visokog } \\
\text { obrazovanja, npr. mjesečne } \\
\text { sesije dijeljenja znanja. }\end{array}$} & \\
\hline Poznavanje alata društvenih medija & 1 & 0,71 & & \\
\hline $\begin{array}{l}\text { Razumijevanje metrike i } \\
\text { metodologije društvenih medija }\end{array}$ & 1 & 0,71 & & \\
\hline $\begin{array}{l}\text { Upoznatost korisnika s mrežama i } \\
\text { njihovim mogućnostima tj. } \\
\text { prednostima }\end{array}$ & 1 & 0,71 & & \\
\hline $\begin{array}{l}\text { Efikasnost u rješavanju konkretnih } \\
\text { problema i zahtjeva } \\
\text { visokoobrazovnih procesa }\end{array}$ & 1 & 0,71 & \multirow{4}{*}{$\begin{array}{c}\text { Proslava uspjeha i učenje iz } \\
\text { neuspjeha. }\end{array}$} & \\
\hline Kvaliteta obrazovnog programa & 1 & 0,71 & & \\
\hline $\begin{array}{l}\text { Sposobnost korisnika za brzu } \\
\text { prilagodbu }\end{array}$ & 1 & 0,71 & & \\
\hline $\begin{array}{l}\text { Vjerodostojnost onoga tko } \\
\text { objavljuje }\end{array}$ & 1 & 0,71 & & \\
\hline Kultura dijeljenja podataka & 1 & 0,71 & \multirow{4}{*}{$\begin{array}{l}\text { Kultura suradnje, koja nije } \\
\text { konkurentna. }\end{array}$} & \\
\hline $\begin{array}{l}\text { Nadilaženje digitalne razdjelnice } \\
\text { (generacijske, između studenata i } \\
\text { nastavnika) }\end{array}$ & 1 & 0,71 & & \\
\hline $\begin{array}{l}\text { „Networking“ kao ključan faktor } \\
\text { uspjeha }\end{array}$ & 1 & 0,71 & & \\
\hline $\begin{array}{l}\text { Učenje kao kolaborativni, ne } \\
\text { kompetitivni proces }\end{array}$ & 1 & 0,71 & & \\
\hline $\begin{array}{l}\text { Jednostavnost korištenja } \\
\text { društvenih medija i pristupa } \\
\text { sadržajima }\end{array}$ & 2 & 1,42 & $\begin{array}{c}\text { Jednostavnost korištenja } \\
\text { DM. }\end{array}$ & $\begin{array}{l}\text { Kvaliteta društvenih } \\
\text { medija (DM) }\end{array}$ \\
\hline
\end{tabular}




\begin{tabular}{|c|c|c|c|c|}
\hline Brzina komunikacije & 1 & 0,71 & & \\
\hline Lakoća komunikacije & 1 & 0,71 & & \\
\hline Primjenjivost društvenih medija & 1 & 0,71 & & \\
\hline Kvaliteta $\mathrm{i}$ ispravnost sadržaja & 2 & 1,42 & \multirow{7}{*}{ Pouzdanost korištenja DM. } & \\
\hline Privatnost podataka & 1 & 0,71 & & \\
\hline Sigurna (kriptirana) komunikacija & 1 & 0,71 & & \\
\hline $\begin{array}{l}\text { Sigurni (kriptirani) dokumenti i } \\
\text { materijali }\end{array}$ & 1 & 0,71 & & \\
\hline $\begin{array}{l}\text { Sigurnost korisnika i njihovih } \\
\text { podataka }\end{array}$ & 1 & 0,71 & & \\
\hline Transparentnost & 1 & 0,71 & & \\
\hline Zaštita autorskih prava & 1 & 0,71 & & \\
\hline Korisnost i vrijednost za korisnika & 2 & 1,42 & \multirow{5}{*}{$\begin{array}{l}\text { Redovitost ažuriranja DM } \\
\text { kako bi odražavalo trenutno } \\
\text { znanje. }\end{array}$} & \\
\hline $\begin{array}{l}\text { Ažuriranje podataka na društvenim } \\
\text { medijima }\end{array}$ & 1 & 0,71 & & \\
\hline Kvaliteta korisničkog sučelja & 1 & 0,71 & & \\
\hline $\begin{array}{l}\text { Mogućnost minimizacije reklama i } \\
\text { drugih marketinških aktivnosti } \\
\text { kojima nije mjesto u } \\
\text { visokoobrazovnom procesu }\end{array}$ & 1 & 0,71 & & \\
\hline Vizualizacija podataka & 1 & 0,71 & & \\
\hline $\begin{array}{l}\text { Interoperabilnost na razini } \\
\text { informacijskih sustava }\end{array}$ & 1 & 0,71 & \multirow{2}{*}{$\begin{array}{l}\text { Odgovarajuće povezivanje } \\
\text { DM s drugim alatima } \\
\text { (interoperabilnost). }\end{array}$} & \\
\hline $\begin{array}{l}\text { Postojanje velikog broja različitih } \\
\text { društvenih medija }\end{array}$ & 1 & 0,71 & & \\
\hline $\begin{array}{l}\text { Priznavanje uloženog truda od } \\
\text { strane nadležnih }\end{array}$ & 1 & 0,71 & $\begin{array}{c}\text { Uspostava ključnih } \\
\text { indikatora uspješnosti } \\
\text { korištenja DM u visokom } \\
\text { obrazovanju kako bi se } \\
\text { mogao pratiti napredak i } \\
\text { olakšalo kontinuirano } \\
\text { poboljšavanje. }\end{array}$ & \multirow{4}{*}{ Metrike uspješnosti (USP) } \\
\hline $\begin{array}{l}\text { Prilagođenost informacije ciljanoj } \\
\text { skupini }\end{array}$ & 2 & 1,42 & \multirow{3}{*}{$\begin{array}{l}\text { Ovisno o i prilagođeno cilju } \\
\text { (privlačenje odnosno } \\
\text { regrutacija novih studenata, } \\
\text { brendiranje odnosno } \\
\text { povećanje ugleda ustanove, } \\
\text { povećanje uspjeha } \\
\text { studenata, suradnja sa } \\
\text { zajednicom...). }\end{array}$} & \\
\hline $\begin{array}{l}\text { Nadilaženje učmalosti akademske } \\
\text { zajednice u regrutaciji }\end{array}$ & 1 & 0,71 & & \\
\hline $\begin{array}{l}\text { PR tj. odnosi s javnostima (interni i } \\
\text { eksterni) }\end{array}$ & 1 & 0,71 & & \\
\hline $\begin{array}{l}\text { Motivacija nastavnika (intrinzična } \\
\text { i ekstrinzična) }\end{array}$ & 4 & 2,84 & \multirow{4}{*}{$\begin{array}{c}\text { Integriranje korištenja DM s } \\
\text { ocjenom uspješnosti i } \\
\text { plaćom. }\end{array}$} & \multirow{4}{*}{$\begin{array}{c}\text { Motivacija nastavnika } \\
\text { (NAST) }\end{array}$} \\
\hline $\begin{array}{l}\text { Stavovi nastavnika o korisnosti } \\
\text { društvenih medija u nastavnom } \\
\text { procesu }\end{array}$ & 4 & 2,84 & & \\
\hline $\begin{array}{l}\text { Spremnost na cjeloživotno } \\
\text { obrazovanje }\end{array}$ & 2 & 1,42 & & \\
\hline $\begin{array}{l}\text { Spremnost nastavnika na } \\
\text { generiranje / korištenje sadržaja na } \\
\text { DM }\end{array}$ & 2 & 1,42 & & \\
\hline Ekonomski uvjeti & 1 & 0,71 & Podrška državnih institucija. & \\
\hline
\end{tabular}




\begin{tabular}{|c|c|c|c|c|}
\hline $\begin{array}{l}\text { Nadilaženje negativne selekcije u } \\
\text { napredovanju u akademskoj } \\
\text { zajednici }\end{array}$ & 1 & 0,71 & & \\
\hline $\begin{array}{l}\text { Podrška u rješavanju općeg } \\
\text { siromaštva visokog obrazovanja i } \\
\text { znanosti }\end{array}$ & 1 & 0,71 & & \\
\hline Stav nadležnih državnih institucija & 1 & 0,71 & & $\begin{array}{l}\text { Nacionalne } \\
\text { politike/strategije }\end{array}$ \\
\hline $\begin{array}{l}\text { Uvjeti usvojeni i propisani od } \\
\text { strane nadležnih državnih } \\
\text { institucija }\end{array}$ & 1 & 0,71 & & obrazovanja (POL) \\
\hline Pravna regulativa & 2 & 1,42 & \multirow{3}{*}{ Pravna regulacija. } & \\
\hline Državna regulacija i politike & 1 & 0,71 & & \\
\hline Veća privatizacija visokih učilišta & 1 & 0,71 & & \\
\hline Interes studenata. & 1 & 0,71 & \multirow{4}{*}{$\begin{array}{l}\text { Predstavljaju novi tip } \\
\text { studenata. }\end{array}$} & \multirow{5}{*}{$\begin{array}{l}\text { Očekivanja studenata } \\
\text { (STU) }\end{array}$} \\
\hline Motivacija studenata & 1 & 0,71 & & \\
\hline $\begin{array}{l}\text { Nedovoljna želja za stvarnim } \\
\text { učenjem i angažmanom }\end{array}$ & 1 & 0,71 & & \\
\hline Stavovi studenata & 1 & 0,71 & & \\
\hline Prevladavajući stil učenja & 1 & 0,71 & Uče na nove načine. & \\
\hline Stav uprave visokih učilišta & 6 & 4,26 & \multirow[b]{2}{*}{$\begin{array}{l}\text { Vodstvo odozgo od strane } \\
\text { uprave visokih učilišta. }\end{array}$} & \multirow{6}{*}{$\begin{array}{c}\text { Podrška vodstva visokih } \\
\text { učilišta (VU) }\end{array}$} \\
\hline $\begin{array}{l}\text { Edukacija, posebno onih koji } \\
\text { donose odluke }\end{array}$ & 1 & 0,71 & & \\
\hline $\begin{array}{l}\text { Sposobnost organizacije (liderstva) } \\
\text { za brzu prilagodbu }\end{array}$ & 3 & 2,13 & \multirow{2}{*}{$\begin{array}{l}\text { Provode dekan, prodekani, } \\
\text { voditelji studija, odsjeka i } \\
\text { katedri. }\end{array}$} & \\
\hline $\begin{array}{l}\text { Nadilaženje organizacijskih otpora } \\
\text { promjenama u sustavu visokog } \\
\text { obrazovanja }\end{array}$ & 2 & 1,42 & & \\
\hline Financijske mogućnosti & 3 & 2,13 & Financijska podrška. & \\
\hline Fleksibilnost institucija & 1 & 0,71 & Etičke i druge norme. & \\
\hline Razvoj tehnologije & 1 & 0,71 & $\begin{array}{l}\text { Digitalna transformacija } \\
\text { društva. }\end{array}$ & \multirow{3}{*}{ Razvoj tehnologija (TEH) } \\
\hline Tehnološki uvjeti & 1 & 0,71 & $\begin{array}{c}\text { Masovnije korištenje } \\
\text { tehnologije, alata i } \\
\text { aplikacija. }\end{array}$ & \\
\hline Jezične 'NLP' tehnologije & 1 & 0,71 & $\begin{array}{c}\text { Više mogućnosti, } \\
\text { personalizacija aplikacija i } \\
\text { sadržaja. }\end{array}$ & \\
\hline $\begin{array}{l}\text { Alternativni kanali za } \\
\text { komunikaciju i podučavanje }\end{array}$ & 1 & 0,71 & \multirow{7}{*}{$\begin{array}{c}\text { Promjena od tradicionalnog } \\
\text { ka inovativnim oblicima } \\
\text { učenja i poučavanja. }\end{array}$} & \multirow{7}{*}{$\begin{array}{l}\text { Strategija upravljanja } \\
\text { znanjem (ZNA) }\end{array}$} \\
\hline Angažiranost & 1 & 0,71 & & \\
\hline $\begin{array}{l}\text { Entuzijazam umjesto } \\
\text { profesionalnosti }\end{array}$ & 1 & 0,71 & & \\
\hline $\begin{array}{l}\text { Izlazak iz trenutnih okvira visokih } \\
\text { učilišta }\end{array}$ & 1 & 0,71 & & \\
\hline $\begin{array}{l}\text { Projektna struktura (za razliku od } \\
\text { hijerarhijske) }\end{array}$ & 1 & 0,71 & & \\
\hline Visoko individualizirano učenje & 1 & 0,71 & & \\
\hline $\begin{array}{l}\text { Optimalan miks DM i klasičnog } \\
\text { pristupa }\end{array}$ & 1 & 0,71 & & \\
\hline
\end{tabular}




\begin{tabular}{l|c|c|c|}
\hline $\begin{array}{l}\text { Definiranje pravila upotrebe DM } \\
\text { za visoko obrazovanje }\end{array}$ & 1 & 0,71 & $\begin{array}{c}\text { Usklađivanje strategije } \\
\text { korištenja DM s poslovnim } \\
\text { modelom i postojećim } \\
\text { sustavima i procesima VU. }\end{array}$ \\
\hline Prethodna priprema za uvođenje & 1 & 0,71 & $\begin{array}{c}\text { Komuniciranje strategije } \\
\text { korištenja DM svim } \\
\text { dionicima. }\end{array}$ \\
\cline { 1 - 4 } Internacionalizacija & 1 & 0,71 & $\begin{array}{c}\text { Internacionalizacija } \\
\text { povezivanje s drugim EU i } \\
\text { svjetskim visokim } \\
\text { učilištima). }\end{array}$ \\
\hline \begin{tabular}{l|c|c|c} 
Dobre prakse EU i svjetskih \\
visokoškolskih institucija
\end{tabular} & 1 & 0,71 & Primjeri dobre prakse. \\
\hline \multicolumn{1}{c|}{ Total } & 141 & $100 \%$ & \\
\hline
\end{tabular}

Tablica 24. pokazuje čimbenike koji, prema mišljenju panelista, utječu na ugradnju društvenih medija u visokoobrazovni proces:

Dostupnost resursa $-8,52 \%$ ukupnog broja odgovora na ovo pitanje;

- financijska sredstva i izvori - u smislu dostupnosti tehnologije i alata koji mogu biti podrška obrazovnom procesu, dostupnost struje i internet veze, dostupnost potrebne opreme te mogućnost nabave uređaja (klijent za pristup mediju), dostupnost mobilnih platformi te cijena i dostupnost društvenih medija,

- administrativna korisnička podrška - u vidu stručne pomoći za nepredviđene situacije.

Društvo u cjelini - 3,55 \% ukupnog broja odgovora na ovo pitanje;

- trendovi - odnosno stav okoline (društva), razina educiranosti stanovništva (primjerice da znaju koristiti računala/mobilne uređaje),

- kulturološke razlike,

- viša sila, npr. pandemija korona virusa Covid-19.

Infrastruktura upravljanja znanjem $-6,39 \%$ ukupnog broja odgovora na ovo pitanje;

- vlasništvo nad društvenim medijima odnosno licencama - odnosno tehnički uvjeti i razvijenost infrastrukture,

- tehnička podrška, stvaranje namjenskih uloga za filtriranje, ažuriranje i održavanje društvenih medija - kao što su prilagođenost sustava za sve namjene visokoobrazovnog procesa, sloboda izbora i korištenja dodatnih alata,

- režimi obuke za korištenje društvenih medija - odnosno standardizacija glavnih platformi,

- prepoznavanje i upravljanje rizicima - odnosno prepoznavanje i upravljanje rizicima.

Kultura razmjene znanja $-23,43 \%$ ukupnog broja odgovora na ovo pitanje; 
- sustavna edukacija o korištenju društvenih medija - i to educiranost (kompetencija) nastavnika, administracije i studenata te digitalna pismenost nastavnika, studenata $\mathrm{i}$ osoblja na visokim učilištima,

- svo osoblje treba stalno biti informirano o novim saznanjima o korištenju DM za potrebe visokog obrazovanja, npr. mjesečne sesije dijeljenja znanja - odnosno dostupnost edukacijskih programa, poznavanje alata društvenih medija, razumijevanje metrike i metodologije društvenih medija, i upoznatost korisnika $s$ mrežama i njihovim mogućnostima tj. prednostima,

- proslava uspjeha i učenje iz neuspjeha - odnosno efikasnost u rješavanju konkretnih problema i zahtjeva visokoobrazovnih procesa, kvalitetu obrazovnih sadržaja, sposobnost korisnika za brzu prilagodbu i vjerodostojnost onoga tko objavljuje,

- kultura suradnje, koja nije konkurentna - kroz nadilaženje digitalne razdjelnice (generacijske, između nastavnika i studenata), „networking“ kao ključan faktor uspjeha i učenje kao kolaborativni, a ne kompetitivni proces.

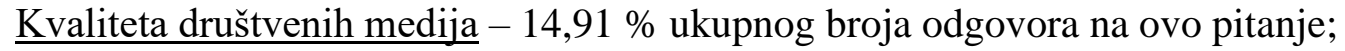

- jednostavnost korištenja društvenih medija - i pristupa sadržajima, brzina i lakoća komunikacije te primjenjivost društvenih medija,

- pouzdanost korištenja društvenih medija - i to kroz kvalitetu i ispravnost sadržaja, sigurnost korisnika i njihovih podataka, privatnost podataka, sigurnu (kriptiranu) komunikaciju, sigurne (kriptirane) dokumente i materijale, transparentnost i zaštitu autorskih prava,

- redovitost ažuriranja društvenih medija kako bi odražavalo trenutno stanje - kroz ažuriranje podataka na društvenim medijima, kvalitetu korisničkog sučelja, mogućnost minimizacije reklama i drugih marketinških aktivnosti kojima nije mjesto $u$ visokoobrazovnom procesu, vizualizaciju podataka, kako bi pružali korisnost i vrijednost za korisnika,

- odgovarajuće povezivanje društvenih medija s drugim alatima (interoperabilnost) - radi postojanja velikog broja različitih društvenih medija.

Metrike uspješnosti - 3,55 \% ukupnog broja odgovora na ovo pitanje;

- uspostava ključnih indikatora uspješnosti korištenja društvenih medija u visokom obrazovanju kako bi se mogao pratiti napredak i olakšalo kontinuirano poboljšavanje tj. priznavanje uloženog truda od strane nadležnih

- ovisno i prilagođeno o cilju (privlačenje odnosno regrutacija novih studenata, brendiranje odnosno povećanje ugleda ustanove, povećanje uspjeha studenata, suradnja 
sa zajednicom...) - pri čemu je važna prilagođenost informacije ciljanoj skupini, nadilaženje učmalosti akademske zajednice u regrutaciji i PR tj. odnosi s javnostima (interni i eksterni).

Motivacija nastavnika - 8,52 \% ukupnog broja odgovora na ovo pitanje;

- poticajni programi koji nagrađuju zaposlenike koji koriste / doprinose za društvene medije - koji mogu utjecati na motivaciju nastavnika (intrinzičnu i ekstrinzičnu) i stavove nastavnika o korisnosti društvenih medija u nastavnom procesu,

- integriranje korištenja društvenih medija s ocjenom uspješnosti i plaćom - kako bi se povećala spremnost nastavnika na cjeloživotno obrazovanje i na generiranje / korištenje sadržaja na društvenim medijima.

Nacionalne politike / strategije obrazovanja - 6,39 \% ukupnog broja odgovora na ovo pitanje;

- podrška državnih institucija - i to kroz stav i uvjete usvojene i propisane od strane nadležnih institucija, nadilaženje negativne selekcije u napredovanju u akademskoj zajednici te ekonomske uvjete i podršku u rješavanju općeg siromaštva visokog obrazovanja i znanosti,

- pravna regulacija - važna je pravna regulativa, i to državna regulacija i politike i veća privatizacija visokih učilišta.

Očekivanja studenata $-3,55 \%$ ukupnog broja odgovora na ovo pitanje;

- predstavljaju novi tip studenata - što je vidljivo kroz njihove interese, motivaciju i stavove, a postoji i nedovoljna želja za stvarnim učenjem i angažmanom

- uče na nove načine - odnosno njihov prevladavajući stil učenja.

Podrška vodstva visokih učilišta - 11,36 \% ukupnog broja odgovora na ovo pitanje;

- vodstvo odozgo od strane uprave visokih učilišta - tj. stav uprave visokih učilišta te edukacija, posebno onih koji donose odluke,

- provode dekan, prodekani, voditelji studija, odsjeka i katedri - što predstavlja sposobnost organizacije (liderstva) za brzu prilagodbu i nadilaženje organizacijskih otpora promjenama u sustavu visokog obrazovanja,

- financijska podrška - tj. financijske mogućnosti,

- etičke i druge norme - odnosno fleksibilnost institucija.

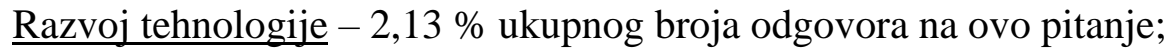

- digitalna transformacija društva - kroz razvoj tehnologije,

- masovnije korištenje tehnologije, alata i aplikacija - tj. tehnološki uvjeti,

- više mogućnosti, personalizacija aplikacija i sadržaja - odnosno jezične 'NLP' tehnologije. 


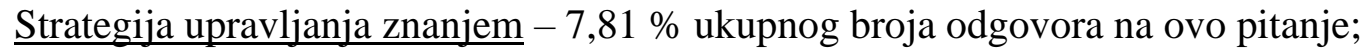

- promjena od tradicionalnog ka inovativnim oblicima učenja i poučavanja - potrebni su alternativni kanali za komunikaciju i podučavanje, angažiranost, entuzijazam umjesto profesionalnosti, izlazak iz trenutnih okvira visokih učilišta, projektna struktura (za razliku od hijerarhijske), visoko individualizirano učenje i optimalan miks društvenih medija i klasičnog pristupa učenju i podučavanju,

- usklađivanje strategije korištenja društvenih medija s poslovnim modelom i postojećim sustavima i procesima na visokim učilištima - tj. definiranje pravila upotrebe društvenih medija za visoko obrazovanje,

- komuniciranje strategije korištenja društvenih medija svim dionicima - tj. prethodna priprema za uvođenje,

- internacionalizacija - tj. povezivanje s drugim EU i svjetskim visokim učilištima,

- primjeri dobre prakse - odnosno dobre prakse EU i svjetskih visokoškolskih institucija.

\subsubsection{4. Čimbenici koji utječu na odnos visokih učilišta, nastavnika i studenata prema korištenju društvenih medija u visokom obrazovanju}

Kako bi se odgovorilo na četvrto istraživačko pitanje IP4.: Koji sve čimbenici utječu na odnos visokih učilišta, nastavnika i studenata prema društvenim medijima? panelistima su postavljena pitanja:

7. Što sve utječe na odnos visokih učilišta prema društvenim medijima?

8. Što sve utječe na odnos nastavnika prema društvenim medijima?

9. Što sve utječe na odnos studenata prema društvenim medijima?

Za potrebe analize kvalitativnih odgovora na sedmo, osmo i deveto postavljeno pitanje otvorenog tipa u ovoj delfi studiji, dobiveni odgovori su iz sirovih podataka kodirani u koncepte kao temeljne jedinice analize, nakon čega je slijedilo grupiranje koncepata koji se odnose na isti fenomen $\mathrm{u}$ apstrahirane i uopćene kategorije koje su međusobno povezane. Zatim su kategorije ujedinjene u teme koje će se koristiti u 2. krugu istraživanja.

Teorijskim uzorkovanjem, odnosno kružnim procesom usporedbe i refleksije poznatih informacija o čimbenicima koji utječu na odnos visokih učilišta, nastavnika i studenata prema korištenju društvenih medija u visokom obrazovanju, ponavljanim nekoliko puta dobiveni su prikazi u Tablici 25., Tablici 26. i Tablici 27. pri čemu se prvi stupac Koncepti odnosi na 
svojstva ili osobine tih čimbenika, drugi stupac Frekvencija odgovora sadrži učestalost čimbenika u odgovorima sudionika istraživanja (iskazanu numerički i postotno), treći stupac sadrži uopćene izjave apstrahirane iz Koncepata u Kategorije koje su bile korištene u 2. krugu istraživanja za opis Tema u koje su grupirane. Teme koje su se pojavile bile su, nakon obrade odgovora na sva istraživačka pitanja, sumarizirane i korištene u 2. krugu istraživanja kao ključni čimbenici promjene komunikacijske paradigme u visokom obrazovanju pod utjecajem društvenih medija.

Zaključno slijedi deskripcija i interpretacija predikcija panelista s naglaskom na razumijevanju čimbenika koji utječu na odnos visokih učilišta, nastavnika i studenata prema korištenju društvenih medija u visokom obrazovanju iz perspektive samih sudionika istraživanja.

\section{A. Čimbenici koji utječu na odnos visokih učilišta prema korištenju društvenih medija u visokom obrazovanju}

Sljedeća tablica (Tablica 25.) prikazuje odgovore panelista delfi stručne skupine u svezi s čimbenicima koji utječu na odnos visokih učilišta prema korištenju društvenih medija u visokom obrazovanju. Ukupni broj panelista koji su odgovarali na ovo pitanje je 37, svi panelisti odgovorili su na ovo pitanje. $\mathrm{U}$ Tablici 25. prikazni odgovori panelista $\mathrm{N}=37$, ukupna frekvencija odgovora bila je 109.

Tablica 25. Rezultati 1. kruga delfi studije: Čimbenici koji utječu na odnos visokih učilišta prema korištenju društvenih medija u visokom obrazovanju, N=37 (izvor: upitnik, Google obrasci, obrada autorice)

\begin{tabular}{|c|c|c|c|c|}
\hline Koncepti & & $\begin{array}{l}\text { ncija } \\
\text { ora } \\
\% \\
\end{array}$ & Kategorije & Teme \\
\hline Dostupnost resursa & 1 & 0,92 & \multirow{4}{*}{ Financijska sredstva i izvori. } & \multirow{4}{*}{ Dostupnost resursa (RES) } \\
\hline Financijski potencijal & 1 & 0,92 & & \\
\hline $\begin{array}{l}\text { Resursi za plaćanje „,community } \\
\text { managera“ }\end{array}$ & 1 & 0,92 & & \\
\hline Smanjenje troškova & 1 & 0,92 & & \\
\hline Društvena klima & 2 & 1,84 & \multirow{6}{*}{ Trendovi. } & \multirow{7}{*}{ Društvo u cjelini (DR) } \\
\hline Trendovi & 2 & 1,84 & & \\
\hline Imidž pojedinih DM u društvu & 1 & 0,92 & & \\
\hline Popularizacija DM & 1 & 0,92 & & \\
\hline $\begin{array}{l}\text { Potreba „mainstream“ } \\
\text { razumijevanja svijeta }\end{array}$ & 1 & 0,92 & & \\
\hline $\begin{array}{l}\text { Svjesnost vremena u kojem se } \\
\text { nalazimo }\end{array}$ & 1 & 0,92 & & \\
\hline Konkurentnost među učilištima & 2 & 1,84 & Konkurencija. & \\
\hline
\end{tabular}




\begin{tabular}{|c|c|c|c|c|}
\hline $\begin{array}{l}\text { Viša sila (npr. COVID-19 } \\
\text { pandemija je snažno katalizirala } \\
\text { uporabu DM) }\end{array}$ & 1 & 0,92 & $\begin{array}{l}\text { Viša sila, npr. pandemija } \\
\text { korona virusa Covid- } 19 .\end{array}$ & \\
\hline Informatička infrastruktura & 2 & 1,84 & $\begin{array}{l}\text { Vlasništvo nad DM odnosno } \\
\text { licencama. }\end{array}$ & \multirow[b]{2}{*}{$\begin{array}{l}\text { Infrastruktura upravljanja } \\
\text { znanjem (INFR) }\end{array}$} \\
\hline $\begin{array}{l}\text { Nesnalaženje nastavnika u } \\
\text { situacijama u kojima studenti bolje } \\
\text { poznaju korištene platforme }\end{array}$ & 1 & 0,92 & $\begin{array}{l}\text { Režimi obuke za korištenje } \\
\text { DM. }\end{array}$ & \\
\hline Educiranost nastavnog kadra & 4 & 3,68 & \multirow{2}{*}{$\begin{array}{l}\text { Sustavna edukacija o } \\
\text { korištenju DM. }\end{array}$} & \multirow{4}{*}{$\begin{array}{l}\text { Kultura razmjene znanja } \\
\text { (KUL) }\end{array}$} \\
\hline Educiranost nenastavnog kadra & 1 & 0,92 & & \\
\hline $\begin{array}{l}\text { Informiranost o novim saznanjima } \\
\text { o korištenju DM za potrebe } \\
\text { visokog obrazovanja }\end{array}$ & 2 & 1,84 & $\begin{array}{l}\text { Svo osoblje treba stalno biti } \\
\text { informirano o novim } \\
\text { saznanjima o korištenju DM } \\
\text { za potrebe visokog } \\
\text { obrazovanja, npr. mjesečne } \\
\text { sesije dijeljenja znanja. }\end{array}$ & \\
\hline Poticajna organizacijska kultura & 1 & 0,92 & $\begin{array}{c}\text { Kultura suradnje, koja nije } \\
\text { konkurentna. }\end{array}$ & \\
\hline $\begin{array}{l}\text { Mogućnost generiranja } \\
\text { relevantnog sadržaja }\end{array}$ & 2 & 1,84 & \multirow{2}{*}{$\begin{array}{c}\text { Jednostavnost korištenja } \\
\text { DM. }\end{array}$} & \multirow{5}{*}{$\begin{array}{l}\text { Kvaliteta društvenih } \\
\text { medija (DM) }\end{array}$} \\
\hline $\begin{array}{l}\text { Jednostavnost korištenja } \\
\text { društvenih medija }\end{array}$ & 1 & 0,92 & & \\
\hline $\begin{array}{l}\text { Kvalitetni i provjereni obrazovni } \\
\text { sadržaji }\end{array}$ & 9 & 8,28 & \multirow[b]{2}{*}{ Pouzdanost korištenja DM. } & \\
\hline $\begin{array}{l}\text { Informacijska sigurnost (zaštita } \\
\text { podataka, autorskih prava, } \\
\text { privatnosti i sigurnosti korisnika, } \\
\text { mogućnost kontrole) }\end{array}$ & 7 & 6,44 & & \\
\hline Velika dostupnost raznih platformi & 1 & 0,92 & $\begin{array}{l}\text { Odgovarajuće povezivanje } \\
\text { DM s drugim alatima } \\
\text { (interoperabilnost). }\end{array}$ & \\
\hline $\begin{array}{l}\text { Brendiranje odnosno povećanje } \\
\text { ugleda ustanove (samopromocija, } \\
\text { prezentiranje različitih aktivnosti } \\
\text { (projekata i akcija) od posebnog } \\
\text { značaja za instituciju) }\end{array}$ & 4 & 3,68 & \multirow{4}{*}{$\begin{array}{l}\text { Ovisno i prilagođeno o cilju } \\
\text { (privlačenje odnosno } \\
\text { regrutacija novih studenata, } \\
\text { brendiranje odnosno } \\
\text { povećanje ugleda ustanove, } \\
\text { povećanje uspjeha } \\
\text { studenata, suradnja sa } \\
\text { zajednicom...). }\end{array}$} & \multirow{4}{*}{ Metrike uspješnosti (USP) } \\
\hline $\begin{array}{l}\text { Privlačenje odnosno regrutacija } \\
\text { novih kvalitetnih studenata }\end{array}$ & 4 & 3,68 & & \\
\hline Odnosi s javnostima & 2 & 1,84 & & \\
\hline Povećanje uspjeha studenata & 1 & 0,92 & & \\
\hline $\begin{array}{l}\text { Poticajni programi koji nagrađuju } \\
\text { nastavnike koji koriste / doprinose } \\
\text { za DM. }\end{array}$ & 3 & 2,76 & \multirow{3}{*}{$\begin{array}{l}\text { Poticajni programi koji } \\
\text { nagrađuju zaposlenike koji } \\
\text { koriste / doprinose za DM. }\end{array}$} & \multirow{4}{*}{$\begin{array}{c}\text { Motivacija nastavnika } \\
\text { (NAST) }\end{array}$} \\
\hline $\begin{array}{l}\text { Stavovi nastavnika o korisnosti } \\
\text { društvenih medija u nastavnom } \\
\text { procesu }\end{array}$ & 3 & 2,76 & & \\
\hline $\begin{array}{l}\text { Spremnost nastavnika na nove } \\
\text { načine učenja i poučavanja }\end{array}$ & 3 & 2,76 & & \\
\hline $\begin{array}{l}\text { Ne postoji valorizacija truda } \\
\text { nastavnika na usklađivanju } \\
\text { kurikuluma }\end{array}$ & 1 & 0,92 & $\begin{array}{c}\text { Integriranje korištenja DM s } \\
\text { ocjenom uspješnosti i } \\
\text { plaćom. }\end{array}$ & \\
\hline
\end{tabular}




\begin{tabular}{|c|c|c|c|c|}
\hline Nacionalne strategije & 1 & 0,92 & \multirow{3}{*}{ Podrška državnih institucija. } & \multirow{3}{*}{$\begin{array}{c}\text { Nacionalne } \\
\text { politike/strategije } \\
\text { obrazovanja (POL) }\end{array}$} \\
\hline $\begin{array}{l}\text { Financiranje ovisno o } \\
\text { implementaciji nacionalne } \\
\text { strategije }\end{array}$ & 1 & 0,92 & & \\
\hline Stav nadležnih institucija & 1 & 0,92 & & \\
\hline $\begin{array}{l}\text { Nove generacije ne percipiraju } \\
\text { klasične DM }\end{array}$ & 1 & 0,92 & \multirow{3}{*}{$\begin{array}{l}\text { Predstavljaju novi tip } \\
\text { studenata. }\end{array}$} & \multirow{5}{*}{$\begin{array}{l}\text { Očekivanja studenata } \\
\text { (STU) }\end{array}$} \\
\hline $\begin{array}{l}\text { Nove generacije nemaju nikakvu } \\
\text { lojalnost prema nekom od DM }\end{array}$ & 1 & 0,92 & & \\
\hline Očekivanja studenata & 1 & 0,92 & & \\
\hline $\begin{array}{l}\text { Spremnost studenata na nove } \\
\text { načine učenja i poučavanja }\end{array}$ & 1 & 0,92 & Uče na nove načine. & \\
\hline Potreba približavanja studentima & 1 & 0,92 & $\begin{array}{l}\text { Komuniciraju i surađuju na } \\
\text { nove načine. }\end{array}$ & \\
\hline Stavovi vodstva VU & 8 & 7,36 & \multirow{4}{*}{$\begin{array}{l}\text { Vodstvo odozgo od strane } \\
\text { uprave visokih učilišta. }\end{array}$} & \multirow{7}{*}{$\begin{array}{c}\text { Podrška vodstva visokih } \\
\text { učilišta (VU) }\end{array}$} \\
\hline $\begin{array}{l}\text { Politika vodstva (uprave) VU } \\
\text { (sadržaj, program i struktura VU) }\end{array}$ & 2 & 1,84 & & \\
\hline Agilnost vodstva VU & 1 & 0,92 & & \\
\hline Educiranost vodstva (uprave) VU & 1 & 0,92 & & \\
\hline $\begin{array}{l}\text { Područje poučavanja (vrsta studija } \\
\text { koje izvode) }\end{array}$ & 2 & 1,84 & $\begin{array}{c}\text { Provode dekan, prodekani, } \\
\text { voditelji studija, odsjeka i } \\
\text { katedri. }\end{array}$ & \\
\hline $\begin{array}{l}\text { "Strah" uprava visokih učilišta od } \\
\text { dodatnih troškova za edukaciju, } \\
\text { licence i trajnu podršku } \\
\text { nastavnicima }\end{array}$ & 1 & 0,92 & Financijska podrška. & \\
\hline $\begin{array}{l}\text { Postojeće ustaljene procedure i } \\
\text { poslovni procesi u VU }\end{array}$ & 1 & 0,92 & Etičke i druge norme. & \\
\hline Tehnički resursi & 1 & 0,92 & $\begin{array}{c}\text { Masovnije korištenje } \\
\text { tehnologije, alata } \mathrm{i} \\
\text { aplikacija. }\end{array}$ & \multirow{2}{*}{ Razvoj tehnologija (TEH) } \\
\hline $\begin{array}{l}\text { Prepoznavanje mogućnosti } \\
\text { tehnologije u unapređenju VU }\end{array}$ & 1 & 0,92 & $\begin{array}{c}\text { Više mogućnosti, } \\
\text { personalizacija aplikacija i } \\
\text { sadržaja. }\end{array}$ & \\
\hline $\begin{array}{l}\text { Inovativni načini učenja i } \\
\text { poučavanja }\end{array}$ & 3 & 2,76 & \multirow{4}{*}{$\begin{array}{c}\text { Promjena od tradicionalnog } \\
\text { ka inovativnim oblicima } \\
\text { učenja i poučavanja. }\end{array}$} & \multirow{7}{*}{$\begin{array}{l}\text { Strategija upravljanja } \\
\text { znanjem (ZNA) }\end{array}$} \\
\hline $\begin{array}{l}\text { Stav akademske zajednice (koja ne } \\
\text { prihvaća „novitete“) }\end{array}$ & 1 & 0,92 & & \\
\hline Digitalizacija učenja i poučavanja & 1 & 0,92 & & \\
\hline $\begin{array}{l}\text { Povećanje kvalitete znanstvenih i } \\
\text { stručnih radova }\end{array}$ & 1 & 0,92 & & \\
\hline $\begin{array}{l}\text { Istraživanje VU kako bi studenti i } \\
\text { nastavnici prihvatili „novu“ } \\
\text { obrazovnu paradigmu }\end{array}$ & 1 & 0,92 & \multirow{3}{*}{$\begin{array}{l}\text { Usklađivanje strategije } \\
\text { korištenja DM s poslovnim } \\
\text { modelom i postojećim } \\
\text { sustavima i procesima VU. }\end{array}$} & \\
\hline $\begin{array}{l}\text { Mogućnost prezentacije vlastitih } \\
\text { znanstvenih i stručnih postignuća }\end{array}$ & 1 & 0,92 & & \\
\hline $\begin{array}{l}\text { Mogućnost prijenosa i dijeljenja } \\
\text { stručnog znanja (edukacijska } \\
\text { misija, prijenosi uživo) }\end{array}$ & 1 & 0,92 & & \\
\hline
\end{tabular}




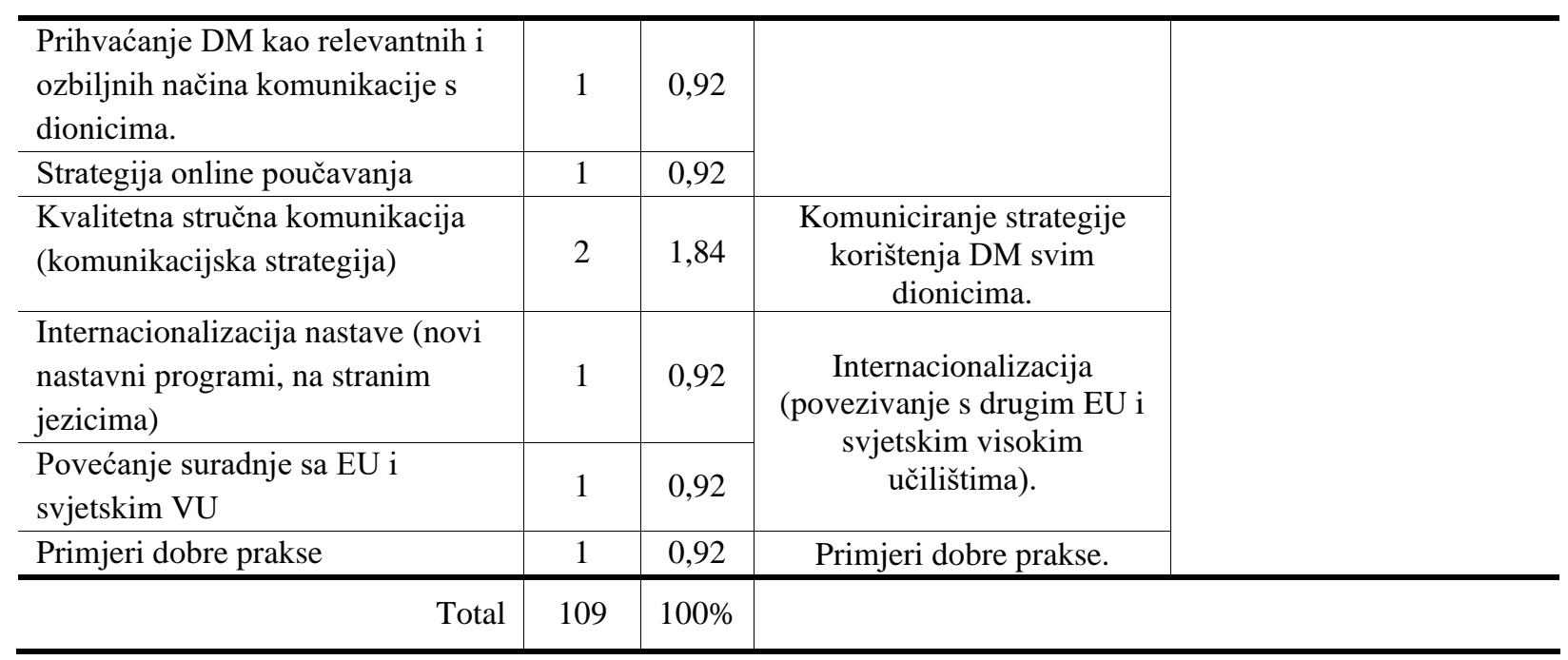

Tablica 25. pokazuje čimbenike koji, prema mišljenju panelista, utječu na odnos visokih učilišta prema korištenju društvenih medija u visokom obrazovanju:

Dostupnost resursa $-3,68 \%$ ukupnog broja odgovora na ovo pitanje;

- financijska sredstva i izvori - u smislu financijskog potencijala i dostupnosti resursa, resursa za plaćanje „,community managera“ te općenito smanjenja troškova.

Društvo u cjelini - 10,12 \% ukupnog broja odgovora na ovo pitanje;

- trendovi - odnosno društvena klima, imidž i popularizacija pojedinih društvenih medija u društvu, svjesnost vremena u kojem živimo i potreba „mainstream“ poimanja svijeta,

- konkurencija- tj. konkurentnost među učilištima,

- viša sila, npr. pandemija korona virusa Covid-19 - koja je snažno katalizirala upotrebu društvenih medija.

Infrastruktura upravljanja znanjem $-2,76 \%$ ukupnog broja odgovora na ovo pitanje;

- vlasništvo nad društvenim medijima odnosno licencama - odnosno informatička infrastruktura,

- režimi obuke za korištenje društvenih medija - zbog nesnalaženja nastavnika u situacijama u kojima studenti bolje poznaju korištene platforme.

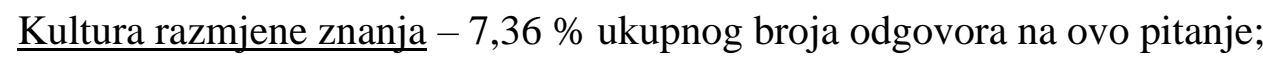

- sustavna edukacija o korištenju društvenih medija - i to posebno educiranost nastavnog, ali i nenastavnog kadra,

- svo osoblje treba stalno biti informirano o novim saznanjima o korištenju DM za potrebe visokog obrazovanja, npr. mjesečne sesije dijeljenja znanja - odnosno informiranost o novim saznanjima o korištenju društvenih medija za potrebe visokog obrazovanja,

- kultura suradnje, koja nije konkurentna - odnosno poticajna organizacijska kultura. 


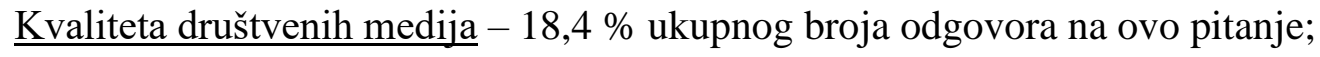

- jednostavnost korištenja društvenih medija - i mogućnost generiranja relevantnog sadržaja,

- pouzdanost korištenja društvenih medija - $\mathrm{i}$ to prvenstveno kroz kvalitetne i provjerene obrazovne sadržaje uz informacijsku sigurnost kao što je zaštita podataka, autorskih prava, privatnosti i sigurnosti korisnika te mogućnost kontrole),

- odgovarajuće povezivanje društvenih medija s drugim alatima (interoperabilnost) odnosno velika dostupnost raznih platformi.

Metrike uspješnosti - 10,12 \% ukupnog broja odgovora na ovo pitanje;

- ovisno i prilagođeno o cilju (privlačenje odnosno regrutacija novih studenata, brendiranje odnosno povećanje ugleda ustanove, povećanje uspjeha studenata, suradnja sa zajednicom...) - tj. brendiranje odnosno povećanje ugleda ustanove kao što je samopromocija, prezentiranje različitih aktivnosti (projekata i akcija) od posebnog značaja za instituciju te općenito odnosi s javnostima, a u svrhu privlačenja i regrutacije novih kvalitetnih studenata te povećanja njihovog uspjeha.

Motivacija nastavnika - 9,2\% ukupnog broja odgovora na ovo pitanje;

- poticajni programi koji nagrađuju zaposlenike koji koriste / doprinose za društvene medije - te spremnost nastavnika na nove načine učenja i poučavanja i stavovi nastavnika o korisnosti društvenih medija u nastavnom procesu,

- integriranje korištenja društvenih medija s ocjenom uspješnosti i plaćom - jer ne postoji valorizacija truda nastavnika na usklađivanju kurikuluma.

Nacionalne politike / strategije obrazovanja - 2,76 \% ukupnog broja odgovora na ovo pitanje;

- podrška državnih institucija - i to nacionalne strategije, financiranje ovisno o implementaciji nacionalne strategije i stav nadležnih institucija.

Očekivanja studenata - 4,6 \% ukupnog broja odgovora na ovo pitanje;

- predstavljaju novi tip studenata - osobito njihova očekivanja, jer nove generacije ne percipiraju klasične društvene medije, nemaju nikakvu lojalnost prema nekom društvenom mediju,

- uče na nove načine - stoga je važna spremnost studenata na nove načine učenja i poučavanja,

- komuniciraju i surađuju na nove načine - i postoji potreba približavanja studentima. 
Podrška vodstva visokih učilišta $-14,72$ \% ukupnog broja odgovora na ovo pitanje;

- vodstvo odozgo od strane uprave visokih učilišta - tj. stavovi vodstva visokih učilišta te politika vodstva (uprave) odnosno sadržaj, program i struktura visokih učilišta, njihova educiranost i agilnost vodstva visokog učilišta,

- provode dekan, prodekani, voditelji studija, odsjeka i katedri - kroz područje podučavanja tj. vrste studija koje izvode,

- financijska podrška - tj. „strah“ uprava visokih učilišta od dodatnih troškova za edukaciju, licence i trajnu podršku nastavnicima,

- etičke i druge norme - odnosno postojeće ustaljene procedure i poslovni procesi.

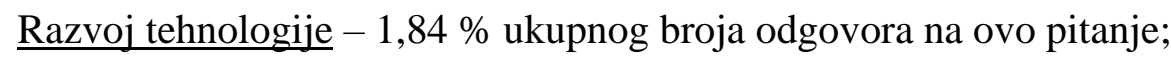

- masovnije korištenje tehnologije, alata i aplikacija - tj. tehnički resursi,

- više mogućnosti, personalizacija aplikacija i sadržaja - odnosno prepoznavanje mogućnosti tehnologije u unaprjeđenju visokih učilišta.

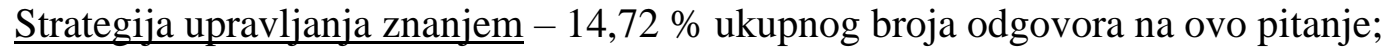

- promjena od tradicionalnog ka inovativnim oblicima učenja i poučavanja - tj. inovativni načini učenja i poučavanja, digitalizacija učenja i poučavanja, povećanje kvalitete znanstvenih i stručnih radova i /ili stav akademske zajednice koja ne prihvaća „novitete“.

- usklađivanje strategije korištenja društvenih medija s poslovnim modelom i postojećim sustavima i procesima na visokim učilištima - tj. strategija online poučavanja, prihvaćanje društvenih medija kao relevantnih i ozbiljnih načina komunikacije $\mathrm{s}$ dionicima, mogućnost prezentacije vlastitih znanstvenih i stručnih postignuća, mogućnost prijenosa i dijeljenja stručnog znanja odnosno edukacijska misija, prijenosi uživo i istraživanje visokih učilišta kako bi studenti i nastavnici prihvatili „novu“ obrazovnu paradigmu,

- komuniciranje strategije korištenja društvenih medija svim dionicima - tj. kvalitetna stručna komunikacija odnosno komunikacijska strategija,

- internacionalizacija - tj. internacionalizacija nastave kroz nove nastavne programe, na stranim jezicima, povećanje suradnje s EU i svjetskim visokim učilištima

- primjeri dobre prakse. 


\section{B. Čimbenici koji utječu na odnos nastavnika prema korištenju društvenih medija u visokom obrazovanju}

Sljedeća tablica (Tablica 26.) prikazuje odgovore panelista delfi stručne skupine u svezi s čimbenicima koji utječu na odnos nastavnika prema korištenju društvenih medija u visokom obrazovanju. Ukupni broj panelista koji su odgovarali na ovo pitanje je 37, svi panelisti odgovorili su na ovo pitanje. U Tablici 26. prikazani odgovori panelista $\mathrm{N}=37$, ukupna frekvencija odgovora bila je 105 .

Tablica 26. Rezultati 1. kruga delfi studije: Čimbenici koji utječu na odnos nastavnika prema korištenju društvenih medija u visokom obrazovanju, N=37 (izvor: upitnik, Google obrasci, obrada autorice)

\begin{tabular}{|c|c|c|c|c|}
\hline Koncepti & & $\begin{array}{l}\text { ncija } \\
\text { ora } \\
\%\end{array}$ & Kategorije & Teme \\
\hline $\begin{array}{l}\text { Dostupnost (raspoloživost) } \\
\text { društvenih medija }\end{array}$ & 2 & 1,9 & Financijska sredstva i izvori. & Dostupnost resursa (RES) \\
\hline Društvena klima & 3 & 2,85 & \multirow{2}{*}{ Trendovi. } & \multirow{5}{*}{ Društvo u cjelini (DR) } \\
\hline Praćenje trendova & 1 & 0,95 & & \\
\hline $\begin{array}{l}\text { Poznavanje što se sve koristi u } \\
\text { svakodnevnom radu u tvrtkama u } \\
\text { kojima će se studenti zapošljavati } \\
\text { nakon završetka studija }\end{array}$ & 1 & 0,95 & Preporuke poslodavaca. & \\
\hline $\begin{array}{l}\text { Korištenje DM u privatnom životu } \\
\text { (i prethodna iskustva) }\end{array}$ & 2 & 1,9 & \multirow{2}{*}{$\begin{array}{l}\text { Privatni utjecaji (prisutnost } \\
\text { prijatelja i obitelji na DM). }\end{array}$} & \\
\hline $\begin{array}{l}\text { Poticaji ili prepreke u okruženju } \\
\text { (obitelji, prijatelja i poznanika) }\end{array}$ & 1 & 0,95 & & \\
\hline $\begin{array}{l}\text { Pristupačnost odnosno } \\
\text { nepristupačnost DM }\end{array}$ & 1 & 0,95 & $\begin{array}{l}\text { Vlasništvo nad DM odnosno } \\
\text { licencama. }\end{array}$ & $\begin{array}{l}\text { Infrastruktura upravljanja } \\
\text { znanjem (INFR) }\end{array}$ \\
\hline Digitalne vještine (pismenost) & 6 & 5,7 & \multirow{7}{*}{$\begin{array}{l}\text { Sustavna edukacija o } \\
\text { korištenju DM. }\end{array}$} & \multirow{8}{*}{$\begin{array}{l}\text { Kultura razmjene znanja } \\
\text { (KUL) }\end{array}$} \\
\hline Poznavanje DM & 3 & 2,85 & & \\
\hline $\begin{array}{l}\text { Poznavanje kako implementirati } \\
\text { DM u VO }\end{array}$ & 3 & 2,85 & & \\
\hline $\begin{array}{l}\text { Kompetencija za metodiku } \\
\text { podučavanja }\end{array}$ & 1 & 0,95 & & \\
\hline Kompetencija za primjenu IKT & 1 & 0,95 & & \\
\hline Mogućnost usavršavanja & 1 & 0,95 & & \\
\hline Sustavna educiranost & 1 & 0,95 & & \\
\hline $\begin{array}{l}\text { Informiranost o potencijalnim } \\
\text { benefitima korištenja DM } \\
\text { (korisnim funkcionalnostima) }\end{array}$ & 8 & 7,6 & $\begin{array}{l}\text { Svo osoblje treba stalno biti } \\
\text { informirano o novim } \\
\text { saznanjima o korištenju DM } \\
\text { za potrebe visokog } \\
\text { obrazovanja, npr. mjesečne } \\
\text { sesije dijeljenja znanja. }\end{array}$ & \\
\hline $\begin{array}{l}\text { Jednostavnost korištenja } \\
\text { društvenih medija }\end{array}$ & 2 & 1,9 & $\begin{array}{l}\text { Jednostavnost korištenja } \\
\text { DM. }\end{array}$ & \multirow{2}{*}{$\begin{array}{l}\text { Kvaliteta društvenih } \\
\text { medija (DM) }\end{array}$} \\
\hline $\begin{array}{l}\text { Informacijska sigurnost (zaštita } \\
\text { podataka i autorskih prava) }\end{array}$ & 2 & 1,9 & Pouzdanost korištenja DM. & \\
\hline
\end{tabular}




\begin{tabular}{|c|c|c|c|c|}
\hline Kvaliteta informacija i sadržaja & 2 & 1,9 & & \\
\hline $\begin{array}{l}\text { Primjerenost DM znanstvenom } \\
\text { pristupu }\end{array}$ & 1 & 0,95 & & \\
\hline $\begin{array}{l}\text { Mogućnost boljeg uvida u } \\
\text { angažman studenata }\end{array}$ & 1 & 0,95 & \multirow{2}{*}{$\begin{array}{l}\text { Ovisno i prilagođeno o cilju } \\
\text { (privlačenje odnosno } \\
\text { regrutacija novih studenata, } \\
\text { brendiranje odnosno } \\
\text { povećanje ugleda ustanove, } \\
\text { povećanje uspjeha } \\
\text { studenata, suradnja sa } \\
\text { zajednicom...). }\end{array}$} & \multirow[b]{2}{*}{ Metrike uspješnosti (USP) } \\
\hline Povećanje uspjeha studenata & 1 & 0,95 & & \\
\hline $\begin{array}{l}\text { Stavovi i navike nastavnika (strah i } \\
\text { predrasude ili otvorenost } \mathrm{i} \\
\text { zainteresiranost nastavnika prema } \\
\text { promjenama) }\end{array}$ & 13 & 12,35 & \multirow{7}{*}{$\begin{array}{l}\text { Poticajni programi koji } \\
\text { nagrađuju zaposlenike koji } \\
\text { koriste / doprinose za DM. }\end{array}$} & \multirow{15}{*}{$\begin{array}{c}\text { Motivacija nastavnika } \\
\text { (NAST) }\end{array}$} \\
\hline $\begin{array}{l}\text { Angažiranost nastavnika (količina } \\
\text { potrebnog truda) i vlastito iskustvo }\end{array}$ & 9 & 8,55 & & \\
\hline $\begin{array}{l}\text { Spremnost nastavnika za } \\
\text { prihvaćanje novih načina } \\
\text { komunikacije (zamjenski ili } \\
\text { komplementarnih kanali) }\end{array}$ & 2 & 1,9 & & \\
\hline Motivacija nastavnika & 1 & 0,95 & & \\
\hline $\begin{array}{l}\text { Osobna procjena korisnosti DM za } \\
\text { postizanje nastavnih/obrazovnih } \\
\text { ciljeva }\end{array}$ & 1 & 0,95 & & \\
\hline $\begin{array}{l}\text { Sklonost prema cjeloživotnom } \\
\text { obrazovanju i stalnom učenju } \\
\text { novih trendova (alata, aplikacija, } \\
\text { platformi) }\end{array}$ & 1 & 0,95 & & \\
\hline Stavovi kolega & 1 & 0,95 & & \\
\hline $\begin{array}{l}\text { Stil komunikacije (preferirani } \\
\text { kanali komunikacije i } \\
\text { komunikacijske navike) }\end{array}$ & 3 & 2,85 & \multirow[t]{2}{*}{$\begin{array}{l}\text { Svo osoblje (nastavnici, } \\
\text { vanjski suradnici) koristi } \\
\text { DM. }\end{array}$} & \\
\hline Potreba za privatnošću & 1 & 0,95 & & \\
\hline Kreativnost nastavnika & 1 & 0,95 & \multirow{6}{*}{$\begin{array}{c}\text { Integriranje korištenja DM s } \\
\text { ocjenom uspješnosti i } \\
\text { plaćom. }\end{array}$} & \\
\hline Inovativnost nastavnika & 1 & 0,95 & & \\
\hline $\begin{array}{l}\text { Godine starosti (stariji nastavnici } \\
\text { nisu ispratili nove tehnologije) }\end{array}$ & 7 & 6,65 & & \\
\hline Osobni brending & 1 & 0,95 & & \\
\hline Vrednovanje rada u nastavi & 2 & 1,9 & & \\
\hline $\begin{array}{l}\text { Ambicija i želja za osobnim } \\
\text { napretkom }\end{array}$ & 1 & 0,95 & & \\
\hline Novi tip studenata & 1 & 0,95 & $\begin{array}{l}\text { Predstavljaju novi tip } \\
\text { studenata. }\end{array}$ & \multirow{2}{*}{$\begin{array}{l}\text { Očekivanja studenata } \\
\text { (STU) }\end{array}$} \\
\hline $\begin{array}{l}\text { Manjak kvalitetne integracije s } \\
\text { pojedinim studentima }\end{array}$ & 1 & 0,95 & $\begin{array}{c}\text { Komuniciraju i surađuju na } \\
\text { nove načine. }\end{array}$ & \\
\hline Stavovi vodstva VU prema DM & 5 & 4,75 & \multirow[b]{2}{*}{$\begin{array}{l}\text { Vodstvo odozgo od strane } \\
\text { uprave visokih učilišta. }\end{array}$} & \multirow[b]{2}{*}{$\begin{array}{c}\text { Podrška vodstva visokih } \\
\text { učilišta }(\mathrm{VU})\end{array}$} \\
\hline $\begin{array}{l}\text { Podrška vodstva (institucionalno } \\
\text { prihvaćanje DM kao sredstva za } \\
\text { promociju i provođenje obrazovnih } \\
\text { programa) }\end{array}$ & 4 & 3,8 & & \\
\hline
\end{tabular}




\begin{tabular}{|c|c|c|c|c|}
\hline Brzi razvoj tehnologija & 1 & 0,95 & $\begin{array}{c}\text { Masovnije korištenje } \\
\text { tehnologije, alata i } \\
\text { aplikacija. }\end{array}$ & Razvoj tehnologija (TEH) \\
\hline Inovativnost $\mathrm{u}$ izvođenju nastave & 1 & 0,95 & \multirow{2}{*}{$\begin{array}{c}\text { Promjena od tradicionalnog } \\
\text { ka inovativnim oblicima } \\
\text { učenja i poučavanja. }\end{array}$} & \multirow{4}{*}{$\begin{array}{l}\text { Strategija upravljanja } \\
\text { znanjem (ZNA) }\end{array}$} \\
\hline $\begin{array}{l}\text { Poznavanje i korištenje različitih } \\
\text { metoda poučavanja }\end{array}$ & 1 & 0,95 & & \\
\hline $\begin{array}{l}\text { Posebnosti svakog pojedinog } \\
\text { kolegija }\end{array}$ & 1 & 0,95 & \multirow{2}{*}{$\begin{array}{l}\text { Usklađivanje strategije } \\
\text { korištenja DM s poslovnim } \\
\text { modelom i postojećim } \\
\text { sustavima i procesima VU. }\end{array}$} & \\
\hline $\begin{array}{l}\text { Prihvaćanje webinara kao } \\
\text { normalnog ali korisnog oblika } \\
\text { prijenosa informacija i znanja }\end{array}$ & 1 & 0,95 & & \\
\hline Total & 105 & $100 \%$ & & \\
\hline
\end{tabular}

Tablica 26. pokazuje čimbenike koji, prema mišljenju panelista, utječu na odnos nastavnika prema korištenju društvenih medija u visokom obrazovanju:

Dostupnost resursa $-1,9 \%$ ukupnog broja odgovora na ovo pitanje;

- financijska sredstva i izvori - u smislu dostupnosti (raspoloživosti) društvenih medija.

Društvo u cjelini - 7,6 \% ukupnog broja odgovora na ovo pitanje;

- trendovi - odnosno društvena klima i praćenje trendova,

- preporuke poslodavaca - tj. poznavanje što se sve koristi u svakodnevnom radu u tvrtkama u kojima će se studenti zapošljavati nakon završetka studija,

- privatni utjecaji (prisutnost prijatelja i obitelji na društvenim medijima - odnosno korištenje društvenih medija u privatnom životu i prethodna iskustva te poticaji ili prepreke u okruženju tj. obitelj, prijatelja i poznanika.

$\underline{\text { Infrastruktura upravljanja znanjem }}-0,95 \%$ ukupnog broja odgovora na ovo pitanje;

- vlasništvo nad društvenim medijima odnosno licencama - odnosno pristupačnost ili nepristupačnost društvenih medija.

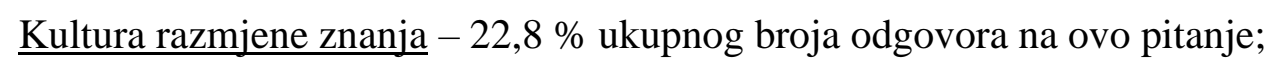

- sustavna edukacija o korištenju društvenih medija - tj. sustavna educiranost $\mathrm{i}$ mogućnost usavršavanja, kompetencija za primjenu informacijsko-komunikacijskih tehnologija, digitalne vještine (pismenost), poznavanje društvenih medija i kako ih implementirati u visoko obrazovanje te kompetencija za metodiku podučavanja,

- svo osoblje treba stalno biti informirano o novim saznanjima o korištenju DM za potrebe visokog obrazovanja, npr. mjesečne sesije dijeljenja znanja - odnosno potrebna je informiranost o potencijalnim benefitima korištenju društvenih medija za potrebe visokog obrazovanja i korisnim funkcionalnostima. 
$\underline{\text { Kvaliteta društvenih medija }}-6,65 \%$ ukupnog broja odgovora na ovo pitanje;

- jednostavnost korištenja društvenih medija,

- pouzdanost korištenja društvenih medija - i to kvaliteta informacija i sadržaja, informacijska sigurnost kroz zaštitu podataka i autorskih prava te primjerenost društvenih medija znanstvenom pristupu.

Metrike uspješnosti - 1,9 \% ukupnog broja odgovora na ovo pitanje;

- ovisno i prilagođeno o cilju (privlačenje odnosno regrutacija novih studenata, brendiranje odnosno povećanje ugleda ustanove, povećanje uspjeha studenata, suradnja sa zajednicom...) - tj. povećanje uspjeha studenata i mogućnost boljeg uvida u njihov angažman.

Motivacija nastavnika - 42,75\% ukupnog broja odgovora na ovo pitanje;

- poticajni programi koji nagrađuju zaposlenike koji koriste / doprinose za društvene medije - tj. motivacija nastavnika i spremnost nastavnika za prihvaćanje novih načina komunikacije kroz zamjenske ili komplementarne kanale, stavovi i navike nastavnika odnosno strah i predrasude ili otvorenost i zainteresiranost prema promjenama, sklonost prema cjeloživotnom obrazovanju i stalnom učenju novih trendova tj. alata, aplikacija, angažiranost nastavnika tj. količina potrebnog truda i vlastito iskustvo, i platformi, osobna procjena korisnosti društvenih medija za postizanje nastavnih / obrazovnih ciljeva te stav kolega,

- svo osoblje (nastavnici, vanjski suradnici) koristi društvene medije - ovisno o stilu komunikacije tj. preferiranim kanalima komunikacije i komunikacijske navike te potreba za privatnošću,

- integriranje korištenja društvenih medija s ocjenom uspješnosti i plaćom - tj. vrednovanje rada u nastavi, ambicija i želja za osobnim napretkom te osobni brending, kreativnost $\mathrm{i}$ inovativnost nastavnika, a posebno godine starosti jer stariji nastavnici nisu ispratili nove tehnologije.

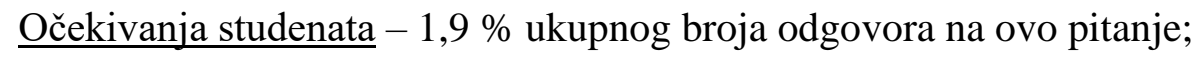

- predstavljaju novi tip studenata,

- komuniciraju i surađuju na nove načine - i postoji manjak kvalitetne integracije s pojedinim studentima.

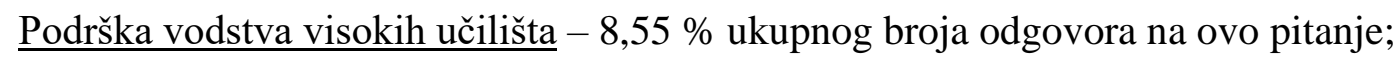

- vodstvo odozgo od strane uprave visokih učilišta - tj. stavovi vodstva visokih učilišta prema društvenim medijima te podrška vodstva odnosno institucionalno prihvaćanje društvenih medija kao sredstva za promociju i provođenje obrazovnih programa. 


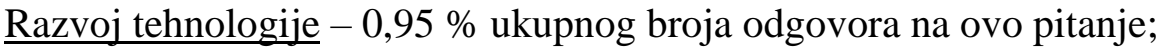

- masovnije korištenje tehnologije, alata i aplikacija - tj. brzi razvoj tehnologija.

Strategija upravljanja znanjem - 3,8 \% ukupnog broja odgovora na ovo pitanje;

- promjena od tradicionalnog ka inovativnim oblicima učenja i poučavanja - tj. inovativnost $\mathrm{u}$ izvođenju nastave i poznavanje te korištenje različitih metoda poučavanja,

- usklađivanje strategije korištenja društvenih medija s poslovnim modelom i postojećim sustavima i procesima na visokim učilištima - tj. posebnosti svakog pojedinog kolegija te prihvaćanje webinara kao normalnog, ali korisnog oblika prijenosa informacija i znanja.

\section{C. Čimbenici koji utječu na odnos studenata prema korištenju društvenih medija u visokom obrazovanju}

Sljedeća tablica (Tablica 27.) prikazuje odgovore panelista delfi stručne skupine u svezi s čimbenicima koji utječu na odnos studenata prema korištenju društvenih medija u visokom obrazovanju. Ukupni broj panelista koji su odgovarali na ovo pitanje je 37, svi panelisti odgovorili su na ovo pitanje. U Tablici 27. prikazni odgovori panelista $\mathrm{N}=37$, ukupna frekvencija odgovora bila je 88 .

Tablica 27. Rezultati 1. kruga delfi studije: Čimbenici koji utječu na odnos studenata prema korištenju društvenih medija u visokom obrazovanju, N=37 (izvor: upitnik, Google obrasci, obrada autorice)

\begin{tabular}{|c|c|c|c|c|}
\hline Koncepti & & $\begin{array}{l}\text { ncija } \\
\text { ora } \\
\%\end{array}$ & Kategorije & Teme \\
\hline $\begin{array}{l}\text { Vrijeme u koje se komunicira } \\
\text { putem društvenih medija }\end{array}$ & 1 & 1,14 & $\begin{array}{c}\text { Raspodjela vremena odnosno } \\
\text { predviđeno vrijeme za } \\
\text { aktivnosti povezane sa } \\
\text { korištenjem DM. } \\
\end{array}$ & Dostupnost resursa (RES) \\
\hline Društvena klima i kultura & 3 & 3,42 & \multirow{3}{*}{ Trendovi. } & \multirow{6}{*}{ Društvo u cjelini (DR) } \\
\hline Globalni trendovi & 3 & 3,42 & & \\
\hline $\begin{array}{l}\text { Popularnost određenih DM među } \\
\text { studentskom populacijom }\end{array}$ & 2 & 2,28 & & \\
\hline $\begin{array}{l}\text { Korištenje DM u privatnom životu } \\
\text { (i prethodna iskustva) }\end{array}$ & 3 & 3,42 & \multirow{3}{*}{$\begin{array}{l}\text { Privatni utjecaji (prisutnost } \\
\text { prijatelja i obitelji na DM). }\end{array}$} & \\
\hline $\begin{array}{l}\text { Izbor kanala za komunikaciju s } \\
\text { važnim osobama }\end{array}$ & 1 & 1,14 & & \\
\hline $\begin{array}{l}\text { Nazočnost prijatelja i obitelji na } \\
\text { određenim DM }\end{array}$ & 1 & 1,14 & & \\
\hline
\end{tabular}




\begin{tabular}{|c|c|c|c|c|}
\hline $\begin{array}{l}\text { Prezir prema mrežama koje koriste } \\
\text { njihovi roditelji }\end{array}$ & 1 & 1,14 & & \\
\hline $\begin{array}{l}\text { Vrijednost socijalne komponente } \\
\text { pojedinog DM }\end{array}$ & 1 & 1,14 & & \\
\hline $\begin{array}{l}\text { Vrijeme koje dnevno provode na } \\
\text { DM }\end{array}$ & 1 & 1,14 & & \\
\hline Digitalne vještine (pismenost) & 4 & 4,56 & \multirow[b]{2}{*}{$\begin{array}{l}\text { Sustavna edukacija o } \\
\text { korištenju DM. }\end{array}$} & \multirow{11}{*}{$\begin{array}{l}\text { Kultura razmjene znanja } \\
\text { (KUL) }\end{array}$} \\
\hline $\begin{array}{l}\text { Potrebne vještine za korištenje } \\
\text { DM (poznavanje funkcionalnosti, } \\
\text { sposobnost analize sadržaja) }\end{array}$ & 4 & 4,56 & & \\
\hline $\begin{array}{l}\text { Percipirana korist za } \\
\text { studij/edukacijske svrhe (npr. } \\
\text { razmjena informacija i materijala } \\
\text { za polaganje ispita te pomoć kod } \\
\text { kolaboracije s drugima u timskim } \\
\text { zadacima) }\end{array}$ & 3 & 3,42 & \multirow{5}{*}{$\begin{array}{l}\text { Svo osoblje treba stalno biti } \\
\text { informirano o novim } \\
\text { saznanjima o korištenju DM } \\
\text { za potrebe visokog } \\
\text { obrazovanja, npr. mjesečne } \\
\text { sesije dijeljenja znanja. }\end{array}$} & \\
\hline $\begin{array}{l}\text { Stupanj informiranosti nastavnika } \\
\text { o digitalizaciji }\end{array}$ & 1 & 1,14 & & \\
\hline $\begin{array}{l}\text { Stupanj informiranosti studenata o } \\
\text { digitalizaciji }\end{array}$ & 1 & 1,14 & & \\
\hline $\begin{array}{l}\text { Stupanj informiranosti visokih } \\
\text { učilišta o digitalizaciji }\end{array}$ & 1 & 1,14 & & \\
\hline Postojanje alternativa & 1 & 1,14 & & \\
\hline $\begin{array}{l}\text { Bijeg od ozbiljnog znanstvenog } \\
\text { rada }\end{array}$ & 1 & 1,14 & $\begin{array}{c}\text { Proslava uspjeha i učenje iz } \\
\text { neuspjeha. }\end{array}$ & \\
\hline Mogućnost projektnog rada & 1 & 1,14 & \multirow{3}{*}{$\begin{array}{l}\text { Kultura suradnje, koja nije } \\
\text { konkurentna. }\end{array}$} & \\
\hline $\begin{array}{l}\text { Sklonost kolaboraciji (u } \\
\text { virtualnom okruženju) }\end{array}$ & 1 & 1,14 & & \\
\hline $\begin{array}{l}\text { Sklonost timskom radu (u } \\
\text { virtualnom okruženju) }\end{array}$ & 1 & 1,14 & & \\
\hline $\begin{array}{l}\text { Jednostavnost i lakoća korištenja } \\
\text { društvenih medija }\end{array}$ & 4 & 4,56 & \multirow{9}{*}{$\begin{array}{c}\text { Jednostavnost korištenja } \\
\text { DM. }\end{array}$} & \multirow{12}{*}{$\begin{array}{l}\text { Kvaliteta društvenih } \\
\text { medija (DM) }\end{array}$} \\
\hline $\begin{array}{l}\text { Dostupnost kanala, informacija, } \\
\text { sadržaja kad su potrebni, na bilo } \\
\text { kojem uređaju, bilo gdje }\end{array}$ & 3 & 3,42 & & \\
\hline $\begin{array}{l}\text { Mogućnost odabira raznih } \\
\text { područja (predmeta) od interesa }\end{array}$ & 1 & 1,14 & & \\
\hline $\begin{array}{l}\text { Nema troškova prijevoza i gubitka } \\
\text { vremena na put }\end{array}$ & 1 & 1,14 & & \\
\hline Olakšana komunikacija & 1 & 1,14 & & \\
\hline Pogodno za zaposlene osobe & 1 & 1,14 & & \\
\hline Preglednost DM & 1 & 1,14 & & \\
\hline $\begin{array}{l}\text { Mogući su razni formati nastavnih } \\
\text { materijala: tekst, video, animacija, } \\
\text { igrice, videokonferencije, virtualne } \\
\text { učionice itd.. }\end{array}$ & 1 & 1,14 & & \\
\hline „User friendly“ sučelja DM & 1 & 1,14 & & \\
\hline $\begin{array}{l}\text { Kvaliteta informacija i sadržaja } \\
\text { DM }\end{array}$ & 2 & 2,28 & \multirow{3}{*}{ Pouzdanost korištenja DM. } & \\
\hline $\begin{array}{l}\text { Korist (benefiti) korištenja DM } \\
\text { (korisnih funkcionalnosti) }\end{array}$ & 2 & 2,28 & & \\
\hline Transparentnost & 1 & 1,14 & & \\
\hline
\end{tabular}




\begin{tabular}{|c|c|c|c|c|}
\hline $\begin{array}{l}\text { Sažete stvari koje su im potrebne s } \\
\text { poveznicama na dublja } \\
\text { istraživanja (sve na jednom } \\
\text { mjestu) }\end{array}$ & 1 & 1,14 & $\begin{array}{l}\text { Odgovarajuće povezivanje } \\
\text { DM s drugim alatima } \\
\text { (interoperabilnost). }\end{array}$ & \\
\hline Motivacija studenata za učenje & 2 & 2,28 & \multirow{3}{*}{$\begin{array}{l}\text { Ovisno i prilagođeno o cilju } \\
\text { (privlačenje odnosno } \\
\text { regrutacija novih studenata, } \\
\text { brendiranje odnosno } \\
\text { povećanje ugleda ustanove, } \\
\text { povećanje uspjeha studenata, } \\
\text { suradnja sa zajednicom...). }\end{array}$} & \multirow{3}{*}{$\begin{array}{c}\text { Metrike uspješnosti } \\
\text { (USP) }\end{array}$} \\
\hline $\begin{array}{l}\text { Mogućnost dobivanja nagradnih } \\
\text { bodova }\end{array}$ & 2 & 2,28 & & \\
\hline $\begin{array}{l}\text { Nedovoljno znanje nastavnika } \\
\text { koje utječe na rezultate studenata }\end{array}$ & 1 & 1,14 & & \\
\hline $\begin{array}{l}\text { Stavovi nastavnika (poticaj od } \\
\text { strane nastavnika) }\end{array}$ & 2 & 2,28 & \multirow{3}{*}{$\begin{array}{c}\text { Poticajni programi koji } \\
\text { nagrađuju zaposlenike koji } \\
\text { koriste / doprinose za DM. }\end{array}$} & \multirow{4}{*}{$\begin{array}{c}\text { Motivacija nastavnika } \\
\text { (NAST) }\end{array}$} \\
\hline $\begin{array}{l}\text { Angažman nastavnika (npr. trud } \\
\text { koji nastavnici ulažu u pripremu } \\
\text { materijala) }\end{array}$ & 2 & 2,28 & & \\
\hline Spremnost nastavnika & 1 & 1,14 & & \\
\hline $\begin{array}{l}\text { Popularnost DM u užoj } \\
\text { akademskoj populaciji }\end{array}$ & 1 & 1,14 & $\begin{array}{l}\text { Svo osoblje (nastavnici, } \\
\text { vanjski suradnici) koristi } \\
\text { DM. }\end{array}$ & \\
\hline $\begin{array}{l}\text { Pripremljenost za metode učenja } \\
\text { korišstenjem DM kroz ranije } \\
\text { školovanje }\end{array}$ & 2 & 2,28 & \multirow{2}{*}{$\begin{array}{l}\text { Uključuje i niže razine } \\
\text { obrazovanja } \\
\text { (osnovnoškolsko, } \\
\text { srednjoškolsko) te } \\
\text { visokoškolsko obrazovanje. }\end{array}$} & \multirow{2}{*}{$\begin{array}{c}\text { Nacionalne } \\
\text { politike/strategije } \\
\text { obrazovanja (POL) }\end{array}$} \\
\hline $\begin{array}{l}\text { Prethodna iskustva } \\
\text { studenata/učenika iz prethodnih } \\
\text { razina edukacije (srednja ili } \\
\text { osnovna škola). }\end{array}$ & 2 & 2,28 & & \\
\hline $\begin{array}{l}\text { Nove generacije nemaju otpora } \\
\text { prema korištenju DM }\end{array}$ & 1 & 1,14 & $\begin{array}{l}\text { Ne poznaju svijet bez } \\
\text { tehnologije. }\end{array}$ & \multirow{9}{*}{$\begin{array}{l}\text { Očekivanja studenata } \\
\text { (STU) }\end{array}$} \\
\hline $\begin{array}{l}\text { Novi tip studenata (osobnost, } \\
\text { ciljevi koje si postavljaju u vezi } \\
\text { studija i privatnog života, } \\
\text { prilagodljivi) }\end{array}$ & 4 & 4,56 & \multirow{3}{*}{$\begin{array}{l}\text { Predstavljaju novi tip } \\
\text { studenata. }\end{array}$} & \\
\hline Generacijski jaz & 1 & 1,14 & & \\
\hline $\begin{array}{l}\text { Stariji studenti manje skloni } \\
\text { koristiti DM }\end{array}$ & 1 & 1,14 & & \\
\hline $\begin{array}{l}\text { Spremnost na aktivnost i izvan } \\
\text { "regularnih" sati za učenje }\end{array}$ & 1 & 1,14 & Uče na nove načine. & \\
\hline $\begin{array}{l}\text { Pristup nastavnim materijalima } \\
\text { moguć je } 0-24 \text { - kada god studentu } \\
\text { odgovara i u količini koja mu } \\
\text { odgovara, s bilo kojeg mjesta }\end{array}$ & 2 & 2,28 & \multirow{4}{*}{$\begin{array}{l}\text { Komuniciraju i surađuju na } \\
\text { nove načine. }\end{array}$} & \\
\hline Nisu lojalni nekom pojedinom DM & 1 & 1,14 & & \\
\hline Pristup im generacijski odgovara & 1 & 1,14 & & \\
\hline Stil učenja & 1 & 1,14 & & \\
\hline $\begin{array}{l}\text { Spremnost VU (institucionalno } \\
\text { prihvaćanje DM ) }\end{array}$ & 1 & 1,14 & $\begin{array}{l}\text { Vodstvo odozgo od strane } \\
\text { uprave visokih učilišta. }\end{array}$ & $\begin{array}{c}\text { Podrška vodstva visokih } \\
\text { učilišta (VU) }\end{array}$ \\
\hline Inovativna nastava & 1 & 1,14 & & \\
\hline
\end{tabular}




\begin{tabular}{l|c|c|c|c}
$\begin{array}{l}\text { Prednosti korištenja u usporedbi s } \\
\text { konvencionalnim metodama } \\
\text { komuniciranja i učenja }\end{array}$ & 1 & 1,14 & $\begin{array}{c}\text { Promjena od tradicionalnog } \\
\text { ka inovativnim oblicima } \\
\text { učenja i poučavanja. }\end{array}$ & $\begin{array}{c}\text { Strategija upravljanja } \\
\text { znanjem (ZNA) }\end{array}$ \\
\hline $\begin{array}{l}\text { Uz učenje na daljinu savladavaju } \\
\text { se i digitalne vještine }\end{array}$ & 1 & 1,14 & \\
\hline Total & 88 & $100 \%$ & \\
\hline
\end{tabular}

Tablica 27. pokazuje čimbenike koji, prema mišljenju panelista, utječu na odnos studenata prema korištenju društvenih medija u visokom obrazovanju:

Dostupnost resursa $-1,14 \%$ ukupnog broja odgovora na ovo pitanje;

- raspodjela vremena odnosno predviđeno vrijeme za aktivnosti povezane za korištenje društvenih medija - u smislu vremena u koje se komunicira putem društvenih medija.

Društvo u cjelini - 18,24 \% ukupnog broja odgovora na ovo pitanje;

- trendovi - odnosno globalni trendovi, kao i društvena klima i kultura te popularnost određenih društvenih medija među studentskom populacijom,

- privatni utjecaji (prisutnost prijatelji i obitelji na društvenim medijima) - tj. korištenje društvenih medija u privatnom životu i prethodna iskustva, vrijeme koje dnevno provode na društvenim medijima, vrijednost socijalne komponente pojedinog društvenog medija i izbor kanala za komunikaciju s važnim osobama, nazočnost prijatelja i obitelji na određenim društvenim medijima, ali i prezir prema mrežama koje koriste njihovi roditelji.

Kultura razmjene znanja $-21,66 \%$ ukupnog broja odgovora na ovo pitanje;

- sustavna edukacija o korištenju društvenih medija - i digitalne vještine (pismenost) i potrebne vještine za korištenje društvenih medija tj. poznavanje funkcionalnosti, sposobnost analize sadržaja,

- svo osoblje treba stalno biti informirano o novim saznanjima o korištenju DM za potrebe visokog obrazovanja, npr. mjesečne sesije dijeljenja znanja - odnosno percipirana korist za studij / edukacijske svrhe kao što je npr. razmjena informacija i materijala za polaganje ispita te pomoć kod kolaboracije s drugima u timskim zadacima, stupanj informiranosti visokih učilišta, nastavnika i samih studenata o digitalizaciji i postojanje alternativa,

- proslava uspjeha i učenje iz neuspjeha - jer postoji tendencija bijega od ozbiljnog znanstvenog rada,

- kultura suradnje, koja nije konkurentna - odnosno mogućnost projektnog rada te sklonost kolaboraciji i timskom radu u virtualnom okruženju. 


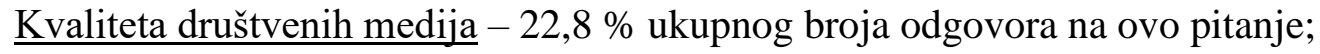

- jednostavnost korištenja društvenih medija - i lakoća korištenja društvenih medija, dostupnost kanala, informacija, sadržaja kada su potrebni, na bilo kojem uređaju i bilo gdje, mogućnost odabira raznih područja i predmeta od interesa, mogući razni formati nastavnih materijala; tekst, video, animacija, igrice, videokonferencije, virtualne učionice itd., „user friendly“ sučelja i preglednost društvenih medija, olakšana komunikacija, to što nema troškova prijevoza i gubitka vremena na put i pogodno je za zaposlene osobe,

- pouzdanost korištenja društvenih medija - i to kvaliteta informacija i sadržaja društvenih medija, benefiti korištenja tj. korisne funkcionalnost društvenih medija i transparentnost,

- odgovarajuće povezivanje društvenih medija s drugim alatima (interoperabilnost) odnosno sažete stvari koje su im potrebne s poveznicama na dublja istraživanja tj. sve na jednom mjestu.

Metrike uspješnosti - 5,7 \% ukupnog broja odgovora na ovo pitanje;

- ovisno i prilagođeno o cilju (privlačenje odnosno regrutacija novih studenata, brendiranje odnosno povećanje ugleda ustanove, povećanje uspjeha studenata, suradnja sa zajednicom...) - tj. motivacija studenata za učenje, mogućnost dobivanja nagradnih bodova i nedovoljno znanje nastavnika koje utječe na rezultate studenata.

Motivacija nastavnika $-6,84 \%$ ukupnog broja odgovora na ovo pitanje;

- poticajni programi koji nagrađuju zaposlenike koji koriste / doprinose za društvene medije - te spremnost nastavnika i stavovi nastavnika tj. poticaj od strane nastavnika, kao i angažman nastavnika; primjerice trud koji nastavnici ulažu u pripremu materijala,

- svo osoblje (nastavnici, vanjski suradnici) koristi društvene medije - tj. popularnost društvenih medija u akademskoj zajednici.

Nacionalne politike / strategije obrazovanja - 4,56 \% ukupnog broja odgovora na ovo pitanje;

- uključuje i niže razine obrazovanja (osnovnoškolsko, srednjoškolsko) te visokoškolsko obrazovanje - i to pripremljenost za metode učenja korištenjem društvenih medija kroz ranije školovanje i prethodna iskustva studenata/učenika iz prethodnih razina edukacije (srednja ili osnovna škola).

Očekivanja studenata - 14,82 \% ukupnog broja odgovora na ovo pitanje;

- ne poznaju svijet bez tehnologije - tj. nove generacije nemaju otpora prema korištenju društvenih medija 
- predstavljaju novi tip studenata - osobnost, ciljevi koje si postavljaju u svezi sa studijem i privatnim životom, prilagodljivi su, a postoji generacijski jaz, čak su i stariji studenti manje skloni koristiti društvene medije,

- uče na nove načine - i spremni su na aktivnost i izvan „regularnih“ sati za učenje,

- komuniciraju i surađuju na nove načine - nisu lojalni nekom pojedinom društvenom mediju, ali im pristup generacijski odgovara, ovisno o stilu učenja, kao i pristup nastavnim materijalima koji je moguć 0-24 odnosno kada god studentu odgovara i u količini koja mu odgovara, s bilo kojeg mjesta.

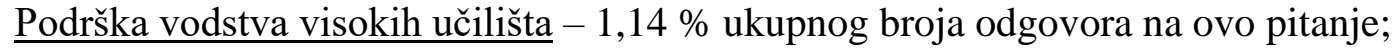

- vodstvo odozgo od strane uprave visokih učilišta - tj. spremnost visokih učilišta kroz institucionalno prihvaćanje društvenih medija.

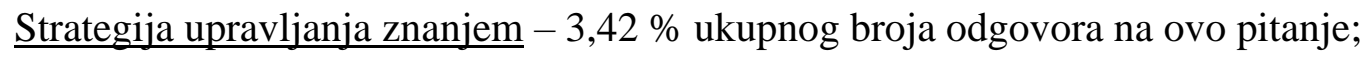

- promjena od tradicionalnog ka inovativnim oblicima učenja $\mathrm{i}$ poučavanja - $\mathrm{tj}$. inovativna nastava, prednosti korištenja u usporedbi s konvencionalnim metodama komuniciranja i učenja, a uz učenje na daljinu savladavaju se i digitalne vještine.

\subsubsection{Potencijali društvenih medija za unaprjeđenje komunikacije u visokom obrazovanju}

Kako bi se odgovorilo na peto istraživačko pitanje IP5.: Na koje bi se sve načine mogli iskoristiti potencijali društvenih medija za unaprjeđenje komunikacije u visokom obrazovanju? panelistima su postavljena pitanja:

10. Što sve utječe na komunikaciju putem društvenih medija u visokoobrazovnom procesu (navedite moguće čimbenike)?

11. Opišite važne čimbenike koji mogu unaprijediti komunikaciju putem društvenih medija u visokoobrazovnom procesu?

Za potrebe analize kvalitativnih odgovora na deseto i jedanaesto postavljeno pitanje otvorenog tipa u ovoj delfi studiji, pri čemu su se odgovori na jedanaesto pitanje tretirali kao dopuna odgovorima na deseto pitanje, dobiveni odgovori su iz sirovih podataka kodirani u koncepte kao temeljne jedinice analize, nakon čega je slijedilo grupiranje koncepata koji se odnose na isti fenomen $\mathrm{u}$ apstrahirane $\mathrm{i}$ uopćene kategorije koje su međusobno povezane. Zatim su kategorije ujedinjene u teme koje će se koristiti u 2. krugu istraživanja. 
Teorijskim uzorkovanjem, odnosno kružnim procesom usporedbe i refleksije poznatih informacija o potencijalima društvenih medija koji mogu unaprijediti komunikaciju $u$ visokoobrazovnom procesu i novog materijala dobivenog $\mathrm{u}$ odgovorima eksperata, ponavljanim nekoliko puta dobiveni su prikazi u Tablici 27. pri čemu se prvi stupac Koncepti odnosi na ključne riječi i opisnice potencijala društvenih medija koji mogu unaprijediti komunikaciju u visokoobrazovnom procesu, drugi stupac Frekvencija odgovora sadrži učestalost Koncepata u odgovorima sudionika istraživanja (iskazanu numerički i postotno), treći stupac sadrži uopćene izjave apstrahirane iz Koncepata u Kategorije koje su bile korištene u 2. krugu istraživanja za opis Tema u koje su grupirane. Teme koje su se pojavile bile su, nakon obrade odgovora na sva istraživačka pitanja, sumarizirane i korištene u 2. krugu istraživanja kao ključni čimbenici promjene komunikacijske paradigme u visokom obrazovanju pod utjecajem društvenih medija.

Zaključno slijedi deskripcija i interpretacija predikcija panelista s naglaskom na razumijevanju potencijala društvenih medija koji mogu unaprijediti komunikaciju u visokoobrazovnom procesu iz perspektive samih sudionika istraživanja.

Sljedeća tablica (Tablica 28.) prikazuje odgovore panelista delfi stručne skupine u svezi s potencijalima društvenih medija koji mogu unaprijediti komunikaciju u visokoobrazovnom procesu. Ukupni broj panelista koji su odgovarali na ovo pitanje je 37, svi panelisti odgovorili su na ovo pitanje. U Tablici 28. prikazni odgovori panelista $\mathrm{N}=37$, ukupna frekvencija odgovora bila je 117.

Tablica 28. Rezultati 1. kruga delfi studije: Potencijali društvenih medija koji mogu unaprijediti komunikaciju u visokoobrazovnom procesu, N=37 (izvor: upitnik, Google obrasci, obrada autorice)

\begin{tabular}{|c|c|c|c|c|}
\hline Koncepti & & $\begin{array}{l}\text { ncija } \\
\text { ora } \\
\% \\
\end{array}$ & Kategorije & Teme \\
\hline $\begin{array}{l}\text { Ulaganje u kontinuirano obrazovanje } \\
\text { nastavnog osoblja }\end{array}$ & 2 & 1,9 & \multirow{3}{*}{$\begin{array}{l}\text { Financijska sredstva i } \\
\text { izvori. }\end{array}$} & \multirow{5}{*}{ Dostupnost resursa (RES) } \\
\hline Dostupnost uređaja & 1 & 0,85 & & \\
\hline Uvođenje dodatnih tehnologija & 1 & 0,85 & & \\
\hline $\begin{array}{l}\text { Konkretnost i redovitost u pružanju } \\
\text { informacija (jasni i pravovremeni } \\
\text { odgovori na upite) }\end{array}$ & 2 & 1,9 & \multirow{2}{*}{$\begin{array}{l}\text { Administrativna korisnička } \\
\text { podrška. }\end{array}$} & \\
\hline $\begin{array}{l}\text { Kvalitetna, brza i dobra korisnička } \\
\text { podrška }\end{array}$ & 1 & 0,85 & & \\
\hline $\begin{array}{l}\text { Privlačenje investitora koji će } \\
\text { podržati unapređenja }\end{array}$ & 1 & 0,85 & Privlačenje investitora & \multirow{2}{*}{ Društvo u cjelini (DR) } \\
\hline $\begin{array}{l}\text { Praćenje trendova u komunikaciji } \\
\text { (korištenje sadržaja) }\end{array}$ & 1 & 0,85 & Trendovi. & \\
\hline
\end{tabular}




\begin{tabular}{|c|c|c|c|c|}
\hline Lako dostupni DM & 1 & 0,85 & Vlasništvo nad DM & \\
\hline Licenciranje programske podrške & 1 & 0,85 & odnosno licencama. & \\
\hline Dobra informatička infrastruktura & 1 & 0,85 & & \\
\hline Kompatibilan IT sustav & 1 & 0,85 & Tehnička podrška; & Infrastruktura upravljanja \\
\hline Korištenje što više platformi & 1 & 0,85 & stvaranje namjenskih uloga & \\
\hline $\begin{array}{l}\text { Adekvatna razina tehničke podrška } \\
\text { pružene nastavnicima }\end{array}$ & 1 & 0,85 & $\begin{array}{c}\text { za f1ltrıranje, ažurıranje } 1 \\
\text { održavanje DM. }\end{array}$ & \\
\hline $\begin{array}{l}\text { Educirati sve korisnike o načinima } \\
\text { službene komunikacije }\end{array}$ & 1 & 0,85 & \multirow{23}{*}{$\begin{array}{l}\text { Sustavna edukacija o } \\
\text { korištenju DM. }\end{array}$} & \multirow{23}{*}{$\begin{array}{l}\text { Kultura razmjene znanja } \\
\qquad(\text { KUL })\end{array}$} \\
\hline $\begin{array}{l}\text { Kompetencija i sposobnost za } \\
\text { korištenje tehnoloških sredstava }\end{array}$ & 1 & 0,85 & & \\
\hline $\begin{array}{l}\text { Kvalitetnije i usmjerenije } \\
\text { podržavanje ciljanih VO procesa }\end{array}$ & 1 & 0,85 & & \\
\hline $\begin{array}{l}\text { Osvijestiti kako DM nisu samo } \\
\text { Facebook, Instagram i Twitter }\end{array}$ & 1 & 0,85 & & \\
\hline $\begin{array}{l}\text { Prihvaćanje DM kao alata koji se } \\
\text { brzo razvija }\end{array}$ & 1 & 0,85 & & \\
\hline $\begin{array}{l}\text { Prihvaćanje DM kao alata kojeg bi } \\
\text { trebalo koristiti u nastavnom procesu }\end{array}$ & 1 & 0,85 & & \\
\hline $\begin{array}{l}\text { Prihvaćanje DM kao alata kojeg bi } \\
\text { trebalo koristiti za unaprjeđenje } \\
\text { komunikacije u VO }\end{array}$ & 1 & 0,85 & & \\
\hline $\begin{array}{l}\text { Razumijevanje vrijednosti koju } \\
\text { donosi komunikacija putem DM }\end{array}$ & 1 & 0,85 & & \\
\hline Simplificirana i brza edukacija & 1 & 0,85 & & \\
\hline Sustavna edukacija & 1 & 0,85 & & \\
\hline $\begin{array}{l}\text { Učiti načine komunikacije (lijepo } \\
\text { izražavanje, pravopisno točno, } \\
\text { poticajno, korištenje emotikona) }\end{array}$ & 1 & 0,85 & & \\
\hline Učenje, učenje, učenje! & 1 & 0,85 & & \\
\hline Uvesti kulturu online komunikacije & 1 & 0,85 & & \\
\hline $\begin{array}{l}\text { Jasno definirani načini (pravila) } \\
\text { komunikacije }\end{array}$ & 2 & 1,9 & & \\
\hline $\begin{array}{l}\text { Adekvatna informiranost o dobrim } \\
\text { praksama u domeni razvoja i } \\
\text { primjene DM prema svim } \\
\text { elementima/sudionicima } \\
\text { komunikacijskih kanala u } \\
\text { visokoobrazovnom procesu }\end{array}$ & 1 & 0,85 & & \\
\hline $\begin{array}{l}\text { Bolje definiranje i šire poznavanje } \\
\text { konvencija u komunikaciji }\end{array}$ & 1 & 0,85 & & \\
\hline $\begin{array}{l}\text { Edukacija o benefitima korištenja } \\
\text { DM za sve dionike }\end{array}$ & 1 & 0,85 & & \\
\hline „Gemifikacija“ u službi učenja & 1 & 0,85 & & \\
\hline $\begin{array}{l}\text { Jasno prezentirati prednosti } \\
\text { korištenja DM svim dionicima }\end{array}$ & 1 & 0,85 & & \\
\hline $\begin{array}{l}\text { Moderiranje i usmjeravanje } \\
\text { komunikacije s ciljem fokusiranja na } \\
\text { specifičnu temu }\end{array}$ & 1 & 0,85 & & \\
\hline Navesti kratka pravila korištenja DM & 1 & 0,85 & & \\
\hline Navesti politike DM & 1 & 0,85 & & \\
\hline $\begin{array}{l}\text { Praćenje komunikacije na što više } \\
\text { kanala }\end{array}$ & 1 & 0,85 & & \\
\hline
\end{tabular}




\begin{tabular}{|c|c|c|c|c|}
\hline $\begin{array}{l}\text { Poznavanje i uporaba specifičnih } \\
\text { komunikacijskih vještina }\end{array}$ & 1 & 0,85 & & \\
\hline $\begin{array}{l}\text { Učiti studente komuniciranju na } \\
\text { mreži }\end{array}$ & 1 & 0,85 & & \\
\hline $\begin{array}{l}\text { Upravljanje komunikacijskim } \\
\text { procesima }\end{array}$ & 1 & 0,85 & & \\
\hline $\begin{array}{l}\text { Usvajanje zajedničkih načela } \\
\text { komuniciranja putem DM }\end{array}$ & 1 & 0,85 & & \\
\hline $\begin{array}{l}\text { Angažiranost oko komunikacije } \\
\text { pogotovo neprikladne odnosno } \\
\text { negativne }\end{array}$ & 1 & 0,85 & \multirow{6}{*}{$\begin{array}{c}\text { Proslava uspjeha i učenje iz } \\
\text { neuspjeha. }\end{array}$} & \\
\hline $\begin{array}{l}\text { Moderiranje i usmjeravanje } \\
\text { komunikacije s ciljem smanjenja } \\
\text { negativnih utjecaja DM }\end{array}$ & 1 & 0,85 & & \\
\hline Navesti primjere e-bontona & 1 & 0,85 & & \\
\hline $\begin{array}{l}\text { Ukazati studentima na prednosti i } \\
\text { koristi komunikacije putem DM }\end{array}$ & 1 & 0,85 & & \\
\hline $\begin{array}{l}\text { Ukazati studentima na prednosti i } \\
\text { koristi učenja putem DM }\end{array}$ & 1 & 0,85 & & \\
\hline Više ciljanih ograničenja & 1 & 0,85 & & \\
\hline $\begin{array}{l}\text { Poticajno nastavno okruženje } \\
\text { (atmosfera) }\end{array}$ & 2 & 1,9 & \multirow{6}{*}{$\begin{array}{c}\text { Kultura suradnje, koja nije } \\
\text { konkurentna. }\end{array}$} & \\
\hline Angažiranost dionika & 1 & 0,85 & & \\
\hline Poticanje otvorenosti & 1 & 0,85 & & \\
\hline Poticanje razmjene ideja & 1 & 0,85 & & \\
\hline Pozitivno nastavno okruženje & 1 & 0,85 & & \\
\hline Uspostava društvene klime & 1 & 0,85 & & \\
\hline $\begin{array}{l}\text { Jednostavnost (za početak) korištenja } \\
\text { društvenih medija }\end{array}$ & 2 & 1,9 & \multirow{3}{*}{$\begin{array}{c}\text { Jednostavnost korištenja } \\
\text { DM. }\end{array}$} & \multirow{11}{*}{$\begin{array}{l}\text { Kvaliteta društvenih } \\
\text { medija (DM) }\end{array}$} \\
\hline Dostupnost informacija & 1 & 0,85 & & \\
\hline Mala potrošnja interneta & 1 & 0,85 & & \\
\hline $\begin{array}{l}\text { Obrazovanje mogu učiniti boljim, } \\
\text { jednostavnijim i pristupačnijim }\end{array}$ & 1 & 0,85 & \multirow{7}{*}{$\begin{array}{l}\text { Redovitost ažuriranja DM } \\
\text { kako bi odražavalo } \\
\text { trenutno znanje. }\end{array}$} & \\
\hline $\begin{array}{l}\text { Osiguranje privatnosti učesnika u } \\
\text { procesu obrazovanja }\end{array}$ & 1 & 0,85 & & \\
\hline Stabilnost platforme & 1 & 0,85 & & \\
\hline Visoka kvaliteta prijenosa sadržaja & 1 & 0,85 & & \\
\hline Dostupnost informacija & 1 & 0,85 & & \\
\hline Prilagodba kretanja kroz sadržaj & 1 & 0,85 & & \\
\hline $\begin{array}{l}\text { Uvođenje koncepata u društvene } \\
\text { medije }\end{array}$ & 1 & 0,85 & & \\
\hline Stimulativne aplikacije & 2 & 1,9 & $\begin{array}{l}\text { Odgovarajuće povezivanje } \\
\text { DM s drugim alatima } \\
\text { (interoperabilnost). }\end{array}$ & \\
\hline $\begin{array}{l}\text { (Kontinuiran rad na) prilagodbi } \\
\text { sadržaja ciljanoj skupini }\end{array}$ & 2 & 1,9 & \multirow{3}{*}{$\begin{array}{l}\text { Ovisno i prilagođeno o } \\
\text { cilju (privlačenje odnosno } \\
\text { regrutacija novih studenata, } \\
\text { brendiranje odnosno } \\
\text { povećanje ugleda ustanove, } \\
\text { povećanje uspjeha }\end{array}$} & \multirow{3}{*}{$\begin{array}{l}\text { Metrike uspješnosti } \\
\text { (USP) }\end{array}$} \\
\hline $\begin{array}{l}\text { Generiranje jako dobrog sadržaja na } \\
\text { temelju kojeg se potencijalni student } \\
\text { upisuje }\end{array}$ & 1 & 0,85 & & \\
\hline $\begin{array}{l}\text { Prezentiranje benefita ciljanim } \\
\text { skupinama }\end{array}$ & 1 & 0,85 & & \\
\hline
\end{tabular}




\begin{tabular}{|c|c|c|c|c|}
\hline $\begin{array}{l}\text { Spojiti struku i marketing/PR za što } \\
\text { kvalitetniju komunikaciju }\end{array}$ & 1 & 0,85 & \multirow[t]{2}{*}{$\begin{array}{l}\text { studenata, suradnja sa } \\
\text { zajednicom...). }\end{array}$} & \\
\hline Svrsishodna i ciljana komunikacija & 1 & 0,85 & & \\
\hline Stimulacija profesora & 1 & 0,85 & Poticajni programi koji & \multirow{8}{*}{$\begin{array}{l}\text { Motivacija nastavnika } \\
\text { (NAST) }\end{array}$} \\
\hline Vrednovanje inicijative & 1 & 0,85 & nagrađuju zaposlenike koji & \\
\hline Vrednovanje uloženog rada & 1 & 0,85 & koriste / doprinose za DM. & \\
\hline Angažman nastavnika & 1 & 0,85 & \multirow{4}{*}{$\begin{array}{c}\text { Svo osoblje (nastavnici, } \\
\text { vanjski suradnici) koristi } \\
\text { DM. }\end{array}$} & \\
\hline Entuzijazam nastavnika & 1 & 0,85 & & \\
\hline Kompetencije edukatora/nastavnika & 1 & 0,85 & & \\
\hline $\begin{array}{l}\text { Želja za korištenjem društvenih } \\
\text { medija }\end{array}$ & 1 & 0,85 & & \\
\hline $\begin{array}{l}\text { Spremnost nastavnika za } \\
\text { sudjelovanje u novih } \\
\text { komunikacijskim kanalima }\end{array}$ & 1 & 0,85 & $\begin{array}{c}\text { Integriranje korištenja DM } \\
\text { s ocjenom uspješnosti i } \\
\text { plaćom. }\end{array}$ & \\
\hline Standardizacija tehnologije & 2 & 1,9 & $\begin{array}{l}\text { Podrška državnih } \\
\text { institucija. }\end{array}$ & $\begin{array}{c}\text { Nacionalne } \\
\text { politike/strategije } \\
\text { obrazovanja (POL) } \\
\end{array}$ \\
\hline Motivacija studenata & 1 & 0,85 & $\begin{array}{l}\text { Predstavljaju novi tip } \\
\text { studenata. }\end{array}$ & \multirow{2}{*}{$\begin{array}{l}\text { Očekivanja studenata } \\
\text { (STU) }\end{array}$} \\
\hline $\begin{array}{l}\text { Očekivane vrste i pristupi } \\
\text { očekivanim studentskim „outputima““ } \\
\text { (rezultat nečijeg rada, djelovanja) }\end{array}$ & 1 & 0,85 & $\begin{array}{l}\text { Komuniciraju i surađuju na } \\
\text { nove načine. }\end{array}$ & \\
\hline $\begin{array}{l}\text { Poticaj od strane top managementa } \\
\text { visokih učilišta }\end{array}$ & 1 & 0,85 & \multirow{3}{*}{$\begin{array}{l}\text { Vodstvo odozgo od strane } \\
\text { uprave visokih učilišta. }\end{array}$} & \multirow{5}{*}{$\begin{array}{c}\text { Podrška vodstva visokih } \\
\text { učilišta (VU) }\end{array}$} \\
\hline $\begin{array}{l}\text { Opredijeljenost uprave visokog } \\
\text { učilišta za digitalna rješenja }\end{array}$ & 1 & 0,85 & & \\
\hline $\begin{array}{l}\text { Spremnost visokih učilišta za } \\
\text { sudjelovanje u novih } \\
\text { komunikacijskim kanalima }\end{array}$ & 1 & 0,85 & & \\
\hline $\begin{array}{l}\text { Poticanje nastavnika da ih više i } \\
\text { češće koriste }\end{array}$ & 2 & 0,85 & $\begin{array}{l}\text { Provode dekan, } \\
\text { prodekani, voditelji } \\
\text { studija, odsjeka i } \\
\text { katedri. }\end{array}$ & \\
\hline Etičke i druge norme & 1 & 0,85 & Etičke i druge norme. & \\
\hline $\begin{array}{l}\text { Razvoj umjetne inteligencije, } \\
\text { virtualne (VR) i proširene stvarnosti } \\
\text { (AR) }\end{array}$ & 1 & 0,85 & $\begin{array}{c}\text { Digitalna transformacija } \\
\text { društva. }\end{array}$ & \multirow{6}{*}{$\begin{array}{l}\text { Razvoj tehnologija } \\
\text { (TEH) }\end{array}$} \\
\hline Poznavanje tehnologije & 1 & 0,85 & $\begin{array}{l}\text { Masovnije korištenje } \\
\text { tehnologije, alata i } \\
\text { aplikacija. }\end{array}$ & \\
\hline $\begin{array}{l}\text { Postojeći/planirani načini korištenja } \\
\text { IKT u obrazovanju na razini } \\
\text { ustanove }\end{array}$ & 1 & 0,85 & \multirow{3}{*}{$\begin{array}{l}\text { Veća dostupnost } \\
\text { tehnologija u visokom } \\
\text { obrazovanju. }\end{array}$} & \\
\hline $\begin{array}{l}\text { Profesionalni pristup kreiranju } \\
\text { različitih platformi }\end{array}$ & 1 & 0,85 & & \\
\hline $\begin{array}{l}\text { Razina uvedenosti IKT u } \\
\text { obrazovanju na razini ustanove }\end{array}$ & 1 & 0,85 & & \\
\hline Interaktivnost u službi učenja & 2 & 1,9 & Veća interaktivnost. & \\
\hline $\begin{array}{l}\text { Radikalna promjena stava o } \\
\text { obrazovanju, ulozi učitelja i } \\
\text { studenata }\end{array}$ & 2 & 1,9 & $\begin{array}{l}\text { Promjena od tradicionalnog } \\
\text { ka inovativnim oblicima } \\
\text { učenja i poučavanja. }\end{array}$ & $\begin{array}{l}\text { Strategija upravljanja } \\
\text { znanjem (ZNA) }\end{array}$ \\
\hline
\end{tabular}




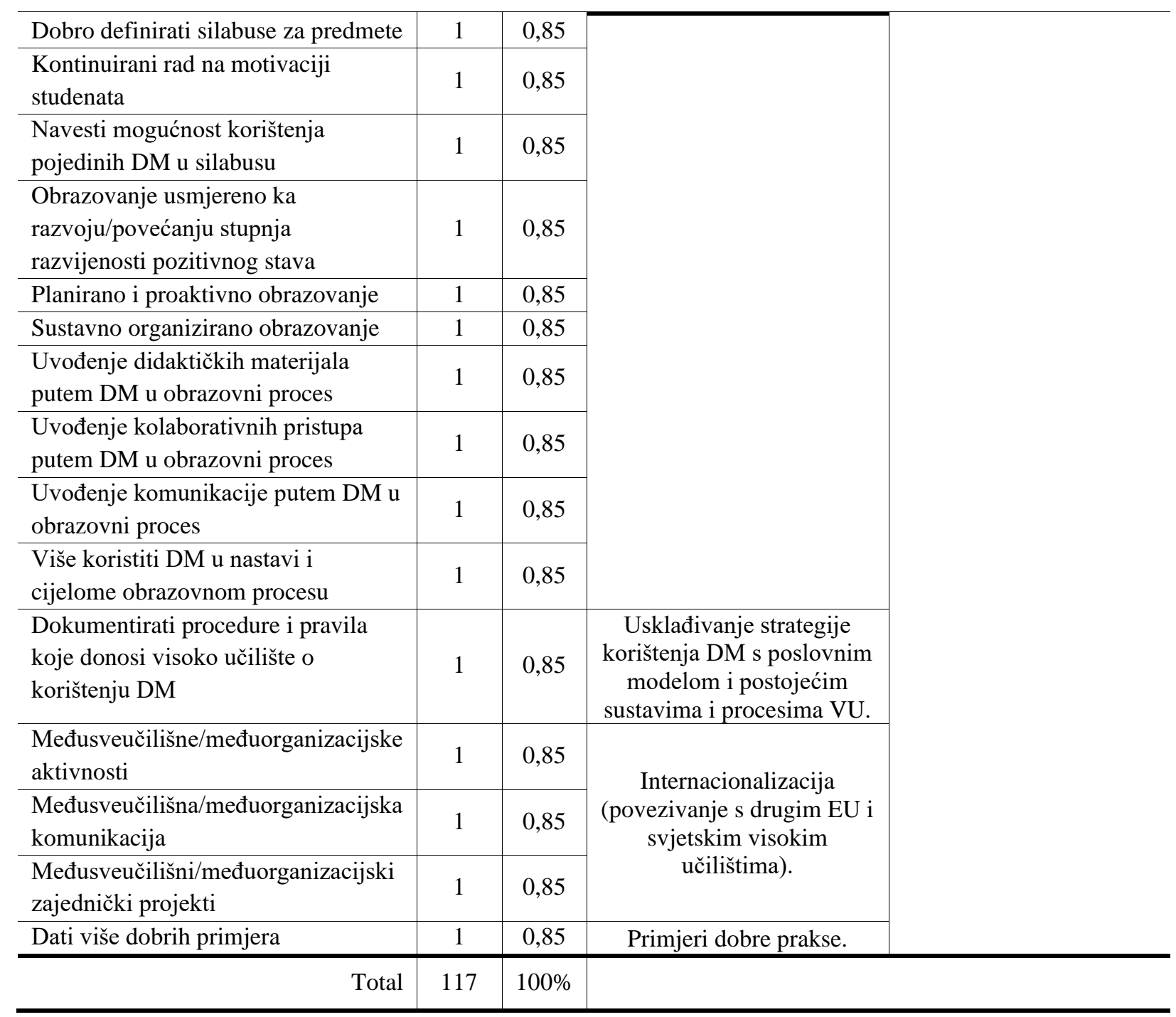

Tablica 28. pokazuje potencijale društvenih medija koji, prema mišljenju panelista, mogu unaprijediti komunikaciju u visokoobrazovnom procesu:

Dostupnost resursa $-5,95 \%$ ukupnog broja odgovora na ovo pitanje;

- financijska sredstva i izvori - u smislu ulaganja u kontinuirano obrazovanje nastavnog osoblja, uvođenje dodatnih tehnologija i dostupnost uređaja,

- administrativna korisnička podrška - kao konkretnost i redovitost u pružanju informacija (jasni i pravovremeni odgovori na upite), te kvalitetna, brza i dobra korisnička podrška.

Društvo u cjelini - 1,9 \% ukupnog broja odgovora na ovo pitanje;

- privlačenje investitora - koji će podržati unaprjeđenja,

- trendovi - konkretnije praćenje trendova u komunikaciji (korištenje sadržaja). 
Infrastruktura upravljanja znanjem $-5,1 \%$ ukupnog broja odgovora na ovo pitanje;

- vlasništvo nad društvenim medijima odnosno licencama - potrebni su lako dostupni društveni mediji i licenciranje programske podrške,

- tehnička podrška, stvaranje namjenskih uloga za filtriranje, ažuriranje i održavanje društvenih medija - kroz dobru informatičku infrastrukturu, kompatibilan IT sustav za korištenje što više platformi i adekvatnu razinu tehničke podrške pružene nastavnicima.

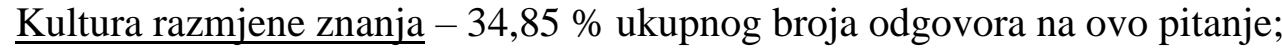

- sustavna edukacija o korištenju društvenih medija - tj. važno je provoditi sustavnu, simplificiranu i brzu edukaciju, educirati sve korisnike o načinima službene komunikacije, učiti načine komunikacije (lijepo izražavanje, pravopisno točno, poticajno, korištenje emotikona), povećati kompetencije i sposobnost za korištenje tehnoloških sredstava, kvalitetnije i usmjerenije podržavati ciljane procese visokih učilišta, prihvaćanje društvenih medija kao alata koji se brzo razvija, kojeg bi trebalo koristiti u nastavnom procesu i kojeg bi trebalo koristiti za unaprjeđenje komunikacije na visokim učilištima, produbiti razumijevanje vrijednosti koju donosi komunikacija putem društvenih medija, uvesti kulturu online komunikacije, osvijestiti da društveni mediji nisu samo Facebook, Instagram i Twitter. Važno je; učenje, učenje, učenje!

- svo osoblje treba stalno biti informirano o novim saznanjima o korištenju DM za potrebe visokog obrazovanja, npr. mjesečne sesije dijeljenja znanja - na način da postoji upravljanje komunikacijskim procesima odnosno da su jasno definirani načini (pravila) komunikacije, da postoji adekvatna informiranost o dobrim praksama u domeni razvoja i primjene društvenih medija prema svim elementima / sudionicima komunikacijskih kanala u visokoobrazovnom procesu, bolje definiranje i šire poznavanje konvencija u komunikaciji, poznavanje i uporaba specifičnih komunikacijskih vještina, važno je učiti studente komuniciranju na mreži, da se provodi edukacija o benfitima korištenja društvenih medija za sve dionike, da su jasno prezentirane prednosti korištenja društvenih medija svim dionicima i navedene politike i kratka pravila korištenja istih, da se usvoje zajednička načela komuniciranja putem društvenih medija, prati komunikacija na što više kanala, moderira i usmjerava komunikacija s ciljem fokusiranja na specifičnu temu te stavi ,gemifikacija“ u službu učenja,

- proslava uspjeha i učenje iz neuspjeha - u smislu ukazivanja studentima na prednosti i koristi učenja i komunikacije putem društvenih medija, navođenje primjera e-bontona, angažiranosti oko komunikacije, osobito neprikladne odnosno negativne, moderiranja i 
usmjeravanja komunikacije s ciljem smanjenja negativnih utjecaja društvenih medija te više ciljanih ograničenja,

- kultura suradnje, koja nije konkurentna - kroz uspostavu društvene klime te poticajnog i pozitivnog nastavnog okruženja (atmosfere), angažiranost dionika, poticanje otvorenosti i razmjene ideja.

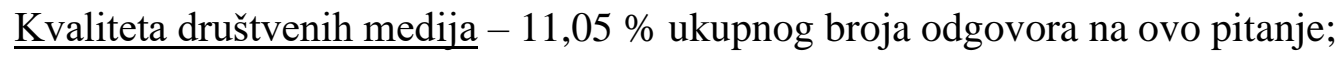

- jednostavnost korištenja društvenih medija - i to za početak, u što ulaze dostupnost informacija i mala potrošnja interneta,

- pouzdanost korištenja društvenih medija - jer obrazovanje mogu učiniti boljim, jednostavnijim i pristupačnijim, no važna je stabilnost platforme, visoka kvaliteta prijenosa sadržaja i osiguranje privatnosti učesnika u procesu obrazovanja,

- redovitost ažuriranja društvenih medija kako bi odražavalo trenutno stanje - kroz dostupnost informacija, prilagodbu kretanja kroz sadržaj i uvođenje koncepata $u$ društvene medije,

- odgovarajuće povezivanje društvenih medija s drugim alatima (interoperabilnost) - kroz stimulativne aplikacije.

Metrike uspješnosti - 5,1 \% ukupnog broja odgovora na ovo pitanje;

- ovisno i prilagođeno o cilju (privlačenje odnosno regrutacija novih studenata, brendiranje odnosno povećanje ugleda ustanove, povećanje uspjeha studenata, suradnja sa zajednicom...) - pri čemu je važna svrsishodna i ciljana komunikacija, za što je potrebno spojiti struku i marketing/PR za što kvalitetniju komunikaciju, kontinuiran rad na prilagodbi sadržaja ciljanoj skupini, generiranje dobrog sadržaja na temelju kojeg se potencijalni student upisuje i općenito prezentiranje benefita ciljanim skupinama.

Motivacija nastavnika $-6,8 \%$ ukupnog broja odgovora na ovo pitanje;

- poticajni programi koji nagrađuju zaposlenike koji koriste / doprinose za društvene medije - tj. stimulacija profesora kroz vrednovanje inicijative i uloženog rada,

- svo osoblje (nastavnici, vanjski suradnici) koristi društvene medije - tj. kompetencije edukatora/nastavnika, angažman i entuzijazam nastavnika te želju za korištenjem društvenih medija,

- integriranje korištenja društvenih medija s ocjenom uspješnosti i plaćom - kako bi se povećala spremnost nastavnika za sudjelovanje u novim komunikacijskim kanalima.

Nacionalne politike / strategije obrazovanja - 1,9 \% ukupnog broja odgovora na ovo pitanje;

- podrška državnih institucija - kroz standardizaciju tehnologije.

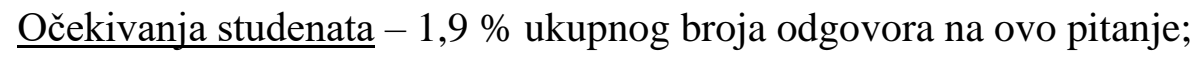


- predstavljaju novi tip studenata - stoga je potrebno povećati motivaciju studenata,

- komuniciraju i surađuju na nove načine - važna je prilagodba očekivanim vrstama i pristupima tj. očekivanim studentskim „outputima“ (rezultatima rada, djelovanja).

Podrška vodstva visokih učilišta $-5,1 \%$ ukupnog broja odgovora na ovo pitanje;

- vodstvo odozgo od strane uprave visokih učilišta - tj. poticaj od strane top managementa visokih učilišta, opredijeljenost uprave visokog učilišta za digitalna rješenja i spremnost visokog učilišta za sudjelovanje u novim komunikacijskim kanalima,

- provode dekan, prodekani, voditelji studija, odsjeka i katedri - poticanje nastavnika da ih više i češće koriste, te

- etičke i druge norme.

Razvoj tehnologija - 5,95\% ukupnog broja odgovora na ovo pitanje;

- digitalna transformacija društva - kroz razvoj umjetne inteligencije, virtualne (VR) i proširene stvarnosti (AR),

- masovnije korištenje tehnologije, alata i aplikacija - tj. poznavanje tehnologije,

- veća dostupnost tehnologija u visokom obrazovanju - odnosno postojeći 7 planirani načini korištenja informacijsko-komunikacije tehnologije u obrazovanju na razini ustanove (IKT) te razina uvedenosti IKT u obrazovanju na razini ustanove te profesionalni pristup kreiranju različitih platformi,

- veća interaktivnost - interaktivnost koja je u službi učenja.

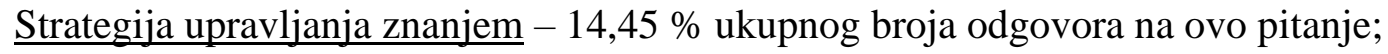

- promjena od tradicionalnog ka inovativnim oblicima učenja i poučavanja - potrebna je radikalna promjena stava o obrazovanju, ulozi učitelja i studenata, planirano i proaktivno, sustavno organizirano obrazovanje, koje je usmjereno ka razvoju / povećanju stupnja razvijenosti pozitivnog stava, dobro definirati silabuse za predmete, navesti mogućnosti korištenja pojedinih društvenih medija u silabusu, uvođenje didaktičkih materijala putem društvenih medija u obrazovni proces, uvođenje kolaborativnih pristupa putem društvenih medija u obrazovni proces, uvođenje komunikacije putem društvenih medija u obrazovni proces, općenito više koristiti društvene medije u cijelome obrazovnome procesu i kontinuirano raditi na motivaciji studenata,

- usklađivanje strategije korištenja društvenih medija s poslovnim modelom i postojećim sustavima i procesima na visokim učilištima - tj. dokumentirati procedure i pravila koje donosi visoko učilište o korištenju društvenih medija, 
- internacionalizacija - tj. međusveučilišna / međuorganizacijska komunikacija, zajednički projekti i aktivnosti,

- $\quad$ primjeri dobre prakse - odnosno dati što više dobrih primjera dobre prakse.

\subsubsection{Drugi krug delfi studije}

U 2. krugu sudionicima je predstavljen objedinjeni popis ključnih čimbenika promjene (kratica KČP) komunikacijske paradigme u visokom obrazovanju pod utjecajem društvenih medija identificiranih u prethodnom krugu. Svaki KČP opisan je pomoću ključnih riječi i opisnica koje su sudionici koristili u 1. krugu, kako bi se sudionicima olakšalo i omogućilo bolje i lakše razumijevanje. Zatim su zamoljeni da ključnim čimbenicima promjene (KČP) komunikacijske paradigme u visokom obrazovanju pod utjecajem društvenih medija dodijele stupanj važnosti prema Likertovoj ljestvici 1-10, pri čemu je 1 je označavao čimbenik koji uopće nije važan, a 10 iznimno važan čimbenik. Kratki opis 12 ključnih čimbenika promjene komunikacijske paradigme u visokom obrazovanju pod utjecajem društvenih medija (vidi Tablica 29.) nalazio se unutar Upitnika 2. (Prilog 11.) kao mehanizam koji pomaže u tumačenju konsenzusnih sredstava generiranih ovom studijom. Ovaj pristup je dokumentiran u literaturi kako je navedeno u poglavlju o istraživačkom pristupu ovog rada, a za potrebe ove delfi studije nakon dobivenih odgovora panelista u 2. krugu provedena je analiza rezultata kako slijedi.

Tablica 29. Kratki opis 12 ključnih čimbenika promjene (KČP) komunikacijske paradigme u visokom obrazovanju pod utjecajem društvenih medija (izvor: izrada autorice)

\begin{tabular}{|c|c|c|}
\hline $\begin{array}{l}\text { Broj } \\
\text { čimbenika }\end{array}$ & $\begin{array}{l}\text { Ključni čimbenici promjene } \\
\text { komunikacijske paradigme u } \\
\text { VO pod utjecajem DM }\end{array}$ & Opis \\
\hline KČP 1 & Razvoj tehnologija & $\begin{array}{l}\text { - } \quad \text { Digitalna transformacija društva. } \\
\text { - } \quad \text { Masovnije korištenje tehnologije, alata i aplikacija. } \\
\text { - } \quad \text { Veća dostupnost tehnologija u visokom obrazovanju. } \\
\text { - } \quad \text { Više mogućnosti, personalizacija aplikacija i sadržaja. } \\
\text { - } \quad \text { Veća interaktivnost. } \\
\text { - } \quad \text { Veća interoperabilnost među sustavima i alatima. }\end{array}$ \\
\hline KČP 2 & $\begin{array}{l}\text { Nacionalne politike/ } \\
\text { strategije obrazovanja }\end{array}$ & $\begin{array}{l}\text { - } \quad \text { Nacionalne strategije obrazovanja. } \\
\text { - Uključuje i niže razine obrazovanja (osnovnoškolsko, } \\
\text { - } \quad \text { Prednjoškolsko) te visokoškolsko obrazovanje. } \\
\text { - } \quad \text { Uključuje odnosnos državnih vs. privatnih visokoškolskih } \\
\text { ustanova. } \\
\text { - Pravna regulacija. }\end{array}$ \\
\hline
\end{tabular}




\begin{tabular}{|c|c|c|}
\hline KČP 3 & Podrška vodstva visokih učilišta & $\begin{array}{ll}\text { - } & \text { Vodstvo odozgo od strane uprave visokih učilišta. } \\
\text { - } & \text { Provode dekan, prodekani, voditelji studija, odsjeka i } \\
\text { katedri. } \\
\text { - } \quad \text { Financijska podrška. } \\
\text { - } & \text { Etičke i druge norme. } \\
\end{array}$ \\
\hline KČP 4 & Strategija upravljanja znanjem & 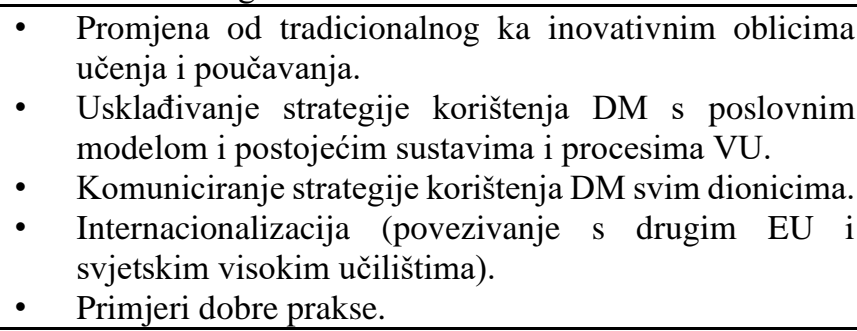 \\
\hline KČP 5 & Metrike uspješnosti & $\begin{array}{l}\text { - Uspostava ključnih indikatora uspješnosti korištenja } \\
\text { DM u visokom obrazovanju kako bi se mogao pratiti } \\
\text { napredak i olakšalo kontinuirano poboljšavanje. } \\
\text { Ovisno i prilagođeno o cilju (privlačenje odnosno } \\
\text { regrutacija novih studenata, brendiranje odnosno } \\
\text { povećanje ugleda ustanove, povećanje uspjeha } \\
\text { studenata, suradnja sa zajednicom...). }\end{array}$ \\
\hline KČP 6 & Infrastruktura upravljanja znanjem & $\begin{array}{l}\text { - } \quad \text { Vlasništvo nad DM odnosno licencama. } \\
\text { - Tehnička podrška; stvaranje namjenskih uloga za } \\
\text { filtriranje, ažuriranje i održavanje DM. } \\
\text { - } \quad \text { Režimi obuke za korištenje DM. } \\
\text { - Prepoznavanje i upravljanje rizicima. }\end{array}$ \\
\hline КС̆Р 7 & Motivacija nastavnika & 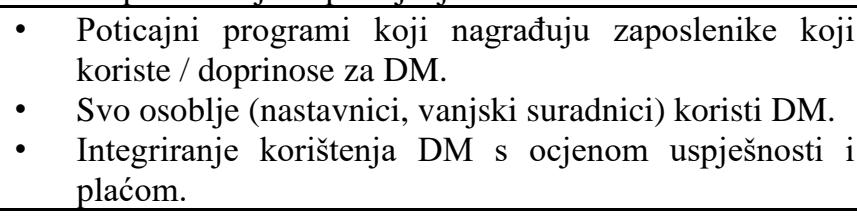 \\
\hline KČP 8 & Očekivanja studenata & $\begin{array}{l}\text { - Ne poznaju svijet bez tehnologije. } \\
\text { - } \quad \text { Predstavljaju novi tip studenata. } \\
\text { - } \quad \text { Koce na nove načine. } \\
\text { - }\end{array}$ \\
\hline KČP 9 & Kultura razmjene znanja & $\begin{array}{l}\text { - } \quad \text { Sustavna edukacija o korištenju DM. } \\
\text { - Svo osoblje treba stalno biti informirano o novim } \\
\text { saznanjima o korištenju DM za potrebe visokog } \\
\text { obrazovanja, npr. mjesečne sesije dijeljenja znanja. } \\
\text { - } \quad \text { Proslava uspjeha i učenje iz neuspjeha. } \\
\text { - } \quad \text { Kultura suradnje, koja nije konkurentna. }\end{array}$ \\
\hline KČP 10 & Dostupnost resursa & $\begin{array}{l}\text { - } \quad \text { Financijska sredstva i izvori. } \\
\text { - Raspodjela vremena odnosno predviđeno vrijeme za } \\
\text { aktivnosti povezane sa korištenjem DM. } \\
\text { - } \text { Administrativna korisnička podrška. }\end{array}$ \\
\hline KČP 11 & Kvaliteta društvenih medija & $\begin{array}{l}\text { - Jednostavnost korištenja DM. } \\
\text { - } \quad \text { Pouzdanost korištenja DM. } \\
\text { Redovitost ažuriranja DM kako bi odražavalo trenutno } \\
\text { znanje. } \\
\text { - Odgovarajuće povezivanje DM s drugim alatima } \\
\text { (interoperabilnost). }\end{array}$ \\
\hline KČP 12 & Društvo u cjelini & $\begin{array}{ll}\text { - } & \text { Preporuke poslodavaca. } \\
\text { - } & \text { Privlačenje investitora. } \\
\text { - } & \text { Trendovi. } \\
\text { - } & \text { Kulturološke razlike. } \\
\text { - } & \text { Konkurencija. } \\
\text { - } & \text { Privatni utjecaji (prisutnost prijatelja i obitelji na DM). } \\
\text { - } \quad \text { Viša sila, npr. pandemija korona virusa Covid-19. }\end{array}$ \\
\hline
\end{tabular}


Tablica 30. koja slijedi prikazuje frekvenciju odgovora sudionika u 2. krugu istraživanja iskazanu numerički i postotno, za svaki stupanj važnosti dodijeljenih svakom pojedinom od 12 ključnih čimbenika promjene (KČP) komunikacijske paradigme u visokom obrazovanju pod utjecajem društvenih medija, prema Likertovoj ljestvici od 10 stupnjeva (1-10), pri čemu 1 označava da čimbenik uopće nije važan, a 10 označava da je čimbenik iznimno važan, N=37.

Tablica 30. Frekvencija odgovora u 2. krugu prema stupnjevima važnosti 12 ključnih čimbenika promjene (KČP) komunikacijske paradigme u visokom obrazovanju pod utjecajem društvenih medija, N=37 (izvor: upitnik, Google obrasci, obrada autorice)

\begin{tabular}{|c|c|c|c|c|c|c|c|c|c|c|c|}
\hline \multicolumn{2}{|c|}{ Stupanj važnosti } & \multirow{2}{*}{$\begin{array}{c}1 \\
0\end{array}$} & \multirow{2}{*}{$\begin{array}{l}2 \\
0\end{array}$} & \multirow{2}{*}{$\begin{array}{l}3 \\
0\end{array}$} & \multirow{2}{*}{$\begin{array}{c}4 \\
1\end{array}$} & \multirow{2}{*}{$\begin{array}{c}5 \\
0\end{array}$} & \multirow{2}{*}{$\begin{array}{c}6 \\
1\end{array}$} & \multirow{2}{*}{$\begin{array}{l}7 \\
2\end{array}$} & \multirow{2}{*}{$\begin{array}{l}8 \\
7\end{array}$} & \multirow{2}{*}{$\begin{array}{c}9 \\
10\end{array}$} & \multirow{2}{*}{$\begin{array}{c}10 \\
16\end{array}$} \\
\hline KČP1 & $\mathbf{N}$ & & & & & & & & & & \\
\hline & $\%$ & $0 \%$ & $0 \%$ & $0 \%$ & $2,7 \%$ & $0 \%$ & $2,7 \%$ & $5,4 \%$ & $18,9 \%$ & $27 \%$ & $43,2 \%$ \\
\hline \multirow[t]{2}{*}{ KČP2 } & $\mathbf{N}$ & 0 & 1 & 1 & 1 & 3 & 2 & 7 & 5 & 6 & 11 \\
\hline & $\%$ & $0 \%$ & $2,7 \%$ & $2,7 \%$ & $2,7 \%$ & $8,1 \%$ & $5,4 \%$ & $18,9 \%$ & $13,5 \%$ & $16,2 \%$ & $29,7 \%$ \\
\hline \multirow[t]{2}{*}{ KČP3 } & $\mathbf{N}$ & 0 & 0 & 0 & 2 & 2 & 1 & 3 & 6 & 8 & 15 \\
\hline & $\%$ & $0 \%$ & $0 \%$ & $0 \%$ & $5,4 \%$ & $5,4 \%$ & $2,7 \%$ & $8,1 \%$ & $16,2 \%$ & $21,6 \%$ & $40,5 \%$ \\
\hline \multirow[t]{2}{*}{ KČP4 } & $\mathbf{N}$ & 0 & 0 & 1 & 0 & 1 & 4 & 5 & 10 & 9 & 7 \\
\hline & $\%$ & $0 \%$ & $0 \%$ & $2,7 \%$ & $0 \%$ & $2,7 \%$ & $10,8 \%$ & $13,5 \%$ & $27 \%$ & $24,3 \%$ & $18,9 \%$ \\
\hline \multirow[t]{2}{*}{ KČP5 } & $\mathbf{N}$ & 0 & 0 & 0 & 1 & 3 & 5 & 4 & 11 & 9 & 4 \\
\hline & $\%$ & $0 \%$ & $0 \%$ & $0 \%$ & $2,7 \%$ & $8,1 \%$ & $13,5 \%$ & $10,8 \%$ & $29,7 \%$ & $24,3 \%$ & $10,8 \%$ \\
\hline \multirow[t]{2}{*}{ KČP6 } & $\mathbf{N}$ & 1 & 1 & 1 & 1 & 5 & 3 & 9 & 8 & 7 & 1 \\
\hline & $\%$ & $2,7 \%$ & $2,7 \%$ & $2,7 \%$ & $2,7 \%$ & $13,5 \%$ & $8,1 \%$ & $24,3 \%$ & $21,6 \%$ & $18,9 \%$ & $2,7 \%$ \\
\hline \multirow[t]{2}{*}{ KČP7 } & $\mathbf{N}$ & 1 & 0 & 0 & 1 & 1 & 0 & 2 & 7 & 12 & 13 \\
\hline & $\%$ & $2,7 \%$ & $0 \%$ & $0 \%$ & $2,7 \%$ & $2,7 \%$ & $0 \%$ & $5,4 \%$ & $18,9 \%$ & $32,4 \%$ & $35,1 \%$ \\
\hline \multirow[t]{2}{*}{ KČP8 } & $\mathbf{N}$ & 0 & 0 & 0 & 1 & 2 & 1 & 4 & 10 & 10 & 9 \\
\hline & $\%$ & $0 \%$ & $0 \%$ & $0 \%$ & $2,7 \%$ & $5,4 \%$ & $2,7 \%$ & $10,8 \%$ & $27 \%$ & $27 \%$ & $24,3 \%$ \\
\hline \multirow[t]{2}{*}{ КС̌P9 } & $\mathbf{N}$ & 0 & 1 & 1 & 0 & 0 & 3 & 8 & 9 & 5 & 10 \\
\hline & $\%$ & $0 \%$ & $2,7 \%$ & $2,7 \%$ & $0 \%$ & $0 \%$ & $8,1 \%$ & $21,6 \%$ & $24,3 \%$ & $13,5 \%$ & $27 \%$ \\
\hline \multirow[t]{2}{*}{ КČP10 } & $\mathbf{N}$ & 1 & 1 & 1 & 1 & 0 & 3 & 9 & 3 & 10 & 8 \\
\hline & $\%$ & $2,7 \%$ & $2,7 \%$ & $2,7 \%$ & $2,7 \%$ & $0 \%$ & $8,1 \%$ & $24,3 \%$ & $8,1 \%$ & $27 \%$ & $21,6 \%$ \\
\hline \multirow[t]{2}{*}{ KČP11 } & $\mathbf{N}$ & 1 & 2 & 0 & 0 & 1 & 4 & 7 & 12 & 5 & 5 \\
\hline & $\%$ & $2,7 \%$ & $5,4 \%$ & $0 \%$ & $0 \%$ & $2,7 \%$ & $10,8 \%$ & $18,9 \%$ & $32,4 \%$ & $13,5 \%$ & $13,5 \%$ \\
\hline \multirow[t]{2}{*}{ KČP12 } & $\mathbf{N}$ & 1 & 1 & 1 & 2 & 1 & 6 & 7 & 7 & 9 & 2 \\
\hline & $\%$ & $2,7 \%$ & $2,7 \%$ & $2,7 \%$ & $5,4 \%$ & $2,7 \%$ & $16,2 \%$ & $18,9 \%$ & $18,9 \%$ & $24,3 \%$ & $5,4 \%$ \\
\hline \multirow{2}{*}{\multicolumn{2}{|c|}{$\begin{array}{l}\text { Frekvencija } \\
\text { odgovora (total) }\end{array}$}} & 37 & & & & & & & & & \\
\hline & & $100 \%$ & & & & & & & & & \\
\hline
\end{tabular}

Nakon dobivenih odgovora panelista u 2. krugu ove delfi studije provedena je deskriptivna statistička analiza, kako slijedi u prikazu Tablice 31. 
Tablica 31. Deskriptivna statistička analiza: rezultati 2. kruga istraživanja, N=37 (izvor: upitnik, Google obrasci, SPSS obrada autorice)

\begin{tabular}{|c|c|c|c|c|c|c|c|c|c|c|c|c|c|}
\hline & & KČP1_2 & KČP2_2 & KČP3_2 & KČP4_2 & KČP5_2 & KČP6_2 & KČP7_2 & KČP8_2 & KČP9_2 & KČP10_2 & KČP11_2 & KČP12_2 \\
\hline \multirow[t]{2}{*}{$\overline{\mathbf{N}}$} & Valid & 37 & 37 & 37 & 37 & 37 & 37 & 37 & 37 & 37 & 37 & 37 & 37 \\
\hline & Missing & 0 & 0 & 0 & 0 & 0 & 0 & 0 & 0 & 0 & 0 & 0 & 0 \\
\hline \multicolumn{2}{|l|}{ Mean } & 8,92 & 7,81 & 8,51 & 8,05 & 7,73 & 6,84 & 8,59 & 8,32 & 8,00 & 7,70 & 7,41 & 7,05 \\
\hline \multicolumn{2}{|c|}{ Std. Error of Mean } &, 220 & ,355 & ,294 & ,263 &, 259 &, 339 & ,309 &, 251 & ,308 &, 373 &, 352 &, 353 \\
\hline \multicolumn{2}{|l|}{ Median } & 9,00 & 8,00 & 9,00 & 8,00 & 8,00 & 7,00 & 9,00 & 9,00 & 8,00 & 8,00 & 8,00 & 7,00 \\
\hline \multicolumn{2}{|l|}{ Mode } & 10 & 10 & 10 & 8 & 8 & 7 & 10 & $8 a^{*}$ & 10 & 9 & 8 & 9 \\
\hline \multicolumn{2}{|l|}{ Std. Deviation } & 1,341 & 2,158 & 1,789 & 1,598 & 1,575 & 2,062 & 1,878 & 1,529 & 1,871 & 2,271 & 2,140 & 2,147 \\
\hline \multicolumn{2}{|l|}{ Variance } & 1,799 & 4,658 & 3,201 & 2,553 & 2,480 & 4,251 & 3,526 & 2,336 & 3,500 & 5,159 & 4,581 & 4,608 \\
\hline \multicolumn{2}{|l|}{ Skewness } & $-1,743$ &,- 934 & $-1,269$ & $-1,000$ &,- 563 & $-1,037$ & $-2,458$ & $-1,078$ & $-1,292$ & $-1,354$ & $-1,480$ & $-1,089$ \\
\hline \multicolumn{2}{|c|}{ Std. Error of Skewness } & ,388 & ,388 & ,388 & ,388 & ,388 & ,388 & ,388 & ,388 & ,388 & ,388 & ,388 & ,388 \\
\hline \multicolumn{2}{|l|}{ Kurtosis } & 3,955 & 308 &, 783 & 1,389 &,- 410 & ,942 & 7,306 & ,993 & 2,472 & 1,704 & 2,520 & ,984 \\
\hline \multicolumn{2}{|c|}{ Std. Error of Kurtosis } & ,759 & ,759 & ,759 & ,759 & ,759 &, 759 &, 759 & ,759 & ,759 & ,759 & ,759 &, 759 \\
\hline \multicolumn{2}{|l|}{ Range } & 6 & 8 & 6 & 7 & 6 & 9 & 9 & 6 & 8 & 9 & 9 & 9 \\
\hline \multicolumn{2}{|l|}{ Minimum } & 4 & 2 & 4 & 3 & 4 & 1 & 1 & 4 & 2 & 1 & 1 & 1 \\
\hline \multicolumn{2}{|l|}{ Maximum } & 10 & 10 & 10 & 10 & 10 & 10 & 10 & 10 & 10 & 10 & 10 & 10 \\
\hline \multicolumn{2}{|l|}{ Sum } & 330 & 289 & 315 & 298 & 286 & 253 & 318 & 308 & 296 & 285 & 274 & 261 \\
\hline \multirow[t]{3}{*}{ Percentiles } & 25 & 8,00 & 7,00 & 8,00 & 7,00 & 6,50 & 5,50 & 8,00 & 8,00 & 7,00 & 7,00 & 7,00 & 6,00 \\
\hline & $\overline{50}$ & 9,00 & 8,00 & 9,00 & 8,00 & 8,00 & 7,00 & 9,00 & 9,00 & 8,00 & 8,00 & 8,00 & 7,00 \\
\hline & 75 & 10,00 & 10,00 & 10,00 & 9,00 & 9,00 & 8,00 & 10,00 & 9,50 & 10,00 & 9,00 & 9,00 & 9,00 \\
\hline
\end{tabular}


Kako bi se ključni čimbenici promjene komunikacijske paradigme u visokom obrazovanju pod utjecajem društvenih medija rangirali prema važnosti, na temelju odgovora panelista u 2. krugu analizirane su aritmetička sredina (M) (prosjek ocjena grupe), pripadajuća standardna devijacija (SD) te suma (engl. Sum) svih ocjena odnosno stupnjeva važnosti koje su panelisti dodijelili pojedinom KČP-u $\left(\sum\right), \mathrm{N}=37$. Delfi rang ključnih čimbenika promjene (KČP) komunikacijske paradigme u visokom obrazovanju pod utjecajem društvenih medija u 2. krugu istraživanja prikazan je u Tablici 32.

Tablica 32. Delfi rang 12 ključnih čimbenika promjene (KČP) komunikacijske paradigme u visokom obrazovanju pod utjecajem društvenih medija u 2. krugu istraživanja, N=37 (izvor: upitnik, Google obrasci, SPSS obrada autorice)

\begin{tabular}{|c|c|c|c|c|c|}
\hline $\begin{array}{l}\text { Broj } \\
\text { čimbenika }\end{array}$ & $\begin{array}{l}\text { Ključni čimbenici promjene komunikacijske } \\
\text { paradigme u VO pod utjecajem DM }\end{array}$ & $M$ & $S D$ & $\sum$ & $\begin{array}{l}\text { Delfi rang } \\
\text { u 2. krugu }\end{array}$ \\
\hline KČP 1 & Razvoj tehnologija & 8,92 & 1,34 & 330 & 1 \\
\hline KČP 2 & Nacionalne politike / strategije obrazovanja & 7,81 & 2,16 & 289 & 7 \\
\hline KČP 3 & Podrška vodstva visokih učilišta & 8,51 & 1,79 & 315 & 3 \\
\hline KČP 4 & Strategija upravljanja znanjem & 8,05 & 1,60 & 298 & 5 \\
\hline KČP 5 & Metrike uspješnosti & 7,73 & 1,57 & 286 & 8 \\
\hline KČP 6 & Infrastruktura upravljanja znanjem & 6,84 & 2,06 & 253 & 12 \\
\hline KČP 7 & Motivacija nastavnika & 8,59 & 1,88 & 318 & 2 \\
\hline KČP 8 & Očekivanja studenata & 8,32 & 1,53 & 308 & 4 \\
\hline KČP 9 & Kultura razmjene znanja & 8,00 & 1,87 & 296 & 6 \\
\hline KČP 10 & Dostupnost resursa & 7,70 & 2,27 & 285 & 9 \\
\hline KČP 11 & Kvaliteta društvenih medija & 7,41 & 2,14 & 274 & 10 \\
\hline KČP 12 & Društvo u cjelini & 7,05 & 2,15 & 261 & 11 \\
\hline
\end{tabular}




\subsubsection{Treći krug delfi studije}

Upitnik 3. kruga započeo je pregledom rezultata 2. kruga, nisu bila prijavljena neslaganja ili primjedbe panelista, stoga je u 3. krugu sudionicima ponovno predstavljen objedinjeni popis ključnih čimbenika promjene (kratica KČP) komunikacijske paradigme u visokom obrazovanju pod utjecajem društvenih medija identificiranih u 1. krugu. Svaki KČP opisan je pomoću ključnih riječi i opisnica koje su sudionici koristili u 1. krugu, kako bi se sudionicima olakšalo i omogućilo bolje i lakše razumijevanje. Uz popis, panelistima su bili grafički predstavljeni odgovori panelista u prethodnom krugu istraživanja, na svako pitanje, i to postotno za svaki stupanj važnosti koji su dodijelili pojedinom KČP. Zatim su zamoljeni da ponovno razmotre i dodijele stupanj važnosti svakom čimbeniku prema Likertovoj ljestvici 1-10 (pri čemu je 1 je označavao čimbenik koji uopće nije važan, a 10 iznimno važan čimbenik) u svrhu mogućeg postizanja konsenzusa. Kratki opis 12 ključnih čimbenika promjene (KČP) komunikacijske paradigme u visokom obrazovanju pod utjecajem društvenih medija (Tablica 29.) te prikaz rezultata iz prethodnog kruga nalazili su se unutar Upitnika 3. (Prilog 13.) kao mehanizam koji pomaže u tumačenju konsenzusnih sredstava generiranih ovom studijom. Ovaj pristup je dokumentiran u literaturi kako je navedeno u poglavlju o istraživačkom pristupu ovog rada, a za potrebe ove delfi studije nakon dobivenih odgovora panelista u 3. krugu provedena je analiza rezultata kako slijedi.

Nakon završenog 3. kruga istraživanja, uvidom u odgovore utvrđeno je da niti u ovom krugu istraživanja, nisu prijavljena neslaganja ili primjedbe panelista. Tablica 33. koja slijedi prikazuje frekvenciju odgovora sudionika u 3. krugu istraživanja iskazanu numerički i postotno, za svaki stupanj važnosti dodijeljenih svakom pojedinom od 12 ključnih čimbenika promjene (KČP) komunikacijske paradigme u visokom obrazovanju pod utjecajem društvenih medija, pri čemu 1 označava da čimbenik uopće nije važan, a 10 označava da je čimbenik iznimno važan, $\mathrm{N}=36$. 
Tablica 33. Frekvencija odgovora u 3. krugu prema stupnjevima važnosti 12 ključnih čimbenika promjene (KČP) komunikacijske paradigme u visokom obrazovanju pod utjecajem društvenih medija, N=36 (izvor: upitnik, Google obrasci, SPSS obrada autorice)

\begin{tabular}{|c|c|c|c|c|c|c|c|c|c|c|c|}
\hline \multicolumn{2}{|c|}{$\begin{array}{l}\text { Stupanj } \\
\text { važnosti }\end{array}$} & \multirow{2}{*}{$\begin{array}{c}1 \\
0\end{array}$} & \multirow{2}{*}{$\begin{array}{c}2 \\
0\end{array}$} & \multirow{2}{*}{$\begin{array}{c}3 \\
0\end{array}$} & \multirow{2}{*}{$\begin{array}{l}4 \\
1\end{array}$} & \multirow{2}{*}{$\begin{array}{l}5 \\
1\end{array}$} & \multirow{2}{*}{$\begin{array}{c}6 \\
0\end{array}$} & \multirow{2}{*}{$\begin{array}{c}7 \\
0\end{array}$} & \multirow{2}{*}{$\begin{array}{c}8 \\
4\end{array}$} & \multirow{2}{*}{$\begin{array}{c}9 \\
10\end{array}$} & \multirow{2}{*}{$\begin{array}{c}10 \\
22\end{array}$} \\
\hline КС̆P1 & $\mathbf{N}$ & & & & & & & & & & \\
\hline & $\%$ & $0 \%$ & $0 \%$ & $0 \%$ & $2,8 \%$ & $2,8 \%$ & $0 \%$ & $0 \%$ & $11,1 \%$ & $22,2 \%$ & $61,1 \%$ \\
\hline \multirow[t]{2}{*}{ KČP2 } & $\mathbf{N}$ & 0 & 0 & 0 & 1 & 1 & 2 & 7 & 4 & 15 & 6 \\
\hline & $\%$ & $0 \%$ & $0 \%$ & $0 \%$ & $2,8 \%$ & $2,8 \%$ & $5,6 \%$ & $19,4 \%$ & $11,1 \%$ & $41,7 \%$ & $16,7 \%$ \\
\hline \multirow[t]{2}{*}{ KČP3 } & $\mathbf{N}$ & 0 & 0 & 0 & 0 & 0 & 0 & 1 & 5 & 10 & 20 \\
\hline & $\%$ & $0 \%$ & $0 \%$ & $0 \%$ & $0 \%$ & $0 \%$ & $0 \%$ & $2,8 \%$ & $13,9 \%$ & $27,8 \%$ & $55,6 \%$ \\
\hline \multirow[t]{2}{*}{ КС̆P4 } & $\mathbf{N}$ & 0 & 0 & 2 & 0 & 0 & 2 & 9 & 16 & 4 & 3 \\
\hline & $\%$ & $0 \%$ & $0 \%$ & $5,6 \%$ & $0 \%$ & $0 \%$ & $5,6 \%$ & $25 \%$ & $44,4 \%$ & $11,1 \%$ & $8,3 \%$ \\
\hline \multirow[t]{2}{*}{ KČP5 } & $\mathbf{N}$ & 0 & 0 & 0 & 0 & 2 & 4 & 10 & 14 & 5 & 1 \\
\hline & $\%$ & $0 \%$ & $0 \%$ & $0 \%$ & $0 \%$ & $5,6 \%$ & $11,1 \%$ & $27,8 \%$ & $38,9 \%$ & $13,9 \%$ & $2,8 \%$ \\
\hline \multirow[t]{2}{*}{ KČP6 } & $\mathbf{N}$ & 0 & 1 & 0 & 1 & 2 & 5 & 13 & 8 & 5 & 1 \\
\hline & $\%$ & $0 \%$ & $2,8 \%$ & $0 \%$ & $2,8 \%$ & $5,6 \%$ & $13,9 \%$ & $36,1 \%$ & $22,2 \%$ & $13,9 \%$ & $2,8 \%$ \\
\hline \multirow[t]{2}{*}{ KČP7 } & $\mathbf{N}$ & 0 & 0 & 0 & 2 & 0 & 0 & 0 & 4 & 7 & 23 \\
\hline & $\%$ & $0 \%$ & $0 \%$ & $0 \%$ & $5,6 \%$ & $0 \%$ & $0 \%$ & $0 \%$ & $11,1 \%$ & $19,4 \%$ & $63,9 \%$ \\
\hline \multirow[t]{2}{*}{ КС̆P8 } & $\mathbf{N}$ & 0 & 0 & 1 & 1 & 1 & 2 & 2 & 13 & 11 & 5 \\
\hline & $\%$ & $0 \%$ & $0 \%$ & $2,8 \%$ & $2,8 \%$ & $2,8 \%$ & $5,6 \%$ & $5,6 \%$ & $36,1 \%$ & $30,6 \%$ & $13,9 \%$ \\
\hline \multirow[t]{2}{*}{ КС̌P9 } & $\mathbf{N}$ & 0 & 1 & 0 & 0 & 2 & 2 & 5 & 12 & 2 & 12 \\
\hline & $\%$ & $0 \%$ & $2,8 \%$ & $0 \%$ & $0 \%$ & $5,6 \%$ & $5,6 \%$ & $13,9 \%$ & $33,3 \%$ & $5,6 \%$ & $33,3 \%$ \\
\hline \multirow[t]{2}{*}{ КС̌P10 } & $\mathbf{N}$ & 1 & 0 & 0 & 1 & 0 & 4 & 9 & 2 & 15 & 4 \\
\hline & $\%$ & $2,8 \%$ & $0 \%$ & $0 \%$ & $2,8 \%$ & $0 \%$ & $11,1 \%$ & $25 \%$ & $5,6 \%$ & $41,7 \%$ & $11,1 \%$ \\
\hline \multirow[t]{2}{*}{ KČP11 } & $\mathbf{N}$ & 1 & 0 & 1 & 0 & 3 & 2 & 8 & 12 & 8 & 1 \\
\hline & $\%$ & $2,8 \%$ & $0 \%$ & $2,8 \%$ & $0 \%$ & $8,3 \%$ & $5,6 \%$ & $22,2 \%$ & $33,3 \%$ & $22,2 \%$ & $2,8 \%$ \\
\hline \multirow[t]{2}{*}{ КС̆P12 } & $\mathbf{N}$ & 0 & 1 & 0 & 1 & 1 & 6 & 7 & 6 & 16 & 2 \\
\hline & $\%$ & $0 \%$ & $2,8 \%$ & $0 \%$ & $2,8 \%$ & $2,8 \%$ & $16,7 \%$ & $8,3 \%$ & $16,7 \%$ & $44,4 \%$ & $5,6 \%$ \\
\hline \multirow{2}{*}{\multicolumn{2}{|c|}{$\begin{array}{l}\text { Frekvencija } \\
\text { odgovora (total) }\end{array}$}} & 36 & & & & & & & & & \\
\hline & & $100 \%$ & & & & & & & & & \\
\hline
\end{tabular}

Nakon dobivenih odgovora panelista u 3. krugu ponovno je provedena deskriptivna statistička analiza, kako slijedi u prikazu Tablice 34. 
Tablica 34. Deskriptivna statistička analiza: rezultati 3. kruga istraživanja, N=36 (izvor: upitnik, Google obrasci, SPSS obrada autorice)

\begin{tabular}{|c|c|c|c|c|c|c|c|c|c|c|c|c|c|}
\hline & & KČP1_3 & KČP2_3 & KČP3_3 & KČP4_3 & KČP5_3 & KČP6_3 & KČP7_3 & KČP8_3 & KČP9_3 & KČP10_3 & KČP11_3 & KČP12_3 \\
\hline \multirow[t]{2}{*}{$\overline{\mathbf{N}}$} & Valid & 36 & 36 & 36 & 36 & 36 & 36 & 36 & 36 & 36 & 36 & 36 & 36 \\
\hline & Missing & 0 & 0 & 0 & 0 & 0 & 0 & 0 & 0 & 0 & 0 & 0 & 0 \\
\hline \multicolumn{2}{|l|}{ Mean } & 9,25 & 8,25 & 9,36 & 7,64 & 7,53 & 7,11 & 9,25 & 8,08 & 8,14 & 7,86 & 7,36 & 7,78 \\
\hline \multicolumn{2}{|c|}{ Std. Error of Mean } &, 227 & ,247 & ,139 & ,249 & ,189 & ,258 & ,244 & ,268 &, 304 & ,309 & ,301 & ,296 \\
\hline \multicolumn{2}{|l|}{ Median } & 10,00 & 9,00 & 10,00 & 8,00 & 8,00 & 7,00 & 10,00 & 8,00 & 8,00 & 9,00 & 8,00 & 8,50 \\
\hline \multicolumn{2}{|l|}{ Mode } & 10 & 9 & 10 & 8 & 8 & 7 & 10 & 8 & $8 a$ & 9 & 8 & 9 \\
\hline \multicolumn{2}{|l|}{$\overline{\text { Std. Deviation }}$} & 1,360 & 1,481 & ,833 & 1,496 & 1,134 & 1,545 & 1,461 & 1,610 & 1,823 & 1,854 & 1,807 & 1,775 \\
\hline \multicolumn{2}{|l|}{ Variance } & 1,850 & 2,193 & ,694 & 2,237 & 1,285 & 2,387 & 2,136 & 2,593 & 3,323 & 3,437 & 3,266 & 3,149 \\
\hline \multicolumn{2}{|l|}{ Skewness } & $-2,646$ & $-1,017$ & $-1,099$ & $-1,451$ &,- 322 & $-1,033$ & $-2,788$ & $-1,491$ & $-1,206$ & $-1,665$ & $-1,684$ & $-1,365$ \\
\hline \multicolumn{2}{|c|}{ Std. Error of Skewness } & ,393 &, 393 &, 393 &, 393 &, 393 &, 393 & ,393 &, 393 & ,393 &, 393 & ,393 &, 393 \\
\hline \multicolumn{2}{|l|}{ Kurtosis } & 7,653 & ,726 & ,364 & 3,835 & 130 & 2,449 & 8,150 & 2,536 & 2,284 & 4,189 & 3,745 & 1,934 \\
\hline \multicolumn{2}{|c|}{ Std. Error of Kurtosis } & ,768 & ,768 & ,768 & ,768 & ,768 & ,768 & ,768 & ,768 & ,768 & ,768 & ,768 & ,768 \\
\hline \multicolumn{2}{|l|}{ Range } & 6 & 6 & 3 & 7 & 5 & 8 & 6 & 7 & 8 & 9 & 9 & 8 \\
\hline \multicolumn{2}{|l|}{ Minimum } & 4 & 4 & 7 & 3 & 5 & 2 & 4 & 3 & 2 & 1 & 1 & 2 \\
\hline \multicolumn{2}{|l|}{ Maximum } & 10 & 10 & 10 & 10 & 10 & 10 & 10 & 10 & 10 & 10 & 10 & 10 \\
\hline \multicolumn{2}{|l|}{$\overline{\text { Sum }}$} & 333 & 297 & 337 & 275 & 271 & 256 & 333 & 291 & 293 & 283 & 265 & 280 \\
\hline \multirow[t]{3}{*}{ Percentiles } & 25 & 9,00 & 7,00 & 9,00 & 7,00 & 6,25 & 9,00 & 9,00 & 8,00 & 7,00 & 7,00 & 7,00 & 6,25 \\
\hline & $\overline{\mathbf{5 0}}$ & 10,00 & 9,00 & 10,00 & 8,00 & 7,00 & 10,00 & 10,00 & 8,00 & 8,00 & 9,00 & 8,00 & 8,50 \\
\hline & $\overline{75}$ & 10,00 & 9,00 & 10,00 & 8,00 & 8,00 & 10,00 & 10,00 & 9,00 & 10,00 & 9,00 & 8,75 & 9,00 \\
\hline
\end{tabular}


Kako bi se ključni čimbenici promjene komunikacijske paradigme u visokom obrazovanju pod utjecajem društvenih medija rangirali prema važnosti, na temelju odgovora panelista u 3. krugu ponovno su analizirane aritmetička sredina (M) (prosjek ocjena grupe), pripadajuća standardna devijacija (SD) te suma (engl. Sum) svih ocjena odnosno stupnjeva važnosti koje su panelisti dodijelili pojedinom KČP-u $\left(\sum\right), \mathrm{N}=36$. Delfi rang ključnih čimbenika promjene (KČP) komunikacijske paradigme u visokom obrazovanju pod utjecajem društvenih medija u 3. krugu istraživanja prikazan je u Tablici 35.

Tablica 35. Delfi rang 12 ključnih čimbenika promjene (KČP) komunikacijske paradigme u visokom obrazovanju pod utjecajem društvenih medija u 3. krugu istraživanja, N=36 (izvor: upitnik, Google obrasci, SPSS, obrada autorice)

\begin{tabular}{llcccc}
\hline $\begin{array}{l}\text { Broj } \\
\text { čmbenika }\end{array}$ & $\begin{array}{l}\text { Ključni čimbenici promjene komunikacijske } \\
\text { paradigme u VO pod utjecajem DM }\end{array}$ & $\boldsymbol{M}$ & $\boldsymbol{S D}$ & $\Sigma$ & $\begin{array}{c}\text { Delfi rang } \\
\text { u 3. krugu }\end{array}$ \\
\hline KČP 1 & Razvoj tehnologija & 9,25 & 1,36 & 333 & $\mathbf{2}$ \\
\hline KČP 2 & Nacionalne politike / strategije obrazovanja & 8,25 & 1,48 & 297 & $\mathbf{4}$ \\
\hline KČP 3 & Podrška vodstva visokih učilišta & 9,36 &, 83 & 337 & $\mathbf{1}$ \\
\hline KČP 4 & Strategija upravljanja znanjem & 7,64 & 1,50 & 275 & $\mathbf{9}$ \\
\hline KČP 5 & Metrike uspješnosti & 7,53 & 1,13 & 271 & $\mathbf{1 0}$ \\
\hline KČP 6 & Infrastruktura upravljanja znanjem & 7,11 & 1,55 & 256 & $\mathbf{1 2}$ \\
\hline KČP 7 & Motivacija nastavnika & 9,25 & 1,46 & 333 & $\mathbf{3}$ \\
\hline KČP 8 & Očekivanja studenata & 8,08 & 1,61 & 291 & $\mathbf{6}$ \\
\hline KČP 9 & Kultura razmjene znanja & 8,14 & 1,82 & 293 & $\mathbf{5}$ \\
\hline KČP 10 & Dostupnost resursa & 7,86 & 1,85 & 283 & $\mathbf{7}$ \\
\hline KČP 11 & Kvaliteta društvenih medija & 7,36 & 1,81 & 265 & $\mathbf{1 1}$ \\
\hline KČP 12 & Društvo u cjelini & 7,78 & 1,77 & 280 & $\mathbf{8}$ \\
\hline & Aritmetička sredina (M): 1 označava da čimbenik uopće nije važan, a 10 označava da je \\
\hline & & & & \\
\hline
\end{tabular}

U ovom radu, rezultati u 2. i 3. krugu prikazani su prema aritmetičkoj sredini, standardnoj devijaciji i te sumi svih stupnjeva važnosti koje su panelisti dodijelili pojedinom ključnom čimbeniku promjene (KČP) komunikacijske paradigme u visokom obrazovanju pod utjecajem 
društvenih medija, jer rangovi nisu slijedili iz slijednosti koje su im dodijelili panelisti, već na temelju dodijeljenih stupnjeva važnosti prema Likertovoj ljestvici 1-10. Zaključno, provedena je neparametrijska statistička analiza kako bi se utvrdio konsenzus.

U Tablici 36. prikazani su usporedno odgovori panelista u 2. i 3. krugu istraživanja odnosno delfi rang ključnih čimbenika (KČP) komunikacijske paradigme u visokom obrazovanju pod utjecajem društvenih medija, koji su rangirani prema rezultatima deskriptivne statističke analize; $\mathrm{u}$ istoj tablici iz sumarnih rezultata deskriptivne statističke analize istaknuti su aritmetička sredina (M) (prosjek ocjena grupe) i pripadajuća standardna devijacija (SD).

Tablica 36. Podaci o konsenzusu: deskriptivna analiza odgovora za 12 ključnih čimbenika promjene (KČP) komunikacijske paradigme u visokom obrazovanju pod utjecajem društvenih medija - usporedba rezultata 2 . i 3. kruga (izvor: upitnik, Google obrasci, SPSS, obrada autorice)

\begin{tabular}{|c|c|c|c|c|c|c|c|c|c|}
\hline \multirow{2}{*}{$\begin{array}{l}\text { Broj } \\
\text { čimbenika }\end{array}$} & \multirow{2}{*}{$\begin{array}{l}\text { Ključni čimbenici promjene } \\
\text { komunikacijske paradigme u } \\
\text { VO pod utjecajem DM }\end{array}$} & \multicolumn{3}{|c|}{ 2. krug } & \multicolumn{5}{|c|}{ 3. krug } \\
\hline & & $N$ & $M$ & $S D$ & Rang & $N$ & $M$ & $S D$ & Rang \\
\hline KČP 1 & Razvoj tehnologija & 37 & 8,92 & 1,34 & 1 & 36 & 9,25 & 1,36 & 2 \\
\hline КС̆P 2 & $\begin{array}{l}\text { Nacionalne politike / strategije } \\
\text { obrazovanja }\end{array}$ & 37 & 7,81 & 2,16 & 7 & 36 & 8,25 & 1,48 & 4 \\
\hline KČP 3 & Podrška vodstva visokih učilišta & 37 & 8,51 & 1,79 & 3 & 36 & 9,36 &, 83 & 1 \\
\hline КС̌P 4 & Strategija upravljanja znanjem & 37 & 8,05 & 1,60 & 5 & 36 & 7,64 & 1,50 & 5 \\
\hline KČP 5 & Metrike uspješnosti & 37 & 7,73 & 1,57 & 8 & 36 & 7,53 & 1,13 & 10 \\
\hline КС̌P 6 & $\begin{array}{l}\text { Infrastruktura upravljanja } \\
\text { znanjem }\end{array}$ & 37 & 6,84 & 2,06 & 12 & 36 & 7,11 & 1,55 & 12 \\
\hline KČP 7 & Motivacija nastavnika & 37 & 8,59 & 1,88 & 2 & 36 & 9,25 & 1,46 & 3 \\
\hline КС̆P 8 & Očekivanja studenata & 37 & 8,32 & 1,53 & 4 & 36 & 8,08 & 1,61 & 6 \\
\hline KČP 9 & Kultura razmjene znanja & 37 & 8,00 & 1,87 & 6 & 36 & 8,14 & 1,82 & 5 \\
\hline KČP 10 & Dostupnost resursa & 37 & 7,70 & 2,27 & 9 & 36 & 7,86 & 1,85 & 7 \\
\hline KČP 11 & Kvaliteta društvenih medija & 37 & 7,41 & 2,14 & 10 & 36 & 7,36 & 1,81 & 11 \\
\hline KČP 12 & Društvo u cjelini & 37 & 7,05 & 2,15 & 11 & 36 & 7,78 & 1,77 & 8 \\
\hline & tmetička sredina $(M): 1$ označ & enik & $\begin{array}{l}\text { nbenik } \\
\text { nimno }\end{array}$ & $\begin{array}{l}\text { pće } \\
\text { žan }\end{array}$ & $\overline{\mathrm{až}}$ & & cav & & \\
\hline
\end{tabular}

Nakon 3. kruga istraživanja korištena je neparametrijska statistička analiza za uspostavljanje konsenzusa. Odgovori panelista iz drugog i trećeg kruga testirani su pomoću Wilcoxonovog testa rangova zavisnih uzoraka. Izmjereni rangovi 12 ključnih čimbenika promjene (KČP) 
komunikacijske paradigme u visokom obrazovanju pod utjecajem društvenih medija iz 2. i 3 . kruga testirani su pomoću Wilcoxonovog testa rangova zavisnih uzoraka. Za ovu analizu usvojena je razina signifikatnosti od $10 \%$ pri tumačenju značaja rezultata, s obzirom na to da je teško otkriti značajne razlike među skupinama kada se koriste male veličine uzoraka (npr. 20), pa bi stoga moglo biti potrebno imati višu razinu alfa za značajnost od tradicionalne razine 0,05 ( $\alpha=0,05)$ (Arcangeli, Houssein, 2013 prema Pallant, 2011). S obzirom da je ukupni broj panelista koji su odgovarali na pitanja u 3. krugu bio 36, jer je 1 panelist odustao nakon 2. kruga istraživanja, iz testa su isključeni odgovori navedenog panelista, te su testirani rangovi 36 panelista koji su sudjelovali u oba kruga istraživanja $(\mathrm{N}=36)$.

Definirana je nul-hipoteza $H_{0}$ :

Ne postoje statističke značajne razlike između rangova ključnih čimbenika promjene komunikacijske paradigme u visokom obrazovanju pod utjecajem društvenih medija u drugom i trećem krugu istraživanja.

te alternativna hipoteza $H_{1}$ :

Postoje statističke značajne razlike između rangova ključnih čimbenika promjene komunikacijske paradigme u visokom obrazovanju pod utjecajem društvenih medija u drugom i trećem krugu istraživanja.

Testiranje se provodi uz značajnost od $10 \%$.

$\mathrm{H}_{0} \ldots \mathrm{p} \leq 0,1 \quad \mathrm{H}_{1} \ldots \mathrm{p}>0,1$

Grupirajuća varijabla „rangovi ključnih čimbenika promjene komunikacijske paradigme u visokom obrazovanju pod utjecajem društvenih medija u drugom i trećem krugu istraživanja” imala je 12 podvarijabli, stoga su definirane pomoćne hipoteze koje su testirane na nivou signifikantnosti 0,10 :

H1.1. Postoje statističke značajne razlike između rangova ključnog čimbenika promjene komunikacijske paradigme $u$ visokom obrazovanju pod utjecajem društvenih medija broj 1 „Razvoj tehnologija “ (KČPl) u drugom i trećem krugu istraživanja.

Navedena razlika nije statistički značajna $(p=0,198)$, pomoćna hipoteza H1.1. se odbacuje.

H1.2. Postoje statističke značajne razlike između rangova ključnog čimbenika promjene komunikacijske paradigme $u$ visokom obrazovanju pod utjecajem društvenih medija broj 2 „Nacionalne politike/strategije obrazovanja“ (K亡̌P2) u drugom i trećem krugu istraživanja. Navedena razlika nije statistički značajna $(p=0,303)$, pomoćna hipoteza H1.2. se odbacuje. 
H1.3. Postoje statističke značajne razlike između rangova ključnog čimbenika promjene komunikacijske paradigme $u$ visokom obrazovanju pod utjecajem društvenih medija broj 3 „Podrška vodstva visokih učilišta“ (KČP3) u drugom i trećem krugu istraživanja.

Navedena razlika je statistički značajna $(\mathrm{p}=0,026)$, pomoćna hipoteza H1.3. se prihvaća.

H1.4. Postoje statističke značajne razlike između rangova ključnog čimbenika promjene komunikacijske paradigme $u$ visokom obrazovanju pod utjecajem društvenih medija broj 4 „Strategija upravljanja znanjem“ (KČP4) u drugom i trećem krugu istraživanja.

Navedena razlika nije statistički značajna $(\mathrm{p}=0,101)$, pomoćna hipoteza H1.4. se odbacuje.

H1.5. Postoje statističke značajne razlike između rangova ključnog čimbenika promjene komunikacijske paradigme u visokom obrazovanju pod utjecajem društvenih medija broj 5 „Metrike uspješnosti“ (KČP5) u drugom i trećem krugu istraživanja.

Navedena razlika nije statistički značajna $(p=0,462)$, pomoćna hipoteza H1.5. se odbacuje.

H1.6. Postoje statističke značajne razlike između rangova ključnog čimbenika promjene komunikacijske paradigme u visokom obrazovanju pod utjecajem društvenih medija broj 6 „, Infrastruktura upravljanja znanjem“ (KС̆P6) u drugom i trećem krugu istraživanja.

Navedena razlika nije statistički značajna $(\mathrm{p}=0,500)$, pomoćna hipoteza H1.6. se odbacuje.

H1.7. Postoje statističke značajne razlike između rangova ključnog čimbenika promjene komunikacijske paradigme $u$ visokom obrazovanju pod utjecajem društvenih medija broj 7 „,Motivacija nastavnika“ (KČP7) u drugom i trećem krugu istraživanja.

Navedena razlika je statistički značajna $(\mathrm{p}=0,048)$, pomoćna hipoteza H1.7. se prihvaća.

H1.8. Postoje statističke značajne razlike između rangova ključnog čimbenika promjene komunikacijske paradigme u visokom obrazovanju pod utjecajem društvenih medija broj 8 „Očekivanja studenata “ (KČP8) u drugom i trećem krugu istraživanja.

Navedena razlika nije statistički značajna $(\mathrm{p}=0,364)$, pomoćna hipoteza H1.8. se odbacuje.

H1.9. Postoje statističke značajne razlike između rangova ključnog čimbenika promjene komunikacijske paradigme u visokom obrazovanju pod utjecajem društvenih medija broj 9 „Kultura razmjene znanja“ (KČP9) u drugom i trećem krugu istraživanja.

Navedena razlika nije statistički značajna $(\mathrm{p}=0,967)$, pomoćna hipoteza H1.9. se odbacuje. 
H1.10. Postoje statističke značajne razlike između rangova ključnog čimbenika promjene komunikacijske paradigme u visokom obrazovanju pod utjecajem društvenih medija broj 10 „Dostupnost resursa“ (KČP10) u drugom i trećem krugu istraživanja.

Navedena razlika nije statistički značajna $(\mathrm{p}=0,914)$, pomoćna hipoteza H1.10. se odbacuje.

H1.11. Postoje statističke značajne razlike između rangova ključnog čimbenika promjene komunikacijske paradigme u visokom obrazovanju pod utjecajem društvenih medija broj 11 „Kvaliteta društvenih medija“ (KČP11) u drugom i trećem krugu istraživanja.

Navedena razlika nije statistički značajna $(\mathrm{p}=0,914)$, pomoćna hipoteza H1.11. se odbacuje.

H1.12. Postoje statističke značajne razlike između rangova ključnog čimbenika promjene komunikacijske paradigme u visokom obrazovanju pod utjecajem društvenih medija broj 12 „Društvo u cjelini““ (KČP12) u drugom i trećem krugu istraživanja.

Navedena razlika je statistički značajna $(\mathrm{p}=0,083)$, pomoćna hipoteza H1.12. se prihvaća.

Na temelju rezultata 12 Wilcoxonovih testova rangova zavisnih uzoraka 12 ključnih čimbenika promjene (KČP) komunikacijske paradigme u visokom obrazovanju pod utjecajem društvenih

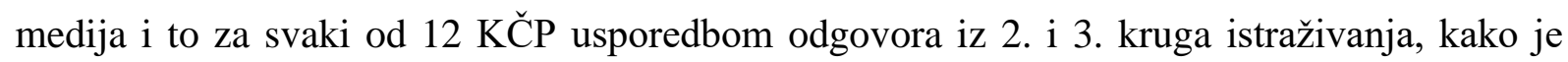
prikazano u Tablici 37., pokazalo se da postoji statistički značajna razlika već na nivou signifikantnosti 0,05 za KČP3 „Podrška vodstva visokih učilišta“ (p = 0,026) i KČP7 „Motivacija nastavnika“ ( $p=0,048)$ te je dodatno uočena i statistički značajna razlika na nivou signifikantnosti 0,10 za KČP12 „Društvo u cjelini“ ( $p=0,083$ ). Kod ostalih ključnih čimbenika promjene komunikacijske paradigme u visokom obrazovanju pod utjecajem društvenih medija ne postoje statistički značajne razlike između rangova u 2. i 3. krugu istraživanja. 
Tablica 37. Neparametrijska statistička analiza: Prikaz rezultata Wilcoxonovog testa rangova zavisnih uzoraka 12 ključnih čimbenika promjene (KČP) komunikacijske paradigme u visokom obrazovanju pod utjecajem društvenih medija, N=36 (izvor: upitnik, Google obrasci, SPSS obrada autorice)

\begin{tabular}{|c|c|c|c|c|c|c|}
\hline \multicolumn{2}{|c|}{$\begin{array}{c}\text { Ključni čimbenici promjene (KČP) } \\
\text { komunikacijske paradigme u VO } \\
\text { pod utjecajem DM }\end{array}$} & \multirow{2}{*}{$\frac{N}{16}$} & \multirow{2}{*}{$\frac{\text { Mean Rank }}{13,09}$} & \multirow{2}{*}{$\begin{array}{c}\begin{array}{c}\text { Sum of } \\
\text { Ranks }\end{array} \\
209,50 \\
\end{array}$} & \multirow[t]{2}{*}{$Z$} & $\begin{array}{c}\text { Asymp. Sig. } \\
\text { (2-tailed) }\end{array}$ \\
\hline \multirow{4}{*}{ KČP1_2 - KČP1_3 } & Negative Ranks & & & & & \multirow{4}{*}{,198 } \\
\hline & Positive Ranks & 9 & 12,83 & 115,50 & \multirow{3}{*}{$-1,29$} & \\
\hline & Ties & 11 & & & & \\
\hline & Total & 36 & & & & \\
\hline \multirow{4}{*}{ KČP2_2 - KČP2_3 } & Negative Ranks & 14 & 15,39 & 215,50 & \multirow{4}{*}{$-1,03$} & \multirow{4}{*}{, 303} \\
\hline & Positive Ranks & 12 & 11,29 & 135,50 & & \\
\hline & Ties & 10 & & & & \\
\hline & Total & 36 & & & & \\
\hline \multirow{4}{*}{ KČP3_2 - KČP3_3 } & Negative Ranks & 16 & 13,13 & 210,00 & \multirow{4}{*}{$-2,23$} & \multirow{4}{*}{, 026} \\
\hline & Positive Ranks & 7 & 9,43 & 66,00 & & \\
\hline & Ties & 13 & & & & \\
\hline & Total & 36 & & & & \\
\hline \multirow{4}{*}{ KČP4_2 - KČP4_3 } & Negative Ranks & 9 & 13,56 & 122,00 & \multirow{4}{*}{$-1,64$} & \multirow{4}{*}{, 101} \\
\hline & Positive Ranks & 18 & 14,22 & 256,00 & & \\
\hline & Ties & 9 & & & & \\
\hline & Total & 36 & & & & \\
\hline \multirow{4}{*}{ KČP5_2 - KČP5_3 } & Negative Ranks & 13 & 15,19 & 197,50 & \multirow{4}{*}{,- 74} & \multirow{4}{*}{,462 } \\
\hline & Positive Ranks & 17 & 15,74 & 267,50 & & \\
\hline & Ties & 6 & & & & \\
\hline & Total & 36 & & & & \\
\hline & Negative Ranks & 15 & 14,43 & 216,50 & & \\
\hline КС̆P6 2 - КС̆Р6 3 & Positive Ranks & 12 & 13,46 & 161,50 & -67 & 500 \\
\hline KCPo_z-KCPo_3 & Ties & 9 & & &,$- 0 /$ &, 500 \\
\hline & Total & 36 & & & & \\
\hline & Negative Ranks & 14 & 9,29 & 130,00 & & \\
\hline КС̆P7 2 - КС̆Р 3 & Positive Ranks & 4 & 10,25 & 41,00 & -198 & 048 \\
\hline КСР7_2-KCP7_3 & Ties & 18 & & & $-1,98$ & ,048 \\
\hline & Total & 36 & & & & \\
\hline & Negative Ranks & 13 & 15,65 & 203,50 & & \\
\hline KČDQ 2 KČDQ & Positive Ranks & 18 & 16,25 & 292,50 & & \\
\hline KCP8_2-KCP8_3 & Ties & 5 & & &,- 91 &, 364 \\
\hline & Total & 36 & & & & \\
\hline & Negative Ranks & 12 & 13,67 & 164,00 & & \\
\hline КС̆Р0 2 - КС̆РО 3 & Positive Ranks & 13 & 12,38 & 161,00 & & \\
\hline КСР9_2-КСР9_3 & Ties & 11 & & &,- 04 & ,967 \\
\hline & Total & 36 & & & & \\
\hline & Negative Ranks & 11 & 12,23 & 134,50 & & \\
\hline KČP10 2 - KČP10 3 & Positive Ranks & 12 & 11,79 & 141,50 & 11 & 014 \\
\hline КСPIO_2-КСРIO_3 & Ties & 13 & & &,- 11 & ,914 \\
\hline & Total & 36 & & & & \\
\hline & Negative Ranks & 13 & 17,77 & 231,00 & & \\
\hline KČP11 ? KČP11 3 & Positive Ranks & 19 & 15,63 & 297,00 & 63 & 531 \\
\hline KCPI1_2-KCPII_3 & Ties & 4 & & &,- 03 & 1531 \\
\hline & Total & 36 & & & & \\
\hline & Negative Ranks & 16 & 13,09 & 209,50 & & \\
\hline 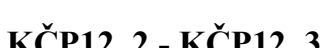 & Positive Ranks & 8 & 11,31 & 90,50 & -173 & 083 \\
\hline КСРГ2_2-КСРГ2_3 & Ties & 12 & & & $-1,73$ & ,083 \\
\hline & Total & 36 & & & & \\
\hline
\end{tabular}


Postupak povratnih informacija u delfi krugovima se nastavlja sve dok se ne postigne konsenzus, pri čemu se može konsenzus unaprijed definirati da postoji konsenzus oko izjava kada se barem $80 \%$ sudionika istraživanja slaže ili se u potpunosti slaže s izjavom, a dodatno se slaganje sudionika s izjavama barem 50\% sudionika može nazvati stabilnošću odnosno točkom nakon koje panelisti više ne revidiraju svoje ljestvice (Sekayi, Kennedy, 2017). Sukladno navedenom, te na temelju rezultata 12 Wilcoxonovih testova rangova zavisnih uzoraka 12 ključnih čimbenika promjene (KČP) komunikacijske paradigme u visokom obrazovanju pod utjecajem društvenih medija, može se zaključiti da na nivou signifikantnosti $\mathrm{p}=0,05$, postoji slaganje $83,3 \%$ sudionika istraživanja, a da na nivou signifikantnosti $\mathrm{p}=0,1$ postoji slaganje $75 \%$ sudionika istraživanja, čime se smatra da je konsenzus postignut, a ova delfi studija završena.

Dodatno je napravljeno 66 Wilcoxon testova za međusobnu usporedbu stupnja važnosti svakog ključnog čimbenika promjene (KČP) komunikacijske paradigme u visokom obrazovanju pod utjecajem društvenih medija iz 3. kruga sa stupnjem važnosti svih ostalih ključnih čimbenika promjene (KČP) komunikacijske paradigme u visokom obrazovanju pod utjecajem društvenih medija iz 3. kruga (Tablica 38.). S obzirom na to da je redoslijed rangova ključnih čimbenika (KČP) komunikacijske paradigme u visokom obrazovanju pod utjecajem društvenih medija izražen u apsolutnim vrijednostima, statistička analiza napravljena je kako bi se utvrdilo postoje li određena preklapanja ključnih čimbenika (KČP) komunikacijske paradigme u visokom obrazovanju pod utjecajem društvenih medija između procjena ispitanika, a za koja nisu pronađena statistički značajne razlike u važnosti. 
Tablica 38. Neparametrijska statistička analiza: Wilcoxonova usporedba svakog ključnog čimbenika promjene (KČP) sa svakim ključnim čimbenikom promjene (KČP) komunikacijske paradigme u visokom obrazovanju pod utjecajem društvenih medija iz 3. kruga (izvor: upitnik, Google obrasci, SPSS obrada autorice)

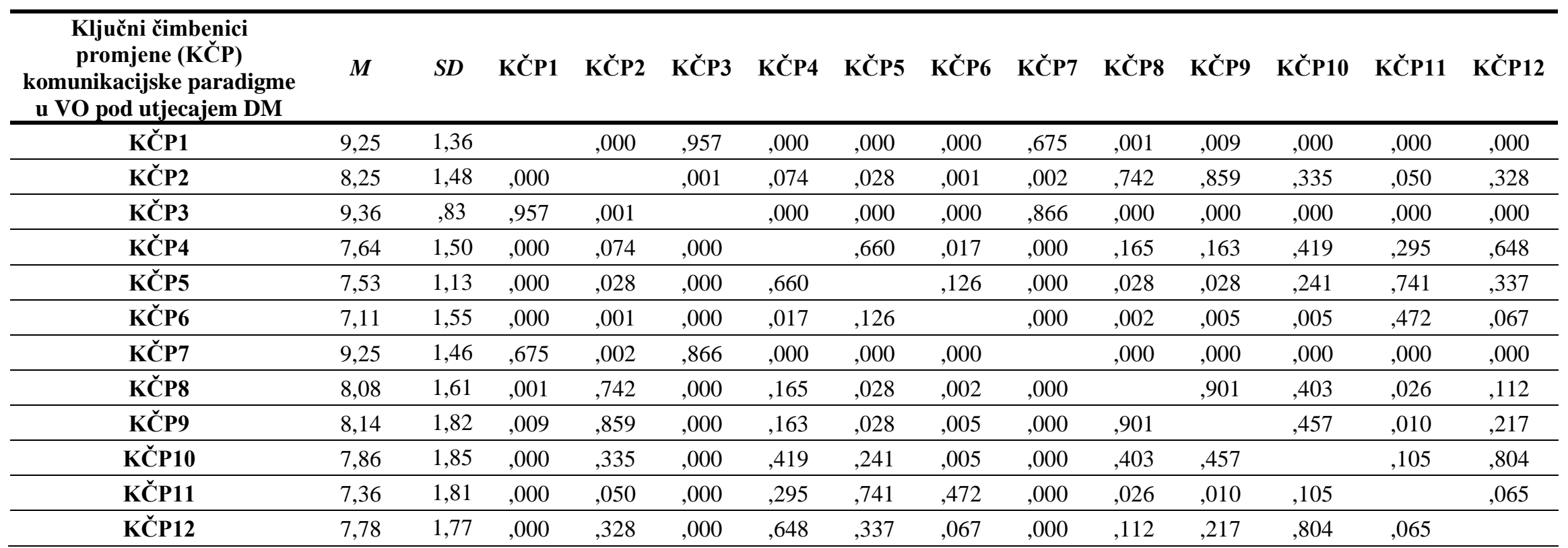

Rezultati 66 Wilcoxon testova međusobne usporedbe stupnja važnosti svakog ključnog čimbenika (KČP) komunikacijske paradigme u visokom obrazovanju pod utjecajem društvenih medija iz 3. kruga sa stupnjem važnosti svih ostalih ključnih čimbenika (KČP) komunikacijske paradigme u visokom obrazovanju pod utjecajem društvenih medija u visokom obrazovanju iz 3. kruga, prikazani su u Tablici 38., zatim su poredani prema aritmetičkoj sredini $(M)$ i standardnoj devijaciji $(D S)$ te su prikazani u Tablici 39. koja slijedi. 
Tablica 39. Neparametrijska statistička analiza: Wilcoxonova usporedba svakog ključnog čimbenika promjene (KČP) sa svakim ključnim čimbenikom promjene (KČP) komunikacijske paradigme u visokom obrazovanju pod utjecajem društvenih medija iz 3. kruga prema aritmetičkoj sredini sa naznačenim (osjenčanim) podudarnostima* (izvor: upitnik, Google obrasci, SPSS obrada autorice)

\begin{tabular}{|c|c|c|c|c|c|c|c|c|c|c|c|c|c|c|}
\hline $\begin{array}{c}\text { Ključni čimbenici } \\
\text { promjene (KČP) } \\
\text { komunikacijske paradigme } \\
\text { u VO pod utjecajem DM }\end{array}$ & $M$ & $S D$ & KČP3 & KČP1 & KČP7 & KČP2 & КС̆P9 & КČP8 & КČP10 & KČP12 & KČP4 & KČP5 & KČP11 & KČP6 \\
\hline KČP3 & 9,36 &, 83 & & ,957 &, 866 & ,001 & ,000 & ,000 &, 000 &, 000 &, 000 & ,000 & ,000 & ,000 \\
\hline KČP1 & 9,25 & 1,36 & ,957 & & ,675 & 000 & 009 & ,001 & ,000 & 000 & 000 & 000 & ,000 & ,000 \\
\hline КС̆Р7 & 9,25 & 1,46 &, 866 & ,675 & &, 002 &, 000 &, 000 &, 000 &, 000 &, 000 &, 000 &, 000 &, 000 \\
\hline KČP2 & 8,25 & 1,48 & ,001 &, 000 & ,002 & &, 859 &, 742 & ,335 & ,328 & ,074 & ,028 &, 050 &, 001 \\
\hline КС̆Р9 & 8,14 & 1,82 &, 000 & ,009 &, 000 & ,859 & & ,901 &, 457 &, 217 &, 163 &, 028 &, 010 &, 005 \\
\hline KČP8 & 8,08 & 1,61 &, 000 &, 001 &, 000 &, 742 & ,901 & &, 403 &, 112 &, 165 &, 028 &, 026 &, 002 \\
\hline KČP10 & 7,86 & 1,85 & ,000 & ,000 & ,000 & ,335 & ,457 & ,403 & & ,804 & ,419 & ,241 &, 105 & ,005 \\
\hline КС̌P12 & 7,78 & 1,77 &, 000 &, 000 &, 000 & ,328 &, 217 &, 112 & ,804 & & ,648 &, 337 &, 065 & ,067 \\
\hline КС̆P4 & 7,64 & 1,50 &, 000 & ,000 &, 000 &, 074 &, 163 &, 165 &, 419 & ,648 & &, 660 & ,295 &, 017 \\
\hline КС̌P5 & 7,53 & 1,13 &, 000 &, 000 &, 000 &, 028 &, 028 &, 028 &, 241 & ,337 &, 660 & &, 741 &, 126 \\
\hline KČP11 & 7,36 & 1,81 &, 000 &, 000 &, 000 &, 050 &, 010 &, 026 &, 105 &, 065 &, 295 &, 741 & &, 472 \\
\hline КС̆P6 & 7,11 & 1,55 &, 000 &, 000 & ,000 & ,001 & ,005 &, 002 &, 005 &, 067 &, 017 &, 126 &, 472 & \\
\hline
\end{tabular}

* (tamno sivom bojom označene podudarnosti na razini statističke značajnosti od 5 \%, a svijelo sivom bojom na razini statističke značajnosti od $10 \%)$

Iz rezultata prikazanih u Tablici 39., u kojoj su tamno sivom bojom označene podudarnosti na razini statističke značajnosti od 5 \% (nivou signifikantnosti $\mathrm{p}=0,05$ ), a svijetlo sivom bojom podudarnosti na razini statističke značajnosti od $10 \%$ (nivou signifikantnosti $\mathrm{p}=0,1$ ), vidljivo je da se tri prvo rangirana odnosno prva tri ključna čimbenika promjene (KČP) komunikacijske paradigme u visokom obrazovanju pod utjecajem društvenih medija s najvišim procjenama važnosti eksperata, a poredanih prema aritmetičkoj sredini $(M)$ i standardnoj devijaciji $(D S)$ međusobno statistički značajno ne razlikuju, ali se jasno izdvajaju kao najvažnije u odnosu na ostale ključne čimbenike promjene (KČP) komunikacijske paradigme u visokom obrazovanju pod utjecajem društvenih medija. 
Sukladno navedenom, te na temelju rezultata 66 Wilcoxonovih testova međusobne usporedbe stupnja važnosti svakog ključnog čimbenika promjene (KČP) komunikacijske paradigme u visokom obrazovanju pod utjecajem društvenih medija sa stupnjem važnosti svih ostalih ključnih čimbenika promjene (KČP) komunikacijske paradigme u visokom obrazovanju pod utjecajem društvenih medija iz 3. kruga, može se zaključiti da su ključni čimbenici „Podrška vodstva visokih učilišta“, „Razvoj tehnologija“ i „Motivacija nastavnika“, koje su eksperti u ovoj studiji označili najvišim stupnjem važnosti, ujedno i čimbenici oko kojih postoji najsnažniji konsenzus eksperata, odnosno statistički najmanje značajne razlike u odgovorima.

\subsection{4. Četvrti krug delfi studije}

U 4. krugu ove delfi studije, prezentirani su konačni rezultati panelistima koji su aktivno sudjelovali u 3. krugu ovog istraživanja (Prilog 14.). Konačna verzija rezultata istraživanja sastoji se od popisa 12 ključnih čimbenika (KČP) komunikacijske paradigme u visokom obrazovanju pod utjecajem društvenih medija s pripadajućim opisima nastalima na temelju rezultata iz 1. kruga, te su rangirani sukladno stupnjevima važnosti koje su im dodijelili panelisti u 3. krugu na ljestvici od 1 do 12, pri čemu čimbenik pod brojem 1 ima najviši stupanj važnosti, a čimbenik pod brojem 12 ima najniži stupanj važnosti za promjenu komunikacijske paradigme $\mathrm{u}$ visokom obrazovanju pod utjecajem društvenih medija, kako je prikazano u Tablici 40.

Tablica 40. Konačni rang ključnih čimbenika promjene (KČP) komunikacijske paradigme u visokom obrazovanju pod utjecajem društvenih medija ove delfi studije, $\mathrm{N}=36$ (izvor: izrada autorice)

\begin{tabular}{|c|c|c|}
\hline Rang & $\begin{array}{l}\text { Ključni čimbenici promjene } \\
\text { komunikacijske paradigme u } \\
\text { VO pod utjecajem DM }\end{array}$ & Opis \\
\hline 1 & Podrška vodstva visokih učilišta & $\begin{array}{l}\text { - } \text { Vodstvo odozgo od strane uprave visokih učilišta. } \\
\text { - } \quad \text { Provode dekan, prodekani, voditelji studija, odsjeka i } \\
\text { katedri. } \\
\text { - } \quad \text { Financijska podrška. } \\
\text { - } \quad \text { Etičke i druge norme. }\end{array}$ \\
\hline 2 & Razvoj tehnologija & $\begin{array}{l}\text { - } \text { Digitalna transformacija društva. } \\
\text { - } \quad \text { Masovnije korištenje tehnologije, alata i aplikacija. } \\
\text { - } \quad \text { Veća dostupnost tehnologija u visokom obrazovanju. } \\
\text { - } \quad \text { Više mogućnosti, personalizacija aplikacija i sadržaja. } \\
\text { - } \quad \text { Veća interaktivnost. } \\
\text { - } \quad \text { Veća interoperabilnost među sustavima i alatima. }\end{array}$ \\
\hline 3 & Motivacija nastavnika & $\begin{array}{l}\text { - Poticajni programi koji nagrađuju zaposlenike koji } \\
\text { koriste / doprinose za DM. } \\
\text { - Svo osoblje (nastavnici, vanjski suradnici) koristi DM. }\end{array}$ \\
\hline
\end{tabular}




\begin{tabular}{|c|c|c|}
\hline & & $\begin{array}{l}\text { - Integriranje korištenja DM s ocjenom uspješnosti i } \\
\text { plaćom. }\end{array}$ \\
\hline 4 & $\begin{array}{l}\text { Nacionalne politike/ } \\
\text { strategije obrazovanja }\end{array}$ & 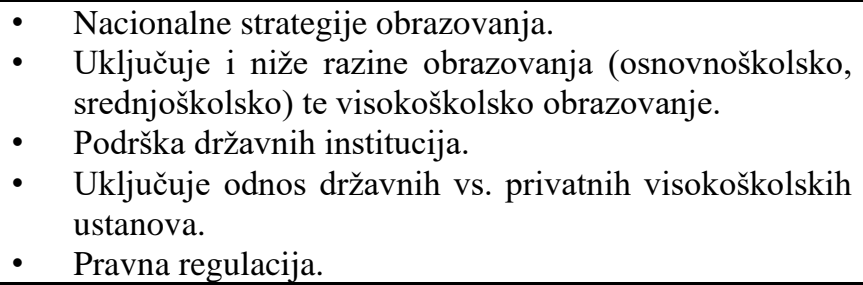 \\
\hline 5 & Kultura razmjene znanja & $\begin{array}{l}\text { - } \quad \text { Sustavna edukacija o korištenju DM. } \\
\text { - Svo osoblje treba stalno biti informirano o novim } \\
\text { saznanjima o korištenju DM za potrebe visokog } \\
\text { obrazovanja, npr. mjesečne sesije dijeljenja znanja. } \\
\text { - } \quad \text { Proslava uspjeha i učenje iz neuspjeha. } \\
\text { - } \quad \text { Kultura suradnje, koja nije konkurentna. }\end{array}$ \\
\hline 6 & Očekivanja studenata & $\begin{array}{ll}\text { - } & \text { Ne poznaju svijet bez tehnologije. } \\
\text { - } & \text { Predstavljaju novi tip studenata. } \\
\text { - } & \text { Uče na nove načine. } \\
\text { - } & \text { Komuniciraju i surađuju na nove načine. }\end{array}$ \\
\hline 7 & Dostupnost resursa & $\begin{array}{l}\text { - } \quad \text { Financijska sredstva i izvori. } \\
\text { - Raspodjela vremena odnosno predviđeno vrijeme za } \\
\text { aktivnosti povezane sa korištenjem DM. } \\
\text { - Administrativna korisnička podrška. }\end{array}$ \\
\hline 8 & Društvo u cjelini & $\begin{array}{ll}\text { - } & \text { Preporuke poslodavaca. } \\
\text { - } & \text { Privlačenje investitora. } \\
\text { - } & \text { Trendovi. } \\
\text { - } & \text { Kulturološke razlike. } \\
\text { - } & \text { Privatni utjecaji (prisutnost prijatelja i obitelji na DM). } \\
\text { - } & \text { Viša sila, npr. pandemija korona virusa Covid-19. } \\
\end{array}$ \\
\hline 9 & Strategija upravljanja znanjem & 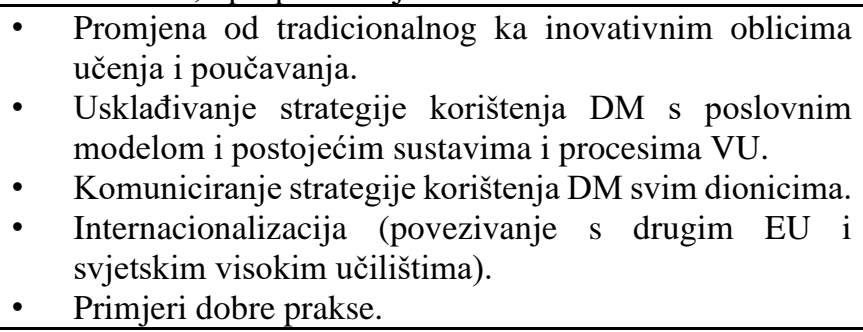 \\
\hline 10 & Metrike uspješnosti & $\begin{array}{l}\text { - Uspostava ključnih indikatora uspješnosti korištenja } \\
\text { DM u visokom obrazovanju kako bi se mogao pratiti } \\
\text { napredak i olakšalo kontinuirano poboljšavanje. } \\
\text { Ovisno i prilagođeno o cilju (privlačenje odnosno } \\
\text { regrutacija novih studenata, brendiranje odnosno } \\
\text { povećanje ugleda ustanove, povećanje uspjeha } \\
\text { studenata, suradnja sa zajednicom...). }\end{array}$ \\
\hline 11 & Kvaliteta društvenih medija & $\begin{array}{l}\text { - } \text { Jednostavnost korištenja DM. } \\
\text { - } \quad \text { Pouzdanost korištenja DM. } \\
\text { - Redovitost ažuriranja DM kako bi odražavalo trenutno } \\
\text { znanje. } \\
\text { Odgovarajuće povezivanje DM s drugim alatima } \\
\text { (interoperabilnost). }\end{array}$ \\
\hline 12 & Infrastruktura upravljanja znanjem & $\begin{array}{l}\text { - } \quad \text { Vlasništvo nad DM odnosno licencama. } \\
\text { - Tehnička podrška; stvaranje namjenskih uloga za } \\
\text { filtriranje, ažuriranje i održavanje DM. } \\
\text { - Režimi obuke za korištenje DM. } \\
\text { - } \quad \text { Prepoznavanje i upravljanje rizicima. }\end{array}$ \\
\hline
\end{tabular}

Ljestvica rangova na skali od 1 do 12: čimbenik pod brojem 1 ima najviši stupanj važnosti, a čimbenik pod brojem 12 ima najniži stupanj važnosti 


\subsection{Izazovi i ograničenja delfi studije}

Kao prednost delfi studije u literaturi se navodi sprečavanje umora od popunjavanja anketnih upitnika i dominacije mišljenja snažnih antagonista u interakcijama licem u lice, provedbom ankete u elektroničkom formatu, tako da sudionici mogu odgovoriti kad im odgovara. Uz to, digitalna anketa pruža potporu kvazi-anonimnosti interakcije, te i sama služi za ublažavanje dominacije mišljenja pojedinih panelista. Ove prednosti su uočene i tijekom provedbe ove delfi studije u nastojanjima da se postigne konsenzus na temu istraživanja.

Kao ograničenja delfi studije, u literaturi se kao dva osnovna ograničenja navode: neodređenost pojmova „stručnjak“ i ,stručnost“; i nedostatak elementarne statističke analize podataka (Ju, Jin, 2013 prema Baruchson-Arbib, Bronstein 2002, Fischer 1978, Goodman 1987). Prvo ograničenje izravno je povezano s postupcima uzorkovanja; kvalifikacije stručnjaka i kvaliteta njihovog unosa ključni su za potvrđivanje određene studije stoga istraživači moraju razviti niz objektivnih kriterija za odabir stručnjaka i procjenu njihove stručnosti (Ju, Jin,2013). Ipak, stvarni postupak odabira i dalje mora biti donekle proizvoljan, a istraživači su odgovorni za dokazivanje i opravdanje da su odabrani stručnjaci dovoljno kompetentni i upućeni da „daju znatno bolje i bitno drugačije odgovore od nestručnjaka“ (Ju, Jin, 2013 prema Goodman 1987). Drugo ograničenje je nedostatak standardnih statističkih analiza, što vjerojatno čini metodu ranjivom na kritike njene pouzdanosti i valjanosti (Ju, Jin, 2013). Također, neki delfi istraživači namjerno ili nenamjerno ignoriraju standardne testove za statističku značajnost, ali da bi se delfi metoda ozbiljno smatrala pouzdanom i valjanom metodom mora se vrednovati prema istim standardima kao i druga metodologija društvenih znanosti (Ju, Jin, 2013 prema Fischer 1978). Izazovi ove provedene delfi studije bili su kako slijedi:

\section{POJAM DRUŠTVENIH MEDIJA:}

Prije same provedbe delfi studije, iako se u literaturi preporuča induktivan pristup u kvalitativnom dijelu studije, već u samom definiranju pojma društvenih medija, otkriveno je nedovoljno jasno teorijsko određenje pojma. Pojam društvenih medija, posebice u hrvatskom jeziku, često se shvaća kao istoznačnica pojmu društvenih mreža, dok se, kako je izloženo u teorijskom dijelu ovog rada, te u informativnom pismu samim ekspertima, kako bi se osigurala dodatna preciznost i pouzdanost odgovora, zapravo društvene mreže odnose samo na jedan od trenutno poznatih trinaest podtipova društvenih medija. Istodobno, pretpostavke i determinante postojeće komunikacijske paradigme društvenih medija su multidimenzionalne, a samim time složene i obuhvaćaju široko teoretsko i praktično područje. Stoga, odgovore panelista koji se tiču 
krize postojeće paradigme, anomalije koje se pojavljuju u korištenju društvenih medija u visokom obrazovanju, nije bilo moguće ispravno smjestiti u kontekst bez predznanja postojećih perspektiva i utemeljenja u postojećoj teoriji te prethodno provedenim istraživanjima.

2. STRUČNJACI:

Identificiranje i traženje kvalificiranih pojedinaca za dragocjen doprinos bili su dodatni izazov, pri čemu je identificiranje eksperata bilo manje izazovno od same regrutacije za sudjelovanje u istraživanju. Stoga je korištena profesionalna mreža kontakata dostupnih autorici, kao i savjeti i profesionalna mreža kontakata mentorica i kolegica/kolega autorice u svezi s prikladnošću potencijalnih stručnjaka za delfi istraživanje, te su eksperti uglavnom svoj pristanak za sudjelovanje dali tek nakon osobnih kontakata autorice, mentorica i kolegica/kolega autorice na privatno-profesionalnoj razini. Isto tako, izazov koji se tiče eksperata, odnosi se još i na nastojanja da se svi eksperti odazovu na sve krugove istraživanja, kako bi se spriječilo rasipanje odnosno odustajanje eksperata, što je dodatno iziskivalo napore u smislu dodatnih osobnih kontakata autorice, mentorica i kolegica/kolega autorice na privatno-profesionalnoj razini $\mathrm{s}$ ekspertima.

3. VRIJEME PROVEDBE DELFI STUDIJE:

Iako su predviđeni rokovi za popunjavanje upitnika u svakom krugu istraživanja bili definirani na samom upitniku kao rok od 7 dana, svaki od krugova trajao je više od 30 dana, te su eksperti opetovano podsjećani na molbu za popunjavanje upitnika, kako bi se spriječilo rasipanje odnosno odustajanje eksperata, te im se produljivanjem rokova omogućilo da upitnike popune u okvirima svojih vremenskih i inih mogućnosti. To je ujedno kao posljedicu nosilo, da je period između provedbe svakog od krugova istraživanja premašio 50 i više dana, jer je potrebno između uračunati i vrijeme potrebno za analizu podataka u prethodnom krugu istraživanja koja se ekspertima u sumarnom obliku daje na uvid u narednom krugu.

4. ANALIZA PODATAKA:

Kao što je već navedeno u poglavlju o metodologiji ove delfi studije, delfi istraživači ili ne provode kvalitativno istraživanje, iako je delfi metoda predviđena kao mješovita metoda koja kombinira kvalitativan i kvantitativan pristup, ili u dijelu provedbe i analize podataka dobivenih kvalitativnim pristupom, propuštaju napisati „kako“ je analiza provedena. Za potrebe ove delfi studije, poseban izazov bila je kvalitativna analiza, jer je analizirano, samo ilustrativno se navodi, 190 stranica odgovora (kojih se dio odnosi i 
na socio-demografske podatke eksperata), odnosno 770 excel ćelija podataka. Ta analiza nije samo vremenski zahtjevna, već i na misaono-stručnoj razini. Dodatni izazov predstavljao je dijapazon elemenata koji uključuje komunikacijska paradigma u visokom obrazovanju pod utjecajem društvenih medija te otvorena pitanja, stoga su odgovori eksperata bili veoma široki i opsežni. Kao takvi, bili su i opsegom i temom veliki izazov u obradi. Osim toga, postavlja se pitanje koje teme odrediti kao prioritetne i u kojem opsegu ih prenijeti u naredne krugove (Ju, Jin, 2013 prema Schmidt, 1997). Isto tako, važno je istaknuti da analizu i interpretaciju dobivenih kvalitativnih rezultata nije bilo moguće napraviti na potpuno induktivan način, kako se predlaže u dijelu literature, jer eksperti barataju višom razinom znanja te koriste izraze za koje je potrebno dodatno tumačenje, za što je onda za potrebe ove delfi studije dodatno napravljena terminologija izraza koje su eksperti koristili. U kvantitativnoj analizi, izazov je bio pronaći odgovarajuće testove, s obzirom na to da je uzorak bio mali, i to eksperata, iz čega slijedi da distribucija vrijednosti promatranih obilježja odnosno dobivenih podataka ne odražava populaciju. Osim toga, u samoj literaturi u samoj literaturi Wilcoxonov test nosi različite nazive, što stvara dodatnu pomutnju radi li se o istom testu. U tom smislu, dodatno vrijeme u istraživanju bilo je uloženo u utvrđivanje da je Wilcoxonov test sume rangova drugi naziv za Wilcoxonov test ranga i predznaka, Wilcoxonov test ekvivalentnih parova, a uz to se još naziva i Wicoxonov test ekvivalentnih nizova, te Wilcoxonov test usklađenih parova, Wilcoxonov t-test. Uz to, u literaturi se navodi da se neparametrijski testovi koriste za obradu podataka kod kojih se distribucija razlikuje od normalne, ali dodatnu pomutnju stvara što isto tako postoji literatura koja navodi da Wilcoxonov test, iako neparametrijski, traži da je pretpostavka za provođenje Wilcoxonov testa da distribucija bude (normalna) simetrična (Laerd Statistics, 2020). Za potrebe ove studije, a u skladu s odlikama neparametrijske statistike, Wilcoxonov test određen kao ispravan statistički test jer je koristan za male uzorke, ne počiva na pretpostavkama da će raspodjela biti normalna, pravilna i jednaka odnosno zvonolika krivulja raspodjele rezultata u populaciji (Cohen i sur., 2007), s obzirom na specifičnost uzorka koji se sastojao od eksperata. Uz to, prikladan je za podatke na nominalnoj i ordinalnoj ljestvici (Cohen i sur., 2007), što je dodatno potvrdilo ispravnost testa jer su podaci bili na ordinalnoj ljestvici.

5. PONAVLJANJE (BROJ) KRUGOVA RADI POVRATNIH INFORMACIJA EKSPERATA 
Iteracija s kontroliranim povratnim informacijama najistaknutija je značajka delfi metode, no u praksi se postavlja pitanje koliko bi krugova traženja povratnih informacija, kako ističu Ju i Jin (2013), bilo dovoljno? Također istaknuo je i Schmidt (1997); jedan od mogućih izazova s kojima se suočavaju istraživači je pitanje kada zaustaviti glasanje; premalo krugova može dovesti do nezrelog ishoda, dok je za previše krugova potrebno opterećenje stručnjaka koji sudjeluju i istraživača koji provode delfi studiju (Ju, Jin, 2013). Iako niti jedno pravilo ne nalaže koliko krugova istraživanja treba provesti, čini se da je većina prethodnih studija delfi prošla kroz dva do tri kruga istraživanja bez dodatnih opravdanja, a da je glavno pitanje za istraživače dobivanje najrigoroznijih podataka uz obzir prema vremenu i naporima stručnjaka koji sudjeluju (Ju, Jin, 2013).

\section{STUPANJ KONSENZUSA}

U literaturi se navodi da je primarna uloga ponavljanja krugova u procesu delfi studije postizanje visokog stupnja konsenzusa, što dovodi, kako pojašnjavaju Ju i Jin (2013) do još jedne važne odluke: kako operativno definirati koncept „stupnja konsenzusa”? Malo je studija dalo jasnu definiciju ovog pojma i, u većini slučajeva, granice između visokih i adekvatnih slaganja među sudionicima studije bile su nejasne; različiti istraživači koristili su različite statističke elemente za predstavljanje granica (Ju, Jin, 2013). Neke studije koristile su ljestvice i postotke slaganja ili neslaganja (Ju, Jin, 2013 prema Ludwig, Starr 2005), dok su druge koristile aritmetičku sredinu i standardna odstupanja (Ju, Jin, 2013 prema Zhang, Salaba 2009, Westbrook 1997, Neuman 1995).

\subsection{Smjernice}

„Znati da bi se predvidjelo - predvidjeti da bi se djelovalo.“

- Auguste Comte

Zaključno, nakon provedene delfi studije i analize dobivenih rezultata, definirane su smjernice za promjenu komunikacijske paradigme u visokom obrazovanju pod utjecajem društvenih medija. Smjernice su kreirane prema elementima „tehnološkog predviđanja“ koje uključuje spajanje ključnih agenata promjena i izvora znanja, kako bi se razvile strateške vizije i anticipativna inteligencija odnosno trebalo bi uključivati sljedeće elemente: 1 . strukturirano predviđanje potreba (tehnologija, društvo, itd.); 2. interakcija različitih dionika, 3. stvaranje mreže dionika s različitom stručnošću; 4. strateška vizija mreže dionika; 5. vizije budućnosti, a 
ne utopija, koje pružaju izričite implikacije na akciju i odluku (politiku); 6. komunikacija između različitih disciplina (Ciarli, Coad i Rafols, 2008 prema Miles i sur., 2008).

Za potrebe ovog rada odnosno interpretacije rezultata, elementi tehnološkog predviđanja idejno su prilagođeni kako slijedi:

i. strukturirano predviđanje potreba u visokom obrazovanju potrebno je bazirati na kontinuiranom praćenju razvoja tehnologije, te djelovati kao društvo u cjelini;

ii. strateška vizija mreže dionika osobito treba uključivati nacionalne politike/strategije obrazovanja te se iste trebaju provoditi uz podršku vodstva visokih učilišta;

iii. stvaranje mreže dionika s različitom stručnošću treba za cilj imati dostupnost resursa i stvaranje infrastruktura upravljanja znanjem;

iv. vizije budućnosti, a ne utopija, trebaju pružati izričite implikacije na akcije, odluke te cjelokupnu politiku visokog obrazovanja kroz strategije upravljanja znanjem te jasno definirane metrike uspješnosti;

v. interakcija različitih dionika u visokom obrazovanju treba polaziti od očekivanja studenata, a realizirati se kroz motivaciju nastavnika;

vi. komunikacija između različitih disciplina, sposobnih objasniti složene pojave koje su rijetko podijeljene u discipline, treba stvoriti most između kvalitetnih društvenih medija i kulture razmjene znanja.

$\mathrm{Na}$ temelju rezultata studije te utvrđenih nedostataka u prethodnom dijelu rada, pripremljen je popis preporuka kako bi se smanjile anomalije i krize nastale u postojećoj komunikacijskoj paradigmi u visokom obrazovanju pod utjecajem društvenih medija. Idejno su osmišljene i proširene prema preporukama za razvoj i primjenu sustava upravljanja znanjem u tvrtkama baziranima na znanju (Amidharmo, 2014). Također, korišteni su neki izrazi iz Strategije obrazovanja, znanosti i tehnologije (Hrvatski sabor, 2014a). Važno je naglasiti da se kao najvažnije, na temelju rezultata provedene delfi studije, ističu podrška vodstva visokih učilišta, razvoj tehnologija i motivacija nastavnika. Preporuke su sažete u Tablici 41. koja slijedi.

Tablica 41. Preporuke za provedbu promjena komunikacijske paradigme u visokom obrazovanju pod utjecajem društvenih medija (izvor: izrada autorice)

\begin{tabular}{lc}
\hline $\begin{array}{l}\text { Ključni čimbenici promjene } \\
\text { komunikacijske paradigme u VO } \\
\text { pod utjecajem DM }\end{array}$ & \multicolumn{1}{c}{$\begin{array}{l}\text { Preporuke za promjenu komunikacijske paradigme } \\
\text { u VO pod utjecajem DM }\end{array}$} \\
\hline Razvoj tehnologija $(\mathrm{TEH})$ & $\bullet \begin{array}{l}\text { Pratiti procese digitalne transformacije društva i brzo pokretati } \\
\text { promjene i prilagodbe u sustavu visokog obrazovanja i znanosti. }\end{array}$ \\
& - $\begin{array}{l}\text { Uključiti masovnije korištenje tehnologije, alata i aplikacija u } \\
\text {,trokut znanja koje čine cjeloživotno učenje, znanost i inovacije“ } \\
\text { (Hrvatski sabor, 2014). }\end{array}$
\end{tabular}




\begin{tabular}{|c|c|}
\hline & $\begin{array}{l}\text { - } \quad \text { Povećati dostupnost tehnologija u visokom obrazovanju. } \\
\text { - U viziju razvoja visokog obrazovanja uključiti više tehnoloških } \\
\text { mogućnosti, personalizaciju obrazovnih aplikacija i sadržaja. } \\
\text { - } \quad \text { Povećati interaktivnost među dionicima. } \\
\text { - Povećati interoperabilnost među obrazovnim sustavima i alatima. }\end{array}$ \\
\hline $\begin{array}{l}\text { Nacionalne politike/ } \\
\text { strategije obrazovanja (POL) }\end{array}$ & 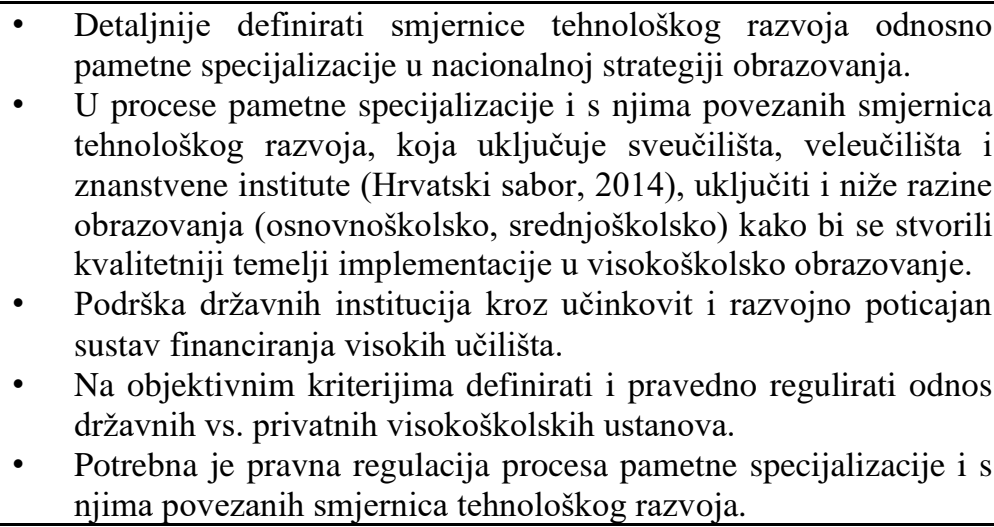 \\
\hline Podrška vodstva visokih učilišta (VU) & $\begin{array}{l}\text { - Uključiti DM kao sastavni dio poslovne vizije i strategije. } \\
\text { - Osigurati i poboljšati financijsku podršku. } \\
\text { Vodstvo odozgo od strane uprave visokih učilišta. Pokazati } \\
\text { vodstvo: inicijative DM kojima će upravljati „odbor“ odnosno } \\
\text { povjerenstvo, a provoditi dekan, prodekani, voditelji studija, } \\
\text { odsjeka i katedri. } \\
\text { Dodijeliti odgovornost za provedbu korištenja DM dekanu ili } \\
\text { imenovati voditelja odnosno „menadžera znanja“ i uspostaviti } \\
\text { ključne pokazatelje uspješnosti. } \\
\text { Definirati etičke i druge norme koje će podržavati i omogućavati } \\
\text { provedbu korištenja DM u visokoobrazovnom procesu. }\end{array}$ \\
\hline Strategija upravljanja znanjem (ZNA) & 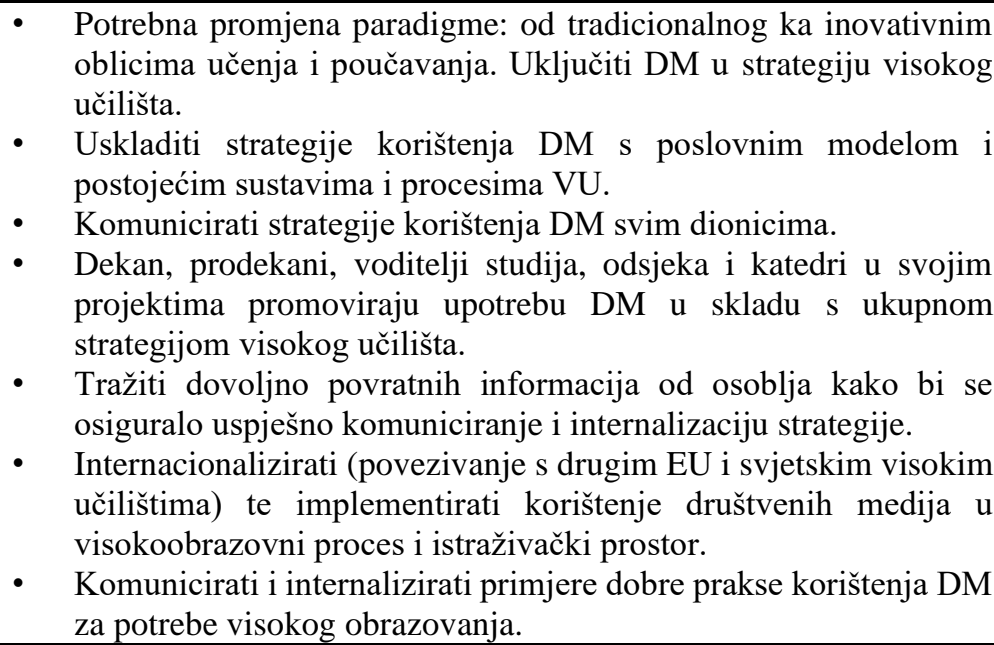 \\
\hline Metrike uspješnosti (USP) & $\begin{array}{l}\text { - Uspostaviti ključne indikatore uspješnosti korištenja DM u } \\
\text { visokom obrazovanju kako bi se mogao pratiti napredak i olakšalo } \\
\text { kontinuirano poboljšavanje. } \\
\text { Ovisno i prilagođeno o cilju (privlačenje odnosno regrutacija novih } \\
\text { studenata, brendiranje odnosno povećanje ugleda ustanove, } \\
\text { povećanje uspjeha studenata, suradnja sa zajednicom...).izraditi } \\
\text { jednostavan zapisnik korištenja DM. } \\
\text { - Povezati zapisnik s pregledom izvedbe. }\end{array}$ \\
\hline $\begin{array}{l}\text { Infrastruktura upravljanja znanjem } \\
\text { (INFR) }\end{array}$ & $\begin{array}{l}\text { - Definirati uloge i odgovornosti voditelja (,menadžera“) znanja, a } \\
\text { zatim uspostaviti ključne indikatore (pokazatelje) uspješnosti } \\
\text { (engl. Key Performance Indicator - KPI). } \\
\text { - Imenovati voditelja (,menadžera“) znanja i dogovoriti se na koji } \\
\text { način treba biti zaposlen. } \\
\text { - Osigurati vlasništvo nad DM odnosno licencama. }\end{array}$ \\
\hline
\end{tabular}


- Omogućiti tehničku podršku; stvarati namjenske uloge za filtriranje, ažuriranje i održavanje DM.

- Planirati i redovito provoditi režime obuke za korištenje DM.

- Prepoznavati i upravljati rizicima korištenja DM.

Motivacija nastavnika (NAST) $\quad$ - Osmisliti, definirati i provoditi poticajne programe koji nagrađuju zaposlenike koji koriste / doprinose za DM.

- Fokusirati se na internalizaciju posvećenosti zaposlenika.

- $\quad$ Podići kvalitetu rada na način da svo osoblje (nastavnici, vanjski suradnici) koristi DM.

- Integrirati korištenje DM s ocjenom uspješnosti i plaćom.

- Educirati osoblje o prednostima korištenja DM.

- Usredotočiti se pritom na kvalitetu DM.

Očekivanja studenata (STU) • - Osvijestiti da studenti danas ne poznaju svijet bez tehnologije.

- $\quad$ Prihvatiti da predstavljaju novi tip studenata i osmisliti načine na koje im se približiti.

- $\quad$ Prilagoditi obrazovni proces spoznaji da uče na nove načine.

- Implementirati potrebne provedbene aktivnosti koje se tiču uspješnije komunikacije i suradnje bazirano na spoznaji da komuniciraju i surađuju na nove načine.

Kultura razmjene znanja (KUL) • Potrebna provoditi sustavnu edukacija o korištenju DM.

- Održavati kvalitetu rada na način da svo osoblje stalno bude informirano o novim saznanjima o korištenju DM za potrebe visokog obrazovanja, npr. mjesečne sesije dijeljenja znanja.

- Važno je slaviti uspjeh i učiti iz neuspjeha.

- Uspostaviti kulturu suradnje, koja nije konkurentna.

- Uprava treba formalizirati i usmjeravati kulturu razmjene znanja.

- Potreban je dosljedan pristup kulturi u svim odjelima i uredima.

Dostupnost resursa (RES) • $\quad$ Osigurati financijska sredstva i izvore na razini države, kao i samih visokih učilišta.

- Financirati aktivnosti DM na razini grupe.

- Dodijeliti potrebno vrijeme i financijska sredstva osoblju za rad na DM.

- Raspodijeliti vrijeme odnosno predviđeno vrijeme za aktivnosti povezane sa korištenjem DM.

- Omogućiti administrativnu korisničku podršku.

Kvaliteta društvenih medija (DM) • $\quad$ Osigurati vlasništvo nad DM neophodno je kako bi se osigurala njegova visoka kvaliteta.

- Usredotočiti se na kvalitetu sadržaja, jednostavnost upotrebe, pouzdanost korištenja DM i dostupnost.

- Dodijeliti resurse i dodijeliti vlasništvo u skladu s tim, kako bi se postigli visokokvalitetni DM.

- Redovito ažurirati DM kako bi odražavalo trenutno znanje.

- Realizirati odgovarajuće povezivanje DM s drugim alatima (interoperabilnost).

Društvo u cjelini (DR) • • Uspostaviti interaktivnu suradnju između inovativnog gospodarstva i društvenih institucija $s$ visokoobrazovnim ustanovama radi stvaranja obrazovne, društvene, gospodarske i kulturne vrijednosti (Hrvatski sabor, 2014).

- Uvažavati preporuke poslodavaca.

- Sustavno raditi na privlačenju investitora.

- $\quad$ Pratiti trendove.

- Uvažavati kulturološke razlike.

- Održavati zdravu konkurenciju.

- Uvažavati privatne utjecaje (prisutnost prijatelja i obitelji na DM).

- Biti pripremljen i spreman odgovoriti na izazove i nepredvidive situacije, imati uvježbane scenarije u slučajevima više sile, kao što je npr. pandemija korona virusa Covid-19. 


\section{ZAKLJUČAK}

„Nevolja s našim vremenom je to što budućnost nije ono što je nekad bila.“ - Paul Valery

Društveni mediji primjer su tehnologija koje su studenti široko usvojili, i posljedično, imaju potencijal da postanu dragocjeni resursi za podržavanje obrazovne komunikacije i suradnju studenata s fakultetom (Arsović, 2012). Ipak, brojna istraživanja ukazuju na digitalni jaz između studenata i njihovih obrazovnih institucija, te postojanje trenda prema ne-adaptaciji novih tehnologija u visokoobrazovnim ustanovama; studenti su voljni koristiti ih, a zaposlenici fakulteta nisu (Roblyer i sur., 2010). Istraživanja provedena o stavovima i iskustvima integracije društvenih medija u visokoobrazovne ustanove (Echeng i sur., 2016; Josefsson, 2017) pokazuju da postoji potreba integracije društvenih medija u nastavni proces (OkelloObura, Ssekitto, 2015) te brojne prednosti i pozitivne učinke na proces učenja i poučavanja (Alsolamy i sur., 2017; Coleman i sur., 2018) kao što je kvaliteta nastave (Silvestru i sur., 2016) i akademski uspjeh studenata (Tamayo i sur., 2014). Dok studenti doživljavaju društvene medije kao nešto što se samopodrazumijeva, nastavnici su skloniji promišljati nedostatke i opasnosti (Raut i sur., 2016; Willems i sur., 2018). U Republici Hrvatskoj se studije isto tako bave pojavom društvenih medija i promjenama koje su nastale uslijed njihove pojave te se raspravlja kako bi sveučilišna zajednica i njezini dionici trebali biti dio tih promjena (Matešić i sur., 2010).

Promjene $u$ društvu koje su nastale pojavom društvenih medija zahtijevaju i promjenu znanstvene paradigme od klasične paradigme koja postepeno postaje prošlost u progresivnu paradigmu usmjerenu na budućnost. $U$ tom periodu akumulacije znanja i istraživanja, kako je tvrdio Kuhn (1962), znanstvenici rade na artikulaciji i proširenju vladajuće paradigme. Stoga je nova komunikacijska paradigma u visokom obrazovanju pod utjecajem društvenih medija na pomolu, a ova disertacija je imala za cilj definirati ju.

Teorijski okvir nalazi se u teoriji medija i masovnog komuniciranja te praćenju razvoja medija masovnog komuniciranja, s posebnim osvrtom na društvene medije. Umrežavanje pojedinaca u suvremenom svijetu novi je način komunikacije, a društveni mediji im to omogućuju. Neminovan je njihov prodor i u visoko obrazovanje gdje društveni mediji još nisu pokazali sve svoje mogućnosti i potencijale. 
Cilj ovog doktorskog istraživanja bio je utvrditi čimbenike koji će omogućiti promjenu postojeće komunikacijske paradigme u visokom obrazovanju putem društvenih medija temeljem predikcija na visokostručnoj razini, te oblikovanje smjernica nove komunikacijske paradigme putem društvenih medija za potrebe visokog obrazovanja.

U teorijskom dijelu disertacije objašnjeni su osnovni pojmovi komunikacijsko - medijske paradigme i aspekti etičkih izazova s kojima se susreće informacijsko društvo, te osnovni pojmovi i teorijski okvir društvenih medija. Također je predstavljen odnos visokog obrazovanja i obrazovne tehnologije kao kontekst korištenja društvenih medija za potrebe visokog obrazovanja. Razvoj tehnologije stvara preduvjete koje je potrebno ispuniti kako bi se komunikacijski potencijal društvenih medija upotrijebio u području visokog obrazovanja.

Za potrebe istraživanja korištena je delfi studija, koja se provodi u nekoliko krugova s odabranim panelistima (ekspertima). Iako je prvotno korištena u vojne, ekonomske i druge svrhe, danas se često primjenjuje u suvremenim istraživanjima odgoja i obrazovanja (Eret, 2017). Najčešći razlozi primjene delfi studije za potrebe istraživanja su prognoziranje događaja obzirom na buduća istraživanja i razvoj u određenim područjima interesa, poželjnost neke buduće okolnosti i sredstva kojima bi se postigle ili izbjegle buduće okolnosti (Eret, 2017 prema Helmer, 1967, Brown, 1968, Sackman, 1974, Gordon, 1994, Mitroff i Turoff, 2002). Ponavljanja krugova u procesu delfi studije ima za cilj postizanje visokog stupnja konsenzusa svih panelista. Empirijsko istraživanje provedeno je u 2020. godini u Republici Hrvatskoj na uzorku 37 značajnih gospodarstvenika s dugogodišnjim iskustvom rada u IT području, istaknutih znanstvenika i istraživača iz IT područja te vodećih stručnjaka iz područja provedbe IT obrazovanja.

Istraživanje je provedeno u četiri kruga.

U prvom je krugu istraživanja korišten kvalitativni pristup, te je na temelju tematske analize odgovora eksperata koji su sudjelovali u studiji, definirano 12 ključnih čimbenika promjene komunikacijske paradigme u visokom obrazovanju pod utjecajem društvenih medija.

U drugom krugu istraživanja, u kojem je korišten kvantitativni pristup, eksperti su svakom od 12 ključnih čimbenika komunikacijske paradigme u visokom obrazovanju pod utjecajem društvenih medija dodijelili stupanj važnosti prema Likertovoj ljestvici od 1 do 10 , pri čemu stupanj 1 označavao da čimbenik uopće nije važan, dok stupanj 10 označavao da je čimbenik iznimno važan.

Treći krug, u kojem je također korišten kvantitativni pristup istraživanju, i u kojem su ekspertima bili predstavljeni ukupni rezultati iz prethodnog kruga istraživanja, te su bili zamoljeni da ponovno revidiraju stupanj važnosti 12 ključnih čimbenika komunikacijske 
paradigme u visokom obrazovanju pod utjecajem društvenih medija prema Likertovoj ljestvici od 1 do 10 u svrhu mogućeg postizanja konsenzusa, dao je sljedeće rezultate: kao najvažniji ključni čimbenici komunikacijske paradigme u visokom obrazovanju pod utjecajem društvenih medija nedvojbeno se ističu podrška vodstva visokih učilišta, razvoj tehnologija i motivacija nastavnika, te za ključne čimbenike promjene gotovo nema razlike u odgovorima eksperata i u mišljenju da su navedeni čimbenici najvažniji čimbenici komunikacijske paradigme u visokom obrazovanju pod utjecajem društvenih medija.

Istraživački pristup obradi i analizi odgovora stručnjaka i znanstvenika (eksperata) dobivenih u prva tri kruga delfi studije bio je metodološka triangulacija, na temelju koje je utvrđeno 12 ključnih čimbenika komunikacijske paradigme u visokom obrazovanju pod utjecajem društvenih medija kako slijedi: podrška vodstva visokih učilišta, razvoj tehnologija, motivacija nastavnika, nacionalne politike/strategije obrazovanja, kultura razmjene znanja, očekivanja studenata, dostupnost resursa, društvo u cjelini, strategija upravljanja znanjem, metrike uspješnosti, kvaliteta društvenih medija, infrastruktura upravljanja znanjem.

Četvrti krug bio je prezentacija rezultata sudionicima prva tri kruga istraživanja.

Zaključno, oblikovane su preporuke nove komunikacijske paradigme putem društvenih medija u visokom obrazovanju koje će profesionalcima u području obrazovanja biti smjernice za poboljšanje kvalitete obrazovnih politika, nastavnih planova i programa kako bi se potencijal društvenih medija koristio za potrebe visokog obrazovanja.

Znanstveni doprinos ove disertacije u području informacijskih i komunikacijskih znanosti odnosno znanstveni doprinos $\mathrm{u}$ teoriji komunikacija je specifično oblikovana nova komunikacijska paradigma društvenih medija, s posebnim osvrtom na visoko obrazovanje. Time je ostvareno multidimenzionalno i kritičko utemeljenje nove komunikacijske paradigme u visokom obrazovanju pod utjecajem društvenih medija.

Daljnji doprinos ove doktorske disertacije su smjernice odnosno preporuke za provedbu nove komunikacijske paradigme primijenjene na društvenim medijima u visokom obrazovanju, koje će profesionalcima u području obrazovanja biti dragocjene smjernice za poboljšanje kvalitete obrazovnih politika, nastavnih planova i programa kako bi se komunikacijski potencijal društvenih medija koristio na najbolji mogući način za potrebe visokog obrazovanja.

Ovo je prvi znanstveni rad u Republici Hrvatskoj koji se bavi komunikacijskom paradigmom u visokom obrazovanju pod utjecajem društvenih medija. 


\section{Znanstveni doprinos istraživanja}

Ovim radom ostvaren je znanstveni doprinos u teoriji komunikacije, specifično u problematici oblikovanja nove komunikacijske paradigme putem društvenih medija u kontekstu visokog obrazovanja. Izvorni uvid u problematiku, uz specifičan doprinos procjene razvojnog smjera u oblikovanju nove komunikacijske paradigme, ostvaren je primjenom delfi metode, kojom je ostvareno multidimenzionalno i kritičko utemeljenje nove komunikacijske paradigme pod utjecajem društvenih medija.

Znanstveni doprinos disertacije u području informacijskih i komunikacijskih znanosti jest spoznajno utemeljenje pojma društveni mediji, utvrđene su prednosti i nedostaci trenutne komunikacijske paradigme u visokom obrazovanju pod utjecajem društvenih medija te su otkriveni pojavni oblici anomalija i krize u postojećoj paradigmi.

Također je znanstveno utvrđeno određenje ključnih čimbenika promjene komunikacijske paradigme u visokom obrazovanju pod utjecajem društvenih medija i utvrđena je njihova važnost.

Daljnji doprinos ove doktorske disertacije je utvrđivanje i opis preporuka za provedbu nove komunikacijske paradigme u visokom obrazovanju pod utjecajem društvenih medija odnosno smjernice za smanjenje anomalije i krize koje su nastale u postojećoj komunikacijskoj paradigmi odnosno smjernice koje će profesionalcima u području obrazovanja omogućiti poboljšanje kvalitete obrazovnih politika, nastavnih planova i programa kako bi se potencijal društvenih medija upotrijebio za potrebe visokog obrazovanja.

Ovo je prvi znanstveni rad u Republici Hrvatskoj koji se bavi komunikacijskom paradigmom u visokom obrazovanju pod utjecajem društvenih medija. 


\section{Buduća istraživanja}

Iako je ovom doktorskom disertacijom utvrđeno 12 ključnih čimbenika koji su temelj komunikacijske paradigme u visokom obrazovanju pod utjecajem društvenih medija, a isto tako provedena je neparametrijska statistička analiza kako bi se čim detaljnije provjerio stupanj važnosti svakog od 12 ključnih čimbenika, u budućnosti bi se moglo doći do još detaljnijeg razlikovanja ključnih čimbenika komunikacijske paradigme u visokom obrazovanju pod utjecajem društvenih medija ako bi se koristila metoda prisilnog izbora.

Isto tako, daljnja istraživanja mogla bi se provesti kako bi se uspostavili i dodijelili specifični ključni indikatori (pokazatelji) uspješnosti (KPI) za svaki ključni čimbenik (KČP) komunikacijske paradigme u visokom obrazovanju pod utjecajem društvenih medija. Relevantni ključni indikatori uspješnosti omogućili bi redovito praćenje i mjerenje uspješnosti svakog pojedinog ključnih čimbenika komunikacijske paradigme u visokom obrazovanju pod utjecajem društvenih medija i uspješnost njegove primjene. Mjerenje izvedbe prema relevantnim ključnim indikatorima uspješnosti također bi podrazumijevalo dobivanje povratnih informacija u neprestanom procesu kontinuiranog poboljšanja. 


\section{Popis slika}

Slika 1. Skala komuniciranja (izvor: izrada autorice prema McQuail, 2010) 11

Slika 2. Lasswellow model komuniciranja (izvor: izrada autorice prema Lasswell, 1948)..... 13

Slika 3. Što se desi na internetu u minuti 2020. godine (izvor: Lori Lewis, 2020). 16

Slika 4. Mnoštvo društvenih medija te aktivnosti i usluga koje pružaju (izvor: Brian Solis, 2008a)

Slika 5. 32 ikone najpoznatijih društvenih medija (izvor: Shayli, 2020)....

Slika 6. Korisnici računala u Republici Hrvatskoj prema dobnim skupinama 2019. godine (izvor: Državni zavod za statistiku RH, 2019)

Slika 7. Korisnici interneta u Republici Hrvatskoj prema dobnim skupinama 2019. godine

(izvor: Državni zavod za statistiku RH, 2019)

Slika 8. Korisnici računala u Republici Hrvatskoj prema radnom statusu 2019. godine (izvor:

Državni zavod za statistiku RH, 2019) 33

Slika 9. Korisnici interneta u Republici Hrvatskoj prema radnom statusu 2019. godine (izvor: Državni zavod za statistiku RH, 2019)

Slika 10. Namjena upotrebe interneta kod pojedinaca u Republici Hrvatskoj 2019. godine (izvor: Državni zavod za statistiku RH, 2019)

Slika 11. Mapa društvenih medija i njihovih karakteristika (izvor: New Zealand Teaching Council, 2013)

Slika 12. Kratki pregled nekih oblika distribucije (izvor: Bubić, 2013) 134

Slika 13. Plan istraživanja - struktura korištenih istraživačkih metoda i instrumenata (izvor: izrada autorice) 


\section{Popis tablica}

Tablica 1. Tipovi društvenih medija s primjerima (izvor: izrada autorice prema Aichner, Jacob, 2015)

Tablica 2. Opis društvenih medija (izvor: izrada autorice prema tipologiji Aichner, Jacob, 2015) 40

Tablica 3. Primjena društvenih medija (izvor: izrada autorice prema Ngai i sur., 2015). 44

Tablica 4. Shema usporedbe dimenzija kognitivnih procesa 1956. i 2001. (izvor: izrada autorice prema Bloom, Andersen, Kratwohl, 2020).

Tablica 5. Svrhe korištenja društvenih medija u visokom obrazovanju (izvor: izrada autorice, 2020).

Tablica 6. Modeli integracije društvenih medija u visoko obrazovanje prema tipovima društvenih medija (izvor: izrada autorice, prilagođeno prema Grosseck, 2009 i Cobbs, 2008).

Tablica 7. Prednosti korištenja društvenih medija u visokom obrazovanju (izvor: izrada autorice, prilagođeno prema Grosseck, 2009; Mabić, 2014; Raut, Patil, 2016).

Tablica 8. Nedostaci korištenja društvenih medija u visokom obrazovanju (izvor: izrada autorice, prilagođeno prema Grosseck, 2009; Mabić, 2014; Raut, Patil, 2016). 58

Tablica 9. Primjeri politika visokih učilišta u Republici Hrvatskoj koje potencijalno obeshrabruju korištenje društvenih medija za potrebe visokog obrazovanja (izvor: izrada autorice, prilagođeno prema Willems i sur., 2018)

Tablica 10. Primjeri politika visokih učilišta u Republici Hrvatskoj koje potencijalno ohrabruju korištenje društvenih medija za potrebe visokog obrazovanja (izvor: izrada autorice, prilagođeno prema Willems i sur., 2018).

Tablica 11. Korištenje društvenih medija u visokom obrazovanju u SAD-u (izvor: izrada autorice prema Davis III i sur., 2012)

Tablica 12. Sumarni prikaz čimbenika koji (ne) utječu na učestalost nastavničkog korištenja društvenih medija za potrebe visokog obrazovanja; Pearsonov hi-kvadrat test (izvor: upitnik, SPSS, obrada autorice)

Tablica 13. Karakteristike društvenih medija koje nastavnici smatraju prednostima (izvor: upitnik, Google obrasci, obrada autorice)

Tablica 14. Karakteristike društvenih medija koje nastavnici smatraju nedostacima (izvor: upitnik, Google obrasci, obrada autorice).

Tablica 15. Faze tematske analize (izvor: izrada autorice prema Braun, Clarke, 2006) 
Tablica 16. Mjere disperzije i odgovarajuće srednje vrijednosti s pripadajućim kraticama (izvor: izrada autorice prema Mužić, 1976; Petz i sur., 2012; Bubić, 2013)

Tablica 17. Trajanje i broj sudionika u svakom krugu provedene delfi studije provedene 2020. godine, $\mathrm{N}=37$ (izvor: izrada autorice)

Tablica 18. Struktura uzorka glavnog istraživanja, N=37 (izvor: izrada autorice)

Tablica 19. Terminologija tehnoloških i ostalih (engleskih) izraza koje su koristili eksperti u svojim odgovorima tijekom1. kruga ove delfi studije (izvor: izrada autorice)

Tablica 20. Rezultati 1. kruga delfi studije: Razvoj tehnologija koje pokreću društvene medije u idućih 5 godina, N=34 (izvor: upitnik, Google obrasci, obrada autorice) 156

Tablica 21. Rezultati 1. kruga delfi studije: Razvoj tehnologija koje pokreću društvene medije u idućih 10 godina, N=27 (izvor: upitnik, Google obrasci, obrada autorice) ...

Tablica 22. Rezultati 1. kruga delfi studije: Preduvjeti koje je potrebno ispuniti kako bi se potencijal društvenih medija mogao koristiti za potrebe visokog obrazovanja u sljedećih 5 godina, N=37 (izvor: upitnik, Google obrasci, obrada autorice)

Tablica 23. Rezultati 1. kruga delfi studije: Preduvjeti koje je potrebno ispuniti kako bi se potencijal društvenih medija mogao koristiti za potrebe visokog obrazovanja u sljedećih 10 godina, $\mathrm{N}=37$ (izvor: upitnik, Google obrasci, obrada autorice)

Tablica 24. Rezultati 1. kruga delfi studije: Čimbenici koji utječu na ugradnju društvenih medija u visokoobrazovni proces, $\mathrm{N}=37$ (izvor: upitnik, Google obrasci, obrada autorice) . 173 Tablica 25. Rezultati 1. kruga delfi studije: Čimbenici koji utječu na odnos visokih učilišta prema korištenju društvenih medija u visokom obrazovanju, N=37 (izvor: upitnik, Google obrasci, obrada autorice)

Tablica 26. Rezultati 1. kruga delfi studije: Čimbenici koji utječu na odnos nastavnika prema korištenju društvenih medija u visokom obrazovanju, N=37 (izvor: upitnik, Google obrasci, obrada autorice)

Tablica 27. Rezultati 1. kruga delfi studije: Čimbenici koji utječu na odnos studenata prema korištenju društvenih medija u visokom obrazovanju, N=37 (izvor: upitnik, Google obrasci, obrada autorice).

Tablica 28. Rezultati 1. kruga delfi studije: Potencijali društvenih medija koji mogu unaprijediti komunikaciju u visokoobrazovnom procesu, N=37 (izvor: upitnik, Google obrasci, obrada autorice)

Tablica 29. Kratki opis 12 ključnih čimbenika promjene (KČP) komunikacijske paradigme u visokom obrazovanju pod utjecajem društvenih medija (izvor: izrada autorice) 205 
Tablica 30. Frekvencija odgovora u 2. krugu prema stupnjevima važnosti 12 ključnih čimbenika promjene (KČP) komunikacijske paradigme u visokom obrazovanju pod utjecajem društvenih medija, N=37 (izvor: upitnik, Google obrasci, obrada autorice)

Tablica 31. Deskriptivna statistička analiza: rezultati 2. kruga istraživanja, $\mathrm{N}=37$ (izvor: upitnik, Google obrasci, SPSS obrada autorice) 208

Tablica 32. Delfi rang 12 ključnih čimbenika promjene (KC̆P) komunikacijske paradigme u visokom obrazovanju pod utjecajem društvenih medija u 2. krugu istraživanja, $\mathrm{N}=37$ (izvor: upitnik, Google obrasci, SPSS obrada autorice) ..... 209

Tablica 33. Frekvencija odgovora u 3. krugu prema stupnjevima važnosti 12 ključnih čimbenika promjene (KČP) komunikacijske paradigme u visokom obrazovanju pod utjecajem društvenih medija, N=36 (izvor: upitnik, Google obrasci, SPSS obrada autorice)

Tablica 34. Deskriptivna statistička analiza: rezultati 3. kruga istraživanja, $\mathrm{N}=36$ (izvor: upitnik, Google obrasci, SPSS obrada autorice)

Tablica 35. Delfi rang 12 ključnih čimbenika promjene (KČP) komunikacijske paradigme u visokom obrazovanju pod utjecajem društvenih medija u 3. krugu istraživanja, $\mathrm{N}=36$ (izvor: upitnik, Google obrasci, SPSS, obrada autorice)

Tablica 36. Podaci o konsenzusu: deskriptivna analiza odgovora za 12 ključnih čimbenika promjene (KČP) komunikacijske paradigme u visokom obrazovanju pod utjecajem društvenih medija - usporedba rezultata 2. i 3. kruga (izvor: upitnik, Google obrasci, SPSS, obrada autorice)

Tablica 37. Neparametrijska statistička analiza: Prikaz rezultata Wilcoxonovog testa rangova zavisnih uzoraka 12 ključnih čimbenika promjene (KČP) komunikacijske paradigme u visokom obrazovanju pod utjecajem društvenih medija, N=36 (izvor: upitnik, Google obrasci, SPSS obrada autorice)

Tablica 38. Neparametrijska statistička analiza: Wilcoxonova usporedba svakog ključnog čimbenika promjene (KČP) sa svakim ključnim čimbenikom promjene (KČP) komunikacijske paradigme u visokom obrazovanju pod utjecajem društvenih medija iz 3. kruga (izvor: upitnik, Google obrasci, SPSS obrada autorice)

Tablica 39. Neparametrijska statistička analiza: Wilcoxonova usporedba svakog ključnog čimbenika promjene (KČP) sa svakim ključnim čimbenikom promjene (KČP) komunikacijske paradigme u visokom obrazovanju pod utjecajem društvenih medija iz 3. kruga prema aritmetičkoj sredini sa naznačenim (osjenčanim) podudarnostima* (izvor: upitnik, Google obrasci, SPSS obrada autorice) ..... 
Tablica 40. Konačni rang ključnih čimbenika promjene (KČP) komunikacijske paradigme u visokom obrazovanju pod utjecajem društvenih medija ove delfi studije, N=36 (izvor: izrada autorice)... 222

Tablica 41. Preporuke za provedbu promjena komunikacijske paradigme u visokom obrazovanju pod utjecajem društvenih medija (izvor: izrada autorice) ..... 228 


\section{Popis literature}

Adams, D. (2002). The Salmon of Doubt. William Heinemann Ltd., London.

Adorio, (2020). Software developer. Dostupno na: https://www.adorio.hr/zanimanje/softwaredeveloper. Pristupljeno: 01.10.2020.

Aichner, T., Jacob, F. (2015). Measuring the Degree of Corporate Social Media Use. International Journal of Market Research. 57.257-275. 10.2501/IJMR-2015-018.

Akademija primijenjenih umjetnosti (2018). Pravilnik o studiranju (pročišćeni tekst). Sveučilište u Rijeci, Rijeka. Dostupno na: https://apuri.hr/wpcontent/uploads/dokumenti/o-nama/propisi-i-dokumenti/studij-istudenti/Pravilnik\%20o\%20studiranju,\%20listopad\%202018.pdf, 26.07.2020.

Alasuutari, P. (1995). Researching culture: Qualitative method and cultural studies. Sage Publications Ltd., London.

Ali, M.,Yaacob, R., Ednut, B., Makki, B. (2017). Determining the academic Use of Social Media with technology Acceptance Models. Pakistan: NFC Institute of Engineering and Fertilizer Research.

Alsolamy, F. (2017). Social networking in higher education: academics' attitudes, uses, motivations and concerns. Doctoral, Sheffield Hallam University.

Amidharmo, S. S. (2014). Critical success factors for the implementation of a knowledge management system in a knowledge-based engineering firm. Masters by Research thesis, Queensland University of Technology. Dostupno na: https://web.njit.edu/ turoff/pubs/delphibook/, pristupljeno: 11.05.2020.

Anderson, L. W., Krathwohl, D. R. (2001). A Taxonomy for Learning, Teaching and Assesing. A Revision of Bloom's taxonomy of educational objectives. Addison Wesley Longman Inc., New York.

Anderson, H. (2003). Myths about 'Not-Knowing'. Familiy Process, Vol. 44, No. 4.

Anglin, J. P. (2002). Pain, Normality, and the Struggle for Congruence: Reinterpreting Residential Care for Children and Youth. Haworth Press, Binghamton, str. 1-183. Dostupno

na: https://www.researchgate.net/publication/286773849_Pain_normality_and_the_struggle 
for_congruence_Reinterpreting_residential_care_for_children_and_youth, pristupljeno: 03.11.2020.

Antaki, C., Billig, M., Edwards, D., Potter, J. (2002). Discourse analysis means doing analysis: A critique of six analytic shortcomings. DAOL Discourse Analysis Online, 1(1).

Arbona (2019). Infografika: Facebook vs. Instagram na početku 2019. godine: tko smo i što nas najviše interesira. Dostupno na: https://www.arbona.hr/blog/drustvenimarketing/infografika-facebook-vs-instagram-na-pocetku-2019-godine-tko-smo-i-stonas-najvise-interesira/2803, pristupljeno 24.06.2020.

Aristotle (350 B.C.E.). Politics; Book Five. Dostupno na: http://classics.mit.edu/Aristotle/politics.5.five.html, pristupljeno: 24.05.2020.

Arsović, B. (2012). Društvene mreže - izazovi mogućnosti za obrazovanje. Tehnika i informatika u obrazovanju., 4. Internacionalna konferencija, Tehnički fakultet Čačak.

Arcangeli, F., Houssein, A. (2013). Emotional disclosure through negative online reviews. Uppsala Univeristet, master thesis. Dostupno na: https://www.divaportal.org/smash/get/diva2:632410/FULLTEXT01.pdf, pristupljeno: 15.11.2020.

Association for Educational Communications and Technology (1977). Educational technology: Definition and glossary of terms. Author, Washington, DC.

Attride-Stirling, J. (2001). Thematic networks: an analytic tool for qualitative research. Qualitative Research, 1(3), str. 385-405.

Babić, S. (2016). Činitelji nastavničkoga prihvaćanja e-učenja i kompetencije za njegou primjenu na visokoškolskim ustanovama. Doktorski rad. Sveučilište u Zagrebu, Fakultet organizacije i informatike, Varaždin. Dostupno na: https://dr.nsk.hr/islandora/object/foi:405/preview, pristupljeno: 14.06.2020.

Babić, T., Grgić, S. (2019). Net generation and a perception of the electronic violence. Mediteranska pitanja, knjiga 2 / ur. Jurčević, K., Kaliterna Lipovčan, Lj., Ramljak, O. Institut Ivo Pilar i Grupa 'VERN', Zagreb, str. 455-462. Dostupno na: http://www.micvis.eu/upload/Zbornik_za_web_2018.pdf, pristupljeno 27.07.2020.

Babić, T., Vunarić, I., Lacković, A. (2019). Informacijska etika na društvenim mrežama: perspektiva studenata. Mediteranska pitanja, knjiga 2 / ur. Jurčević, K., Kaliterna Lipovčan, Lj., Ramljak, O. Institut Ivo Pilar i Grupa 'VERN', Zagreb, str. 455-462. Dostupno na: http://www.mic-vis.eu/upload/Zbornik_za_web_2018.pdf, pristupljeno 27.07.2020. 
Babić, T., Vilović, G., Bakić-Tomić, Lj. (2019). The Usage of Social Media for Higher Education Purposes. The Future of Information Sciences / ur. Bago, P., Hebrang Grgić, I., Ivanjko, T., Juričić, V., Miklošević, Ž., Stublić, H. Faculty of Humanities and Social Sciences, University of Zagreb, Department of Information and Communication Sciences, FF press, Zagreb, str. 206-216. doi:10.17234/INFUTURE.2019.25. Dostupno na: https://infoz.ffzg.hr/INFuture/images/papers/INFuture\%202019\%20Proceedings.pdf, pristupljeno 27.07.2020.

Banditvilai, Ch. (2016). Enhancing Students' Language Skills through Blended Learning. The Electronic Journal of e-Learning Volume 14 Issue 3. Str. 220-229. Dostupno na: www.ejel.org, pristupljeno 27.06.2020.

Baruchson-Arbib, S., Bronstein, J. (2002). A view to the future of the library and information science profession: a Delphi study. Journal of the American Society for Information Science and Technology, 53 (5), str. 397-408.

Batarelo I. (2005). Priprema nastavnika za korištenje obrazovne tehnologije u nastavi: međunarodna iskustva, Međunarodna iskustva: primjeri dobre prakse. U: Cjeloživotno obrazovanje učitelja i nastavnika: višestruke perspective, urednica Vizek. V.V. Institut za društvena istraživanja, Zagreb, str. 207-214. Dostupno na: http://idiprints.knjiznica.idi.hr/638/1/Cjelo\%C5\%BEivotno\%20obrazovanje\%20u\%C4\% 8Ditelja\%20i\%20nastavnika.pdf, pristupljeno: 31.05.2020.

Bateson, G. (1951). Communication: The Social Matrix of Psychiatry. Ruesch and Bateson, str. 209.

Bauman, Z. (2010). Forty-four letters from the liquid modern world. Polity, Cambridge.

Berthon, P.R., Pitt, L.F., Plangger, K., Shapiro, D. (2012). Marketing meets Web 2.0, social media, and creative consumers: implications for international marketing strategy. Business Horizons, 55, 3, str. 261-271. Dostupno na: https://www.sciencedirect.com/science/article/pii/S0007681312000080, pristupljeno: 31.05.2020.

Biberović, M., (2014). Vrijeme je da provjerite postavke privatnosti na Facebooku - kaže Facebook!, Netokracija. Dostupno na: http://www.netokracija.com/facebook-postavkeprivatnosti-85046, pristupljeno 03.04.2017.

Bilić, V. (2015). Načini učenja, online aktivnosti i ishodi odgoja net-generacije. U: GazdiAlerid, T. i Rijavec, M. (ur.) Istraživanje paradigmi djetinjstva, odgoja i obrazovanja, Učiteljski fakultet, Zagreb. Str. 593-607.

Birdsall, I. (2004). It seemed like a good idea at the time: The forces affecting implementation 
of strategies for an information technology project in the Department of Defense. Digital Abstracts International, 65, 2756.2 Dostupno na: https://shareok.org/bitstream/handle/11244/33188/International\%20Journal\%20of\%20Q ualitative \%20Methods-2015-Brady-.pdf?sequence=4, pristupljeno: 22.10.2020.

Bloom, B. S. (1956). The Taxonomy of Educational Objectives, The Classification of Educational Goals, Handbook I: Cognitive Domain. David McKay Company Inc., New York.

Bolje je hrvatski! (2020a). Razvojni inženjer - developer. Dostupno na: https://bolje.hr/rijec/developer-gt-razvojni-inzenjer/193/. Pristupljeno: 01.10.2020.

Bolje je hrvatski! (2020b). Mediji glavne struje, prevladavajući mediji - mainstream mediji. Dostupno na: https://bolje.hr/rijec/mainstream-mediji-gt-mediji-glavne-strujeprevladavajuci-mediji/51/. Pristupljeno: 01.10.2020.

Bolje je hrvatski! (2020c). Prilagođen korisnicima - user friendly. Dostupno na: https://bolje.hr/rijec/user-friendly-gt-prilagodjen-korisnicima/96/. 01.10.2020.

Booz-Allen \& Hamilton (1995). Zukunft Multimedia - Grundlagen, Märkte und Perspektiven in Deutschland. 2. izdanje. IMK, Frankfurt a.M.

Boyatzis, R. E. (1998). Transforming qualitative information: Thematic analysis and code development. Thousand Oaks, Sage, CA.

Bradley, A. J. (2010). A New Definition of Social Media. Gartner Blog Network. Dostupno na: https://blogs.gartner.com/anthony_bradley/2010/01/07/a-new-definition-of-socialmedial, pristupljeno: 06.06.2020.

Brady, Sh. R. (2015). Utilizing and Adapting the Delphi Method for Use in Qualitative Research. International Journal of Qualitative Methods, 1-6. Dostupno na: https://shareok.org/bitstream/handle/11244/33188/International\%20Journal\%20of\%20Q ualitative\%20Methods-2015-Brady-.pdf?sequence=4, pristupljeno: 22.10.2020.

Braun, V., Clarke, V. (2006). Using thematic analysis in psychology. Qualitative Research in Psychology, 3(2), str. 77-101. Dostupno na: https://uwerepository.worktribe.com/output/1043060, pristupljeno: 23.10.2020.

Brautović, M. (2011). Online novinarstvo. Školska knjiga, Zagreb. 
Briggs, A., Burke P. (2011). Socijalna povijest medija: od Gutenberga do Interneta. Pelago, Zagreb.

Brooks, K. W. (1979). Delphi technique: Expanding applications. North Central Association Quarterly, 53, str. 377-385.

Brooks, S. (2015). Does personal social media usage affect efficiency and well-being. Computers in Human Behavior 46, str. 26-37. Dostupno na: https://psycnet.apa.org/record/2015-08825-005, pristupljeno 28.06.2020.

Brown, B. B. (1968). Delphi process: A methodology used for the elicitation of opinions of experts. Rand Corporation. Dostupno na: https://www.rand.org/pubs/papers/P3925.html, pristupljeno: 17.10 .2020 .

Bruns, A. (2008). Blogs, Wikipedia, Second Life and Beyond: From Production to Produsage. Peter Lang, New York.

Bubić, A. (2013). Osnove statistike u društvenim i obrazovnim znanostima (Priručnik u postupku recenzije). Filozofski fakultet, Sveučilište u Splitu.

Buckley, C., Pitt, E., Norton, B., Owens, T. (2010). Students' approaches to study, conceptions of learning and judgements about the value of networked technologies. U: Active Learning in Higher Education, 11 (1), str. 55-65, 2010. Dostupno na: https://www.researchgate.net/publication/254075862_Students'_approaches_to_study_co nceptions_of_learning_and_judgements_about_the_value_of_networked_technologies, pristupljeno 15.06.2020.

Burić, I. (2018). Uvod u deskriptivnu i inferencijalnu statistiku. Nastavni materijali, Odjel za psihologiju, Sveučilište $\mathrm{u}$ Zadru. Dostupno na: http://www.unizd.hr/Portals/12/Nastavnici/Irena\%20Buric/Uvod\%20u\%20deskriptivnu \%20i\%20inferencijalnu\%20statistiku.pdf, pristupljeno: 14.11.2020.

BVDW (Njemačka savezna udruga digitanoga gospodarstva) (2004). Statut od 28. lipnja 2004, čl. 3. st. 1. Dostupno na: http://www.bvdw.org/de/data/pdf/bvdw_satzung_2004.pdf, pristupljeno: 28.06 .2020 .

Camiel, D. L., Goldman-Levine, J., Kostka-Rokosz, M., McCloskey,W. (2014). Twitter as a medium for pharmacy students personal learning network development. Currents in Pharmacy Teaching and Learning 6, str. 463-470. Dostupno na: https://www.researchgate.net/publication/262921659_Twitter_as_a_medium_for_pharm acy_students'_personal_learning_network_development, pristupljeno: 28.06.2020. 
Canough, J. (2013). Effective Implementation of Technology. Fisher Digital Publications. St. John Fisher College. Dostupno na: https://fisherpub.sjfc.edu/cgi/viewcontent.cgi?article=1262\&context=education_ETD_m asters, pristupljeno: 28.06 .2020 .

CARNet, Hrvatska akademska i istraživačka mreža (2008). Netiquette. Dostupno na: https://helpdesk.carnet.hr/Netiquette, pristupljeno: 03.07.2020.

CARNet, Hrvatska akademska i istraživačka mreža (2020). Komunikacija - općenito. Dostupno na: https://tesla.carnet.hr/pluginfile.php/22146/mod_resource/content/1/COURSE_9469299_ $\mathrm{M} / \mathrm{my}$ files/html2.1.htm, pristupljeno: 24.06.2020.

Carr, N. (2010). The Web Shatters Focus, Rewires Brains. U: Wired. Dostupno na: https://www.wired.com/2010/05/ff-nicholas-carr/, pristupljeno 15.06.2020.

Castells M. (1996). The Information Age: Economy, Society and Culture vol 1: The Rise of the Network Society. Basil Blackwell Publishers, Oxford, London.

Castells, M. (2000). Uspon umreženoga društva. U: Informacijsko doba: Ekonomija, društvo i kultura, Svezak I. Golden marketing, Zagreb.

Castells, M. (2002). Informacijsko doba. U: Ekonomija, društvo i kultura (svezak 2) - Moć identiteta. Golden marketing, Zagreb. ISBN 953-212-002-5.

Castells, M. (2003). Internet galaksija - Razmišljanja o internetu, poslovanju i društvu. Jesenski i Turk, Zagreb.

Chakrabarti, S., Ester, M., Fayyad, U., Gehrke, J., Han, J., Morishita, Sh., Piatetsky-Shapiro, G., Wang; W. (2006). Data Mining Curriculum: A Proposal (Version 1.0). Intensive Working Group of ACM SIGKDD Curriculum Committee. Dostupno na: https://www.kdd.org/exploration_files/CURMay06.pdf, pristupljeno 26.08.2020.

Championing Science (2019). In honor of Albert Einstein's birthday - Everything should be made as simple as possible, but no simpler. Dostupno na: https://championingscience.com/2019/03/15/everything-should-be-made-as-simple-aspossible-but-nosimpler/\#: :text=\%E2\%80\%9CEverything\%20should\%20be $\% 20$ made $\% 20$ as, of $\% 20$ how $\% 20$ to $\% 20$ conduct $\% 20$ science.\&text $=\mathrm{It} \% 20$ was $\% 20$ attributed $\% 20$ to $\% 20$ Albert,times $\%$ 5B1\%5D\%20in\%201950. Pristupljeno: 04.11.2020.

Cheung, C., Chiu, P., Lee, M. (2011). Online social networks: Why do students use Facebook? Computers in Human Behavior, 27 (4), str. 1337-1343. Dostupno na: 
https://www.researchgate.net/publication/220495008_Online_Social_Networks_Why_do _Students_use_Facebook, pristupljeno: 28.06.2020.

Chickering, A. W., and Ehrmann, S. C. (1996). Implementing the Seven Principles: Technology as Lever. The TLT Group, Teaching, Learning and Technology. AAHE Bulletin.

Cho, H., Gay, G., Davidson, B., Ingraffea, A. (2007). Social networks, communication styles, and learning performance in a CSCL community. Computers \& Education, 49 (2), str. 309-329.

Dostupno

na: https://www.researchgate.net/publication/223260798_Social_Networks_Communication _Styles_and_Learning_Performance_in_a_CSCL_Community, pristupljeno 28.06.2020.

Christensen, C M. (1997). The Innovator's Dilemma. Harvard Business School, Massachusetts.

Ciarli, T., Coad, A. i Rafols, I. (2013). Quantitative Analysis of Technology Futures. Part I: Techniques, Contexts, and Organizations. Nesta Working Paper 13/08. Dostupno na: https://media.nesta.org.uk/documents/quantitative_analysis_of_technology_futures_part _1_techniques_contexts_and_organizations.pdf. Pristupljeno: 10.10.2020.

Cisco (2013). The Internet of Everything. Global Public Sector Economic Analysis. Dostupno na: https://www.cisco.com/c/dam/en_us/about/business-insights/docs/ioe-value-at-stakepublic-sector-analysis-faq.pdf, pristupljeno 19.10.2020.

Cloudflare (2020). What is a Bot - Bot definition. Dostupno na: https://www.cloudflare.com/learning/bots/what-is-a-bot/, pristupljeno 19.10.2020.

Coates (1975). In Defense of Delphi: A Review of Delphi Assessment, Expert Opinion, Forecasting, and Group Process by H.Sackman. Technological Forecasting and Socilal Change 7, 193-194.

Cobbs, J.T. (2008). Learning 2.0 for Associations. Dostupno na: http://blog.missiontolearn.com/files/Learning_20_for_Associations_eBook_v1.pdf . Pristupljeno: 01.02.2008.

Cohen, L., Manion, L., Morrison, K. (2007). Metode istraživanja u obrazovanju. Udžbenici Sveučilišta u Zagrebu. Naklada slap, Jastrebarsko.

Coleman, B., Petitt, S., Buning, M., (2018). Social Media Use in Higher Education: Do Members of the Academy Recognize Any Advantages? The Journal of Social Media in Society, Vol. 7, NO. 1, 420-442.

Conole, G., Alevizou, P. (2010). A literature review of the use of web 2.0 tools in higher 
education. Higher Education Academy. Dostupno na: https://s3.eu-west2.amazonaws.com/assets.creode.advancehe-documentmanager/documents/hea/private/conole_alevizou_2010_1568036804.pdf, pristupljeno 14.06.2020.

Continuousdev (2020). Obrada prirodnog jezika (NLP). Dostupno na: https://hr.continuousdev.com/653-natural-language-processing-nlp-353. Pristupljeno: 01.10.2020.

Cooke, S. (2017). Social Teaching: Student Perspectives on the Inclusion of Social Media in Higher Education. Education and Information Technologies 22, str. 255-269. Dostupno na: https://link.springer.com/article/10.1007/s10639-015-9444-y, pristupljeno: 28.06.2020.

Coudert, F. R. (1939). Proceedings of the Academy of Political Science. The Academy of Political Science.

Council of the European Union (2012). Europski kvalifikacijski okvir za cjeloživotno učenje (EKO) (engl. EQF - European Qualifications Framework). Dostupno na: https://ec.europa.eu/eqf/documentation_en.htm, pristupljeno: 10.06.2016.

Crook, C. (2008). Theories of formal and informal learning in the world of web 2.0. U: Livingstone, S. (ed.). Theorising the benefits of new technology for youth. Oxford University Press, London.

Cuellar, P. M, Delgado, M., Pegalajar, C.M.(2011). Improving learning management through semantic web and social networks. Expert Systems with Applications. Vol. 38 (4), str. 4181-4189. Dostupno na https://www.researchgate.net/publication/220215832_Improving_learning_management _through_semantic_web_and_social_networks_in_e-learning_environments, pristupljeno: 28.06.2020.

Čačić, T. (2012). Stranice društvenih mreža i kultura net-generacije, doktorski rad, Zagreb. Dostupno na: https://www.academia.edu/1963857/Stranice_dru\%C5\%A1tvenih_mre\%C5\%BEa_i_kul tura_net_-_generacije, pristupljeno: 21.08.2016.

Dahr, V. (2013). Dana Science and Prediction. Communications of the ACM, Vol. 56, NO. 12, str. 64-73. Dostupno na: https://cacm.acm.org/magazines/2013/12/169933-data-scienceand-prediction/fulltext\#body-2, pristupljeno 19.10.2020.

Dalbelo Bašić, B. (2020). Umjetna inteligencija - Uvod u strojno učenje. Fakultet elektrotehnike i računarstva, Sveučilište u Zagrebu. Dostupno na: https://www.fer.unizg.hr/_download/repository/UI_10_UvodUStrojnoUcenje.pdf, 
pristupljeno 19.10.2020.

Dalkey, N. C., Helmer, O. (1962). An experimental application of the Delphi method to the use of experts (Abridged, Report No. RM-727-PR). The RAND Corporation. Santa Monica, California.

Dostupno

na: https://www.rand.org/pubs/research_memoranda/RM727z1.html, pristupljeno: 17.10.2020.

Data Science Croatia (2020). In Data We Trust. Dostupno na: http://datascience.com.hr/, pristupljeno 19.10.2020.

Davis III, Ch.H.F., Dell-Amen, R., Rios-Aguilar, C., Gonzales Canche, M.S. (2012). Social Media in Higher Education. A literature review and research directions. The Center for the Study of Higher Education, The University of Arizona \& Claremont Graduate University. Dostupno na: https://www.coe.arizona.edu/sites/coe/files/HED/Social-Media-in-HigherEducation\%20report_0.pdf, pristupljeno: 31.05.2020.

Dedić, N., Stanier, Cl. (2017). Measuring the Success of Changes to Existing Business Intelligence Solutions to Improve Business Intelligence Reporting. 10th International Conference on Research and Practical Issues of Enterprise Information Systems (CONFENIS). Dostupno na: https://hal.inria.fr/hal01630541/file/432749_1_En_17_Chapter.pdf, pristupljeno 19.10.2020.

Demers, D. (2005). Dictionary of Mass Communication and Media Research: a guide for students, scholars and professionals. Marquette Books, Michigan, str. 143.

Deterding, S., Dixon, D., Khaled, R., Nacke, L. (2011). From game design elements to gamefulness: defining gamification, in: Proceedings of the 15th International Academic MindTrek Conference: Envisioning Future Media Environments. ACM, str. 9-15.

Downes, S. (2010). Deinstitutionalizing education. U: Huffington Post. Dostupno na: https://www.huffpost.com/entry/deinstitutionalizing-educ_b_777132?guccounter=1, pristupljeno 14.06.2020.

Dragičević D. (2004). Kompjuterski kriminalitet i informacijski sustavi. IBS, Zagreb.

Drokina, E. (2017) Top 10 Skills for The Future. CareerProfessor.works ${ }^{\mathrm{TM}}$. Dostupno na: https://careerprofessor.works/top-10-skills-for-the-future/, pristupljeno 27.06.2020.

Drucker, P. (1997). Seeing things as they really are. An interview by Robert Lenzner and Stephen S. Johnson. Forbes. 
Družeta, E., Zgrabljić Rotar, N. (2017). Uloga Facebooka u sentimentalnim odnosima mladih, Medijske studije, Vol. 8 No. 16. Dostupno na https://hrcak.srce.hr/192921, pristupljeno 08.09.2020.

Državni zavod za intelektualno vlasništvo (2017). O intelektualnom vlasništvu. Dostupno na: http://www.dziv.hr/hr/intelektualno-vlasnistvo/o-intelektualnom-vlasnistvu/, pristupljeno 13.03.2017.

Državni zavod za statistiku Republike Hrvatske (2019). Priopćenje. Primjena informacijskih i komunikacijskih tehnologija (IKT) u kućanstvima i kod pojedinaca u 2019., prvi rezultati. Godina LVI., broj: 2.3.2. Zagreb. Dostupno na: https://www.dzs.hr/Hrv_Eng/publication/2016/02-03-02_01_2016.htm, pristupljeno: 24.06.2020.

Echeng, R., Usoro, A., Ewuzie, I. (2016). Factors to Consider when Enhancing the Use of Web 2.0 Technologies in Higher Education: Students' and Lectures' Views for Quality Use. International Journal of Digital Society (IJDS), Volume 7, Issue 1.

Ehlers, U. D. (2007). Quality literacy - competencies for quality development in education and e-learning, Technology \& Society, 10 (2), 96-108. Dostupno na: https://www.researchgate.net/publication/220374078_Quality_Literacy__Competencies_for_Quality_Development_in_Education_and_e-Learning, pristupljeno: 14.06.2020.

Eisenstein, E. (1993). The Printing Press as an Agent of Change. Communications and Cultural Transformations in Early-Modern Europe, Cambridge University Press, Cambridge.

Ellison, N., Steinfield, C., Lampe, C. (2007). The Benefits of Facebook "Friends:" Social Capital and College Students' Use of Online Social Network Sites. Journal of ComputerMediated Communication. Dostupno na: https://onlinelibrary.wiley.com/doi/full/10.1111/j.1083-6101.2007.00367.x, pristupljeno: 28.06.2020.

Eret, L. (2017). Neka razmatranja o primjeni delfi metode u kvalitativnim istraživanjima odgoja i obrazovanja. Školski vjesnik: časopis za pedagogijsku teoriju i praksu, 66(1), str. 77-93. Dostupno na: https://hrcak.srce.hr/file/275500, pristupljeno: 19.10.2018.

Eshet-Alkalai, Y. (2004). Digital literacy: A conceptual framework for survival skills in the digital era. Journal of Educational Multimedia and Hypermedia 13 (1), str. 93-106. Dostupno na: https://www.researchgate.net/publication/250721430_Digital_Literacy_A_Conceptual_F ramework_for_Survival_Skills_in_the_Digital_Era, pristupljeno 28.06.2020.

Etika bibliotekarstva (2016). Informacijska etika - etika informacija: prava i očekivanja. 
Dostupno na: https://pdfslide.net/documents/1-informacijska-etika-etika-informacijauvodna-razmatranja.html, pristupljeno: 16.10.2016.

European Commission (2010a). Europe 2020 A strategy for smart, sustainable and inclusive growth.

https://ec.europa.eu/eu2020/pdf/COMPLET\%20EN\%20BARROSO\%20\%20\%20007\%2 0-\%20Europe\%202020\%20-\%20EN\%20version.pdf, pristupljeno: 31.05.2020.

European Commission (2010b). Europe 2020 Digital Agenda for Europe. Dostupno na: https://www.europarl.europa.eu/factsheets/en/sheet/64/digital-agenda-for-europe, pristupljeno: 31.05 .2020 .

European Commission (2010c). Europe 2020 Flagship Initiative Innovation Union. Dostupno na: https://ec.europa.eu/research/innovation-union/pdf/innovation-union-communicationbrochure en.pdf, pristupljeno: 31.05.2020.

European Commission (2011). Horizon 2020 The Framework Programme for Research and Innovation, European Commission. Dostupno na: https://ec.europa.eu/research/horizon2020/pdf/proposals/communication_from the com mission_-_horizon_2020_-

the framework_programme_for_research_and_innovation.pdf, pristupljeno: 31.05.2020.

Europska komisija, Predstavništvo u Hrvatskoj (2020a). Virtualna stvarnost - stvarnost u kojoj živimo. Dostupno na: https://ec.europa.eu/croatia/virtual_reality_reality_we_live_in_hr, pristupljeno 26.08.2020.

Europska komisija, Predstavništvo u Hrvatskoj (2020b). Što je zapravo digitalna transformacija i kakve nas promjene očekuju. Dostupno na: https://ec.europa.eu/croatia/what_is_digital_transformation_changing_hr, pristupljeno 19.10.2020.

Europska komisija, Predstavništvo u Hrvatskoj (2020c). Što možemo očekivati od nove 5G tehnologije?

https://ec.europa.eu/croatia/content/what_can_we_expect_from_new_5G_technology_hr , pristupljeno 19.10.2020.

Europska komisija, Predstavništvo u Hrvatskoj (2020d). Kriptovalute i blockchain - sve što trebate znati. Dostupno na: https://ec.europa.eu/croatia/cryptocurrencies_and_blockchain_all_you_need_to_know_h r, pristupljeno 18.10.2020.

European Parliament and the Council of the European Union (2016). General Data Protection 
Regulation.

Dostupno

na:

https://eur-lex.europa.eu/legalcontent/HR/TXT/?uri=uriserv:OJ.L_.2016.119.01.0001.01.ENG\&toc=OJ:L:2016:119:T OC, pristupljeno: 24.06 .2020 .

Eurydice (2020). Focus On: What has the covid-19 crisis taught us about online teaching? European Commission. Dostupno na: https://eacea.ec.europa.eu/nationalpolicies/eurydice/content/focus-what-has-covid-19-crisis-taught-us-about-onlineteaching_en, pristupljeno: 26.06.2020.

Fakultet građevinarstva, arhitekture i geodezije u Splitu (2020). Smjernice za učenje i rad na daljinu. Sveučilišta $\mathrm{u}$ Splitu. Dostupno na: http://gradst.unist.hr/Portals/9/docs/novosti/2020/Smjernice\%20za\%20ucenje\%20i\%20ra d\%20na\%20daljinu\%20FGAG\%20u\%20Splitu.pdf, pristupljeno: 27.07.2020.

Fakultet organizacije i informatike (FOI), (2016). Procjena rizika. Kolegij Sigurnost informacijskih sustava, Varaždin.

Falvin, M. (2012). Disruptive technologies in higher education. Research in Learning Technology, 20, str. 102-111. Dostupno na: https://journal.alt.ac.uk/index.php/rlt/article/view/1352?trendmd-shared=0, pristupljeno: 03.07.2020.

Fang, I. (1997). A history of mass communication: six information revolutions. FocalPress, Boston, Oxford, Johannesburg, Melbourne, New Delhi, Singapore, Str. 280.

FDM (2020). 5 Exciting Uses for Virtual Reality. Dostupno na: https://www.fdmgroup.com/5exciting-uses-for-virtualreality/\#: :text=VR\%20can\%20transport\%20a\%20trainee, boot\%20camp\%2C\%20amon g\%20other\%20things, pristupljeno 19.10.2020.

Fischer, R. G. (1978). The Delphi method: a description, review and criticism. The Journal of Academic Librarianship, 4 (2), str. 67-70.

Fleck, J. (2007). Technology and the business school world. Journal of Management Development, 27 (4), str. 415-425. Dostupno na: https://www.researchgate.net/publication/48991420_Technology_and_the business_sch ool_world, pristupljeno 27.06.2020.

Forkosh-Baruch, A., Hershkovitz, A. (2012). A case study of Israeli higher-education institutes sharing scholarly information with the community via social networks. The Internet and Higher Education, 15 (1), str. 58-68. Dostupno na: https://www.researchgate.net/publication/251645847_A_case_study_of_Israeli_highereducation_institutes_sharing_scholarly_information_with_the_community_via_social_n etworks, pristupljeno: 28.06.2020. 
Foundry (2020). VR? AR? MR? Sorry, I'm confused. F. Insights Hub. Dostupno na: https://www.foundry.com/insights/vr-ar-mr/vr-mr-ar-confused, pristupljeno 19.10.2020.

Friesen, N. (2012). Report: Defining Blended Learning. Dostupno na: https://www.normfriesen.info/papers/Defining_Blended_Learning_NF.pdf, pristupljeno 27.06.2020.

Gagne, B., Briggs, L., Wager, W. (1992). Principles of instructional design, 4th ed. Harcourt Brace Jovanovich, New York.

Galvan, J. L. (2004). Writing Literature Reviews: A Guide for Students of the Social and Behavioral Sciences. Pyrczak, Glendale.

Gao, F., Luo, T., Zhang, K. (2012). Tweeting for learning: a critical analysis of research on microblogging in education published 2008-2011. British Journal of Educational Technology, 43(5), str. 783-801. Dostupno na: https://www.researchgate.net/publication/256911594_Tweeting_for_learning_A_critical _analysis_of_research_on_microblogging_in_education_published_in_2008-2011, pristupljeno: 28.06 .2020 .

Gasser, M. (1988). Building a Secure Computer System.Van Nostrand Reinhold. Dostupno na: https://www.researchgate.net/publication/242363259_Building_a_Secure_Computer_Sy stem, pristupljeno: 23.06.2020.

Gates, B. (1995). The Road Ahead. Viking Press, United States of America.

Glaser, B. G., Holton, J. (2004). Remodeling Grounded Theory. The Grounded Theory, Vol. 4., No. 1.

Glīzds, L. (2017). Computer Security. Rēzekne : Rēzeknes Tehnologiju akadēmija. Dostupno na: $\quad$ http://journals.rta.lv/index.php/HET/article/view/3588/3557, pristupljeno: 23.06.2020.

Goodman, C. M. (1987). The Delphi technique: a critique. Journal of Advanced Nursing, 12, str. 729-734.

Goodyear, P. and Ellis, R. (2008). University students' approaches to learning: rethinking the place of technology. U: Distance Education, 29, 2, str. 141-152. Dostupno na: https://www.tandfonline.com/doi/abs/10.1080/01587910802154947, $\quad$ pristupljeno 14.06.2020. 
Golubić, K., Lasić-Lazić, J., (2012). Analysis of On-line Survey about Need for Presence of Higher Education Institutions on Social Networks: a Step towards Creation of Communication Strategy. Journal of computing and information technology 20 (3), 189194.

Gordon, T. J. (1994). The delphi method. Futures research methodology, 2, str. 1-9.

Gotal, V. (2006). Poslovna inteligencija. Poslovni dnevnik. Dostupno na: https://www.poslovni.hr/lifestyle/poslovna-inteligencija-2-2980, pristupljeno 19.10.2020.

Gouseti, A. (2010). Web 2.0 and education: Not just another case of hype, hope and disappointment? U: Learning, Media and Technology, 35, 3, str. 351-56. Dostupno na: https://www.researchgate.net/publication/233023252_Web_20_and_education_Not_just _another_case_of_hype hope_and_disappointment, pristupljeno 15.06.2020.

Građevinski i arhitektonski fakultet Osijek (2019). Pravilnik o obradi i zaštiti podataka. Sveučilište Josipa Jurja Strossmayera, Osijek. Dostupno na: http://www.gfos.unios.hr/download/pravilnik-o-zastiti-osobnih-podataka-grafos-20192.pdf, pristupljeno: 26.07 .2020 .

Gray, K., Thompson, C., Sheard, J., Clerehan, R., Hamilton, M. (2010). Students as web 2.0 authors: Implications for asessment design and conduct. U: Australasian Journal of Educational Technology, 26, 1, str. 105-22. Dostupno na: https://www.researchgate.net/publication/242556195_Students_as_Web_20_authors_Im plications_for_assessment_design_and_conduct, pristupljeno 15.06.2020.

Gray, R., Vitak, J., Easton, E.W., Ellison, N. (2013). Examining social adjustment to college in the age of social media factors influencing successful transitions and persistence. Computers \& Education, vol. 67, str. 193-207. Dostupno na: https://www.researchgate.net/publication/257171390_Examining_social_adjustment_to college_in_the_age_of_social_media_Factors_influencing_successful_transitions_and_p ersistence, pristupljeno: 28.06.2020.

Greenhow, C., Robelia, B., Hughes, J. E. (2009). Learning, Teaching, and Scholarship in a Digital Age. Web 2.0 and Classroom Research - What Path Should We Take „Now“? Educational Researcher. 38 (4), str. 246-259. Dostupno na: https://www.researchgate.net/publication/234590255_Learning_Teaching_and_Scholars hip_in_a_Digital_Age_Web_20_and_Classroom_Research-What_Path_Should_We_Take_Now, pristupljeno: 27.06.2020.

Greenhow, C., Burton, L. (2011). Help from my "friends:" social capital in the social networksites of low-income high school students. Journal of Educational Computing Research, 45(2), str. 223-245. Dostupno na: https://www.researchgate.net/publication/270412914_Help_from_my_Friends_Social_C apital_in_the_Social_Network_Sites_of_Low-Income_Students, pristupljeno: 
28.06.2020.

Grof, S. (1981). Mind, Nature, and Consciousness: Gregory Bateson and the New Paradigm. Journal of Transpersonal Psychology. 5/2/31:72, Phoenix. Dostupno na: https://web.archive.org/web/20111018103753/http://www.stanislavgrof.com/pdf/Gregor y_Bateson.pdf, pristupljeno: 25.06.2020.

Gronlund, N. E. (1981). Measurement and Evaluation in Teaching (fourth edition). Macmillan Publishing Company, New York.

Grosseck, G. (2009). To use or not to use web 2.0 in higher education? Procedia Social and Behavioral Sciences 1, str. 478.-482. Dostupno na: https://core.ac.uk/download/pdf/81119017.pdf . Pristupljeno: 22.10.2018.

Gummesson, E. (2002). Total Relationship Marketing: Marketing Management, Relationship Strategy and CRM Approaches for the Network Economy. 2nd Edition, ButterworthHeinemann, Oxford.

Gupta, U. G., Clarke, R.E. (1996). Theory and Applications of the Delphi Technique: A Bibliography (1975-1994). Technological Forecasting and Social Change, 53: str. 185211. Elsevier Science Inc., New York.

Gutierrez, O. (1989). Experimental Techniques for Information Requirement Analysis, Information and Management 16, str. 31-43.

Hadjina N. (2009). Zaštita i sigurnost informacijskih sustava. Nastavni materijali sa zbirkom zadataka). Fakultet elektrotehnike i računarstva (FER), Zavod za primijenjeno računarstvo, Sveučilište u Zagrebu.

Haigh, G.V., Schmidt, W. (1956). The learning of subject matter in teacher-centered and groupcentered classes. Journal of Educational Psychology, 47 (5), str. 295-301. Dostupno na: https://psycnet.apa.org/record/1958-01992-001, pristupljeno 28.06.2020.

Halmi, A. (1996). Kvalitativna metodologija u društvenim znanostima. Naklada Slap, Samobor.

Halmi, A., Crnoja, J. (2003). Kvalitativna istraživanja u društvenim znanostima i humanoj ekologiji. Socijalna ekologija, $12(3-4)$, str. 195-210. Dostupno na: https://hrcak.srce.hr/47897, pristupljeno: 03.11.2020.

Hammersley, M. (1992). What's Wrong With Ethnography? Routledge, London. 
Hasson, F., Keeney, S., McKenna, H. (2000). Research guidelines for the Delphi survey technique. Journal of Advanced Nursing, 32(4), str. 1008-1015.

Hayes, A. (2020). Wilcoxon Test. Dostupno https://www.investopedia.com/terms/w/wilcoxontest.asp\#: :text=The\%20Wilcoxon\%20test\%20is\%20a,in\%20a\%20statistically $\% 20$ signif icant\%20manner, pristupljeno: 22.11.2020.

Hawawini, G. (2005). The future of business schools. Journal of Management Development, 24 (1), str. 70-83. Dostupno na: https://www.researchgate.net/publication/235274512 The future of business_schools, pristupljeno 27.06.2020.

Helmer, O. (1967). Analysis of the future: The Delphi method. Rand Corporation. Dostupno na: https://www.rand.org/pubs/papers/P3558.html, pristupljeno: 17.10.2020.

Helsper, E., Eynon, R. (2009). Digital natives: where is the evidence? U: British Educational Research Journal, 36, 3, str. 503-20. Dostupno na: http://eprints.1se.ac.uk/27739/1/Digital_natives_\%28LSERO\%29.pdf, pristupljeno 15.06.2020.

Hicks, A., Graber, A. (2010). Shifting paradigms: Teaching, Learning and Web 2.0. Reference Services Review, 38 (4), str. 621 - 633. Dostupno na: https://www.researchgate.net/publication/221669242_Shifting_paradigms_Teaching_Le arning and_Web_20, pristupljeno: 27.06.2020.

Holbrook Lewis, J. (2014). A Delphi Study Assessing Effective Peer Faculty E-Mentoring to Support Scaling Distance Education Programs, Texas A\&M University. Dostupno na: https://oaktrust.library.tamu.edu/handle/1969.1/152568. Pristupljeno: 14.05.2020.

Holloway, I., Todres, L. (2003). The status of method: flexibility, consistency and coherence. Qualitative Research, 3(3), str. 345-357.

Horvat, A., (2006). Slobodan pristup informacijama. Natsvani materijali za kolegij Informacijska etika. Filozoski fakultet Sveučilišta u Zagrebu. Dostupno na: http://dzs.ffzg.hr/text/horvat_slobodan.htm, pristupljeno 13.12.2016.

Hosein, A., Ramanau, R., Jones, C. (2010). Learning and living technologies: A longitudinal study of first-year students' frequency and competence in the use of ICT. U: Learning, Media and Technology, 35, 4, str. 403-18. Dostupno na: https://www.researchgate.net/publication/48990304_Learning_and_living_technologies_ 
A longitudinal_study_of_first-

year_students'_frequency_and_competence_in_the_use_of_ICT, 15.06.2020.

pristupljeno

Hox, J. J., Boeije, H., R. (2005). Dana Collection, Primary vs. Secondary. Encyclopedia of Social Measurment, Volume 1. Elsevier Inc. Dostupno na: http://dspace.library.uu.nl/handle/1874/23634, pristupljeno: 21.10.2020.

Hrvatska enciklopedija (2020). Automatizacija. Dostupno na: https://enciklopedija.hr/natuknica.aspx?ID=4745, pristupljeno 19.10.2020.

Hrvatska narodna banka (HNB), (2006). Smjernice za upravljanje informacijskim sustavom u cilju smanjenja operativnog rizika. Dostupno na: https://www.hnb.hr/documents/20182/639854/h-smjernice-za-upravljanjeinformacijskim-sustavom.pdf/e5579931-e846-47ab-af23-6809debef700, pristupljeno: 23.06.2020.

Hrvatski sabor (2007). Zakon o informacijskoj sigurnosti. Narodne novine 79/07. Dostupno na: https://www.zakon.hr/z/218/Zakon-o-informacijskoj-sigurnosti, pristupljeno: 23.06.2020.

Hrvatski sabor (2014a). Strategija obrazovanja, znanosti i tehnologije. Dostupno na: https://narodne-novine.nn.hr/clanci/sluzbeni/full/2014_10_124_2364.html, pristupljeno: 10.10.2018.

Hrvatski sabor (2014b). Ustav RH. Narodne novine 56/1990, 135/1997, 8/1998, 113/2000, 124/2000, 28/2001, 41/2001, 55/2001, 76/2010, 85/2010, 5/2014. Zagreb. Dostupno na: https://www.sabor.hr/hr/o-saboru/vazniji-propisi/ustav-republike-hrvatskenarodne-novine-broj-561990-1351997-81998-1132000, pristupljeno: 25.06.2020.

Hrvatski sabor (2015). Zakon o pravu na pristup informacijama. Narodne novine 25/2013, 85/2015), pročišćeni tekst, Zagreb. Dostupno na: https://www.zakon.hr/z/126/Zakon-opravu-na-pristup-informacijama, pristupljeno 25.06.2020.

Hunter, M. (2008). Social Media for Adult Online Learners and Educators. U: Education for a Digital World. Advice, guidelines, and effective practice from around the globe. BCcampus, Vancouver. Dostupno na: https://open.umn.edu/opentextbooks/textbooks/education-for-a-digital-world-adviceguidelines-and-effective-practice-from-around-globe, pristupljeno: 14.06.2020.

Hussain, I. A. (2012). Study to Evaluate the Social Media Trends among University Students. Procedia - Social Behavior Sciences, 64, str. 639-645. Dostupno na: https://www.researchgate.net/publication/257717938_A_Study to_Evaluate the Social_ Media_Trends_among_University_Students, pristupljeno: 28.06.2020. 
Hussein, K. A. (2013). A Framework for implementing Social Computing in Higher Education in Gulf States. Ph.D. Thesis. University of Salford, Manchester, UK. Dostupno na: https://core.ac.uk/download/pdf/18410329.pdf, pristupljeno 12.11.2018.

Ilić, V. (1999). Neuronske mreže. Dostupno na: http://solair.eunet.rs/ ilicv/neuro.html, pristupljeno: 19.10 .2020 .

Instrument Society of America (1969). Advances in Instrumentation. Proceedings of the ISA Conference and Exhibit.

Internet Live Stats (2020). Dostupno na: https://www.internetlivestats.com/, pristupljeno: 09.06.2020.

Izvršni odbor IFLA (1999). Izjava IFLA-e: Knjižnice i intelektualna sloboda. Prevela Barbarić, A. Dostupno na: http://dzs.ffzg.unizg.hr/text/kiis.htm, pristupljeno: 13.12.2016.

Jandrić, P., Livazović, G. (2013). Priručnik iz e-obrazovanja za osobe treće živote dobi. Medicinska škola, Osijek. Dostupno na: http://bib.irb.hr/datoteka/864942.Prirucnik_P_Jandric_i_G_Livazovic.pdf, pristupljeno: 14.06 .2020 .

Jasno\&Glasno tim (2013). 6 stvari koje radi community manager. Dostupno na: https://www.jasnoiglasno.com/6-stvari-koje-radi-community-manager-2120/.

Pristupljeno: 01.10.2020.

Jeđud, I. (2007). Alisa u zemlji čuda - kvalitativna metodologija i metoda utemeljene teorije. Hrvatska revija za rehabilitacijska istraživanja, Vol. 43, br. 2, str. 83-101. Dostupno na: https://hrcak.srce.hr/26371, pristupljeno: 21.10.2020.

Johnson, B. (2007). 39 College \& University Presidents Who Blog. Dostupno na: http://bobjohnsonconsulting.com/blog 1/2007/07/15_presidents_who_blog_saint_v.html, pristupljeno: 06.08.2008.

Johnson, L., Adams Becker, S., Cummins, M., Estrada, V., Freeman, A., Hall, C. (2016). NMC Horizon Report: 2016 Higher Education Edition. Dostupno na: https://www.sconul.ac.uk/sites/default/files/documents/2016-nmc-horizon-report-he-EN1.pdf, pristupljeno: 03.07.2020.

Jokić, M. (2017). Haptička tehnologija. See busines, travel and meetings. Dostupno na: https://www.seebtm.com/hapticka-tehnologija/, pristupljeno: 19.10.2020.

Jokić-Begić, N. (2020). Nedjeljom u 2: Nataša Jokić-Begić. HRT Vijesti. Dostupno na: 
https://vijesti.hrt.hr/626635/nedjeljom-u-2-natasa-jokic-begic, pristupljeno: 26.06.2020.

Jones, L. (2007). The Student-centered Classroom. Cambridge University Press, Cambridge.

Jones, S., Fox, S. (2009). Generations online in 2009. Washington, DC, Pew Internet and American Life Project, 2009. Dostupno na: https://www.pewresearch.org/internet/2009/01/28/generations-online-in-2009/, pristupljeno 15.06.2020.

Jones, S., Johnson-Yale, C., Millermaier, S., Seoane Perez, F. (2009). U.S. College Students' Internet Use: Race, Gender and Digital Divides. U: Journal of Computer-Mediated Communication, 14, str. 244-64. Dostupno na: https://onlinelibrary.wiley.com/doi/full/10.1111/j.1083-6101.2009.01439.x, pristupljeno 15.06.2020.

Jordan, L. (2012). Video for feedback and reflection: embedding mainstream engagement into learning and teaching practice. Research in learning technology, 20 (4), str. 221-245. Dostupno na: https://www.researchgate.net/publication/269425670_Video_for_peer_feedback_and_ref lection_Embedding_mainstream_engagement_into_learning_and_teaching_practice, pristupljeno: 27.06.2020.

Josefsson, P. (2017). Higher education meets private use of social media technologies. Doctoral, KTH Royal Institute of Technology.

Ju, B., Jin, T. (2013). Incorporating nonparametric statistics into Delphi studies in library and information science. Information research, Vol. 18., No. 3. Dostupno na: https://files.eric.ed.gov/fulltext/EJ1044687.pdf, pristupljeno: 15.11.2020.

Junco, R. (2012). The relationship between frequency of Facebook use, participation in Facebook activities, and student engagement. Computers \& Education 58, str. 162-171. . Dostupno na: https://www.researchgate.net/publication/220030167_The_relationship_between_freque ncy_of_Facebook_use_participation_in_Facebook_activities_and_student_engagement, pristupljeno 28.06.2020.

Junco, R. (2015). Student class standing, Facebook use, and academic performance. Journal of Applied Development Psychology 36, str. 18-29. Dostupno na: https://www.researchgate.net/publication/271021551_Student_class_standing_Facebook _use_and_academic_performance, pristupljeno 28.06.2020.

Juniper Research. (2007). Social Networking Sites: Defining Advertising Opportunities in a Competitive Landscape. Dostupno na: https://www.jupiterresearch.com/bin/item.pl/research:vision/1231/id=98881/, 
pristupljeno: 07.08.2008.

Kabilan, M., Ahmad, N., Abidin, M. (2010). Facebook: An online environment for learning of English in institutions of higher education. The Internet and Higher Education, 13 (4), 179-187. Dostupno na: https://www.researchgate.net/publication/222250561_Facebook_An_online_environmen t_for_learning_of_English_in_institutions_of_higher_education, pristupljeno 28.06.2020.

Kanižaj, I., Ciboci, L. (2011). Kako je nasilje preko medija ušlo u naše domove, u: Ciboci, L., Kanižaj, I., Labaš, D., Djeca medija - Od marginalizacije do senzacije, Matica hrvatska, Zagreb. Str. 11-34

Kaplan, A. M., Haenlein, M. (2010). Users of the world, unite! The challenges and opportunities of social media. Business Horizons, 53, 1, str. 59-68.

Keen, A. (2007). The cult of the amateur. Nicholas Brealey, London.

Kemp, S. (2020). Digital 2020: Croatia. Datareportal. Dostupno na: https://datareportal.com/reports/digital-2020-croatia, pristupljeno: 09.06.2020.

Kennedy, H. P. (2003). Enhancing Delphi research: methods and results. Journal of Advanced Nursing, 45(5), 504-511. doi: 10.1046/j.1365-2648.2003.02933.x

Kent, M. L. (2015). Social Media Circa 2015: Directions in Social Media Theory. Atlantic Journal of Communication, 23:1-4, DOI:10.1080/15456870.2015.972407.

Kerlinger, F. (1986). Foundations of behavioral research. Holt, Rinehart \& Winston, New York.

Kibber, R.J., Baker. L.L., Miles, D.R. (1970). Behavioral Objectives and Instruction. Allyn and Bacon, Boston.

Kietzmann, J. H., Hermkens, K., McCarthy, I.P. \& Silvestre, B.S. (2011) Social media? Get serious! Understanding the functional building blocks of social media. Business Horizons, 54,3 , str. 241-251.

Kirschner, P. A., Karpinski, A. C. (2010). Facebook and academic performance. Computers in Human Behavior, 26 (6), str. 1237-1245. Dostupno na: https://www.sciencedirect.com/science/article/pii/S0747563210000646, pristupljeno 28.06.2020.

Kleiner, B., Thomas, N., Lewis, L. (2007). Educational technology in teacher education 
programs for initial licensure (NCES 2008-040). National Center for Education Statistics, Institute of Education Sciences, U.S. Department of Education, Washington, DC.

Knešaurek, I., Matanović Vučković, R., Petrović, V., Sučić, T. (2015). Upravljanje intelektualnim vlasništvom na sveučilištu. Centar za istraživanje, razvoj i transfer tehnologije. Projekt „BISTEC - Building innovation suppoert through efficient cooperation network", Sveučilište u Zagrebu, Zagreb. Dostupno na: http://cirtt.unizg.hr/ea/wp-content/uploads/2014/06/Upravljanje-intelektualnimvlasnistvom_web.pdf, pristupljeno: 26.07.2020.

Kolar, M. (2013). Kako su mediji mijenjali svijet (Asa Brigs, Peter Burke: "Socijalna povijest medija", Zagreb, Pelago, 2011.). In medias res : časopis filozofije medija, 2(2), 2013. Str. 244-247. Dostupno na: https://hrcak.srce.hr/1144599, pristupljeno 12.08.2016.

Kolšek, M. (2017). Lead generation i njegov značaj za vašu tvrtku. Shopper's Mind. Accelerating Ecomerce. Dostupno na: https://smind.hr/lead-generation-i-njegov-znacajza-vasu-tvrtku/, pristupljeno: 29.06.2020.

Kučina Softić, S., Jandrić, I., Rako, S. (2016). Rezultati ankete o potrebama nastavnika za obrazovnim aktivnostima iz područja, Zagreb.

Kuhn, T. S. (1962). The structure of scientific revolutions. University of Chicago Press, Chicago.

Kunczik, M., Zipfel, A. (2006). Uvod u znanost o medijima i komunikologiju. Zagreb: Zaklada Friedrich Ebert.

Labaš, D. (2011). Djeca u svijetu interneta - zatočenici virtualnog svijeta; Pedagoški modeli i otvorena pitanja, u: Ciboci, L., Kanižaj, I., Labaš, D., Djeca medija - Od marginalizacije do senzacije, Matica Hrvatska, Zagreb. Str. 35-64.

Laerd Statistics (2020). Wilcoxon Signed-Rank Test using SPSS Statistics. Dostupno na: https://statistics.laerd.com/spss-tutorials/wilcoxon-signed-rank-test-using-spssstatistics.php, pristupljeno: 02.11.2020.

Laing, R. D., (1967). The politics of experience. Pantheon, New York.

Landeta, J. (2006). Current validity of the Delphi method in social sciences. Technological Forecasting and Social Change, 73, str. 467-482.

Lanner (2019). Top Mixed Reality Applications Today. Dostupno na: https://www.lanner- 
america.com/blog/top-mixed-reality-applications-today/, pristupljeno: 19.10.2020.

LaRue, E. (2012). Using Facebook as course management software: A case study. Teaching and Learning in Nursing, 7 (1), str. 17-22. Dostupno na: https://www.researchgate.net/publication/251690326_Using_Facebook_as_course_mana gement_software_A_case_studye, pristupljeno 28.06.2020.

Lee, M., McLoughlin, C. (2010). Web 2.0-based E-learning: Applying Social Informatics for Tertiary Teaching. Hershey, New York.

Lee, R. B., Baring, R., Sta Maria, M., Reysen, S. (2017). Attitude towards technology, social media usage and grade-point average as predictors of global citizenship identification in Filipino University Students. International Journal of Psychology, 52 (3), str. 213-219. Dostupno na: https://onlinelibrary.wiley.com/doi/abs/10.1002/ijop.12200, pristupljeno 28.06.2020.

Lévy, P. (2001). Cyberculture. University of Minnesota Press, Minneapolis, London.

Lewthwaite, S. (2011). Student experiences of social networking and disability in higher education. PhD thesis, University of Nottingham, 2011.

Lewis, L. (2020). Infographic: What Happens In An Internet Minute 2020. AllAccess. Dostupno na: https://www.allaccess.com/merge/archive/31294/infographic-whathappens-in-an-internet-minute, pristupljeno: 09.06.2020.

Lewis, S., Pea, R., Rosen, J. (2010). Collaboration with Mobile Media-Shifting from 'Participation' to 'Co-Creation'. VMUTE, vol.1, str. 112-116. Dostupno na: https://www.computer.org/csdl/proceedingsarticle/wmute/2010/3992a112/12OmNyyO8HR, pristupljeno: 28.06.2020.

Li, C. and J. Bernoff (2008). Groundswell: winning in a world transformed by social technologies. Boston, Harvard Business School Publishing.

Littlefield, J. (2020). Razlika između sinkronog i asinkronog učenja na daljinu. EFerrit. Dostupno na: https://hr.eferrit.com/razlika-izmedju-sinkronog-i-asinkronog-ucenja-nadaljinu/, pristupljeno: 26.06.2020.

Linstone, H. A., Turoff, M. (1975). The Delphi method: Techniques and applications. Reading, Addison-Weshley Educational Publishers Inc., Massachusetts. 
Linstone, H., Turoff, M. (2011). Delphi: A brief look backward and forward. Technological Forecasting and Social Change, 78 (9), str. 1712-1719.

Logično (2020). Samsung otkrio neke informacije o tome kada bismo mogli vidjeti 6G tehnologiju; otkrivene stvari zvuče kao nešto iz znanstveno-fantastičnih filmova. Saša F. Dostupno na: https://www.logicno.com/zivotni-stil/samsung-otkrio-neke-informacije-otome-kada-bismo-mogli-vidjeti-6g-tehnologiju-otkrivene-stvari-zvuce-kao-na-nesto-izznanstveno-fantasticnih-filmova.html, pristupljeno: 19.10.2020.

Love, H. (2003). Early modern print culture. Assessing the models. U: The Book History Reader, ur. Finkelstein, McCleery, D. Routledge, London - New York, str. 47.-65.

Lovrenčić, S., Plantak Vukovac, D., Šlibar, B., Nahod, B., Andročec, D., Šestak, M., Stapić, Z. Igrifikacija: prema sistematizaciji termina na hrvatskom jeziku. Računalne igre 2018. Sveučilište u Zagrebu, Fakultet organizacije i informatike Varaždin, Institut za hrvatski jezik i jezikoslovlje, Zagreb. Dostupno na: https://bib.irb.hr/datoteka/956596.racunalneigre-2018-zbornik-igrifikacija.pdf . Pristupljeno: 01.10.2020.

Ludwig, L., Starr, S. (2005). Library as place: results of a Delphi study. Journal of Medical Library Association, 93 (3), str. 315-326.

Mabić, M. (2014). Društvene mreže u obrazovanju: Što misle studenti Sveučilišta u Mostaru. Društvo i tehnologija 2014 - Dr. Juraj Plenković, XXI. Međunarodni znanstveni skup, Opatija, str. 374-378. Dostupno na: https://www.researchgate.net/publication/268208102_Drustvene_mreze_u_obrazovanju_ Sto_misle_studenti_Sveucilista_u_Mostaru, pristupljeno: 29.10.2018.

Madge, C., Meek, J., Wellens, J., Hooley, T. (2009). Facebook, social integration and informal learning at university: It is more for socializing and talking to friends about work than for actually doing work. Learning, Media and Technology, vol. 34 (2), str. 141-155. Dostupno na: https://www.tandfonline.com/doi/full/10.1080/17439880902923606, pristupljeno: 28.06.2020.

Madhusudhan, M. (2012). Use of social networking sites by research scholars of the University of Delhi: A study. The International Information \& Library Review, 44 (2), str. 100-113. Dostupno na: https://www.researchgate.net/publication/257473871_Use_of_social_networking_sites_b y_research_scholars_of the University_of_Delhi_A_study, pristupljeno: 28.06.2020.

Maqableh, M., Rajab, L., Quteshat, W., Masa'deh, M. T. R., Khatib, T., Karajeh, H. (2015). The Impact of Social Media Networks Websites Usage on Students' Academic Performance. Communications and Network, 7 (4), str. 159-171. Dostupno na: https://www.researchgate.net/publication/282186221_The_Impact_of_Social_Media_Ne tworks_Websites_Usage_on_Students'_Academic_Performance, pristupljeno 
28.06.2020.

Malekoff, A. ( 1997). Group work with adolescents: Principles and Practice. Guilford Press, New York.

Malita, L. (2010). Social media time management tools and tips. Procedia Computer Science, Vol. 3, str. 747-753. Dostupno na: https://www.sciencedirect.com/science/article/pii/S1877050910004989, pristupljeno 06.06.2020.

Malović, S. (2005). Osnove novinarstva. Golden marketing-Tehnička knjiga, Zagreb.

Malović, S., Maletić, S., Vilović, G., Kurtić, N. (2014). Masovno komuniciranje. Golden marketing-Tehnička knjiga, Sveučilište Sjever, Zagreb.

Manasijević, D., Živković, D., Arsić, S., Milošević, I. (2016). Exploring students’ purposes of usage and educational usage of Facebook. Computers in Human Behavior, vol. 60, str. 441-450. Dostupno na: https://www.sciencedirect.com/science/article/pii/S0747563216301510, $\quad$ pristupljeno: 28.06.2020.

Mangold, W. G., Faulds, D. J. (2009). Social media: the new hybrid element of the promotion mix. Business Horizons, Vol. 52 No. 4, str. 357-365. Dostupno na: https://www.sciencedirect.com/science/article/pii/S0007681309000329, pristupljeno 06.06.2020.

Marczewski, A. (2012). Gamification for your company. Capgemini Worldw.

Martinić, T. (1985). Lasswellova paradigma masovnog komuniciranja. Politička misao: časopis za politologiju, 22 (1-2), 1985. Str. 130-137. Dostupno na: https://hrcak.srce.hr/114136, pristupljeno 10.08.2016.

Mason, J. (1996). Qualitative researching. Sage Publications Ltd., London.

Matešić, M., Vučković, K., Dovedan, Z. (2010). Care About Online Reputation Management and Monitoring? Stančić, H., Seljan, S.,Bawden, D., Lasić-Lazić, J., Slavić, A. (ur.), (2009). The Future of Information Sciences: Digital Resources and Knowledge Sharing. Zagreb. Department of Information Sciences, Faculty of Humanities and Social Sciences, University of Zagreb, str. 433-442.

Matijević, M. (2002): Mediji u odgoju i obrazovanju. U: Bognar; L., Matijević, M. (ur.): Didaktika. Školska knjiga, Zagreb, str. 324-353. 
Matković, T. (2000). Manuel Castells; The Information Age: conomy, Society and Culture, vol 1: The Rise of the Network Society. Diskrepancija, sv.1, broj 1, str. 65-68. Dostupno na: https://hrcak.srce.hr/file/32361, pristupljeno 24.06.2020.

Mazer, J. P., Murphy, R. E., Simonds, C. J. (2007). I'll see you on 'Facebook': The effects of computer-mediated teacher self-disclosure on student motivation, affective learning, and classroom climate. Communication Education,vol. 56 (1), str. 1-17. Dostupno na: https://www.tandfonline.com/doi/abs/10.1080/03634520601009710, pristupljeno 28.06.2020.

Maxwell, J. A. (1992). Understanding and validity in qualitative research. Harvard Education Review, 62 (3), str. 279-300

Mayer, A., Puller, S. (2008). The Old Boy (and Girl) Network: Social Network Formation on University Campuses. U: Journal of Public Economics, 92, 1-2, str. 329-47. Dostupno na: http://conference.iza.org/conference_files/TAM2007/mayer_a3365.pdf, pristupljeno 15.06.2020.

Merriam, S. B. (2009). Qualitative research: A guide to design and implementation (3rd ed.). Jossey-Bass, San Francisco.

Merriam-Webster Dictionary (2017). Communication. Dostupno na: https://www.merriamwebster.com/dictionary/communication, pristupljeno: 10.10.2017.

McConnell, M. (2019). The Interactive Virtual Avatar. Virtway Events. Dostupno na: https://www.virtwayevents.com/virtual-avatar/, pristupljeno: 19.10.2020.

McLuhan, M. (1962). The Gutenberg Galaxy: The Making of Typographic Man. University of Toronto Press.

McLuhan, M., Powers, B. R. (1989). The Global Village: Transformations in World Life and Media in the 21st Century (Communication and Society). Oxford University Press.

McLuhan, M. (2008). Razumijevanje medija: mediji kao čovjekovi produžeci. Golden marketing - Tehnička knjiga, Zagreb.

McQuail, D. (2010). Mass Coomunication Theory: An Introduction. Sage, Los Angeles, London, New Delhi, Singapore, Washington DC, 6th edition.

Mernit, S. (2006). FAQ: What is Web 2.0? Dostupno na: https://susanmernit.com/2006/04/faq_what_is_web_20/, pristupljeno: 27.06.2020. 
Mesarić, M. (2005). Informatička revolucija i njezin utjecaj na stvaranje informatičke, mrežne, globalne ekonomije - analiza Manuela Castellsa. U: Ekonomski pregled, 58 (5-6). Str. 389-422.

Michikyan, M.; Subrahmanyam, K.; Dennis, J. (2015). Facebook use and academic performance among college students - A mixed-methods study with a multi-ethnic sample. Computers in Human Behavior 45, str. 265-272. Dostupno na: https://www.researchgate.net/publication/270455171_Facebook_use_and_academic_perf ormance_among_college_students_A_mixed-methods_study_with_a_multiethnic_sample, pristupljeno 28.06.2020.

Middleman, R. R., Goldberg Wood, G. (1990). Skills for direct practice in social work. Columbia University Press, New York.

Miles, I., Harper, J. C., Georghiou, L., Keenan, M. , Popper, R. (2008). The Many Faces of Foresight. The Handbook of Technology Foresight: Concepts and Practice, Edward Elgar, str. 3.-23.

Miliša, Z. (2006). Manipuliranje potrebama mladih, MarkoM, Zagreb.

Miliša, Z., Tolić, M., Vertovšek, N. (2009). Mediji i mladi - Prevencija ovisnosti o medijskoj manipulaciji, Sveučilišna knjižara, Zagreb.

Ministarstvo znanosti i obrazovanja (2014-2020). Hrvatski kvalifikacijski okvir (HKO). Dostupno na: http://www.kvalifikacije.hr/hr, pristupljeno: 14.06.2020.

Ministarstvo znanosti, obrazovanja i sporta (2012). Smjernice za strategiju odgoja obrazovanja, znanosti i tehnologije, Dostupno na: http://novebojeznanja.hr/UserDocsImages/Dokumenti\%20i\%20publikacije/Dokumenti\% 20i\%20publikacije\%20referirani\%20u\%20SOZTu\%20(popis\%201)/013\%20149\%20Smjernice\%20za\%20Strategiju\%20obrazovanja,\%20 znanosti\%20i\%20tehnologije.pdf, pristupljeno: 31.05.2020.

Mitchell, T. (1997). Machine Learning, McGraw Hill.

Mitroff, I., Turoff, M. (2002). Philosophical and Methodological Foundations of Delphi. U: H. A. Linstone i M. Turoff (Ur.) The Delphi Method: Techniques and applications. Addison-Wesley, Advanced Book Program, California State Library, str. 17-34. Dostupno na: https://web.njit.edu/ turoff/pubs/delphibook/, pristupljeno: 17.10.2020.

Mohamad, R. (2011). The Effectiveness of Social Networking Applications in E-Learning. Education Management, Education Theory and Education Application. U: AINSC, vol. 
109, str. 79-85. Dostupno na: https://link.springer.com/chapter/10.1007/978-3-64224772-9_12, pristupljeno: 28.06.2020.

Moj Posao (2011). Networking - koristan alat u potrazi za poslom. Dostupno na: https://www.moj-posao.net/Savjet/69703/Networking-koristan-alat-u-potrazi-zaposlom/4/. Pristupljeno: 01.10.2020.

Moore, M. (1997). Theory of transactional distance. U Keegan, D., ed. Theoretical Principles of Distance Education, Routledge, pp. 22-38. Dostupno na: https://www.researchgate.net/publication/262488021_The_Theory_of_Transactional_Di stance, pristupljeno: 13.06.2020.

Moskaliuk, J. Kimmerle, J., Cress, U. (2009). Wiki-supported learning and knowledge building. U: Journal of Computer Assisted Learning, 25, 6, str. 549-61. Dostupno na: https://www.academia.edu/15734520/Wikisupported_learning_and_knowledge_building_effects_of_incongruity_between_knowled ge and_information, pristupljeno 14.06.2020.

Mreža za izgradnju mira (2020). Znate li štro je networking. Dostupno na: https://www.mrezamira.net/vijesti/razno/znate-li-sta-je-networking//. Pristupljeno: 01.10.2020.

Mrežnik (2020). Pojmovnik. Dostupno na: http://ihjj.hr/mreznik/page/pojmovnik/6/ . Pristupljeno: 01.10.2020.

Mungofa, M. F., Peter, T. (2015). Social Media in Tertiary Education-Vhembe Further Education Training College Case Study. The IAFOR Journal of Education. Technologies \& Education Special Edition. Dostupno na: https://files.eric.ed.gov/fulltext/EJ1100619.pdf, pristupljeno: 28.06.2020.

Munoz, C., Towner, T. (2009). Opening Facebook: How to Use Facebook in the College Classroom. SITE Proceedings. Association for the Advancement of Computing in Education (AACE), Waynesville. Dostupno na: https://www.learntechlib.org/primary/p/31031/, pristupljeno: 28.06.2020.

Muslić, Lj. (2020). Korona virus kao prijetnja mentalnom zdravlju. U: Koronavirus i mentalno zdravlje; Psihološki aspekti, savjeti i preporuke. Hrvatska psihološka komora, str. 4-7. Dostupno na: http://psiholoska-komora.hr/static/documents/HPKKoronavirus_i_mentalno_zdravlje.pdf, pristupljeno: 26.06.2020.

Mutula, S M. (2013). Ethical Dimension of the Information Society: implications for Africa. $\mathrm{U}$ : Information Ethics in Africa: Cross-Cutting Themes, Pretoria. Dostupno na: https://www.researchgate.net/publication/317613403_Ethical_Dimension_of_Informatio n_Society, pristupljeno 27.06.2020. 
Mužić, V. (1976). Programirane osnove pedagoške statistike. Školska knjiga, 2. izdanje, Zagreb.

Nacionalni repozitorij završnih i diplomskih radova ZIR (2015). Što je znanstvena čestitost? Nacionalna si sveučilišna knjižnica u Zagrebu. Dostupno na: https://zir.nsk.hr/node/19, pristupljeno: 03.07.2020.

Ngai, E. W. T., Moon, K. K., Lam, S. S., Chin, E. S. K., Tao, S. S. C. Social media models, technologis, and applications. An academic review and case study, Emerald Insight, 2015. Dostupno na: https://www.emerald.com/insight/content/doi/10.1108/IMDS-03-20150075/full/html, pristupljeno: 11.01.2017.

Network Working Group (1995). Netiquette Guidelines. Intel Corp., S. Hambridge. Dostupno na: https://tools.ietf.org/html/rfc1855, pristupljeno: 03.07.2020.

Neuman, D. (1995). High school students' use of databases: results of a national Delphi study. Journal of the American Society for Information Science, 46 (4), str. 284-298.

Nevins, T. (2004). The Effects of Media Violence on Adolescent Health; A research report written for Physicians for Global Survival.

Newberry, Ch. (2018). 23 Benefits of Socila Media for Business. Hootsuite. Dostupno na: https://blog.hootsuite.com/social-media-for-business/, pristupljeno: 29.06.2020.

Newcomb, A. (2018) Facebook data harvesting scandal widens to 87 million people. NBC News. Dostupno na: https://www.nbcnews.com/tech/tech-news/facebook-dataharvesting-scandal-widens-87-million-people-n862771, pristupljeno 25.06.2020.

New Zealand Teaching Council (2013). What is Social Media. Dostupno na: http://www.teachersandsocialmedia.co.nz/sites/default/files/resources/social-media-mapand-characteristics-poster_0.pdf, pristupljeno: 16.08.2016.

Novaković, B. (2018). Robotika. Portal hrvatske tehničke baštine, Leksikografski zavod Miroslav Krleža. Dostupno na: https://tehnika.lzmk.hr/robotika/, pristupljeno: 19.10.2020.

Novi svijet (2015). Panta rhei - „Samo mijena stalna jest،“ Klub RDD. Dostupno na: https://www.rukedoreduhovne.org/panta-rhei-samo-mjena-stalna-jest/, $\quad$ pristupljeno: 21.06.2020.

Okello-Obura, C., Ssekitto, F. (2015). Web 2.0 tecnologies application in teaching and learning 
by Makerere University academic staff. Library Philosophy and Practice (e-journal). University of Nebraska, Lincoln. Dostupno na: https://www.researchgate.net/publication/280889283_WEB_20_TECHNOLOGIES_AP PLICATION_IN_TEACHING_AND_LEARNING_BY_MAKERERE_UNIVERSITY ACADEMIC_STAFF, pristupljeno 27.06.2020.

Okoli, C., Pawlowski, S. (2004). The Delphi method as a research tool: an example, design considerations and applications. Information and Management, 42 (1), str. 15-29.

Ong, J. (2020). The Power of Social Media. Hustrl. Dostupno na: https://www.hustlr.com/power-of-social-media/, pristupljeno: 09.06.2020.

Opća skupština Ujedinjenih naroda (1948). Odluka o objavi Opće deklaracije o ljudskim pravima. Rezolucija 217 A (III), Narodne novine 28/96. Dostupno na: http://narodnenovine.nn.hr/clanci/medunarodni/2009_11_12_143.html, pristupljeno: 13.12.2016.

O'Reilly, T. (2005). What is Web 2.0. Design Patterns and Business Models for the Next Generation of Software. O'Reilly Network. Dostupno na: https://www.oreilly.com/pub/a/web2/archive/what-is-web-20.html, pristupljeno: 27.06.2020.

Paine, J. (2020). 10 real Use Cases for Augmented Reality. Inc. Dostupno na: https://www.inc.com/james-paine/10-real-use-cases-for-augmented-reality.html, pristupljeno: 19.10.2020.

Paliktzoglou, V., Suhonen, J. (2014). Facebook as an assisted learning tool in problem-based learning: the Bahrain case. International Journal of Social Media and Interactive Learning Environments, 2(1), str. 85-100. Dostupno na: https://www.researchgate.net/publication/260563540_Facebook_as_an_assisted_learning _tool_in_problem-based_learning_The_Bahrain_case, pristupljeno: 28.06.2020.

Pallant, J. (2011). SPSS survival manual: A step by step guide to data analysis using SPSS. Open University Press. Dostupno na: http://www.fao.org/tempref/AG/Reserved/PPLPF/ftpOUT/Gianluca/stats/SPSS.Survival. Manual.ISBN.0-335-20890-8.pdf , pristupljeno: 15.11.2020.

Pandit, N. R. (1996). The Creation of Theory: A Recent Application of the Grounded Theory Method. The Qualitative Report, Vol. 2, Number 4. Dostupno na: https://core.ac.uk/download/pdf/51087317.pdf , pristupljeno: 21.10.2020.

Panian, Ž., Klepac, G. (2003). Poslovna inteligencija,/Business Intelligence, Masmedia, Zagreb. 
Papić, A., Jakopec, T., Mičunović, M. (2011). Informacijske revolucije i širenje komunikacijskih kanala: osvrt na divergenciju i/ili konvergenciju medija. Libellarium, IV, 1, Odjel za informacijske znanosti, Sveučilište u Zadru, Zadar. Str. 83-94. Dostupno na: https://hrcak.srce.hr/92395, pristupljeno: 29.10.2018.

Pasek, J., More, E., Hargittai, E. (2009). Facebook and Academic Performance: Reconciling a Media Sensation with Data. First Monday, vol. 14 (5). Dostupno na: https://journals.uic.edu/ojs/index.php/fm/article/view/2498/2181, 28.06.2020.

Paul, J., Baker, H., Cochran, J. (2012). Effect of online social networking on student academic performance. Computers in Human Behavior, 28 (6), str. 2117-2127. Dostupno na: https://www.researchgate.net/publication/257252604_Effect_of_Online_Social_Network ing_on_Student_Academic_Performance, pristupljeno 28.06.2020.

PCMag Encyclopedia (2020). Computer security. Ziff Davis. Dostupno na: https://www.pcmag.com/encyclopedia/term/computer-security, pristupljeno: 24.06.2020.

Petz, B., Kolesarić, V., Ivanec, D. (2012). Petzova statistika. Osnovne statističke metode za nematematičare. Naklada Slap, Jastrebarsko.

Pfeiffer, J. (1968). New look at education. Odyssey Press, Poughkeepsie, New York.

Pimmer, C., Linxen, S., Grohbiel, U. (2012). Facebook as a learning tool? A case study on the Appropriation of social network sites from mobile phones in developing countries. British Journal of Educational Technology, 43(5), str. 726-738. Dostupno na: https://www.researchgate.net/publication/235719233_Facebook_as_a_learning_tool_A case_study_on_the appropriation_of_social_network_sites_from_mobile_phone_in_dev eloping_countries, pristupljeno: 28.06.2020.

Poliklinika za zaštitu djece i mladih Grada Zagreba, Nasilje preko interneta - cyberbullying, 2010. Dostupno na: https://www.poliklinika-djeca.hr/publikacije/nasilje-preko-interneta/, pristupljeno: 03.06.2020.

Poliska, C. (2016). The power of social media. Pedowitz Group. Dostupno na: https://www.pedowitzgroup.com/the-power-of-socialmedia/\#: :text=The \%20true\%20power\%20of\%20social,helps\%20them $\% 20$ make $\% 20 \mathrm{a} \%$ 20decision., pristupljeno: 09.06.2020.

Pollard, C., Pollard, R. (2004). Research Priorities in Educational Technology: A Delphi Study. Journal of Research on Technology in Education, 37:2, str. 145-160, DOI: 10.1080/15391523.2004.10782430. 
Potočnik, D. (2014). Studenti u umreženom društvu. Ilišin, V. (ur.) Sociološki portret hrvatskih studenata. Zagreb, Institut za društvena istraživanja u Zagrebu, 377-398.

Potter, W. J. (1999). On media violence; Thousand Oaks, SAGE Publications, London, New Delhi.

Povjerenik za informiranje (2017). O pravu na pristup informacijama. Dostupno na: http://www.pristupinfo.hr/sto-je-pravo-na-pristup-informacijama/, $\quad$ pristupljeno: 03.04.2017.

Povjerenik za informiranje (2020a). Otvoreni podaci Povjerenika za informiranje. Dostupno na: https://www.pristupinfo.hr/djelokrug/otvoreni-podaci-povjerenika-za-informiranje/, pristupljeno: 25.06 .2020 .

Povjerenik za informiranje (2020b). Tijela javne vlasti u Republici Hrvatskoj. Dostupno na: http://tjv.pristupinfo.hr./?sort=1\&page=4, pristupljeno: 25.06 .2020 .

Puljić, D. (2019). Transakcijska udaljenost. Prezi. Dostupno na: https://prezi.com/p/lbrcdlb_aujj/transakcijska-udaljenost/, pristupljeno: 13.06.2020.

Punto marinero (2019). Mainstream je što? Suština fenomena i značenje riječi. Dostupno na: https://hr.puntomarinero.com/mainstream-is-what-the-essence/. Pristupljeno: 01.10.2020.

Radovan, M. (2014). Informacijska tehnologija i društvo. Društveno umrežavanje i slobodni softver. Dostupno na: http://www.inf.uniri.hr/ mradovan/skripte.html, pristupljeno: 24.05.2020.

Ranieri, M., Manca, S., Fini, A. (2012). Why (and how) do teachers engage in social networks? An exploratory study of professional use of Facebook and its implications for lifelong learning. British Journal of Educational Technology, 43 (5), str. 754-769. Dostupno na: https://www.researchgate.net/publication/230856009_Why_and_how_do_teachers_enga ge_in_social_networks_An_exploratory_study_of_professional_use_of_Facebook_and_i ts_implications_for_lifelong_learning, pristupljeno: 28.06.2020.

Ras, E., Rech, J. (2009). Using Wikis to support the Net Generation in improving knowledge acquisition in capstone projects. The Journal of Systems and Software , 82 (4), str. 553.

Raut, V., Patil, P. (2016). Use of Social Media in Education: Positive and Negative impact on the students. International Journal on Recent and Innovation Trends in Computing and Communication, Volume: 4 Issue: 1, 281 - 285. Dostupno na: https://ijritcc.org/download/conferences/ICRRTET_2016/ICRRTET_Track/1455261816 _12-02-2016.pdf, pristupljeno: 22.10.2018. 
Ray, P., Sahu, S. (1990). Productivity Management in India: A Delphi Study, International Journal of Operations and Production Management 10, str. 25-51.

Regan, K. (2015). Amazing Social Media Growth Stats From 2015. Social MediaToday. Dostupno na: https://www.socialmediatoday.com/social-networks/kadie-regan/2015-0810/10-amazing-social-media-growth-stats-2015/, pristupljeno: 09.06.2020.

Reuben, R. (2008). The Use of Social Media in Higher Education for Marketing and Communications: A Guide for Professionals in Higher Education. Dostupno na: https://rachelreuben.com/2008/08/19/social-media-uses-higher-education-marketingcommunication/, pristupljeno: 07.06.2020.

Rice, A. (2011). Students Push Their Facebook Use Further into Course Work. The Chronicle of Hgher Education.

Rice, M. (2020). 17 dana Science Applications \& Examples. BuiltIn. Dostupno na: https://builtin.com/data-science/data-science-applications-examples, pristupljeno: 19.10.2020.

Roblyer, M. D., McDaniel, M., Webb, M., Herman, J., Witty, J. V. (2010). Findings on Facebook in higher education: A comparison of college faculty and student uses and perceptions of social network sites. Intenet and Higher Education, 13, 134-140, Elsevier Inc.

Romm, T. (2019). U.S. government issues stunning rebuke, historic $\$ 5$ billion fine against Facebook for repeated privacy violations. The Washington Post, Tech Policy. Dostupno na: $\quad$ https://www.washingtonpost.com/technology/2019/07/24/us-government-issuesstunning-rebuke-historic-billion-fine-against-facebook-repeated-privacy-violations/, pristupljeno 25.06.2020.

Rosen, L., Carrier, M. L., Cheever, N. (2013). Facebook and texting made me do it: Mediainduced task-switchingwhile studying. Computers in Human Behavior, 29 (3), str. 948 958. Dostupno na: https://www.researchgate.net/publication/235991109_Author's_personal_copy_Faceboo k_and_texting_made_me_do_it_Media-induced_task-switching_while_studying, pristupljeno 28.06.2020.

Rosmala, F., Rosmala, D. (2012). Study of Social Networking usage in Higher Education Environment. Procedia - Social Behavioral Sciences 67, str. 156-166. Dostupno na: https://www.researchgate.net/publication/257718008_Study_of_Social_Networking_Usa ge_in_Higher_Education_Environment, pristupljeno 28.06.2020.

Rouse, M. (2015). Social engineering. TechTarget. Dostupno na: https://searchsecurity.techtarget.com/definition/social-engineering, pristupljeno: 
Rowlands, I., Nicholas, D., Williams, P., Huntington, P., Filedhouse, M. (2009). The Google generation: the information behaviour of the researcher of the future. Oxford, London. Dostupno

na: https://www.researchgate.net/publication/215500461_The_Google_generation_The_info rmation_behaviour_of the researcher_of the future, pristupljeno 15.06.2020.

Rumble , G. (1986). The Planning and Management of Distance Education. St Martins Press, New York.

Ružić, N. (2008). Zakonska ograničenja ili sloboda izražavanja na internetu? MediAnali : međunarodni znanstveni časopis za pitanja medija, novinarstva, masovnog komuniciranja i odnosa s javnostima, 2(4), str. 101-111. Dostupno na: http://hrcak.srce.hr/39349, pristupljeno: 22.06 .2016 .

Sackman, H. (1974). Delphi assessment: Expert opinion, forecasting, and group process. Rand Corporation. Dostupno na: https://www.rand.org/pubs/reports/R1283.html, pristupljeno: 17.10.2020.

Sánchez, A. R., Cortijo, V., Javed, U. (2014). Students' perceptions of Facebook for academic purposes. Computers \& Education, 70, str. 138-149. Dostupno na: https://www.researchgate.net/publication/259288869_Students_perceptions_of_Faceboo k_for_academic_purposes, pristupljeno 28.06.2020.

Sagadin, J. (1991). Kvalitativno empirično pedagoško raziskovanje. Slobodna pedagogika, 78, Zveza društev pedagoških delavcev Slovenije, Ljubljana, str. 343-355.

Saldana, J. (2009). The Coding Manual for Qualitative Researchers. SAGE Publications LTD, London.

Schatz, D., Bashroush, R.,; Wall, J. (2017). Towards a more representative definition of cyber security. Journal of Digital Forensics, Security and Law, 12 (2). Dostupno na: https://commons.erau.edu/jdfs1/vol12/iss2/8/, pristupljeno: 23.06.2020.

Schneckenberg, D., Johannes, W. (2006). Understanding the concept of ecompetence for academic staff. The challenge of ecompetence in academic staff developement, 29-35. Dostupno

na: https://www.researchgate.net/publication/255570154_UNDERSTANDING_THE_CON CEPT_OF_ECOMPETENCE_FOR_ACADEMIC_STAFF, pristupljeno: 14.06.2020.

School for Analytics (2020). Machine Learning. Dostupno na: https://schoolforanalytics.com/machine.html, pristupljeno: 18.10.2020. 
Schradie, J. (2011). The digital production gap: The digital divide and Web 2.0 collide. Elsevier B.V. Dostupno na: https://www.sciencedirect.com/science/article/abs/pii/S0304422X1100012X, pristupljeno 15.06.2020.

Shannon, C. E., Weaver, W. (1949). The Mathematical Theory of Communication. Urbana, The University of Illinois Press, Illinois, str. 1-117.

Sekayi, D., Kennedy, A. (2017). Qualitative Delphi Method: A Four Round Process with a Worked Example. The Qualitative Report, TQR, Volume 22, Number 10. Dostupno na: https://nsuworks.nova.edu/cgi/viewcontent.cgi?article=2974\&context=tqr, pristupljeno: 11.05.2020.

Selwyn, N. (2011). Social media in higher education. Education and technology Continuum, Routledge, London - New York. Dostupno na: https://pdfs.semanticscholar.org/e661/e51ce237ded12da9b1ef126a842663b8fb53.pdf, pristupljeno: 09.01.2018.

Shayli (2020). 32 logos set popular social media icons vector image. Image ID: 25199519. VectorStock. Dostupno na: https://www.vectorstock.com/royalty-free-vector/32-logosset-popular-social-media-icons-vector-25199519, pristupljeno: 09.06.2020.

Shirky, C. (2008). Here comes everybody. Allen Lane, London.

Siemens, G. (2004). Connectivism: a learning theory for the digital age. Dostupno na: https://jotamac.typepad.com/jotamacs_weblog/files/Connectivism.pdf, pristupljeno 14.06.2020.

Sigurnosno-obavještajna agencija (SOA), (2020). Republika Hrvatska. Dostupno na: https://www.soa.hr/hr/podrucja-rada/informacijska-sigurnost/, pristupljeno: 23.06.2020.

Silvestru, C.I., Lupescu, M-E., Draistaru, A.S. (2016). The Impact of Using Social Media in Adult Education, Studies from Education and Society.

Sinarm Software (2020). Što je cloud computing ili usluga u „oblaku“? Dostupno na: http://www.sinarm.net/sto-je-cloud-computing-ili-usluga-u-oblaku/. Pristupljeno: 01.10.2020.

Skulmoski, G., Hartman, F., Krahn, J. (2007). The Delphi Method for Graduate Research. Journal of Information Technology Education, 6, str. 1-21. 
Slišković, A. (2017). Kvalitativne istraživačke metode u psihologiji. Nastavni materijali. Dostupno na: http://www.unizd.hr/Portals/12/pdf/Nastava/KIMP.pdf, pristupljeno: 22.10.2020.

Smerdon, B., Cronen, S., Lanahan, L., Anderson, J., Iannotti, N., Angeles, J. (2000): Teachers' Tools for the 21st Century: A Report on Teachers' Use of Technology. National Center for Education Statistics, U.S. Department of Education. Dostupno na: https://nces.ed.gov/pubs2000/2000102.pdf, pristupljeno: 21.10.2018.

Solis, B. (2007). The Definition of Social Media. Dostupno na: http://www.webpronews.com/blogtalk/2007/06/29/the-definition-ofsocial-media, pristupljeno: 2010.

Solis, B. (2008a). Introducing The Coversation Prism. Dostupno na: https://www.briansolis.com/2008/08/introducing-conversationprism.html, pristupljeno: 30.05 .2020 .

Solis, B. (2008b). The Essential Guide to Social Media. Dostupno na: https://www.socialmediatoday.com/content/essential-guide-social-media-free-ebook. Pristupljeno: 07.06.2020.

Spafford, E. H. (1989). Quotable Spaf. Dostupno na: https://spaf.cerias.purdue.edu/quotes.html, pristupljeno: 24.06.2020.

Stahl, G., Sharplin, E., Kehrwald, B. (2016). Developing pre-service teachers' confidence: realtime coaching in teacher education. Reflective Practice, 7 (6), str. 724-736. Dostupno na: https://www.tandfonline.com/doi/full/10.1080/14623943.2016.1206882, pristupljeno: 03.07.2020.

Staker, H., Horn, M. B. (2012). Classifying K-12 blended learning. Innosight Institute. Dostupno na: https://web.archive.org/web/20130821034813/http://www.innosightinstitute.org/innosigh t/wp-content/uploads/2012/05/Classifying-K-12-blended-learning2.pdf\#, pristupljeno 27.06.2020.

Standish, P. (2008). Preface. U: Journal of Philosophy of Education, 42, 3-4,str. 349-53. Dostupno na: https://onlinelibrary.wiley.com/doi/abs/10.1111/j.1467-9752.2008.00659.x, pristupljeno 15.06.2020.

Statista (2018). Social media Statistics \& Facts. Dostupno na: https://www.statista.com/topics/1164/social-networks/, pristupljeno: 21.10.2018. 
Statista (2019). Active social media penetration in selected European countries in January 2019. Dostupno na: https://www.statista.com/statistics/295660/active-social-media-penetrationin-european-countries/, pristupljeno: 09.06.2020.

Statista (2020). Global digital population as of April 2020 (in billions). Dostupno na: https://www.statista.com/statistics/617136/digital-population-worldwide/, pristupljeno: 09.06.2020.

Strauss, A., Corbin, J. (1990). Basics of qualitative research: Grounded theory procedures and techniques. SAGE Publications LTD, London.

Stevens, T. (2018). Global Cybersecurity: New Directions in Theory and Methods. Politics and Governance. 6 (2): 1-4. Dostupno na: https://kclpure.kcl.ac.uk/portal/files/97261726/PaG_6_2_Global_Cybersecurity_New_Di rections_in_Theory_and_Methods.pdf, pristupljeno: 24.06.2020.

Strmšek, Z. (2020). Online mentori su na online studiju iznimno važni. Newsletter June 21, 2020. Doba Fakultet, Maribor.

Studentski zbor Sveučilišta u Rijeci (2018). Akademska čestitost. Projekt Akademsko pisanje. Dostupno na: http://akademsko-pisanje.sz-ri.com/wp-content/uploads/2018/01/B1akademska-\%C4\%8Destitost.pdf, pristupljeno: 03.07.2020.

Subrahmanyam, K., Šmahel, D. (2011). Digital youth. Springer, Berlin.

Suzuki, S. (2006). Zen Mind, Beginner's Mind. Shambhala Publications, Boston.

Sveučilište Jurja Dobrile u Puli (2020). Obavijesti za studente oelektroničkoj pošti i Google Suite usluzi, Pula. Dostupno na: https://www.unipu.hr/novosti?@=2f2ea\#news_107442, pristupljeno: 27.07.2020.

Sveučilište Josipa Jurja Strossmayera u Osijeku (2011). Strategija Sveučilišta Josipa Jurja Strossmayera u Osijeku 2011.-2020., Osijek. Dostupno na: http://www.stucos.unios.hr/wpcontent/uploads/2018/02/SJJS_Strategija_Sveucilista_HR.pdf, pristupljeno: 26.07.2020.

Sveučilište Sjever (2020). Online nastava. Varaždin. Dostupno na: https://www.unin.hr/onlinenastava-upute-2/, pristupljeno: 27.07.2020.

Sveučilište u Dubrovniku (2016). Strategija razvoja Sveučilišta u Dubrovniku 2016.-2025. Dubrovnik.

Dostupno na:

https://www.unidu.hr/wp- 
content/uploads/2020/03/STRATEGIJA_RAZVOJA_SVEUCILISTA_U_DUBROVNI KU_2016-2025.pdf, pristupljeno: 27.07.2020.

Sveučilište u Rijeci (2018). Etički kodeks Sveučilišta u Rijeci. Rijeka. Dostupno na: https://www.phy.uniri.hr/files/pravilnici/Eticki_kodeks.pdf, pristupljeno: 03.07.2020.

Sveučilište u Rijeci (2018). Pravilnik o stegovnoj odgovornosti nastavnika i suradnika $\begin{array}{lllll}\text { Sveučilišta } \mathrm{u} \text { Rijeci. Rijeka. } & \text { Dostupno }\end{array}$ http://www.riteh.uniri.hr/media/filer_public/7e/7a/7e7a8168-a421-4f35-97462162c45b3e74/pravilnik_o_stegovnoj_odgovornosti_nastavnika_i_suradnika_sveucilista _u_rijeci.pdf, pristupljeno: 27.07.2020.

Sveučilište u Splitu (2009). Statut Sveučilišta u Splitu. Split. Dostupno na: http://umas.unist.hr/wp-content/uploads/2008/12/Statut_veljaca-2009.pdf, pristupljeno: 26.07.2020.

Sveučilište u Splitu (2015). Strategija 2015-2020. Split. Dostupno na: http://www.szst.unist.hr/wp-content/uploads/2018/03/STRATEGIJAunist-1.pdf, pristupljeno: 27.07.2020.

Sveučilište u Zadru (UNIZD), (2016). Sigurnost informacijskih sustava. Zloporaba informacijskih tehnologija. Nastavni materijali iz kolegija Etički izazovi primjene informacijskih tehnologija. Dostupno na: http://www.unizd.hr/Portals/1/Primjena_rac/Poseban_program/Predavanja/sigurnost_pre davanje.pdf, pristupljeno: 23.06.2020.

Sveučilište u Zadru (2017). Stategija razvoja Sveučilišta u Zadru 2017.-2022. Zadar. Dostupno na:

https://www.unizd.hr/Portals/0/doc/doc_pdf_dokumenti/strategije/Strategija_razvoja_Sv eucilista_u_Zadru_2017_2022.pdf, pristupljeno: 27.07.2020.

Sveučilište u Zagrebu (2014). Strategija studija i studiranja u Zagrebu 2014.-2025. Zagreb. Dostupno

na: http://www.unizg.hr/fileadmin/rektorat/O_Sveucilistu/Dokumenti_javnost/Dokumenti/St rateski_dokumenti/Izvjesca/Strategija_studija_i_studiranja.pdf, pristupljeno: 27.07.2020.

Sveučilište u Zagrebu (2020). Alati i servisi za nstavu na daljinu. Zagreb. Dostupno na: http://www.unizg.hr/studiji-i-studiranje/alati-i-servisi-za-nastavu-na-daljinu/, pristupljeno: 27.07.2020.

Tamayo, J.D., Cruz, G.S.G., (2014). The Relationship of Social Media with the Academic Performance of Bachelor of Science in Information Technology Students of Centro Escolar University - Malolos. International Journal of Scientific and Research Publications, 4(5), 1-9. Dostupno na: http://www.ijsrp.org/research-paper- 
0514.php?rp=P292725, pristupljeno: 29.10.2018.

Tapscott, D., Williams, A. (2007). Wikinomics. How Mass Collaboration Changes Everything. Atlantic, New York.

Tapscott, D. (2011). Odrasti digitalno: Kako mrežna generacija mijenja vaš svijet, Mate d.o.o. i ŽŠEM, Zagreb.

Telegraf (2018). Otkrivano: Koja je razlika između hakera, programera i developera? Dostupno na: $\quad$ https://www.telegraf.rs/hi-tech/edukacija/2973903-otkrivamo-koja-je-razlikaizmedju-hakera-programera-i-developera. Pristupljeno: 01.10.2020.

Teng, C., Lin, B. (2013) Applying Facebook as a Management Method for the Teaching Platform to Develop Product Design. HCI International Proceedings, Part II, Las Vegas. Dostupno na: https://www.researchgate.net/publication/287058486_Applying_Facebook_as_a_Manag ement_Method_for_the_Teaching_Platform_to_Develop_Product_Design, pristupljeno: 28.06.2020.

Tess, P. (2013). The role of social media in higher education classes (real and virtual)-A literature review. Computers in Human Behavior, 29 (5), str. A60-A68. Dostupno na: https://www.researchgate.net/publication/257252942_The_role_of_social_media_in_hig her_education_classes_real_and_virtual_-_A_literature_review, pristupljeno 05.11.2018.

Theunissen, P. (2015). The Quantum Entanglement of Dialogue and Persuasion in Social Media: Introducing the Per-Di Principle. Atlantic Journal of Communication, 23:1, 5-18, DOI: $\quad 10.1080 / 15456870.2015 .972405 \quad$ Dostupno na: https://www.tandfonline.com/doi/abs/10.1080/15456870.2015.972405, pristupljeno: 12.02.2019.

Thomas, D., Seely Brown, J. (2011). A new culture of learning. Charleston, SC, Createspace.

Thomas, M., Thomas, H. (2012). Using new social media and Web 2.0 technologies in business school teaching and learning, Journal of Management Development. 31 (4), str. 358 -367. Dostupno na: https://www.researchgate.net/publication/235308669_Using_new_social_media_and_W eb_20_technologies_in_business_school teaching_and_learning, pristupljeno: 12.02.2019.

Thompson, C., Gray, K., Kim, H. (2014). How social are social media technologies (SMTs)? A linguistic analysis of university students' experiences of using SMTs for learning. The Internet and Higher Education 21, str. 31-40. Dostupno na: https://www.researchgate.net/publication/259521146_How_social_are_social_media_tec hnologies_SMTs_A_linguistic_analysis_of_university_students'_experiences_of_using 
SMTs_for_learning, pristupljeno 28.06.2020.

Tottossy, A. P. (2005). Teacher Selection: A Delphi Study, Doctoral Dissertation, Faculty of the Virginia Polytechnic Institute and State University, Blacksburg, Virginia. Dostupno na: https://vtechworks.lib.vt.edu/handle/10919/26442, pristupljeno: 18.07.2020.

Tower, M., Latimer, S., Hewitt, J. (2014). Social networking as a learning tool Nursing students' perception of efficacy. Nurse Educ Today 34 (6), str. 1012-1017. Dostupno na: https://pubmed.ncbi.nlm.nih.gov/24314881/, pristupljeno: 28.06.2020.

Tuncay, T., Uzunboylu, H., Teker, T. (2011). Students evaluation of EDU 2.0: A case study. Procedia Social and Behavioral Scineces 28, str. 948-956. Dostupno na: https://www.researchgate.net/publication/271617627_Students_evaluation_of_EDU_20 A_case_study, pristupljeno: 28.06.2020.

Tyagi, S. (2012). Adoption of Web 2.0 technology in higher education: A case study of Universities in National Capital Region, India. International Journal of Education and Development using Information and Communication Technology (IJEDICT), 8(2), str. 2843. Dostupno na: https://files.eric.ed.gov/fulltext/EJ1084132.pdf, pristupljeno: 27.06.2020.

Ulbrich, F., Jahnke, I. Martensson, P. (2011). Special Issue on knowledge development and the net generation. International Journal of Sociotechnology and Knowledge Development.

Uldrijan, I. (2011). Zašto odgajati za medije? Mediji kao „odgojitelji“ u doba odgojne krize, u: Labaš, D. (ur.), Komunikacija i mediji u krizi, Hrvatski studiji, Zagreb. Str. 173-192.

Underwood, P. (2014). Privacy Checkup Is Now Rolling Out. Facebook. Dostupno na: http://newsroom.fb.com/news/2014/09/privacy-checkup-is-now-rolling-out/, pristupljeno 03.04.2017.

Universities and Colleges Information Systems Association in the United Kingdom, UCISA (2015). Social Media Toolkit: a practical guide to achieving benefits and managing risks. Univeristy of Oxford. Dostupno na: https://www.ucisa.ac.uk/Imedia/Files/UCISA/Publication-

files/TOOLKITS/2015/Social_media_toolkit.pdf?la=en, pristupljeno: 03.07.2020.

University of South Australia, (2020). Anderson's Taxonomy. Dostupno na: https://lo.unisa.edu.au/mod/book/view.php?id=611025\&chapterid=106371, pristupljeno: 14.06.2020.

Ured vijeća za nacionalnu sigurnost (UVNS), (2020). Što je to informacijska sigurnost? Republika Hrvatska. Dostupno na: https://www.uvns.hr/hr/sto-je-to-informacijska- 
sigurnost, pristupljeno: 23.06.2020.

Uzelac, A. (2004). Digitalna kulturna dobra u informacijskom društvu između javne domene i privatnog vlasništva. U: Medijska istraživanja: znanstveno-stručni časopis za novinarstvo i medije, (10/1). Str.37-53. Dostupno na: https://hrcak.srce.hr/23010, pristupljeno: 07.08.2016.

Van Dijck, J., Poell, T. (2013). Understanding social media logic. Media and Communication 1 (1), str. 2-14. Dostupno na: http://www.librelloph.com/mediaandcommunication/article/view/MaC-1.1.2, pristupljeno: 26.02 .2019 .

Van Dijk, J. (1990). Delphi Method as a Learning Instrument: Bank Employees Discussing an Automation Project, Technological Forecasting and Social Change 37, str. 399-407.

Van Doren, M. (1943). Liberal Education. H. Holt, Michigan.

Van Doren, C. (2005). Povijest znanja. Mozaik knjiga, Zagreb.

Vaša Europa (2020). Zaštita podataka na temelju Opće uredbe o zaštiti podataka. Europska unija. Dostupno na: https://europa.eu/youreurope/business/dealing-with-customers/dataprotection/data-protection-gdpr/index_hr.htm, pristupljeno: 24.06.2020.

Veljković, N. (2015). Vendor menadžment: Prodavci pod kontrolom. PC Press. Dostupno na: https://pcpress.rs/vendor-menadzment-prodavci-pod-kontrolom/.

Pristupljeno: 01.10 .2020 .

Venkatesh, V., Morris, M. G., Davis, G. B., Davis, F. D. (2003). User Acceptance of Information Technology: Toward a Unified View. MIS Quarterly. Vol. 27, No. 3:2003, pp. 425-478. Dostupno na: https://canvas.utwente.nl/courses/1550/files/136468/download?verifier...wrap=1, pristupljeno: 29.10.2018.

Vijeće Europe (2009). (Europska) Konvencija o pristupu službenim dokumentima. Dostupno na: $\quad$ https://www.coe.int/en/web/conventions/full-list//conventions/treaty/205?fbclid=IwAR1ywGune6ooFjN1HU4O7fC_BHPiHAN8YNBok NcXJB69PvMceOC5bzMkXk8, pristupljeno 25.06.2020.

Vijeće Europe (2010). (Europska) Konvencija za zaštitu ljudskih prava i temeljnih sloboda. Međunarodni ugovori 18/97, 6/99, 14/02, 13/03, 9/05, 1/06, 2/10, pročišćeni tekst, Rim. Dostupno na: http://www.zakon.hr/z/364/(Europska)-Konvencija-za-za\%C5\%A1tituljudskih-prava-i-temeljnih-sloboda, pristupljeno 13.12.2016. 
Vijeće Europske unije (2020). Informacijska sigurnost. Europska Unija. Dostupno na: https://www.consilium.europa.eu/hr/general-secretariat/corporate-policies/classifiedinformation/information-assurance/, pristupljeno: 23.06.2020.

Visagie, S., de Villiers, C. (2010). The consideration of Facebook as an academic tool by ICT lecturers across five countries. Proceedings of the SACLA conference (SACLA2010), University of Pretoria, Pretoria, South Africa. Dostupno na: https://www.academia.edu/329278/The_Consideration_of_Facebook_As_An_Academic _Tool_by_ICT_Lecturers_Across_Five_Countries, pristupljeno 28.06.2020.

Visoko učilište Algebra (2018a). Etički kodeks Visokog učilišta Algebra. Dostupno na: https://www.algebra.hr/visoko-uciliste/wpcontent/uploads/sites/2/2017/11/Eti\%C4\%8Dki-kodeks-2.pdf, pristupljeno 07.06.2020.

Visoko učilište Algebra (2018b). Kodeks ponašanja studenata Visokog učilišta Alegbra. Dostupno na: https://www.algebra.hr/visoko-uciliste/wpcontent/uploads/sites/2/2019/04/Kodeks-pona\%C5\%A1anja-studenata.pdf, pristupljeno 07.06.2020.

Vivian, R., Barnes, A., Geer, R., Wood, D. (2014). The academic journey of university students on Facebook: an analysis of informal academic-related activity over a semester, Association for learning technology, Open Access Journal.

Vivodinac, Ž. (2010). Je li kodeks potreba ili hir?, Dijete, vrtić, obitelj, broj 61, Split. Dostupno na: http://hrcak.srce.hr/file/188910, pristupljeno 11.12.2016.

Vlada Republike Hrvatske (2013). Strategija obrazovanja, znanosti i tehnologije. Radni materijal. Dostupno na: http://www.finhed.org/media/files/01-Strategija_OZTRadni_materijal_rujan_2013.pdf, pristupljeno: 31.05.2020.

Vrabec Mojzeš (2019). Komunikacijske i kulturološke vrijednosti primjene audiovizualne politike EU u Republici Hrvatskoj. Sveučilište u Zagrebu, Filozofski fakultet, Odsjek za informacijske i komunikacijske znanosti, Zagreb. Dostupno na: https://repozitorij.ffzg.unizg.hr/islandora/object/ffzg:829, pristupljeno: 29.10.2020.

Vrocharidou, A., Efthymiou, I. (2012). Computer mediated communication for social and academic purposes: Profiles of use and University students' gratifications. Computers \& $\begin{array}{lllll}\text { Education } & 58, & \text { str. } & 609-616 . & \text { Dostupno }\end{array}$ https://dl.acm.org/doi/10.1016/j.compedu.2011.09.015, pristupljeno 28.06.2020.

Vouk, D., Malus, D., Carević, D. (2011). Neuralne mreže i njihova primjena u vodnom gospodarstvu. Građevinar 63 (6), str. 547-554. Dostupno na: https://hrcak.srce.hr/70618, pristupljeno: 19.10 .2020 . 
Waycott, J., Bennett, S., Kennedy, G., Dalgarno, B., Gray, K. (2010). Digital divides? Student and staff perceptions of information and communication technologies. U: Computers and Education, 54, 4, str. 1202-11. Dostupno na: https://www.researchgate.net/publication/222998775_Digital_divides_Student_and_staff _perceptions_of_information_and_communication_technologies, pristupljeno 15.06.2020.

Waycott, J., Sheard, J., Thompson, C., Clerehan, R. (2013). Making students work visible on the social web: A blessing or a curse? Computers \& Education 68, str. 86-95. Dostupno na:

https://www.researchgate.net/publication/257171634_Making_students'_work_visible_o n_the_social_web_A_blessing_or_a_curse, pristupljeno 28.06.2020.

Wankel, C. (2009). Management education using social media. Organization Management Journal , 6 (4), 251-262.

Weinberg, B.D., Pehlivan, E. (2011). Social spending: managing the social media mix. Business Horizons, 54, 3, str. 275-282.

Weiner, R. (1996). Webster's New world Dictionary of Media and Communications. MacMillan, New York. Str. 134.

Weinert, F. E. (2001). Concept of Competence: a conceptual definition. U: Rychen, D.S., Salganik, L. H. (eds.), Defining and Selecting Key Competencies. Hogrefe \& Huber Publishers, Seattle, 45-66.

Wesch, M. (2008). A Vision of Students Today (\& What Teachers Must Do). Encyclopedia Britannica Blog. Dostupno na: http://blogs.britannica.com/2008/10/a-vision-of-studentstoday-what-teachers-must-do, pristupljeno: 27.06.2020.

Westbrook, L. (1997). Information access issued for interdisciplinary scholars: results of a Delphi study on women's studies research. The Journal of Academic Librarianship, 23 (3), str. 211-216.

Willems, J., Adachi, Ch., Grevtseva, Y. (2016). Working with social media in tertiary education: A contest space between academics and policies. ASCILITE, Adelaide, str. 648-653. Dostupno na: http://2016conference.ascilite.org/wpcontent/uploads/ascilite2016_willems_concise.pdf, pristupljeno: 03.07.2020.

Willems, J., Adachi, Ch., Busssey, F., Doherty, I., Huijser, H. (2018). Debating the use of social media in higher education in Australasia: Where are we now? Australasian Journal of Educational Technology, 34 (5), str. 135-149. Dostupno na: 
https://ajet.org.au/index.php/AJET/article/view/3843/1539, pristupljeno: 03.07.2020.

Wimmer, R. D., Dominick, J. R. (2013). Mass Media Reserach. Wadworth, Cengage Learning, Ninth edition, Boston. Dostupno na: https://saleemabbas2008.files.wordpress.com/2013/02/1353087914wimmer_dominick_mass_media_research_2011.pdf, pristupljeno: 15.11.2020.

Winzenreid, A. (1997). Delphi studies: The value of expert opinion bridging the gap - Data to knowledge. Rad prezentiran na godišnjoj konferenciji International Association of School Librarianship held u suradnji s International Association of Teacher-Librarianship.

Wir, N., Fayyad, U.M., Djorgovski, S. (1995). Automated Star/Galaxy Classification for Digitized POSS-II, The Astronomical Journal, Volume 109, Number 6. Dostupno na: https://www.researchgate.net/publication/234223141_Automated_StarGalaxy_Classifica tion_for_Digitized_Poss-II, pristupljeno: 19.10.2020.

Wodzicki, K., Schwämmlein, E., Moskaliuk, J. (2012). “Actually, I Wanted to Learn”: StudyRelated knowledge exchange on social networking sites. The Internet and Higher Education, $15 \quad$ (1), $\quad$ str. $\quad 9-14 . \quad$ Dostupno na: https://www.researchgate.net/publication/215652929_Actually_I_Wanted_to_Learn_Stu dy-related_knowledge_exchange_on_social_networking_sites, pristupljeno: 28.06.2020.

Worldometer (2020). Current World Population. Dostupno na: https://www.worldometers.info/world-population/, pristupljeno: 09.06.2020.

Yang, Y. N. (2003). Testing the stability of experts' opinions between successive rounds of Delphi studies. Rad prezentiran na godišnjem skupu American Educational Research Association.

Yu, A., Tian, S., Vogel, D., Kwok, R. (2010). Can learning be virtually boosted? An investigation of online social networking impacts. Computers \& Education, vol. 55 (4), str. 1494-1503. Dostupno na: https://www.researchgate.net/publication/220449471_The_impact_of_online_social_net working_on_learning_A_social_integration_perspective, pristupljeno: 28.06.2020.

Zhang, Y., Salaba, A. (2009). What is next for functional requirements for bibliographic records? A Delphi study. Library Quarterly, 79 (2), str. 233-255.

Zuckerman, E. (2007). Web 2.0 tools for development: simple tools for smart people. Participatory learning and action. Dostupno na: https://pubs.iied.org/pdfs/G02845.pdf, pristupljeno: 20.06.2020. 
Žena.hr, (2020). Što je webinar i čemu služi? Dostupno na: https://zena.rtl.hr/clanak/ostalo/sto_je_webinar_i_cemu_sluzi/32608. Pristupljeno: 01.10 .2020 .

Žižak, M. (2018). Kako MEF unapređuje svoju nastavu - diskusija. E-učenje je budućnost koja se događa sada. IEEE Croatia Section. Dostupno na: https://www.youtube.com/watch?v=6WX5Z-DkerM, pristupljeno: 31.05.2020. 


\section{Prilozi}

\section{Prilog 1. - Prikaz „Upitnik - Korištenje društvenih mreža kao komunikacijskog kanala studenata za potrebe visokog obrazovanja“"}

Poštovani studenti i poštovane studentice,

molim Vas izdvojite nekoliko minuta Vašeg vremena kako biste ispunili ovaj upitnik. Upitnik je sastavni dio istraživanja u okviru doktorskog rada kojim se želi utvrditi koriste li studenti društvene mreže kao primarni komunikacijski kanal za širenje informacija o studiju, studentskim obvezama, ispitnoj literaturi i sl. Molimo Vas da odaberete jedan ili više odgovora koji najbliže opisuju Vaš stav o navedenom pitanju. Unaprijed zahvaljujem, Tihana Babić.

\section{Razina studija: a) preddiplomski $\quad$ b) diplomski}

Smjer studija:

Godina studija:

Status studija: a) redovni

b) izvanredni
Spol:
a) $\mathrm{M}$
b) $\check{Z}$

1. Na koji se način obično informirate o studiju, studentskim obvezama, ispitnoj literaturi...?

a) Od nastavnika

b) Od nenastavnog i/li administrativnog osoblja

c) Od drugih studenata

d) $\mathrm{Na}$ web stranicama škole

e) Preko sustava digitalne referade Infoeduka

f) Preko društvenih mreža

g) Drugo (što)?

2. Što obično koristite na internetu?

a) Pretraživače sadržaja

b) Platforme na kojima možete skidati i/li slušati i gledati glazbu i/li filmove

c) Slanje i primanje e-mailova

d) Društvene mreže

e) Drugo (što)?

3. Za koje svrhe obično koristite internet?

a) Za poslovne potrebe

b) Za potrebe studija

c) Za druženje i zabavu

d) Drugo (što)?

4. Imate li profil na nekoj od društvenih mreža?

a) $\mathrm{Ne}$

b) $\mathrm{Da}$

5. Ako da, na kojoj/kojima? 

a) Facebook
b) Twitter
c) Instagram
d) LinkedIn
e) Drugo (molimo navedite)
6. Koliko često ste prisutni na društvenim mrežama?
a) Nikad
b) Rijetko
c) Povremeno
d) Često
e) Vrlo često/Svaki dan

7. Koliko vremena dnevno provodite na društvenim mrežama?
a) Ne koristim društvene mreže
b) Manje od sat vremena
c) Dva do tri sata
d) Tri do pet sati
e) Više od pet sati

8. U koje svrhe obično koristite društvene mreže?

a) Za druženje s poznanicima

b) Za druženje i dogovore s prijateljima

c) Za upoznavanje novih ljudi

d) Za potrebe studija

e) U poslovne svrhe

9. Koristite li društvene mreže za potrebe studiranja?
a) Nikad
b) Rijetko
c) Povremeno
d) Često
e) Vrlo često/Svaki dan

10. Za koje potrebe studiranja obično koristite društvene mreže?
a) Općenitu informiranost
b) U svezi informiranja o nastavnicima i kolegijima
c) U svezi informiranja o nastavnoj literaturi
d) U svezi informiranja o ispitima
e) Drugo (što?)

Hvala Vam na sudjelovanju. 


\section{Prilog 2. - Prikaz „Upitnik - Elektroničko nasilje prilikom studentskog korištenja društvenih mreža za potrebe studiranja“}

Poštovani studenti i poštovane studentice,

molim Vas izdvojite nekoliko minuta Vašeg vremena kako biste ispunili ovaj upitnik. Upitnik je sastavni dio istraživanja u okviru doktorskog rada kojim se želi utvrditi jesu li studenti koji koriste društvene mreže kao komunikacijski kanal upoznati s pojmovima i vrstama radnji koji se tiču sigurnosti komuniciranja $i$ elektroničkog nasilja. Molimo Vas da odaberete jedan ili više odgovora koji najbliže opisuju Vaš stav o navedenom pitanju. Unaprijed zahvaljujem, Tihana Babić.
Razina studija:
a) preddiplomski
b) diplomski

Studij:

Smjer studija:

Godina studija:

Status studija: a) redovni

b) izvanredni
Spol:
a) $\mathrm{M}$
b) $\check{Z}$

1. Na što se odnosi pojam ,sigurnost“" na društvenim mrežama?

a) Sprječavanje direktne prijetnje javnoj ili osobnoj sigurnosti na društvenim mrežama

b) Sprječavanje samoranjavanja ili samoubojstva

c) Sprječavanje prijetnji vandalizma

d) Sprječavanje prijetnji financijske štete

e) Nešto drugo (što)?

2. Što je „cyberbullying“ (elektroničko nasilje)?

a) Opći pojam za svaku komunikaciju cyber tehnologijom koja se može smatrati štetnom za pojedinca

b) Opći pojam za svaku komunikaciju cyber tehnologijom koja se može smatrati štetnom za društvo

c) Opći pojam za svaku komunikaciju cyber tehnologijom koja se može smatrati štetnom i za pojedinca i za opće dobro

d) Ne znam

e) Nešto drugo (što)?

3. Što spada u „bullying“ i uznemiravanje na društvenim mrežama (primjerice Facebooku)?

a) Stranice koje identificiraju i sramote privatne osobe

b) Fotografije koje degradiraju privatne osobe

c) Fotografije ili video snimke fizičkog bullyinga objavljene da osramote žrtvu

d) Dijeljenje osobnih informacija radi ucjenjivanja ili uznemiravanja ljudi

e) Ponavljano targetiranje drugih ljudi s neželjenim zahtjevima za prijateljstvo ili porukama

f) Nešto drugo (što)?

4. ̌ Što spada u napade na javne osobe na društvenim mrežama (primjerice Facebooku)?

a) Otvorena i kritička rasprava o ljudima koji se pojavljuju u vijestima ili imaju široku publiku

b) Govor mržnje upućen ljudima koji se pojavljuju u vijestima ili imaju široku publiku

c) Nešto drugo (što)? 
5. Što sve obuhvaća elektroničko nasilje na društvenim mrežama?

a) Bilo kakav oblik višestruko slanih poruka internetom ili mobitelom čiji je cilj povrijediti, uznemiriti ili na bilo koji drugi način oštetiti dijete, mlade ili odrasle koji se ne mogu zaštiti od takvih postupaka

b) Tekstualne ili videoporuke čiji je cilj povrijediti, uznemiriti ili na bilo koji drugi način oštetiti dijete, mlade ili odrasle koji se ne mogu zaštiti od takvih postupaka

c) Fotografije čiji je cilj povrijediti, uznemiriti ili na bilo koji drugi način oštetiti dijete, mlade ili odrasle koji se ne mogu zaštiti od takvih postupaka

d) Pozivi čiji je cilj povrijediti, uznemiriti ili na bilo koji drugi način oštetiti dijete, mlade ili odrasle koji se ne mogu zaštiti od takvih postupaka

e) Na sve navedeno

f) Nešto drugo (što)?

6. Kako se reguliraju seksualno nasilje $i$ iskorištavanje na društvenim mrežama (primjerice Facebook-u)?

a) Zabrana objavljivanja sadržaja koji prijete ili promiču seksualno nasilje ili iskorištavanje (seksualno iskorištavanje maloljetnika ili seksualni napadi)

b) Zabrana objavljivanja fotografija ili video zapisa koji prikazuju incidente seksualnog nasilja

c) Zabrana objavljivanja fotografija ili video zapisa podijeljenih iz osvete

d) Zabrana objavljivanja fotografija ili video zapisa bez pristanka osoba koje se nalaze na fotografiji ili video zapisu

e) Sve navedeno

f) Nešto drugo (što)?

7. Jeste li ikada bili žrtva elektroničkog nasilja na društvenim mrežama?

a) Nikad

b) Rijetko

c) Povremeno

d) Često

e) Vrlo često

8. Ako ste bili žrtva elektroničkog nasilja, kojoj vrsti elektroničkog nasilja ste bili izloženi?

a) Poticane grupne mržnje

b) Napada na privatnost

c) Širenja nasilnih i uvredljivih komentara

d) Slanja prijetećih, okrutnih poruka

e) Uznemiravanja, uhođenja i vrijeđanja

f) Kreiranja stranica koje sadrže priče, crteže, slike i šale na račun vršnjaka

g) Lažnog predstavljanja

h) Provaljivanja u vašu e-mail adresu

i) Krađe i promjene lozinke

j) Slanja vaših fotografija od strane vaših kolega te traženje ostalih da ih procjenjuju po određenim karakteristikama

k) Iznošenja osobnih ili obiteljskih prilika

1) Slanja virusa, fotografija i neželjene pošte na e-mail ili mobitel

m) Dječje pornografije

9. Kad biste čuli za slučaj elektroničkog nasilja među svojim kolegama na studiju, smatrate da biste trebali nešto poduzeti?

a) $\mathrm{Ne}$

b) Djelomično ne

c) Niti da, niti ne

d) Djelomično da

e) $\mathrm{Da}$ 
10. Jeste li ikada sudjelovali u elektroničkom nasilju nad nekom osobom na društvenim mrežama?
a) Nikad
b) Rijetko
c) Povremeno
d) Često
e) Vrlo često

11. Ako ste sudjelovali u elektroničkom nasilju nad nekom osobom na društvenim mrežama, u kojoj vrsti elektroničkog nasilja ste sudjelovali?

a) Poticanje grupne mržnje

b) Napada na privatnost drugih

c) Širenja nasilnih i uvredljivih komentara o drugima

d) Slanja prijetećih, okrutnih poruka drugima

e) Uznemiravanja, uhođenja i vrijeđanja drugih

f) Kreiranja stranica koje sadrže priče, crteže, slike i šale na račun drugih

g) Lažnog predstavljanja

h) Provaljivanja u tuđu e-mail adresu

i) Krađe i promjene tuđe lozinke

j) Slanja tuđih fotografija te traženje ostalih da ih procjenjuju po određenim karakteristikama

k) Iznošenja osobnih ili obiteljskih prilika drugih

1) Slanja virusa, fotografija i neželjene pošte na e-mail ili mobitel drugih

m) Dječje pornografije

12. Smatrate li da je elektroničko nasilje bezopasno i zabavno?
a) $\mathrm{Ne}$
b) Djelomično ne
c) Niti da, niti ne
d) Djelomično da
e) $\mathrm{Da}$

Hvala Vam na sudjelovanju. 


\section{Prilog 3. - Prikaz „Upitnik - Informacijska etika studenata prilikom korištenja društvenih mreža za potrebe studiranja“"}

Poštovani studenti i poštovane studentice,

molim Vas da izdvojite nekoliko minuta Vašeg vremena kako biste ispunili ovaj upitnik. Upitnik je sastavni dio istraživanja u okviru doktorskog rada kojim se želi utvrditi da li studenti na etičan način pristupaju proizvodnji, prikupljanju, širenju i korištenju informacija, osobito na društvenim mrežama. Molim Vas da na svako pitanje odaberete jedan odgovor koji najbliže opisuje Vaš stav o navedenom pitanju. Unaprijed zahvaljujem, Tihana Babić.

Razina studija: a) preddiplomski $\quad$ b) diplomski

Smjer studija:

Godina studija:

Status studija: a) redovni $\quad$ b) izvanredni

$\begin{array}{lll}\text { Spol: } & \text { a) } M & \text { b) } \check{Z}\end{array}$

1. Jeste li upoznati s etičkim kodeksom odnosno temeljnim vrijednostima Visokog učilišta Algebra?

a) Uopće ne

b) Uglavnom ne

c) Djelomično

d) Uglavnom da

e) U potpunosti sam upoznat/a

2. Jeste li upoznati s Pravilima ponašanja na društvenim mrežama (primjerice na Facebook-u)?

f) Uopće ne

g) Uglavnom ne

h) Djelomično

i) Uglavnom da

j) U potpunosti sam upoznat/a

3. Čitate li propise zajednice odnosno Pravila ponašanja na društvenim mrežama prilikom stvaranja profila?

a) Uopće ne

b) Uglavnom ne

c) Djelomično

d) Uglavnom da

e) U potpunosti sam upoznat/a

4. Koristite li pravo ime i prezime odnosno vlastiti identitet na društvenim mrežama (primjerice Facebooku)?

a) $\mathrm{Da}$

b) Koristim samo svoje ime ili samo svoje prezime

c) Koristim tuđe ime ili prezime

d) Koristim izmišljeno ime ili prezime 
e) Drugo (̌̌to)?

5. Imate li više od jednog korisničkog računa (profila) na istoj društvenoj mreži (primjerice na Facebook-u)?

a) $\mathrm{Ne}$

b) Da, dva

c) Da, tri i više

6. Koliko prijatelja imate na istoj društvenoj mreži (primjerice na Facebooku)?

a) Manje od 50

b) Od 50 do 100

c) Između 100 i 500

d) Više od 500

e) Više od 1000

7. Smatrate li da je važno poštovati prava drugih ljudi na privatnost odnosno njihov osobni i obiteljski život, dostojanstvo, ugled i čast prilikom prikupljanja i objave informacija na društvenim mrežama?

a) Jako je važno

b) Uglavnom je važno

c) Donekle je važno

d) Uglavnom nije važno

e) Uopće nije važno

8. Smatrate li da je intelektualna sloboda važna odnosno da svaka osoba ima pravo reći, misliti, učiti i pisati o tome što želi?

a) Jako je važna

b) Uglavnom je važna

c) Donekle je važna

d) Uglavnom nije važna

e) Uopće nije važna

9. Smatrate li da je intelektualna sloboda važna odnosno da svaka osoba ima pravo reći, misliti, učiti i pisati o tome što želi čak i ako to zadire u prava drugih ljudi?

a) Jako je važna

b) Uglavnom je važna

c) Donekle je važna

d) Uglavnom nije važna

e) Uopće nije važna

10. Smatrate li da imate slobodan i pravodoban pristup informacijama koje se tiču Vašeg studija, te da su te informacije potpune i točne?

a) Uopće se ne slažem

b) Ne slažem se

c) Niti se slažem, niti se ne slažem

d) Slažem se

e) U potpunosti se slažem

11. Smatrate li da je važno poštovati pravila citiranja (navodite li pravog autora, nakladnika i godinu objave) prilikom prikupljanja, širenja u korištenja informacija vezano za studij?

a) Jako je važno

b) Uglavnom je važno

c) Donekle je važno

d) Uglavnom nije važno

e) Uopće nije važno 
12. Smatrate li da je važno poštovati pravila citiranja (navodite li pravog autora, nakladnika i godinu objave) prilikom prikupljanja i objave informacija na društvenim mrežama?

a) Jako je važno

b) Uglavnom je važno

c) Donekle je važno

d) Uglavnom nije važno

e) Uopće nije važno

Hvala Vam na sudjelovanju. 


\section{Prilog 4. - Prikaz „Upitnik - Nastavničko korištenje društvenih medija za potrebe visokog obrazovanja ${ }^{66}$}

Poštovani / poštovana,

molimo Vas da izdvojite nekoliko minuta Vašeg vremena kako biste ispunili ovaj upitnik o korištenju društvenih medija za potrebe visokog obrazovanja. Ovaj upitnik je sastavni dio istraživanja u okviru doktorskog rada kojim se želi utvrditi koriste li nastavnici društvene medije za potrebe visokog obrazovanja kao što su primjerice informiranje studenata o studiju, studentskim obvezama, ispitnoj literaturi i sl. Molimo Vas da odaberete jedan ili više odgovora koji najbliže opisuju Vaš stav o navedenom pitanju. Unaprijed zahvaljujem, Tihana Babić.

Korištenje društvenih medija za potrebe visokog obrazovanja

Društveni mediji, besplatne su online usluge koje nudi internet kao kombinaciju moderne tehnologije i društvene interakcije, te obuhvaćaju 13 podtipova: blogove, mikroblogove, alate za poslovne i društvene mreže, suradničke projekte, forume, alate za dijeljenje fotografija, alate za poslovnu suradnju, recenzije proizvoda $i$ usluga, društvene knjižne oznake, društvene igre, alate za dijeljenje fotografija/videozapisa i virtualne svjetove (Aichner, Jacob, 2015).

Demografski podaci:

Molimo da na pitanja koja slijede odaberete samo jedan od ponuđenih odgovora.

1. Vi ste:
a) muškarac
b) žena

2. Kojoj dobnoj skupini pripadate:
a) do 20 godina
b) 21-30 godina
c) 31-40 godina
d) 41-50 godina
e) 51-60 godina
f) $61 \mathrm{i}$ više godina

3. Zaposlenik / Zaposlenica ste na:
a) Veleučilištu Baltazar Zaprešić
b) Visokom učilištu Algebra
c) vanjski suradnik/ica

4. Koliko godina radnog iskustva imate kao nastavnik/ica?
a) manje od 5 godina
b) između 5 i 10 godina
c) između 10 i 20 godina
d) između 20 i 30 godina
e) više od 30 godina 
Molim da od ponuđenih odgovora odaberite sve odgovore koji se odnose na Vas.

5. Označite razinu na kojoj predajete:
a) preddiplomski studiji
b) diplomski studiji
c) na preddiplomskim na diplomskim studijima

6. Označite znanstveno područje Vašeg znanstveno-nastavnog zvanja:
a) prirodne znanosti
b) tehničke znanosti
c) biomedicina i zdravstvo
d) biotehničke znanosti
e) društvene znanosti
f) humanističke znanosti
g) umjetničko područje
h) interdisciplinarna područja znanosti
i) interdisciplinarna područja umjetnosti

7. Označite znanstveno područje studija na kojima predajete:
a) prirodne znanosti
b) tehničke znanosti
c) biomedicina i zdravstvo
d) biotehničke znanosti
e) društvene znanosti
f) humanističke znanosti
g) umjetničko područje
h) interdisciplinarna područja znanosti
i) interdisciplinarna područja umjetnosti

Informacije o korištenju društvenih medija za potrebe visokog obrazovanja:

Molim odaberite jedan od ponuđenih odgovora.

8. Koristite li društvene medije za potrebe visokog obrazovanja?
a) nikad
b) rijetko
c) povremeno
d) često
e) svaki dan/uvijek

9. Koliko vremena provodite koristeći društvene medije za potrebe visokog obrazovanja?
a) ne koristim društvene medije
b) manje od sat vremena dnevno
c) nekoliko sati dnevno
d) nekoliko sati tjedno
e) nekoliko sati mjesečno

Molim da od ponudenih odgovora odaberite sve odgovore koji se odnose na Vas.

10. Koje društvene medije koristite za potrebe visokog obrazovanja?
a) blogove (primjerice Mojblog, Blog...)
b) mikroblogove (primjerice Twitter, Tumbir...)
c) suradničke projekte (primjerice Wikipedia, Mozilla...)
d) poslovne mreže (LinkedIn, Europska poduzetnička mreža...)
e) društvene mreže poduzeća (Yammer, Informacijski sustav visokih učilišta RH - ISVU...), 
f) forume (primjerice Forum, Bug Online Forum...)

g) za dijeljenje fotografija (primjerice Instagram, Flickr...)

h) za dijeljenje videozapisa (primjerice YouTube, Vimeo...)

i) za pregled proizvoda/usluga (primjerice Amazon, Njuškalo...)

j) za knjižno označavanje (primjerice Pinterest, Reddit...)

k) društvene igre (primjerice World of Warcraft, Mafia Wars...)

1) društvene mreže (primjerice Facebook, Google+...)

lj) virtualne svjetove (primjerice Second Life, Twinity...)

m) ništa od navedenog

$\underline{\text { Svrha korištenja društvenih medija u visokom obrazovanju }}$

Molim odaberite jedan odgovarajući od ponuđenih odgovora u svakom redu.

11. Koliko često koristite društvene medije za:

\begin{tabular}{|l|l|l|l|l|l|}
\hline & nikad & $\begin{array}{c}\text { manje od } \\
\text { jednom } \\
\text { mjesečno }\end{array}$ & $\begin{array}{c}\text { svaki } \\
\text { mjesec }\end{array}$ & $\begin{array}{c}\text { svaki } \\
\text { tjedan }\end{array}$ & svaki dan \\
\hline $\begin{array}{l}\text { a) općenitu informiranost o nastavnim } \\
\text { sadržajima }\end{array}$ & & & & & \\
\hline b) prezentaciju nastavih sadržaja & & & & & \\
\hline c) informiranje studenata o kolegijima & & & & & \\
\hline d) informiranje studenata o nastavnoj literaturi & & & & & \\
\hline e) informiranje studenata o ispitima & & & & & \\
\hline f) informiranje studenata o praksi & & & & & \\
\hline g) dijeljenje informacija koje se tiču studija & & & & & \\
\hline i) istraživačke svrhe i rada na projektima & & & & & \\
\hline $\begin{array}{l}\text { j) objavu stručnih ili znanstvenih radova } \\
\text { samostalno ili s kolegama nastavnicima }\end{array}$ & & & & & \\
\hline $\begin{array}{l}\text { k) objavu stručnih ili znanstvenih radova sa } \\
\text { studentima }\end{array}$ & & & & & \\
\hline
\end{tabular}

Očekivani učinak

12. Označite stupanj slaganja s izjavama o mogućim učincima korištenja društvenih medija za potrebe visokog obrazovanja:

\begin{tabular}{|c|c|c|c|c|c|}
\hline & $\begin{array}{l}\text { uopće se } \\
\text { ne } \\
\text { slažem }\end{array}$ & $\begin{array}{c}\text { uglavnom } \\
\text { se ne } \\
\text { slažem }\end{array}$ & $\begin{array}{c}\text { niti se } \\
\text { slažem, } \\
\text { niti se ne } \\
\text { slažem }\end{array}$ & $\begin{array}{l}\text { uglavnom } \\
\text { se slažem }\end{array}$ & $\begin{array}{l}\text { potpuno } \\
\text { se slažem }\end{array}$ \\
\hline $\begin{array}{l}\text { a) Smatram da su društveni mediji korisni } \\
\text { sustav za potrebe visokog obrazovanja. }\end{array}$ & & & & & \\
\hline $\begin{array}{l}\text { b) Društveni mediji omogućavaju mi brže i } \\
\text { lakše održavanje nastave. }\end{array}$ & & & & & \\
\hline $\begin{array}{l}\text { c) Društveni mediji povećavaju moju } \\
\text { učinkovitost kao nastavnika. }\end{array}$ & & & & & \\
\hline
\end{tabular}




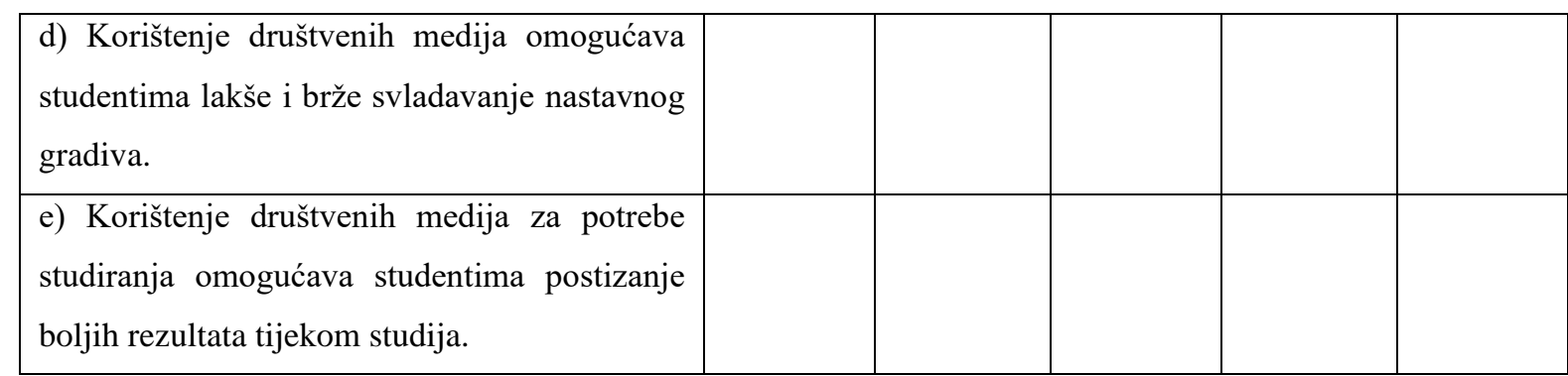

Očekivani trud (napor)

13. Označite stupanj slaganja s izjavama o očekivanoj lakoći korištenja društvenih medija za potrebe visokog obrazovanja:

\begin{tabular}{|l|l|l|l|l|l|}
\hline & $\begin{array}{c}\text { uopće se } \\
\text { ne } \\
\text { slažem }\end{array}$ & $\begin{array}{c}\text { uglavnom } \\
\text { se ne } \\
\text { slažem } \\
\text { slažem, } \\
\text { niti se ne } \\
\text { slažem }\end{array}$ & $\begin{array}{c}\text { uglavnom } \\
\text { se slažem }\end{array}$ & $\begin{array}{c}\text { potpuno } \\
\text { se slažem }\end{array}$ \\
\hline $\begin{array}{l}\text { a) Korištenje društvenih medija za mene je } \\
\text { jasno je i razumljivo. }\end{array}$ & & & & & \\
\hline $\begin{array}{l}\text { b) Vješt/a sam u korištenju društvenih medija. } \\
\text { korištenje. }\end{array}$ & & & & & \\
\hline $\begin{array}{l}\text { d) S lakoćom komuniciram, surađujem putem } \\
\text { društvenih medija, dijelim i pretražujem } \\
\text { sadržaje te na druge načine koristim društvene } \\
\text { medije. }\end{array}$ & & & & & \\
\hline
\end{tabular}

$\underline{\text { Stav prema korištenju društvenih medija }}$

14. Označite stupanj slaganja s izjavama koje se tiču Vaših stavova o korištenju društvenih medija za potrebe visokog obrazovanja:

\begin{tabular}{|l|l|l|l|l|l|}
\hline & $\begin{array}{c}\text { uopće se } \\
\text { ne } \\
\text { slažem }\end{array}$ & $\begin{array}{c}\text { uglavnom } \\
\text { se ne } \\
\text { slažem }\end{array}$ & $\begin{array}{c}\text { niti se } \\
\text { slažem, } \\
\text { niti se ne } \\
\text { slažem }\end{array}$ & $\begin{array}{l}\text { uglavnom } \\
\text { se slažem }\end{array}$ & $\begin{array}{c}\text { potpuno } \\
\text { se slažem }\end{array}$ \\
\hline $\begin{array}{l}\text { a) Smatram da bi korištenje društvenih medija } \\
\text { za potrebe poučavanja trebala biti obveza } \\
\text { svakog nastavnika. }\end{array}$ & & & & \\
\hline $\begin{array}{l}\text { b) Smatram da bi nastavnici trebali aktivnije } \\
\text { koristiti društvene medije za potrebe } \\
\text { poučavanja studenata. }\end{array}$ & & & & & \\
\hline $\begin{array}{l}\text { c) Smatram da bi hrvatske visokoškolske } \\
\text { ustanove trebale usvojiti politiku korištenja } \\
\text { društvenih medija za potrebe studiranja. }\end{array}$ & & & & & \\
\hline $\begin{array}{l}\text { d) Smatram da bi hrvatske visokoškolske } \\
\text { ustanove trebale provoditi educiranje }\end{array}$ & & & & & \\
\hline
\end{tabular}




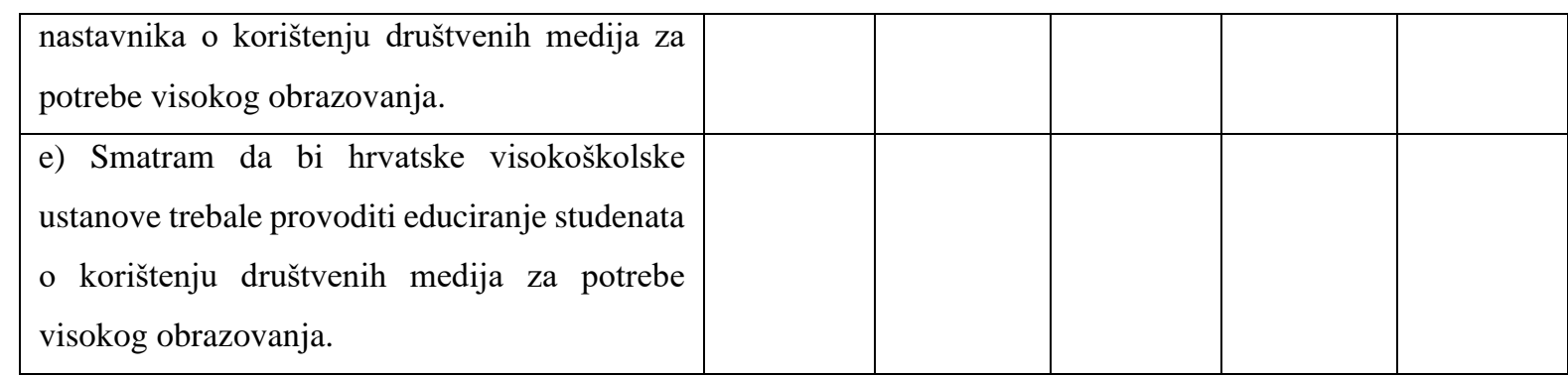

Društveni utjecaj za korištenje društvenih medija

15. Na moje uključivanje u korištenje društvenih medija za potrebe visokog obrazovanja utječu ili bi mogli utjecati:

\begin{tabular}{|l|c|c|c|c|c|}
\hline & $\begin{array}{c}\text { uopće se } \\
\text { ne } \\
\text { slažem }\end{array}$ & $\begin{array}{c}\text { uglavnom } \\
\text { se ne } \\
\text { slažem }\end{array}$ & $\begin{array}{c}\text { niti se } \\
\text { slažem, } \\
\text { niti se ne } \\
\text { slažem }\end{array}$ & $\begin{array}{c}\text { uglavnom } \\
\text { se slažem }\end{array}$ & $\begin{array}{c}\text { potpuno slažem } \\
\text { se }\end{array}$ \\
\hline $\begin{array}{l}\text { a) Kolege nastavnici koji koriste društvene } \\
\text { medije za potrebe visokog obrazovanja. }\end{array}$ & & & & & \\
\hline $\begin{array}{l}\text { b) Studenti koji smatraju da trebam koristiti } \\
\text { društvene medije za potrebe visokog } \\
\text { obrazovanja. }\end{array}$ & & & & & \\
\hline $\begin{array}{l}\text { c) Prijatelji i bliski poznanici koji koriste } \\
\text { društvene medije za potrebe visokog } \\
\text { obrazovanja. }\end{array}$ & & & & & \\
\hline $\begin{array}{l}\text { d) Uprava fakulteta koja podržava korištenje } \\
\text { društvenih medija za potrebe visokog } \\
\text { obrazovanja. }\end{array}$ & & & & & \\
\hline
\end{tabular}

Olakšavajući uvjeti prilikom korištenja društvenih medija

16. Označite stupanj slaganja s izjavama o postojanju čimbenika koji olakšavaju korištenje društvenih medija za potrebe visokog obrazovanja:

\begin{tabular}{|l|c|c|c|c|c|}
\hline & $\begin{array}{c}\text { uopće se } \\
\text { ne } \\
\text { slažem }\end{array}$ & $\begin{array}{c}\text { uglavnom } \\
\text { se ne } \\
\text { slažem }\end{array}$ & $\begin{array}{c}\text { niti se } \\
\text { slažem, } \\
\text { niti se ne } \\
\text { slažem }\end{array}$ & $\begin{array}{c}\text { uglavnom } \\
\text { se slažem }\end{array}$ & $\begin{array}{c}\text { potpuno } \\
\text { se slažem }\end{array}$ \\
\hline $\begin{array}{l}\text { a) Imam resurse potrebne za korištenje } \\
\text { društvenih medija za potrebe visokog } \\
\text { obrazovanja (primjerice pristup internetu, } \\
\text { računalo/tablet/mobilni uređaj...). }\end{array}$ & & & & & \\
\hline $\begin{array}{l}\text { b) Imam znanje potrebno za korištenje } \\
\text { društvenih medija za potrebe visokog } \\
\text { obrazovanja. }\end{array}$ & & & & & \\
\hline
\end{tabular}




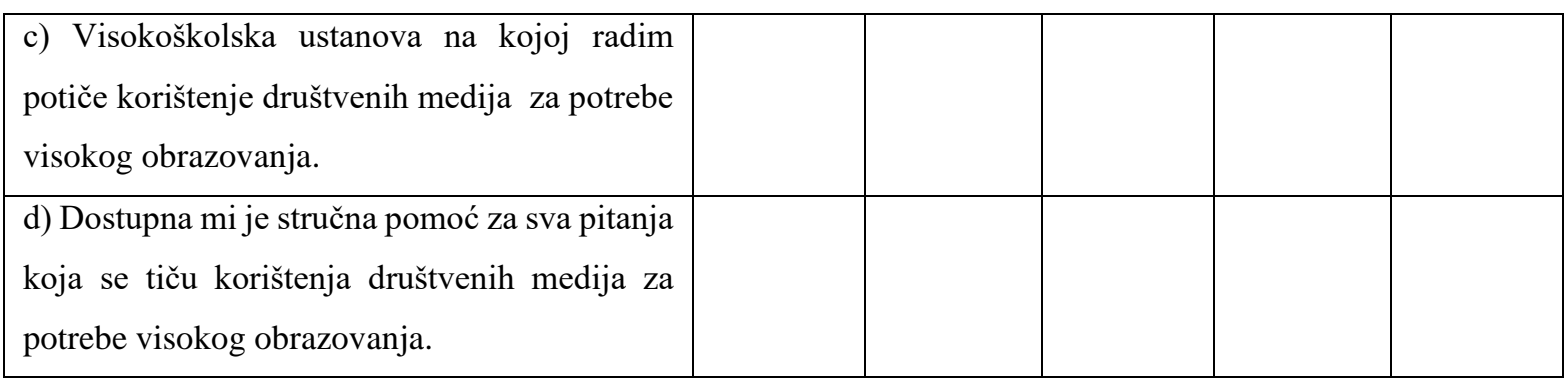

$\underline{\text { Samopouzdanje prilikom korištenja društvenih medija }}$

17. Označite stupanj slaganja s izjavama Vašem samopouzdanju prilikom korištenja društvenih medija za potrebe visokog obrazovanja:

\begin{tabular}{|c|c|c|c|c|c|}
\hline & $\begin{array}{l}\text { uopće se } \\
\text { ne } \\
\text { slažem }\end{array}$ & $\begin{array}{l}\text { uglavnom } \\
\text { se ne } \\
\text { slažem }\end{array}$ & $\begin{array}{l}\text { niti se } \\
\text { slažem, } \\
\text { niti se ne } \\
\text { slažem }\end{array}$ & $\begin{array}{l}\text { uglavnom } \\
\text { se slažem }\end{array}$ & $\begin{array}{l}\text { potpuno } \\
\text { se slažem }\end{array}$ \\
\hline $\begin{array}{l}\text { a) Mogao/mogla bih dovršiti posao korištenjem } \\
\text { društvenih medija za potrebe visokog } \\
\text { obrazovanja čak i kad ne bi bilo nikoga tko bi } \\
\text { mi rekao što da radim tijekom izvršavanja. }\end{array}$ & & & & & \\
\hline $\begin{array}{l}\text { b) Mogao/mogla bih dovršiti posao } \\
\text { korištenjem društvenih medija za potrebe } \\
\text { visokog obrazovanja kad bih imao/imala na } \\
\text { raspolaganju stručnu pomoć kad zapnem. }\end{array}$ & & & & & \\
\hline $\begin{array}{l}\text { c) Mogao/mogla bih dovršiti posao korištenjem } \\
\text { društvenih medija za potrebe visokog } \\
\text { obrazovanja kad bih imao/imala dovoljno } \\
\text { vremena na raspolaganju. }\end{array}$ & & & & & \\
\hline $\begin{array}{l}\text { d) Mogao/mogla bih dovršiti posao } \\
\text { korištenjem društvenih medija za potrebe za } \\
\text { potrebe visokog obrazovanja ako bih } \\
\text { imao/imala ugrađen sustav za pomoć. }\end{array}$ & & & & & \\
\hline
\end{tabular}

\section{Anksioznost prilikom korištenja društvenih medija}

18. Označite stupanj slaganja s izjavama Vašem osjećaju tjeskobe prilikom korištenja društvenih medija za potrebe visokog obrazovanja:

\begin{tabular}{|l|c|c|c|c|c|}
\hline & $\begin{array}{c}\text { uopće se } \\
\text { ne } \\
\text { slažem }\end{array}$ & $\begin{array}{c}\text { uglavnom } \\
\text { se ne } \\
\text { slažem }\end{array}$ & $\begin{array}{c}\text { niti se } \\
\text { slažem, } \\
\text { niti se ne } \\
\text { slažem }\end{array}$ & $\begin{array}{c}\text { uglavnom } \\
\text { se slažem }\end{array}$ & $\begin{array}{c}\text { potpuno slažem } \\
\text { se scem }\end{array}$ \\
\hline $\begin{array}{l}\text { a) Osjećam se zabrinuto zbog korištenja } \\
\text { društvenih medija za potrebe visokog } \\
\text { obrazovanja. }\end{array}$ & & & & \\
\hline
\end{tabular}




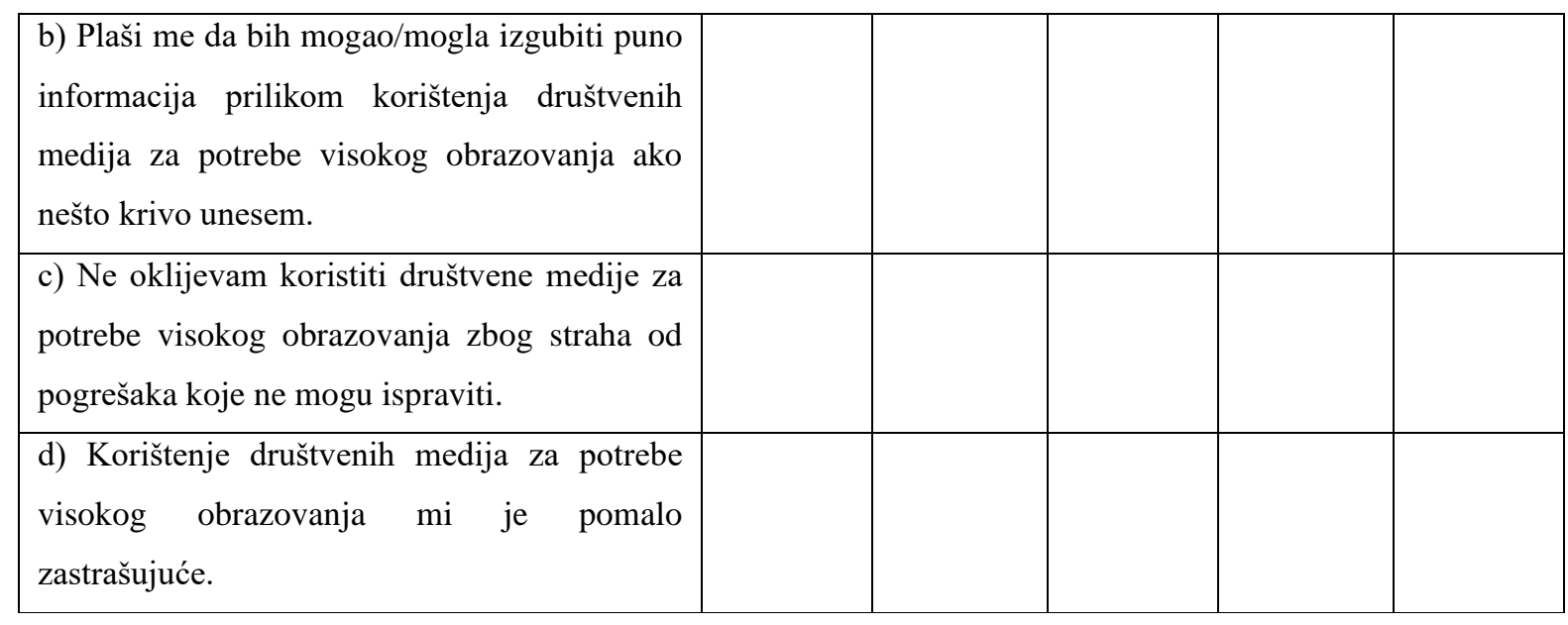

\section{Namjera ponašanja prilikom korištenja društvenih medija}

19. Označite stupanj slaganja s izjavama o Vašim namjerama o korištenju društvenih medija za potrebe visokog obrazovanja:

\begin{tabular}{|l|l|l|l|l|l|}
\hline & $\begin{array}{c}\text { uopće se } \\
\text { ne } \\
\text { slažem }\end{array}$ & $\begin{array}{c}\text { uglavnom } \\
\text { se ne } \\
\text { slažem }\end{array}$ & $\begin{array}{c}\text { niti se } \\
\text { slažem, } \\
\text { niti se ne } \\
\text { slažem }\end{array}$ & $\begin{array}{l}\text { uglavnom } \\
\text { se slažem }\end{array}$ & $\begin{array}{c}\text { potpuno } \\
\text { se slažem }\end{array}$ \\
\hline $\begin{array}{l}\text { a) Namjeravam koristiti društvene medije za } \\
\text { potrebe visokog obrazovanja u sljedećih 12 } \\
\text { mjeseci. }\end{array}$ & $\begin{array}{l}\text { b) Namjeravam koristiti društvene medije za } \\
\text { komunikaciju i suradnju sa studentima. }\end{array}$ & & & & \\
\hline $\begin{array}{l}\text { c) Namjeravam koristiti društvene medije za } \\
\text { edukacijske i istraživačke svrhe. }\end{array}$ & & & & & \\
\hline $\begin{array}{l}\text { d) Namjeravam koristiti društvene medije za } \\
\text { komunikaciju i suradnju s visokoškolskom } \\
\text { ustanovom na kojoj radim. }\end{array}$ & & & & & \\
\hline
\end{tabular}

Organizacijski čimbenici visokoškolskih ustanova

20. Označite stupanj slaganja s izjavama o organizacijskim čimbenicima fakulteta na kojem radite:

\begin{tabular}{|l|l|l|l|l|l|}
\hline & $\begin{array}{c}\text { uopće se } \\
\text { ne } \\
\text { slažem }\end{array}$ & $\begin{array}{c}\text { uglavnom } \\
\text { se ne } \\
\text { slažem }\end{array}$ & $\begin{array}{c}\text { niti se } \\
\text { slažem, } \\
\text { niti se ne } \\
\text { slažem }\end{array}$ & $\begin{array}{l}\text { uglavnom } \\
\text { se slažem }\end{array}$ & $\begin{array}{c}\text { potpuno } \\
\text { se slažem }\end{array}$ \\
\hline $\begin{array}{l}\text { a) Visokoškolska ustanova na kojoj radim } \\
\text { otvorena je i fleksibilna za nove ideje. }\end{array}$ & & & & & \\
\hline $\begin{array}{l}\text { b) Smatram da bi nastavnici trebali aktivnije } \\
\text { koristiti društvene medije za potrebe } \\
\text { poučavanja studenata. }\end{array}$ & & & & \\
\hline
\end{tabular}




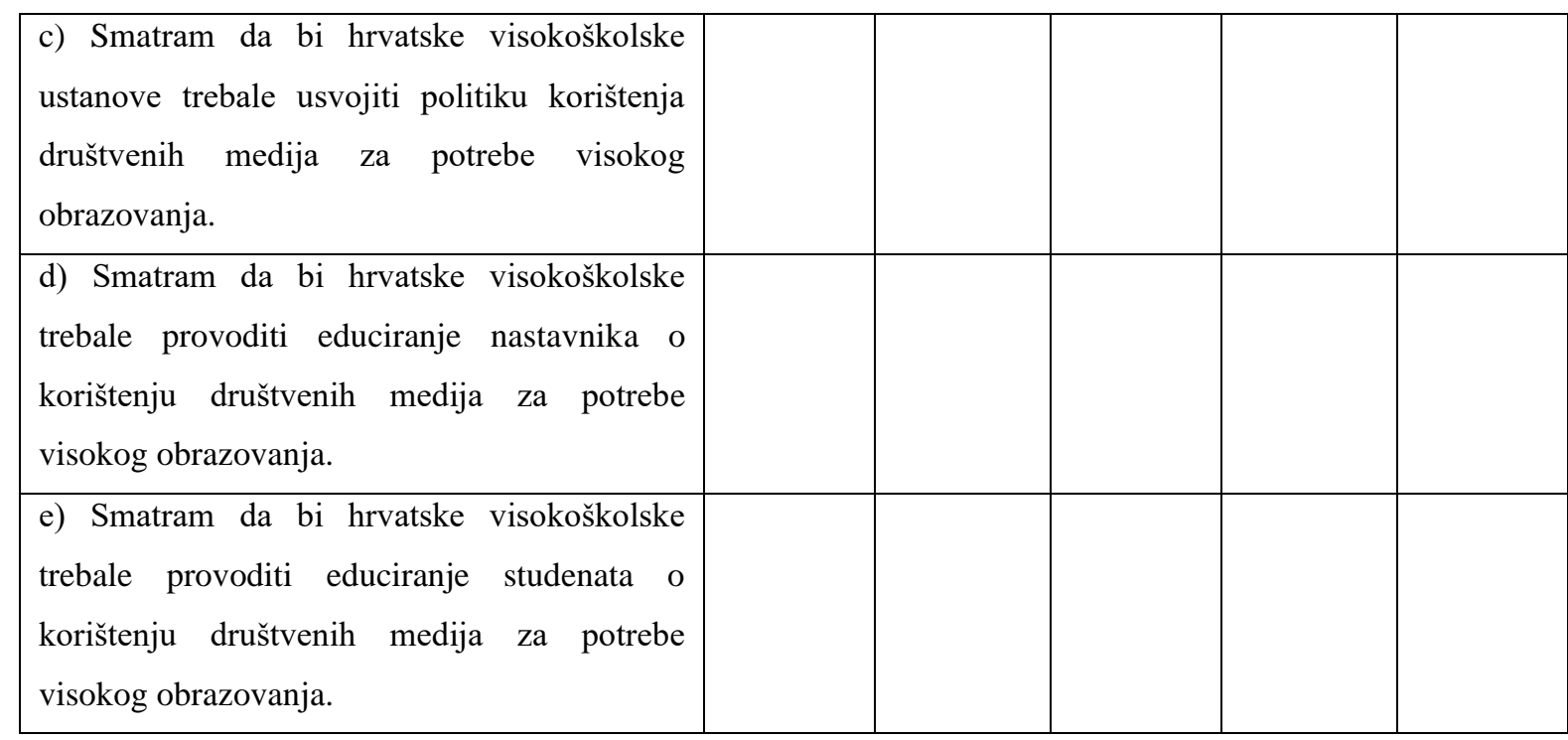

$\underline{\text { Prednosti korištenja društvenih medija za potrebe visokog obrazovanja }}$

21. Označite karakteristike društvenih medija za potrebe visokog obrazovanja koje smatrate važnima:

\begin{tabular}{|c|c|c|c|c|c|}
\hline & $\begin{array}{l}\text { uopće se } \\
\text { ne } \\
\text { slažem }\end{array}$ & $\begin{array}{l}\text { uglavnom } \\
\text { se ne } \\
\text { slažem }\end{array}$ & $\begin{array}{l}\text { niti se } \\
\text { slažem, } \\
\text { niti se ne } \\
\text { slažem }\end{array}$ & $\begin{array}{l}\text { uglavnom } \\
\text { se slažem }\end{array}$ & $\begin{array}{l}\text { potpuno } \\
\text { se slažem }\end{array}$ \\
\hline a) Smanjenje troškova & & & & & \\
\hline b) Fleksibilnost što se tiče odabira tehnologija & & & & & \\
\hline c) Neobavezan pristup & & & & & \\
\hline $\begin{array}{l}\text { d) Lakši i brži pristup informacijama, kada i } \\
\text { gdje je to potrebno }\end{array}$ & & & & & \\
\hline $\begin{array}{l}\text { e) Mogućnost integracije raznih web } 2.0 \\
\text { tehnologija u aktivnostima učenja i poučavanja }\end{array}$ & & & & & \\
\hline $\begin{array}{l}\text { f) Mogućnost kontrole pristupa putem } \\
\text { autentifikacije korisnika }\end{array}$ & & & & & \\
\hline g) Dijeljenje ideja i iskustava & & & & & \\
\hline $\begin{array}{l}\text { h) Neovisnost od pojedine platforme (npr. } \\
\text { računala, dostupnost već uz pristup internetu i } \\
\text { preglednik) }\end{array}$ & & & & & \\
\hline i) Kompatibilnost s područjima obrazovanja & & & & & \\
\hline $\begin{array}{l}\text { j) Niska razina složenosti upotrebe (potrebne } \\
\text { minimalne vještine) }\end{array}$ & & & & & \\
\hline $\begin{array}{l}\text { k) Pouzdanost u kontinuiranom korištenju } \\
\text { tijekom duljeg vremenskog razdoblja }\end{array}$ & & & & & \\
\hline $\begin{array}{l}\text { 1) Manje vremena i napora potrebno za } \\
\text { pretraživanje i upravljanje informacijama }\end{array}$ & & & & & \\
\hline
\end{tabular}




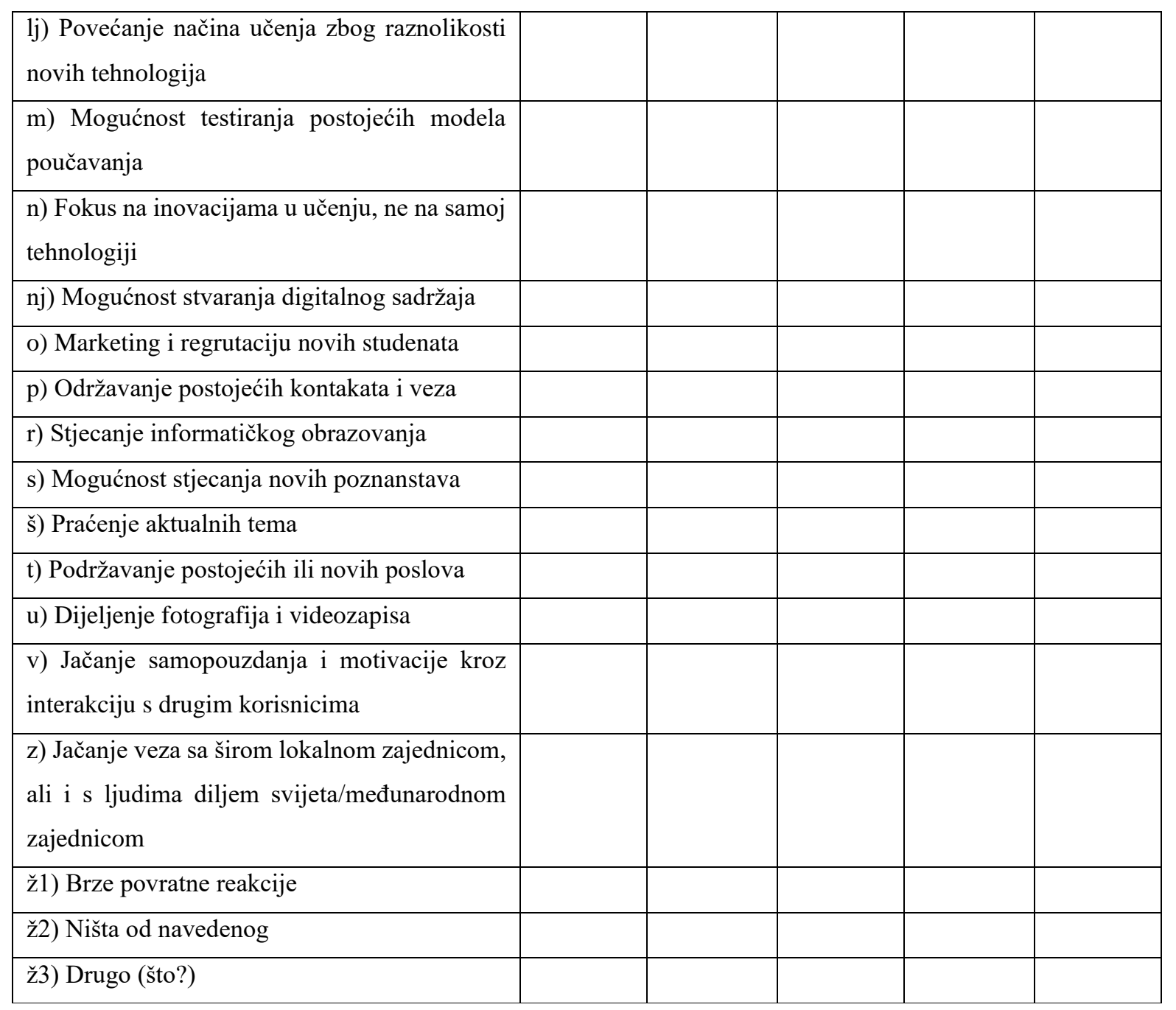

Nedostaci korištenja društvenih medija za potrebe visokog obrazovanja

22. Označite stupanj slaganja s izjavama o nedostacima korištenja društvenih medija u visokom obrazovanju:

\begin{tabular}{|l|l|l|l|l|l|}
\hline & $\begin{array}{c}\text { uopće se } \\
\text { ne } \\
\text { slažem }\end{array}$ & $\begin{array}{c}\text { uglavnom } \\
\text { se ne } \\
\text { slažem }\end{array}$ & $\begin{array}{c}\text { niti se } \\
\text { slažem, } \\
\text { niti se ne } \\
\text { slažem }\end{array}$ & $\begin{array}{c}\text { uglavnom } \\
\text { se slažem }\end{array}$ & $\begin{array}{c}\text { potpuno } \\
\text { se slažem }\end{array}$ \\
\hline $\begin{array}{l}\text { a) Pitanja privatnosti (nedostatak } \\
\text { privatnosti...) }\end{array}$ & & & & & \\
\hline b) Mogućnost postojanja lažnih identiteta & & & & & \\
\hline c) Mogućnost razvijanja ovisnosti & & & & & \\
\hline d) Elektroničko nasilje & & & & & \\
\hline e) Uhođenje (engl. Stalking) & & & & & \\
\hline $\begin{array}{l}\text { f) Zapostavljanje direktne komunikacije } \\
\text { (licem-u-lice) }\end{array}$ & & & & & \\
\hline $\begin{array}{l}\text { g) Potrebna je internetska veza (osobito } \\
\text { širokopojasna veza) }\end{array}$ & & & & & \\
\hline
\end{tabular}




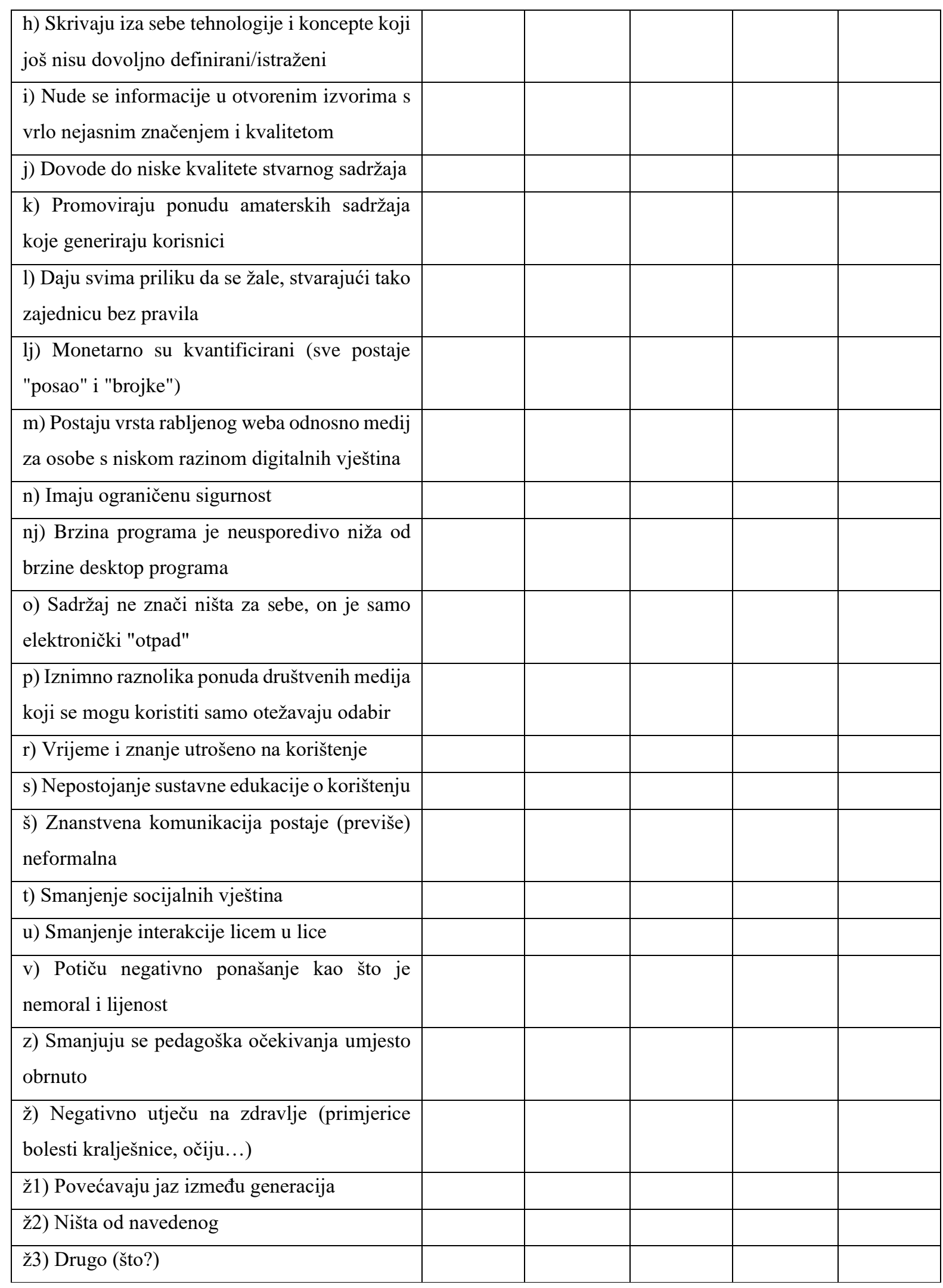

Hvala Vam na sudjelovanju. 


\section{Prilog 5. - Prikaz „Panelisti delfi stručne skupine - sudionici istraživanja ${ }^{66}$}

Doc. dr. sc. Snježana Babić

Veleučilište u Rijeci

Bojan Bajac, magistar inženjer informacijske i komunikacijske tehnologije

A1 Hrvatska, Products Catalogue Expert

Doc. dr. sc. Mislav Balković

Visoko učilište Algebra, dekan

Izv. prof. dr. sc. Domagoj Bebić

Fakultet političkih znanosti (FPZG), Sveučilište u Zagrebu

Ivan Božajić, struč. spec. ing. sec.

Visoko učilište Effectus, viši predavač, voditelj IT službe

Visoko učilište Algebra, viši predavač

Tomislav Bronzin, mag. ing. el.

CEO | CITUS d.o.o., Microsoft Regional Director

Visoko učilište Algebra, predavač

Dr. sc. Slaven Brumec, dipl. ing. rač.

Sveučilište Sjever, Visoko učilište Algebra, viši predavač

Koris d.o.o., voditelj razvoja u području primjene informacijskih tehnologija u poslovanju, modeliranje poslovnih procesa i razvoj informacijskih sustava

Marko Buljan

Media Net d.o.o.

IT Projekt manager

Voditelj odjela za monitoring i analitiku društvenih mreža

Prof. dr. sc. Vlatko Cvrtila,

Sveučilište VERN, rektor

Prof. dr. sc. Marina Čičin-Šain

Međunarodna konferencija Mipro, voditeljica savjetovanja Računala u obrazovanju

Predsjednica udruge Društvo Kibernetičara

Izv. prof. dr. sc. Mario Dumančić

Učiteljski fakultet, Sveučilište u Zagrebu

razvoj e-learning sadržaja

Doc. dr. sc. Goran Đambić

Visoko učilište Algebra, profesor visoke škole

Voditelj katedre za Programsko inženjerstvo 
Siniša Đurđević, dipl. ing. traff.

Halo, Bing, obrt za usluge, vlasnik

Algebra d.o.o., voditelj projekata - vanjski suradnik

Mr. sc. Mario Fraculj

Visoko učilište Algebra, predavač na studiju Digitalnog marketinga

Voditelj katedre za ekonomiju

$\mathrm{PhDc}$

Zoran Jančić, dipl. ing.

Visoko učilište Algebra, voditelj projekata, konzultant za digitalno obrazovanje

Irena Jandrić, prof. def. - logoped

Sveučilišni računski centar Sveučilišta u Zagrebu (Srce)

Voditeljica službe za obrazovne programe

Doc. dr. sc. Damir Jugo, prof. v. š.

Edward Bernays Visoka škola, dekan

Darko Jureković, mag. ing. el.

Oracle Hrvatska, Oracle Academy Manager

Željka Knezović, prof.

Visoko učilište Algebra, predavač

INFINITY, Obrt za intelektualne i informatičke usluge, IT konzultant

Dr. sc. Sandra Kucina Softić

Sveučilišni računski centar Sveučilišta u Zagrebu (Srce)

pomoćnica ravnatelja za obrazovanje i podršku korisnicima

Zdravko Kunić, struč. spec. ing. comp.

Visoko učilište Algebra, predavač

$\mathrm{PhDc}$

Prof. dr. sc. Stjepan Malović

umirovljeni profesor, Sveučilište u Zadru

Vedran Mandić, struč. spec. ing. comp.

FUNCTOR, obrt za usluge, vlasnik

Tomislav Mesić, struč. spec. ing. comp.

Visoko učilište Algebra, predavač

Zlatan Morić, struč. spec. ing. comp.

Visoko učilište Algebra, predavač i voditelj katedre za kibernetičku sigurnost

$\mathrm{PhDc}$

Doc. dr. sc. Leo Mršić

Visoko učilište Algebra, profesor visoke škole u trajnom zvanju

Prodekan za istraživanje i razvoj 
Izv. prof. dr. sc. Predrag Pale

Fakultet elektrotehnike i računarstva (FER), Sveučilište u Zagrebu

Igor Pavleković, bacc. ing. comp.

Microsoft, Cloud Solution Architect for Security and Compliance in Microsoft

Lordan Prelog, mag. rel. publ.

Sveučilište u Zagrebu

stručni suradnik za društvene mreže u Uredu za odnose s javnošću

Tona Radobolja, prof. fizike i politehnike

Sveučilišni računski centar Sveučilišta u Zagrebu (Srce)

Instrukcijski dizajner u Centru za e-učenje Sveučilišnog računskog centra

Aleksander Radovan, dipl. ing. rač.

BISS d.o.o., direktor isporuke softvera

Radovan d.o.o., direktor

Visoko učilište Algebra, viši predavač

Sabina Rako, prof.

Sveučilišni računski centar Sveučilišta u Zagrebu (Srce)

Predstojnica Sektora za obrazovne usluge

Vanja Šebek, dipl. oec.

Visoko učilište Algebra, predavač i voditelj studija Digitalni marketing

Prof. dr. sc. Vladimir Šimović

Veleučilište Baltazar Zaprešić, dekan

Doc. dr. sc. Ernest Vlačić

NOVAMINA CIT;

predsjednik Tematskog Inovacijskog Vijeća Energetike i Održivog Okoliša

Visoko učilište Algebra, profesor visoke škole

Izv. prof. dr. sc. Mirza Žižak, dr. med.

Medicinski fakultet, Sveučilište u Zagrebu

voditelj Ureda za e-učenje

Predsjednik povjerenstva za e-učenja 


\section{Prilog 6. - Prikaz, „Inicijalna uputa panelistima o sudjelovanju u istraživanju“"}

Poštovani/Poštovana,

pozivamo Vas da u svojstvu panelista sudjelujete u istraživanju koje se provodi u sklopu izrade doktorske disertacije Tihane Babić, prof. na Filozofskom fakultetu, pod naslovom „Promjena komunikacijske paradigme u visokom obrazovanju pod utjecajem društvenih medija“ (mentorice: prof. dr. sc. Gordana Vilović i prof. dr. sc. Ljubica Bakić-Tomić).

\section{Sudjelovanje u studiji:}

Kao vrhunski stručnjak, odabrani ste za člana delfi stručne skupine koja sudjeluje u istraživanju „Promjena komunikacijske paradigme u visokom obrazovanju pod utjecajem društvenih medija “.

Tijekom sljedećih nekoliko tjedana, od Vas će očekuje da ispunite tri kruga upitnika (svaki traje cca $20 \mathrm{~min}$.). Na kraju ovog razdoblja, rezultati upitnika bit će Vam dostupni kao znak zahvalnosti za Vaš doprinos. Vaše sudjelovanje je na dobrovoljnoj osnovi. Uvjeti dobrovoljnosti su:

- povjerljivost

- anonimnost

- ne traži se otkrivanje nikakvih poslovnih informacija.

Molimo Vas pažljivo pročitajte Informativno pismo o sudjelovanju u istraživanju (u privitku) u kojem se objašnjavaju razlozi provođenja istraživanja, te koje bi mogle biti koristi / rizici ukoliko pristanete sudjelovati. U slučaju nerazumijevanja bilo kojeg dijela Informativnog pisma, svakako obratite istraživačici. Vaše sudjelovanje u ovom istraživanju je u potpunosti dobrovoljno i možete se u bilo kojem trenutku predomisliti i povući pristanak. Ukoliko odlučite sudjelovati u ovom istraživanju od Vas se očekuje potpisivanje Suglasnosti za sudjelovanje u istraživanju uz naznaku datuma (radi se o doktorskom istraživanju pa je preciznost iznimno važna).

U nastavku se nalaze pitanja iz 1. kruga istraživanja, primjenom metode Brainstorminga (,oluja ideja“): pitanja koja zahtijevaju Vaše odgovore u prvom krugu su otvorenog tipa. Ta pitanja se nalaze na linku: UPITNIK 1 te Vas molimo da na njih odgovorite sada. Za ispunjavanje upitnika potrebno je najmanje 20 minuta.

Ljubazno molimo dostavu ispunjenog upitnika u roku od tjedan dana od njegova primitka. Unaprijed hvala na Vašem vremenu i stručnom doprinosu.

U Zagrebu, 21. svibnja, 2020.

Istraživačica:

Tihana Babić, prof. 


\section{Prilog 7. - Prikaz „Informativno pismo o sudjelovanju u istraživanju“"}

Poštovani/poštovana,

pozivamo Vas da u svojstvu panelista sudjelujete u istraživanju koje se provodi u sklopu doktorske disertacije Tihane Babić, prof. pod naslovom „Promjena komunikacijske paradigme u visokom obrazovanju pod utjecajem društvenih medija“" (mentorice: prof. dr. sc. Gordana Vilović i prof. dr. sc. Ljubica Bakić-Tomić).

Molimo Vas da pažljivo pročitate ovo Informativno pismo o sudjelovanju u istraživanju u kojem se objašnjava zašto se istraživanje provodi i koje bi mogle biti koristi / rizici ukoliko pristanete sudjelovati. U slučaju da ne razumijete bilo koji dio Informativnog pisma molimo Vas da se za objašnjenje obratite istraživačici. Vaše sudjelovanje u ovom istraživanju je u potpunosti dobrovoljno i možete se u bilo kojem trenutku predomisliti $i$ povući pristanak.

Ukoliko odlučite sudjelovati u ovom istraživanju od Vas se očekuje potpisivanje Suglasnosti za sudjelovanje u istraživanju uz naznaku datuma. Važno je razumjeti što se od Vas očekuje i da ste suglasni s navedenim.

\section{$\underline{\text { PODACI O ISTRAŽIVANJU }}$}

Društveni mediji (SNS) temelje se na web 2.0 tehnologiji, omogućavaju stvaranje i dijeljenje informacija, ideja $i$ interesa kroz virtualne zajednice i mreže čija je svrha komunikaciju preokrenuti u interaktivni dijalog. Obuhvaćaju 13 podtipova: blogove, mikroblogove, alate za poslovne i društvene mreže, suradničke projekte, forume, alate za dijeljenje fotografija, društvene knjižne oznake, recenzije proizvoda i usluga, istraživačke mreže, društvene igre, alate za dijeljenje fotografija/videozapisa i virtualne svjetove (Aichner, Jacob, 2015).

Društveni mediji danas su nezaobilazan dio svakodnevice, a umrežavanje pojedinaca i novi načini komunikacije $i$ interakcije imaju svoje dosege i u akademskom svijetu. Društveni mediji nisu samo oruđe za širenje informacija, već više nego bilo koji drugi postojeći medij nude mnoštvo komunikacijskih mogućnosti. O njima se često raspravlja, ali najčešće na razini onoga što se već zna da nude, a vrlo rijetko o njihovim potencijalima i novim mogućnostima.

Upravo stoga, cilj ovog istraživanja jest razumijevanje mogućnosti korištenja i budućeg razvoja društvenih medija te oblikovanje komunikacijske paradigme putem društvenih medija za potrebe visokog obrazovanja temeljem predikcija na visoko stručnoj razini koji će biti dobiveni kroz delfi studiju.

Delfi studija je metoda istraživanja mišljenja grupe eksperata o njezinim idejama o budućnosti. Anketni upitnik bit će anoniman, tako da niti jedna osoba ne može dominirati ili nepotrebno utjecati na grupu prema svojim procjenama. Distribucija procjena bit prikazana isto tako anonimno, ali razmatrana s posebnim osvrtom na razloge na kojima određena grupa stručnjaka temelji svoje procjene.

Delfi studija provodit će se u nekoliko krugova, kao što je navedeno u nastavku.

1. krug: Brainstorming (,oluja ideja“): bit će Vam postavljena pitanja otvorenog tipa koja će zahtijevati Vaše odgovore. Ta pitanja su niže (u privitku) te Vas molimo da na njih odgovorite sada.

2. krug: Poredak SNS: Vaši odgovori i odgovori ostalih panelista iz prvog kruga istraživanja bit će sumirani te formulirani u seriju specifičnijih pitanja, za koje ćete biti zamoljeni da odgovorite na njih.

3. krug: Poboljšanje SNS popisa: Pitanja iz drugog kruga istraživanja bit će Vam postavljena ponovno, ali ovaj puta ćete vidjeti i prosječne odgovore ostalih panelista i tada ćete biti zamoljeni da, ako to želite, prilagodite svoje odgovore iz drugog kruga ili da to ne učinite, ako to ne želite.

Prezentacija rezultata 


\section{POVJERLJIVOST I ZAŠTITA OSOBNIH PODATAKA}

Sudionici istraživanja bit će unaprijed informirani o svrsi istraživanja te će im biti zajamčena anonimnost. Svi podaci prikupljeni od individualnih sudionika bit će kodirani prilikom obrade. Podaci prikupljeni u istraživanju bit će anonimizirani, ali sudionici istraživanja bit će navedeni u doktorskoj disertaciji kao panelisti.

\section{NAČIN ČUVANJA PODATAKA}

Protokoli za prikupljanje informacija tijekom projekta bit će čuvani u osobnoj arhivi istraživačice i to u sljedećim oblicima :

- ispunjenim upitnicima dostavljenim u elektroničkom obliku

- ispisu usustavljenih podataka nakon obrade podataka.

\section{POTENCIJALNI RIZICI / ŠTETE ZA PANELISTE}

Iz istraživačke perspektive mogućnost štete za sudionike istraživanja ne postoji jer je zagarantirana anonimnost u prikazu iskaza.

\section{DOBROVOLJNO SUDJELOVANJE}

Sudjelovanje u ovom istraživanju je u potpunosti dobrovoljno i u bilo kojem trenutku možete prekinuti sudjelovanje bez posljedica.

\section{PITANJA O ISTRAŽIVANJU I KONTAKT PODACI}

$\mathrm{Za}$ dodatna pitanja o samom istraživanju možete se obratiti istraživačici na e-mail adresu ck_tihana_babic@yahoo.com.

U Zagrebu, 21. svibnja, 2020.

Istraživačica:

Tihana Babić, prof.

Unaprijed Vam zahvaljujem na iskrenim odgovorima i suradnji! Tihana Babić, doktorandica Filozofskog fakulteta u Zagrebu 


\section{Prilog 8. - Prikaz „Suglasnost za sudjelovanje u istraživanju“}

Filozofski fakultet Sveučilišta u Zagrebu

Odsjek za informacijske i komunikacijske znanosti

Etičko povjerenstvo

Ivana Lučića 3

10000 Zagreb

Naziv istraživanja:

Promjena komunikacijske paradigme u visokom obrazovanju pod utjecajem društvenih medija

Istraživačica:

Tihana Babić, prof.

\section{SUGLASNOST ZA SUDJELOVANJE U ISTRAŽIVANJU}

Svojim potpisom izražavam svoj pristanak za sudjelovanje u istraživanju i potvrđujem da sam informiran/a:

- $\quad$ o svrsi, cilju i postupcima istraživanja

- $\quad$ da je moje sudjelovanje u potpunosti dobrovoljno te da imam pravo odustati u bilo kojem trenutku bez navođenja razloga

- $\quad$ o razini anonimnosti svoga sudjelovanja pri čemu će podaci prikupljeni istraživanjem biti anonimizirani, ali će u doktorskoj disertaciji biti navedeni u grupi panelista

- o načinima pohranjivanja i čuvanja podataka u svrhu zaštite njihove tajnosti

- $\quad$ o kontakt osobi kojoj se mogu obratiti s pitanjima vezanim za istraživanje, njegovo provođenje i rezultate

- da je istraživačica obvezna pridržavati se Etičkog kodeksa istraživanja s djecom.

Mjesto:

Datum:

Ime i prezime:

Vlastoručni potpis: 


\title{
Prilog 9. - Prikaz „Upitnik 1“ - Instrument delfi studija - prvi krug istraživanja
}

\author{
Tema istraživanja: Promjena komunikacijske paradigme u visokom obrazovanju pod utjecajem društvenih \\ medija \\ Istraživačica: Tihana Babić, prof.
}

\section{UPITNIK O KORIŠTENJU DRUŠTVENIH MEDIJA ZA POTREBE VISOKOG OBRAZOVANJA - PRVI KRUG}

Poštovani / Poštovana,

pred Vama je upitnik o korištenju društvenih medija za potrebe visokog obrazovanja. Molim Vas da pažljivo pročitate i iskreno odgovorite na pitanja jer sudjelujete u znanstvenom istraživanju!

Unaprijed Vam zahvaljujem na iskrenim odgovorima i suradnji!

Tihana Babić, prof.

doktorandica Filozofskog fakulteta u Zagrebu

\section{VAŠI SOCIO-DEMOGRAFSKI PODACI}

MOLIMO ZAOKRUŽITE I/ILI DOPUNITE ODGOVARAJUĆE SOCIO-DEMOGRAFSKE PODATKE:

1. Vaše ime i prezime je? (traži se samo za potrebe praćenja ispunjenosti upitnika, osobni podaci bit će poznati samo istraživačici, a bit će nepoznati ostalim panelistima te anonimizirani u rezultatima istraživanja)

2. Kojoj dobnoj skupini pripadate?
a) $18-30$
b) $31-40$
c) $41-50$
d) $51-60$
e) $61 \mathrm{i}$ više

3. Kojeg ste spola? M $\quad \check{Z}$

4. Vaša stručna sprema je:

a) SSS

b) VŠS ili prvostupnik,

c) VSS ili magistar struke/specijalist

d) Magisterij znanosti

e) Doktorat znanosti

5. Vaša titula je?

6. Institucija na kojoj radite je? 
7. Posao obavljate:

a) kao gospodarstvenik u IT području

b) kao znanstvenik i istraživač iz IT područja

c) kao stručnjak iz područja provedbe IT obrazovanja

d) ostalo (opišite)

8. Pojasnite svoj odnos prema društvenim medijima (moguće je unijeti više odgovora):

a) promičem korištenje društvenih medija u svojoj organizaciji

b) redoviti sam korisnik društvenih medija

c) redovito doprinosim korištenju društvenih medija

d) redovito doprinosim razvoju društvenih medija

e) redovito doprinosim istraživanju društvenih medija

f) redovito doprinosim educiranju o korištenju društvenih medija

f) dizajnirao sam alate društvenih medija

g) ostalo (molimo opišite)

9. Koliko godina se bavite društvenim medijima?
a) 0
b) $1-5$
c) $6-10$
d) $10-15$
e) 15 i više

PRVI KRUG - „BRAINSTORMING“(,Oluja ideja“)

MOLIMO DOPUNITE VAŠE ODGOVORE:

10. Kakav razvoj tehnologija (koje pokreću društvene medije) Vi očekujete u sljedećih 5 godina?

11. Kakav razvoj tehnologija (koje pokreću društvene medije) Vi očekujete u sljedećih 10 godina?

12. Koje je (ekonomske i druge) preduvjete potrebno ispuniti da se potencijal društvenih medija može upotrijebiti za potrebe visokog obrazovanja, u sljedećih 5 godina?

13. Koje je (ekonomske i druge) preduvjete potrebno ispuniti da se potencijal društvenih medija može upotrijebiti za potrebe visokog obrazovanja, u sljedećih 10 godina?

14. Koji sve čimbenici utječu na korištenje društvenih medija u visokoobrazovnom procesu (molimo navedite moguće čimbenike)?

15. Opišite važne čimbenike koji mogu unaprijediti korištenje društvenih medija u visokoobrazovnom procesu? 
16. Što sve utječe na odnos visokih učilišta prema društvenim medijima?

17. Što sve utječe na odnos nastavnika prema društvenim medijima?

18. Što sve utječe na odnos studenata prema društvenim medijima?

19. Što sve utječe na komunikaciju putem društvenih medija u visokoobrazovnom procesu (navedite moguće čimbenike)?

20. Opišite važne čimbenike koji mogu unaprijediti komunikaciju putem društvenih medija u visokoobrazovnom procesu?

Bilješke (ovo je za bilo koji komentar koji želite, ali ne morate, dodati)

Ivala Vam što ste sudjelovali u Prvom krugu delfi studije
visokom obrazovanju pod utjecajem društvenih medija.

Istraživačica:

Tihana Babić, prof. 


\section{Prilog 10. - Prikaz „Druga uputa panelistima o sudjelovanju u istraživanju“"}

Poštovani/Poštovana,

pozivamo Vas da u svojstvu panelista, sudjelujete u Drugom krugu istraživanja koje se provodi u sklopu izrade doktorske disertacije Tihane Babić, prof. na Filozofskom fakultetu, pod naslovom „Promjena komunikacijske paradigme u visokom obrazovanju pod utjecajem društvenih medija“ (mentorice: prof. dr. sc. Gordana Vilović i prof. dr. sc. Ljubica Bakić-Tomić).

Hvala Vam što ste popunili upitnik u Prvom krugu delfi studije na temu: Promjena komunikacijske paradigme u visokom obrazovanju pod utjecajem društvenih medija. Na temelju Vaših odgovora u prethodnom krugu istraživanja, izdvojeno je ukupno 12 ključnih čimbenika promjene (KČP). Molimo Vas da u ovom krugu istraživanja navedete stupanj važnosti čimbenika, prema Vašoj procjeni, koji bi mogli utjecati na korištenje društvenih medija (DM) za potrebe visokog obrazovanja! Kratki opis čimbenika odnosno na što se odnose, nalazi se u samim pitanjima unutar anketnog upitnika.

Na linku: UPITNIK 2 nalaze pitanja iz 2. kruga istraživanja, te Vas molimo da na njih odgovorite sada. Za ispunjavanje upitnika potrebno je približno 10 minuta.

Molimo da dostavite ispunjeni upitnik u roku od 7 dana od primitka upitnika, ako je ikako moguće. Unaprijed hvala na Vašem vremenu i doprinosu. Ako imate bilo kakvih pitanja o istraživanju, molimo ne ustručavajte se kontaktirati istraživačicu.

U Zagrebu, 13. srpnja, 2020.

Istraživačica:

Tihana Babić, prof. 


\title{
Prilog 11. - Prikaz „Upitnik 2“ - Instrument delfi studija - drugi krug istraživanja
}

\author{
Tema istraživanja: Promjena komunikacijske paradigme u visokom obrazovanju pod utjecajem društvenih \\ medija \\ Istraživačica: Tihana Babić, prof.
}

\section{UPITNIK O KORIŠTENJU DRUŠTVENIH MEDIJA ZA POTREBE VISOKOG OBRAZOVANJA -DRUGI KRUG}

Poštovani / Poštovana, pred Vama je upitnik o korištenju društvenih medija za potrebe visokog obrazovanja. Molim Vas da pažljivo pročitate i iskreno odgovorite na pitanja jer sudjelujete u znanstvenom istraživanju!

Unaprijed Vam zahvaljujem na iskrenim odgovorima i suradnji!

Tihana Babić, prof.

doktorandica Filozofskog fakulteta u Zagrebu

\section{MOLIMO DOPUNITE:}

Vaše ime i prezime je? (traži se samo za potrebe praćenja ispunjenosti upitnika, osobni podaci bit će poznati samo istraživačici, a bit će nepoznati ostalim panelistima te anonimizirani u rezultatima istraživanja)

\section{„LIKERTOVA SKALA PROCJENE (VAŽNOSTI)“}

Na temelju Vaših odgovora u prethodnom krugu istraživanja, izdvojeno je ukupno 12 ključnih čimbenika promjene (KČP). Molimo Vas da u ovom krugu istraživanja navedete stupanj važnosti čimbenika, prema Vašoj procjeni, koji bi mogli utjecati na korištenje društvenih medija (DM) za potrebe visokog obrazovanja!

12 ključnih čimbenika promjene (KČP):

KČP 1: Razvoj tehnologija

KČP 2: Nacionalne politike/strategije obrazovanja

KČP 3: Podrška vodstva visokih učilišta

KČP 4: Strategija upravljanja znanjem

KČP 5: Metrike uspješnosti

KČP 6: Infrastruktura upravljanja znanjem

KČP 7: Motivacija nastavnika

KČP 8: Očekivanja studenata

KČP 9: Kultura razmjene znanja

KČP 10: Dostupnost resursa

KČP 11: Kvaliteta društvenih medija

KČP 12: Društvo u cjelini

Kratki opis 12 ključnih čimbenika promjene (KČP): 


\begin{tabular}{|c|c|c|}
\hline Broj & $\begin{array}{l}\text { Ključni čimbenici promjene } \\
\text { komunikacijske paradigme u VO } \\
\text { pod utjecajem DM }\end{array}$ & Opis \\
\hline KČP 1 & Razvoj tehnologija & $\begin{array}{ll}\text { - } & \text { Digitalna transformacija društva. } \\
\text { - } & \text { Masovnije korištenje tehnologije, alata i aplikacija. } \\
\text { - } & \text { Veća dostupnost tehnologija u visokom obrazovanju. } \\
\text { - } & \text { Veća interaktnosti, personalizacija aplikacija i sadržaja. } \\
\text { - } & \text { Veća interoperabilnost među sustavima i alatima. }\end{array}$ \\
\hline KČP 2 & $\begin{array}{l}\text { Nacionalne politike/ } \\
\text { strategije obrazovanja }\end{array}$ & 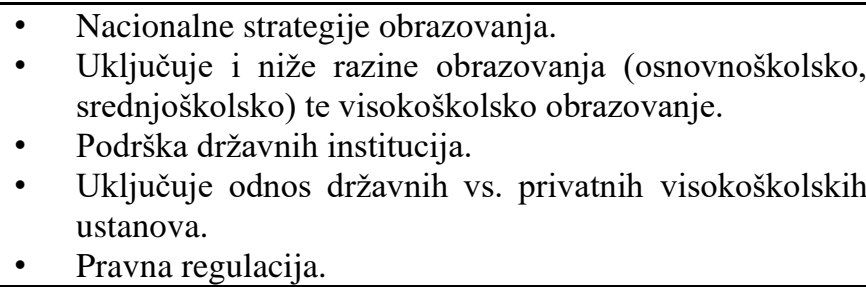 \\
\hline KČP 3 & Podrška vodstva visokih učilišta & 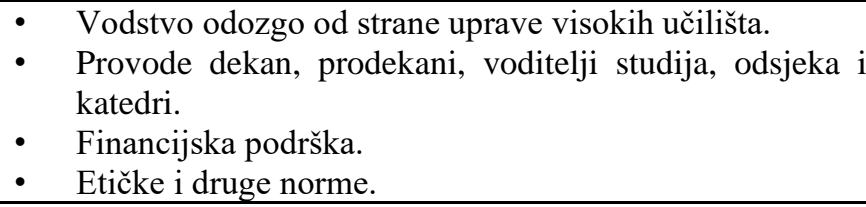 \\
\hline KČP 4 & Strategija upravljanja znanjem & $\begin{array}{l}\text { Promjena od tradicionalnog ka inovativnim oblicima } \\
\text { učenja i poučavanja. } \\
\text { - Usklađivanje strategije korištenja DM s poslovnim } \\
\text { modelom i postojećim sustavima i procesima VU. } \\
\text { - Komuniciranje strategije korištenja DM svim dionicima. } \\
\text { - Internacionalizacija (povezivanje s drugim EU i } \\
\text { svjetskim visokoim učilištima). } \\
\text { Primjeri dobre prakse. }\end{array}$ \\
\hline KČP 5 & Metrike uspješnosti & $\begin{array}{l}\text { - Uspostava ključnih indikatora uspješnosti korištenja DM } \\
\text { u visokom obrazovanju kako bi se mogao pratiti napredak } \\
\text { i olakšalo kontinuirano poboljšavanje. } \\
\text { Ovisno i prilagođeno o cilju (privlačenje odnosno } \\
\text { regrutacija novih studenata, brendiranje odnosno } \\
\text { povećanje ugleda ustanove, povećanje uspjeha studenata, } \\
\text { suradnja sa zajednicom...). }\end{array}$ \\
\hline KČP 6 & Infrastruktura upravljanja znanjem & $\begin{array}{l}\text { - } \quad \text { Vlasništvo nad DM odnosno licencama. } \\
\text { - Tehnička podrška; stvaranje namjenskih uloga za } \\
\text { filtriranje, ažuriranje i održavanje DM. } \\
\text { - Režimi obuke za korištenje DM. } \\
\text { - Prepoznavanje i upravljanje rizicima. }\end{array}$ \\
\hline KČP 7 & Motivacija nastavnika & $\begin{array}{l}\text { - Poticajni programi koji nagrađuju zaposlenike koji } \\
\text { koriste / doprinose za DM. } \\
\text { - Svo osoblje (nastavnici, vanjski suradnici) koristi DM. } \\
\text { Integriranje korištenja DM s ocjenom uspješnosti } \\
\text { plaćom. }\end{array}$ \\
\hline КČP 8 & Očekivanja studenata & $\begin{array}{ll} & \text { Ne poznaju svijet bez tehnologije. } \\
\text { - } & \text { Predstavljaju novi tip studenata. } \\
\text { - } & \text { Komu nove načine. } \\
& \text { Komiciraju i surađuju na nove načine. }\end{array}$ \\
\hline KČP 9 & Kultura razmjene znanja & $\begin{array}{l}\text { - Sustavna edukacija o korištenju DM. } \\
\text { - Svo osoblje treba stalno biti informirano o novim } \\
\text { saznanjima o korištenju DM za potrebe visokog } \\
\text { obrazovanja, npr. mjesečne sesije dijeljenja znanja. } \\
\text { - Proslava uspjeha i učenje iz neuspjeha. } \\
\text { - Kultura suradnje, koja nije konkurentna. }\end{array}$ \\
\hline KČP 10 & Dostupnost resursa & $\begin{array}{ll}\text { - } & \text { Financijska sredstva i izvori. } \\
\text { Raspodjela vremena odnosno predviđeno vrijeme za } \\
\text { aktivnosti povezane sa korišstenjem DM. }\end{array}$ \\
\hline
\end{tabular}




\begin{tabular}{|llll|}
\hline & & & Administrativna korisnička podrška. \\
\hline KČP 11 & Kvaliteta društvenih medija & $\bullet$ & Jednostavnost korištenja DM. \\
& & & Pouzdanost korištenja DM. \\
& & Redovitost ažuriranja DM kako bi odražavalo trenutno \\
& & znanje. \\
& & Odgovarajuće povezivanje DM s drugim alatima \\
& & (interoperabilnost). \\
\hline KČP 12 & Društvo u cjelini & & \\
& & & Preporuke poslodavaca. \\
& & & Privlačenje investitora. \\
& & Kulturološke razlike. \\
& & Konkurencija. \\
& & Privatni utjecaji (prisutnost prijatelja i obitelji na DM). \\
& & Viša sila, npr. pandemija korona virusa Covid-19. \\
\hline
\end{tabular}

1. Molimo Vas da navedete stupanj važnosti KČP 1: Razvoj tehnologija!

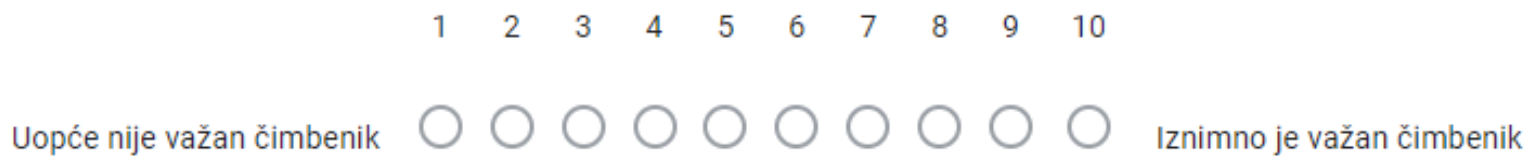

2. Molimo Vas da navedete stupanj važnosti KČP 2: Nacionalne politike/strategije obrazovanja!

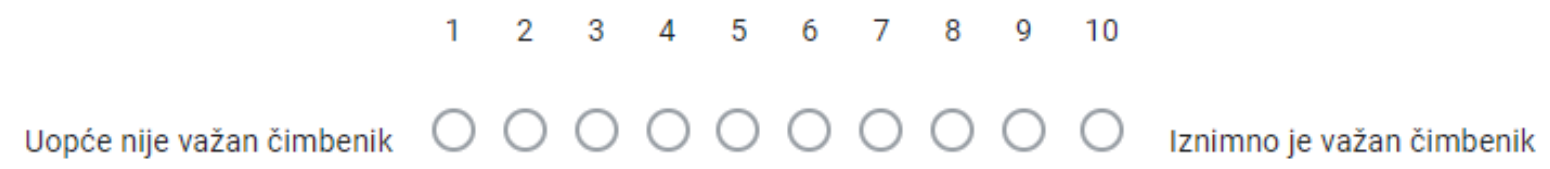

3. Molimo Vas da navedete stupanj važnosti KČP 3: Podrška vodstva visokih učilišta!

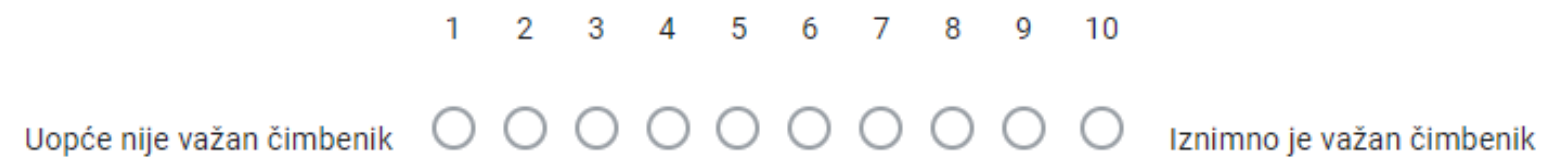

4. Molimo Vas da navedete stupanj važnosti KČP 4: Strategija upravljanja znanjem!

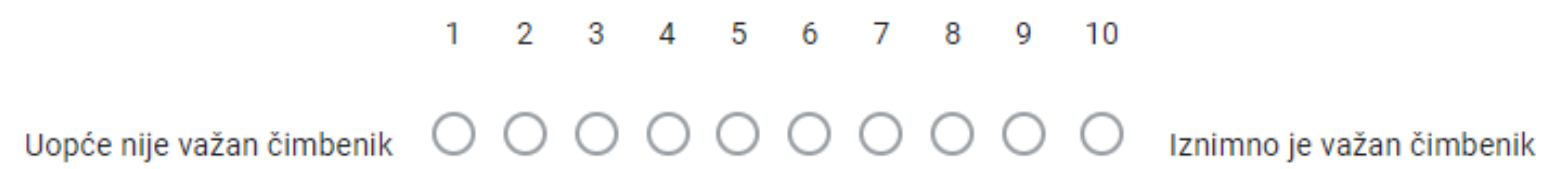

5. Molimo Vas da navedete stupanj važnosti KČP 5: Metrike uspješnosti!

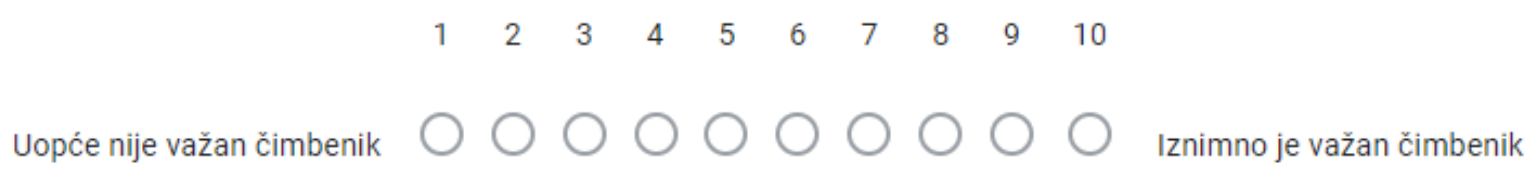

6. Molimo Vas da navedete stupanj važnosti KČP 6: Infrastruktura upravljanja znanjem! 
Uopće nije važan čimbenik $\bigcirc \bigcirc \bigcirc \bigcirc \bigcirc \bigcirc \bigcirc \bigcirc \bigcirc$ Iznimno je važan čimbenik

7. Molimo Vas da navedete stupanj važnosti KČP 7: Motivacija nastavnika!

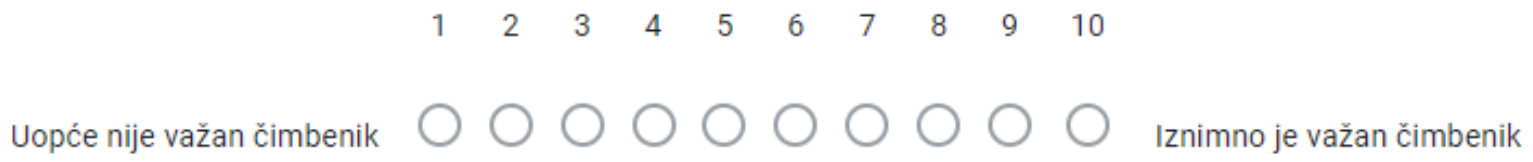

8. Molimo Vas da navedete stupanj važnosti KČP 8: Očekivanja studenata!

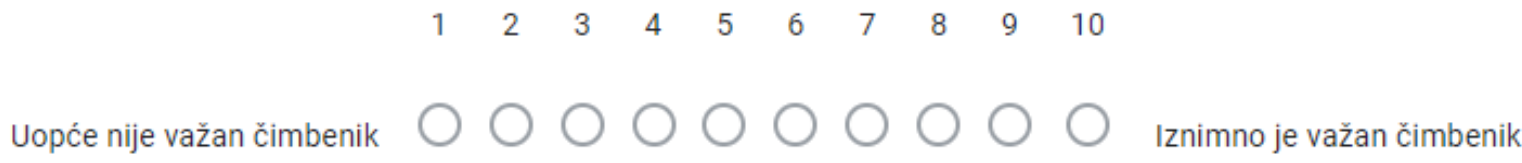

9. Molimo Vas da navedete stupanj važnosti KČP 9: Kultura razmjene znanja!

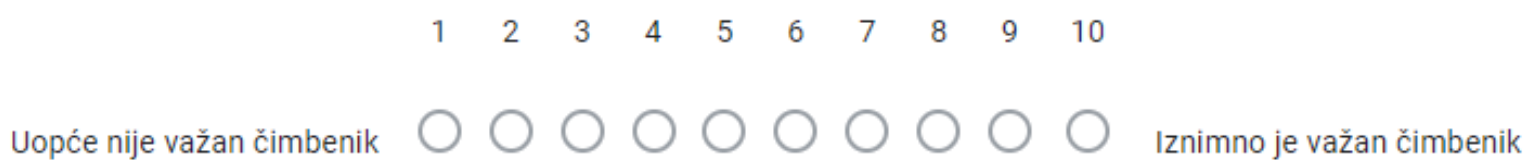

10. Molimo Vas da navedete stupanj važnosti KČP 10: Dostupnost resursa!

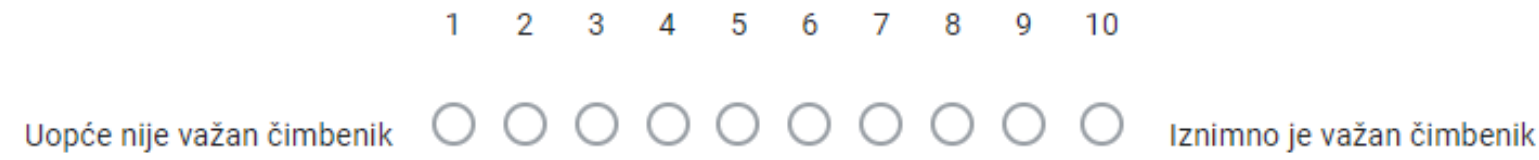

11. Molimo Vas da navedete stupanj važnosti KČP 11: Kvaliteta društvenih medija!

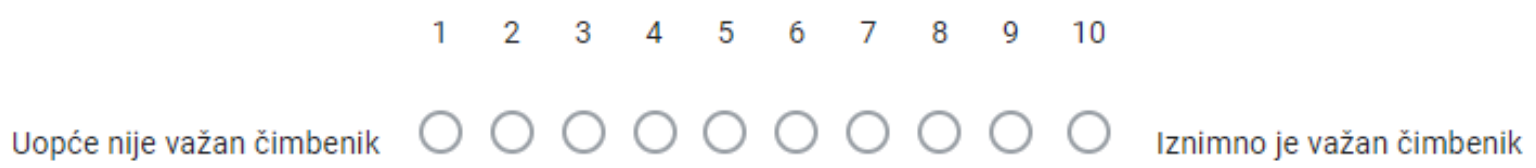

12. Molimo Vas da navedete stupanj važnosti KČP 12: Društvo u cjelini!

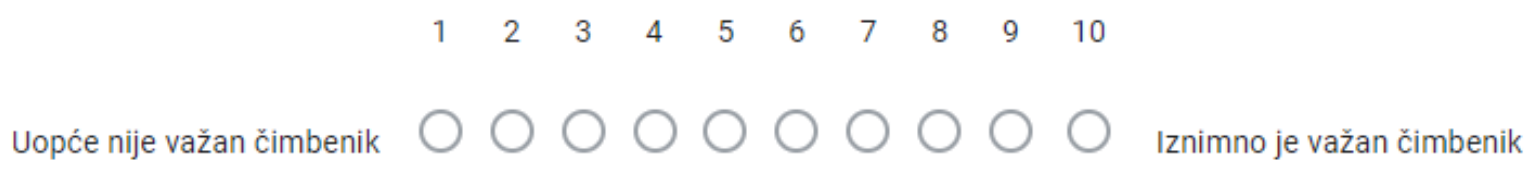

Bilješke (ovo je za bilo koji komentar koji želite, ali ne morate, dodati) 
Hvala Vam što ste sudjelovali u Drugom krugu delfi studije na temu: Promjena komunikacijske paradigme u visokom obrazovanju pod utjecajem društvenih medija.

Istraživačica:

Tihana Babić, prof. 


\section{Prilog 12. - Prikaz „,Treća uputa panelistima o sudjelovanju u istraživanju“"}

Poštovani/Poštovana,

pozivamo Vas da u svojstvu panelista, sudjelujete u Trećem i zadnjem krugu istraživanja koje se provodi u sklopu izrade doktorske disertacije Tihane Babić, prof. na Filozofskom fakultetu, pod naslovom „Promjena komunikacijske paradigme u visokom obrazovanju pod utjecajem društvenih medija“ (mentorice: prof. dr. sc. Gordana Vilović i prof. dr. sc. Ljubica Bakić-Tomić).

Hvala Vam što ste popunili upitnike u Prvom i Drugom krugu delfi studije. Na temelju Vaših odgovora u Prvom krugu istraživanja, izdvojeno je ukupno 12 ključnih čimbenika promjene (KČP), koji bi mogli utjecati na komunikacijske paradigme putem društvenih medija (DM) za potrebe visokog obrazovanja. U ovom, posljednjem krugu molimo Vas da, prema Vašoj procjeni, a u svrhu postizanja mogućeg konsenzusa, ponovno označite stupanj važnosti pojedinih čimbenika.

Na linku: UPITNIK 3 nalaze pitanja iz 3. kruga istraživanja, te Vas molimo da na njih odgovorite sada. Za ispunjavanje upitnika potrebno je približno 10 minuta.

Molimo da dostavite ispunjeni upitnik u roku od 7 dana od primitka upitnika, ako je ikako moguće. Unaprijed hvala na Vašem vremenu i doprinosu. Ako imate bilo kakvih pitanja o istraživanju, molimo ne ustručavajte se kontaktirati istraživačicu.

U Zagrebu, 7. rujna, 2020.

Istraživačica:

Tihana Babić, prof. 


\title{
Prilog 13. - Prikaz „Upitnik 3“ - Instrument delfi studija - treći krug istraživanja
}

\author{
Tema istraživanja: Promjena komunikacijske paradigme u visokom obrazovanju pod utjecajem društvenih \\ medija \\ Istraživačica: Tihana Babić, prof.
}

\section{UPITNIK O KORIŠTENJU DRUŠTVENIH MEDIJA ZA POTREBE VISOKOG OBRAZOVANJA - TRECI KRUG}

\begin{abstract}
Poštovani / Poštovana, pred Vama je upitnik o korištenju društvenih medija za potrebe visokog obrazovanja. Molim Vas da pažljivo pročitate i iskreno odgovorite na pitanja jer sudjelujete u znanstvenom istraživanju!
\end{abstract}

Unaprijed Vam zahvaljujem na iskrenim odgovorima i suradnji!

Tihana Babić, prof.

doktorandica Filozofskog fakulteta u Zagrebu

\section{MOLIMO DOPUNITE:}

Vaše ime i prezime je? (traži se samo za potrebe praćenja ispunjenosti upitnika, osobni podaci bit će poznati samo istraživačici, a bit će nepoznati ostalim panelistima te anonimizirani u rezultatima istraživanja)

\section{„LIKERTOVA SKALA PROCJENE (VAŽNOSTI) “U SVRHU MOGUĆEG POSTIZANJA KONSENZUSA}

Na temelju Vaših odgovora u Prvom krugu istraživanja, izdvojeno je ukupno 12 ključnih čimbenika promjene (KČP), koji bi mogli utjecati na komunikacijsku paradigmu putem društvenih medija (DM) za potrebe visokog obrazovanja. U ovom, posljednjem krugu molimo Vas da, prema Vašoj procjeni, a u svrhu postizanja mogućeg konsenzusa, ponovno označite stupanj važnosti pojedinih čimbenika!

12 ključnih čimbenika promjene (KČP):

KČP 1: Razvoj tehnologija

KČP 2: Nacionalne politike/strategije obrazovanja

KČP 3: Podrška vodstva visokih učilišta

KČP 4: Strategija upravljanja znanjem

KC̆P 5: Metrike uspješnosti

KČP 6: Infrastruktura upravljanja znanjem

KC̆P 7: Motivacija nastavnika

KČP 8: Očekivanja studenata

KČP 9: Kultura razmjene znanja

KC̆P 10: Dostupnost resursa

KČP 11: Kvaliteta društvenih medija

KČP 12: Društvo u cjelini

Kratki opis 12 ključnih čimbenika promjene (KČP): 


\begin{tabular}{|c|c|c|}
\hline Broj & $\begin{array}{l}\text { Ključni čimbenici promjene } \\
\text { komunikacijske paradigme u VO } \\
\text { pod utjecajem DM }\end{array}$ & Opis \\
\hline KČP 1 & Razvoj tehnologija & $\begin{array}{ll}\text { - } & \text { Digitalna transformacija društva. } \\
\text { - } & \text { Masovnije korištenje tehnologije, alata i aplikacija. } \\
\text { - } & \text { Veća dostupnost tehnologija u visokom obrazovanju. } \\
\text { - } & \text { Veća interaćnostivi, personalizacija aplikacija i sadržaja. } \\
\text { - } & \text { Veća interoperabilnost među sustavima i alatima. }\end{array}$ \\
\hline KČP 2 & $\begin{array}{l}\text { Nacionalne politike/ } \\
\text { strategije obrazovanja }\end{array}$ & $\begin{array}{ll}\text { - } & \text { Nacionalne strategije obrazovanja. } \\
\text { - Uključuje i niže razine obrazovanja (osnovnoškolsko, } \\
\text { srednjoškolsko) te visokoškolsko obrazovanje. } \\
\text { - Podrška državnih institucija. } \\
\text { - Uključuje odnos državnih vs. privatnih visokoškolskih } \\
\text { ustanova. } \\
\text { - Pravna regulacija. }\end{array}$ \\
\hline KČP 3 & Podrška vodstva visokih učilišta & $\begin{array}{l}\text { - Vodstvo odozgo od strane uprave visokih učilišta. } \\
\text { - } \\
\text { katedri. } \\
\text { - } \\
\text { - } \\
\text { Etinancičke i druge norme. } \\
\end{array}$ \\
\hline KČP 4 & Strategija upravljanja znanjem & $\begin{array}{l}\text { Promjena od tradicionalnog ka inovativnim oblicima } \\
\text { učenja i poučavanja. } \\
\text { - Usklađivanje strategije korištenja DM s poslovnim } \\
\text { modelom i postojećim sustavima i procesima VU. } \\
\text { - Komuniciranje strategije korištenja DM svim dionicima. } \\
\text { - Internacionalizacija (povezivanje s drugim EU i } \\
\text { svjetskim visokim učilištima). } \\
\text { Primjeri dobre prakse. }\end{array}$ \\
\hline KČP 5 & Metrike uspješnosti & $\begin{array}{l}\text { - Uspostava ključnih indikatora uspješnosti korištenja DM } \\
\text { u visokom obrazovanju kako bi se mogao pratiti napredak } \\
\text { i olakšalo kontinuirano poboljšavanje. } \\
\text { Ovisno i prilagođeno o cilju (privlačenje odnosno } \\
\text { regrutacija novih studenata, brendiranje odnosno } \\
\text { povećanje ugleda ustanove, povećanje uspjeha studenata, } \\
\text { suradnja sa zajednicom...). }\end{array}$ \\
\hline KČP 6 & Infrastruktura upravljanja znanjem & $\begin{array}{l}\text { - Vlasništvo nad DM odnosno licencama. } \\
\text { - Tehnička podrška; stvaranje namjenskih uloga za } \\
\text { filtriranje, ažuriranje i održavanje DM. } \\
\text { - Režimi obuke za korištenje DM. } \\
\text { - Prepoznavanje i upravljanje rizicima. }\end{array}$ \\
\hline KČP 7 & Motivacija nastavnika & $\begin{array}{l}\text { - Poticajni programi koji nagrađuju zaposlenike koji } \\
\text { koriste / doprinose za DM. } \\
\text { - Svo osoblje (nastavnici, vanjski suradnici) koristi DM. } \\
\text { - Integriranje korištenja DM s ocjenom uspješnosti } \\
\text { plaćom. }\end{array}$ \\
\hline КČP 8 & Očekivanja studenata & $\begin{array}{ll}\text { - } & \text { Ne poznaju svijet bez tehnologije. } \\
\text { - } & \text { Predstavljaju novi tip studenata. } \\
\text { - } & \text { Uče na nove načine. } \\
\text { - } & \text { Komuniciraju i surađuju na nove načine. } \\
\end{array}$ \\
\hline KČP 9 & Kultura razmjene znanja & $\begin{array}{l}\text { - Sustavna edukacija o korištenju DM. } \\
\text { - Svo osoblje treba stalno biti informirano o novim } \\
\text { saznanjima o korištenju DM za potrebe visokog } \\
\text { obrazovanja, npr. mjesečne sesije dijeljenja znanja. } \\
\text { - Proslava uspjeha i učenje iz neuspjeha. } \\
\text { - Kultura suradnje, koja nije konkurentna. }\end{array}$ \\
\hline KČP 10 & Dostupnost resursa & $\begin{array}{ll}\text { - } & \text { Financijska sredstva i izvori. }\end{array}$ \\
\hline
\end{tabular}




\begin{tabular}{|c|c|}
\hline & $\begin{array}{l}\text { - Raspodjela vremena odnosno predviđeno vrijeme za } \\
\text { aktivnosti povezane sa korištenjem DM. } \\
\text { - Administrativna korisnička podrška. }\end{array}$ \\
\hline KČP 11 Kvaliteta društvenih medija & $\begin{array}{ll} & \text { Jednostavnost korištenja DM. } \\
\text { - } & \text { Pouzdanost korištenja DM. } \\
\text { Redovitost ažuriranja DM kako bi odražavalo trenutno } \\
\text { znanje. } \\
\begin{array}{l}\text { Odgovarajuće povezivanje DM s drugim alatima } \\
\text { (interoperabilnost). }\end{array} \\
\end{array}$ \\
\hline KČP 12 Društvo u cjelini & $\begin{array}{ll} & \text { Preporuke poslodavaca. } \\
\text { - } & \text { Privlačenje investitora. } \\
\text { - } & \text { Trendovi. } \\
\text { - } & \text { Kulturološke razlike. } \\
\text { - } & \text { Privatnu utjencija. } \\
\text { - } & \text { Viša sila, npr. pandemija korona virusa Covid-19. }\end{array}$ \\
\hline
\end{tabular}

1. Na pitanje „Molimo Vas da navedete stupanj važnosti KČP 1: Razvoj tehnologija!“ bilo je najviše odgovora (43\%) - stupanj važnosti 10. Molimo da razmotrite još jednom stupanj važnosti koji biste Vi dodijelili ovom faktoru te ga ponovno označite niže!

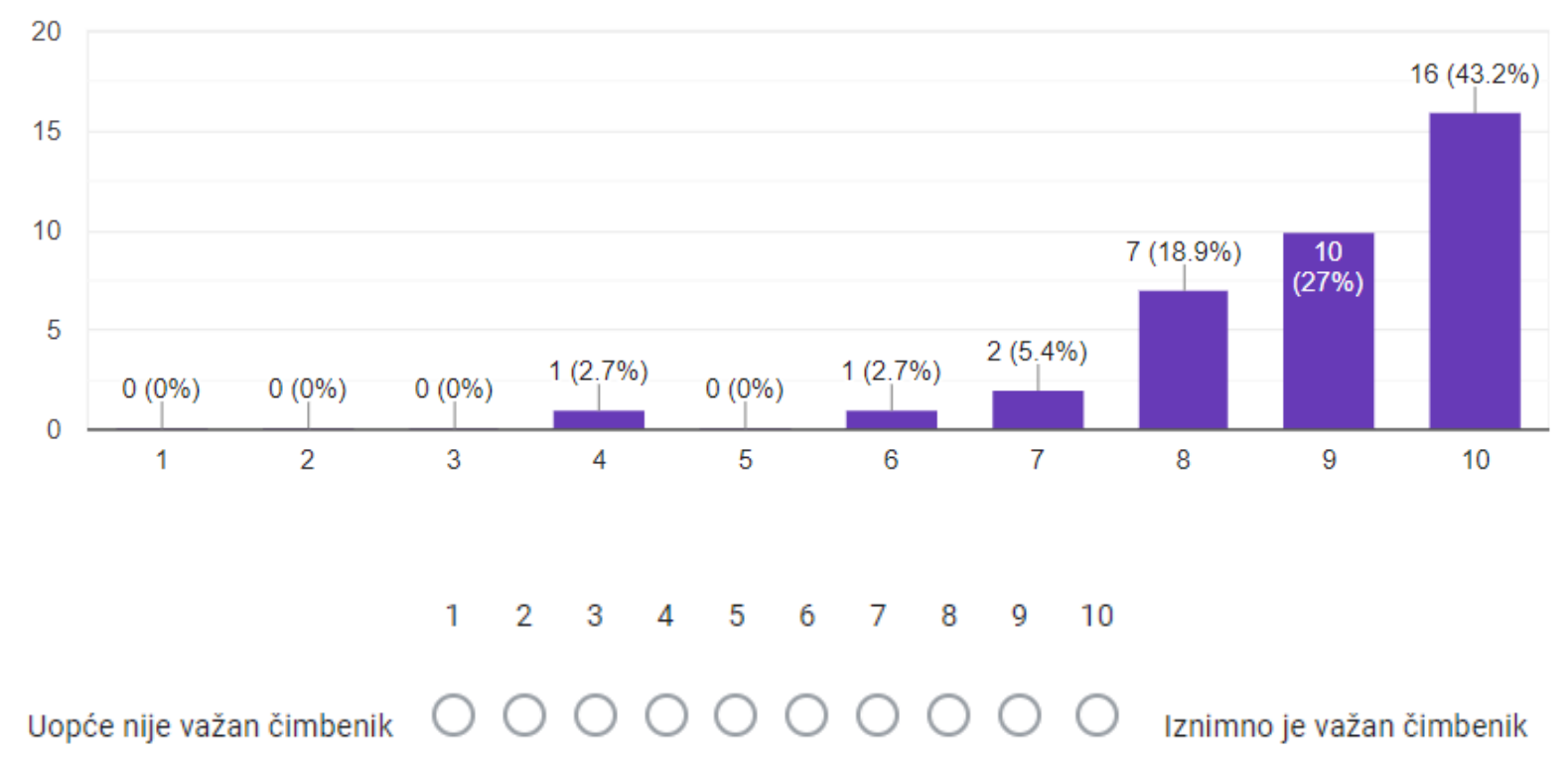

2. Na pitanje „Molimo Vas da navedete stupanj važnosti KČP 2: Nacionalne politike/strategije obrazovanja!"“ bilo je najviše odgovora (29.7 \%) - stupanj važnosti 10. Molimo da razmotrite još jednom stupanj važnosti koji biste Vi dodijelili ovom faktoru te ga ponovno označite niže! 


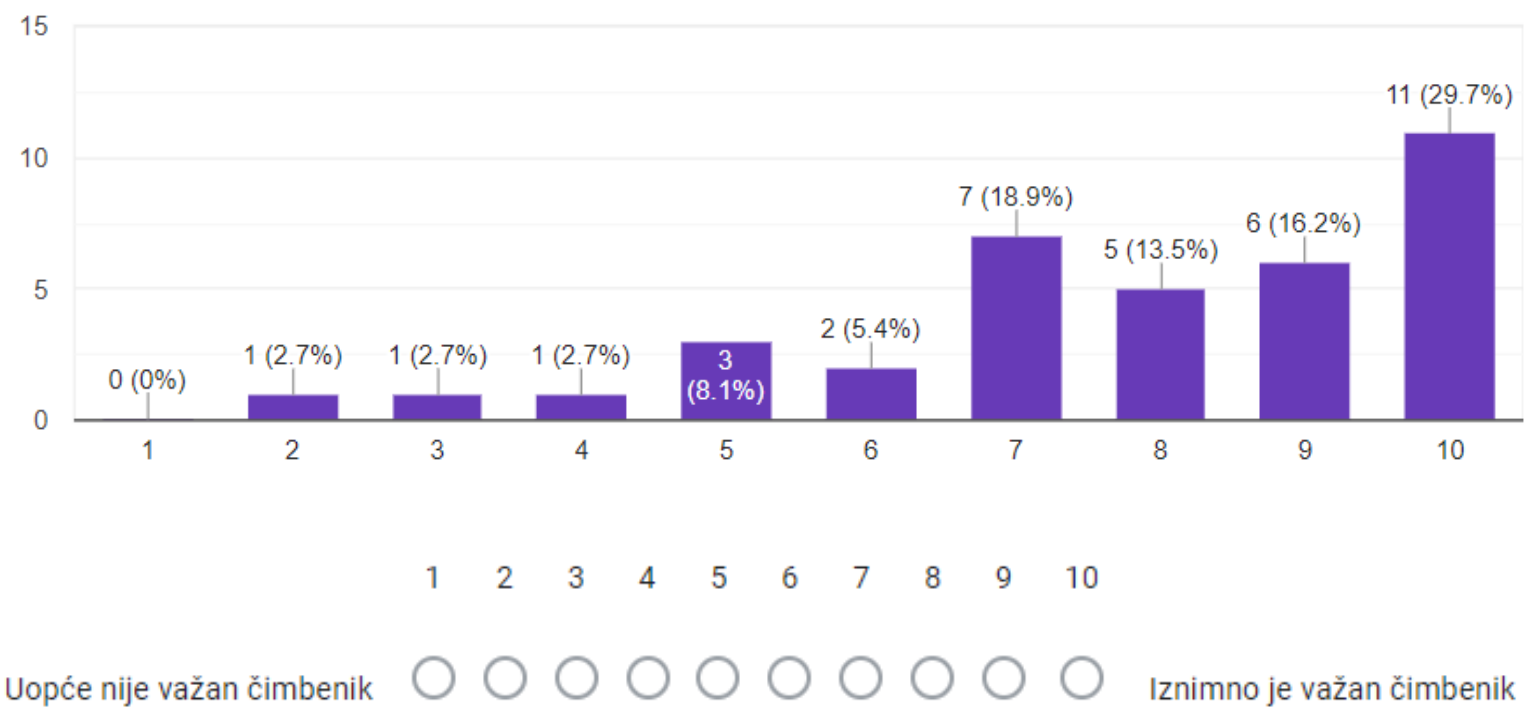

3. Na pitanje „Molimo Vas da navedete stupanj važnosti KČP 3: Podrška vodstva visokih učilišta!“ bilo je najviše odgovora (40.5 \%) - stupanj važnosti 10.Molimo da razmotrite još jednom stupanj važnosti koji biste Vi dodijelili ovom faktoru te ga ponovno označite niže!

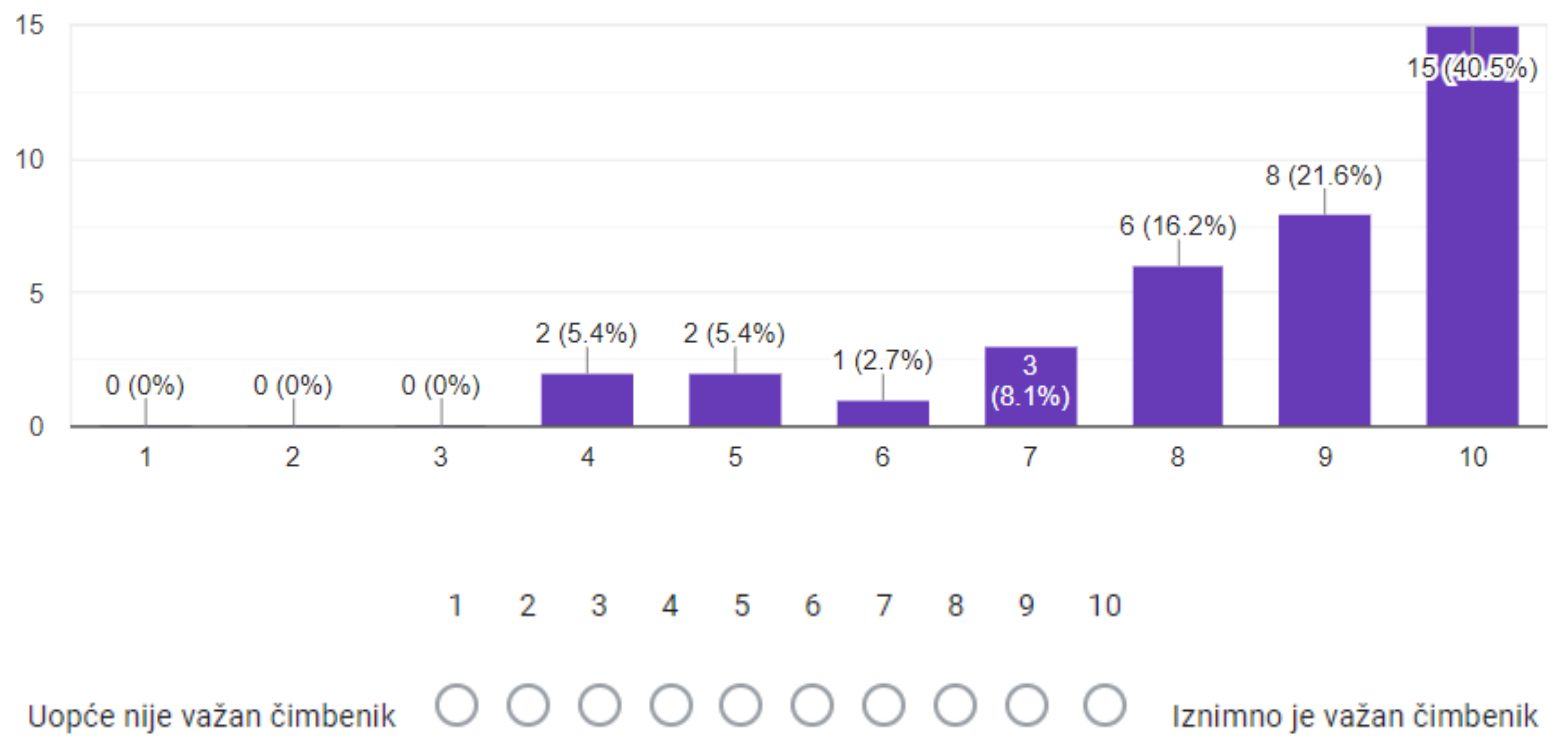

4. Na pitanje „Molimo Vas da navedete stupanj važnosti KČP 4: Strategija upravljanja znanjem!“ bilo je najviše odgovora $(27 \%)$ - stupanj važnosti 8 . Molimo da razmotrite još jednom stupanj važnosti koji biste Vi dodijelili ovom faktoru te ga ponovno označite niže! 


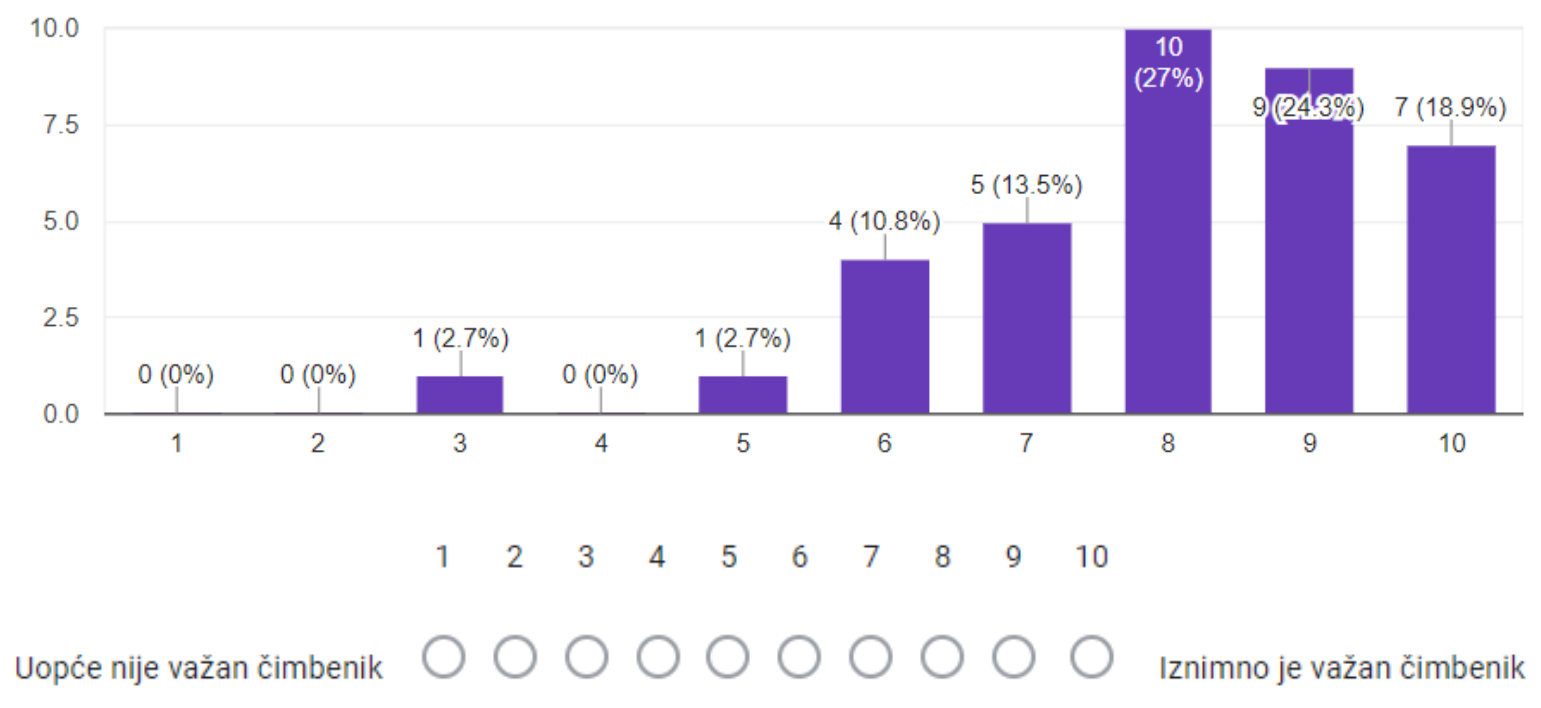

5. Na pitanje „Molimo Vas da navedete stupanj važnosti KČP 5: Metrike uspješnosti!“ bilo je najviše odgovora (29.7\%) - stupanj važnosti 8 . Molimo da razmotrite još jednom stupanj važnosti koji biste Vi dodijelili ovom faktoru te ga ponovno označite niže!

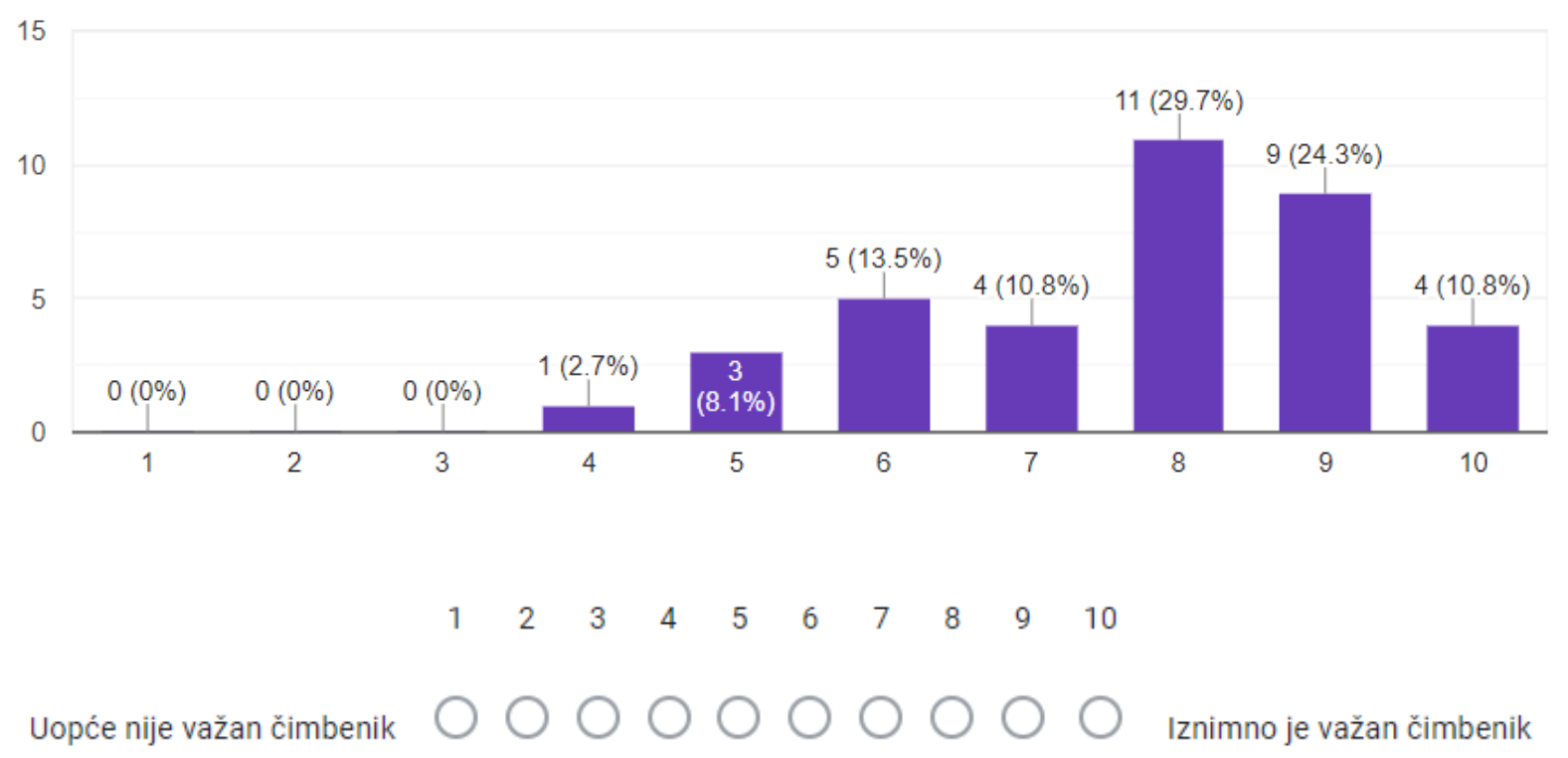

6. Na pitanje „Molimo Vas da navedete stupanj važnosti KČP 6: Infrastruktura upravljanja znanjem“" bilo je najviše odgovora (24.3\%) - stupanj važnosti 7. Molimo da razmotrite još jednom stupanj važnosti koji biste Vi dodijelili ovom faktoru te ga ponovno označite niže! 


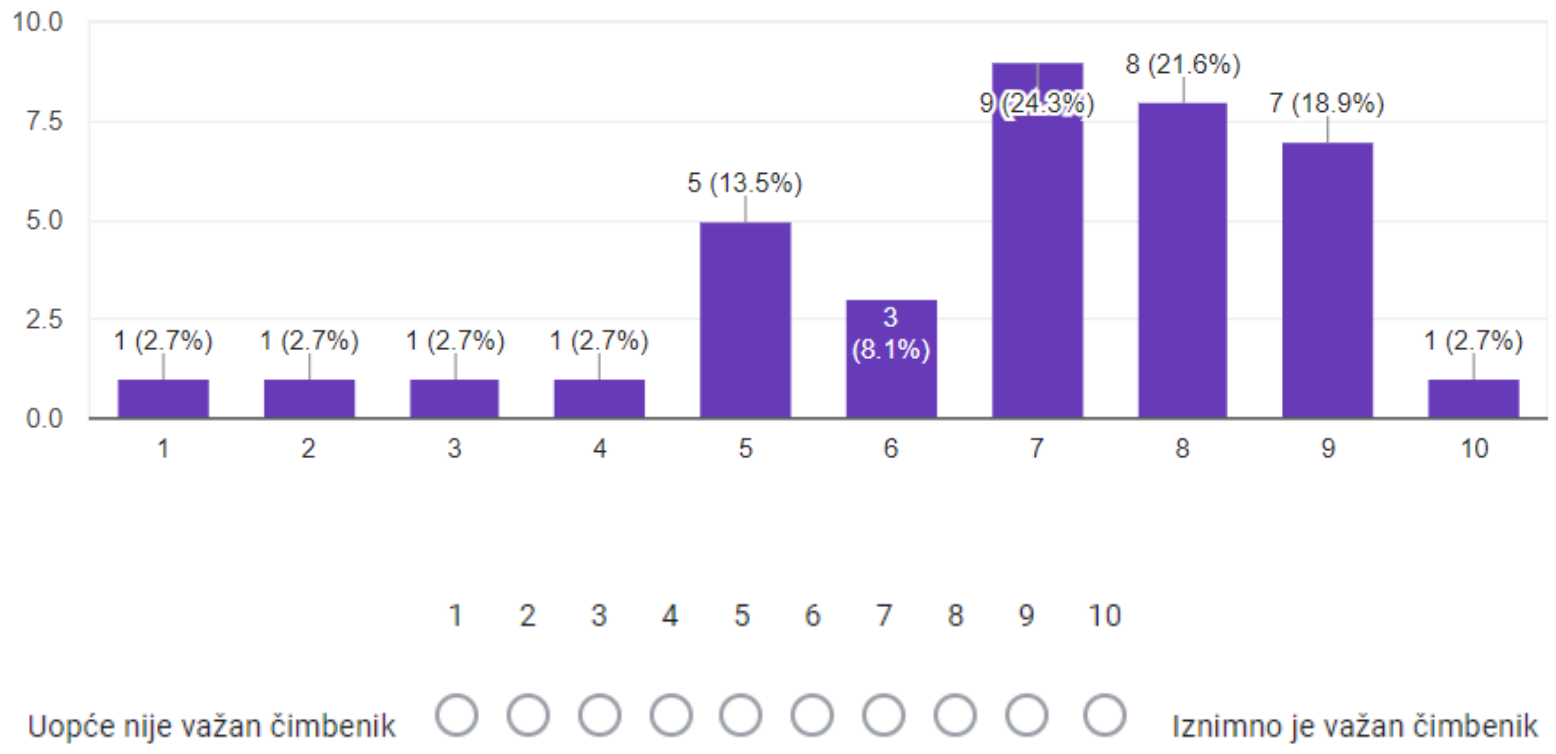

7. Na pitanje „Molimo Vas da navedete stupanj važnosti KČP 7: Motivacija nastavnika!“ bilo je najviše odgovora (35.1\%) - stupanj važnosti 10. Molimo da razmotrite još jednom stupanj važnosti koji biste Vi dodijelili ovom faktoru te ga ponovno označite niže!

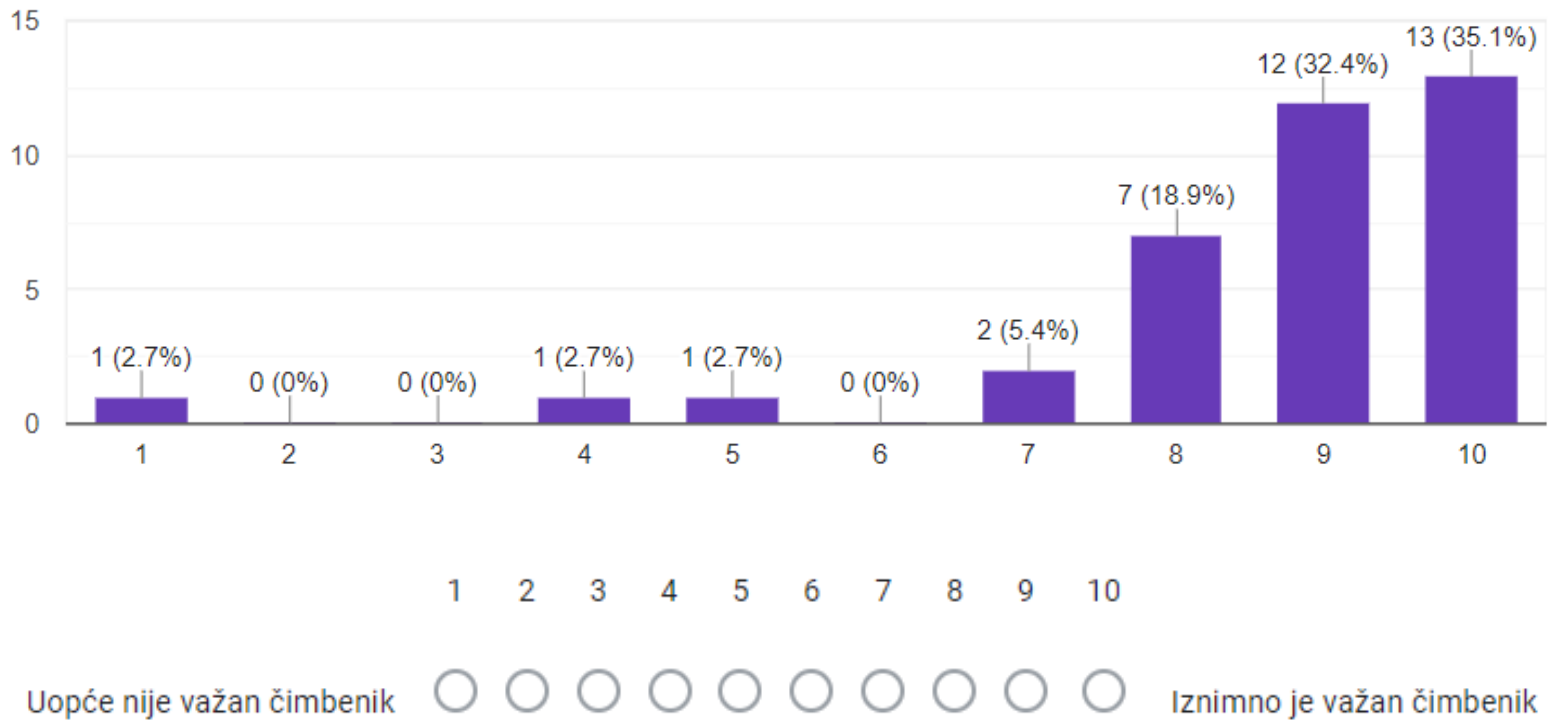

8. Na pitanje „Molimo Vas da navedete stupanj važnosti KČP 8: Očekivanja studenata!“ bilo je najviše odgovora (27 \%) - za dva stupnja važnosti 8 i 9 . Molimo da razmotrite još jednom stupanj važnosti koji biste Vi dodijelili ovom faktoru te ga ponovno označite niže! 


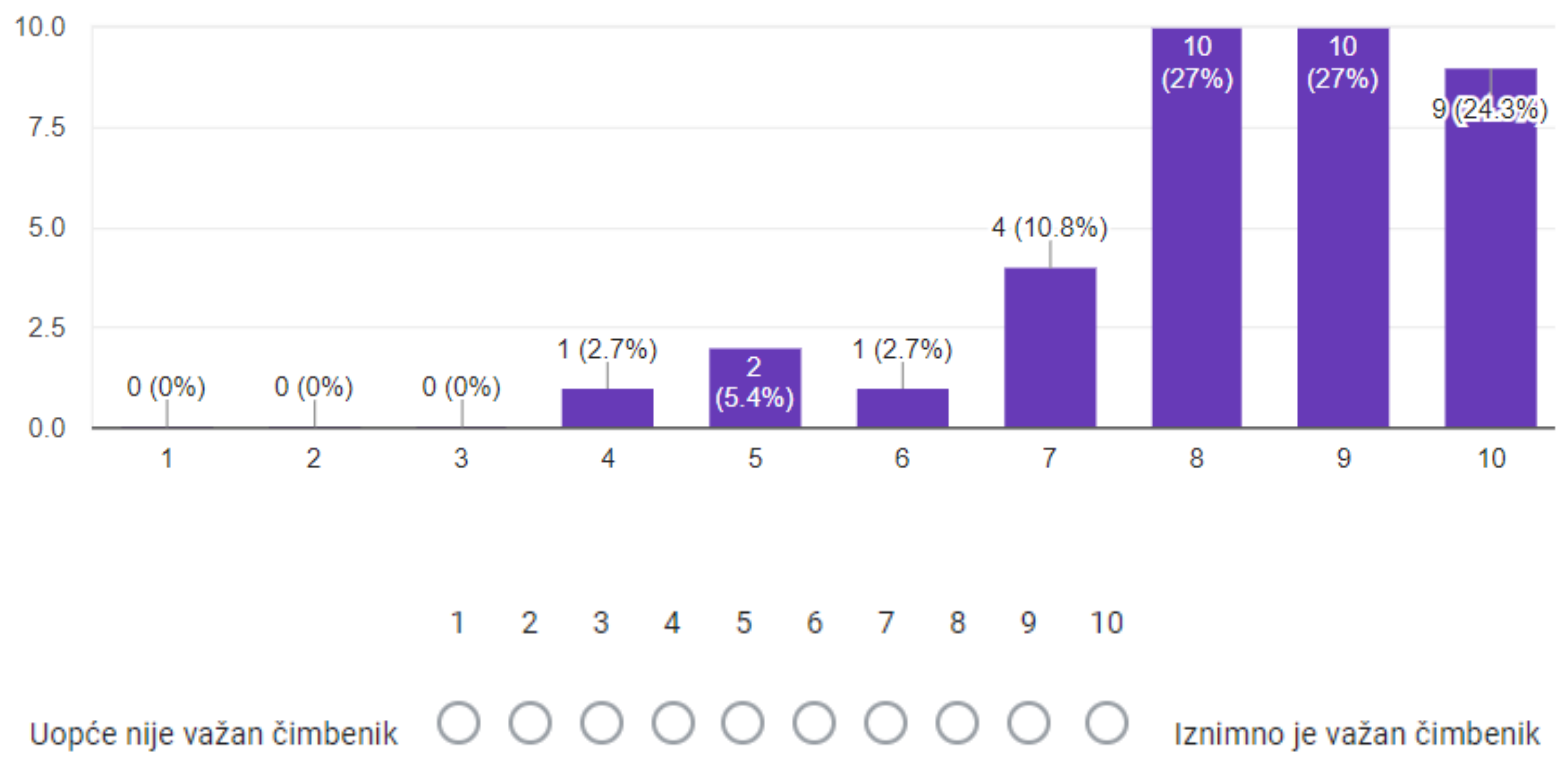

9. Na pitanje „Molimo Vas da navedete stupanj važnosti KČP 9: Kultura razmjene znanja!“ bilo je najviše odgovora (27\%) - stupanj važnosti 10. Molimo da razmotrite još jednom stupanj važnosti koji biste Vi dodijelili ovom faktoru te ga ponovno označite niže!

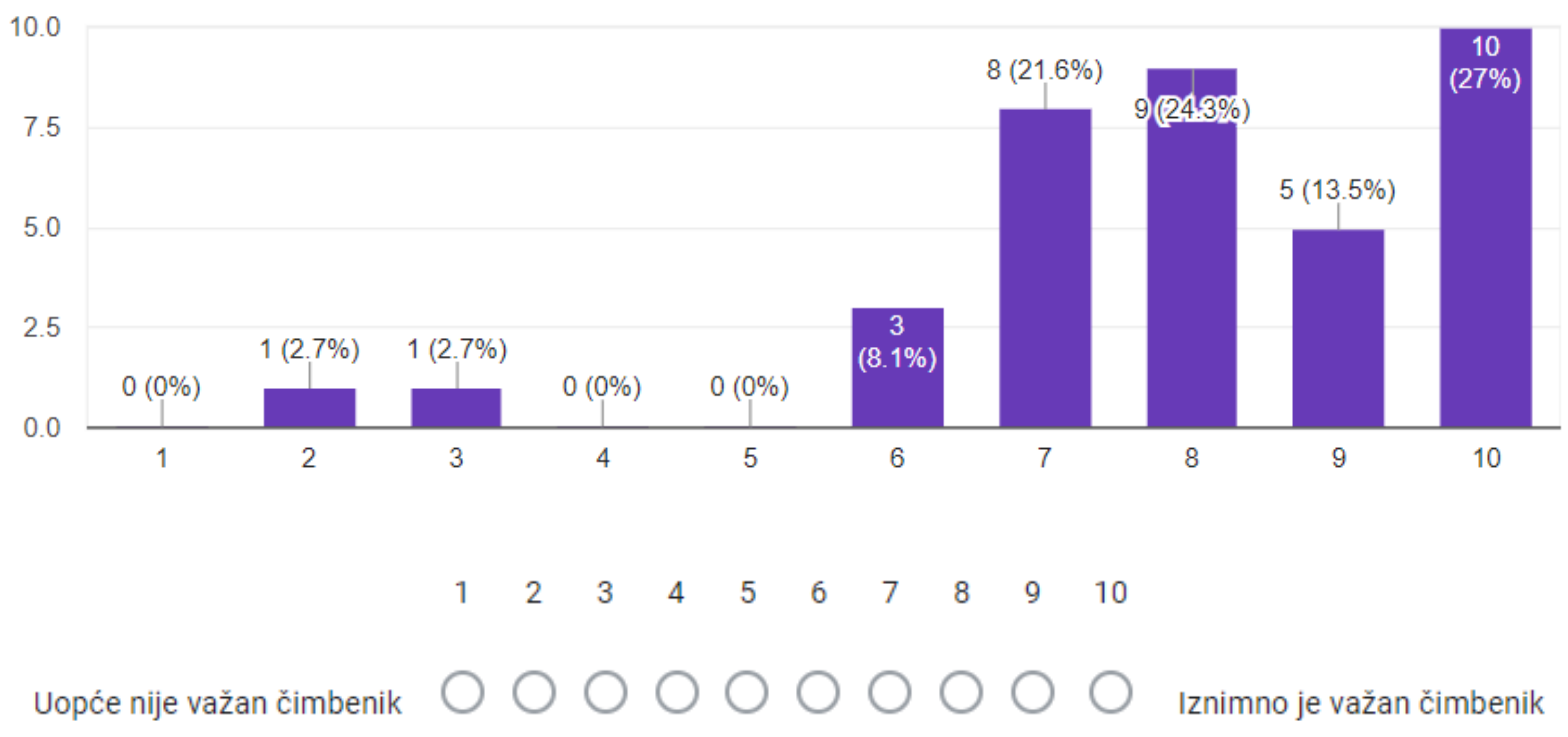

10. Na pitanje „Molimo Vas da navedete stupanj važnosti KČP 10: Dostupnost resursa!“ bilo je najviše odgovora (27 \%) - stupanj važnosti 9. Molimo da razmotrite još jednom stupanj važnosti koji biste Vi dodijelili ovom faktoru te ga ponovno označite niže! 


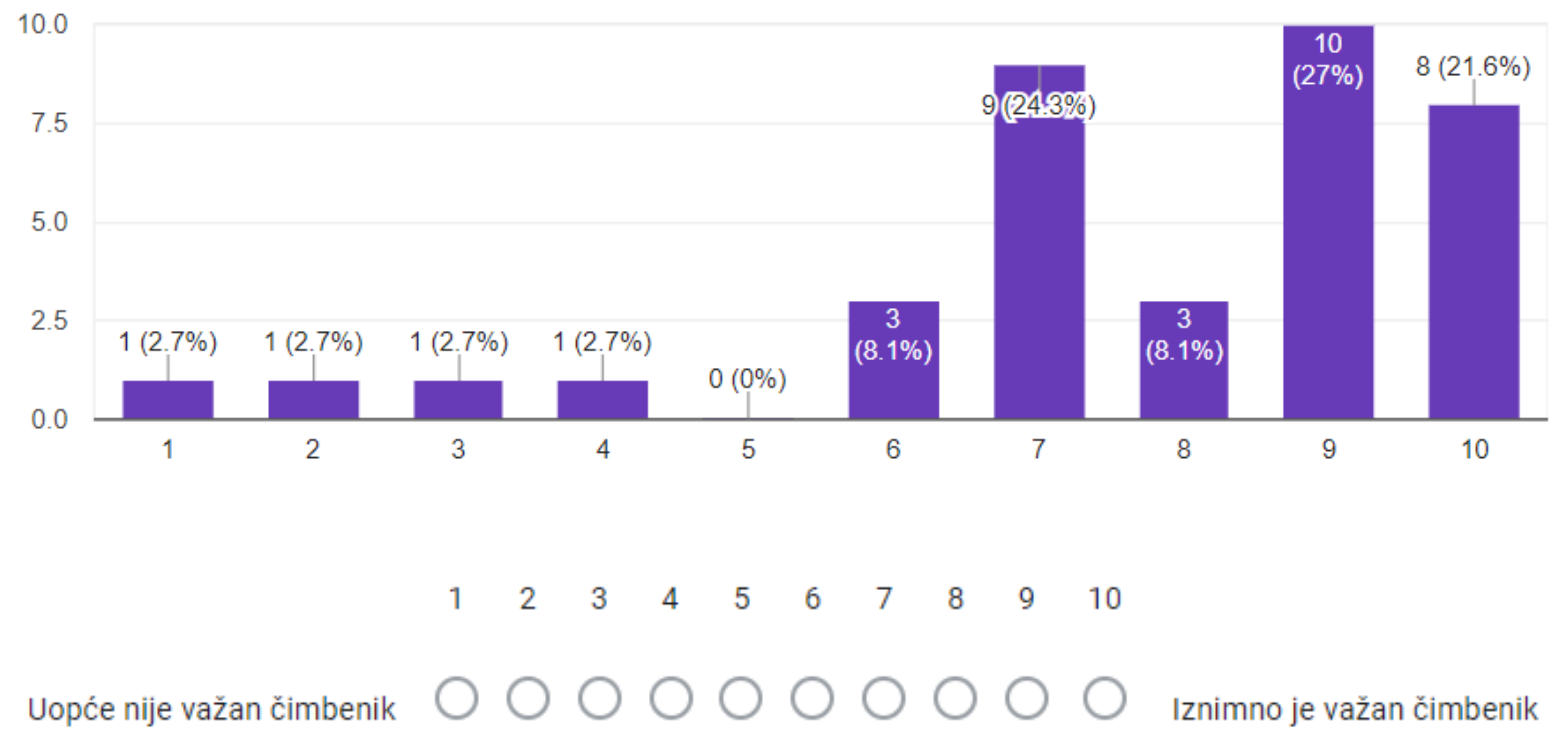

11. Na pitanje „Molimo Vas da navedete stupanj važnosti KČP 11: Kvaliteta društvenih medija!“ bilo je najviše odgovora (32.4 \%) - stupanj važnosti 8 . Molimo da razmotrite još jednom stupanj važnosti koji biste Vi dodijelili ovom faktoru te ga ponovno označite niže!

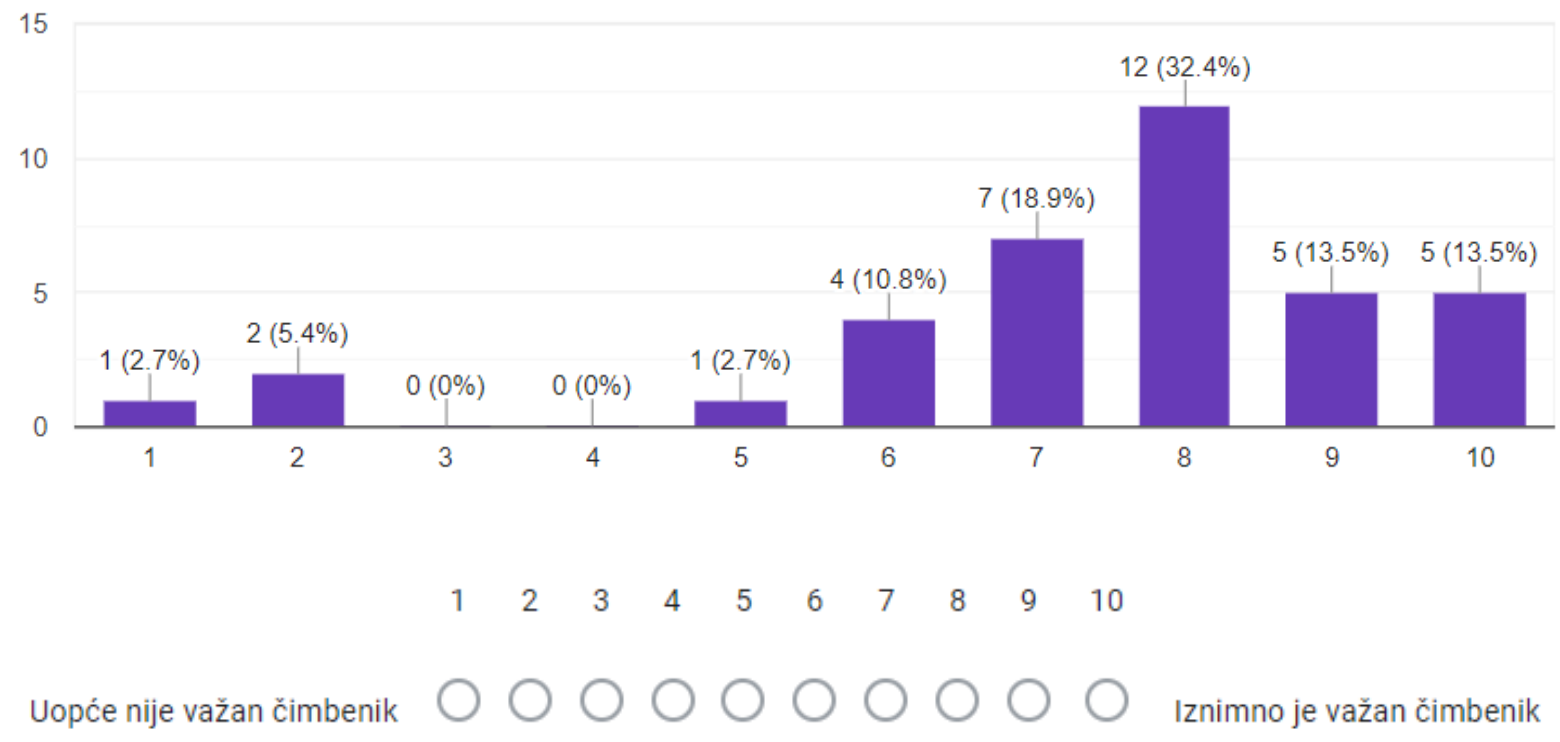

12. Na pitanje „Molimo Vas da navedete stupanj važnosti KC̆P 12: Društvo u cjelini!“ bilo je najviše odgovora $(24.3 \%)$ - stupanj važnosti 9. Molimo da razmotrite još jednom stupanj važnosti koji biste Vi dodijelili ovom faktoru te ga ponovno označite niže! 


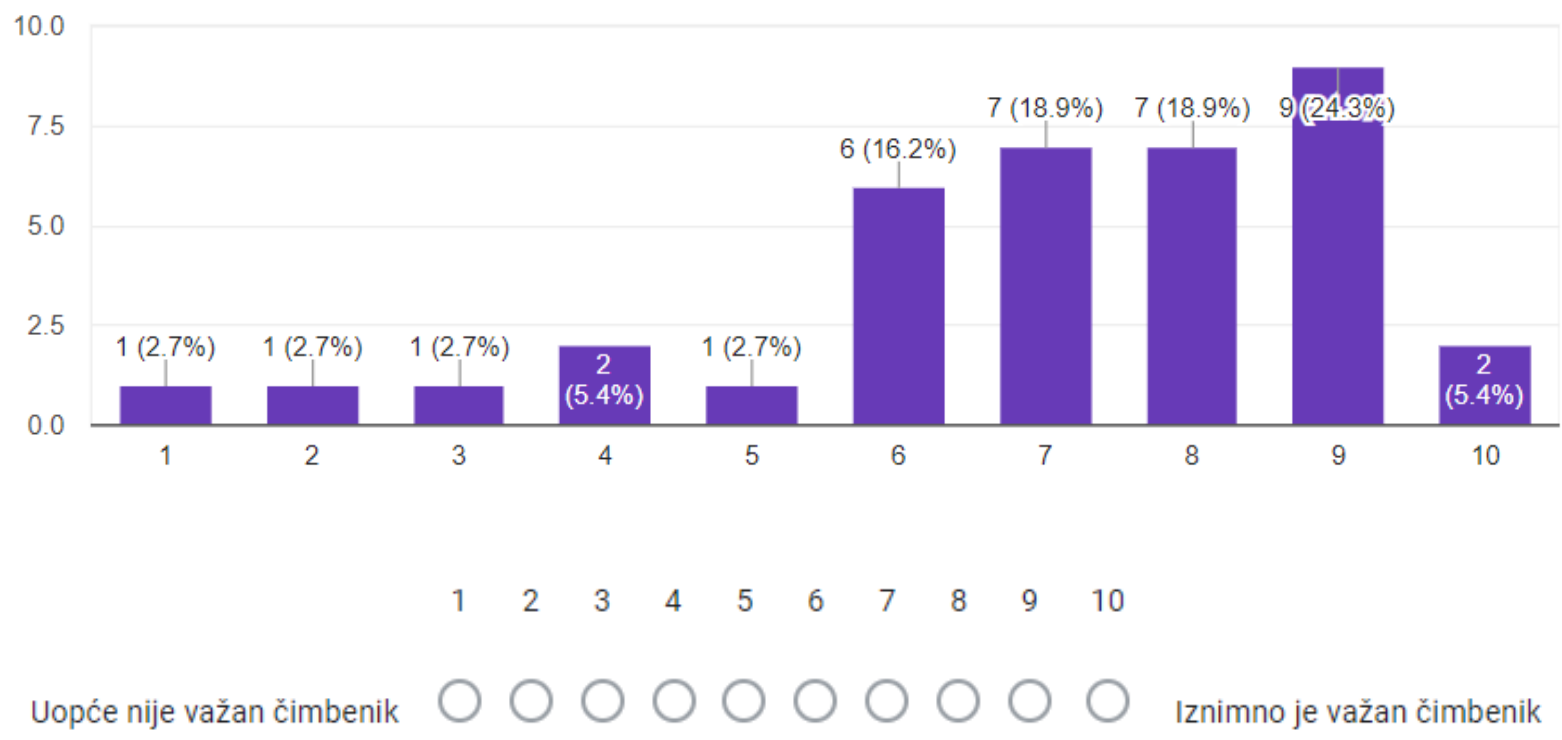

Bilješke (ovo je za bilo koji komentar koji želite, ali ne morate, dodati)

Hvala Vam što ste sudjelovali u Trećem krugu delfi studije na temu: Promjena komunikacijske paradigme u visokom obrazovanju pod utjecajem društvenih medija.

Istraživačica:

Tihana Babić, prof. 


\title{
Prilog 14. - Prikaz „Prezentacija rezultata“ - Instrument Sumarni prikaz rezultata delfi studije - četvrti krug istraživanja
}

\author{
Tema istraživanja: Promjena komunikacijske paradigme u visokom obrazovanju pod utjecajem društvenih \\ medija \\ Istraživačica: Tihana Babić, prof.
}

\section{PREZENTACIJA REZULTATA DELFI STUDIJE O PROMJENI KOMUNIKACIJSKE PARADIGME PUTEM DRUŠTVENIH MEDIJA ZA POTREBE VISOKOG OBRAZOVANJA - ČETVRTI KRUG}

\begin{abstract}
Poštovani / Poštovana, pred Vama je sumarni prikaz rezultata delfi studije o korištenju društvenih medija za potrebe visokog obrazovanja koji se temelje na ukupnim rezultatima Vaših i odgovorima drugih eksperata koji su sudjelovali u prethodna tri kruga ove delfi studije.

Najljepše se zahvaljujemo na suradnji i na Vašem sudjelovanju u ovom znanstvenom istraživanju! Tihana Babić, prof.

doktorandica Filozofskog fakulteta u Zagrebu
\end{abstract}

Konačni rang ključnih čimbenika promjene (KČP) komunikacijske paradigme u visokom obrazovanju pod utjecajem društvenih medija ove delfi studije, $\mathrm{N}=36$

\begin{tabular}{|c|c|c|}
\hline Rang & $\begin{array}{l}\text { Ključni čimbenici promjene } \\
\text { komunikacijske paradigme u VO } \\
\text { pod utjecajem DM }\end{array}$ & Opis \\
\hline 1 & Podrška vodstva visokih učilišta & $\begin{array}{l}\text { - } \text { Vodstvo odozgo od strane uprave visokih učilišta. } \\
\text { - } \\
\text { Provode dekan, prodekani, voditelji studija, odsjeka i } \\
\text { katedri. } \\
\text { - } \text { Financijska podrška. } \\
\text { - } \\
\text { Etičke i druge norme. }\end{array}$ \\
\hline 2 & Razvoj tehnologija & $\begin{array}{l}\text { - } \quad \text { Digitalna transformacija društva. } \\
\text { - } \quad \text { Masovnije korištenje tehnologije, alata i aplikacija. } \\
\text { - } \quad \text { Veća dostupnost tehnologija u visokom obrazovanju. } \\
\text { - } \quad \text { Više mogućnosti, personalizacija aplikacija i sadržaja. } \\
\text { - } \quad \text { Veća interaktivnost. } \\
\text { - Veća interoperabilnost među sustavima i alatima. }\end{array}$ \\
\hline 3 & Motivacija nastavnika & $\begin{array}{l}\text { - Poticajni programi koji nagrađuju zaposlenike koji } \\
\text { koriste / doprinose za DM. } \\
\text { - Svo osoblje (nastavnici, vanjski suradnici) koristi DM. } \\
\text { - Integriranje korištenja DM s ocjenom uspješnosti i } \\
\text { plaćom. }\end{array}$ \\
\hline 4 & $\begin{array}{l}\text { Nacionalne politike/ } \\
\text { strategije obrazovanja }\end{array}$ & $\begin{array}{l}\text { - } \quad \text { Nacionalne strategije obrazovanja. } \\
\text { - Uključuje i niže razine obrazovanja (osnovnoškolsko, } \\
\text { - } \quad \text { Prednjoškolsko) te visokoškolsko obrazovanje. } \\
\text { - } \quad \text { Uključuje odnos državnih vs. privatnih visokoškolskih } \\
\text { ustanova. } \\
\text { - Pravna regulacija. }\end{array}$ \\
\hline
\end{tabular}




\begin{tabular}{|c|c|c|}
\hline 5 & Kultura razmjene znanja & $\begin{array}{l}\text { - } \quad \text { Sustavna edukacija o korištenju DM. } \\
\text { - Svo osoblje treba stalno biti informirano o novim } \\
\text { saznanjima o korištenju DM za potrebe visokog } \\
\text { obrazovanja, npr. mjesečne sesije dijeljenja znanja. } \\
\text { - } \quad \text { Proslava uspjeha i učenje iz neuspjeha. } \\
\text { - } \quad \text { Kultura suradnje, koja nije konkurentna. }\end{array}$ \\
\hline 6 & Očekivanja studenata & $\begin{array}{ll} & \text { Ne poznaju svijet bez tehnologije. } \\
\text { - } & \text { Predstavljaju novi tip studenata. } \\
\text { - } & \text { Uče na nove načine. } \\
\text { - } & \text { Komuniciraju i surađuju na nove načine. } \\
\end{array}$ \\
\hline 7 & Dostupnost resursa & $\begin{array}{ll}\text { - } & \text { Financijska sredstva i izvori. } \\
\text { - } & \text { Raspodjela vremena odnosno predviđeno vrijeme za } \\
\text { aktivnosti povezane sa korištenjem DM. } \\
\text { - } \\
\text { Administrativna korisnička podrška. }\end{array}$ \\
\hline 8 & Društvo u cjelini & $\begin{array}{ll}\text { - } & \text { Preporuke poslodavaca. } \\
\text { - } & \text { Privlačenje investitora. } \\
\text { - } & \text { Trendovi. } \\
\text { - } & \text { Kulturološke razlike. } \\
\text { - } & \text { Konkurencija. } \\
\text { - } & \text { Privatni utjecaji (prisutnost prijatelja i obitelji na DM). } \\
\text { - Viša sila, npr. pandemija korona virusa Covid-19. }\end{array}$ \\
\hline 9 & Strategija upravljanja znanjem & 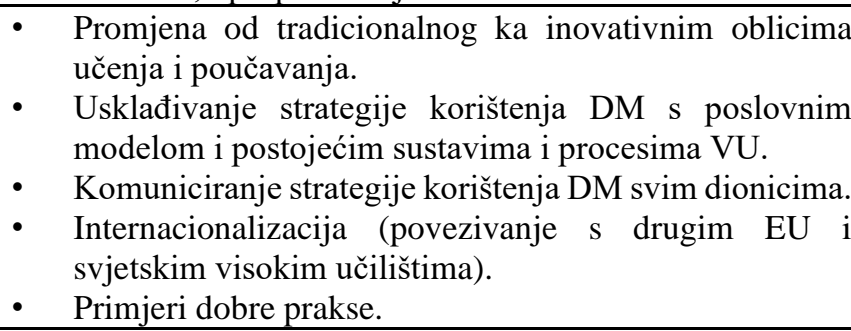 \\
\hline 10 & Metrike uspješnosti & $\begin{array}{l}\text { - Uspostava ključnih indikatora uspješnosti korištenja } \\
\text { DM u visokom obrazovanju kako bi se mogao pratiti } \\
\text { napredak i olakšalo kontinuirano poboljšavanje. } \\
\text { Ovisno i prilagođeno o cilju (privlačenje odnosno } \\
\text { regrutacija novih studenata, bradiranje odnosno } \\
\text { povećanje ugleda ustanove, povećanje uspjeha } \\
\text { studenata, suradnja sa zajednicom...). }\end{array}$ \\
\hline 11 & Kvaliteta društvenih medija & $\begin{array}{l}\text { - } \text { Jednostavnost korištenja DM. } \\
\text { - } \quad \text { Pouzdanost korištenja DM. } \\
\text { - Redovitost ažuriranja DM kako bi odražavalo trenutno } \\
\text { znanje. } \\
\text { Odgovarajuće povezivanje DM s drugim alatima } \\
\text { (interoperabilnost). }\end{array}$ \\
\hline 12 & Infrastruktura upravljanja znanjem & $\begin{array}{l}\text { - } \quad \text { Vlasništvo nad DM odnosno licencama. } \\
\text { - Tehnička podrška; stvaranje namjenskih uloga za } \\
\text { filtriranje, ažuriranje i održavanje DM. } \\
\text { - Režimi obuke za korištenje DM. } \\
\text { - } \quad \text { Prepoznavanje i upravljanje rizicima. } \\
\end{array}$ \\
\hline \multicolumn{3}{|c|}{$\begin{array}{l}\text { Ljestvica rangova na skali od } 1 \text { do 12: čimbenik pod brojem } 1 \text { ima najviši stupnj važnosti, a čimbenik pod } \\
\text { brojem } 12 \text { ima najniži stupnj važnosti }\end{array}$} \\
\hline
\end{tabular}




\section{IX. Životopis kandidatkinje s popisom objavljenih djela}

Tihana Babić rođena je 25.02.1982. godine u Čakovcu. Diplomirala je filozofiju i kroatologiju, područje humanističkih znanosti, 2009. godine na Sveučilištu u Zagrebu, na Hrvatskim studijima. Godine 2021. obranila je disertaciju na Sveučilištu u Zagrebu, na Filozofskom fakultetu, područje društvenih znanosti, polje informacijske i komunikacijske znanosti.

Radno iskustvo stjecala je od 2009. do 2012. godine kao nastavnica etike i administrativna referentica u Graditeljskoj školi u Čakovcu, te je 2012. godine uspješno je položila stručni ispit za zanimanje nastavnika etike pri Ministarstvu znanosti, obrazovanja i sporta i Agenciji za odgoj i obrazovanje u Zagrebu. Godine 2013. radila je kao voditeljica studentske službe/tajništva Visoke škole za odnose s javnošću i studij medija Kairos (sada Veleučilište Vern) u Zagrebu, od 2013. godine do danas radi na Visokom učilištu Algebra, prvo na radnom mjestu voditeljice studentske službe, od 2018. do 2021. godine kao glavna tajnica visokog učilišta, te od 2021. godine kao nastavnica i znanstvenica u punom radnom vremenu.

Godine 2019. izabrana je u naslovno nastavno zvanje predavač u znanstvenom području humanističkih znanosti, polje filozofija, a 2021. godine izabrana je u naslovno nastavno zvanje viši predavač u znanstvenom području društvenih znanosti, polje interdisciplinarne društvene znanosti. Nositeljica je kolegija na preddiplomskim i diplomskim studijima.

Objavila je više znanstvenih i stručnih radova te sudjelovala na konferencijama u zemlji i inozemstvu. Govori engleski i njemački jezik.

Relevantni radovi:

1. Babić, Tihana; Musa, Zvonimir (2020). The significance of transformational team members. MIPRO 2020 Proceedings / Skala, Karolj (ur.). Opatija, str. 950-955 (međunarodna recenzija, objavljeni rad, znanstveni).

2. Radoš, Ivan; Babić, Tihana (2020). Digital transformation as a process of using digital technologies for monitoring and designing the user experience. MIPRO 2020 Proceedings / Skala, Karolj (ur.). Opatija, str. 956-961 (međunarodna recenzija, objavljeni rad, znanstveni). 
3. Mikšić, Irena; Babić, Tihana; Bakić-Tomić, Ljubica (2020). Intuitive and rational information management. MIPRO 2020 Proceedings / Skala, Karolj (ur.). Opatija, str. 826-831 (međunarodna recenzija, objavljeni rad, znanstveni).

4. Pavlica, Marcela; Babić, Tihana; Cuculić, Petra (2020). Effective decision making: the added value of including humanities in STEM studies. MIPRO 2020 Proceedings / Skala, Karolj (ur.). Opatija, str. 726-731 (međunarodna recenzija, objavljeni rad, znanstveni).

5. Cuculić, Petra; Babić, Tihana; Pavlica, Marcela (2020). Internationalization and Student Mobility: STEAM Students Case Study. MIPRO 2020 Proceedings / Skala, Karolj (ur.). Opatija, str. 711-716 (međunarodna recenzija, objavljeni rad, znanstveni).

6. Borysiuk, Yelyzaveta; Babić, Tihana (2020). A meaningful and value-driven workplace as a premise of STEAM students' expectations for future quality life. MIPRO 2020 Proceedings / Skala, Karolj (ur.). Opatija, str. 861-866 (međunarodna recenzija, objavljeni rad, znanstveni).

7. Jadanec, Ana-Marija; Babić, Tihana (2020). Students' attitudes toward value-driven digital marketing. MIPRO 2020 Proceedings / Skala, Karolj (ur.). Opatija, str. 849-854 (međunarodna recenzija, objavljeni rad, znanstveni).

8. Knežević, Antea; Babić, Tihana; Musa, Zvonimir (2020). Cryptocurrency as the currency of the future: a case study among Algebra University College student. MIPRO 2020 Proceedings / Skala, Karolj (ur.). Opatija, str. 867-872 (međunarodna recenzija, objavljeni rad, znanstveni).

9. Babić, Tihana; Vilović, Gordana; Bakić Tomić, Ljubica (2019). The Usage of Social Media for Higher Education Purposes. The Future of Information Sciences / Bago, Petra; Hebrang Grgić, Ivana; Ivanjko, Tomislav; Juričić, Vedran; Miklošević, Željka; Stublić, Helena (ur.). Faculty of Humanities and Social Sciences, University of Zagreb, Department of Information and Communication Sciences, FF press, Zagreb: str. 206- 
216. doi:10.17234/INFUTURE.2019.25 (predavanje, međunarodna recenzija, cjeloviti $\operatorname{rad}$ (in extenso), znanstveni).

10. Magzan, Maša; Babić, Tihana (2019). Negotiation and Conflict Resolution: Perfecting the Skills We Use Daily / Ćosić, Barbara (ur.). Algebra Ltd., Zagreb.

11. Babić, Tihana; Lacković, Andrej; Matejić, Martina (2019). Critical Thinking and Creative Thinking - the self-assessment of Algebra University College students. MIPRO 2019 Proceedings / Skala, Karolj (ur.). Opatija, str. 963-968 (međunarodna recenzija, objavljeni rad, znanstveni).

12. Babić, Tihana; Vunarić, Iva; Lacković, Andrej (2019). Information ethics on social networks: students perspective // Mediterranean Issues, Book 2 /Jurčević, Katica; Kaliterna Lipovčan, Ljiljana; Ramljak, Ozana (ur.). Institut Ivo Pilar i Grupa 'VERN', Zagreb, str. 455-462 (predavanje, međunarodna recenzija, objavljeni rad, znanstveni).

13. Babić, Tihana; Papić, Silvio; Babić, Manuela (2019). Intuitive communication versus rational communication among students of computing at the Algebra University College. MIPRO 2019 Proceedings / Skala, Karolj (ur.). Opatija, str. 845-850 (međunarodna recenzija, objavljeni rad, znanstveni).

14. Babić, Tihana; Grgić, Silvija (2019). Net generation and a perception of the electronic violence. Mediterranean Issues, Book 2 / Jurčević, Katica; Kaliterna Lipovčan, Ljiljana; Ramljak, Ozana (ur.). Institut Ivo Pilar i Grupa 'VERN', Zagreb, str. 445-454 (predavanje, međunarodna recenzija, objavljeni rad, znanstveni).

15. Babić, Tihana; Kunić, Tamara (2018). European Refugee Crisis 2015: Press Coverage on Website Dnevno.hr. Communication Management Forum 2017; Living in Crisis Mode: Time to Reconsider Definition, Meaning and Practice?, Proceedings / Verhoeven, Piet; Jugo, Damir; Jakopović, Hrvoje; Ciboci, Lana (ur.). Edward Bernays University College, Zagreb, str. 265-283 (predavanje, međunarodna recenzija, objavljeni rad, znanstveni). 
16. Babić, Tihana; Papić, Silvio; Babić, Manuela (2018). The importance of multiple intelligences and growth mindset - Research among students of University College Algebra. MIPRO 2018 Proceedings / Karolj, Skala (ur.). Opatija, str. 911-916 (predavanje, međunarodna recenzija, objavljeni rad, znanstveni).

17. Matejić, Martina; Babić, Tihana; Holjenko, Marina (2018). Važnost Centra karijera u kvalitetnoj pripremi za buduće zanimanje u informacijskom okruženju. Science \& Practice of Business Studies; Godina II, broj 2 / Klincov, Radovan (ur.). University of Business Studies, Banja Luka, str. 411-428 (međunarodna recenzija, objavljeni rad, znanstveni).

18. Babić, Tihana; Vunarić, Iva; Lokas Ćošković, Ana (2017). Interakcija i komunikacija studenata prilikom učenja - primjer studenata Visokog učilišta Algebra. MIPRO 2017 Proceedings / Biljanović, Petar (ur.). Opatija, str. 1165-1169 (međunarodna recenzija, objavljeni rad, znanstveni).

19. Babić, Tihana; Vunarić, Iva; Lokas Ćošković, Ana (2017). Netspeak kao obilježje računalno posredovane komunikacije - primjer studenata Visokog učilišta Algebra. MIPRO 2017 Proceedings / Biljanović, Petar (ur.). Opatija, str. 1128-1132 (međunarodna recenzija, objavljeni rad, znanstveni).

20. Babić, Tihana; Lacković, Andrej; Babić, Manuela (2017). Upravljanje znanjem kao ključna tržišna prednost intelektualnih radnika. MIPRO 2017 Proceedings / Biljanović, Petar (ur.). Opatija, str. 1117-1122 (međunarodna recenzija, objavljeni rad, znanstveni).

21. Babić, Tihana, Ogrin, Ana, Babić, Manuela (2016). Informacijsko-komunikacijske znanosti u nastavi - digitalizirani materijali za učenje. MIPRO 2016 Proceedings / Biljanović, Petar (ur.). Opatija, str. 1239-1244 (međunarodna recenzija, objavljeni rad, znanstveni).

22. Babić, Tihana; Grgić, Silvija; Rajković, Eugen (2016). Istraživanje stavova i očekivanja studenata prilikom upisa na studij kao metoda povećanja kvalitete usluge u visokom obrazovanju. MIPRO 2016 Proceedings / Biljanović, Petar (ur.). Opatija, str. 1245-1249 (predavanje,međunarodna recenzija, objavljeni rad, znanstveni). 
23. Grgić, Silvija; Vunarić, Iva; Babić, Tihana (2016). Metodologija izrade E - learning sadržaja za edukaciju o izradi Standarda zanimanja. MIPRO 2016 Proceedings / Biljanović, Petar (ur.). Opatija, str. 1230-1234 (međunarodna recenzija, objavljeni rad, stručni).

24. Babić, Tihana; Ogrin, Ana; Šarkanj, Klaudija (2015). Žene i informacijskokomunikacijske tehnologije: zašto su studentice rijetkost na studiju računarstva? MIPRO 2015 Proceedings / Biljanović, Petar (ur.). Opatija, str. 1134-1137 (međunarodna recenzija, objavljeni rad, znanstveni). 